\title{
The influence of fold and fracture development on reservoir behavior of the Lisburne Group of northern Alaska
}

\section{Final report}

Reporting period: September, 1998 to September, 2002

\author{
Principal investigator \\ Wesley K. Wallace \\ Co-principal investigators: \\ Catherine L. Hanks \\ Jerry Jensen ${ }^{1}$ \\ Michael T. Whalen \\ Other contributors: \\ Paul Atkinson, Joseph Brinton, \\ Thang Bui ${ }^{1}$, Margarete Jadamec, \\ Alexandre Karpov, John Lorenz ${ }^{2}$, \\ Michelle M. McGee, T.M. Parris ${ }^{3}$, \\ Ryan Shackleton \\ Report date: July, 2004 \\ Department of Energy Award DE-AC26-98BC15102 \\ Submitting organization: \\ Geophysical Institute \\ University of Alaska \\ Fairbanks, Alaska \\ 99775-5780

\footnotetext{
${ }^{1}$ Department of Petroleum Engineering and Department of Geology and Geophysics, Texas A\&M University, College Station, Texas 77843-3116

${ }^{2}$ Sandia National Laboratory, Albuquerque, New Mexico

3 Petro-Fluid Solutions, Loveland, Colorado
} 


\section{Disclaimer}

This report was prepared as an account of work sponsored by an agency of the United States Government. Neither the United States Government nor any agency thereof, nor any of their employees, makes any warranty, express or implied, or assumes any legal liability or responsibility for the accuracy, completeness, or usefulness of any information, apparatus, product, or process disclosed, or represents that its use would not infringe privately owned rights. Reference herein to any specific commercial product, process, or service by trade name, trademark, manufacturer, or otherwise does not necessarily constitute or imply its endorsement, recommendation, or favoring by the United States Government or any agency thereof. The views and opinions of authors expressed herein do not necessarily state or reflect those of the United States Government or any agency thereof. 


\begin{abstract}
The Carboniferous Lisburne Group is a major carbonate reservoir unit in northern Alaska. The Lisburne is folded and thrust faulted where it is exposed throughout the Brooks Range, but is relatively undeformed in areas of current production in the subsurface of the North Slope. The objectives of this study were to develop a better understanding of four major aspects of the Lisburne:

1. The geometry and kinematics of folds and their truncation by thrust faults.

2. The influence of folding on fracture patterns.

3. The influence of deformation on fluid flow.

4. Lithostratigraphy and its influence on folding, faulting, fracturing, and reservoir characteristics.
\end{abstract}

Symmetrical detachment folds characterize the Lisburne in the northeastern Brooks Range. In contrast, Lisburne in the main axis of the Brooks Range is deformed into imbricate thrust sheets with asymmetrical hangingwall anticlines and footwall synclines. The Continental Divide thrust front separates these different structural styles in the Lisburne and also marks the southern boundary of the northeastern Brooks Range. Field studies were conducted for this project during 1999 to 2001 in various locations in the northeastern Brooks Range and in the vicinity of Porcupine Lake, immediately south of the Continental Divide thrust front. Results are summarized below for the four main subject areas of the study.

\title{
Stratigraphy
}

The Lisburne Group represents a laterally extensive carbonate ramp deposited during the middle Carboniferous. This study focused on Lisburne in the northeastern Brooks Range in the north and the central-eastern Brooks Range to the south, as well as analysis of subsurface drill core and gamma ray logs. From bottom to top, the Lisburne includes the Wachsmuth, Alapah, and Wahoo Limestones, both of which are subdivided into three members. The Wachsmuth Limestone occurs mainly in the central-eastern Brooks Range. The Alapah is much thicker in the south and the three members in the north are almost entirely represented, chronostratigraphically, by the upper Alapah in the south. The Wachsmuth and the lower and middle Alapah have no temporal equivalents to the north except in the southernmost northeastern Brooks Range.

We defined 16 facies within the Wachsmuth and Alapah Limestones of the central-eastern Brooks Range. These facies were deposited dominantly in middle- to outer-ramp environments that include open-marine settings both below and above fairweather wavebase on the outer ramp, shoal and nearshoal environments, and open- and restricted-platform environments on the middle ramp. Facies commonly are stacked in either non-cyclic or cyclic packages. Cyclic packages, or parasequences, shallow upward, recording a relative fall in sea level. Parasequences in the northeastern Brooks Range are significantly different because of their more proximal paleogeographic setting and usually contain shoal, open- and restricted-platform, and intertidal or supratidal facies.

Data from subsurface drill cores and subsurface gamma ray logs and one outcrop gamma ray log provided criteria for subsurface stratigraphic subdivisions and correlation between the outcrops in the Brooks Range and the North Slope subsurface. These data were combined with outcrop stratigraphic data, information on facies stacking patterns, and biostratigraphy to identify six depositional sequences in the Lisburne Group. These sequences define a pattern of progressive northward onlap in the Lisburne Group.

The mechanical stratigraphy of the Lisburne Group is reflected in part by large-scale outcrop weathering patterns. In the central-eastern Brooks Range, the lower Wachsmuth is generally mechanically incompetent, whereas the middle and upper Wachsmuth and the lower and upper Alapah are competent. The middle Alapah is comparable to or slightly less competent than the 
lower Wachsmuth. In the northeastern Brooks Range, the lower Alapah is relatively incompetent but increases in competency upward. The middle Alapah is less competent than the lower Alapah or the competent upper Alapah.

The Lisburne Group is a poor reservoir rock with very low porosities in most of the field area, and hence probably low permeability. Fracturing likely enhances both porosity and permeability but the presence of many shale-based parasequences further reduces the reservoir potential. Some thin dolomitized intervals within the Alapah in the subsurface are oil stained and might be reservoir intervals. Organic-rich shales interbedded with Lisburne carbonates in the central-eastern Brooks Range could have been source rocks, albeit fair to poor and gas-prone.

\section{Folds}

Carbonates of the Mississippian and Pennsylvanian Lisburne Group and the underlying Mississippian Kayak Shale display two different types of map-scale folds in the eastern Brooks Range of Alaska. This study characterized these folds, reconstructed their evolution, and identified factors that may have influenced their formation.

\section{Detachment folds}

In the northeastern Brooks Range, the folds are upright and symmetrical detachment folds that are cut only rarely by thrust faults. At low to intermediate shortening, the folds range from angular throughout to an angular inner arc that grades outward to a box or rounded geometry. With increasing shortening, folds display increasing flattening by bulk strain, typically with thickening of hinges and thinning of limbs.

The fold mechanism changed from flexural slip at low to intermediate shortening to fold flattening by bulk strain as shortening increased. Flattening probably superseded flexural slip due to a combination of resistance to continued folding by flexural slip and more ductile conditions of deformation. The formation of symmetrical detachment folds was favored by a regionally horizontal detachment, a weak detachment, a low ratio of competent to incompetent unit thickness, an absence of overlying thrust sheets, and/or an orogenic wedge with a low taper angle. A hybrid geometric-kinematic model for the detachment folds of the northeastern Brooks Range describes geometry at different stages of evolution, but does not predict how fold geometry will evolve.

Extension fractures may have formed during layer-parallel shortening before or early during folding. Flexural-slip under brittle conditions could lead to fracturing resulting from shear strain associated with bed-parallel slip and/or tangential longitudinal strain due to bending of beds. New fractures probably did not form during fold flattening under ductile conditions and existing fractures probably were closed and annealed, but new fractures likely formed during minor late flexural slip.

\section{Thrust-truncated asymmetrical folds}

South of the northeastern Brooks Range, the folds are inclined and asymmetrical and typically are cut and displaced by thrust faults. The folds are mostly angular, and display a smaller range of fold shortening and less fold flattening than in the northeastern Brooks Range. Forelimbs commonly contain a large parasitic anticline-syncline pair and backlimbs are long and gently folded. Forelimbs typically are cut and displaced above one or more thrust faults and backlimbs overlie a flat near the base of the Lisburne. Thrust faults commonly are gently folded into antiforms. Local folds that are not visibly cut by thrust faults display greater fold shortening, steeper inclination, and more thickness change than folds that have been cut by thrusts. 
The competency contrast between Kayak and Lisburne, some folds that have not been cut by thrust faults, and a transition to detachment folds in the same rock units to the north suggest that the folds originated as detachment folds. Forelimbs of the folds were steepened and thickened, mainly by parasitic folding. Thrust faults broke through forelimbs as shortening increased and the truncated fold was fault-bend folded as it was displaced over the footwall ramp. Thrusts underlying displaced folds were gently folded by deformation in the footwall.

Inclination of layering with respect to maximum compressive stress or simple shear acting along layering favored formation of asymmetrical folds. Field observations support top-to-north bedparallel shear and that fold asymmetry favored thrust breakthrough. The formation and eventual breakthrough of asymmetrical folds was favored by a regionally inclined detachment, a high ratio of competent to incompetent unit thickness, the presence of overlying and underlying thrust sheets, and/or an orogenic wedge that lacks an unusually low taper angle.

Some fractures formed oblique to bedding as a result of bed-parallel shear prior to folding. Flexural-slip under brittle conditions may have been accompanied by fracturing related to bedparallel slip in limbs, and/or tangential longitudinal strain due to bending of beds in hinges. Fixed hinges would result in little overlap between hinge- and limb-related fractures. Fractures may have formed related to thrust breakthrough and thrust-related strain. Late bending of displaced folds resulted in abundant fractures and veins in or near hinges of displaced folds and the bends in their backlimbs.

\section{Fractures}

Fractures formed at different times in the evolution of individual detachment folds in Lisburne Group carbonates of the northeastern Brooks Range, providing clues to the mechanism of folding and the conditions under which the folds formed. Rocks in advance of the visible thrust front experienced low-magnitude differential stresses of the same orientation as in the fold-and-thrust belt, resulting in orogen-perpendicular extension fractures in undeformed rocks of the foreland basin. These rocks were later incorporated into the thrust belt, where they were folded and thrustfaulted. The distribution of fractures and other mesoscopic structures in individual folds suggests that folding occurred both by flexural slip and homogeneous flattening. Flexural slip and associated fracturing occurred early in the development of the fold and/or in the outer arc of the fold. These early fractures typically were overprinted and/or destroyed by ductile strain as later homogeneous flattening accommodated additional shortening. The penetrative strain was in turn overprinted by late extension fractures, which probably formed during the waning phases of folding and/or unroofing of the orogenic wedge.

The distribution and character of open fractures at any particular stage in the evolution of the foldand-thrust belt has significant implications for fluid flow into reservoirs active at that time.

Subsequent fluid flow out of those same reservoirs, including production, may be governed by an entirely different set of open fractures. However, fracture spacing and character are controlled by a variety of complex factors, including lithostratigraphy, mechanical stratigraphy, and structural position. Because of this, simple univariant statistical techniques do not adequately predict fracture distribution in detachment folds. Neural network analysis has some potential for addressing this issue, but further study is needed. 


\section{Petroleum engineering}

\section{Connectivity and wellbore placement in the Lisburne Group}

Fractures play a key role in Lisburne Group fluid-flow behavior. Field data from relatively undeformed grainstone in the Wahoo Limestone in the eastern Sadlerochit Mountains were analyzed to develop fracture distributions and models for a range of possible cases. The "base" case assumed two sets of vertical fractures as observed in the field and no effect of fracture intersection. Other models allowed more variability in fracture strike and interaction. These models were interrogated for wellbore placement and hydraulic connectivity behavior. The wellbore trajectory analysis showed the following. A positive correlation was observed for the base case between number and area of fractures connected to wellbores. This relationship, however, diminished for the other cases. Optimal horizontal well azimuth orientations are in the range $0^{\circ}$ to $30^{\circ}$ for the base case and the case with variable fracture strike and dip. Wells with this orientation will be connected to the maximum number and area of fractures. Variability in strike and dip increases the number and area of fractures connected to the wellbore. However, it does not change the optimal wellbore orientation. Termination of ENE-striking fractures against the NNW-striking fractures increases the number and decreases the area of fractures connected to the wellbore. It also affects wellbore placement by shifting the optimal wellbore trajectory from the bisector between the two sets $\left(30^{\circ}\right)$ toward the direction perpendicular to the NNW-striking set $\left(60^{\circ}\right)$.

The hydraulic connectivity analyses showed the following. The fracture network is weakly anisotropic if uniform fracture transmissivity is assumed. The system remains weakly anisotropic if the relative transmissivities of the sets are changed. ENE-striking fractures provide critical connections in the fracture network, as opposed to the NNW-striking set, whose transmissivity is important only for NNW flow. The fracture system is above the percolation threshold in all cases. The smaller fractures become important if termination of ENE-striking fractures and strike and dip variability are included in the model: the "realistic" case is less interconnected, closer to the percolation threshold, and more sensitive to removal of smaller fractures.

\section{Fracture timing and flow implications in folded Lisburne}

Field evidence and statistical analysis in exposed detachment-folded Lisburne Group carbonates suggest that a significant population of fractures formed late during or after folding. Both prefold fractures and penetrative strain associated with peak folding are overprinted by late- and post-fold fractures. The late-fold fractures strike EW parallel to the fold axes, are perpendicular to bedding, are commonly only partially filled with cement, and generally terminate at bedding planes. These and earlier structures are consistently overprinted by pervasive late NS-striking extension fractures. These later fractures strike perpendicular to the fold axes, and are vertically extensive, evenly spaced, and unfilled. Both the late-fold and post-fold fracture sets have similar average and median spacing.

Statistical analysis of fold interlimb angle and fracture spacing indicates that, as the folds tighten, the spacing of both the EW- and NS-striking fracture sets increases by a factor of two or three and becomes slightly more variable. This is opposite from the behavior expected if the fractures were closely related to folding and suggests that the two sets are similar to each other and only weakly related to folding.

The weak genetic relationship between folding and formation of the most obvious and open fractures serves as an important example with major consequences for reservoir modeling. Complex genetic and timing relationships between fractures and folds may result in several fracture sets, each having different characteristics. If they are not distinguished, genetically disparate fractures may be combined into one or a few sets to produce a reservoir model with fracture properties that do not apply to any of the sets. This could result in inappropriate wellbore placement or inaccurate estimates of productivity and recovery. 
Relationships of fracture density and mechanical stratigraphy in folded Lisburne using neural nets

In this research we used a neural network to investigate the relationship between fracture spacing and mechanical stratigraphic parameters for fracture data in exposed detachment folded Lisburne Group carbonates. The results suggest a complex relationship between fracture spacing and mechanical properties. Bed thickness has the greatest effect on the fracture density, followed by the interlimb angle and formation lithology. The use of neural networks enabled us to trace the effect of single parameters on fracture spacing and to give us more insight into the relationship between the mechanical properties and fracture density. 


\section{Table of contents}

Part A: Introduction and geologic setting, by Wesley K. Wallace

Definition of problem and objectives

Scope of this report

Geologic setting

References

A-4

Figures

\section{Part B: Baseline stratigraphy of the Lisburne Group,} by Michelle M. McGee and Michael T. Whalen

Abstract

Introduction

General stratigraphy

Methods and database

B-6

Lisburne Group lithofacies

Dolostone (facies 1)

Wackestone/banded black chert (facies 2)

Peloid-calcisphere wacke/packstone (facies 3)

Peloid-brachiopod-calcisphere-ostracod wacke/packstone (facies 4)

Skeletal-peloid pack/grainstone (facies 5)

Skeletal grain/rudstone (facies 6)

B-12

Peloid pack/grainstone (facies 7)

Peloid-coral-brachiopod wacke/packstone (facies 8)

Coral pack/grainstone (facies 9)

Brachiopod pack/grainstone (facies 10)

Solitary rugose coral wacke/packstone (facies 11)

Peloid-skeletal wacke/packstone (facies 12)

Skeletal wacke/packstone (facies 13)

Foram wacke/packstone (facies 14)

Crinoid-solitary rugose coral floatstone (facies 15)

Mudstone and calcareous shale (facies 16) 
Shoal and shallow open marine environment

B-21

Middle ramp: Open marine environment

B-23

Outer ramp: Deep open marine environment

B-23

Stratigraphy and biostratigraphy of the Lisburne Group, central-eastern Brooks Range

B-24

Wachsmuth Limestone

B-24

Crinoidal limestone member

B-26

Middle member

B-28

Banded limestone member

B-28

Alapah Limestone

B-30

Lower member

B-30

Middle member

B-31

Upper member

B-31

Facies stacking patterns

B-32

Non-cyclic intervals

B-32

Parasequences

B-33

Biostratigraphy

B-36

Conodonts

B-36

Foraminifera

B-37

Outcrop gamma ray data

B-37

Subsurface analysis

B-38

North Slope stratigraphy and parasequences

B-38

Alapah Limestone

B-42

Wahoo Limestone

B-43

Subsurface to surface correlation

B-45

Sequence stratigraphy

B-45

Central-eastern Brooks Range

B-46

Sequence 1

B-46

Sequence 2

B-48

Sequence 3

B-48

Sequence 4

B-49

Sequence 5

B-51

Sequence 6

B-52

Mechanical stratigraphy

B-54

Diagenesis of the Lisburne Group

B-57

Grain micritization and neomorphism

B-57

Compaction and pressure solution

B-58 
$\begin{array}{lr}\text { Cementation } & \text { B-58 }\end{array}$

$\begin{array}{ll}\text { Dissolution } & \text { B-59 }\end{array}$

$\begin{array}{lr}\text { Silicification } & \text { B-59 }\end{array}$

$\begin{array}{ll}\text { Dolomitization } & \text { B-60 }\end{array}$

$\begin{array}{ll}\text { Authigenic albite } & \text { B-61 }\end{array}$

$\begin{array}{ll}\text { Fractures } & \text { B-62 }\end{array}$

$\begin{array}{ll}\text { Other diagenetic features } & \text { B-62 }\end{array}$

$\begin{array}{ll}\text { Lisburne petroleum potential } & \text { B-62 }\end{array}$

$\begin{array}{ll}\text { Reservoir properties } & \text { B-62 }\end{array}$

$\begin{array}{ll}\text { Source rock potential } & \text { B-63 }\end{array}$

$\begin{array}{lr}\text { References } & \text { B-66 }\end{array}$

Part C: Geometry and evolution of detachment folds and thrust-truncated asymmetrical folds in the eastern Brooks Range, by Wesley K. Wallace, Paul Atkinson, Margaret Jadamec, Ryan Shackleton, and Catherine L. Hanks

$\begin{array}{lr}\text { Abstract } & \mathrm{C}-1 \\ \text { Introduction } & \mathrm{C}-2 \\ \text { Detachment folds } & \mathrm{C}-3 \\ \quad \text { Basis for analysis } & \mathrm{C}-3 \\ \text { Mechanical stratigraphy } & \mathrm{C}-3 \\ \text { Fold characteristics } & \mathrm{C}-4 \\ \quad \text { Intermediate shortening } & \mathrm{C}-5 \\ \quad \text { Low shortening } & \mathrm{C}-6 \\ \quad \text { High shortening } & \mathrm{C}-7 \\ \text { Interpretation of fold evolution } & \mathrm{C}-7 \\ \quad \text { Low shortening } & \mathrm{C}-7 \\ \quad \text { Intermediate shortening } & \mathrm{C}-8 \\ \quad \text { High shortening } & \mathrm{C}-8 \\ \text { Controls on fold geometry and evolution } & \mathrm{C}-8 \\ \text { Comparison with models for detachment folds } & \mathrm{C}-10 \\ \text { Questions about northeastern Brooks Range detachment folds } & \mathrm{C}-11 \\ \text { Summary and conclusions } & \mathrm{C}-12 \\ \text { Fold geometry and evolution } & \mathrm{C}-12 \\ \text { Implications for fracture } & \mathrm{C}-13 \\ \text { Thrust-truncated asymmetrical folds } & \mathrm{C}-14\end{array}$


$\begin{array}{ll}\text { Basis for analysis } & \text { C-14 }\end{array}$

$\begin{array}{ll}\text { Mechanical stratigraphy } & \text { C-14 }\end{array}$

$\begin{array}{ll}\text { Fold and thrust characteristics } & \text { C-15 }\end{array}$

$\begin{array}{ll}\text { Interpretation of fold and thrust evolution } & \mathrm{C}-18\end{array}$

Detachment folds or fault-propagation folds? $\quad$ C-18

$\begin{array}{ll}\text { History of evolution } & \text { C-19 }\end{array}$

$\begin{array}{ll}\text { Controls on fold and thrust geometry and evolution } & \text { C-20 }\end{array}$

Questions about thrust-truncated asymmetrical folds in the Porcupine Lake area C-22

$\begin{array}{ll}\text { Summary and conclusions } & \mathrm{C}-23\end{array}$

Fold and thrust geometry and evolution $\quad$ C-23

$\begin{array}{ll}\text { Implications for fracture } & \text { C-24 }\end{array}$

$\begin{array}{ll}\text { References } & \text { C-26 }\end{array}$

$\begin{array}{ll}\text { Figures } & \text { C-30 }\end{array}$

Tables $\quad$ C-59

Part D: Implications of fracture distribution and character in detachment folds in the Lisburne Group of northeastern Alaska, by C.L. Hanks, J.R. Shackleton, J. Brinton, J. Jensen, T. Bui, A. Karpov, T. Parris, and J. Lorenz

Abstract $\quad$ D-1

Introduction $\quad$ D-2

$\begin{array}{ll}\text { Background } & \text { D-3 }\end{array}$

Detachment folds $\quad$ D-3

Fold mechanisms: Flexural flow, flexural slip, and homogeneous flattening D-3

$\begin{array}{ll}\text { Controls on fracture spacing } & \text { D-4 }\end{array}$

$\begin{array}{ll}\text { Lithostratigraphy \& mechanical stratigraphy } & \text { D-4 }\end{array}$

$\begin{array}{ll}\text { Structural position } & \text { D-6 }\end{array}$

$\begin{array}{ll}\text { Methodology } & \text { D-7 }\end{array}$

Part I: Conditions \& timing of fracture formation - observation and interpretation $\quad$ D-7

$\begin{array}{ll}\text { Summary of field observations } & \text { D-7 }\end{array}$

$\begin{array}{ll}\text { Thermal constraints } & \text { D-8 }\end{array}$

$\begin{array}{ll}\text { Discussion } & \text { D-8 }\end{array}$

Implications of ductile vs. brittle structures for folding mechanism $\quad$ D-8

$\begin{array}{ll}\text { General deformation conditions - structural constraints D-10 } & \text { D }\end{array}$

Sequence of fracture formation: Pressure-temperature-time-deformation path D-11

$\begin{array}{ll}\text { Pre-60 Mybp D-11 } & \end{array}$ 
60 Ma regional deformational event

D-12

Early Tertiary deformation and uplift

D-13

Part II: Controls on fracture spacing-observations and interpretation

D-14

Fracture spacing and lithostratigraphy/mechanical stratigraphy

D-14

Incorporating structural position

D-16

Neural network analysis

D-17

Implications

D-18

Fracture evolution in fold-and-thrust belts

D-18

Timing and conditions of fracturing in the Colville basin and implications for petroleum exploration and production

D-20

Influence of mechanical stratigraphy and structural position on fracture character

D-21

Conclusions

D-22

References

D-24

Figures

D-31

Tables

D-47

\section{Part E: Connectivity and wellbore placement in the Lisburne Group,} by A.V. Karpov, J. L. Jensen, and C. L. Hanks

Abstract $\quad$ E-1

Introduction $\quad$ E-1

$\begin{array}{ll}\text { Literature overview } & \text { E-2 }\end{array}$

$\begin{array}{ll}\text { Fracture statistical properties } & \mathrm{E}-2\end{array}$

Fracture property assessment $\quad$ E-2

Wellbore placement in fractured reservoirs $\quad$ E-3

Connectivity and flow in fractured systems $\quad$ E-3

Lisburne Group fracture data analysis $\quad$ E-3

Data description $\quad$ E-3

Analysis results $\quad$ E-4

NNW fracture set $\quad$ E-4

ENE fracture set $\quad$ E-4

Lisburne Group fracture modeling $\quad$ E-5

Fracture models $\quad$ E-6

Wellbore modeling results $\quad$ E-6

Wellbore modeling comments $\quad$ E-7

Fracture system conductivity evaluation $\quad$ E-8

$\begin{array}{ll}\text { Conductivity comments } & \text { E-8 }\end{array}$ 
$\begin{array}{ll}\text { Conclusions } & \text { E-9 }\end{array}$

Acknowledgements $\quad$ E-9

References $\quad$ E-10

Appendix A. Sample L-moment calculations $\quad$ E-11

Appendix B. Jack-knifing analysis $\quad$ E-12

Figures $\quad$ E-12

Part F: Fracture timing and flow implications in folded Lisburne, by T.D. Bui, J.L. Jensen, J. Brinton, and C. L. Hanks

Abstract

Introduction

Fracture data

Data observations

Orientation

Filling

Fracture termination

Statistical analysis

Spacing, bed thickness, and interlimb angle

Spacing, interlimb angle, and orientation

Spacing and structural position

Fracture size analysis

Implications for reservoir performance

Conclusions

Acknowledgements

References

Tables

Figures

Part G: Relationship of fracture density and mechanical stratigraphy in folded Lisburne using neural nets,

by T.D. Bui, J.L. Jensen, J. Brinton, and C. L. Hanks

Abstract

Background

Neural networks 
MLP's $\quad$ G-2

Modeling the fracture density $\quad$ G-4

Geological setting $\quad$ G-4

Fracture data $\quad$ G-4

Data preparation $\quad$ G-5

Parameters of the model $\quad$ G-7

$\begin{array}{ll}\text { Results } & \text { G-7 }\end{array}$

Discussion $\quad$ G-7

$\begin{array}{ll}\text { Fracture spacing and interlimb angle } & \text { G-7 }\end{array}$

Fracture spacing and bed thickness $\quad$ G-8

$\begin{array}{ll}\text { Fracture spacing and structural position } & \text { G-8 }\end{array}$

$\begin{array}{ll}\text { Fracture spacing and fracture orientation } & \text { G-8 }\end{array}$

$\begin{array}{ll}\text { Fracture spacing and formation } & \text { G-8 }\end{array}$

Relative importance of input variables in explaining fracture spacing G-9

$\begin{array}{ll}\text { Conclusions } & \text { G-12 }\end{array}$

References $\quad$ G-13

Tables $\quad$ G-15

$\begin{array}{ll}\text { Figures } & \text { G-16 }\end{array}$

\section{Part H. Summary and conclusions}

Stratigraphy $\quad H-1$

Detachment folds $\quad \mathrm{H}-2$

$\begin{array}{ll}\text { Fold geometry and evolution } & \mathrm{H}-2\end{array}$

$\begin{array}{ll}\text { Implications for fracture } & \mathrm{H}-3\end{array}$

Thrust-truncated asymmetrical folds $\quad \mathrm{H}-4$

Fold and thrust geometry and evolution $\quad \mathrm{H}-4$

Implications for fracture $\quad$ H-5

Fractures $\quad$ H-6

$\begin{array}{ll}\text { Petroleum engineering } & \mathrm{H}-7\end{array}$

$\begin{array}{ll}\text { Connectivity and wellbore placement in the Lisburne Group } & \mathrm{H}-7\end{array}$

$\begin{array}{ll}\text { Fracture timing and flow implications in folded Lisburne } & \mathrm{H}-8\end{array}$

Relationships of fracture density and mechanical stratigraphy in folded Lisburne $\begin{array}{ll}\text { using neural nets } & \text { H-8 }\end{array}$ 


\section{List of figures}

\section{Part A: Introduction and geologic setting}

Figure 1. Map of western part of northeastern Brooks Range

Figure 2. Cross section showing difference in structural style across the Continental Divide thrust front

\section{Part B: Baseline stratigraphy of the Lisburne Group}

Figure 1. Outcrops of Lisburne Group and locations of stratigraphic sections

Figure 2. Stratigraphic nomenclature of the Lisburne Group

Figure 3. Photomicrographs and field photographs, facies 1

Figure 4. Photomicrographs and field photographs, facies 2, 3, and 4

Figure 5. Photomicrographs and field photographs, facies 5 and 6

B-12

Figure 6. Photomicrographs and field photographs, facies 7 and 8

B-13

Figure 7. Photomicrographs and field photographs, facies 9 and 10

B-15

Figure 8. Photomicrographs and field photographs, facies 11 and 12

B-16

Figure 9. Photomicrographs and field photographs, facies 13 and 14

B-18

Figure 10. Photomicrographs and field photographs, facies 15 and 16

B-19

Figure 11. Carbonate ramp depositional model for the Lisburne Group

Figure 12. Composite Lisburne Group stratigraphy, central-eastern Brooks Range

Figure 13. Large-scale weathering patterns of the Lisburne Group

Figure 14. Chert morphologies in the Lisburne Group

Figure 15. Type 1 and 2 parasequences

B-34

Figure 16. Type 3 and 4 parasequences

B-35

Figure 17. Subsurface to surface correlation and stratigraphic nomenclature

Figure 18. Subsurface to surface correlation of parasequences and zones

Figure 19. Sequence stratigraphic interpretation of the Lisburne Group

Figure 20. Parasequence stacking patterns within the Lisburne Group

Figure 21. Outcrop photo of Lisburne Group sequence stratigraphic subdivision

Figure 22. Outcrop photo of Lisburne Group sequence stratigraphic subdivision,

$$
\text { Forks field area }
$$

Figure 23. Evaporites and evidence of subaerial exposure

Figure 24. Outcrop of Lisburne Group in the eastern Sadlerochit Mountains

Figure 25. Evidence of subaerial exposure, karstification, and cave development

B-54

Figure 26. Van Krevelen diagram with hydrogen index vs. oxygen index 


\section{Part C: Geometry and evolution of detachment folds and thrust-truncated asymmetrical}

\section{folds in the eastern Brooks Range}

Figure 1. Simplified terrane map of northern Alaska, showing location of study area C-30

Figure 2. Map of western part of northeastern Brooks Range C-31

Figure 3a. Cross section across the northern part of the northeastern Brooks Range C-32

Figure 3b. Cross section across the Continental Divide thrust front C-33

Figure 4. Mechanical stratigraphy of the northeastern Brooks Range C-34

Figure 5. Surveys of detachment folds from the northeastern Brooks Range C-35

Figure 6a. Low-shortening detachment folds within lower Lisburne C-36

Figure 6b. Low-shortening detachment folds within upper Lisburne C-36

Figure 6c. Box-fold geometry in low- to intermediate-shortening detachment folds $\quad \mathrm{C}-37$

$\begin{array}{ll}\text { Figure 6d. Typical intermediate-shortening detachment folds } & \text { C-37 }\end{array}$

Figure 6e. Intermediate-shortening syncline in upper Lisburne C-38

Figure 6f. Low-shortening anticline in lower Lisburne $\quad$ C-38

Figure $6 \mathrm{~g}$. Anticline-syncline pair exposed from the Kayak to the upper Lisburne C-39

Figure 6h. High-shortening detachment fold $\quad$ C-39

Figure 6j. Recumbent detachment anticline $\quad$ C-40

Figure 7. Evolution of detachment folds in the northeastern Brooks Range C-41

Figure 8. Idealized geometry of intermediate-shortening detachment folds $\quad$ C-42

Figure 9. Idealized models for geometry and evolution of detachment folds $\quad$ C-42

Figure 10. Comparison of surveyed fold with different detachment fold models $\quad$ C-43

Figure 11. Comparison of surveyed fold with different detachment fold models $\quad$ C-44

Figure 12. Schematic stratigraphic column of Lisburne Group, Porcupine Lake area C-45

Figure 13. Asymmetrical folds surveyed using theodolite and laser rangefinder $\quad$ C-46

$\begin{array}{ll}\text { Figure 14a. Forelimb of asymmetrical anticline } & \text { C-48 }\end{array}$

Figure 14b. Truncated and displaced asymmetrical anticline $\quad$ C-48

Figure 14c. Truncated and displaced asymmetrical anticline $\quad$ C-49

Figure 14d. Truncated and displaced asymmetrical anticline with angular hinge $\quad$ C-49

Figure 14e. Anticline-syncline pair that is not cut by a thrust fault $\quad$ C-50

Figure 14f. Probable tri-shear fault-propagation fold $\quad$ C-50

Figure 14g. Footwall syncline of thrust-truncated asymmetrical anticline-syncline pair C-51

Figure 14h. Hangingwall anticline of thrust-truncated asymmetrical anticline-syncline

pair C-51

Figure 15. Idealized asymmetrical fold geometry in the Porcupine Lake area C-52

Figure 16. Serial cross sections south of Porcupine Lake C-53 
Figure 17. Idealized geometry of thrust-truncated asymmetrical fold $\quad$ C-55

Figure 18. Kinematic evolution of a thrust-truncated detachment fold $\quad$ C-56

Figure 19. Kinematic evolution of a thrust-truncated fault-propagation fold $\quad$ C-57

Figure 20. Evolution of a thrust-truncated asymmetrical fold $\quad$ C-58

\section{Part D: Implications of fracture distribution and character in detachment folds in the}

\section{Lisburne Group of northeastern Alaska}

Figure 1. Tectonic map of northern Alaska $\quad$ D-31

Figure 2. Detachment fold models $\quad$ D-32

Figure 3. Possible fold mechanisms active in detachment folds D-33

Figure 4. Example of temporal stress changes associated with migrating hinges $\quad$ D-34

Figure 5. Tectonic map of the western part of the northeastern Brooks Range D-35

Figure 6. Regional cross section across the northwestern part of the northeastern

$\begin{array}{ll}\text { Brooks Range } & \text { D-36 }\end{array}$

Figure 7. Generalized stratigraphy of the northeastern Brooks Range D-37

Figure 8. Conceptual relationship between folding mechanism, fracture development, $\begin{array}{ll}\text { depth of deformation, and amount of shortening } & \text { D-38 }\end{array}$

Figure 9. Depth/temperature/time graph showing possible burial and uplift path $\quad$ D-39

Figure 10. Univariant plots of observed fracture spacing vs. lithologic characteristics $\quad$ D-40

Figure 11a. Stratigraphic attributes and fracture density in lower Lisburne D-41

Figure 11b. Stratigraphic attributes and fracture density in upper Lisburne D-42

$\begin{array}{ll}\text { Figure 12a. Lower and middle Alapah fracture stratigraphy } & \text { D-43 }\end{array}$

$\begin{array}{ll}\text { Figure 12b. Upper Alapah fracture stratigraphy } & \text { D-44 }\end{array}$

Figure 13. Summary statistics of sets 3 and 4 fracture spacing vs. interlimb angle D-45

$\begin{array}{ll}\text { Figure 14. Schematic diagram of a fold-and-thrust belt } & \text { D-46 }\end{array}$

\section{Part E: Connectivity and wellbore placement in the Lisburne Group}

Figure 1. Results of Monte Carlo simulations on probability plots, NS fracture height E-12

Figure 2. L-moment plot for fracture height and spacing $\quad$ E-13

Figure 3. Jack-knifing simulation results shown on L-moment plot E-13

Figure 4. Probability plots for NS fracture spacing $\quad$ E-14

Figure 5. Probability plots for EW fracture height $\quad$ E-14

Figure 6. Probability plots for EW fracture spacing $\quad$ E-15

Figure 7. Fracman model of megafractures $\quad$ E-15

Figure 8. Fracman model showing only fracture traces $\quad$ E-16

Figure 9. Different cases simulated in Fracman software E-16 
Figure 10. Number of fractures contacted by the wellbore vs. matrix area accessed E-17

Figure 11. Orientations of wellbores used for the anisotropy analysis

Figure 12. Conductance vs. flow direction for the "base case" and six cases with variable relative transmissibility of the sets $\quad$ E-18

Figure 13. Orientations of wellbores used for the sensitivity study $\quad$ E-18

\section{Part F: Fracture timing and flow implications in folded Lisburne}

Figure 1. Geologic map of the northern part of the northeastern Brooks Range

Figure 2. Balanced cross section through the western part of the northeastern

Brooks Range

Figure 3. Fracture orientation for all fracture data

Figure 4. Fracture spacing vs. bed thickness for two orientations

Figure 5. Fracture spacing and interlimb angle for two orientations

Figure 6. Box plot of fracture spacing for two groups of interlimb angle

Figure 7. Box plot of fracture spacing for different interlimb angles and orientations

Figure 8. Box plot of fracture spacing for different interlimb angle and structural position

Figure 9. Fracture spacing for two orientations in limbs of different folds

Figure 10. Average conductance in EW and NS directions
F-10

F-11

F-12

F-12

F-13

F-13

F-14

F-14

F-15

\section{Part G: Relationship of fracture density and mechanical stratigraphy in folded Lisburne using neural nets}

Figure 1. Multilayer neural network

G-16

Figure 2. Neural network used for the fracture spacing study

G-16

Figure 3. Decrease in error during neural network training

Figure 4. Average fracture spacing: model vs. observed

Figure 5. Predicted NS fracture spacing vs. interlimb angle in fold hinge in Alapah

Figure 6. Predicted NS fracture spacing vs. interlimb angle in fold limb in Alapah

G-18

Figure 7. Predicted NS fracture spacing vs. interlimb angle in fold hinge in Wahoo

G-19

Figure 8. Predicted NS fracture spacing vs. interlimb angle in fold limb in Wahoo

G-19

Figure 9. Predicted EW fracture spacing vs. interlimb angle in fold limb in Wahoo

G-20

Figure 10. Predicted EW fracture spacing vs. interlimb angle in fold hinge in Wahoo

G-20

Figure 11. Predicted EW fracture spacing vs. interlimb angle in fold hinge in Alapah

Figure 12. Predicted EW fracture spacing vs. interlimb angle in fold limb in Alapah

Figure 13. Relative importance of bed thickness

G-22

Figure 14. Connection weight between bed thickness and first hidden node 


\section{List of tables}

Part B: Baseline stratigraphy of the Lisburne Group

Table 1. Lisburne Group lithofacies

B-10

Table 2. Age assignments for members of Lisburne Group formations

B-36

Table 3. Results of rock eval pyrolysis on calcareous shale, Marsh Fork area

B-64

Part C: Geometry and evolution of detachment folds and thrust-truncated asymmetrical folds in the eastern Brooks Range

Table 1. Characteristics of detachment folds of the northeastern Brooks Range

Table 2. Characteristics of asymmetrical folds of the Porcupine Lake area, central-eastern Brooks Range

Part D: Implications of fracture distribution and character in detachment folds in the Lisburne Group of northeastern Alaska

Table 1. Characteristics, orientation, and relative age of fracture sets $\quad$ D-47

$\begin{array}{ll}\text { Table 2. Results of fluid inclusion analyses } & \text { D-48 }\end{array}$

Table 3. Input parameters used for predictive fracture density models, figures $12 \mathrm{a}$ and $\mathrm{b}$ D-49

Part F: Fracture timing and flow implications in folded Lisburne

Table 1. Fracture spacing summary

Table 2. Fracture height summary

Table 3. Fracture length summary

Table 4. T test on mean fracture spacing

Table 5. KS test on fracture spacing

Table 6. Bootstrapped inference on median fracture spacing

Part G: Relationship of fracture density and mechanical stratigraphy in folded Lisburne using neural nets

Table 1. Fracture data used in neural network modeling

Table 2. Relative importance of the mechanical stratigraphic variables on fracture density from the neural network 


\title{
Executive Summary
}

\section{The influence of fold and fracture development on reservoir behavior of the Lisburne Group of northern Alaska}

\author{
Final report \\ Department of Energy Award DE-AC26-98BC15102 \\ Reporting period: September, 1998 to September, 2002
}

This is the final technical report on a study of the influence of folding and fracturing on the reservoir behavior of the Lisburne Group of northern Alaska. Project objectives included:

-Establish 'baseline' reservoir characteristics in a relatively undeformed section and develop fracture and fluid flow models and a wellbore placement strategy in such reservoir.

-Document the evolution of trap-scale fold geometry with increasing shortening, with emphasis on changes in thickness across the fold and with respect to mechanical stratigraphy.

- Characterize the differences between folds that continue to shorten by tightening vs. those that are cut by thrust faults as shortening increases.

-Determine patterns in reservoir enhancement and destruction within a fold trap as a function of mechanical stratigraphy and of position within folds at different stages of evolution.

-Use observations of natural folds to constrain predictive models for the evolution of trap-scale fold geometry with increasing shortening and for the resulting modifications of reservoir characteristics.

-Use observations of natural folds and predictive fold models as a basis for fracture models for fluid flow and wellbore placement strategies in fold traps.

This report summarizes data from field work during the summers of 1999-2001 and the resulting analyses and interpretations. The major results of the project include the following:

-Michael Whalen and a Ph.d. student conducted stratigraphic studies with a focus on the previously less studied Alapah and Wachsmuth Limestones of the Lisburne Group. Partial stratigraphic sections were measured, described, and analyzed in the northern (7) and southern (2) northeastern Brooks and in the Porcupine Lake area (9) of the central-eastern Brooks Range. Three subsurface drill cores, five subsurface gamma ray logs, and one composite surface gamma ray log were also analyzed. Results included identification and correlation of16 lithofacies, four parasequence types, and six sequences.

-Wes Wallace and two Master's students conducted structural studies to characterize and compare symmetrical detachment folds and thrust-truncated asymmetrical folds. Detachment folds in the northeastern Brooks Range were studied in detail in five different areas and elsewhere in reconnaissance. Six selected folds were surveyed using laser rangefinder. Fold flattening progressively succeeds initial growth by flexural slip in detachment folds of the northeastern Brooks Range. Thrust-truncated asymmetrical folds in the Porcupine Lake area were studied in detail in two different areas and elsewhere in reconnaissance. Eight selected folds were surveyed using laser rangefinder and theodolite. Thrust breakthrough succeeds initial growth by flexural slip in asymmetrical folds of the Porcupine Lake area. Displacement of the truncated fold and folding of the thrust require significant modification of the fold geometry.

-C.L. Hanks and two Master's students conducted studies of fractures in both symmetrical detachment folds and thrust-truncated asymmetrical folds. The focus was on the influence that mechanical stratigraphy and position within folds has on fracturing. Fractures were studied in detail in several folds of each type. Statistical analysis of outcrop surveys of fractures revealed that fracturing is controlled by a complex variety of factors. The fractures observed in outcrop formed by a variety of mechanisms before, during, and after folding, and early-formed fractures may later be filled or annealed, particularly during fold flattening. 
-Jerry Jensen, a Master's student and a Ph.d. student studied the influence of fractures on fluid flow behavior in both non-folded and folded Lisburne carbonates. Statistical analysis and modeling of fracture populations in non-folded Lisburne reveal complex relations among number, area, and connectivity of fractures and optimal wellbore trajectory depending on orientation, interaction, and termination of fractures. Statistical analysis of fracture populations in detachment folds indicates that the most obvious and open fractures formed late during and after folding. These fractures have little or no relation to folding, but have orientations similar to some earlier sets of fractures. This emphasizes the importance of assigning fractures to the correct genetic set in order to attain the best possible wellbore placement and productivity and recovery estimates. Use of a neural network to investigate relations between fracture spacing and mechanical stratigraphy indicate that bed thickness has the greatest effect on fracture density, followed by fold interlimb angle and lithology. 


\section{Introduction and geologic setting}

by Wesley K. Wallace, Geophysical Institute and Department of Geology and Geophysics, University of Alaska, Fairbanks, Alaska 99775-5780

\section{Definition of problem and objectives}

Carbonate rocks of the Carboniferous Lisburne Group are found throughout a vast region of northern Alaska, including the subsurface of the North Slope and the northern Brooks Range. The Lisburne is a major hydrocarbon reservoir in the North Slope: It was the original target at Prudhoe Bay and is the reservoir currently producing in the Lisburne oil field. Folded and thrust-faulted Lisburne has been a past exploration target in the foothills of the Brooks Range, and is becoming increasingly important as interest grows in exploration for gas. It also is an important potential future target for oil and gas exploration in the coastal plain of the Arctic National Wildlife Refuge (1002 area). However, relatively little is known about the reservoir characteristics and behavior of the Lisburne and how they change as a result of deformation.

As in many carbonate reservoirs, most of the hydrocarbon production from the Lisburne Group is from naturally occurring fractures. Natural fractures play an essential role in production from the reservoir, but the geologic factors that control the origin, distribution, and character of these fractures are poorly understood. In the Lisburne oil field, less than $10 \%$ of the 2 billion barrels in place is recoverable at the present time. A clearer understanding of the nature and origin of these fractures has the potential to aid in the development of secondary and tertiary recovery programs for a reservoir that is large but difficult to produce.

Likely targets for exploration in the Lisburne are along the northern edge of the Brooks Range orogen, where the Lisburne has been modified by fold-and-thrust deformation. Such deformation has long been recognized both to enhance porosity and permeability, largely through the formation of fractures, and to reduce them by the formation of cleavage and stylolites during compression. However, the ability to predict patterns of enhancement or reduction in porosity and permeability and how they vary within a particular fold trap remain quite limited. Recent rapid advances in the understanding of the geometry and kinematics of different types of folds that form in fold-andthrust settings offer great potential to improve the systematic understanding of enhancement or reduction in porosity and permeability in fold traps, but these advances have only begun to be applied.

The Lisburne Group is a structurally competent unit that overlies an incompetent unit. Hence, the Lisburne undergoes a progressive evolution from its undeformed state to tightening detachment folds as shortening increases. In the latest stages of shortening, detachment folds either continue to tighten or are truncated by thrust faults, depending on whether they are symmetrical or asymmetrical. How trap geometry and reservoir characteristics vary as this evolution progresses is not systematically understood, particularly with respect to differences in lithology and position within a fold. The basic objective of this study is to document and develop predictive models for structurally induced changes in reservoir geometry and characteristics at different stages in the evolution of detachment folds in the Lisburne Group.

Extensive exposures of the Lisburne Group in the northeastern Brooks Range fold-and-thrust belt offer the opportunity to develop a clearer understanding of the origin, distribution, and character of structurally induced enhancement and reduction of porosity and permeability in the Lisburne Group. Detachment folds in the Lisburne Group have evolved to different degrees, and thus provide a series of natural experiments in which to observe those structures and to develop models both for their formation and for the resulting patterns of enhancement and reduction of porosity and permeability. The results of these field-based observations and models can then be used to develop quantitative models for characterization of Lisburne reservoirs and the fluid flow within them. Such 
models can be applied to a spectrum of traps from relatively undeformed to highly folded and thrust faulted.

This study of the Lisburne Group has the following major objectives:

-Establish 'baseline' reservoir characteristics in a relatively undeformed section and develop fracture and fluid flow models and a wellbore placement strategy in such reservoir.

-Document the evolution of trap-scale fold geometry with increasing shortening, with emphasis on changes in thickness across the fold and with respect to mechanical stratigraphy.

- Characterize the differences between folds that continue to shorten by tightening vs. those that are cut by thrust faults as shortening increases.

-Determine patterns in reservoir enhancement and destruction within a fold trap as a function of mechanical stratigraphy and of position within folds at different stages of evolution.

-Use observations of natural folds to constrain predictive models for the evolution of trap-scale fold geometry with increasing shortening and for the resulting modifications of reservoir characteristics.

- Use observations of natural folds and predictive fold models as a basis for fracture models for fluid flow and wellbore placement strategies in fold traps.

The results of this study will apply to current production in relatively undeformed Lisburne and to future exploration in deformed Lisburne. The results also will apply generally to carbonate reservoirs and to folded reservoirs, both of which are major producers and exploration targets worldwide.

\section{Scope of this report}

This report summarizes results of the project's three seasons of field work, which were conducted during the summers of 1999 to 2001 . The report presents field and laboratory observations, data compilation and analysis, and interpretations.

Contributors to this report include five Master's students (P.K. Atkinson, J. Brinton, M.A. Jadamec, A.V. Karpov, and J.R. Shackleton ), two Ph.D. students (T.D. Bui and M.M. McGee), three University of Alaska faculty (W.K. Wallace, C.L. Hanks, and M.T. Whalen), and one Texas A \& M faculty (J.L. Jensen). Two researchers from other organizations also contributed (J. Lorenz and T.M. Parris).

The report includes seven chapters that each summarize a different aspect of the study and are written by different authors. These are:

-A. Introduction and geologic setting, by W.K. Wallace

-B. Baseline stratigraphy of the Lisburne Group, by M.M. McGee and M.T. Whalen

-C. Geometry and evolution of detachment folds and thrust-truncated asymmetrical folds in the eastern Brooks Range, by W.K. Wallace, P.K. Atkinson, M.A. Jadamec, J.R. Shackleton, and C.L. Hanks

-D. Implications of fracture distribution and character in detachment folds in the Lisburne Group of northeastern Alaska, by C.L. Hanks, J.R. Shackleton, J. Brinton, J. Jensen, T. Bui, A. Karpov, T. Parris, and J. Lorenz

-E. Connectivity and wellbore placement in the Lisburne Group, by A.V. Karpov, J. L. Jensen, and C. L. Hanks

-F. Fracture timing and flow implications in folded Lisburne, by T.D. Bui, J.L. Jensen, J. Brinton, and C. L. Hanks

-G. Relationship of fracture density and mechanical stratigraphy in folded Lisburne using neural nets, by T.D. Bui, J.L. Jensen, J. Brinton, and C. L. Hanks

A final chapter presents a summary and conclusions. 


\section{Geologic Setting}

The Lisburne Group is the most abundant and widely distributed rock unit in the northern Brooks Range, where it forms the range front in most places and extends a significant distance southward into the range. This rock unit displays two distinct structural styles in different parts of the northern Brooks Range. Imbricately stacked thrust sheets characterize the Lisburne south of the range front in the western and central Brooks Range and south of the projection of that range front into the eastern Brooks Range. These thrust sheets commonly display asymmetrical hangingwall anticlines and footwall synclines, but asymmetrical folds that have not been cut by thrust faults are very rare. In contrast, symmetrical detachment folds that are only rarely cut by thrust faults characterize the northeastern Brooks Range. The "Continental Divide thrust front" marks the boundary between these two structural styles (Figures 1 and 2) (Wallace and Hanks, 1990; Wallace, 1993).

Folds both north and south of the Continental Divide thrust front formed in the competent Mississippian to Pennsylvanian Lisburne Limestone above the incompetent Mississippian Kayak Shale. The Lisburne lies beneath another incompetent unit that consists dominantly of shale and sandstone, the Permian to Triassic Sadlerochit Group.

In the northeastern Brooks Range north of the Continental Divide thrust front, the Kayak forms the roof thrust for a duplex of horses formed in the underlying basement rocks (Wallace and Hanks, 1990; Wallace, 1993). In the western part of the northeastern Brooks Range, individual fault-bend anticlines are separated by synclines because thrust faults are spaced farther apart than their displacement. These fault-bend folds are an order of magnitude larger than the upright and symmetrical detachment folds within the cover and are superimposed on the overlying cover to form anticlinoria and synclinoria (Figures 1 and 2). The detachment folds in the synclinoria generally reflect the greatest shortening, although significant shortening has also occurred over some anticlinoria. A general decrease in detachment fold shortening is evident to the north, approaching the range front, but shortening still displays considerable local variation.

By contrast, south-dipping imbricate thrust sheets dominate the structural style south of the Continental Divide thrust front (Figures 1 and 2). Asymmetrical hangingwall anticlines and footwall synclines commonly characterize the leading and trailing edges, respectively, of these thrust sheets. These folds are interpreted to be asymmetrical detachment folds that have been broken through by thrust faults (Wallace, 1993; Wallace et al., 1997; Wallace and Homza, in press). This interpretation is based on an apparent transition from the detachment folds of the northeastern Brooks Range and the local preservation of unbroken detachment folds south of the boundary. The change in structural style across the Continental Divide thrust front coincides with the dramatic southward thickening of a Middle Devonian to Lower Mississippian clastic succession beneath the Kayak Shale and the disappearance of basement-cored anticlinoria as a major influence on the structure of the cover.

A regional structural low in the Porcupine Lake area (Figures 1 and 2) provides a particularly good location to study rocks and structures that span the Continental Divide thrust front. Thrusttruncated asymmetrical folds are especially well exposed along a local range front that bounds the structural low to the south. This local range front likely represents an eastward remnant of the range front that formed along the northern edge of the main axis of the Brooks Range during Paleocene time. The range front was preserved along the southern edge of the Porcupine Lake structural low following Eocene and later formation of the northeastern Brooks Range to the north. 


\section{References}

Imm, T.A., Dillon, J.T., and Bakke, A.A., 1993, Generalized geologic map of the Arctic National Wildlife Refuge, northeastern Brooks Range, Alaska: Alaska Division of Geological and Geophysical Surveys Special Report 42, scale 1:500,000, 1 sheet.

Wallace, W.K., 1993, Detachment folds and a passive-roof duplex: Examples from the northeastern Brooks Range, Alaska, in Solie, D.N., and Tannian, F., eds., Short Notes on Alaskan Geology 1993: Alaska Division of Geological and Geophysical Surveys Geologic Report 113, p. 81-99.

Wallace, W.K., and Hanks, C.L., 1990, Structural provinces of the northeastern Brooks Range, Arctic National Wildlife Refuge, Alaska: American Association of Petroleum Geologists Bulletin, v. 74, no. 7, p. 1100-1118.

Wallace, W.K., and Homza, T.X., in press, Detachment folds, their truncation by thrust faults, and their distinction from fault-propagation folds, in McClay, K.R., editor, Thrust tectonics and petroleum systems: American Association of Petroleum Geologists Memoir.

Wallace, W.K., Moore, T.E., and Plafker, G., 1997, Multistory duplexes with forward dipping roofs, north central Brooks Range, Alaska: Journal of Geophysical Research, v. 102, no. B9, p. 20,773-20,796. 
Mississippian Kayak Shale,

Carboniferous Lisburne Limestone \&

Triassic Sadlerochit/Siksikpuk

7GM pre-Mississippian metasedimentary rocks

pM \& Mississippian Kekiktuk conglomerate

Middle Devonian to Mississippian clastic rocks

Pror

Devonian to Mississippian Kanayut Conglomerate \&

MDK locally overlying Mississippian Kayak Shale \& Carboniferous Lisburne Limestone

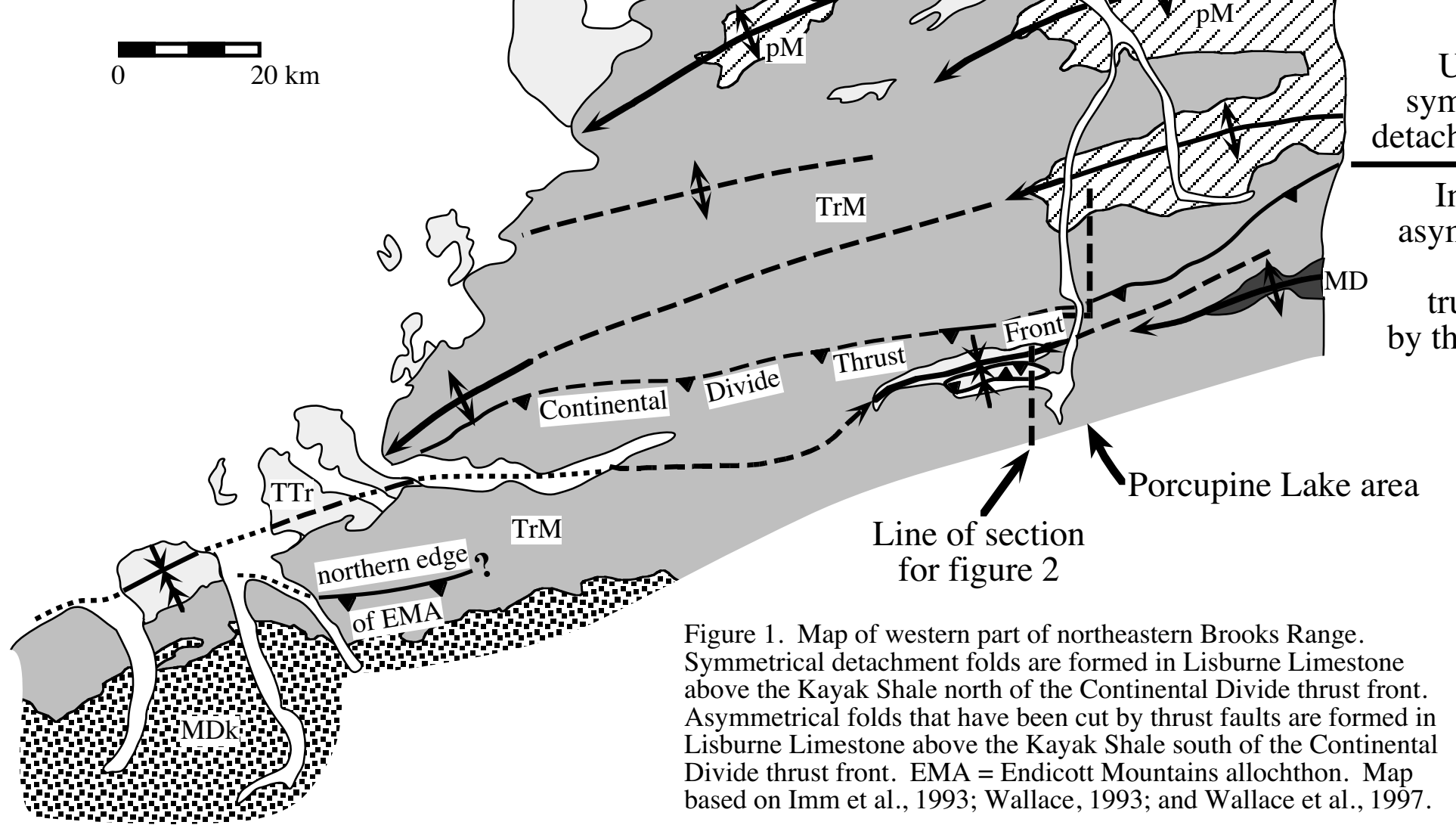

Upright symmetrical detachment folds

Inclined asymmetrical folds

truncated by thrust faults 

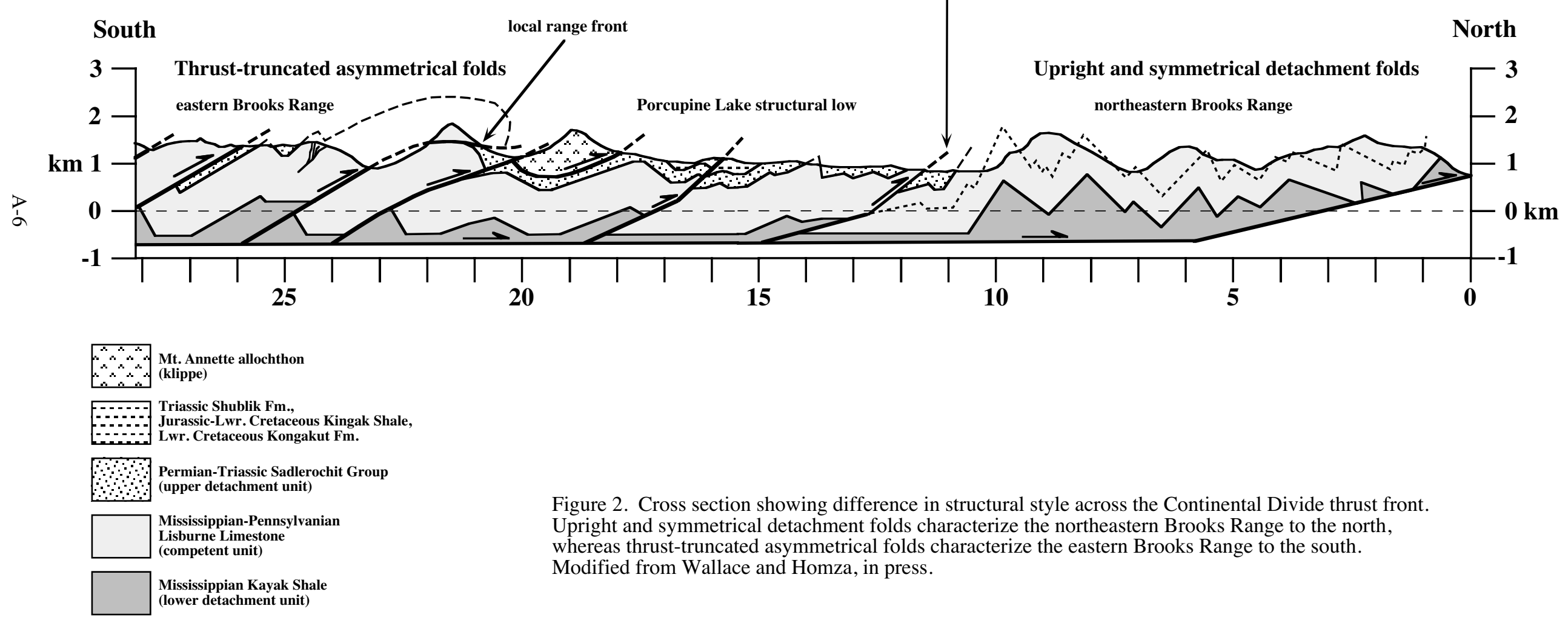

Figure 2. Cross section showing difference in structural style across the Continental Divide thrust front. Upright and symmetrical detachment folds characterize the northeastern Brooks Range to the north, whereas thrust-truncated asymmetrical folds characterize the eastern Brooks Range to the south. Modified from Wallace and Homza, in press. 


\title{
Baseline stratigraphy of the Lisburne Group
}

By Michael T. Whalen and Michelle M. McGee, Geophysical Institute and Department of Geology and Geophysics, University of Alaska, Fairbanks, Alaska 99775-5780

\begin{abstract}
The Lisburne Group represents a laterally extensive carbonate ramp that was deposited during the middle Carboniferous (middle Mississippian to middle Pennsylvanian). In this study we focused on two separate field areas, the northeastern Brooks Range in the north and the centraleastern Brooks Range to the south as well as analysis of subsurface drill core and gamma ray logs. The Lisburne gradationally overlies relatively fine-grained rocks of Kayak Shale, the uppermost unit in the Endicott Group or rests disconformably over pre-Mississippian Rocks. Locally, in the Sadlerochit Mountains and the North Slope subsurface the Lisburne is underlain by siliciclastic-rich and carbonate rocks of the Itkilyariak Formation. The Lisburne consists of the Wachsmuth, Alapah, and Wahoo Limestones. The former two units were the focus of the field portion of this project. The Wahoo Limestone was examined in outcrop but no detailed data were collected except from the subsurface. Both the Wachsmuth and the Alapah are subdivided into three members. The Wachsmuth is made up of the crinoidal limestone, middle, and banded limestone members. The Alapah is subdivided into lower, middle, and upper members. Stratigraphic relationships between the major field study areas are quite complex with the Wachsmuth Limestone mainly occurring in the central-eastern Brooks Range and partly in the southernmost northeastern Brooks Range. The Alapah is much thicker in the south and the three members in the north are almost entirely represented, chronostratigraphically, by the upper Alapah in the south. Like the Wachsmuth, the lower and middle Alapah have no temporal equivalents to the north except in the southernmost northeastern Brooks Range.
\end{abstract}

Detailed facies analysis during this study was mainly confined to rocks of the central-eastern Brooks Range. Here we define 16 facies within the Wachsmuth and Alapah Limestones. Facies were deposited dominantly in middle to outer ramp environments that include settings ranging from open marine settings both below and above fairweather wavebase on the outer ramp, shoal and near-shoal environments and open and restricted platform environments on the middle ramp. Facies are commonly stacked in either non-cyclic or cyclic packages. Cyclic packages or parasequences, are bounded by flooding surfaces that signify significant changes in relative sea level, and shallow upward recording a relative fall in sea level. Four different types parasequences were identified in the central eastern Brooks Range that usually record deposition in open marine environments near fairweather wave base that shallow upward to shoal or open or restricted platform environments. Open marine facies are typically skeletal wackestones and packstones with some chert, shoal facies consist of skeletal packstones, grainstones, and locally rudstones, and platform facies are dominated by skeletal and peloidal wackestones and packstones with more cherty facies indicating restricted platform environments. Parasequences in the northeastern Brooks Range are significantly different due to the more proximal paleogeographic setting and usually contain shoal, open and restricted platform, and intertidal or supratidal facies with evidence of subaerial exposure. 
Analysis of three subsurface drill cores and five subsurface gamma ray logs and one composite outcrop gamma ray log provide criteria for subsurface stratigraphic subdivisions and correlation between the outcrops in the Brooks Range and the North Slope subsurface. This along with outcrop stratigraphic data, information on facies stacking patterns, and biostratigraphy provides criteria for the identification of depositional sequences and associated systems tracts. We have subdivided the Lisburne Group into 6 depositional sequences. Sequences 1 and 2 are entirely within the Wachsmuth Limestone and only lap as far north as the southernmost northeastern Brooks Range. Sequence 3 is represented by the uppermost Wachsmuth and the lower and middle Alapah and is the first package to onlap into the northern northeastern Brooks Range where it is represented by a very thin shallow water succession in the lowermost Alapah. Sequence 4 is represented by the Upper Alapah in the central-eastern Brooks Range and the entire remainder of the Alapah in the northeastern Brooks Range. Sequences 5 and 6 are roughly equivalent to the lower and Upper Wahoo Limestones respectively and are preserved only in the northeastern Brooks Range and the adjacent subsurface. If they were ever deposited to the south they were subsequently eroded.

The mechanical stratigraphy of the Lisburne Group is reflected in part by large scale outcrop weathering patterns. In the central-eastern Brooks Range the Wachsmuth crinoidal limestone member is generally incompetent, the Wachsmuth middle $(\sim 130 \mathrm{~m})$ and banded limestone $(\sim 140 \mathrm{~m})$ members and lower and upper Alapah are mechanically competent, and the middle Alapah is comparable to or slightly less competent than the Wachsmuth crinoidal limestone. In the northeastern Brooks Range the lower Alapah is relatively incompetent but becomes increasingly more competent in the upper $25 \mathrm{~m}$ of the unit. The middle Alapah is less competent than the lower or upper Alapah which in general is mechanically competent.

The Lisburne Group in most of the field area is a poor reservoir rock with very low porosities. Permeability was never measured but the low porosities probably indicate low permeability as well. Fracturing of the Lisburne likely enhances both porosity and permeability but the occurrence of many shale-based parasequences, that would serve as barriers to flow, further reduces the reservoir potential. Some thin dolomitized intervals within the Alapah in the subsurface are oil stained and might be reservoir intervals. Rock eval analyses on organic rich shales interbedded with Lisburne carbonates in the central-eastern Brooks Range imply that some of these could have been source rocks, albeit fair to poor, gas prone source rocks.

\section{Introduction}

The goals of this phase of the research project were to establish a "baseline" for Lisburne stratigraphy and reservoir characteristics in relatively undeformed rocks. These goals were met through a multi-phase approach including collection of high-resolution lithostratigraphic, petrographic, mineralogic, and X-ray diffraction data, outcrop spectral gamma ray profiles and comparable subsurface geophysical logs. Analysis of this data permitted recognition of lithologic variations such as those recorded in shale-based cycles or parasequences (Jameson, 1994; Watts and others, 1995) that helped in identifying genetic packages that act as reservoirs, reservoir partitions and as important mechanical units. These data and interpretations in conjunction with seismic-scale outcrop and outcrop-to-subsurface cross sections aid in the identification of larger- 


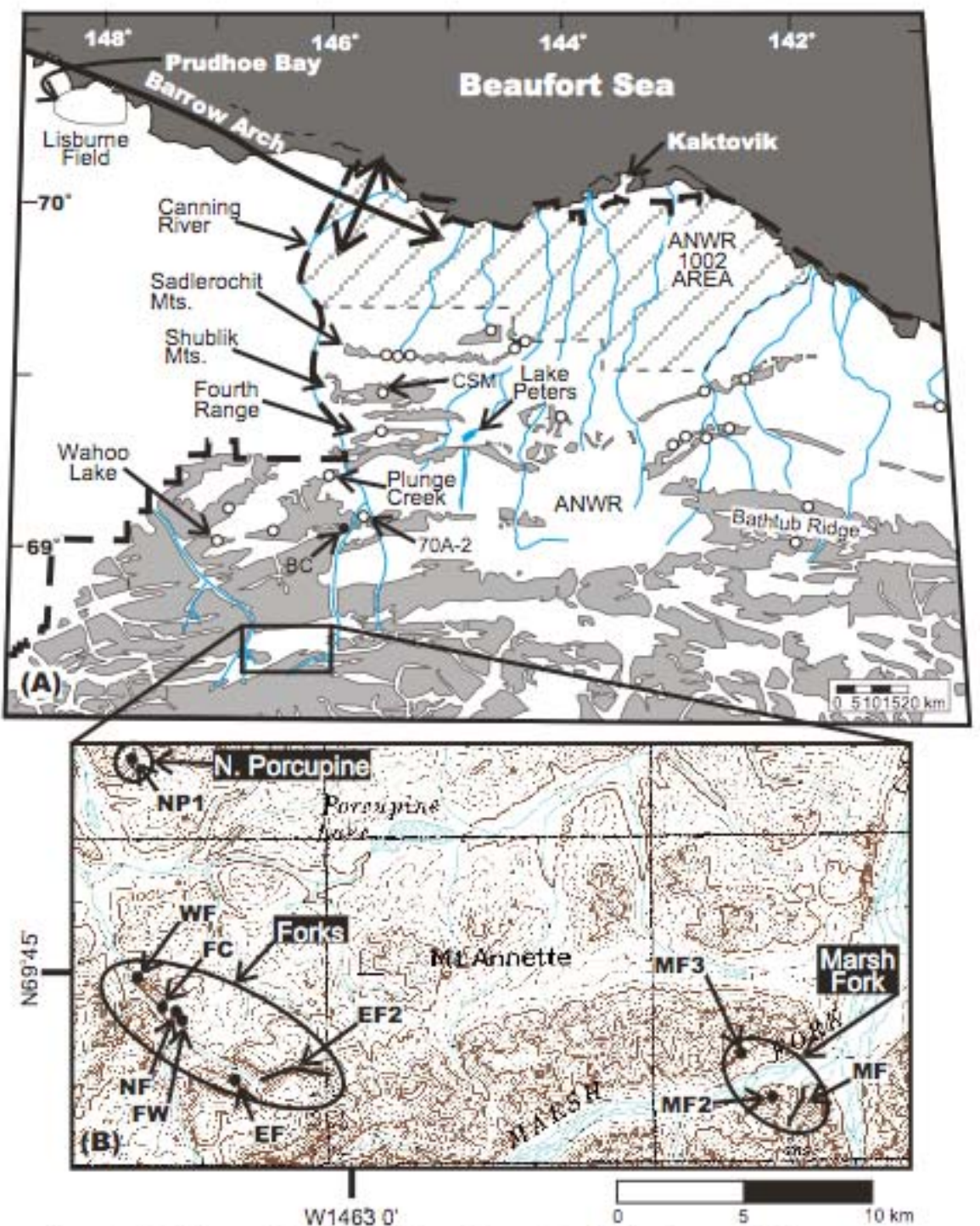

Figure 1. A) Outcrops of the Lisburne Group in the eastern Brooks Range and their relationship to Prudhoe Bay and Lisburne Field, the Arctic National Wildlife Refuge (east of heavy dashed line) and coastal plain (cross-hashed arca). White circles indicate sections measured by previous workers (Mamet and Armstrong, 1972, 70A-2; Carlson 1987; Gruzlovic, 1991,CSM, Fourth Range, Plunge Creek; Krumhardt, 1992; Eckstein, 1994; Carlson, 1995; Watts et al,, 1995). Black circles represent measured sections from this study. Modified from Watts et al, 1995. B) Topographic map illustrating the central-eastern Brooks Range field areas (open ovals) and the locations of measured stratigraphic sections (black dots and lines).

scale depositional sequences, the boundaries of which may be related to subaerial exposure surfaces or other stratal discontinuities with reservoir or mechanical significance. 
The project began by collecting data from previously studied sections in the northeastern Brooks Range but then moved south to the central-eastern Brooks Range where the stratigraphy is more poorly understood (Figure 1). The relationship between the Lisburne Group exposed in the central-eastern Brooks Range to that in the northeastern Brooks Range was largely untested prior to this study but considerable progress has been made in deciphering the depositional history of the more distal rocks in the central-eastern Brooks Range and their stratigraphic correlation with the Lisburne Group exposed further to the north.

\section{General Stratigraphy}

Previous workers (Brosgé et al., 1962; Armstrong and Mamet, 1972) had noted the similarity between the Carboniferous stratigraphy of the Marsh Fork area and the Lisburne Group exposed in the central Brooks Range. Due to a lack of surface exposures north of the central Brook Range the best area to determine the stratigraphic relationship between these distal, and potentially allochthonous, rocks and more proximal parautochthonous rocks is where exposures are available along a north-south transect from the northeastern Brooks Range and the central eastern Brooks Range.

In the northeastern Brooks Range the Lisburne Group either rests conformably above the Kayak Shale or Itkiliariak Formation or sits unconformably atop a pre-Mississippian unconformity (Figure 2; Mull and Mangus, 1972; Armstrong and Mamet, 1974; Bird and Jordan, 1977; Watts et al., 1995). The Lisburne Group here consists of the dominantly late Mississippian Alapah Limestone and early Pennsylvanian Wahoo Limestone. The Alapah is subdivided into three members and the Wahoo into two (Figure 2; Watts et al., 1995).

Watts et al. (1995) subdivide the Alapah Limestone in the northeastern Brooks Range into a lower member with "algal" (i.e. microbial) limestone and cross-bedded skeletal grainstone ("Egaksrak grainstone"), a middle member consisting of bryozoan-pelmatozoan limestone, and an upper member characterized by spiculitic dolomite and lime mudstone (Figure 2). Jamison et al., (1980) consolidated the Alapah into two informal members in the subsurface at Prudhoe Bay (a lower sandy carbonate interval and an upper dolomitic unit). Jameson (1994) recognized three informal members somewhat similar to the outcrop subdivision and these were further subdivided into five zones (A-E). The last two of these zones (D\&E) are actually correlative with the lower Wahoo in outcrop exposures. Substantially high oil flow rates were tested in the Alapah Formation during development drilling of the Lisburne Group (Jameson, 1994). Some production from dolomites in the Alapah exists (Schafer, pers. comm.), but extensive development has not yet occurred because of difficulty in delineating the Alapah reservoirs.

The Wahoo Limestone conformably overlies the Alapah Limestone in the northeastern Brooks Range and was first described by Brosgé et al. (1962) at Wahoo Lake (Figure 1). The AlapahWahoo Limestone boundary in outcrop is placed at the last of the dark-colored, recessive weathering Alapah Limestone and the start of the light-colored slope and ledge forming lower Wahoo Limestone (Watts et al., 1995). This slope and ledge forming unit is thus equivalent to 


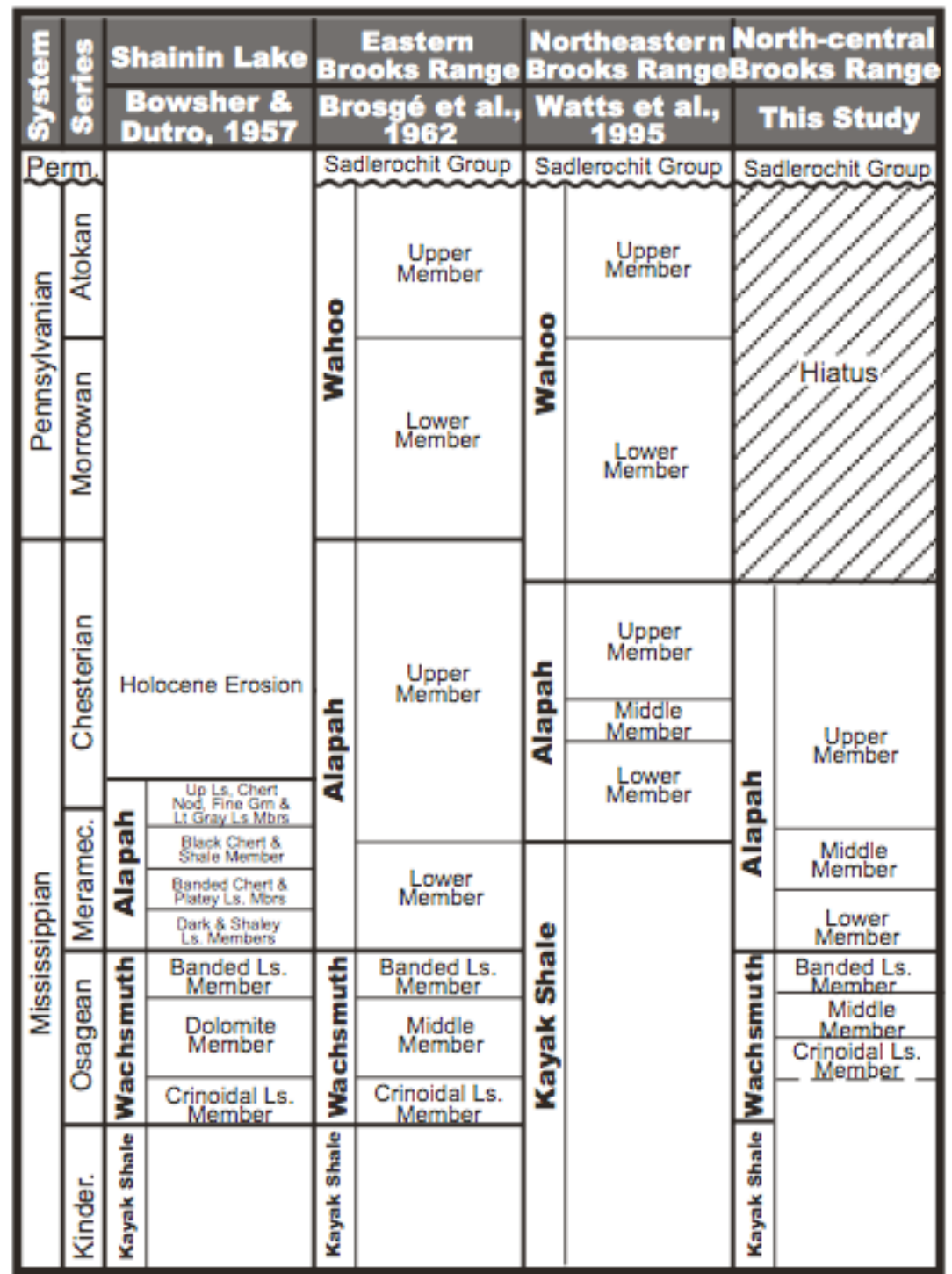

Figure.2. Stratigraphic nomenclature of the Lisburne Group including the Wachsmuth type section at Shainin Lake (Bowsher and Dutro, 1957), eastern Brooks Range (BrosgJ et al., 1962), northeastern Brooks Range (Watts et al., 1995), and central-easternl Brooks Range (this study). Note the variation in Alapah Formation member stratigraphy especially between the northeastern and central-eastern Brooks Range (see text). Age assignments reflect new data from this study.

the uppermost Alapah zones D and E in the subsurface where the boundary between the units is placed at a distinctive green shale at the Mississippian-Pennsylvanian boundary (Jameson, 1994). Watts et al. (1995) subdivide the Wahoo Limestone in the northeastern Brooks Range into an uppermost Mississippian to Pennsylvanian slope and ledge forming lower member and a Pennsylvanian cliffy upper member with high frequency shoaling-upward cycles (Figure 2) that is similar to the upper Wahoo at Prudhoe Bay (Jameson; 1994). The Wahoo Limestone ranges in thickness from 200 to $>300 \mathrm{~m}$. No age-equivalent Lisburne Group was documented in the central-eastern Brooks Range during this study. The Wahoo Limestone in the northeastern Brooks Range is unconformably overlain by the conglomerates, sandstones and siltstones of the 
Permian Echooka Formation, Sadlerochit Group (Figure 2). Reservoir zonation in the Wahoo is defined by 8-15 $\mathrm{m}$ thick shoaling-upward cycles that grade from a skeletal-rich shaly base into burrowed skeletal packstone and well-sorted grainstone (Jameson, 1994). Shaly intervals have a distinctive log character and have been correlated throughout the Lisburne field (Jameson, 1994). Outcrop cycles are similar to those recorded in the subsurface but the shaly base, which is seldom exposed, has only been documented in a few sections in the northeastern Brooks Range (Jameson, 1994; Watts and others, 1995; Hanks and others, 1997).

The stratigraphy of the Marsh Fork area and the central-eastern Brooks Range in general consists of the early to middle Mississippian Wachsmuth Limestone and middle to late Mississippian Alapah Limestone (Brosgé et al., 1962; this study). Each unit can be subdivided into three informal members. The lithostratigraphy, member subdivision, and facies stacking patterns of these units is described in detail below. Lithostratigraphic correlation of the Alapah stratigraphy is complicated by variations in mechanical stratigraphy between proximal (northeastern Brooks Range) and distal (central-eastern Brooks Range) sections and temporal correlation was hindered by the poor recovery of biostratigraphically useful conodonts and forams. Our stratigraphic analysis; however, has improved our understanding of the relationship between the stratigraphy of the northeastern Brooks Range and the central-eastern Brooks Range which will be the main focus of this chapter.

\section{Methods and Database}

High-resolution lithostratigraphic data were collected from six partial stratigraphic sections of the Lisburne Group in the northeastern Brooks Range and from eleven partial sections in the central-eastern Brooks Range. Data collection was mainly in the previously less-studied Alapah and Wachsmuth limestones, although part of the lower Wahoo Limestone was also examined in outcrop.

Stratigraphic sections were measured using a tape and/or Jacob's staff. Sections were described at centimeter scale and sampled at approximately meter intervals for petrographic and x-ray diffraction analysis. High-resolution stratigraphic data collected included: general mineralogic composition (limestone/dolostone), grain size, fossils, sedimentary structures, macroscopic porosity and fracturing, bed thickness and geometry, and other post-depositional fabrics that will help define mechanically important horizons and other Lisburne reservoir characteristics. Both conodont and foram biostratigraphic data was collected to aid in temporal correlations. One 3-8 $\mathrm{kg}$ conodont sample was collected every 40-80 meters for biostratigraphy. Conodont samples (60) were processed according to the standard procedures (Stone, 1987). Samples were crushed to approximately $1 \mathrm{~cm}$ in diameter and then placed in a 5\% acetic acid bath. The samples were routinely washed through nested Tyler no. 20 and 140 screens to remove mud and concentrate the insoluble residue. The conodont elements were separated from the residue using sodium polytungstate set at a specific gravity of 2.85. The conodont elements were hand picked and identified by Andrea Krumhardt at the University of Alaska, Fairbanks. Foraminifera, in thin section, were analyzed by Paul Brenckle, biostratigraphic consultant, for age determination.

Outcrop spectral gamma ray profiles were acquired through seven partial measured stratigraphic sections in the northeastern Brooks Range. Comparable industry data are available from well 
borings from the Lisburne field in Prudhoe Bay. Five subsurface gamma ray logs and a composite log from the northeastern Brooks Range are presented here to aid in correlation. Unfortunately the lack of continuous exposure in the central-eastern Brooks Range precluded collection of useful gamma ray data. Gamma ray profiles aid in the identification of stratal surfaces such as parasequence and sequence boundaries and assist in the accurate correlation from outcrop to the subsurface. Identification of argillaceous or shaly intervals in outcrop is important not only in defining the bases of parasequences but also in identifying relatively impermeable zones or incompetent horizons that separate more mechanically competent lithologic units. Shaly intervals at the bases of genetic packages are commonly poorly exposed in outcrop, but outcrop gamma ray data have successfully identified some of these horizons.

Identification of lithofacies is based on outcrop descriptions and the examination of 775 thin sections. Mineralogy of the samples was determined through x-ray diffraction analysis of 1117 samples on a computer controlled Rigaku Geigerflex x-ray diffractometer, set at $30 \mathrm{kV}$ and 25 $\mathrm{mA}$, running DataScan v.3.1 software. Relative percentages of calcite and dolomite were determined from peak area analysis of the main calcite and dolomite peaks using Jade $\mathrm{v} 3.0$ software.

\section{Lisburne Group Lithofacies}

Individual lithofacies (Table 1) described below are classified according to the scheme of Dunham (1962) as modified by Embry and Klovan (1972). Detailed facies descriptions, associations, and stacking patterns for the Lisburne Group in the northeastern Brooks Range and adjacent subsurface are available in the literature (Carlson, 1987; 1995: Gruzlovic, 1991; Jameson, 1994; Watts et al., 1995). This section will concentrate on facies analysis of rocks exposed in the central-eastern Brooks Range.

\section{Dolostone (Facies 1)}

Rocks containing $>50 \%$ dolomite relative to calcite are considered dolostones and are grouped into this diagenetic facies if the dolomite is nonmimetic and the original depositional texture cannot be inferred. In those dolomitized samples where the original texture can be surmised they are grouped with the appropriate sedimentary facies. Overall, dolostones are rare in the centraleastern Brooks Range when compared with sections in the northeastern Brooks Range described by Carlson (1987; 1995), Gruzlovic (1991), and Watts et al. (1995).

Both fine and coarsely crystalline nonmimetic dolostones occur (Figure 3). Finely crystalline dolostone (average crystal size $<30 \mathrm{~m}$ ) is found only in the Alapah Limestone and also includes white calcite nodules with irregular boundaries ranging in size between $0.25 \mathrm{~cm}$ and 4 $\mathrm{cm}$ in diameter. Coarsely crystalline dolostone (average crystal size $>30 \mathrm{~m}$ ), appears to replace skeletal-peloid pack/grainstone and skeletal grain/rudstone in the Wachsmuth banded limestone member and lower Alapah member. Dolostones typically display hydrocarbon stain or occlusion of intercrystalline porosity. 

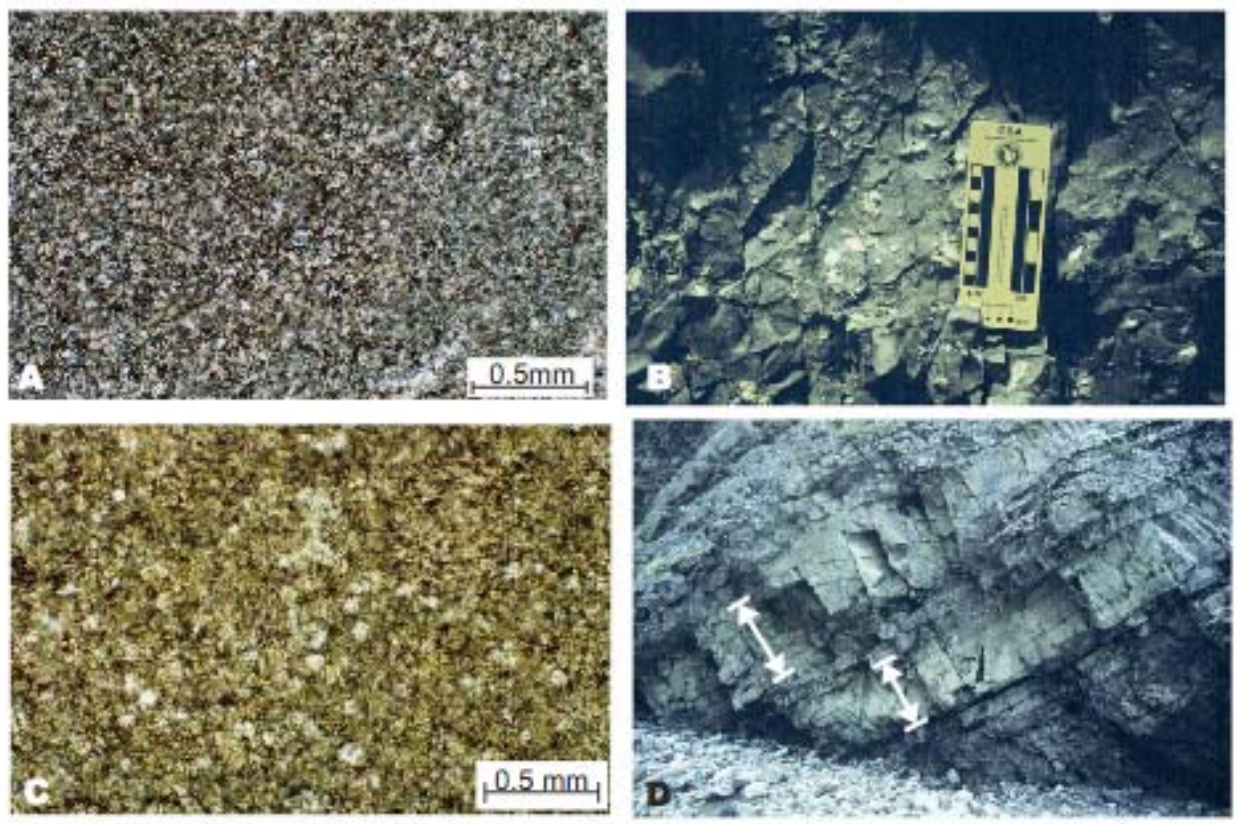

Figure 3. Facies 1 (crystalline dolostone). A) Photomicrograph illustrating a relatively uniform finely crystalline dolostone at the top of the middle Alapah. B) Field photograph of small white calcite andules in a matrix of finely crystalline dolomitized mud fepresented in A.

Calcite nodules range in size from a few $\mathrm{mm}$ to several $\mathrm{cm}$ in diameter and have irregular jagged boundaries. C) Photomictograph of coarsely erystalline dolostone replacing skeletal grain/ rudstone near the in the Wachsmuth banded limestone member. D) Field photograph of dolomitized skeletal grainstone/rudstone (arrows) represented in (C). Individual grains/ rudstone beds (arrows) are approximately $10-20 \mathrm{~cm}$ thick and occur in meter-thick packages.

\section{Wackestone/Banded Black Chert (Facies 2)}

Dark-gray wackestone "interbedded" with banded black chert is the distinguishing characteristic of this facies (Figure 4). The couplets of wackestone and banded chert are generally 10 to $25 \mathrm{~cm}$ thick. Individual chert beds display uniform thickness and can be traced the entire length of the outcrop. The faunal components observed in the wackestone are relatively sparse and consist of undifferentiated skeletal fragments, crinoids, fenestrate bryozoans, sponge spicules, and ostracods (Figure 4). Peloids are the dominate component of the wackestone. Skeletal molds of crinoids, sponge spicules, and rare forams are observed in the chert and are typically occluded with "dead" hydrocarbons. Dolomitized limestone is common and phosphate in fenestrate bryozoan zooecia is rare. Wackestone/banded black chert occurs only in the Wachsmuth middle member and is associated with skeletal wacke/packstone, coral pack/grainstone, peloid-coralbrachiopod wacke/packstone, and coarsens-up into skeletal-peloid pack/grainstone. Wackestone/banded chert is not observed in section MF3.

\section{Peloid-Calcisphere Wacke/Packstone (Facies 3)}

This facies consists of medium- to dark-gray recessive wackestones and packstones that coarsenup from thin platy lime mudstone bases. Beds range in thickness from 0.25 to $0.5 \mathrm{~m}$ and have a 


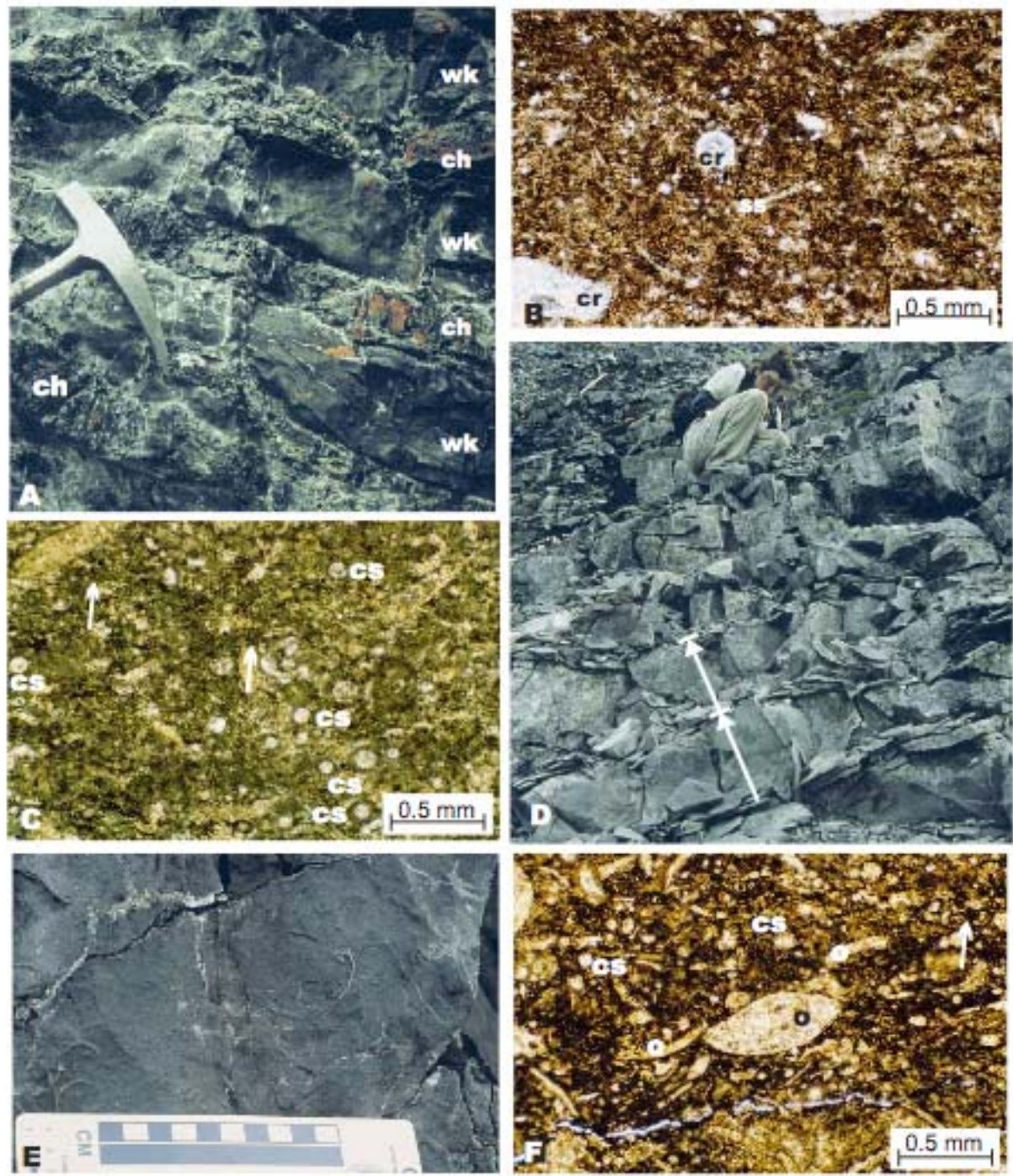

Figure 4. Facies 2 (Wackestone/banded chert), 3 (Peloid ealcisphere wacke/packstone), and 4 (Peloid brachiopod calcisphere ostracod wacke(packstone). A) Field photograph of wackestone (wk)/ banded chert (ch) couplets at the base of the Wachsmuth middle member. Chert is black, highly fractured and has a uniform thickness that ean be traced laterally many meters. B) Photomicrograph of Facies 2 illustrating Ssonge spicules (ss), crinoids (cr), and unidentifiable skeletal fragments in a mud matrix. C) Photomicrograph of Facies 3 illustrating ealcispheres (es) and peloids (arrows) in a mud matrix. D) Outerop photograph of Facies 3 illustrating the thin packages of wacke/packstone (arrows)that are separated by flaggy mud/wackestone. E. Outerop photograph of Facies 4 illustrating large thin-shelled brachiopods. F. Photomicrograph of Facies 4 illustrating ostracods (o), calcispheres (cs), and peloids (arrows).

stair-step weathering appearance in the field (Figure 4). Peloids, calcispheres, crinoids, fenestrate bryozoans, undifferentiated bioclasts and shells, and ostracods are abundant constituents (Figure 4) and sponge spicules, forams, and brachiopods are minor. Gastropods are rare to absent. Pyrite and black nodular and lenticular chert are common. "Dead" hydrocarbons commonly stain the outcrop and are observed occluding intergranular porosity and rarely along microfractures.

This facies is found almost exclusively in the middle Alapah member with rare occurrences in the lower-most upper Alapah member. Peloid-calcisphere wacke/packstone generally occurs 


\begin{tabular}{|c|c|c|c|}
\hline FACIES & $\begin{array}{c}\text { DIAGENTIC } \\
\text { FEATURES/ } \\
\text { SEDIMENTARY } \\
\text { STRUCTURES }\end{array}$ & $\begin{array}{l}\text { SKELETAL/NON- } \\
\text { SKELETAL GRAINS }\end{array}$ & $\begin{array}{l}\text { DEPOSITIONAL } \\
\text { ENVIRONMENT }\end{array}$ \\
\hline 1. Dolostone & Recrystallization & $\begin{array}{l}\text { Crinoids, bryozoans, peloids, } \\
\text { shell frags., sponge spicules, } \\
\text { ostracods }\end{array}$ & Diagenetic \\
\hline $\begin{array}{l}\text { 2. Wackestone/Banded } \\
\text { Black Chert }\end{array}$ & $\begin{array}{l}\text { Banded black chert, } \\
\text { minor dolomite }\end{array}$ & $\begin{array}{l}\text { Crinoids, peloids, fenestrate } \\
\text { bryozoans, shell frags., sponge } \\
\text { spicules, ostracods }\end{array}$ & Open Platform \\
\hline $\begin{array}{l}\text { 3. Peloid-Calcisphere } \\
\text { Wacke/Packstone }\end{array}$ & $\begin{array}{l}\text { Nodular black chert, } \\
\text { coarsening-up beds }\end{array}$ & $\begin{array}{l}\text { Peloids, calcispheres, crinoids, } \\
\text { fenestrate bryozoans, skeletal } \\
\text { and shell fragments, ostracods, } \\
\text { minor sponge spicules and } \\
\text { forams }\end{array}$ & Open Platform \\
\hline $\begin{array}{l}\text { 4. Peloid-Brachiopod- } \\
\text { Calcisphere-Ostracod } \\
\text { Wacke/Packstone }\end{array}$ & $\begin{array}{l}\text { Coarsening-up beds, } \\
\text { brachiopods occur in } \\
\text { bed tops }\end{array}$ & $\begin{array}{l}\text { Peloids, brachiopods, } \\
\text { calcispheres, ostracods, crinoids, } \\
\text { fenestrate bryozoans, minor } \\
\text { forams and sponge spicules }\end{array}$ & Open Platform \\
\hline $\begin{array}{l}\text { 5. Skeletal-Peloid } \\
\text { Pack/Grainstone }\end{array}$ & Micritization & $\begin{array}{l}\text { Peloids, skeletal frags., } \\
\text { fenestrate bryozoans, crinoids, } \\
\text { minor ostracods }\end{array}$ & Shoal to Near Shoal \\
\hline $\begin{array}{l}\text { 6. Skeletal Grain/ } \\
\text { Rudstone }\end{array}$ & $\begin{array}{l}\text { Syntaxial overgrowth } \\
\text { cement, rare planar- } \\
\text { and cross-laminations }\end{array}$ & $\begin{array}{l}\text { Crinoids, fenestrate bryozoans, } \\
\text { skeletal frags., minor forams, } \\
\text { solitary rugose corals, } \\
\text { brachiopods }\end{array}$ & Shoal to Near Shoal \\
\hline $\begin{array}{l}\text { 7. Peloid Pack/ } \\
\text { Grainstone }\end{array}$ & $\begin{array}{l}\text { Abundant black chert } \\
\text { nodules, rare planar } \\
\text { laminations }\end{array}$ & $\begin{array}{l}\text { Peloids, crinoids, bryozoans, and } \\
\text { minor solitary rugose corals, } \\
\text { ostracods, sponge spicules }\end{array}$ & $\begin{array}{l}\text { Open Marine - Above } \\
\text { Fair-Weather Wave } \\
\text { Base }\end{array}$ \\
\hline $\begin{array}{l}\text { 8. Peloid-Coral- } \\
\text { Brachiopod Wacke/ } \\
\text { Packstone }\end{array}$ & $\begin{array}{l}\text { Abundant black chert } \\
\text { nodules, rare } \\
\text { phosphate in } \\
\text { bryozoan zooecia, } \\
\text { rare planar } \\
\text { laminations } \\
\end{array}$ & $\begin{array}{l}\text { Peloids, colonial corals, solitary } \\
\text { rugose corals, brachiopods, } \\
\text { crinoids, skeletal frags., } \\
\text { ostracods }\end{array}$ & $\begin{array}{l}\text { Open Marine - At or } \\
\text { Above Fair-Weather } \\
\text { Wave Base }\end{array}$ \\
\hline 9. Coral Pack/Grainstone & $\begin{array}{l}\text { Rare nodular to } \\
\text { lenticular black chert }\end{array}$ & $\begin{array}{l}\text { Colonial corals, solitary rugose } \\
\text { corals, peloids, fenestrate } \\
\text { bryozoans, crinoids, ostracods, } \\
\text { skeletal frags., minor } \\
\text { brachiopods, rare gastropods, } \\
\text { sponge spicules, forams, ramose } \\
\text { bryozoans, calcispheres }\end{array}$ & $\begin{array}{l}\text { Open Marine - Below } \\
\text { to Above Fair-Weather } \\
\text { Wave Base }\end{array}$ \\
\hline $\begin{array}{l}\text { 10. Brachiopod } \\
\text { Pack/Grainstone }\end{array}$ & $\begin{array}{l}\text { Rare black chert } \\
\text { nodules }\end{array}$ & $\begin{array}{l}\text { Brachiopods, crinoids, skeletal } \\
\text { frags., minor colonial corals, } \\
\text { calcispheres, ostracods }\end{array}$ & $\begin{array}{l}\text { Open Marine - Below } \\
\text { to Above Fair-Weather } \\
\text { Wave Base }\end{array}$ \\
\hline $\begin{array}{l}\text { 11. Solitary Rugose Coral } \\
\text { Wacke/ Packstone }\end{array}$ & $\begin{array}{l}\text { Minor banded black } \\
\text { chert, dolomite }\end{array}$ & $\begin{array}{l}\text { Solitary rugose corals, crinoids, } \\
\text { skeletal frags., crinoids, } \\
\text { fenestrate bryozoans, peloids, } \\
\text { minor forams brachiopods, } \\
\text { ramose bryozoans }\end{array}$ & $\begin{array}{l}\text { Open Marine - At or } \\
\text { Below Fair-Weather } \\
\text { Wave Base }\end{array}$ \\
\hline
\end{tabular}

Table 1. Lisburne Group Lithofacies 


\begin{tabular}{|l|l|l|l|}
\hline $\begin{array}{l}\text { 12. Peloid-Skeletal } \\
\text { Wacke/Packstone }\end{array}$ & Black Chert Nodules & $\begin{array}{l}\text { Peloids, skeletal frags., sponge } \\
\text { spicules, ostracods, crinoids, } \\
\text { forams, fenestrate bryozoans, } \\
\text { minor solitary rugose corals }\end{array}$ & $\begin{array}{l}\text { Open Marine - At or } \\
\text { Below Fair-Weather } \\
\text { Wave Base }\end{array}$ \\
\hline $\begin{array}{l}\text { 13. Skeletal Wacke/ } \\
\text { Packstone }\end{array}$ & $\begin{array}{l}\text { Rare black chert } \\
\text { nodules, rare normal } \\
\text { graded beds }\end{array}$ & $\begin{array}{l}\text { Skeletal frags., crinoids, } \\
\text { fenestrate bryozoans, rare } \\
\text { forams }\end{array}$ & $\begin{array}{l}\text { Open Marine - At or } \\
\text { Below Fair-Weather } \\
\text { Wave Base }\end{array}$ \\
\hline $\begin{array}{l}\text { 14. Foram Wacke/ } \\
\text { Packstone }\end{array}$ & $\begin{array}{l}\text { Abundant nodular } \\
\text { black chert, minor } \\
\text { banded black chert }\end{array}$ & $\begin{array}{l}\text { Forams, peloids, skeletal frags., } \\
\text { ostracods, minor sponge } \\
\text { spicules, crinoids, fenestrate } \\
\text { bryozoans }\end{array}$ & $\begin{array}{l}\text { Open Marine - Below } \\
\text { Fase }\end{array}$ \\
\hline $\begin{array}{l}\text { 15. Crinoid-Solitary } \\
\text { Rugose Coral Floatstone }\end{array}$ & $\begin{array}{l}\text { Erosive base, fine- } \\
\text { upward }\end{array}$ & $\begin{array}{l}\text { Crinoids, solitary rugose corals, } \\
\text { forams, ostracods, brachiopods, } \\
\text { skeletal frags. }\end{array}$ & $\begin{array}{l}\text { Open Marine - At } \\
\text { Storm Wave Base }\end{array}$ \\
\hline $\begin{array}{l}\text { 16. Mudstone and } \\
\text { Calcareous Shale }\end{array}$ & $\begin{array}{l}\text { Black nodular to } \\
\text { lenticular chert, } \\
\text { planar laminations }\end{array}$ & $\begin{array}{l}\text { Rare crinoids, fenestrate } \\
\text { bryozoans, forams, brachiopods }\end{array}$ & $\begin{array}{l}\text { Open Marine - Below } \\
\text { Storm Wave Base }\end{array}$ \\
\hline
\end{tabular}

Table 1, continued. Lisburne Group Lithofacies

above platy lime mudstone bases and commonly coarsens-up into peloid-brachiopodcalcisphere-ostracod wacke/packstone.

\section{Peloid-Brachiopod-Calcisphere-Ostracod Wacke/Packstone (Facies 4)}

These limestones are medium- to dark-gray with abundant peloids, brachiopods, calcispheres, ostracods, crinoids, and fenestrate bryozoans (Figure 4). Minor to rare forams, sponge spicules, gastropods, and solitary rugose corals are also observed. This facies occurs at the top of 0.25 to $0.5 \mathrm{~m}$ thick recessive beds that coarsen-upward from platey lime mudstone to peloid-calcisphere wacke/packstone in section WF. The brachiopods are articulated near the base of the beds, become disarticulated, and then fragmented at the tops of the beds (Figure 4). Hydrocarbon staining is observed in outcrop and occluding intergranular porosity and rarely microfractures in thin section. This facies occurs only in the Alapah lagoonal facies, where it caps beds that coarsen-up from platey lime mudstone and peloid-calcisphere wacke/packstone.

\section{$\underline{\text { Skeletal-Peloid Pack/Grainstone (Facies 5) }}$}

Resistant light- to medium-gray limestone with peloids, undifferentiated bioclasts, fenestrate bryozoans, crinoids, minor ostracods, and rare sponge spicules are typical of this facies (Figure 5). Beds are 1 to $2 \mathrm{~m}$ thick and are extensively bioturbated. Peloids have varying sizes and shapes and do not appear to be compacted. Diagenetic features include minor dolomite, pyrite, and phosphate in fenestrate bryozoan zooecia. Black nodular to lenticular chert is also a minor diagenetic component of this facies. In thin section, rare authigenic albite is observed near the top of the Wachsmuth banded limestone member .

Skeletal-peloid pack/grainstone is relatively rare in the middle Wachsmuth, but when it does occur it is underlain by either skeletal wacke/packstone or wackestone/banded chert. In the Wachsmuth banded limestone member, skeletal-peloid pack/grainstone occurs at the top of beds 
that coarsen-up from peloid-skeletal wacke/packstone and coral wacke/packstone/ grainstone. Within the lower Alapah skeletal-peloid pack/grainstone commonly occurs at the tops of beds that coarsen-up from skeletal wacke/packstone, calcareous shale, peloid packstone/ grainstone or coral pack/grainstone. Most intervals above and below the skeletal-peloid pack/grainstone facies in the middle Alapah lagoonal. In rare instances where there is no cover, this facies coarsens-up from either coral pack/grainstone or skeletal wacke/packstone. Skeletal-peloid pack/grainstone is most abundant in the upper Alapah, where it is either interbedded with skeletal grain/rudstone or coarsens-up from skeletal wacke/packstone, peloid-skeletal wacke/packstone, brachiopod wacke/packstone/ grainstone, or peloid pack/grainstone.

\title{
$\underline{\text { Skeletal Grain/rudstone (Facies 6) }}$
}

This facies weathers light yellowish-gray and is composed of coarse, slightly abraded undifferentiated bioclasts, crinoids with syntaxial overgrowths, fenestrate bryozoans and ostracods. Rare brachiopods, shell fragments, and gastropods are also observed. In thin section, fenestrate bryozoans, ostracods, and forams are often micritized and/or pyritized (Figure 6).
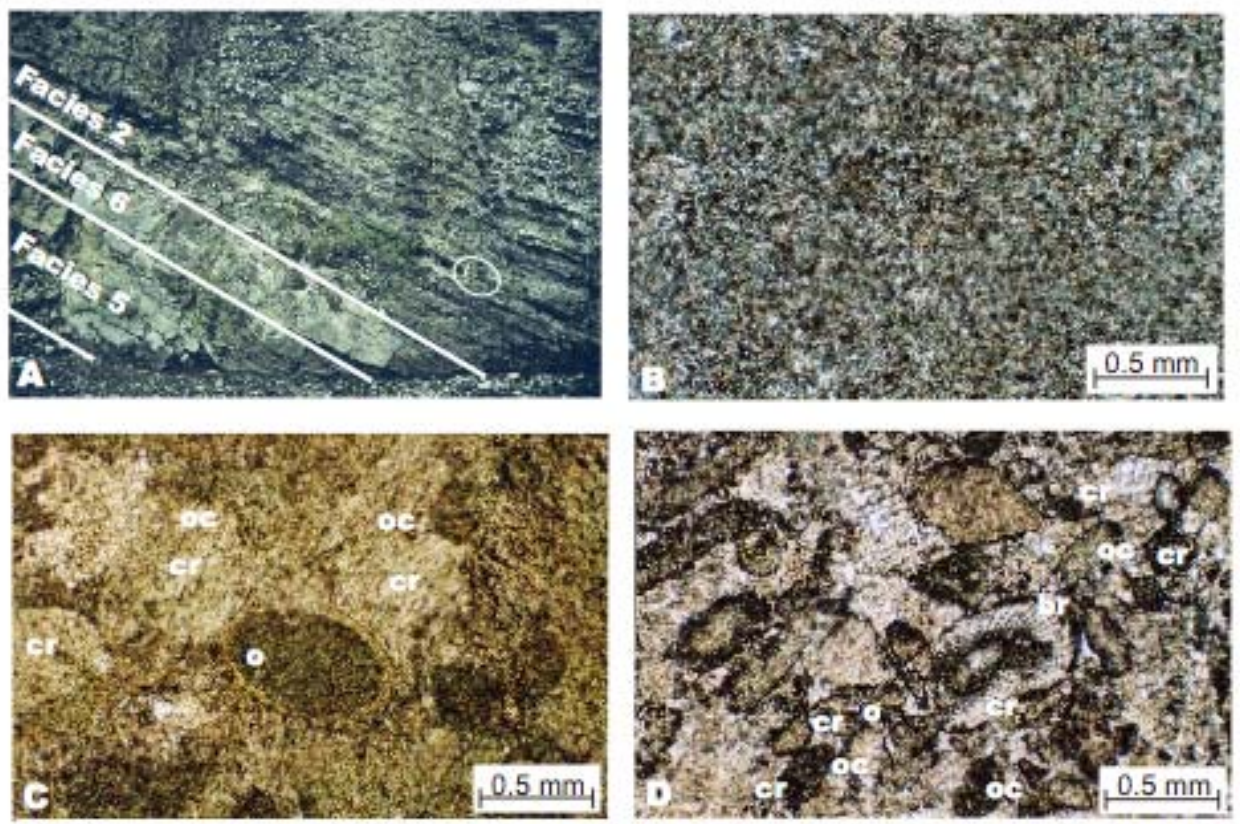

\begin{abstract}
Figure 5. Facies 5 and 6 (Skeletal-peloid pack/grainstone and Skeletal grain/rudstone). A) Outcrop photogrph of Facies 5 and 6 from the base of the Wachsmuth middle member Crinoids are the dominate grain type in the field. Hammer, for scale, is circled. B) Peloids and fine-grained skeletal debris with minof calciet cement. C. Skeletal grainstone with crinoids (cr), ostracods (o), and syntaxial overgrowth cement (oc) that occurs near the base of the Wachsmuth banded limestone member. D) Bioclastic grainstone near the top of the Wachsmuth banded limestone member illustrating crinoids (cr) with syntaxial overgrowth eement (oc), fenestrate bryozoans (br), and ostracods (o). Bryozoans are typically pyritized, whereas ostracod shells are micritized and rarely pyritized.
\end{abstract}

Skeletal grain/rudstone occurs in 1-2 m thick beds with minor planar laminations at the tops and/or bases of the beds (Figure 6). Rudstones are typically brittle from solution cleavage and have minor hydrocarbon staining. Diagenetic features include pyrite, minor dolomite, and rare phosphate in the zooecia of fenestrate bryozoans. 
In the Wachsmuth middle and banded limestone members, skeletal grain/rudstone occurs at the top of beds that coarsen-up from peloid-skeletal pack/grainstone, calcareous shale, foram wacke/packstone, skeletal wacke/packstone, skeletal-peloid pack/grainstone, or coral pack/grainstone. Skeletal grain/rudstone is also observed at the top of coarsening-upward beds in the lower Alapah, where it coarsens-up from skeletal wacke/packstone or skeletal-peloid pack/grainstone. In the upper Alapah it occurs as 1 to $5 \mathrm{~m}$ thick beds that coarsen-upward from either skeletal-peloid pack/grainstone, peloid-skeletal wacke/packstone, skeletal wacke/packstone, brachiopod pack/grainstone, or peloid pack/grainstone.

\title{
$\underline{\text { Peloid Pack/grainstone (Facies 7) }}$
}

Abundant peloids characterize this medium- to dark gray limestone (Figure 6). Other constituents include crinoids and fenestrate bryozoans, and minor solitary rugose corals, ostracods, and sponge spicules. Calcispheres and forams are rare. Peloids have varying sizes and are irregularly shaped. Beds are commonly $\geq 1 \mathrm{~m}$ thick and have rare planar laminations.

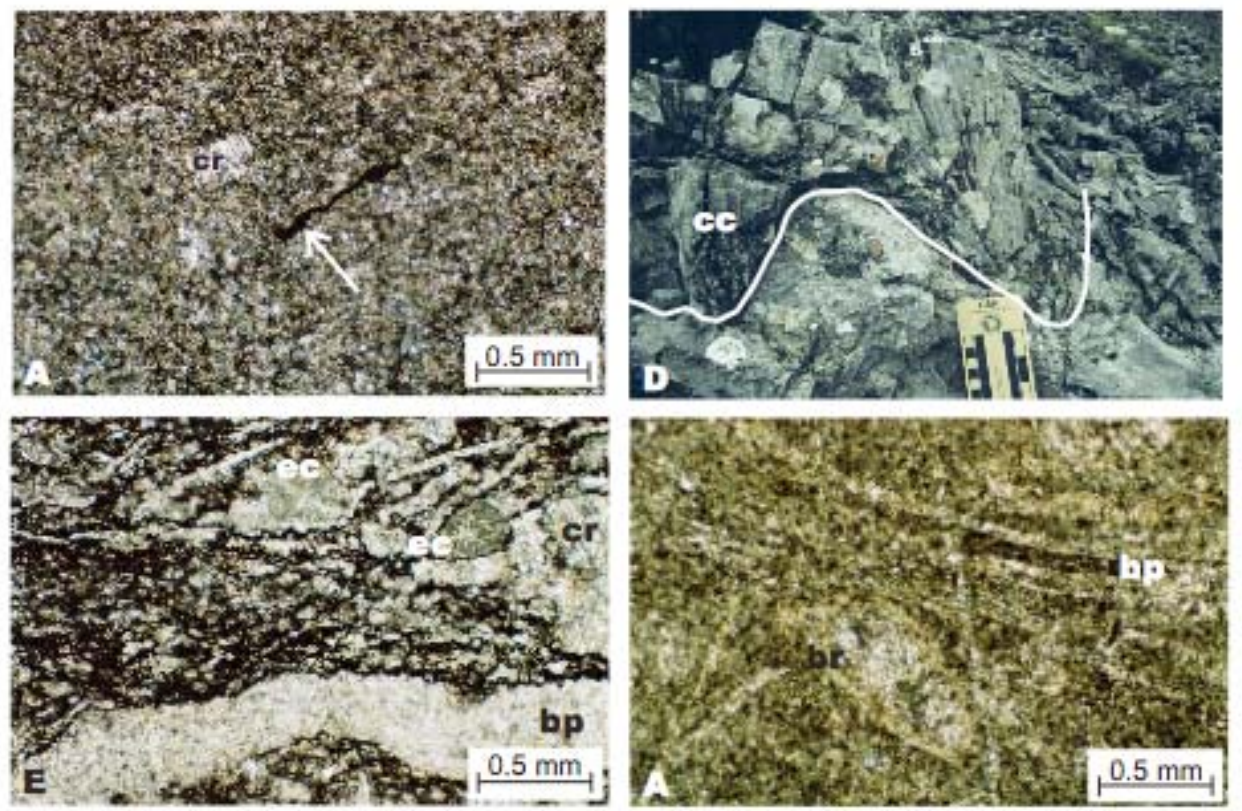

\begin{abstract}
Figure 6. Facies 7 (peloid packstone/grainstone). and 8 (peloid-coral-brachiopod wacke/packstone). A) Photomicrograph of Facies 7 with peloids occuring in a variety of sizes and rafe crinoids (cr). Hydrocarbons are observed in the moldic (?) porosity (arrow). B) Outerop photograph of Facies 8 illustrating colonial rugose corals (cc) in growth position. C\&D) Photomicrographs of Facies 8 illustrating brachiopods (bp), erinoids ( $\mathrm{er}$ ) and other echinoderm debris in a mud matrix within the Alapah lower member.
\end{abstract}

Diagenetic features include minor pyrite, dolomite, and rare phosphate in fenestrate bryozoan zooecia. In the field, black chert nodules are abundant. Hydrocarbon staining is common in the Wachsmuth banded limestone member and the middle Alapah, minor in the middle Wachsmuth, and rare in the upper Alapah. Most "dead" oil occludes intergranular porosity in thin section.

Peloid pack/grainstone is most common in the upper Alapah where it occurs at the top of beds that coarsen-up from skeletal wacke/packstone and at the base of beds that coarsen-up into 
skeletal-peloid pack/grainstone and/or skeletal grain/rudstone. Peloid packstone/ grainstone in the middle Wachsmuth occurs at the top of beds that coarsen-upward from foram wacke/packstone, peloid-skeletal wacke/packstone, and/or coral wacke/packstone. In the middle Alapah peloid pack/grainstone occurs at the top of beds that coarsen-upward from peloidbrachiopod-calcisphere-ostracod wacke/packstone and it coarsens-up into skeletal-peloid pack/grainstone or skeletal grain/rudstone.

\section{Peloid-Coral-Brachiopod Wacke/packstone (Facies 8)}

This limestone is medium to dark gray with beds ranging in thickness between 0.25 and $0.75 \mathrm{~m}$. Colonial corals, solitary rugose corals, brachiopods, crinoids, fenestrate bryozoans, and undifferentiated skeletal fragments are abundant in outcrop, whereas ostracods, peloids, and rare forams, ramose bryozoans, and calcispheres are abundant in thin section (Figure 7). Solitary rugose corals are found as small fragments and brachiopods are usually articulated.

Syringoporid, lithostrotionoid, and colonial rugose corals occur as small fragments and in growth position. This facies is extensively bioturbated.

Diagenetic features include abundant black chert nodules and minor banded black chert and dolomite, and rare phosphate in fenestrate bryozoan zooecia and pyrite. Minor hydrocarbon staining is observed in the middle Wachsmuth and lower Alapah.

Peloid-coral-brachiopod wacke/packstone is associated with crinoid-solitary rugose coral floatstone in the Wachsmuth crinoidal limestone member, wackestone/banded chert in the middle Wachsmuth and coral pack/grainstone, brachiopod pack/grainstone, and peloid-skeletal wacke/packstone in the Wachsmuth banded limestone member. In the lower Alapah this facies is commonly underlain by calcareous shale and coarsens-up into skeletal-peloid pack/grainstone. It is absent in the middle Alapah but is associated with peloid-calcisphere wacke/packstone, skeletal-peloid pack/grainstone, peloid pack/grainstone, and peloid-skeletal wacke/packstone in the upper Alapah.

\section{Coral Pack/grainstone (Facies 9)}

Abundance of solitary rugose and colonial corals in a medium- to dark-gray limestone are the distinguishing characteristics of this facies. The corals are associated with abundant peloids, and a diverse fauna including crinoids, fenestrate bryozoans, forams, ostracods, sponge spicules, and undifferentiated skeletal fragments (Figure 7). Solitary rugose corals are typically found in small fragments and colonial corals are found in growth position and as fragments of all sizes and orientations. Coral fragments and rare planar laminations generally occur at the tops of coarsening-upward beds that are 0.25 to $1 \mathrm{~m}$ thick. Dolomite, pyrite, and rare phosphate in fenestrate bryozoan zooecia are also observed. Hydrocarbon staining is minor in the Wachsmuth Limestone.

Lithostrotionoid and syringoporid colonial corals are abundant in the Wachsmuth middle and banded limestone members. Their abundance significantly decreases near the top of the Wachsmuth and they disappear altogether in the lower-most Alapah. Colonial rugose corals start 
to appear near the top of the Wachsmuth banded limestone member, become the dominate colonial coral in the lower Alapah, and drastically decrease and ultimately disappear in the middle Alapah.

This facies is commonly associated with calcareous shale bases, wackestone/banded chert, skeletal wacke/packstone, and peloid pack/grainstone in the middle Wachsmuth and skeletal wacke/packstone in the Wachsmuth banded limestone member. In the lower Alapah this facies is associated with skeletal wacke/packstone but is rare to absent in the middle and upper Alapah..

\section{Brachiopod Pack/grainstone (Facies 10)}

Abundance of brachiopods in a medium- to dark-gray colored limestone is the distinguishing characteristic of this facies. Some brachiopods are articulated but most are disarticulated. Other constituents include peloids, crinoids and undifferentiated bioclasts, and minor colonial corals, calcispheres, and ostracods (Figure 8). Sponge spicules, gastropods, and fenestrate bryozoans are rare. Beds are between 0.5 and $1 \mathrm{~m}$ thick with rare graded beds and planar- and crosslaminations. Diagenetic features include minor dolostone, pyrite, nodular to lenticular black chert, and phosphate. Minor hydrocarbon staining is observed in the Wachsmuth middle and banded limestone members and the lower Alapah.
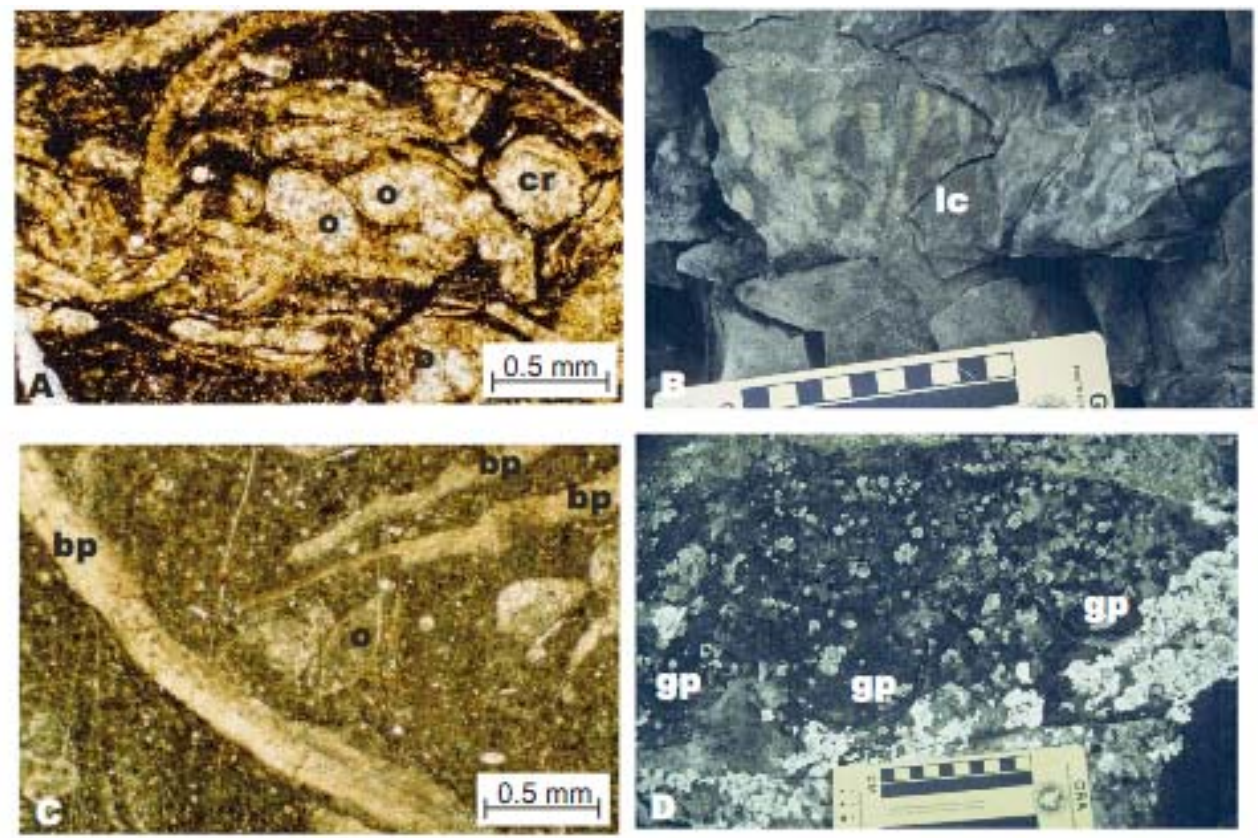

\footnotetext{
Figure 7. Facies 9 (Coral wacke/packstone) and 10 (brachiopod wacke/packstone). A) Photomicrograph of Facies 9 with ostracods (o) and crinoids (cr) in a mud matrix associated with rugose corals in the Wachsmuth banded limestone member. B) Lithostrotionoid coral (lc) in growth position within the lower Alapah. C) Photonictograph of Facies 10 illustrating brachiopod shell fragments (bp), ostracods (o), and undifferentiated skeletal fragments in a mud matrix. D) Outerop photograph of Facies 10 with Gigantosproductus? (gp) brachiopods at the base of the upper Alapah
}

Brachiopod pack/grainstone is associated with peloid-skeletal wacke/packstone, skeletal wacke/packstone, and coral-brachiopod wacke/packstone in the middle Wachsmuth and peloidskeletal, skeletal grain/rudstone, and coral wacke/packstone in the Wachsmuth banded limestone 
member. This facies is associated with skeletal wacke/packstone and skeletal-peloid pack/grainstone in the lower Alapah and peloid-skeletal wacke/packstone, skeletal-peloid pack/grainstone, and skeletal grain/rudstone in the upper Alapah.

\section{$\underline{\text { Solitary Rugose Coral Wacke/packstone (Facies 11) }}$}

This facies is characterized by 0.5 to $\geq 1 \mathrm{~m}$ thick beds of medium- to dark-gray limestone with abundant fragments of solitary rugose corals. Other constituents include crinoids, forams, undifferentiated bioclasts, and minor fenestrate bryozoans, brachiopods, calcispheres, sponge spicules, and undifferentiated shell fragments (Figure 8). Diagenetic features include nodular and banded chert and minor dolomite, pyrite, and phosphate. Phosphate occurs in the zooecia of bryozoans. Hydrocarbons stain in outcrop was observed in the Wachsmuth banded limestone member.

This facies occurs mainly in the Wachsmuth Limestone where it is associated with peloidskeletal wacke/packstone. This facies is commonly underlain by calcareous shale, skeletal wackestone/ packstone, and foram wacke/packstone in the Wachsmuth banded limestone member. This facies is rare in the lower Alapah but when it does occur, it is associated with skeletal-peloid pack/grainstone.
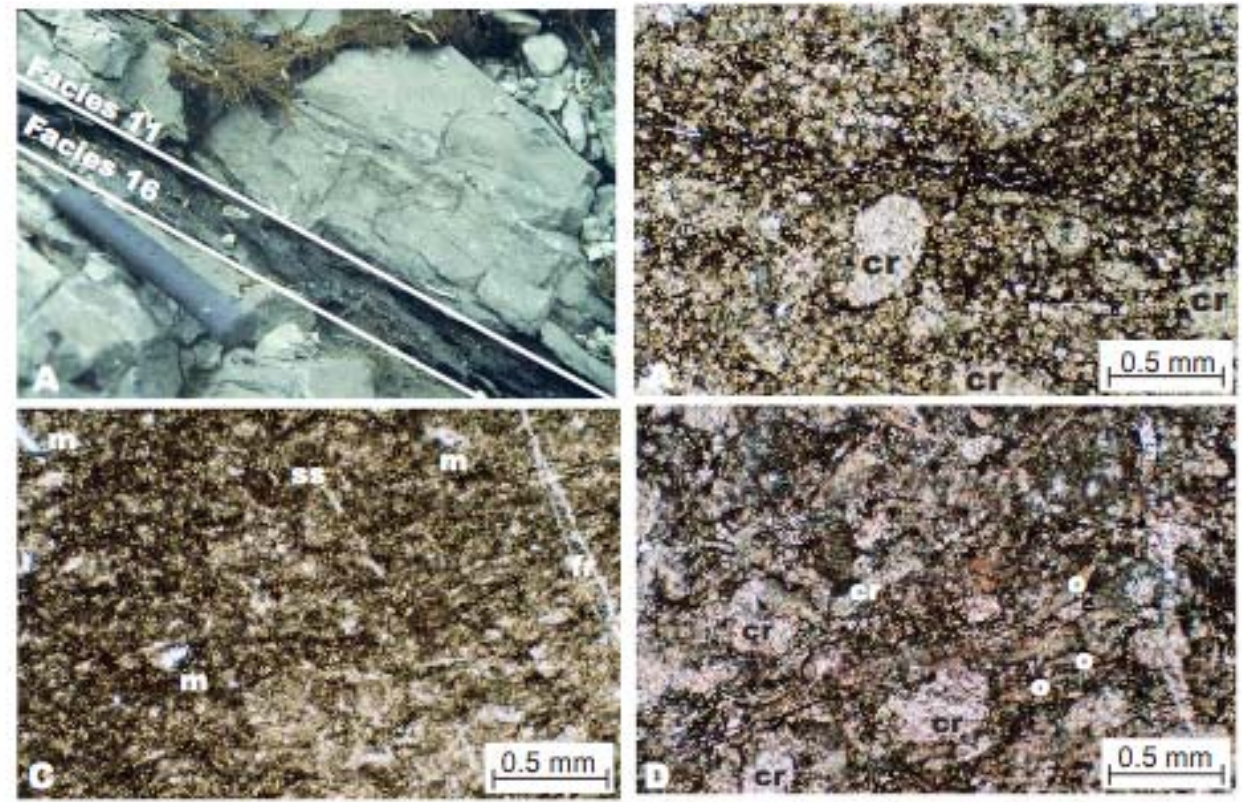

Figure 8. Facies 11 (solitary rugose coral wacke/packstone) and 12 (peloid-skeletal wacke) packstone). A) Outcrop photograph of Facies 11 shown overlying calcarcous shale (facies 16). B) Photomicrograph of Facies 11 illustrating crinoids (cr) and small undifferentiated skeletal fragments that commonly oceur with corals in a mud matrix near the base of the Wachsmuth crinoidal limestone member. C) Photomicrograph of Facies 12 with peloids of varying sizes, sponge spicules (ss), and undifferentiated skeletal fragments with a mud matrix in the lower Alapah. Moldic porosity $(\mathrm{m})$ is minor to rare D) Photomicrograph of Facies 12 illustrating peloids, crinoids (cr), ostracods (o), and undifferentiated skeletal fragments within the Wachsmuth middle member. 


\section{Peloid-Skeletal Wacke/packstone (Facies 12)}

This facies is composed of medium- to dark-gray limestone with abundant peloids and skeletal fragments. Abundant normal marine constituents, such as crinoids, fenestrate bryozoans, undifferentiated bioclasts and shell fragments, and forams are mixed with impoverished fauna such as sponge spicules, and ostracods (Figure 9). Colonial and solitary rugose corals, calcispheres, and brachiopods are rare. Beds are $\geq 1 \mathrm{~m}$ thick with rare planar laminations and thin graded beds. Extensive bioturbation destroys bedding and sedimentary structures. Black chert nodules are abundant and dolomite, pyrite, and phosphate in fenestrate bryozoan zooecia are minor to rare. Hydrocarbon staining is frequently observed in the Wachsmuth banded limestone member and seldom in the middle Wachsmuth.

This facies is commonly observed in the Wachsmuth Limestone with minor occurrences in the upper Alapah. Peloid-skeletal wacke/packstone is associated with skeletal wacke/packstone and crinoid-solitary rugose coral floatstone in the Wachsmuth crinoidal limestone member. This facies coarsens-upward into skeletal grain/rudstone, peloid pack/grainstone, brachiopod pack/grainstone, and/or solitary rugose coral wacke/packstone. In the middle Wachsmuth, this facies is associated with foram wacke/packstone, skeletal wacke/packstone, brachiopod pack/grainstone, and coral pack/grainstone. Peloid-skeletal wacke/packstone also coarsensupward to skeletal-peloid pack/grainstone and/or skeletal grain/rudstone. In the lower Alapah this facies is associated with brachiopod pack/grainstone and coarsens-up into skeletal-peloid pack/grainstone and/or skeletal grain/rudstone.

\section{$\underline{\text { Skeletal Wacke/packstone (Facies 13) }}$}

Medium- to dark-gray limestone consisting of undifferentiated skeletal fragments, crinoids, fenestrate bryozoans, and ostracods characterizes this facies (Figure 9). Peloids, calcispheres, ostracods, sponge spicules, solitary and colonial coral fragments, brachiopods, and gastropods are rare. Beds are $\geq 1 \mathrm{~m}$ thick and are homogenized by bioturbation. Sedimentary structures are generally rare, but include planar laminations, thin graded beds with scoured bases, and small discrete burrows.

Pyrite is common in the Wachsmuth banded limestone member and the Alapah Limestone. Dolostone and dolomitic limestone are minor diagenetic elements, except in the middle Wachsmuth where most of the skeletal wacke/packstones are dolomitized. Phosphate occurs in the zooecia of fenestrate bryozoans and is relatively rare in the Wachsmuth banded limestone member. Black nodular to lenticular chert is generally a minor to rare. Hydrocarbon staining is observed in the Wachsmuth banded limestone member, with minor occurrences in the middle Wachsmuth and the lower Alapah and middle Alapah.

In the middle Wachsmuth skeletal wacke/packstone is associated with wackestone/banded chert. Foram wacke/packstone and peloid-skeletal wacke/packstone are associated with this facies in the Wachsmuth banded limestone member. Beds in the Wachsmuth banded limestone member also coarsen-up from calcareous shale bases through this facies to bioclastic grain/rudstone. Skeletal wacke/packstone is relatively rare within the Wachsmuth crinoidal limestone member, but where it occurs it is associated with crinoid-solitary rugose coral floatstone and foram 

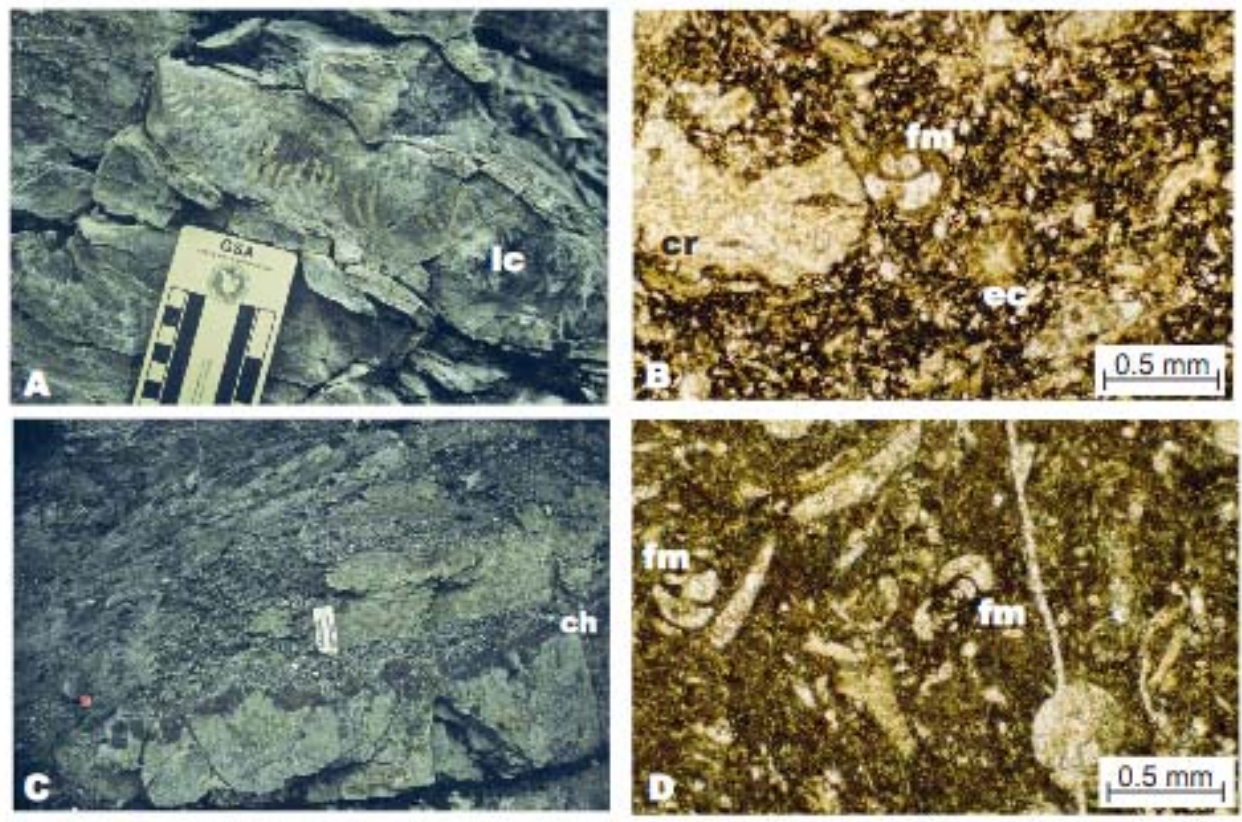

\begin{abstract}
Figure 9. Facies 13 (Skeletal wacke/packstone) and 14 (Foram wacke/packstone). A) Outcrop photograph of Facies 13 in the Wachsmuth middle member. Rare lithostrotionoid coral

fragments (lc) occur in this facies. Left side of scalebar is in $\mathrm{cm}$. B) Photomicrograph of Facies

13 with crinoids ( $\mathrm{er}$ ), forams (fm), echinoids (ec), and unidentifiable skeletal fragments in a mud matrix near the top of the Wachsmuth banded limestone member. C) Outerop photograph of Facies 14 near the top of the Wachsmuth banded limestone member. A band of lenticular to slightly nodular black chert (ch) occurs in the center of the photograph. Left side of scale bar is in cm. D) Photomicrograph of Facies 14 illustrating forams (fm) and other skeletal fragments within a mud matrix.
\end{abstract}

wackestone/ packstone. Skeletal wacke/packstone also occurs in the lower Alapah where it is associated with coral pack/grainstone and brachiopod pack/grainstone. This facies also coarsensupward to skeletal-peloid pack/grainstone and/or skeletal grain/rudstone. In the middle and upper Alapah it coarsens-upward into skeletal-peloid pack/grainstone.

\title{
Foram Wacke/packstone (Facies 14)
}

Dark-gray limestone with abundant micritized forams, peloids, undifferentiated skeletal fragments, and ostracods are common constituents of this facies, whereas sponge spicules, fenestrate bryozoans, and colonial rugose and syringoporid corals are minor (Figure 10). Beds are 0.75 to $\geq 1 \mathrm{~m}$ thick with rare planar laminations occurring in the middle of the Wachsmuth banded limestone member. Dolomitized limestone, pyrite, and hydrocarbon staining seldom occur in the Wachsmuth crinoidal limestone member. Dolomitized limestone increases upward through the middle Wachsmuth. In the Wachsmuth banded limestone member pyrite and hydrocarbon staining are abundant and dolomitized limestone is minor to rare.

This facies occurs only in the Wachsmuth Limestone, being most abundant in the upper-most banded limestone member. In the crinoidal limestone member, this facies occurs at the tops of beds that fine-upward from crinoid-solitary rugose coral floatstone. Foram wacke/packstone is associated with peloid pack/grainstone in the middle Wachsmuth and peloid-skeletal wacke/packstone, calcareous shale, coral pack/grainstone, and skeletal wacke/packstone in the Wachsmuth banded limestone member. Foram wacke/packstone is most abundant at the top of 
the Wachsmuth Limestone, where it occurs above calcareous shales that coarsen-upward into packstone with large colonial rugose coral fragments.

\section{Crinoid-Solitary Rugose Coral Floatstone (Facies 15)}

Dark-gray crinoid-solitary rugose coral floatstone occurs at the base of beds that fine-up into fine-grained skeletal wacke/packstone and/or foram wacke/packstone. Crinoids, solitary rugose corals, undifferentiated skeletal fragments, brachiopods, ostracods, and forams are common constituents (Figures 10) of facies 15, whereas calcispheres and gastropods are rare to absent. Solitary rugose corals occur as fragments ranging in size between 2 and $5 \mathrm{~cm}$ above an erosional surface at the base of the beds. The erosional surfaces have relief of a few $\mathrm{mm}$ to a few $\mathrm{cm}$. These fining-upward beds are 0.12 to $2 \mathrm{~m}$ thick. Graded bedding, scours, and extensive bioturbation at the tops of the beds are the only sedimentary structures observed. Diagenetic elements include a minor increase in dolomite and rare pyrite and black lenticular chert. This facies is found almost exclusively in the Wachsmuth crinoidal limestone member and is overlain by coral pack/grainstone and foram wacke/packstone; however, rare occurrences are also observed in the Wachsmuth middle (associated with coral pack/grainstone) and banded limestone members (associated with solitary rugose coral wacke/packstone, skeletal wacke/packstone, and calcareous shale).
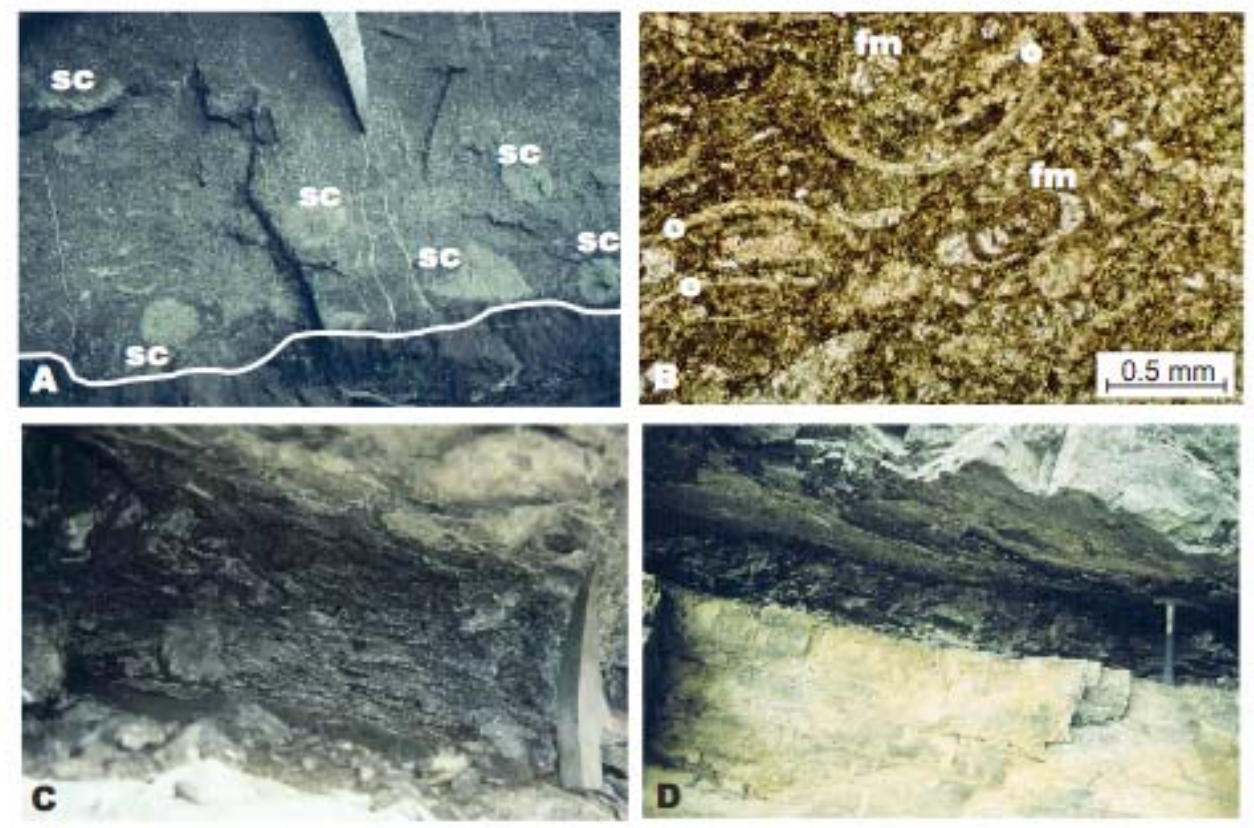

Figure 10. Facies 15 (crinoid-solitary rugose coral floatstone) and 16 (calcarcous shale).

A. Outcrop photograph of Facies 15 illustrating whole and fragmented solitary rugose corals (sc)

in a normally graded bed with an irregular erosive base (white line) from near the base of the

Wachsmuth crinoidal limestone member. B. Photomicrograph of Facies 15 illustrating other

common grains including ostracods (o) and forams (fm). C) Outerop photograph of Facies 16

illustrating a $15 \mathrm{~cm}$ thick calcareous shale with mm-scale laminations in the Wachsmuth banded

limestone membet. D) Outerop photography of a $25 \mathrm{~cm}$ thick calcarcous shale (arrows) with

abundant black nodular chert in the lower Alapah. 
Mudstone and Calcareous Shale (Facies 16)

Facies 16 consists of thin $(\leq 10 \mathrm{~cm}$ thick) to thick ( $\leq 10 \mathrm{~cm}$ to $1 \mathrm{~m})$ beds of dark-gray to black calcareous shale (Figure 10) composed mainly of argillaceous and lime mud. This facies is commonly observed at the bases of coarsening-upward beds. Skeletal components associated with the calcareous shale includes: crinoids, fenestrate bryozoans, undifferentiated skeletal fragments, and rare solitary and colonial rugose corals, sponge spicules, brachiopods, gastropods, forams, and ostracods. Peloids are an important non-skeletal component. Sedimentary structures include $\mathrm{mm}$ to $\mathrm{cm}$ laminations, burrows, and bioturbation. Diagenetic components include abundant black lenticular to nodular chert, minor dolomite, and rare pyrite.

This facies is observed at the base of coarsening-upward successions in the Wachsmuth banded limestone member, where it is associated with foram wacke/packstone, peloid-skeletal wacke/packstone, crinoid-solitary rugose coral floatstone, skeletal grain/rudstone, coral pack/grainstone, solitary rugose coral wacke/packstone, and skeletal wacke/packstone. It is also observed in the lower and middle Alapah associated with peloid-calcisphere wacke/packstone, peloid-brachiopod-calcisphere-ostracod wacke/packstone, and skeletal-peloid pack/grainstone, and the lower-most upper Alapah associated with peloid-calcisphere wacke/packstone.

\section{Facies Associations and Depositional Interpretations}

Beginning in a landward direction and proceeding along a seaward directed transect, homoclinal carbonate ramp environments change from an inner ramp represented by peritidal and shallow subtidal open or restricted platform settings bounded seaward by shoal environments (Figure 11; Read, 1985; Burchette and Wright, 1992). Outboard is a middle ramp characterized by open marine environments below fairweather but above storm wavebase and the outer ramp that is below storm wave base and dips seaward into basinal environments (Read, 1985; Burchette and Wright, 1992). Peritidal environments are only represented by facies in the northeastern Brooks Range (Watts et al., 1995) and will not be discussed further here. The shallowest environments recorded in the central-eastern Brooks Range are open or restricted platform facies but much of the stratigraphy is dominated by shoal and progressively deeper open marine facies. The juxtaposition of below storm wavebase deposits and open marine facies above storm wave base without abundant gravity flow deposits implies a relatively low-angle depositional profile and supports a homoclinal ramp interpretation for the Lisburne Group.

Inner Ramp

Open/Restricted Platform Environment

Between pertidal and shoal environments is either an open or restricted platform or lagoon (Figure 11). This environment corresponds to Wilson's (1975) open sea shelf and shelf lagoon with open circulation or to the inner ramp lagoon of Burchette and Wright (1992). Many ramp facies models imply a relatively narrow lagoon behind high energy shoals but facies distributions between the northeastern Brooks Range (Watts et al., 1995) and the central-eastern Brooks Range (this study) support the existence of a much more extensive open platform or lagoon. Facies in this setting are typically cherty, burrowed, peloid-rich lime mudstone, wackestone and 
packstone (Table 1; Figure 11; Schlager, 1992a; Scholle et al., 1983; Burchette and Wright, 1992). Water depths are interpreted to range from 5 to $25 \mathrm{~m}$ (Burchette and Wright, 1992, James, 1997). Open platforms have normal marine salinity resulting from unimpeded water circulation and sediments will have a diverse fauna and extensive bioturbation (Burchette and Wright, 1992). High diversity faunas contain abundant echinoderms (dominantly crinoids but includes other pelmatozoans as well), colonial and solitary rugose corals, bryozoans,

brachiopods, bivalves, sponges, ostracods, benthic forams, calcareous algae, and calcispheres. Open platform sediments are very similar to those deposited in the open marine realm. Lateral and vertical changes in lithofacies are the best criteria for differentiating between sediments deposited in an open platform and those deposited in an open marine environment.

Restricted platforms have limited circulation potentially causing anoxic bottom waters, nutrient deficiencies, abnormal salinities, sparse fauna, and/or elevated temperatures (Oschmann, 1991; Burchette and Wright, 1992; Watts et al., 1995). Fauna is generally low diversity and includes bivalves, benthic forams, ostracods, gastropods, calcispheres, and algal oncoids (Scholle et al., 1983). The restricted platform is protected or restricted sea-ward by shoals (Burchette and Wright, 1992; Schlager, 1992a); however, restriction may also be caused by extensive shallowwater expanses on an inner ramp that dampen wave energy and tidal influence. The restricted platform environment is recognized primarily by its lateral associations with open platform, shoal, and/or intertidal environments and not necessarily by diagnostic sedimentary structures or fauna (Enos, 1983).

Facies deposited in open platform environments include the Peloid-calcisphere wacke/packstone and the Peloid-brachiopod-calcisphere-ostracod wacke/packstone (Table 1; Figure 11). The relatively abundant fauna present in these facies implies generally normal marine salinities and the abundance of nodular and banded chert and sponge spicules points toward relatively copious sponge populations. Similar facies described in sections in the southern northeastern Brooks Range by Mamet and Armstrong (1972) and Armstrong (1974) were interpreted as having been deposited in open platform environments. The Wackestone/banded black chert, Mudstone and Calcareous shale facies are interpreted to have been deposited in restricted platform environments. Restricted platform facies are more common in the northeastern Brooks Range (Watts et al., 1995) which is likely related their more proximal location and the existence of nearby shoals that effectively restricted a much more narrow lagoon than the more broad open platform in the more distal central-eastern Brooks Range. Shoals in this environment were likely in somewhat deeper water and thus were not as effective in establishing restriction of water circulation.

\section{Shoal and Shallow Open Marine Environment}

Shoals consist of cross-bedded carbonate sands that are highly agitated by wave and tidal energy (Fig. 11; Wilson, 1975; Read, 1985; Schlager, 1992a). Muds in shoal settings are winnowed out by high-energy water movement leaving highly abraded, well-rounded, and well-sorted grains (Wilson, 1975; Burchette and Wright, 1992). Skeletal components include brachiopods, algae, mollusks, forams, corals, echinoderms, bryozoans, and sponges and non-skeletal grains, such as ooids and intraclasts, are also common. (Read, 1985; Burchette and Wright, 1992).

Occasionally, storms will breach the shoals and wash coarser-grained sediment into the open or 


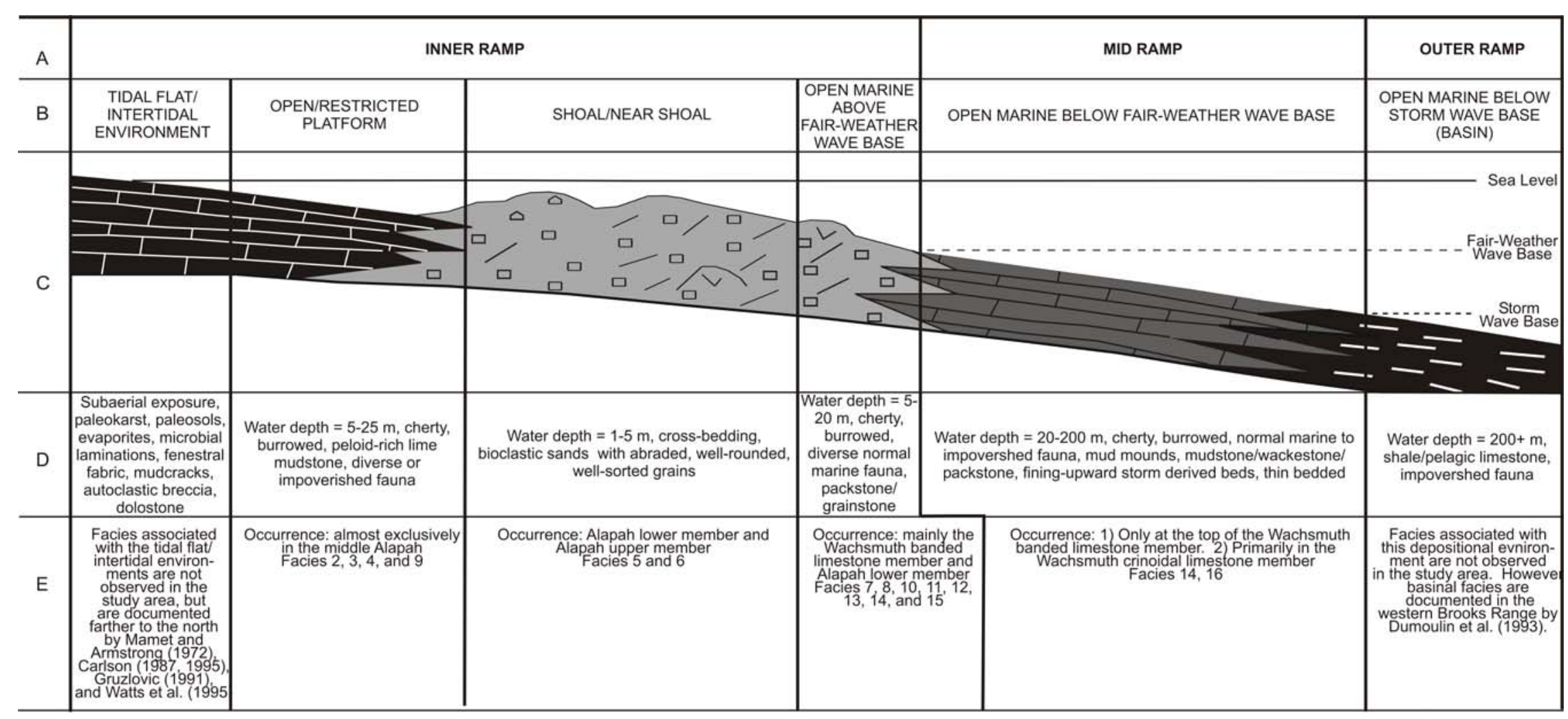

Figure 11.. Carbonate ramp depositional model with generalized facies models for the Lisburne Group. A) and B) Carbonate depositional environments. C) Ramp cross section. D) Characteristics of depositional environments. E) Stratigraphic occurrence of associated facies in the Lisburne Group. Modified from Burchette and Wright (1992) 
restricted platform environment. Shoals form in relatively shallow water depths (0 to $5 \mathrm{~m})$ and pass seaward into the open marine realm (Read, 1985; Burchette and Wright, 1992). The inner ramp open marine environment consists of facies deposited above fairweather wave base either just seaward of shoals or on open subtidal ramps without shoals.

The Skeletal-peloid pack/grainstone and Skeletal grain/rudstone are interpreted to have formed in shoal settings (Table 1; Figure 11) based on grain size and sorting, the occurrence of planar and cross-laminated units, and abundant normal marine fauna much of which consists of abraded skeletal fragments indicating intense wave working. These facies are similar to deepshoal lime grainstones and packstones described by Wendte (1992) and shelf edge lime sand described by Pfeil and Read (1980). A similar diverse faunal assemblage, abundant bioturbation, and a greater proportion of lime mud indicate a normal marine environment above fairweather wave base for facies like the Peloid pack/grainstone, Peloid-coral-brachiopod wacke/packstone, Coral pack/grainstone, and the Brachiopod pack/grainstone.

\section{Middle Ramp: Open Marine Environment}

The open-marine environment is generally below fairweather wavebase and is bounded landward by shoals or open marine environments above fairweather wave base and seaward by the deep basin (Figure 11). Water depths range from 20 to $200 \mathrm{~m}$ and is well-circulated, well oxygenated, and has normal marine salinity. Open-marine facies are often cherty, bioturbated, highly fossiliferous, grainy to muddy limestones (Read, 1985; Schlager, 1992; Burchette and Wright, 1992) with crinoids, brachiopods, bryozoans, and corals. Thin, storm-generated fining-upward beds are also common (Read, 1995).

Facies deposited within the open marine middle ramp setting include Solitary rugose coral wacke/packstone, Peloid-bioclast wacke/packstone, Bioclast wacke/packstone, foram wacke/packstone, and Crinoid-solitary rugose coral floatstone (Table 1; Figure 11). These facies indicate relatively quite water deposition due to the abundance of lime mud and normal marine conditions due to the abundant and diverse fauna. Sinclair, et al. (1998) and Light, et al. (1998) have identified foram wacke/packstones similar to those in the Lisburne and interpreted them to be deposited in an open marine environment that was below fair-weather wave base. Finingupward beds with erosional bases are common deposited during storms below fair-weather wave base in open marine environments (Scholle et al., 1983; Read, 1995). The occurrence of solitary rugose, syringoporid, and lithostrontionioid corals within fining upward muddier facies also supports a relatively quiet water environment occasionally influenced by storm deposition. The association with underlying calcareous shales or thin flaggy limestones indicates, by Walther's law, that these facies are slightly more proximal than outer ramp calcareous shales.

\section{Outer Ramp: Deep Open Marine Environment}

Outer ramp facies were deposited below storm wavebase and include laminated $\mathrm{mud} /$ wackestones and/or terrigenous shales and calcareous shales deposited dominantly from gravitational settling (Figure 11; Burchette and Wright, 1992). Rare silty or very fine sand-sized sediments may be delivered to the outer ramp during severe storm reworking. The only facies that can unequivocally be interpreted as an outer ramp deposit are mudstones and calcareous shales found at the bases of many shallowing upward cycles (Table 1; Figure 11). These 
laminated rocks contain sparse fauna, little bioturbation, and appear to indicate the deepest water settings recorded in the central-eastern Brooks Range. Other laminated mudstone or wackestone facies that occur in the open-marine middle ramp could potentially represent outer ramp deposits within some successions depending on over- and under-lying facies relationships.

\section{Stratigraphy and Biostratigraphy Of The Lisburne Group, Central-Eastern Brooks Range}

A single continuous stratigraphic section was never identified in the central-eastern Brooks Range but based on a composite of several sections (Figure 12) the total thickness of the Lisburne Group is between 700-850 m. Our lithostratigraphy in the central-eastern Brooks Range is based on data collected from two different areas: the Marsh Fork and Forks field areas (Figure 1). The Lisburne Group in the central-eastern Brooks Range appears to range in age from middle Osagean to upper-most Chesterian (Figure 2, Table 2).

Subdivisions of the Lisburne Group are based on large-scale weathering patterns that are easily recognizable in the field (Figure 13). Brosgé et al.'s (1962) tripartite subdivision of the Wachsmuth Limestone was confirmed by this study (Figure ). We have informally subdivided the Alapah Limestone into lower, middle, and upper members (Figures 13). Note that the Alapah Limestone in the central-eastern Brooks Range appears to contain rocks that are older than the Alapah Limestone to the north. Our informal Alapah subdivisions for the centraleastern Brooks Range thus do not correspond to those of Watts et al. (1995) in the northeastern Brooks Range (Figure 2). Our lower and middle Alapah members are for the most part not represented in the northeastern Brooks Range. Only the uppermost portion of the Wachsmuth middle member of the central-eastern Brooks Range onlaps into the southern northeastern Brooks Range (Figure 2). This very thin interval onlaps as far north as the Central Shublik a Mountains and makes up the basal lower Alapah in that area. A northward thinning rubbly limestone interval is observed at the top of the Lisburne Group in the central-eastern Brooks Range (Figure 13). The rubbly interval is most likely Lisburne Group that was affected by erosion associated with development of the pre-Upper Permian unconformity. This unit is either the uppermost Alapah or a thin erosional remnant of the Wahoo Formation and is unconformably overlain by recessive red shales and siltstones of the Permian Kavik Shale, Sadlerochit Group (Figure 12).

\section{Wachsmuth Limestone}

The Wachsmuth Limestone has a minimum thickness of $340 \mathrm{~m}$ and is relatively resistant and dark-colored (Figure 13). A complete section of Wachsmuth Limestone was not observed in the central-eastern Brooks Range due to a thrust fault truncating the base of the most complete section (MF). A complete exposure of the Wachsmuth Limestone at Shainin Lake is $375 \mathrm{~m}$ thick (Bowsher and Dutro, 1957) so the section in the central-eastern Brooks Range is probably relatively complete. Due to a lack of biostratigraphic resolution the Wachsmuth Limestone in the central-eastern Brooks Range appears to range in age from approximately early Osagean to perhaps as young as early Chesterian (Table 2). The middle Osagean to middle Meramecian age range reported by Armstrong et al. (1970) from the central Brooks Range might be more 


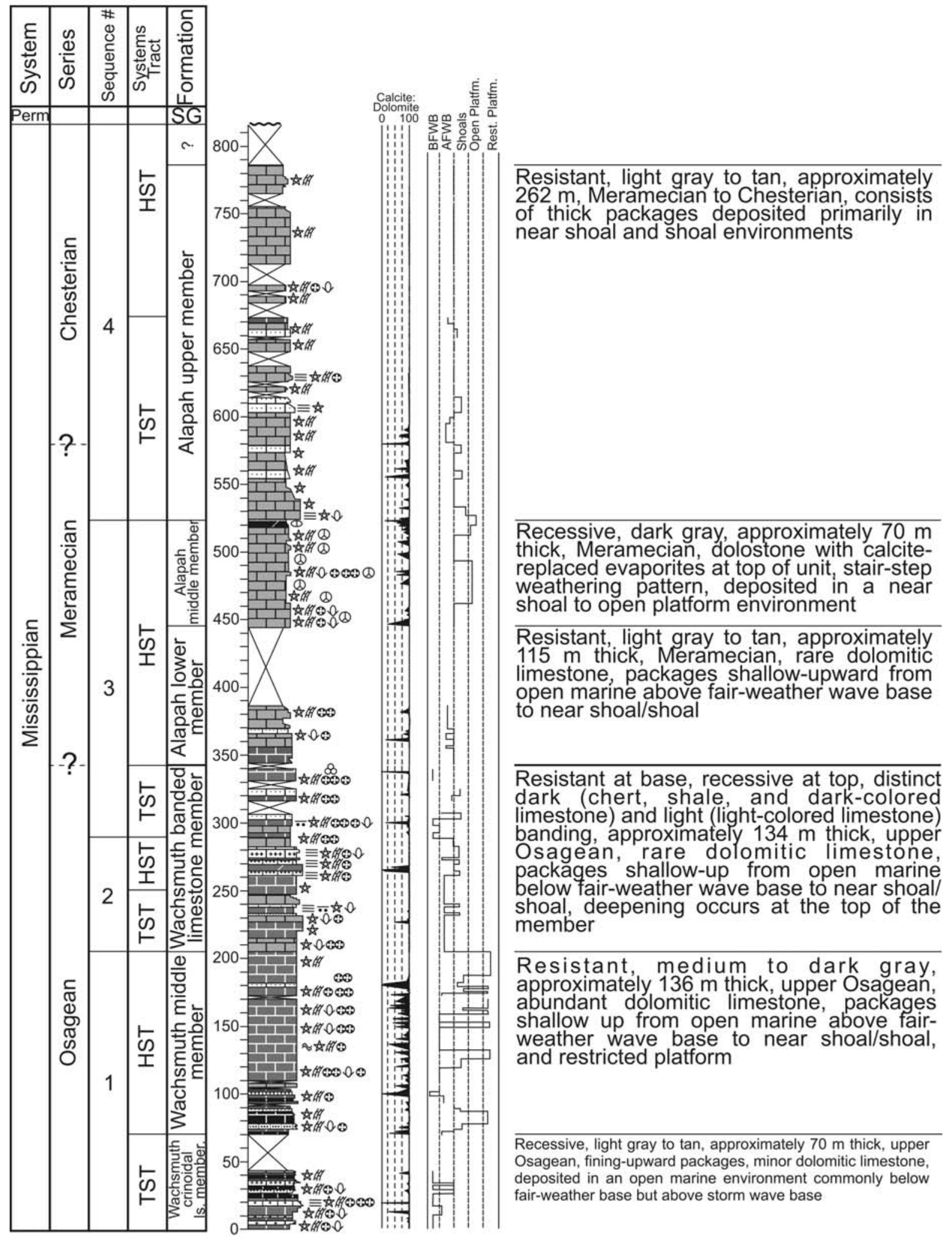

Figure 12. Composite Lisburne Group stratigraphy, central-eastern Brooks Range illustrating age, sequence stratigraphy, nomenclature, lithology, faunal components, relative percent calcite (white) and dolomite (black), and depositional environments. The Wachsmuth Limestone (0$340 \mathrm{~m}$ ) is from section MF and the Alapah Limestone is from section EF2 (340-780 m). 
LITHOLOGY

Dolostone
Dolomitic Limestone

BEDDING CHARACTERISTICS

$<0.25 \mathrm{~m}$ thick

\begin{tabular}{|c|c|}
\hline 1. & $0.25-0.75 \mathrm{~m}$ thick \\
\hline & $0.75-1 \mathrm{~m}$ thick \\
\hline & $>1 \mathrm{~m}$ thick \\
\hline & Wavy bedding \\
\hline
\end{tabular}

SKELETAL GRAINS

$\star$ Echinoderm

ffy Bryozoan (Fenestrate)

y Bryozoan (Ramose)

๑ Brachiopod

Q Ostracod

\& Foraminifera

× Sponge Spicules

$\$$ Colonial Coral

(1) Solitary Coral

$\approx$ Algae (undifferentiated)

( Bioclast (undifferentiated)

ح Shell Frags.

(1) Calcisphaera $s p$.

\& Gastropod

$\checkmark$ Bivalve

fि Trilobite

\section{NON-SKELETAL GRAINS}

$\odot$ Ooid

- Superficial Ooid

(?) Oncoid

- Peloid

$\checkmark$ Intraclast

qtz Detrital Quartz

\begin{tabular}{|c|c|}
\hline ABUNI & DANCE \\
\hline & $\begin{array}{l}>10 \% \\
>50 \%\end{array}$ \\
\hline MinpI) & $\begin{array}{l}<10 \% \\
<1 \%\end{array}$ \\
\hline
\end{tabular}

\author{
SEDIMENTARY STRUCTURES \\ $\equiv$ Planar Laminae or Bedding \\ —Cross-Bedding \\ ₹ Herringbone Cross-Bedding \\ - Graded Bedding \\ $\approx$ Wavy Laminae \\ 5 Bioturbated \\ sss Highly Bioturbated \\ $\checkmark$ Burrow Structure \\ -๑- Fenestral Fabric \\ v Mudcracks \\ Cu Coarsening-Upward \\ tu Fining-Upward
}

\section{DIAGENETIC FEATURES}

- Nodular, Lensoidal, and/or

Banded Chert

c) Chert Replacement of Grains

(1) Calcitized and/or Silicified Evaporite Nodules

(s) Solution Collapse Breccia

\) Open to Crystal-Lined Vugs

MM Stylolite

« Fracture

Py Pyrite

$\mathrm{Ph}$ Phosphate

F Fluorite

C Iron Concretions

A Authigenic Albite

G Glauconite

Highly Compacted Grains

Figure 12 continued. Key to patterns and symbols used in measured stratigraphic sections, cores, and sequence stratigraphy. Also refer to this key for Figures 15, 16, 18, and 19.

representative of the true age range in the central-eastern Brooks Range as well. The poor biostratigraphic resolution in the central-eastern Brooks Range precludes more rigorous age assessment of the members described below.

\section{Crinoidal Limestone Member}

The crinoidal limestone member is $70 \mathrm{~m}$ thick, weathers light gray to tan, and is dark gray when fresh. Most beds are 1 to $4 \mathrm{~m}$ thick and fines-upward from erosionally based beds of crinoidsolitary rugose coral floatstone to skeletal wacke/packstone. Crinoids, solitary rugose corals, and fenestrate bryozoans are major faunal components in the grain-rich intervals. Skeletal fragments, crinoids, fenestrate bryozoans, and brachiopods occur in the finer-grained intervals at the tops of the beds. Minor dolomitic limestone occurs at the top and/or the base of the floatstones. Rare 
normal graded beds occur near the base of the member and are 2 to $5 \mathrm{~cm}$ thick and fine-upward from skeletal-crinoid pack/grainstone with minor forams to a skeletal wackestone. Chert occurs as discrete round to oval chert nodules and is relatively rare at the base of the unit, but increases in abundance towards the top. Overall, the crinoidal limestone member is relatively fine-grained with minor dolomitic limestone and is interpreted to have been deposited in an open marine depositional environment below fair-weather wave base, but above storm wave base, on the basis of erosionally based, fining-upward beds that display little evidence of wave or current working.
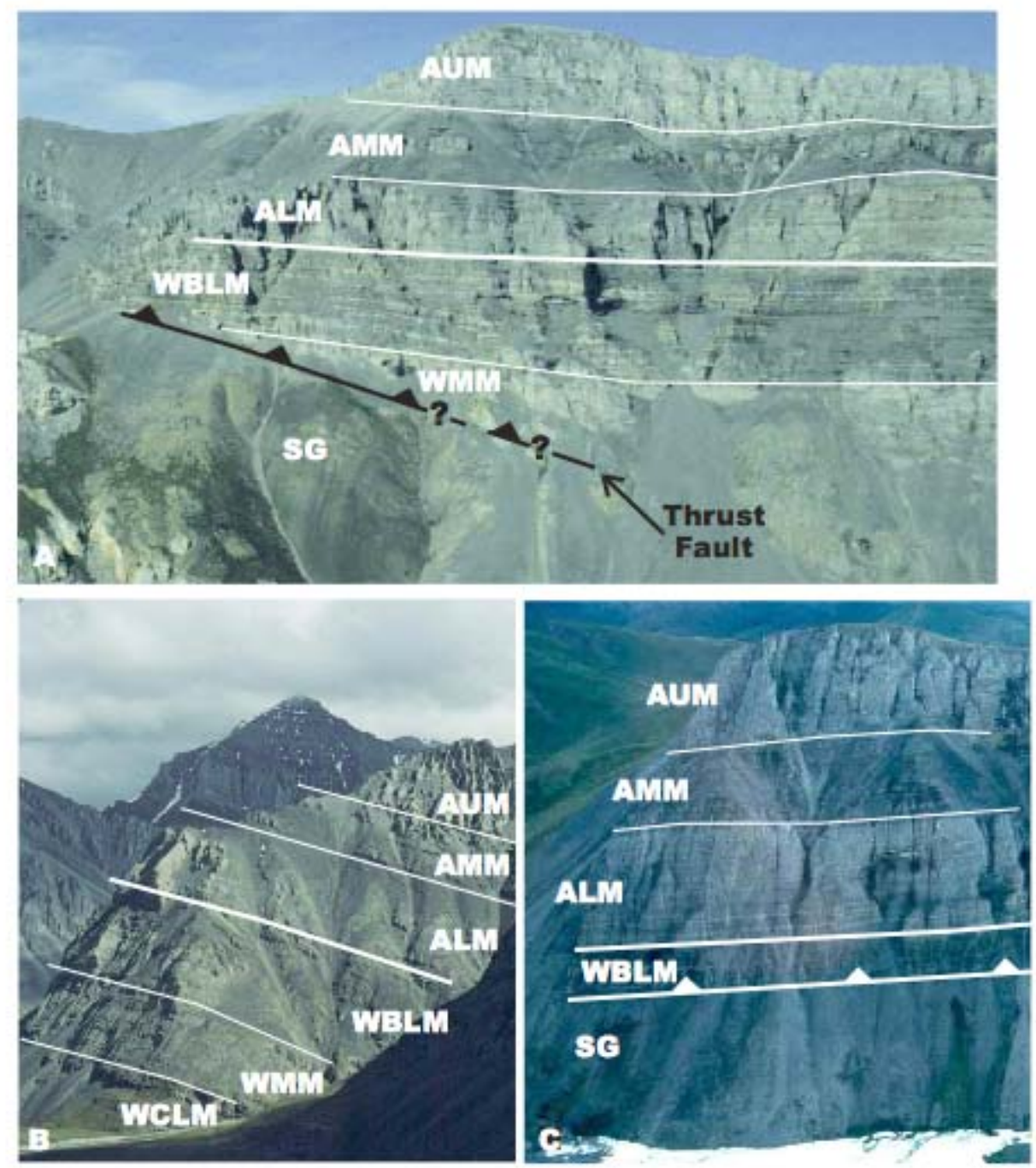

Figure 13. Large-scale weathering patterns of the Lisburne Group in the Marsh Fork (A, B) and Forks (C) field area, central-eastem Brooks Range. The Wachsmuth crinoidal limestone member (WCLM) is recessive and dark-colored and is overlain by the resistant, light-colored cherty and dolomitic limestones of the Wachsmuth middle member (WMM). The Wachsenuth banded limestone member (WBL.M) is resistant and characterized by distinctive dark (chert, shale, dark-colored limestone) and light (limestone) banding. The lowerAlapah (ALM) is fesistant, light-colored limestone. The middle Alapah (AMM) consists of recessive, darkcolored limestone. The upper Alapah (AUM) is resistant and light-colored. The upper-most Lisburne Group is rubbly and truncated by the pre-Upper Permian unconformity and the recessive red shales and siltstones of the Permian Sadlerochit Group.

Middle Member 
The Wachsmuth middle member is approximately $136 \mathrm{~m}$ thick, weathers darker in color than the crinoidal limestone member, and is dark gray on a fresh surface. Near the base of the member are decimeter thick fine-grained skeletal wacke/packstones. Just above the base of the member are two several-meter thick light-gray to yellowish skeletal-peloid pack/grainstones. Together these units comprise an $8 \mathrm{~m}$ thickening and coarsening upward package. Crinoids and fenestrate bryozoans are the major faunal elements with rare solitary corals and brachiopods. Above the skeletal-peloid pack/grainstones, is an $8 \mathrm{~m}$ thick interval of wackestone "interbedded" with banded black chert. Above the wackestone-banded chert couplets are about $13 \mathrm{~m}$ of coarsening upward packages with basal calcareous shales and meter-thick wackestone and/or packstone. Grain types include crinoids, fenestrate bryozoans, brachiopods, solitary rugose corals, and colonial corals. The middle member then returns to about $14 \mathrm{~m}$ of decimeter thick wackestone chert couplets. Crinoids, fenestrate bryozoans, solitary rugose corals, and small colonial corals are the most abundant skeletal grain types in the these units.

Overlying the wackestone-chert couplets are about $14 \mathrm{~m}$ of meter thick packages with shaly limestone bases that coarsen-upward to wackestone or packstone. Each bed is "capped" by banded black chert. Crinoids, fenestrate bryozoans, brachiopods, and small colonial corals are important faunal components. Solitary rugose coral fragments are rare. Banded black chert abundance decreases and then increases upward. This package is overlain by about $24 \mathrm{~m}$ of decimeter bedded wackestone banded black chert interbedded with packstones. A $12 \mathrm{~m}$ thick package that coarsens upward from skeletal wacke/packstones to skeletal grain/rudstone overlies the wackestone banded black chert interval. The several-meter thick skeletal grain/rudstone package is dolomitized and contains abundant crinoids, skeletal fragments, bryozoans, and minor brachiopods, ostracods, forams, and solitary rugose corals. Overall, the amount of dolomitization increases upward through the unit (Figure 12). This grainstone unit can be traced a great distance along strike and can also be correlated between all three sections within the Marsh Fork field area. Also, the skeletal grain/rudstone beds are slightly thicker and more numerous in section MF3 than sections MF and MF2. Wackestone-banded chert couplets the remaining $23 \mathrm{~m}$ at the top of the middle Wachsmuth. Faunal elements in this upper interval include crinoids, fenestrate bryozoans, small colonial rugose corals, lithostrotionoid corals, and syringoporid corals.

Depositional environments of the middle member include open platform and shoal to near shoal settings. Fine-grained, skeletal wackestones with abundant chert and coarser-grained facies with abundant corals and brachiopods are interpreted to have been deposited in an open platform environment on the basis of facies associations, the included open marine fauna, and lateral correlations with restricted to open platform environments documented to the north (Armstrong and Mamet, 1972). Skeletal grain/rudstone is interpreted to be deposited in shoal to near shoal environments.

\section{Banded Limestone Member}

The Wachsmuth banded member measured in the Marsh Fork is about $150 \mathrm{~m}$ thick and characterized by dark and light banding (Figures 13). The distinct banding is caused by alternations of black chert, calcareous shale, and dark-colored limestone alternating with lightcolored limestone. In the Marsh Fork area, packages are 3 to $15 \mathrm{~m}$ thick and coarsen-up from dark calcareous shale or wackestone to lighter colored packstone or grainstone and locally 
grain/rudstone. Numerous several-meter thick skeletal grain/rudstones with planar laminations at their base and/or top occur in the middle of the unit. Chert is rare in the rudstones, but abundant in other lithologies as discrete nodules. The smaller chert nodules may represent crosssections through silicified burrows. Silicified burrows are observed on bedding planes and have a sinuous, elongate, branching morphology (Figure 14). Teichart (1975) and Whidden and Bottjer (1989) describe similar burrow morphologies and identified them as Thalassinoides.

In the Forks area, the banded limestone member facies are coarser-grained and has abundant large colonial rugose corals and significantly less chert. Poor outcrop quality and thrust faulting obscures a complete description of this subunit in the Forks field area. The limestone weathers tan-brown to gray and is dark-gray on a fresh surface. The beds described in the lower half of the banded limestone member in the Forks area are 2 to $4 \mathrm{~m}$ thick with abundant crinoids and fenestrate bryozoans, minor colonial corals, brachiopods, solitary rugose corals, and rare gastropods. Chert is lenticular to nodular and rarely banded (Figure 14). Beds in the upper half of the unit are 0.25 to $0.5 \mathrm{~m}$ thick with basal shales typically underlying and draping colonial rugose corals or coarsening-up into crinoid-bryozoan-coral grainstone (Figure 3.5E).
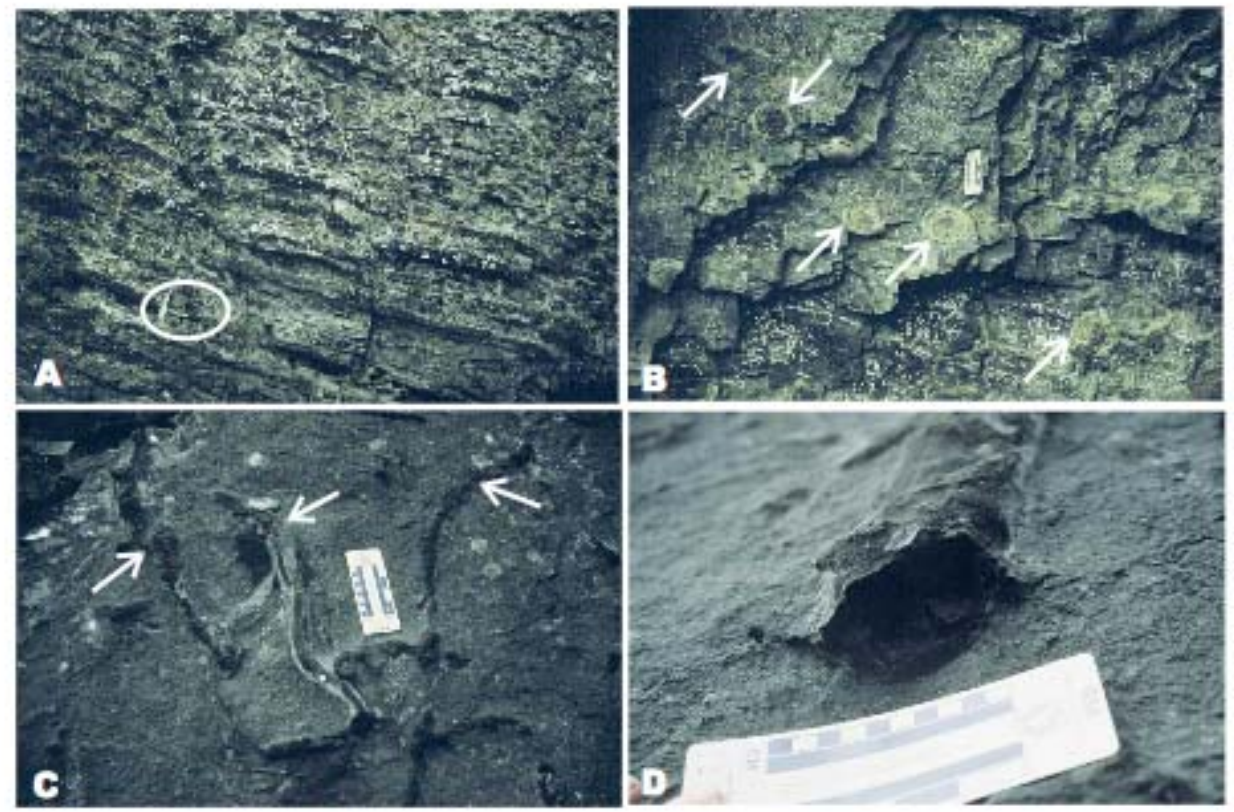

\begin{abstract}
Figure 2.23. Chert morphologies present in the Lisburne Group. A) Banded chert (dark bands in photo) is black, uniform in thickness, has smooth abrupt boundaries with adjacent limestone, and can be traced over long distances. Banded black ehert is found only in the Wachsmuth middle member in Section MF. Hammer for seale (circled). B) Concentrically laminated chert nodules (arrows) near the top of the Alapah middle member. Left side of scalebar is in $\mathrm{cm}$.

C) Long sinuous chert nodules (arrows) on a bedding plane in the Wachsmuth banded limestone member. Note the branching morphology of the chert suggesting that it represents silicified burrows. D) Cross section through a chert nodule similar to that in $\mathrm{C}$. The burrow morphology is not readily apparent when viewed in cross section.
\end{abstract}

The Wachsmuth-Alapah boundary is above beds that coarsen-up from calcareous shale to foram wacke/packstone with abundant forams, sponge spicules, and ostracods. In the Marsh Fork area, large fragments of colonial rugose corals occur near the tops of the coarsening-upward beds Calcareous shales at the base of the coarsening-up beds are more numerous and thinner than 
those in the Marsh Fork area. There is no biostratigraphic evidence of an unconformity at the Wachsmuth-Alapah Limestone boundary. However, biostratigraphic resolution is very low due to poor recovery and absence of short-lived conodont and foram species. Lithofacies occurring at the top of the Wachsmuth Limestone actually indicates a deepening event and not exposure.

The banded limestone member is interpreted to have been deposited at or below fair-weather wave base in an open marine setting. Facies throughout the Wachsmuth banded limestone member progressively change from those deposited at or above fair-weather wave base to those deposited at or below fair-weather wave base with the deepest water facies occurring at the top of the member. Skeletal wacke/packstone is most abundant at the base of the member; whereas facies deposited below fair-weather wave base (foram wacke/packstone and calcareous shale) increase in abundance near the top of the member.

\section{$\underline{\text { Alapah Limestone }}$}

The Alapah Limestone in the central-eastern Brooks Range is approximately $475 \mathrm{~m}$ thick. We have subdivided the Alapah into informal lower, middle, and upper members on the basis of large-scale weathering patterns and facies. These subdivisions are for the study area only and should not be confused with Watts et al.'s (1995) nomenclature for the Alapah Limestone in the northeastern Brooks Range. This study indicates that the entire Alapah in most of the northeastern Brooks Range is temporally equivalent to only the upper Alapah in the centraleastern Brooks Range. These stratigraphic relationships will be more fully developed in our sequence stratigraphic model presented below. Alapah descriptions are largely from the Forks field area. A complete section of Alapah Limestone occurs in the Marsh Fork area, but was not described due to time constraints and inaccessibility of the upper portion of the unit.

\section{Lower Member}

The Alapah lower member overlies the Wachsmuth Limestone, is 111 to $115 \mathrm{~m}$ thick, and is relatively resistant (Figure 3.6B). In the Forks field area, beds are thicker than $5 \mathrm{~m}$ and coarsenup from wackestone or packstone with abundant nodular to lenticular black chert to packstone or grainstone lacking chert. Undifferentiated skeletal fragments, crinoids, fenestrate bryozoans are the most abundant faunal components. Colonial rugose corals (Figures 7) in growth position are common in the middle of the member and are associated with minor to rare lithostrotionoid corals and rare brachiopods and solitary corals. This interval represents small, localized coral buildups.

In the Marsh Fork area, the lowermost $43 \mathrm{~m}$ of the Alapah lower member was described. The lower member is lithologically similar between the Forks and Marsh Fork areas. The facies and depositional textures of the Alapah lower member indicate a shallowing calcareous shale and foram wacke/packstone of the Wachsmuth Limestone deposited below fair-weather wave base to an open marine setting at or above fair-weather wave base. The Alapah lower member continues to shallow to the open platform environment of the middle Alapah.

Middle Member 
The middle Alapah is 69 to $71 \mathrm{~m}$ thick, darkest colored, and recessive. Beds in section WF are 0.25 to $0.5 \mathrm{~m}$ thick and coarsen-up from platy lime mudstone bases to peloid-calcisphere wacke/packstone and peloid-brachiopod-calcisphere-ostracod wacke/packstone, and rarely skeletal grain/rudstone (Figure 6). Crinoids, fenestrate bryozoans, calcispheres, forams, ostracods, peloids, and undifferentiated skeletal fragments are the characteristic components of this member. Sponge spicules and gastropods are minor. Brachiopods occur in the tops of the beds.

To the southeast in section EF2, the middle Alapah are less pronounced, slightly coarser-grained, and have a minor solitary rugose and colonial rugose coral component. Finely-crystalline dolostone with abundant small white calcite nodules occur just below the middle Alapah-Alapah upper member contact in sections FW and EF2 (Figures 3). The calcite nodules are very similar to replaced evaporites documented by Watts et al. (1995). The middle Alapah is interpreted to have been deposited in an open to slightly restricted platform depositional environment on the basis of facies associations, abundant normal marine fauna, and its stratigraphic correlation with lagoonal facies farther to the north (Section 70A-2; Armstrong and Mamet, 1972).

\section{Upper Member}

The $262 \mathrm{~m}$ thick upper member is relatively resistant, light in color, and coarser-grained than the middle Alapah. Upper member facies change laterally over short distances within the Forks area.

In section WF, the lowermost 2 meters is wackestone to packstone underlain by rare calcareous shales. Crinoids, fenestrate bryozoans, and brachiopods are abundant. The next 16 meters are characterized by beds that are thicker than $1 \mathrm{~m}$ and composed of wackestones to packstones with peloids, sponge spicules, crinoids, fenestrate bryozoans, calcispheres, forams, brachiopods, ostracods, and rare gastropods and solitary rugose corals. Coarsening-upward beds of wackestones to grainstones are thicker than $1 \mathrm{~m}$ and contain crinoids, fenestrate bryozoans, brachiopods, with minor solitary rugose corals and colonial corals characterize the remainder of the upper member.

Section EF2 displays significant variations from section WF. First, the lower-most part of the subunit does not contain impoverished fauna comparable to section WF. Instead the lower third of the upper member is composed of packstones to grainstones with normal marine fauna and rare surficial ooids. A $0.5 \mathrm{~m}$ muddy dolomite interval occurs approximately $55 \mathrm{~m}$ above the base of the member in section EF2 (269.5 m above the base of the section). Conodont biostratigraphy indicates that the Alapah below this dolomite interval is Meramecian and Chesterian above. Beds for the $15 \mathrm{~m}$ immediately above the dolomite are slightly muddier, significantly thinner, and have normal marine fauna with an increase in ostracods and peloids. The abundance of black lenticular chert also increases in this $15 \mathrm{~m}$ thick interval. Once again the beds become thicker than $1.0 \mathrm{~m}$ that is composed primarily of skeletal-peloid packstone and/or skeletal grain/rudstone with the upper-most portion of the member being silicified.

A $0.5 \mathrm{~m}$ thick "bed" of lenticular and nodular black chert is observed within a skeletal grain/rudstone in the Alapah upper member sections WF, NF, and EF2 (Figures 6). The chert bed may also exist in section FW; however, the upper part of section was not described because 
of indeterminable fault displacement. The chert bed distorts bed boundaries and is composed of nodular and lenticular black chert.

The upper-most Lisburne Group in the Forks area is rubbly and recessive (Figure 13). The rubbly interval is 11 to $33 \mathrm{~m}$ thick, appears to thin to the north, and may either be eroded upper Alapah, an unrecognized Alapah member, or lower Wahoo Limestone. It was not described in detail because of its recessive and rubbly nature. The rubbly limestone just below the prePermian Unconformity is upper-most Chesterian and is overlain by the recessive, red shales and siltstones of the Permian Sadlerochit Group. The pre-Upper Permian unconformity was either the result of simple erosion subsequent to a Permian drop in relative sea level, due to Permian uplift and related erosion, or a combination of both (Watts et al., 1995).

A change from the calcisphere-rich facies of the middle Alapah and lower-most Alapah upper member to packstones and grainstones with normal marine fauna and minor superficial ooids represents a change from an open platform setting to shoal and near shoal depositional environments. The increase in ostracods and peloids at and above the Chesterian-Meramecian boundary indicates a deepening to an open marine setting above fair-weather wave base. Skeletal packstones and grainstones in the upper third of the unit are interpreted to represent a return to a near shoal to shoal depositional environment.

\section{$\underline{\text { Facies Stacking Patterns }}$}

The arrangement of facies into vertical successions provides information about the change in depositional environments through time and by Walther's law provides insight into lateral facies relationships as well. The landward and seaward migration of facies recorded in vertical successions provides objective criteria for determining changes in relative sea level and will form the basis for our sequence stratigraphic analysis. Here we present empirically observed facies relationships based on outcrop data and petrographic analyses that can be used to subdivide the stratigraphic sections into a variety of cyclic or non-cyclic depositional packages that provide insight into the stratigraphic evolution of the Lisburne Group.

\section{Non-Cyclic Intervals}

Several intervals that do not contain pronounced cyclicity were identified in the (mainly the middle Wachsmuth and middle and upper Alapah Limestones) in the central-eastern Brooks Range. These intervals largely consist of various types of wackestone and cherty wackestone lithofacies that were deposited in subtidal environments that were likely below the depth of all but the most significant relative sea-level variations. In most cases the non-cyclic intervals are within transgressive portions of stratigraphic successions that deepen upward. Regressive packages more commonly contain shallowing upward cycles or parasequences.

\section{Parasequences}

Analysis of facies stacking patterns has permitted the identification of four different types of stratigraphic cycles or parasequences in the central-eastern Brooks Range. Type 1 parasequences (Figure 15) occur within the Wachsmuth middle and banded limestone members. 
They are between 4 and $25 \mathrm{~m}$ thick and contain skeletal wacke/packstones, bioclastic grainstones and rudstones, and finally bioturbated wackestones with banded or nodular black chert. The upper bioturbated wackestones tend to be thicker in the middle Wachsmuth as opposed to the banded limestone member. These parasequences record shoaling from middle ramp environments above fair-weather wave base through shoal or near shoal and finally restricted platform environments. 

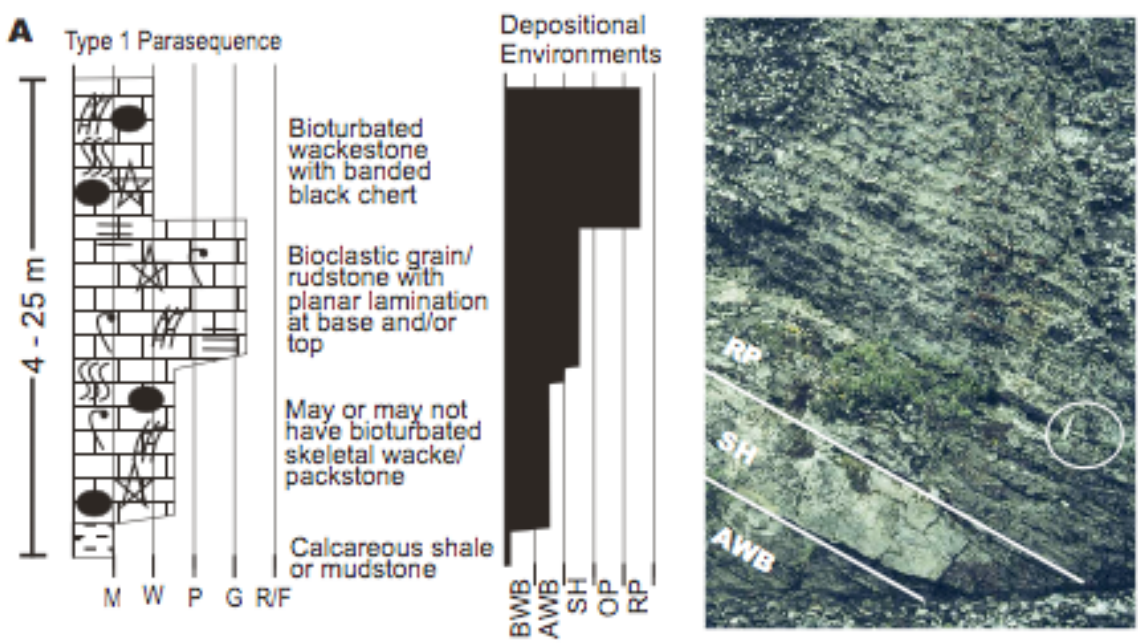

B Type 2 Parasequence
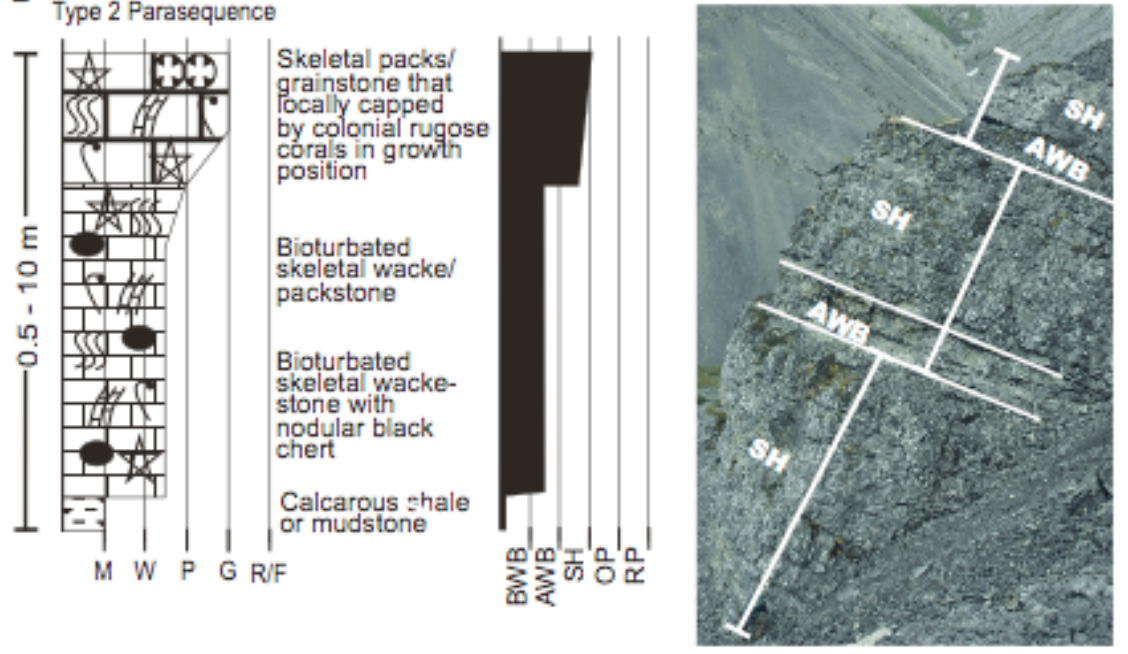

Figure 15. Type 1 and 2 parasequences. Left side illustrates parasequence thickness,

lithologies, and depositional interptation. Right hand side is an field photograph of characteristic outcrop expression of the parasequence. A. Type 1 parasequence that shallows-up from rare shale or mudstone through open marine skeletal wackestone/packstone to near shoal shoal bioclastic packstone/grainstone/rudstone, and is capped by a variable thickness of either open or restricted platform wackestone with banded black chert. Photograph illustrates a single parasequence, the top of which is off the photo, near the base of the middle Wachsmuth. B. Type 2 parasequence that coarsens-up fromlocal basal calcareous shales to skeletal wacke packstone and grainstone with local colonial rugose corals in growth position. Photograph illustrates three thinning upward parasequences (arrows) from the lowermost lower Alapah. Abbreviations are as follows: $\mathrm{M}=$ mudstone, $\mathrm{W}=$ wackestone, $\mathrm{P}=$ packstone, $\mathrm{G}=$ grainstone, $\mathrm{R} / \mathrm{F}=$ rudstone/floatstone, $\mathrm{BWB}=$ below fair-weather wavebase, $\mathrm{AWB}=$ above fair-weather wavebase, $\mathrm{SH}=$ shoal, $\mathrm{OP}=$ open platform, $\mathrm{RP}=$ restricted platform.

Type 2 parasequences occur in the lower Alapah (Figure 15) and have either calcareous shale or skeletal wackestones at the base. Facies then coarsen upward through bioturbated skeletal wacke/packstones and skeletal pack/grainstones. Locally, Type 2 parasequences are capped by in situ colonial rugose corals. These parasequences are from 0.5-10 m thick and record shallowing upward from open marine below or above fair-weather wave base deposits to near shoal/shoal environments with localized colonies of rugose corals that grew in quiet areas landward of the shoals There are approximately 5 Type 2 parasequences with thicknesses of approximately $6 \mathrm{~m}$ in well-exposed parasequences; however three of these parasequences are very thick and have numerous covered intervals that may mask additional flooding intervals. 
Type 3 parasequences (Figure 16) occur with in the middle Alapah are approximately 0.25 to 0.5 $\mathrm{m}$ thick, recessive, dark-colored, and have numerous covered intervals. Facies change from recessive platey lime mudstone to peloid-calcisphere wacke/packstone and peloid-brachiopodcalcisphere-ostracod wackepackstone. These parasequences record only minor change in water depths from open marine to open platform environments.
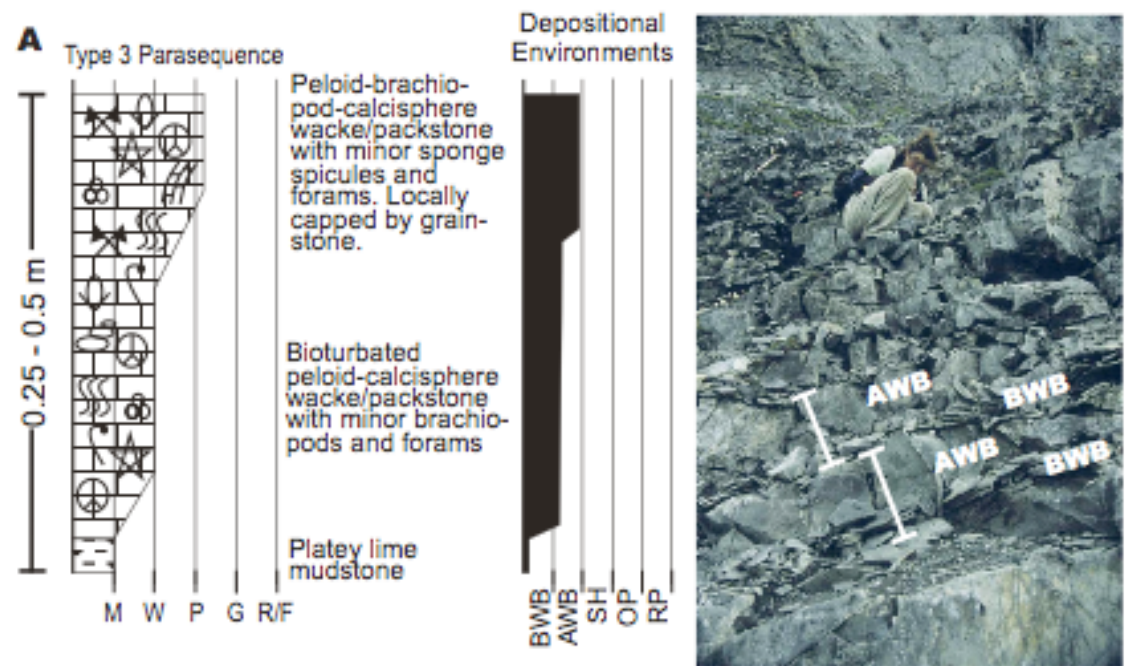

B
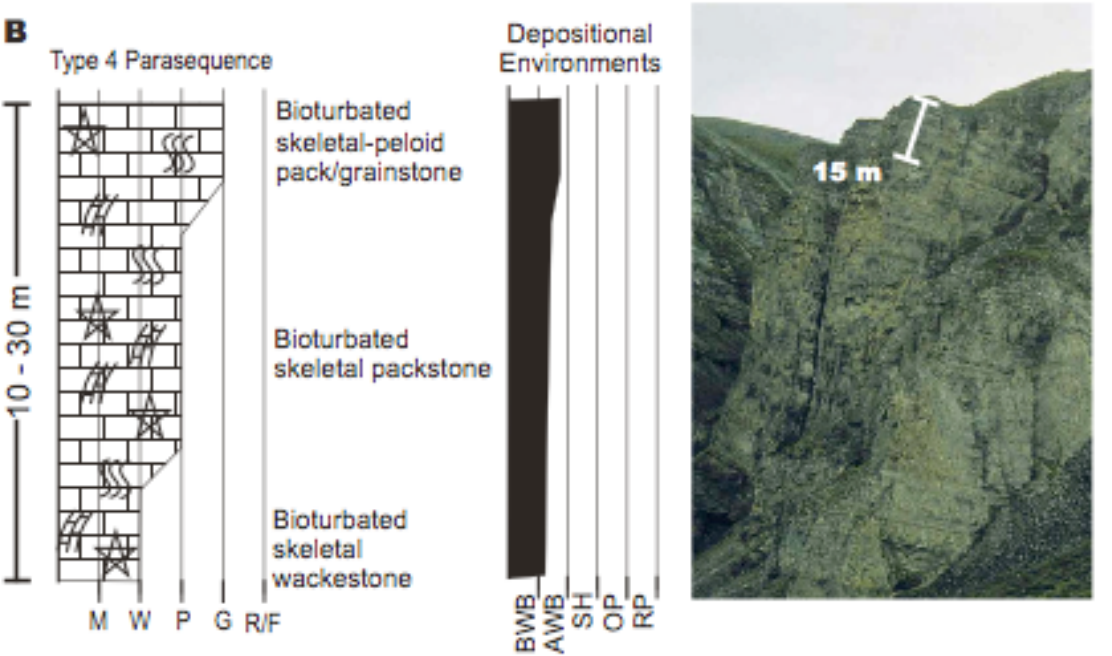

Figure 16. Type 3 and 4 Parasequences. Left side illustrates parasequence thickness, lithologies, and depositional interptation. Right hand side is an field photograph of characteristic outcrop expression of the parasequence. A) Generalized Type 3 parasequence that coarsens-up from platey lime mudstone to peloid-calcisphere wacke/packstone and peloid-brachiopodcalcisphere wack/packstone. Photograph illustrates two of these thin parasequences that occur only in the middle Alapah. B) Generalized Type 4 parasequence that shallows-up from open marine above wavebase to near shoal environments. Photograph illustrates one $15 \mathrm{~m}$ thick parasequence near the top of the upper Alapah. Abbreviations as in Figure 15.

Type 4 parasequences are 10-30 m thick packages in the upper Alapah (Figure 16). They record change from bioturbated skeletal wackestones, to bioturbated skeletal packstone, to bioturbated 
skeletal-peloid pack/grainstone. Depositional environments in these parasequences fluctuated from open marine above fair-weather wave base settings to near shoal environments producing thick packages of sediment that show minimal variation in relative water depth within the parasequence (Figure 16). Several covered intervals in the upper Alapah may have obscured some parasequence boundaries.

\section{$\underline{\text { Biostratigraphy }}$}

\section{Conodonts}

One 3-8 kg conodont sample was collected every 40-80 meters. A total of sixty samples from the central-eastern Brooks Range were processed, picked, and identified for conodonts. Conodont biostratigraphy was completed by Andrea Krumhardt at the University of Alaska Fairbanks where samples were crushed, processed in glacial acetic acid, subjected to heavy mineral separation, picked, and identified for conodonts according to standard procedures (Stone, 1987). Conodont recovery from the samples was generally poor; the most abundant sample only yielded 30 elements per kilogram. Elements are commonly abraded and broken and have a sugary texture indicating exposure to caustic hydrothermal fluids. In addition, dolomite crystals are in some cases stuck to the surface of the elements making positive identification difficult. Preliminary analysis of the color alteration indices (CAI) ranged from 4.5 to 6 with the values of 6 most likely hydrothermally induced.

Age determinations for samples range from the Early to Late Mississippian (Table 2). Precise series assignments for the Wachsmuth and lower Alapah cannot be determined due to a lack of short ranging conodont species. Age assignments for the middle and upper Alapah are a bit more precise and indicate a general temporal correlation of the upper Alapah of the centraleastern Brooks Range with the entire Alapah in the northeastern Brooks Range. Series age assignments by member are outlined in Table 2 .

\begin{tabular}{|l|l|l|}
\hline Member & Conodont Age Date & Foram Age Date \\
\hline $\begin{array}{l}\text { Wachsmuth Crinoidal } \\
\text { Limestone }\end{array}$ & Osagean to early Chesterian & \\
\hline Middle Wachsmuth & Osagean to early Chesterian & \\
\hline $\begin{array}{l}\text { Wachsmuth Banded } \\
\text { Limestone }\end{array}$ & Osagean to early Chesterian & late to latest Osagean \\
\hline Lower Alapah & Osagean to early Chesterian & Meramecian \\
\hline Middle Alapah & $\begin{array}{l}\text { late Meramecian to early } \\
\text { Chesterian }\end{array}$ & \\
\hline Upper Alapah & $\begin{array}{l}\text { late Meramecian to early } \\
\text { Chesterian }\end{array}$ & Meramecian \\
\hline
\end{tabular}

Table 2. Age assignments for Lisburne Group Formation members from central-eastern Brooks Range. 
Foraminifera

Selected thin sections with abundant forams were sent to Paul Brenckle for biostratigraphic analysis. Brenkle examined 31 thin sections and determined that none of the rocks examined are older than early Osagean with the oldest verifiable date of Meramecian (Table 2). The foram assemblage is not highly diverse and there are few short-ranging taxa to tie directly to other occurrences in North America or Eurasia. A late Osagean (early Visean) age can be assigned to samples from the middle of the Wachsmuth banded limestone member based on the occurrences of Eoendothyranopsis, Skippella and Globoendothyra. The interval approximately equates to the Keokuk-lower Warsaw formations of the type Mississippian. Specimens similar to primitive Paraarchaediscus sp. In samples from the top of the banded limestone member also occur within the latest Osagean (lower Warsaw Formation) in the Mississippi River Valley suggesting that the lowest Alapah correlates approximately to an interval around the OsageanMeramecian (early-late Visean) boundary. The presence of Endothyranopsis compressa, Dainella? anivikensis and possible Neoparadainella in the lower Alapah upper Member suggests correlation to the early part of the late Visean (Tulsky? Horizon of the Russian Platform) and by extrapolation to the early Meramecian of the Midcontinent.

These age assignments are generally in good agreement with age dates determined from conodonts and provide us with some age data that conodonts did not. Forams help constrain the middle of the Wachsmuth banded limestone member to the late Osagean and further constraining the Osagean/Meramecian boundary . However, the early Meramecian call for one sample in the lower upper Alapah appears to be at odds with the conodont date of late Meramecian to early Chesterian. Samples from the lowermost Alapah in the central-eastern Brooks Range are dated as near the Osagean-Meramecian boundary so the boundary between the Wachsmuth and Alapah Limestones is relatively well constrained but Chesterian rocks have not definitively been identified so the Meramec-Chester boundary has not been pinned down stratigraphically.

\section{Outcrop Gamma Ray Data}

Gamma ray data were collected in the eastern Sadlerochit Mountains and the central Shublik Mountains to aid with correlation to the subsurface (Figures 17, 18). Data from the eastern Sadlerochit Mountains provided the most continuous outcrop exposure and detailed gamma ray data were collected through five partial stratigraphic sections at this locality. Four of these sections (ES -1 through 4) represent a relatively continuous succession from the lower Alapah through the lower upper Wahoo Limestones. The fifth section (ES-5) was in the lower Alapah Limestone and provides preliminary correlations between ES-1 and ES-5 based on gamma ray curves. In the central Shublik Mountains (section FC-1) exposure was less continuous but we were able to collect considerable gamma ray data through well exposed portions of the outcrop. In general, the Alapah Limestone appears to exhibit a higher degree of variation in gamma ray signature than the Wahoo. Peaks in gamma ray signature are most commonly associated with the bases of stratigraphic cycles where argillaceous facies or thin covered intervals, that probably represent non-resistant shaly facies, are present. Local gamma ray peaks in the upper portions of some stratigraphic cycles appear to coincide with cherty or stylolitized horizons and might be related to diagenesis. 


\section{Subsurface Analysis}

The Lisburne Group, specifically the Wahoo Limestone, is the principal reservoir in the Lisburne Field at Prudhoe Bay (Missman and Jameson, 1991; Jameson, 1994). The Lisburne Group is approximately 1600-2000 feet (500-600 m) thick at Prudhoe Bay and is subdivided into Mississippian Alapah and Pennsylvanian Wahoo Formations (Figure 17; Jameson, 1994). Each formation is further subdivided into zones that are bounded by shales (Missman and Jameson, 1991; Jameson, 1994; Watts et al., 1995). Most subsurface work has focused on the Wahoo Limestone because it is currently producing oil (Missman and Jameson, 1991; Jameson, 1994). The medial dolomite unit (Bird and Jordan, 1977; dolomite interval, Jamison et al., 1980; Alapah $\mathrm{C}$ of this study) has also received some attention because of its favorable reservoir potential, but it is below the oil-water contact (Bird and Jordan, 1977).

Well logs from five wells and core from three of those wells along a northeast-southwest transect west of Prudhoe Bay (Figure 18) were examined to determine depositional environments and parasequence facies stacking patterns and thickness. The cores and associated thin sections were described during an internship with ConocoPhillips. Descriptions were completed at inch scale and include: depositional textures (Dunham, 1962; Embry and Klovan, 1971), sedimentary structures, faunal components, chert content, dolostone, and types and amount of porosity.

\section{North Slope Stratigraphy And Parasequences}

The Lisburne Group at Prudhoe Bay is underlain by the Kekiktuk Conglomerate and Kayak Shale of the Mississippian Endicott Group and intermittently by the Itkilyariak Formation. The Kekituk Conglomerate was first recognized in the northeastern Brooks Range by Brosgé et al. (1962) and it consists of sandstone and conglomerate that was deposited in a fluvial depositional environment overlying the pre-Mississippian basement (Brosgé et al., 1962; Nilsen, 1981; Melvin, 1987; LePain, 1993; LePain et al., 1994). The Kekiktuk Conglomerate in the North Slope subsurface is thicker and finer-grained than the coeval rocks in the northeastern Brooks Range (LePain, 1993). With continued transgression, the Kekiktuk Conglomerate grades upward into the marginal marine black organic-rich shales and siltstones of the Kayak Shale (LePain, 1993).

The red and gray sandy fossiliferous limestones and calcareous sandstone of the Itkilyariak Formation gradationally overlies the Endicott Group in the northern-most areas of the North Slope subsurface (Mull and Mangus, 1972; Armstrong and Mamet, 1974; Jamison et al., 1980; Woidneck et al., 1987). In the northeastern Brooks Range, the Itkilyariak Formation occurs in the eastern Sadlerochit Mountains where the Endicott Group is absent (Watts et al., 1995). The Itkilyariak Formation in the northeastern Brooks Range consists of sandy and silty limestones occurring in 5 to $10 \mathrm{~m}$ thick discontinuous lenses representing near-shore transgressive sediments that filled paleovalleys where underlying sandy sediments became mixed with carbonates (Armstrong and Mamet, 1974; Bird and Jordan, 1977; Jamison et al., 1980). The Itkilyariak Formation was originally included at the top of the Endicott Group (Mull and Mangus, 1972), but Watts et al. (1995) suggests that for mapping purposes it may be easiest to 


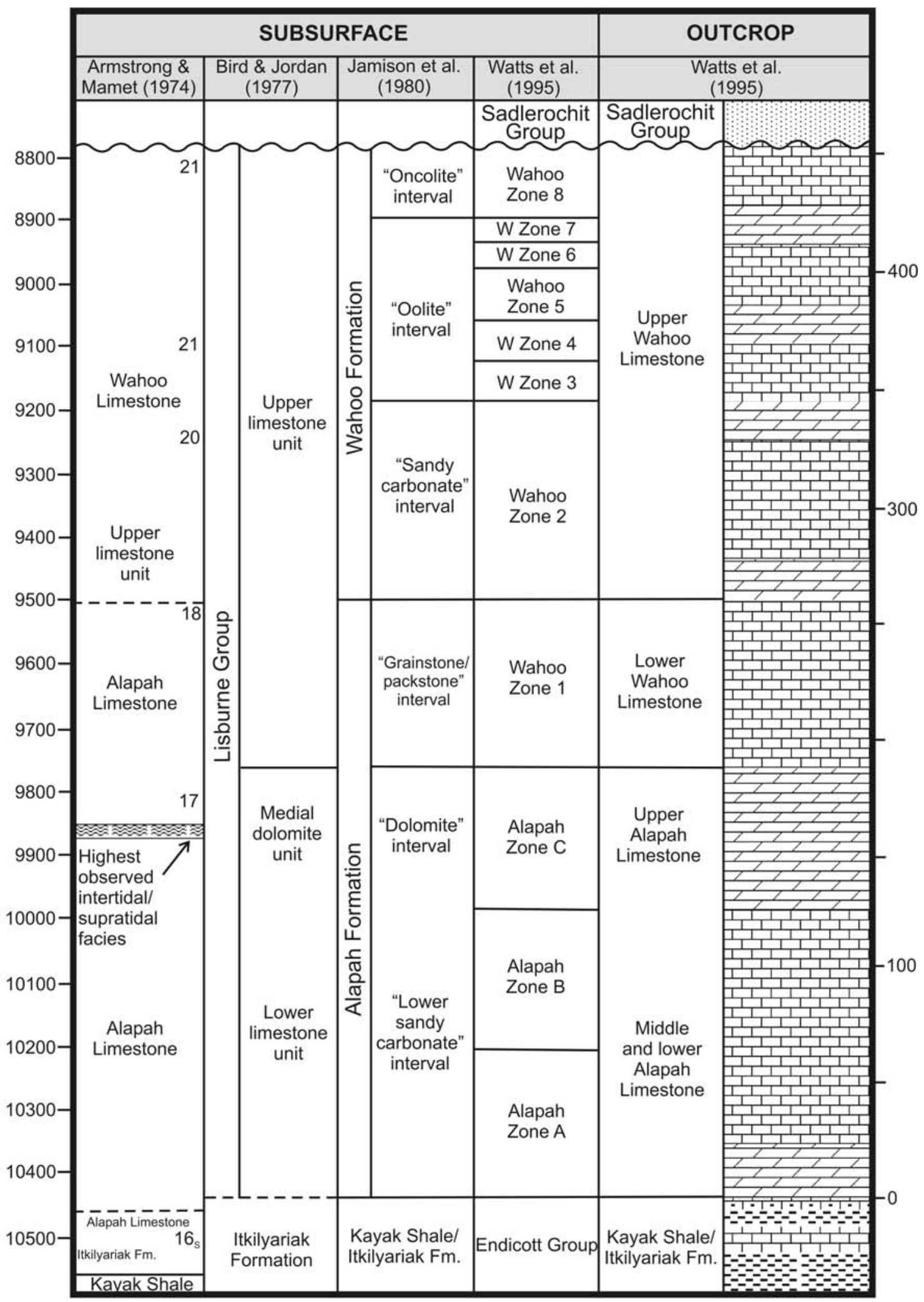

Figure 17. Subsurface-to-surface correlation and stratigraphic nomenclature. Subsurface depths are in feet and are from Prudhoe Bay State \# 1 (Jamison et al., 1980). Surface thicknesses are in meters. Modified from Watts et al., (1995). 
include it in the Lisburne Group. The Endicott Group and the Itkilyariak Formation, where present, gradually grade into the shallow marine carbonates of the Lisburne Group.

The Lisburne Group at Prudhoe Bay was deposited in shallow-marine depositional environments and consists of limestone and dolostone with varying amounts of shale, sandstone, chert, and replaced evaporites (Bird and Jordan, 1977). Shale and sandstone abundance increase from the northeastern Brooks Range to Prudhoe Bay (Bird and Jordan, 1977; Watts et al., 1995). The Lisburne Group is subdivided into the Alapah and Wahoo Limestones (Figures 17, 18). In the subsurface, the Alapah Limestone is subdivided into zones A through E and the Wahoo is subdivided into zones 1 through 7 on the basis of regionally correlatable shales (Jameson, 1994). A thick green shale corresponding to the first thick interval with a high gamma ray response forms the boundary between the Alapah and Wahoo Limestones (Jameson, 1994; Watts et al., 1995).

Throughout the northeastern Brooks Range, the Lisburne Group is truncated by the pre-Upper Permian Unconformity and is overlain by the greenish-gray argillaceous sandstone and shale transgressive sediments of the Echooka Formation of the Sadlerochit Group (Detterman, 1970; Bird and Jordan, 1977). The Echooka Formation thins and is ultimately absent near Prudhoe Bay (Detterman, 1970; Eckelmann et al, 1975; Bird and Jordan, 1977). At Prudhoe Bay the Lisburne Group is unconformably overlain by the prodelta facies of the Kavik Member of the Ivishak Formation (Sadlerochit Group; Detterman, 1970; Eckelmann et al., 1975; Bird and Jordan, 1977). The Lower Cretaceous Unconformity removed a significant portion of the upper Ellesmerian Sequence (Mississippian through Jurassic) east of Prudhoe Bay (Figure 1.1; Jamison et al., 1980), leaving the Lisburne Group unconformably overlain by the Cretaceous marine calcareous shales of the Brookian Sequence (Lerand, 1973; Bird and Jordan, 1977; Watts et al., 1995).

Watts et al. (1995) revised the subsurface subdivisions by attempting to correlate units between outcrops in the northeastern Brooks Range and the subsurface. Watts et al. (1995) suggested that the north slope Alapah $\mathrm{C}$ dolomites correspond to the upper Alapah spiculitic dolomites and dolomitic lime mudstones/wackestones in the northeastern Brooks Range. They further suggested that the green shale represented by the second thick interval a with high gamma ray response corresponds to an increase in siliciclastics and the sequence boundary between the Alapah and Wahoo Limestones in the northeastern Brooks Range and should therefore be considered the Alapah-Wahoo boundary in the subsurface. With this redefinition of the AlapahWahoo boundary, the Alapah Limestone in the subsurface is subdivided into three zones (A, B, and C), not five. Alapah Zones D and E now form the Wahoo Zone 1. The top of Wahoo Zone 1 is now placed at the shale that is represented by the first thick interval with a high gamma ray response, which also corresponds to an increase in siliciclastics and a sequence boundary at the top of the lower Wahoo Limestone in the northeastern Brooks Range (Watts et al., 1995). With this redefinition of nomenclature, the Wahoo Limestone in the well studied in Watts et al. (1995) is subdivided into 8 zones (Figure 17, 18).

Our subdivisions of the Lisburne Group at Prudhoe Bay incorporate the revisions made by Watts et al. (1995; Figures 17, 18). The Alapah-Wahoo boundary is placed at the second downhole interval with high gamma ray response. The Alapah Limestone is subdivided into three zones 


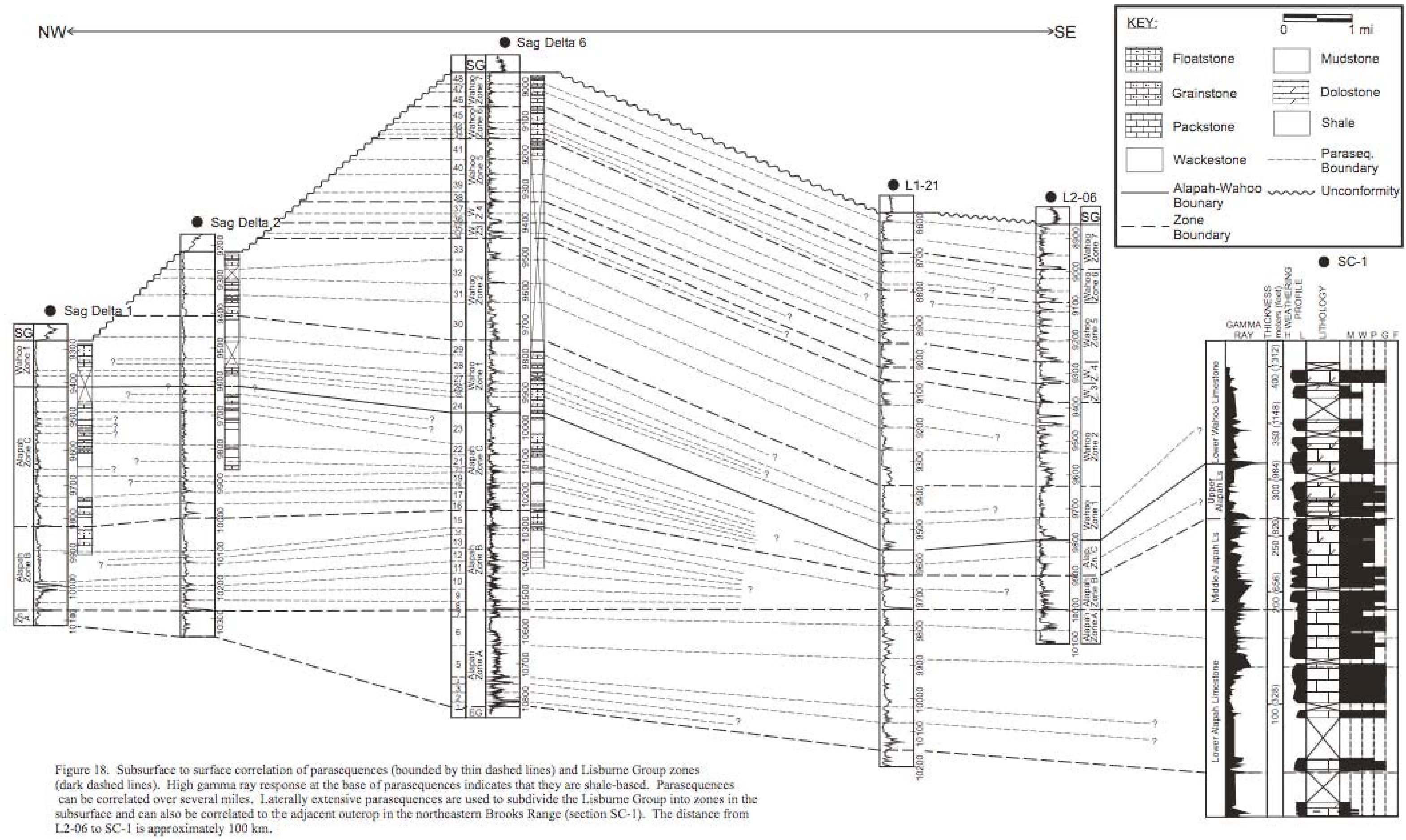


(A, B, and C) and the Wahoo Limestone into seven zones (1 through 7). In the wells studied, erosion associated with the pre-Upper Permian Unconformity is greatest to the north in Sag Delta 1 (Figure 18). Zonation of the Lisburne Group in this study is based on regionally correlatable shales with relatively high gamma ray response. Each zone defined below shares a similar pattern of elevated gamma ray response at the base and a general progressive decline in gamma ray response upsection ("cleaning-upward" trend) followed by a gamma ray spike indicating the base of the next zone. This implies that the clay content decreases in each zone with progressively more carbonate-rich facies upsection. It is unclear whether the individual shaly intervals at the bases of zones indicate abrupt flooding, incipient drowning, and a temporary decrease in carbonate production (Osleger and Read, 1991) or if they represent progradation of fine-grained siliciclastics at relative sea-level lowstand (Watts et al., 1995).

\section{Alapah Limestone}

Alapah zones A and B correspond to Bird and Jordan's (1977) lower limestone unit and Jamison et al.'s (1980) lower sandy carbonate interval (Figure 4.1). Alapah Zone C corresponds to Bird and Jordan's (1977) medial dolomite and Jamison et al.'s (1980) dolomite interval (Figure 18). Alapah Zone A is approximately 75 to 300 feet (22.9 to $91.4 \mathrm{~m})$ thick, begins above the Endicott Group, and thins to the north (Figure 4.3). Alapah Zone A consists primarily of "dirty" limestone with minor amounts of shale and dolomitic limestone and is composed of seven parasequences that range between 12.0 and 93.3 feet (3.7 and $28.4 \mathrm{~m}$; Figure 18) thick with an average thickness of 40.1 feet $(12.2 \mathrm{~m})$. The composition of the parasequences in the Alapah Zone A are unknown because the cores studied did not penetrate the unit.

Alapah Zone B begins at a third, but much thinner, down-hole interval with a high gamma ray response. Alapah Zone B is between 50 and 250 feet (15.2 to $76.2 \mathrm{~m}$ ) thick, thins to the south, consists of limestone with minor amounts of shale and dolomitic limestone (Figure 18), and is composed of eight parasequences that range in thickness between 21.4 and 49.5 feet ( 6.5 and $15.1 \mathrm{~m}$; Figure 18), with an average thickness of 37.3 feet $(11.4 \mathrm{~m})$. Parasequences observed in core have thin green shale bases that coarsen-upward into thick packages of cross-bedded and/or planar laminated oolitic-skeletal grainstones (shoal) and then fine-upward into highly bioturbated skeletal wacke/packstone with minor brachiopods and solitary rugose corals (open platform). The parasequences of Alapah Zone B are rarely capped by algal laminations (intertidal).

Alapah Zone $\mathrm{C}$ is 100 to 400 feet ( 30.5 to $121.9 \mathrm{~m}$ ) thick, being thinnest to the south, and is characterized mainly by diagenetic features such as dolostone, evaporites, and karst (Figures 18), which makes this zone difficult to correlate over very large distances. Alapah Zone $\mathrm{C}$ is composed of eight parasequences that range in thickness between 12.0 and 91.0 feet (3.7 and $27.7 \mathrm{~m}$; Figure 18), with an average parasequence thickness of 35.6 feet $(10.8 \mathrm{~m})$. Alapah Zone $\mathrm{C}$ is primarily dolostone with rare, thin limestone and shale intervals. Thin shales occur at the base of several parasequences, but generally the parasequences have a thin skeletal-oolitic packstone to grainstone base (shoal) and fine-upward into dolomitic skeletal wackestone to packstone (open platform) and are often capped by thick packages with microbial laminations, calcite- and/or silica-replaced evaporite nodules, and evidence of karst. Karst zones commonly consist of auto-brecciated intervals and solution cavities with abundant calcite spar cement and are often associated with green shale, carbonate, and chert clast paleocave deposits. Regionally 
correlatable porous and permeable zones occur at the base and top of the Alapah Zone C. The Alapah Zone $\mathrm{C}$ also has numerous thin porous and permeable zones that occur throughout the unit, but are generally localized and cannot be correlated between more than two or three wells.

\section{Wahoo Limestone}

Our subdivision of the Wahoo Limestone into eight zones is similar to the subdivision of Jameson et al. (1994) and is based on the positions of regionally correlatable shales as previously noted by Watts et al. (1995). These shales are relatively easy to identify in well logs and they correspond to green shales that are generally several feet thick in core. A significant portion of the Wahoo Limestone (zones 3 through 7) was removed by erosion associated with the preUpper Permian Unconformity north of Sag Delta 6. The Wahoo Limestone (Zones 1-7) corresponds to the upper limestone unit of Bird and Jordan (1977; Figure 18). Jamison et al. (1980; Figure 18) subdivided the Wahoo Limestone into a grainstone/packstone interval (Wahoo Zone 1), a sandy carbonate interval (my Wahoo Zone 2), an oolitic interval (Wahoo Zones 3-5), and an oncolitic interval (Wahoo Zones 6-7).

Wahoo Zone 1 is correlative with the lower Wahoo member in Brooks Range outcrops. The base of Zone 1 is represented by a thick green shale overlying Alapah Zone C. The top of Zone 1 is the last carbonate interval overlain by the second thick green shale within the Wahoo. These shales are represented in well logs by the first and second thick down-hole intervals with high gamma ray response. Wahoo Zone 1 ranges in thickness between 125 to 200 feet (38.1 to $61 \mathrm{~m}$ ), is truncated to the north in Sag Delta 1, and thins to the south of Sag Delta 6 (Figure 18). Six parasequences were identified in the Wahoo Zone 1 (Figure 4.5). Parasequence thickness ranges between 15.1 and 52.6 feet $(4.6$ and $16.0 \mathrm{~m})$ with an average thickness of 39.2 feet $(11.9 \mathrm{~m})$. Parasequences in core generally consist of thick skeletal-oolitic packstone to grainstone (shoal) that fines-up into dolomitized skeletal wackestone (open platform). Quartz sand becomes abundant in the upper third of the Wahoo Zone 1.

The base of Wahoo Zone 2 coincides with a sharp contact between carbonates of zone 1 and a thick green shale interveral that is represented by a high gamma ray response. Wahoo Zone 2 is missing in Sag Delta 1, truncated in Sag Delta 2, is 300 feet $(91.4 \mathrm{~m})$ thick in Sag Delta 6, and thins slightly to the south (275 feet or $83.8 \mathrm{~m}$; Figure 18). Four parasequences were identified in Wahoo Zone 2 and are between 50.5 and 112.0 feet (15.4 and $34.1 \mathrm{~m}$; Figure 18) thick with an average thickness of 74.5 feet $(22.8 \mathrm{~m})$. Parasequences of the Wahoo Zone 2 fine-upward from quartz-rich oolitic-skeletal grainstone deposited in a high-energy shoal to skeletal wackestone and packstone deposited in an open platform setting that was rarely subjected to subaerial exposure. Wahoo Zone 2 contains the highest amount of quartz sand when compared to other Lisburne Group units.

The base of Wahoo Zone 3 is represented in core by an abrupt gamma ray spike overlying the last carbonate-rich facies of Zone 2. Wahoo Zone 3 is absent in Sag Delta 1 and 2 and is approximately 40 feet $(12.2 \mathrm{~m})$ thick in the remaining wells studied (Figure 18). Two parasequences with thicknesses of 15.1 and 26.0 feet (4.6 and $7.9 \mathrm{~m}$; Figure 18) were identified in the Wahoo Zone 3. The composition of the parasequences in the Wahoo Zone 3 is unknown 
because the interval was not cored in Sag Delta 6 and it has been removed by erosion associated with the pre-Upper Permian Unconformity in Sag Delta 1 and 2.

The base of Wahoo Zone 4 is represented by an abrupt gamma ray spike overlying the last carbonate-rich facies of Zone 3. Wahoo Zone 4 is also absent in Sag Delta 1 and 2 and has a relatively uniform thickness of 64 feet $(19.5 \mathrm{~m})$ in the remaining wells studied (Figure 18). Two parasequences were identified in the Wahoo Zone 4. The parasequences have thicknesses of 26.0 and 37.0 feet (7.9 and $11.3 \mathrm{~m}$; Figure 18). The composition of the parasequences in the Wahoo Zone 4 is unknown because the interval was not cored in Sag Delta 6 and it has been removed by erosion associated with the pre-Upper Permian Unconformity in Sag Delta 1 and 2.

The base of Wahoo Zone 5 is represented by an abrupt gamma ray spike overlying the last carbonate-rich facies of Zone 4. Wahoo Zone 5 has a thickness of approximately 175 feet $(53.3$ m) from Sag Delta 6 to the south (Figure 18). Wahoo Zone 5 consists of four parasequences that are between 26.0 and 62.0 feet (7.9 and $18.9 \mathrm{~m}$; Figure 18) thick, with an average thickness of 45.5 feet $(14 \mathrm{~m})$. Only the upper-most parasequences in the Wahoo Zone 5 were cored. At the base of the parasequences is a thick package of oolitic-skeletal grainstone deposited in a shoal environment that shallows-upward into highly bioturbated mudstones deposited in an open platform setting.

The base of Wahoo Zone 6 is represented by an abrupt gamma ray spike associated with a thick green shale in lower-most Wahoo Zone 6.overlying the last carbonate-rich facies of Zone 5. Wahoo Zone 6 has a thickness of approximately 100 feet $(30.5 \mathrm{~m})$ in Sag Delta 6, L1-21, and L2-06 (Figure 4.3). Four parasequences were identified in the Wahoo Zone 6. These parasequences are between 12.0 and 46.4 feet (3.7 and $14.1 \mathrm{~m}$; Figure 18) thick and have an average thickness of 22.8 feet $(7.1 \mathrm{~m})$. Parasequences of the Wahoo Zone 6 shallow from ooliticskeletal grainstones deposited in a high-energy shoal setting to skeletal wackestones/packstones deposited in an open platform environment. This zone corresponds to Jamison et al.'s (1980) oncolite interval, however, no oncolites were observed in core and thin section coverage of this interval was poor.

The base of Wahoo Zone 7 is represented by an abrupt gamma ray spike and a thick green shale overlying the last carbonate-rich facies of Zone 6. Wahoo Zone 7 has a thickness of 100 to 125 feet $(30.5$ to $38.1 \mathrm{~m})$, being slightly thicker to the south (Figure 18). Three parasequences were identified in the Wahoo Zone 7 and are between 24.5 and 43.3 feet (7.5 and $13.2 \mathrm{~m}$; Figure 4.5) thick, with an average thickness of 33.9 feet $(10.3 \mathrm{~m})$. The upper part of the Wahoo Zone 7 has been truncated by erosion associated with the pre-Upper Permian Unconformity. Wahoo Zone 7 parasequences commonly consist of thick skeletal-oolitic grainstone deposited in a shoal setting and fine-upward into a thin package of bioturbated skeletal wacke/packstone (open platform) that is rarely subaerially exposed as indicated by rare mudcracks. Even though the Wahoo Zone 7 corresponds to Jamison et al.'s (1980) Wahoo oncolite interval (Figure 18), no oncolites were observed in core. However, thin section coverage of this zone is sparse. 


\section{$\underline{\text { Subsurface To Surface Correlation }}$}

Surface to subsurface stratigraphic correlation of the Lisburne Group is facilitated by shales, influx of terrigenous sediment, and lithofacies that occur in both the subsurface at Prudhoe Bay and in the adjacent northeastern Brooks Range outcrops (Figure 18). The Lisburne Group at Prudhoe Bay is subdivided using shales that can be correlated across the North Slope and in outcrop by changes in weathering patterns and lithofacies. Shales occurring at the base of the parasequences in the subsurface are often difficult to correlate to the adjacent outcrop because of poor exposure and numerous covered intervals.

The Alapah-Wahoo boundary in the subsurface is gradational and occurs within a thick interval of green shale/siltstone. Significant karst development within the Alapah Zone C and the influx of quartz sand in the upper-most Alapah Limestone represents a major lowstand in relative sea level and a sequence boundary and is overlain by the packstones and grainstones of the Wahoo Limestone (Watts et al., 1995). The Alapah-Wahoo boundary in the northeastern Brooks Range also corresponds to a major lowstand in relative sea level and a sequence boundary (Watts et al., 1995). The upper-most Alapah consists of dark-colored, slope-forming spiculitic dolomitic mudstone with minor terrigenous sediment deposited in restricted platform and intertidal depositional environments. The Alapah Limestone is overlain by the light-colored, cliffforming, coarse-grained packstones and grainstones of the Wahoo Limestone.

In the subsurface, the boundary between Wahoo Zones 1 and 2 is also marked by a thick interval of green shale/siltstone and green shaley limestone and high terrigenous input that corresponds to a maximum regression and a sequence boundary (Watts et al., 1995). Wahoo Zone 1 is characterized few indistinct parasequences of bryozoan-pelmatozoan wackestone, packstone, grainstone, peloidal packstone and grainstone, and minor superficial oolitic and oolitic grainstone and dolostone (Watts et al., 1995). Numerous thin parasequences composed of a variety of lithologies characterizes the Wahoo Zones 2 through 7. The Wahoo Limestone in the adjacent northeastern Brooks Range outcrops share several characteristics with the Wahoo Limestone in the subsurface. In outcrop, the lower Wahoo Limestone contains few indistinct parasequences of bryozoan-pelmatozoan wackestone, packstone, and grainstone and the upper Wahoo Limestone is composed of numerous thin parasequences with a variety of lithologies (Gruzlovic, 1991). The maximum lowstand in relative sea level and a sequence boundary occurs near the boundary between the members (Watts et al., 1995).

\section{Sequence Stratigraphy}

Watts et al. (1995) proposed the only sequence stratigraphic analysis of the Lisburne Group to date. Their work was based exclusively on outcrops in the northeastern Brooks Range and subdivided the Alapah and Wahoo Limestones into 3 sequences. Our analysis builds on that work and provides perspective for recognition of part of an additional sequence in the northeastern Brooks Range and two older sequences in the more distal central-eastern Brooks Range (Fig. 19). The major criteria used to define our sequence stratigraphic subdivision are facies stacking patterns, large scale stratal geometries, and the identification of flooding and subaerial exposure surfaces. 


\section{Central-Eastern Brooks Range}

The stratigraphic data outlined in the previous section provide the criteria for our sequence stratigraphic interpretations for the central-eastern Brooks Range. Unfortunately a basal contact of the Lisburne with the underlying Kayak Shale was never identified in the distal central-eastern Brooks Range. These lowermost exposed rocks appear to expose a portion of a transgressive package overlying the Kayak. If any lowstand facies were deposited they are within the underlying Kayak Shale. The nature of the underlying sequence boundary also remains undocumented in this distal location but nearby exposures of a thin Kekiktut conglomerate underlying the Kayak might indicate lowstand deposits overlying a subaerial exposure surface.

\section{Sequence 1}

The base of sequence one is not exposed in the central-eastern Brooks Range field areas (Figure 19). The sequence boundary likely occurs within the Endicott Group which overlies preMississippian rocks and underlies the Wachsmuth Limestone. The upper Endicott Group Kayak Shale was documented at the Bear Creek locality but the unit is complexly folded. Kayak Shale exposures further to the north represent younger rocks deposited during progressive northward onlap of the Kayak and Lisburne through the Mississippian. One could speculate that a Type 1 sequence boundary might occur within the Kekiktut conglomerate that was dominantly deposited in fluvial environments with onlap of the Kayak Shale indicating initial transgression. The lack of exposure of these units precludes any detailed sequence stratigraphic inferences.

The lower Crinoidal member of the Wachsmuth Limestone consists of a series of erosionally based fining upward Type 1 parasequences that generally thicken upward. Facies indicate deposition from below fairweather wave base to near storm wavebase. This packages forms a landward thinning wedge-shaped unit that either onlaps or laterally grades into Kayak Shale in the southernmost northeastern Brooks Range. The facies stacking pattern and general onlapping nature indicates progressively increasing accommodation and a retrogradational transgressive systems tract (TST; Figure 19).

The overlying middle Wachsmuth Limestone records a series of progressively shallowing parasequences (Figure 20) that contain more abundant coarser-grained and dolomitized units upsection. Parasequences are generally thin and develop shaly bases upsection indicating decreasing accommodation space and a decrease in carbonate production and/or an increase in clastic sedimentation near parasequence boundaries. Facies within parasequences shoal-upward and record deposition in open platform to shoal environments and ultimately restricted platform environments at the top of the sequence. The coarser grained facies indicate the maximum shallowing recorded within the sequence and the first establishment of shoal environments in the Lisburne. The thinning upward facies stacking patterns, dolomitization, and generally coarsergrained shoaling deposits in the middle Wachsmuth indicate progradation and regressive conditions indicating deposition as a highstand systems tract (HST; Figures 19, 21). The uppermost restricted platform facies may have been slightly deeper than seaward shoals but they represent continued progradation and the final deposits of sequence 1 . The overlying sequence boundary appears to be a correlative conformity. No updip subaerial unconformity was 


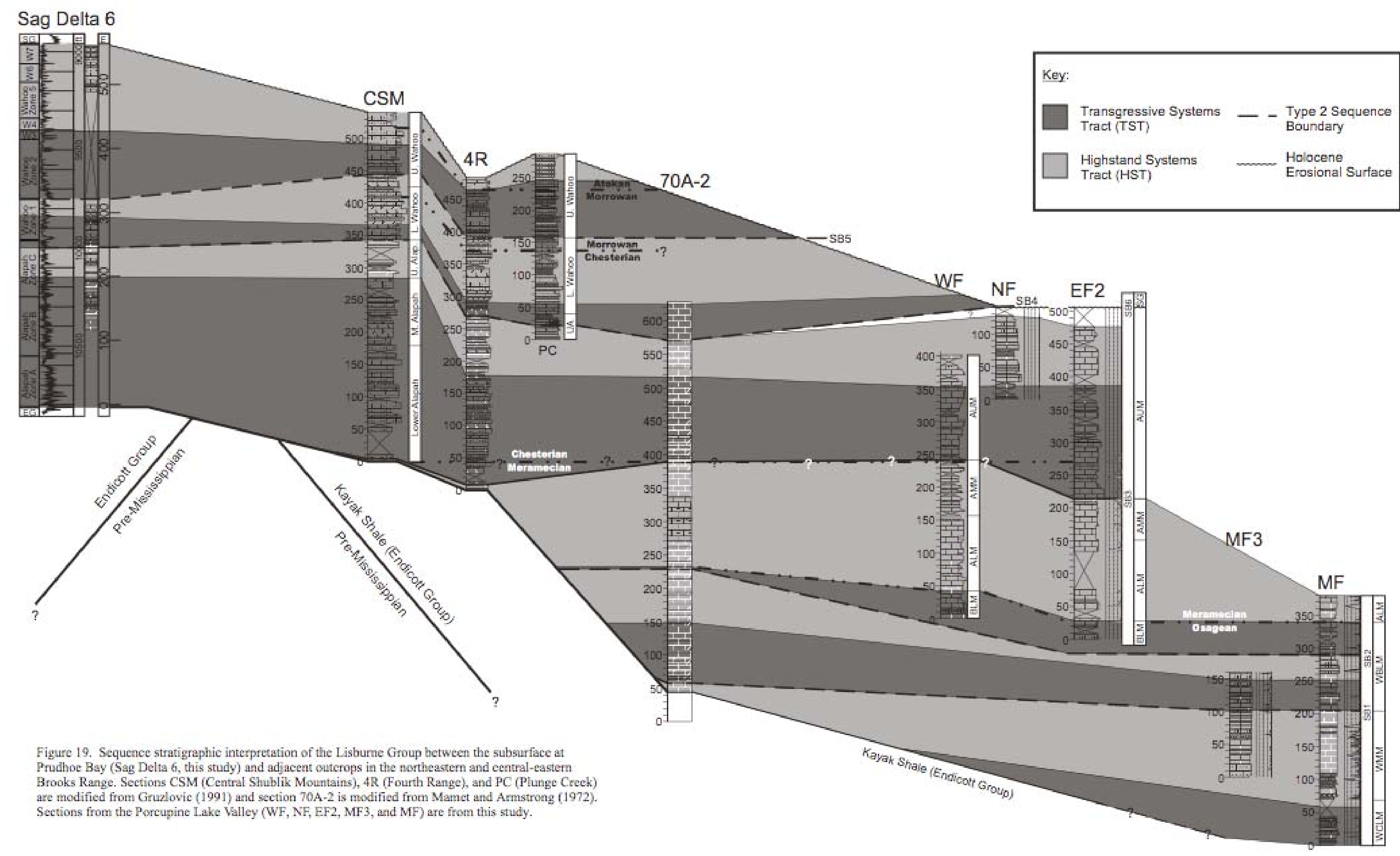


documented in the central-eastern or northeastern Brooks Range. The exposed portion of sequence 1 is approximately $200 \mathrm{~m}$ thick in the central-eastern Brooks Range and the package onlaps and pinches out to the south of the northeastern Brooks Range (Figures 19, 21).

\section{Sequence 2}

The top of the middle Wachsmuth is a pronounced flooding surface overlain by deeper-water facies of the lower Banded Limestone Member and is interpreted as a sequence boundary (SB-1; Figure 19). Facies stacking patterns in the lower Banded Limestone member continue to record significant terrigenous input with shaly based parasequences (Figure 20) that shoal upward to wackestones or packstones. Shaly bases laterally appear to grade into spicule-rich foram wackestones. The general increase in the proportion of shale in parasequences upsection likely indicates a decrease in carbonate production during flooding intervals and maximum flooding appears to occur with the second of two meter-thick calcareous shale units that represent the top of the TST (Figures 19, 21). Above this shale, are a series of Type 1 parasequences. Facies become progressively grainier, from skeletal wacke/packstone to skeletal-peloid pack/grainstone indicating open platform and shoal facies. These facies are overlain by a series of thin meterscale shale-based parasequences indicating decreasing accommodation space and deposition in restricted and open platform environments (Figure 20). The progradational nature of the facies and the thinning upward of parasequences indicated deposition as a HST (Figures 19, 21). The upper boundary of sequence 2 , near the middle of the member, is at the top of the relatively coarse-grained facies open or restricted platform facies, indicating the furthest seaward progradation. These are abruptly overlain by finer-grained outer to middle ramp calcareous shales and foram wacke/ packstones.

\section{Sequence 3}

The abrupt change from packstones and grainstones of the HST of sequence 2 to interbedded calcareous shales and mud/wackestones near the middle of the Wachsmuth banded limestone member is taken to indicate a significant deepening and a sequence boundary (SB-2; Figures 19, 21). Above the sequence boundary are a series of Type 1 parasequences with calcareous shale bases that grade upward into skeletal wacke/packstones (Figure 20). The thickness and abundance of calcareous shale increases upsection to near the top of the Wachsmuth Limestone indicating maximum facies retrogradation and is interpreted to represent maximum flooding at the top of a TST (Figure 19, 21).

The overlying lower Alapah member contains a series of Type 3 parasequences that shoal upward from wacke/packstones with abundant nodular or lenticular chert to pack/grainstones, lacking chert some of which are cross bedded. The general increase in grain size and associated cross bedding indicates progressive shallowing into shoal environments within a HST (Figure 19, 21, 22). Shallowing continues into the overlying middle member of the Alapah that records dominantly open to slightly restricted platform (lagoon) environments. The occurrence of finelycrystalline dolostone and replaced evaporite nodules within normal marine facies near the top of the middle Alapah (Figures 3, 23) indicate downdip flow of dense saline evaporitic waters from peritidal environments further to the north. It is likely that this sequence is the first unit to onlap progressively northward into the northeastern Brooks Range (Figure 19). While biostratigraphic 

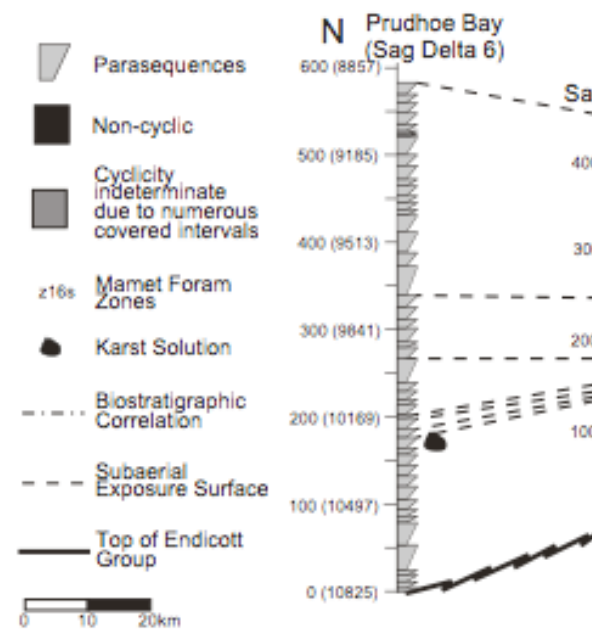

\footnotetext{
Figure 20. Diagram illustrating parasequence stacking patterns within the Lisbume Group along a N-S transect between Prudhoe Bay, the northeastern Brooks Range and Porcupine Lake area of the central eastern Brooks Range. Note the generally thicker parasequences and non-cyclic intervals in the distal Wachsmuth and Alapah Limestones, central-eastern Brooks Range compared to the generally thinner proximal parasequences in the Wahoo Limestone, northeastern Brooks Range. Sea level curve for the Wachsmuth and Alapah Limestones is from this study. The sea level curve for the Wahoo is from (Watts et al., 1995). The distance between the subsurface (Sag Delta 6) and the central Shublik Mountains is approximately $100 \mathrm{~km}$. Modified from Carlson (1995).
}

data is equivocal facies relationships at the base of the Alapah in the Fourth Range and central Shublik Mountains records a thin interval that shallows upward from intertidal to supratidal deposits characterized by collapse breccias and calcite replaced evaporites (Figure 23) also documented by Carlson (1987; 1995), Gruzlovic (1991), and Watts et al. (1995). This shallowing to emersion appears to be coeval with the deposition of open platform deposits of the middle Alapah in the central-eastern Brooks Range that contain finely crystalline dolostone and abundant small white calcite nodules also interpreted as replaced evaporites. An abrupt deepening above these facies is interpreted as a sequence boundary (SB-3).

\section{Sequence 4}

Sequence 4 (Figure 19) includes the upper Alapah member of this study and Sequence A of Watts et al. (1995), which includes most of the lower and the middle and upper Alapah members in the northeastern Brooks Range. Sequence 4 represents the first thick accumulation of the Lisburne Group deposition north of the Shublik Mountains and initial Lisburne deposition at Prudhoe Bay (Figure 19). In the eastern Sadlerochit Mountains the sequence boundary (SB-3) is a spectacularly exposed angular unconformity where the lower Alapah onlaps tilted preMississippian rocks (Figure 24). In the subsurface Sequence 4 is represented by Alapah zones A through C (Figure 18). The top of the middle Alapah records a deepening event heralded by the re-establishment of shoal environments in the lowermost portion of sequence 4. Landward migration of shoal environments over open platform inner ramp deposits of the middle Alapah indicates initiation of a TST (Figures 19, 21, 22). Shoal facies of the lowermost upper Alapah 


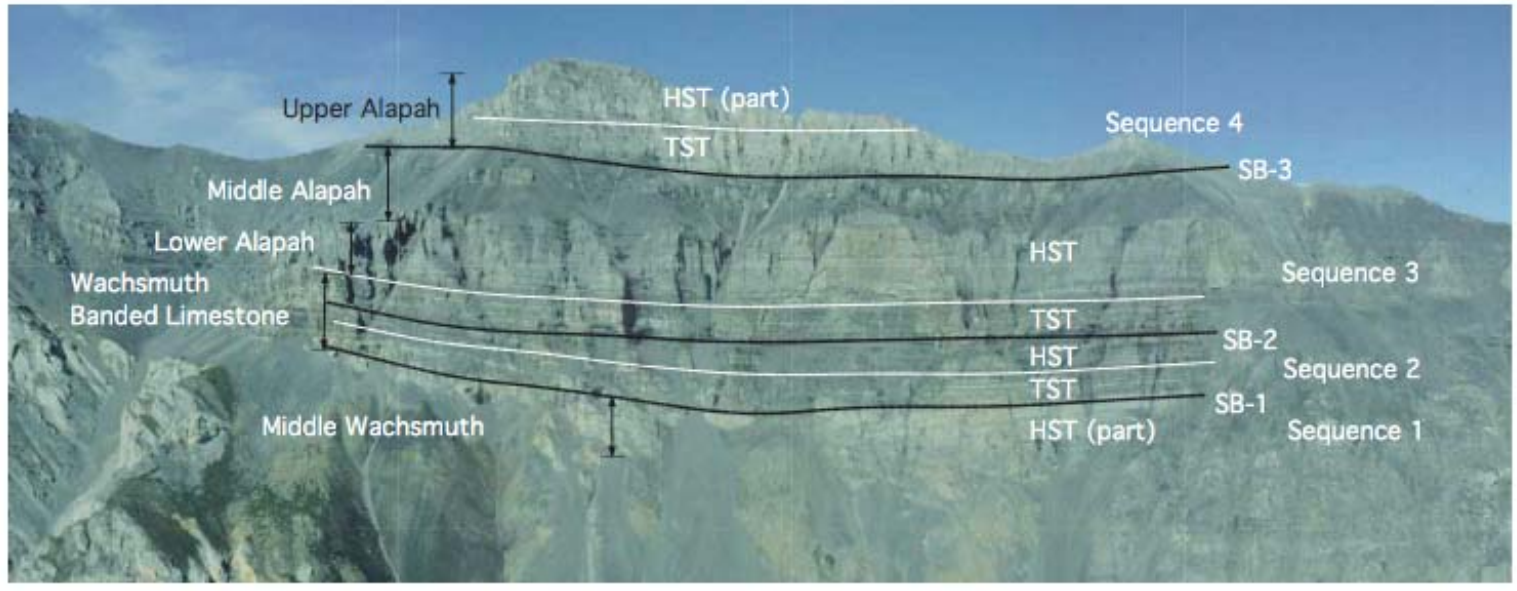

Figure 21. Outerop photo mosaic illustrating the sequence stratigraphic subcivision of the Lisburne Group in the Marsh Fork area, central-eastern Brooks Range. The base of the Lisburne is truncated by a thrust fault that is covered by scree beneath the middle Wachsmuth. Wachsmuth and Alapah members are labeled and thier stratigraphic distribution is indicated by dauble ended antows on the left side of the photo. Seçuence houndaries (SB) are represented by black lines, maximum flooding surface, that separate transgressive (TST) from highstand systems tracts (1IST), are indiested with white lines. Illustrated are the upper portion of Sequence 1, all of Seçuences 2 and 3 , and the lower portion of Sequerce 4 which is truncated by a Holocene or older erosional surface.

deepen upward to below fairweather wavebase deposits during transgression. Overlying are Type 4 parasequences that coarsen upward from wackestones to grainstones and rudstones indicate a return to dominantly shoal deposits during highstand (Figures 19, 20, 22). This interpretation is supported by the presence of superficial ooids, indicating well agitated conditions, in many of the upper Alapah parasequences. Depositional environments of the upper Alapah fluctuated between open marine above fair-weather wave base and near shoal/shoal environments producing thick packages of sediment that show minimal variation in relative water depth within the parasequence. These thick Type 4 parasequences occur in both the TST and HST of Sequence 4. There are approximately four Type 4 parasequences that range in thicknesses between 10 to $30 \mathrm{~m}$ (Figure 20); however, they are dissected by numerous thin covered intervals that might conceal additional intervals of shallowing or deepening.

The dominantly shoal environments in the east-central Brooks Range grade into an extensive restricted platform to peritidal depositional setting in the northeastern Brooks Range and adjacent subsurface. Thick packages of fenestral mud/wackestones with autoclastic breccias, calcite and silica replaced evaporites, microdolomite, eolianites, and paleosols (Figures 23, 25) in the north support these interpretations (Watts et al., 1995). Replaced evaporite textures in the upper Alapah were documented as far south as the Fourth Range in this study.

The upper boundary of sequence 4 is not well exposed in the central-eastern Brooks Range. The rubbly outcrop present at some sections may represent an erosional remnant of either the upper Alapah or possibly the lowermost Wahoo. In the Sadlerochit Mountains the uppermost Alapah contains thick cross-bedded intervals interpreted as eolian dunes (Figure 25). These facies as well as other upper Alapah facies in the subsurface and as far south as the central Shublik Mountains contain evidence of extensive karst development. Sinkholes and caverns with cavefill breccias, collapse structures, and coarse late stage calcite cement are documented in the Sadlerochit and Shublik Mountains (Figure 25; Watts et al., 1995; this study). These relationships indicate that the Sadlerochit Mountains area remained a relative paleogeographic 
high throughout Lisburne deposition and that the relative sea-level fall associated with the

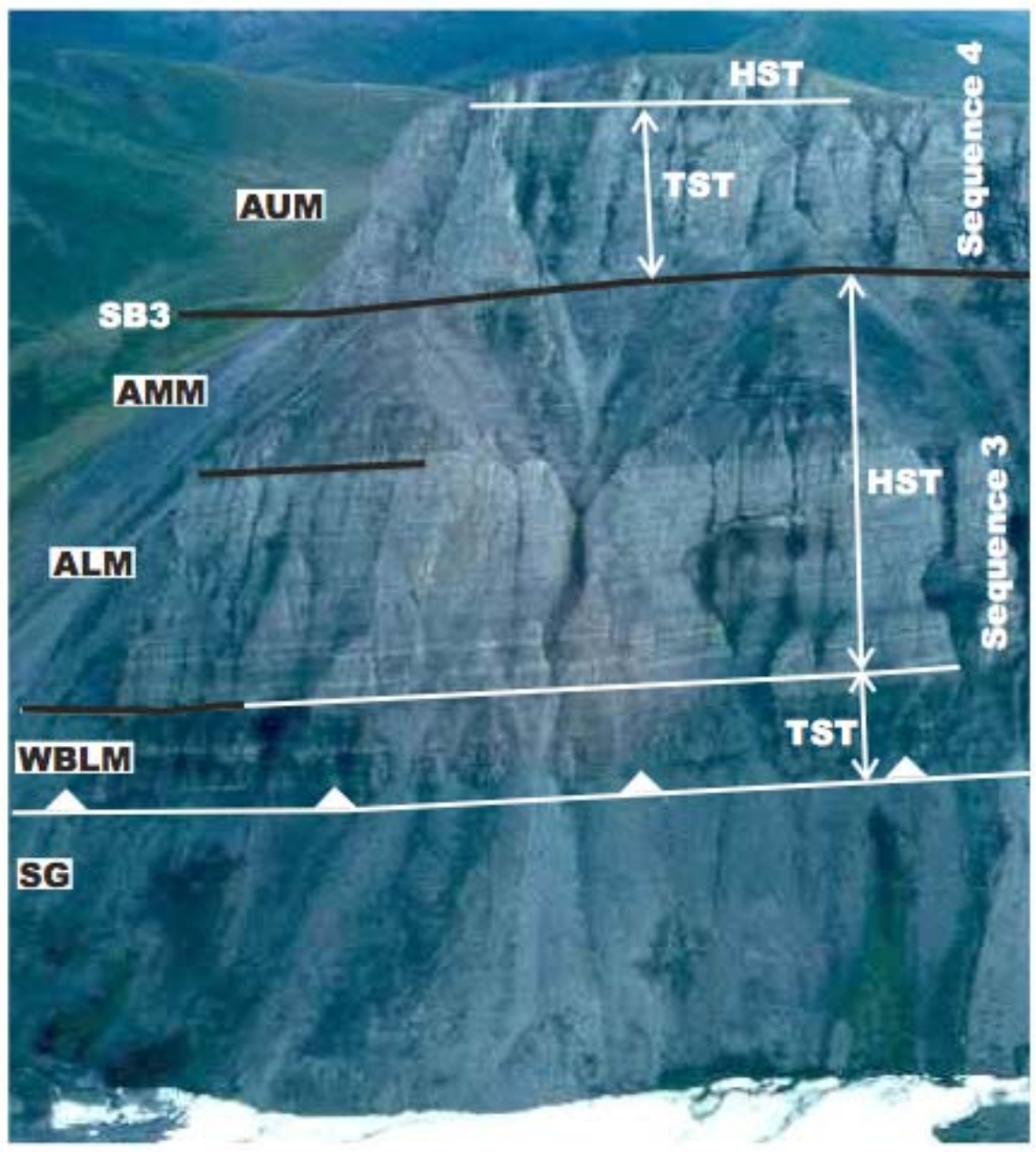

\begin{abstract}
Figure 22. Outerop photograph from the Forks field area (section WF) illustrating the sequence stratigraphic subdivision of the Lisburne Group exposed at this location. Unit abbreviations are on the left in black. Unit subdivisions are shown with a solid black line on the left and one conicides with sequence boundary 3 (SB3 - continuous black line). Maximum flooding surface separating transgressive (TST) from highstand systems tracts (HST) are in white. The base of the Lisburne is truncated by a trust fault (barbed line) underlain by the Sadlerochit Group (SG). The exposed section begins in the TST of sequence 3 in the Wachsmuth banded limestone member (WBLM). The Alapah lower member (ALM) and middle member (AMM) make up the HST of sequence 3. Sequence 4 consists of the Alapah upper member (AUM) but most of the HST has bee removed by holocene or earlier erosion.
\end{abstract}

development of the upper boundary of sequence 4 exposed a significant portion of the Lisburne ramp to subaerial conditions.

\title{
Sequence 5
}

The last two sequences are entirely unrepresented in the central-eastern Brooks Range due to subsequent erosion and/or non-deposition. These two sequences are represented in the northeastern Brooks Range and the adjacent subsurface but were not studied in detail during this project. Watt's et al. (1995) interpreted the lower and upper members of the Wahoo Formation as containing two sequences (B and C) here referred to as sequences 5 and 6 (Figures 18, 19, 24). 
Sequence 5 encompasses the lower and lowermost upper Wahoo (Watts et al., 1995) and Wahoo zone 1 in the subsurface. The lower boundary of sequence 5 as noted above is a well developed karst surface (Figure 25). Above this surface the lower Wahoo consists dominantly of open marine facies deposited near fairweather wave base. These facies shoal upward into peritidal facies with local microbially laminated and fenestral mud/wackestones and an influx of quartz sand. These facies indicate maximum regression. Some evidence of subaerial exposure including collapse breccias, replaced evaporites, and karst and cave development also occur near the top of Sequence 5 in the Sadlerochit Mountains and possibly in the adjacent subsurface (Watts et al., 1995; this study). Also, replaced evaporite textures occur within the lower Wahoo as far south as the Fourth Range. Lack of extensive subaerial exposure features south of the Sadlerochit Mountains implies that the sequence boundary is a Type 2 boundary with only partial exposure of the inner ramp.

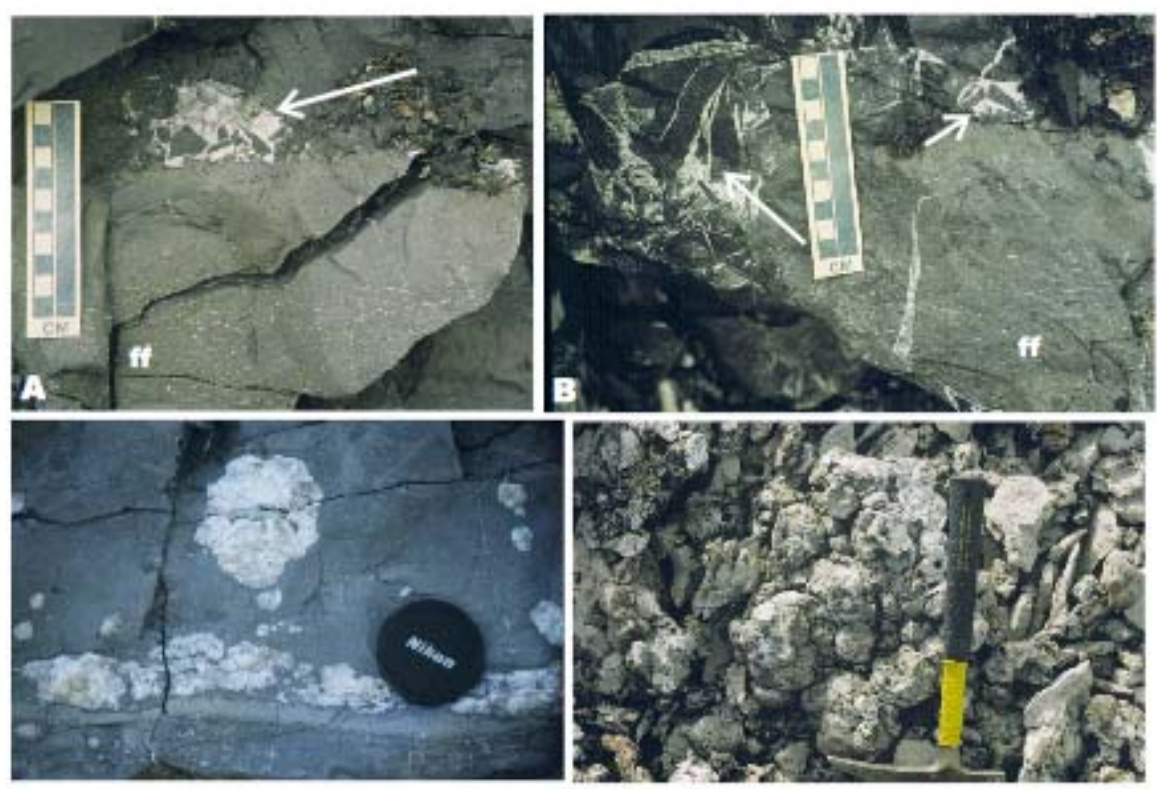

Figure 23. Evaporites and evidence of subaerial exposure at the top of Sequenees 3 and 4. A and B) Autoclastic breccia (arrows) and fenestral fabric (ft) near the top of Sequence 3 in the lowermost Alapah, Fourth Range, northeastem Brooks Range. C) Calcite replaced evaporites nodules just below the breceias pietured above (section SC). D) Quartz replaced evaporite nodules near the top of Sequenee 4, uppermost Alapah, Central Shublik Mountains (section FC).

Sequences 6

Sequence 6 is represented by most of the upper Wahoo in outcrop and Wahoo zones 2 through 8 in the subsurface (Figures 19, 24). In outcrop the lower portion of sequence 6 includes skeletalspiculitic parasequences (restricted platform) to skeletal-oolitic parasequences (shoal) to open marine shale-based parasequences (open marine; Gruzlovic, 1991; Watts et al., 1995). Skeletaloolitic parasequences thin southward and shallow-upward from bryozoan-pelmatozoan packstone (open marine above fair-weather wave base) to oolitic grainstone (shoal) with minor 
parasequences capped by peloidal packstone (restricted platform). These facies above the sequence boundary record a retrogradational facies stacking pattern and indicate deposition of a

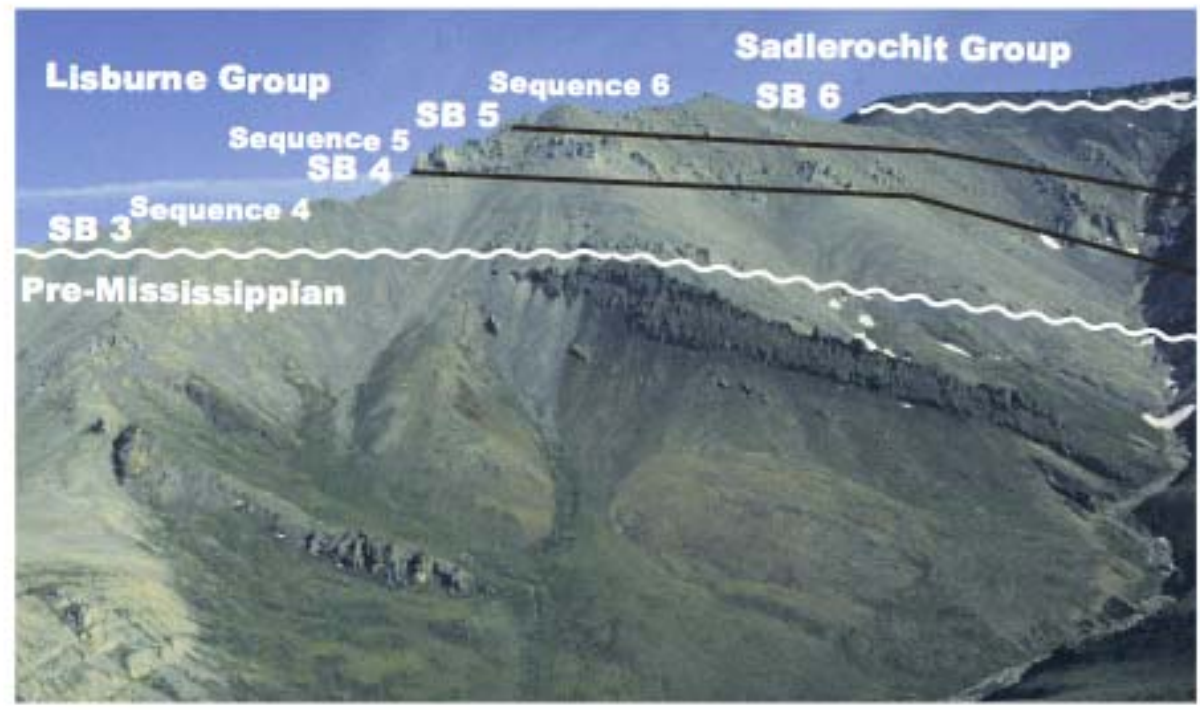

Figure 24. Outerop of the Lisbume Group in the eastern Sadlerochit Mountains (sections ES 1-4) illustrating the sequence stratigraphic subdivision. Sequence 3, consisting of most of the Alapah Limestone, rests on an angular unconformity (SB 3) atop tilted preMississippian rocks. The Kayak Shale is absent. Sequence 5 is represented by most of the lower Wahoo Limestone and Sequence 6 consists mainly of the upper Wahoo. The uppet Wahoo is truncated by the pre-Upper Permian unconformity (SB 6) and overlain by the Sadlerochit Group.

TST (Figure 19; Gruzlovic, 1991; Watts et al., 1995). Parasequences generally become thicker and more numerous to the south (Figure 20; Gruzlovic, 1991; Watts et al., 1995). A similar parasequence set trend is also observed in the subsurface. In the lower-most Wahoo Zone 2, parasequences consist of facies deposited in a restricted platform environment (skeletal cryptalgal parasequences) and are overlain by skeletal-oolitic parasequences (Wahoo Zone 3 and 4) and Oolitic-Donezella parasequences (Wahoo Zone 5) deposited in a shoal environment. Shale-based parasequences are absent in the subsurface, but appear to be laterally equivalent to the Oolitic-Donezella parasequences (Wahoo Zone 5).

The upper part of the upper Wahoo Limestone in northeastern Brooks Range outcrops consists of three to six skeletal-oolitic parasequences that shallow-upward from ooid shoals to open platform facies (Gruzlovic, 1991; Watts et al., 1995). In the subsurface, the upper-most Wahoo Limestone (Zones 6 and 7) consist of seven parasequences that are composed of Donezellaoolitic (Wahoo Zone 6) and Oolitic-capped (Wahoo Zone 7) parasequences (Figure 18). Peloidal-oncolitic parasequences (Carlson, 1987) in the uppermost Wahoo Limestone in the Sadlerochit Mountains are similar to oncolitic parasequences described in the subsurface (Zone 8 ) and represent continued southward progradation of the restricted platform environment. The 
wide-spread occurrence of shoals in both outcrop and the subsurface and the progradation of shoals and restricted platform facies to the south indicates a HST (Figure 19; Watts et al., 1995).
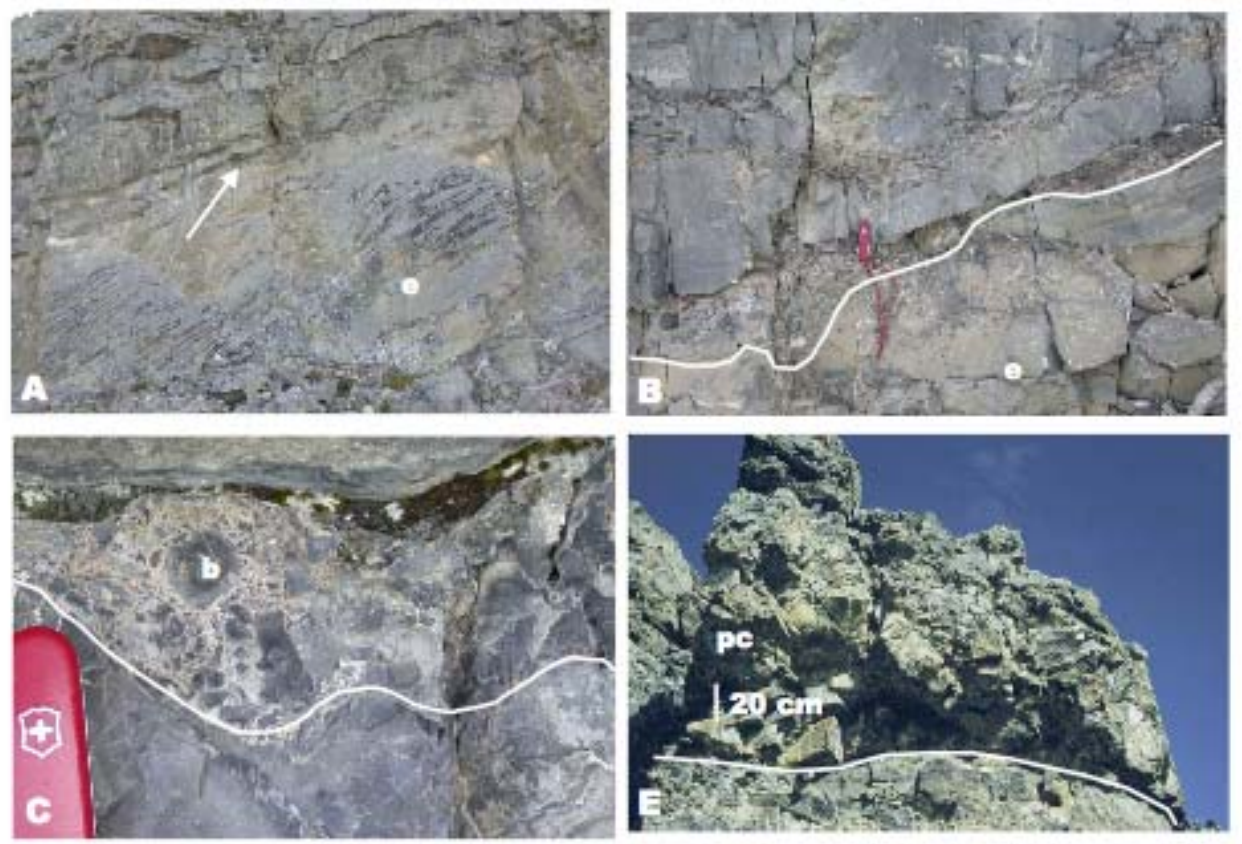

\begin{abstract}
Figure 25. Evidence of subaerial exposure, karstification and cave development near the top of Sequence 4, eastern Sadlerochit Mountains, northeastern Brooks Range. A) Large-scale crossbedding, outlined by black silicified cross laminae, in a carbonate eolianite (e) overlain by an irregular karst surface (arrow). B) Closet view of irregular karst surface (white line) pictured in A. C) Close-up of karst surface (white line) and infilling karst breceia (b) overlying surface illustrated in A and B. D. Coarse-grained paleo-cave (pe) deposit associated with karst development. White line indicates base of cave. Cave deposits contain clasts up to $0.5 \mathrm{~m}$ in diameter and occur as much as $10 \mathrm{~m}$ beneath the karst surface pictured above.
\end{abstract}

The top of the Wahoo, the upper boundary of sequence 6, is a significant regional unconformity overlain by the Permian Echooka Formation, Sadlerochit Group (Figure 24). This is a Type 1 sequence boundary characterized by significant incision into the upper Wahoo (Crowder, 1990). The age of the upper Wahoo is older (Morrowan or Chesterian) in southern and western ANWR but younger (Atokan) in the north Watts et al., 1992). At Prudhoe Bay Atokan age rocks also occur and are slightly thicker than in northern ANWR (Armstron and Mamet, 1974; Jameson, 1994). Bird et al., (1987) interpreted the upper boundary of sequence 6 as due to regional postMiddle Pennsylvanian epeirogenic uplift. Marine Echooka facies overlie the Lisburne as far north as the Third Range but north of there the lowermost Echooka contains local lenticular deposits interpreted as fluvial facies that are confined to incised paleovalleys (Crowder, 1990). The age of the lower Echooka is not well constrained but according to Detterman et al. (1975) ranges from Gruadelupian (Kazanian) in the north to Leonardian (Artinskian to Ufimian) in the south. Facies overlying the Lisburne Group in the central-eastern Brooks Range appear to be distal facies that may be equivalent to the Siksikpuk Formation of the central Brooks Range (Siok, 1985; Adams, 1991). If so this would indicate renewed marine inundation of much of northern Alaska after a hiatus of approximately 38 m.y. (Watts et al., 1995) 


\section{Mechanical Stratigraphy}

Mechanical stratigraphy refers to the response of a package of lithologically heterogeneous rock to deformation (Narr and Suppe, 1991; Erickson, 1996). Field and laboratory studies have demonstrated a general relationship between lithology, bed thickness, and response to deformation with features like fractures being most abundant in finer-grained lithologies and/or thinner beds (Ladeira and Price, 1981; Hancock and Engelder, 1989; Narr and Suppe, 1991; Hanks et al., 1997). Large-scale outcrop weathering patterns provide a first-order approximation of mechanical stratigraphic properties. Weathering patterns are largely controlled by bed thicknesses and degree of lithologic heterogeneity and different facies stacking patterns will result in different mechanical properties through a vertical stratigraphic section. Variations in facies distribution and stacking patterns along depositional dip insure that there will be lateral variations in mechanical stratigraphy as well.

Due to the difference in stratigraphy and age of the rocks in northeastern and central-eastern Brooks Range a direct comparison of mechanical properties of age equivalent rocks is only possible for the Alapah Limestone. The different members of the Lisburne Group in the northern and southern field areas are defined based on lithologic properties and thus provide a reasonable subdivision for generalizations about their mechanical properties.

In the central-eastern Brooks Range the Wachsmuth crinoidal limestone member $(\sim 70 \mathrm{~m})$ displays a recessive weathering pattern and is generally incompetent probably due to pronounced lithologic heterogeneity (Figure 13$)$. The Wachsmuth middle $(\sim 130 \mathrm{~m})$ and banded limestone $(\sim 140 \mathrm{~m})$ members are both relatively resistant to weathering, contain abundant chert, and are mechanically competent (Figure 13). The lower Alapah $(\sim 100 \mathrm{~m})$ is resistant to weathering and forms prominent cliffs indicating its mechanically competence (Figure 13). The middle Alapah $(\sim 70 \mathrm{~m})$ is relatively non-resistant to weathering and is comparable to or slightly less competent than the Wachsmuth crinoidal limestone (Figure 13). The upper Alapah ( $280 \mathrm{~m})$, similar to the lower, is resistant and mechanically competent (Figure 13).

In the northeastern Brooks Range the Alapah Limestone is equivalent to the uppermost middle and upper Alapah of the central eastern Brooks Range (Figures 2, 19). In the northeastern Brooks Range the Alapah contains a more heterogeneous assemblage of facies and thus also displays a wider range of mechanical properties. In an earlier report we subdivided the Alapah into four mechanical units but here we lump units 3 and 4 together because their mechanical properties are relatively similar and this subdivision more closely matches the member subdivision of Watts et al. (1995). The lower Alapah $(\sim 120 \mathrm{~m})$ is generally recessive weathering and relatively incompetent but becomes increasingly more competent in the upper $25 \mathrm{~m}$ of the unit. The middle Alapah $(\sim 100 \mathrm{~m})$ is recessive weathering and less competent than the lower or upper. The upper Alapah $(\sim 110 \mathrm{~m})$ is thicker bedded, more resistant than either the middle or lower members and is mechanically competent in general.

Several generalizations about mechanical properties can be made based on overall facies stacking patterns in different parts of the Lisburne Group. Those units that are characterized by shale-based parasequences contain obvious heterogeneities that would reduce their mechanical competence. Shaly units would serve as small scale detachment surfaces that might result in 
bedding plane slip as the rocks deform. Other lithologic heterogeneities within, and variations in thickness between parasequences should also influence the mechanical properties of different units. Mechanical properties do not always correlate directly with genetic lithostratistratigraphic units (cycles or parasequences). In general, parasequences tend to coarsen upward and beds within cycles tend to thicken upward, reflecting a change from finer-grained, open marine, argillaceous facies to coarser-grained shoal deposits. Mechanical competence generally increases upsection in such cyclic units. Locally, however, cycles are capped by fine-grained, thin-bedded peritidal facies. The peritidal facies might be relatively incompetent so a mechanical boundary would exist within the cycle. A direct correlation between increasing grain-size and bed thickness and mechanical competence is also not entirely borne out by field observations. Several thick-bedded, coarse-grained grainstones exhibited solution cleavage and were recessive weathering, and are mechanically less competent than some finer-grained units. Portions of the Alapah and Wachsmuth Limestones also appear to be relatively non-cyclic. The thickest of these non-cyclic intervals occur in the upper Alapah, northeastern Brooks Range and the middle Wachsmuth and upper Alapah, central-eastern Brooks Range. These units consist of relatively fine-grained, non-cyclic facies with abundant chert nodules. Thick non-cyclic packages were probably deposited at depths below the influence of short-term relative sea-level changes, and facies do not record trends in grain size and bed thickness that would yield mechanical heterogeneities. These packages, thus appear to be the most mechanically competent units and their overall homogeneity implies a more internally consistent mechanical response to deformation.

The four parasequence types identified in the central-eastern Brooks Range display variations in both lithology and thickness. Type 1 parasequences are relatively thick (4-25 $\mathrm{m})$ and display fairly abrupt variations in lithofacies with the upper and lower portions of the parasequences dominated by wackestones and the middle portion dominated by grain/rudstones. Type 2 parasequences are generally thinner $(0.5-10 \mathrm{~m})$ and display a gradual change in lithofacies upsection from basal calcareous shales through wackestones, wacke/packstones and pack/grainstones. Type 3 parasequences are the thinnest $(0.25-0.5 \mathrm{~m})$ and display the little heterogeneity other than the platy mudstone at the base as the rest of each parasequence consists entirely of wacke/packstone that may coarsen upward slightly. Type 4 parasequences are relatively thick (10-30 m) and display a gradation from wackestone at the base through packstone and pack/grainstone. As Hanks et al. (2001) noted intervals where there is little lithologic contrast across bedding planes display a more uniform fracture density and character. We would thus expect that shale based parasequences (Type 2) might display the least and those with relatively gradational facies changes (Types $3 \& 4$ ) the most uniform pattern of fracture character and density across parasequence boundaries. The heterogeneity within Type 1 parasequences would probably result in the most variation in fracture character and density within each parasequence. Where parasequences are well defined by changes in grain-size and bed thickness they should permit some level pf predictability of mechanical competence/ incompetence.

Parasequences in the northeastern Brooks Range differ significantly from those further to the south due mainly to their more proximal paleogeographic setting and the deposition of evaporiterich inner ramp facies. Facies in the northeastern Brooks Range are also more commonly dolomitized than those in the central-eastern Brooks Range but the influence of dolomitization 
on mechanical stratigraphy has not been examined systematically. In the north, the lower Alapah is dominantly recessive weathering and extends from the gradational contact with the underlying Kayak Formation up to a thick resistant package of packstones and grainstones. Parasequences on the inner ramp of the lower Alapah are commonly argillaceous or marly at the base and coarsen up through bioturbated packstones and are capped by finer-grained mud/wackestones with replaced evaporites and/or collapse breccias. The middle Alapah is dominated by grainstones and packstones and was poorly exposed in the section most intensively examined for this project. It is generally less cherty than the lower or upper members which might influence its relatively recessive outcrop character. Inner ramp parasequences of the upper Alapah have cross-bedded pack/grainstone shoal facies that grade upward into restricted platform mudstones and think bedded dolomudstones with replaced evaporites. The lithologic heterogeneity would probably result in variable mechanical properties within such units. Upper Alapah middle ramp parasequences are similar to the Type 3 parasequences in the lower Alapah of the central-eastern Brooks Range.

The Wahoo Limestone is in general more competent than most Alapah facies. However, the highly cyclic nature, presence of shale-based parasequences, and the ledge- and cliff-forming topography of the Wahoo Limestone (Gruzlovic, 1991; Watts et al, 1995) imply an internally variable mechanical stratigraphy as well. The Wahoo was not examined in detail during this study so a more comprehensive analysis of its mechanical stratigraphy cannot be presented.

Another major type of heterogeneity is introduced where silicification has produced abundant nodular and lenticular chert within Lisburne limestones. The competency contrast between the chert and limestone probably has a major influence on their response to stress with the cherts reacting in a much more brittle fashion than surrounding limestones. Moderate to thickly bedded limestones with abundant chert appear to be some of the most mechanically competent lithologies forming steep sided cliff faces in many outcrops (upper lower Alapah and upper Alapah in northeastern Brooks Range and the Wachsmuth middle and banded limestone members in the central eastern Brooks Range). Some units are more dominated by chert and are more homogeneously brittle.

\section{Diagenesis Of the Lisburne Group}

The Lisburne Group in the central-eastern Brooks Range was subjected to cementation, grain micritization, neomorphism, dissolution, silicification, dolomitization, and compaction. Cementation and silicification are probably the two most important processes that negatively affected the reservoir properties of Lisburne facies by reducing interparticle porosity.

\section{$\underline{\text { Grain Micritization and Neomorphism }}$}

Micritization is a common diagenetic process in shallow tropical to subtropical seas where algae, fungi, and bacteria bore into carbonate grains producing fine-grained carbonate mud or facilitating precipitation of micritic cement (Bathurst, 1975; Reid et al., 1992; MacIntyre and Reid, 1995; MacIntyre and Reid, 1998; Reid and MacIntyre, 1998). Grains can still be identified 
if only partially micritized but the original identity of wholly micritized grains is often difficult to ascertain.

Many of the grains identified as peloids in the Lisburne Group may represent micritized skeletal or other types of grains. In thin section, peloids are round to oval and are found in a variety of sizes indicating a polygenetic origin. Differentiation of true fecal pellets from rounded micritized grains was not possible.

Neomorphism is a wet recrystallization process that can result in the stabilization of aragonitic or high-magnesium calcite (HMC) components to low-magnesium calcite (LMC)(Folk, 1959; Bathurst, 1975). Neomorphism can be degrading or aggrading but Lisburne Group samples display aggrading neomorphism and an increase in crystal size. The most common components subjected to neomorphism are original lime mud, echinoderm grains, and bivalves. Grains dominantly composed of LMC to begin with, like rugose corals, brachiopods, and bryozoans, were much less likely to succumb to neomorphism. Most what appears to have originally been lime mud or micritized grains observed in thin section have undergone aggrading neomorphism and now consist of microspar $(5-30 \mu \mathrm{m})$ or pseudospar $(30-50 \mu \mathrm{m})$.

\section{$\underline{\text { Compaction and Pressure Solution }}$}

Most Lisburne Group facies are relatively well compacted and display tangential to embayed grain contacts. Much of the primary porosity was probably eliminated by early compaction processes. Also common, especially in coarser-grained packstone and grainstone facies, are sutured grain contacts, fitted fabric, dissolution seams, and well developed stylolites. Stylolites cross cut many other diagenetic fabrics but more detailed analysis is necessary to determine the timing and relationship of stylolites and other diagenetic phases. Stylolitization has been documented to occur in rocks buried as shallowly as few hundred meters but is most common in limestones buried several hundred meters or more (Bathurst, 1975).

\section{$\underline{\text { Cementation }}$}

Several types of cement have been documented elsewhere in the Lisburne Group (Wood and Armstrong, 1975; Carlson, 1995). Wood and Armstrong (1975) described an early phase of isopachous cement with stubby, bladed crystals mostly $<30$ um in length that lines intercrystalline pores in packstones and grainstone. They interpreted these cements as well as some syntaxial rim cements around echinoderm grains to be early diagenetic features. Wood and Armstrong (1975) also implied that these potentially vadose zone cements but more recent research suggest that these are more likely a an active marine phreatic cement (Melim et al, 1995). Later phases of sparry calcite cement essentially occlude all primary interparticle and intraparticle porosity (Wood and Armstrong, 1975; Carlson, 1995). Carlson's (1995) cathodoluminescence analysis of the Lisburne Group in the northeastern Brooks Range identified several phases of sparry calcite most of which were interpreted to be meteoric cements related to the development of subaerial exposure surfaces. Most of the cements within the Lisburne samples analyzed for this study appear to fall into the latter category but many have likely undergone neomorphism or wholesale recrystallization during burial. A final, apparently late stage, calcite cement is very coarsely crystalline, highly cleaved, and a creamy white color, fills 
large scale cavernous porosity and solution pipes, en echelon fractures, and other larger scale fractures in deformed Lisburne carbonates (Figure 26). Other evidence of relatively high temperatures experienced by the Lisburne Group during burial (Tmax from Rock Eval, CAIs, authigenic albite discussed below) imply hydrothermal processes and it seems likely that this coarsely crystalline calcite might also be related to the flow of hydrothermal fluids; however, more detailed analysis possibly employing fluid inclusions or stable isotopes would be necessary to confirm this.

\section{$\underline{\text { Dissolution }}$}

Dissolution is not a common feature in Lisburne Group from the central-eastern Brooks Range but local dissolution of skeletal grains that were probably originally aragonite has been observed. Molds of sponge spicules, foams, echinoderms, and undifferentiated skeletal fragments are commonly observed within chert and this dissolution might have been concomitant with silicification. In the northeastern Brooks Range a wide array of dissolution features occur and most are related to the development of subaerial exposure surfaces (Jameson, 1994; Carlson, 1995; Watts et al., 1995). Dissolution cavities range in size from microscopic molds or voids to large scale dissolution pipes ( $0.5 \mathrm{~m}$ wide and up to tens of $\mathrm{m}$ long) and caverns (Figure 25$)$. The sparse dissolution documented in distal sections is very likely related to their paleogeographic position and decreased likelihood that the rocks were subjected to the influence of subaerial exposure.

\section{$\underline{\text { Silicification }}$}

Nodular, lenticular, and banded black chert is abundant throughout the Lisburne Group (Figure 14). Selleck (1985) describes similar chert morphologies in the Devonian Onondaga Limestone in New York State. Nodules are discrete, circular to oval in shape, and range in size from 4 to 10 $\mathrm{cm}$ in size (Figure 14). Chert nodules may be controlled by preexisting burrows that were silicified (Figure 14). Lenticular chert (Figure 14) is irregularly shaped, less than $10 \mathrm{~cm}$ thick, can be up to several meters long, and may have a stringy appearance. Banded chert (Figure 14) can be traced laterally for tens of meters, has a uniform thickness with relatively smooth, abrupt boundaries with the surrounding limestone, and is typically found in dolomitized wackestone with depauperate normal marine fauna.

At the microscale there is also significant silicification that is not necessarily associated with chert nodules or bands. Replacement of echinoderm grains, brachiopods, bryozoans, bivalves, and muddy matrix by quartz is quite common and locally quartz fills molds or other voids. Quartz morphologies include microcrystalline quartz, spherulitic and fibrous chalcedony, and coarsely crystalline quartz.

Possible sources of silica include: carbonate replacement of detrital silicates (Walker, 1960), dewatering of shale, dissolution of bentonite layers, expulsion of siliceous fluids from volcanic vents, weathering of clay minerals, and dissolution of biogenic opal (Wilson, 1966; Meyers, 1977; Nolte and Benson, 1998; Wind, 1998). In the Lisburne Group, chert is generally abundant in wackestone, minor in calcareous shales and packstones, and rare in grainstones and rudstones. 
Molds of sponge spicules, foams, and undifferentiated skeletal fragments are commonly observed within the cherts.

Detrital silicates in the Lisburne Group are commonly associated with subaerial exposure in the North Slope subsurface (Jamison et al., 1980) and in the northeastern Brooks Range (Carlson, 1987; Gruzlovic, 1991; Carlson, 1995; Watts et al., 1995), but are very rare in the central-eastern Brooks Range. It is unlikely that replacement of detrital quartz is responsible for the large volume of chert observed in the Lisburne Group throughout the Brooks Range and North Slope. Other minor sources of silica might include siliceous fluids associated with volcanic vents and intrusive rocks in northwestern Alaska (Tailleur et al., 1977a) and the dewatering of shales including the underlying Kayak Shale, the partially laterally equivalent Kuna Formation and the overlying Etivluk Group to the south and west of the central-eastern Brooks Range, (Mull et al., 1982; Brosgé et al., 2001).

Siliceous sponges and radiolarians are thought to be a significant source of non-basinal biogenic chert in the Paleozoic (Carson, 1991; Casey, 1993; Racki, 1999; Kidder, 2001). Amorphous biogenic (opaline) silica readily converts to chert and the process is enhanced by rising temperatures (Kastneret al, 1977; Williams and Crerar, 1985; Williams et al., 1985; Knauth, 1994). Spiculitic dolomites deposited in restricted platform settings are common in the upper Alapah, northeastern Brooks Range in (Carlson, 1987; Gruzlovic, 1991; Carlson, 1995, Watts et al. 1995). Deep-water environments with abundant sponge spicules and radiolarians have also been documented in the lower-most Lisburne Group in the west-central Brooks Range (Dumoulin et al., 1993). Even though such deep-water deposits were not observed in the eastcentral Brooks Range, they may potentially exist farther to the south. In thin section, sponge spicules are generally rare and usually only observed in chert. Wind (1998) makes a similar observation in the Thirtyone Formation in Midland County, Texas. He suggests that the sponge spicules were either deposited only in the cherty intervals or were dissolved from other lithologies and the silica remobilized and precipitated elsewhere. The sponge spicule molds would then become compacted, leaving no trace of their existence in the host facies (Wind, 1998). Wood and Armstrong (1975) hypothesized, and we concur, that dissolution of biogenic opal is the likely source of most of the chert in the Lisburne Group.

\section{$\underline{\text { Dolomitization }}$}

Most models of dolomitization of platform carbonates rely on the pumping of seawater or modified seawater to supply the magnesium necessary to create dolomite. One of the most accepted models for dolomitization of platform carbonates is what has grown to be called the sabkha model which incorporates processes such as seepage reflux (Adams and Rhodes, 1960; Jones and Rostron, 2000; Melim and Scholle, 2002) and evaporative pumping to move magnesium-rich fluids through the sediment and foster dolomitization. The $\mathrm{Mg} / \mathrm{Ca}$ ratio and density of water in shallow lagoons is raised through evaporation especially as gypsum precipitates and removes calcium. The evaporative process draws water upward by capillary action while seepage reflux results in downward density driven flow of dense brines.

Replaced evaporites and dolostones are common in the tidal flat and restricted platform environments to the north in the northeastern Brooks Range (Figure 23; Carlson, 1987; 
Gruzlovic, 1991; Carlson, 1995; Watts et al., 1995) and at Prudhoe Bay. In the northeastern Brooks Range, calcite- and silica-replaced evaporite nodules are observed in the lower Alapah Limestone and are abundant in the upper Alapah and lower Wahoo Limestones (Gruzlovic, 1991; Carlson 1995; Watts et al., 1995). The upper Alapah Limestone in the northeastern Brooks Range is the lateral equivalent to the upper Alapah (Alapah Zone C, see Chapter 4) at Prudhoe Bay. The Alapah Zone $\mathrm{C}$ is characterized by extensive dolomitization, karst development, and calcite- and silica-replaced evaporite nodules. Karst development is associated with a sequence boundary at the top of the Alapah Limestone in the subsurface and in the northeastern Brooks Range. This sequence boundary occurs at the top of the Alapah middle member in the central-eastern Brooks Range and is underlain by a $0.5 \mathrm{~m}$ thick dolostone with calcite-replaced evaporites. The lateral correlation of the Alapah Zone C at Prudhoe Bay, the upper Alapah in the northeastern Brooks Range, and top of the Alapah middle member in the central-eastern Brooks Range suggests that dense brines were probably formed to the north and migrated down-gradient through the sediment. Most dolomitic limestones and dolostones that occur within the central-eastern Brooks Range are laterally equivalent with facies to the north that were deposited in tidal flat and restricted platform environments further supporting this interpretation.

According to Wood and Armstrong (1975) there are two types of dolomite that occur within the Lisburne Group: syngenetic and diagenetic dolomite. Syngenetic dolomite forms prior to lithification and is very fine-grained, homogenous, associated with sulfate minerals or intertidal environments, and occurs only at the end of depositional cycles. Bird and Jordan (1977) suggests that the syngenetic dolomite is related to deposition in a sabkha environment and of early diagenetic origin. Diagenetic dolomite is medium- to coarse-grained, consists of zoned crystals, partial dolomitization is common, and the dolomite may be interbedded with nondolomitic intervals (Figure 3). Diagenetic dolomite is thought to have formed during late diagenesis (Bird and Jordan, 1977). Diagenetic dolomite in the central-eastern Brooks Range is rare. Two dolomite intervals are observed in the Wachsmuth Limestone that consist of mediumto coarse-grained dolomite crystals, although zoned and partially dolomitized crystals are a minor component (Figure 3). However, these two intervals are interbedded with non-dolomitic intervals.

\section{$\underline{\text { Authigenic Albite }}$}

Authigenic albite is common, albeit in low abundance, in Paleogene or older carbonate rocks (Kastner, 1971; Misik, 1994). There are several lines of evidence that are used to support an authigenic origin for the albite that occurs in carbonate rocks. Albite occurring in igneous and metamorphic rocks has distinctively different habit, twinning, and cathodoluminescent properties than authigenic albite, which is found as distinct crystals and as overgrowths (Kastner, 1971). Individual crystals are subhedral to euhedral, homogeneous and uniform in size, not restricted to certain lithologies or horizons, not associated with conduits of fluid flow such as fractures, lack detrital cores, replace skeletal fragments and matrix, and they frequently have inclusions of the host rock (Honess and Jeffries, 1940; Kastner, 1971; Spotl et al., 1999). Most studies conclude that authigenic albite is formed at medium to high temperatures that corresponds to maximum burial (Kastner, 1971; Spotl et al., 1999); however it may also form in lower temperatures 
(Honess and Jeffries, 1940; Moore, 1950; Kastner, 1971; Spotl et al., 1999). Albite with potassium is interpreted to be formed from hydrothermal solutions (Hatch et al., 1938).

Authigenic albite is observed in several thin sections from the study area. Subhedral to euhedral crystals are scattered throughout thin sections and replace skeletal fragments and matrix. The insoluble residue from one sample (MF-75), that contained authigenic albite in thin section, consisted of abundant clear, flat, platy crystals. The mineralogy of these crystals was determined to be albite through x-ray diffraction. The albite occurring in the Lisburne Group is similar in nature to euhedral to subhedral albite that is interpreted to be authigenic in origin (Kastner, 1971; Spotl et al., 1999). The burial history of the study area suggests that the albite was probably formed by hydrothermal fluids at relatively high temperatures. Maximum burial temperatures on the basis of Rock Eval pyrolysis was approximately $450{ }^{\circ} \mathrm{C}$. Conodont alteration indices (CAIs) of 4.5 to 6 (Brosgé et al., 2001; McGee et al., 2002) also support burial temperatures of 250 to $>360^{\circ} \mathrm{C}$ (Epstein et al., 1977). The highest CAIs are probably hydrothermally induced an interpretation supported by the sugary textures of the conodont elements (Krumhardt, 1992).

\section{$\underline{\text { Fractures }}$}

The Lisburne Group is highly fractured in most sections where it was examined in both the northeastern central-eastern Brooks Range. Relatively undeformed or mildly deformed Lisburne carbonates display two distinctive fracture sets, one entirely extensional and another that is related to extension and shearing (Hanks et al., DOE 2). Lisburne Group rocks incorporated into detachment folds contain up to four types of extensional fractures, three of which occur in echelon sets indicating a shear component to the deformation (Shackleton et al., DOE 4). Details of the distribution of different fracture types and their relationship to positions within folds is discussed in detail in Chapter ... Fracture porosity was demonstrated to be a major influence on Lisburne reservoir properties and petroleum production from the subsurface (Jameson, 1994).

\section{Other Diagenetic Features}

Several other diagenetic phases occur as authigenic minerals filling primary or secondary porosity or replacing carbonate grains and matrix. Pyrite in the form of small cubes or mutlicrystal clusters is common especially in more organic rich facies. Locally skeletal grains and peloids are replaced by a brownish phosphatic mineral that is likely carbonate fluorapatite.

\section{Lisburne Petroleum Potential}

\section{$\underline{\text { Reservoir Properties }}$}

Based on petrographic analysis the microporosity of all facies in the central-eastern Brooks Range is very low; generally between $0-3 \%$ with a maximum of about $5 \%$. Primary porosity was somewhat higher but much has been occluded with cement (sparry calcite and/or silica). Some chert-rich intervals have high macroscopic moldic porosity (Figure 26).

A few hydrocarbon stained intervals were identified in outcrop and "dead oil" is observed in thin section occluding intercrystalline porosity of medium- to coarse-crystalline dolomites 
(Figure 2.26B), moldic porosity in both carbonate and chert (Figure 2.26C\&D), inter- and intragranular porosity in bioclastic grainstones/rudstones (Figure 2.26E); and small microfractures (Figure 2.26F). The amount of included hydrocarbons is always low $(<3 \%)$ and does not represent a significant amount of primary porosity that has been occluded by hydrocarbons. Fracturing of muddy, low porosity facies may potentially enhance permeability.

Hydrocarbons are associated with a variety of lithologies throughout the Lisburne Group in central-eastern Brooks Range but the majority of those facies (Skeletal, Coral and Peloid-skeletal wacke/packstone, Foram pack/grainstone, dolomitized bioclastic grain/rudstone) are within the Wachsmuth banded limestone member. This suggests that the Wachsmuth banded limestone member may have the most promising reservoir potential when compared to all other Lisburne Group units in the central-eastern Brooks Range. Bioclastic grainstones/rudstones probably have the highest reservoir potential but only when dolomitized. Dumoulin et al. (1997) made a similar observation of hydrocarbons staining in dolomitized bioclastic grainstones in the Wachsmuth Limestone at Shainin Lake.

\section{Source Rock Potential}

There is geochemical and stratigraphic evidence that the Lisburne Group is a source rock in the western Brooks Range (Magoon et al., 2003). The source rock potential of the Lisburne Group in the central-eastern Brooks Range remains unclear but organic-rich intervals with source potential are rare in the central-eastern Brooks Range. ConocoPhillips conducted Rock Eval pyrolysis of 16 calcareous shales and one graphitic shale from section MF. Rock Eval provides data on total organic carbon (TOC), the thermal maturity of the organic matter, and the quality of hydrocarbons that could be generated from the included kerogen. Petroleum source rocks are characterized by TOC values greater than $2 \%$ by weight (Magoon et al., 2003). Only the graphitic shale $(9.75 \%$ TOC) and one calcareous shale $(3.01 \%$ TOC) fall into the source rock category (Table 3 ). The graphitic shale is $0.5 \mathrm{~m}$ thick and the calcareous shales that were analyzed are generally less than $0.25 \mathrm{~m}$ thick.

$\mathrm{S}_{2}$ peaks obtained through Rock Eval pyrolysis (Table 3) indicates the hydrocarbon generating potential of the rock, with values less than 5 indicating poor to fair source rock potential (Clementz et al., 1979). $\mathrm{S}_{2}$ values for the Lisburne samples are all less than 1 (Table 3), which suggests that the source rock potential is very low. The ratio $\mathrm{S}_{2}: \mathrm{S}_{3}$ is an indicator of whether the organic material is gas or oil prone, with values less than 2.5 indicating gas prone and values from 2.5 - 5 representing oil prone samples (Clementz et al., 1979). The $\mathrm{S}_{2}: \mathrm{S}_{3}$ for Lisburne Group samples are all less than 2.5 (Table 3), indicating that the rare organic matter present in the rock is gas prone. Oxygen and hydrogen index values plotted on a standard Van Krevelen diagram also indicate that the rock is gas prone (Figure 26).

Burial temperatures in the study area are generally high. Tmax values derived from Rock Eval indicate maximum burial temperatures of $303-453^{\circ} \mathrm{C}$ (Table 3 ). This is in good agreement with temperature estimates based on Conodont Color Alteration Indices (CAI; Epstein et al., 1977). CAIs throughout the study area range from 4.5 - 6 (Appendix 4) indicating temperatures of 250 to $>360^{\circ} \mathrm{C}$ (Epstein et al., 1977). The highest CAIs are likely hydrothermally induced on the 
basis of the sugary textures exhibited by the conodonts (McGee et al., 2002). Tmax and CAI temperature estimates indicate that these rocks are mature to overmature.

$$
\begin{aligned}
& \text { = \& 횽 }
\end{aligned}
$$

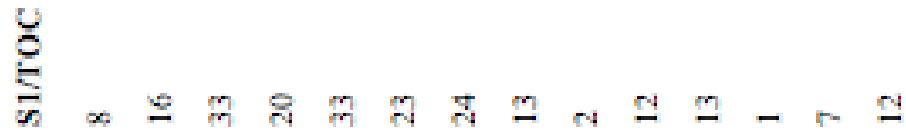

$$
\begin{aligned}
& \text { ప m }
\end{aligned}
$$

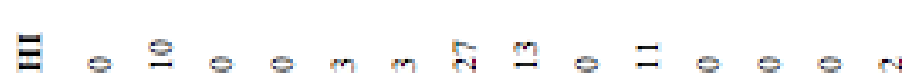

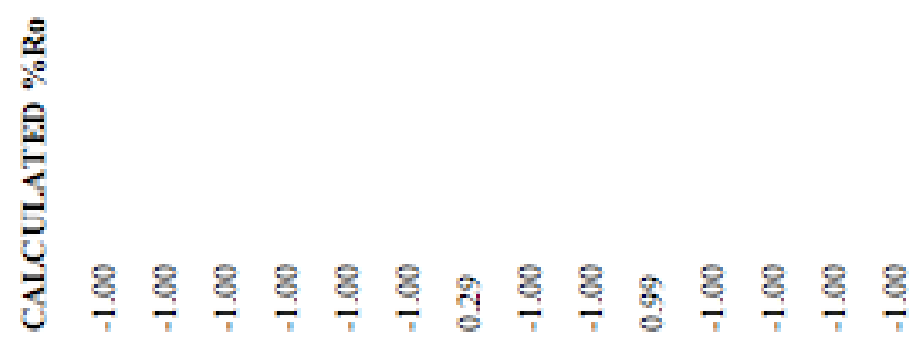

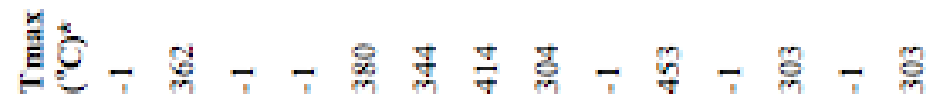

$$
\begin{aligned}
& \text { की }
\end{aligned}
$$

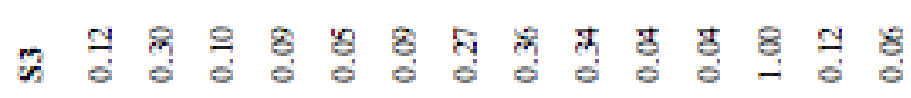

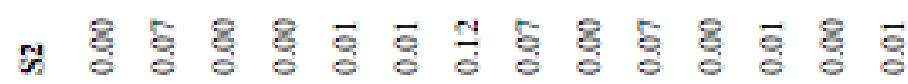

$$
\begin{aligned}
& \text { 万 }
\end{aligned}
$$

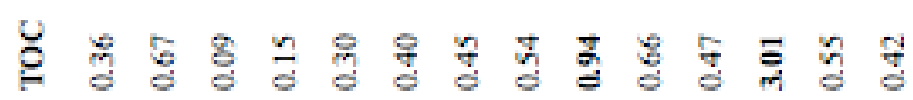

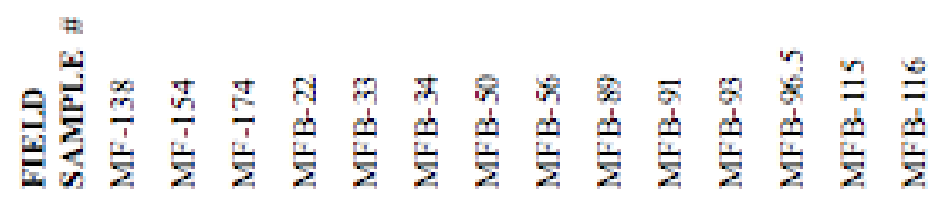

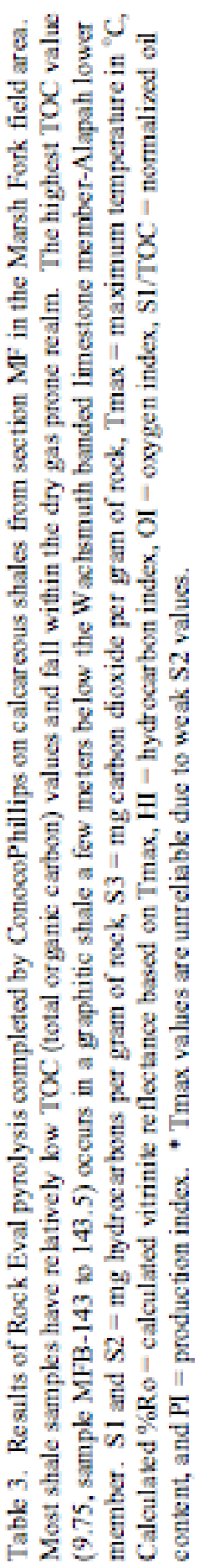


The data thus indicate that of the source rocks evaluated none are potential sources of oil but could be gas producers. If the shaly source rocks are laterally extensive and thicken significantly south of the central-eastern Brooks Range they could potentially source significant amounts of gas.

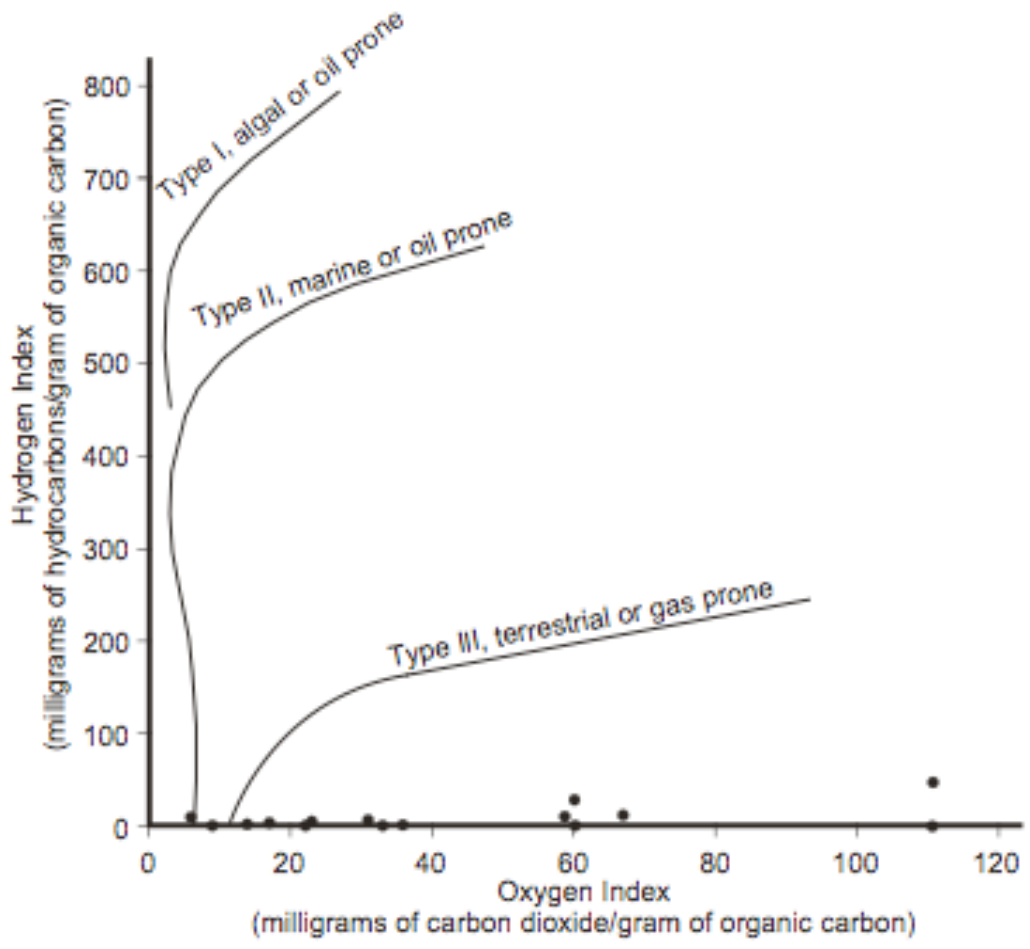

Figure 26. Van Krevelen diagram with Hydrogen Index vs Oxygen Index. Data are from shales collected at the bases of parasequences in the central-eastern Brooks Range. Organic matter from these samples clearly fall into the gas prone field. 


\section{References}

Adams, J.E., and M.L. Rhodes, 1960, Dolomitization by seepage refluxion: American Association of Petroleum Geologists Bulletin, v. 44, p. 1912-1920

Adams, K. E., 1991, Permian sedimentation in the northcentral Brooks Range, Alaska : implications for tectonic reconstructions, Thesis (M.S.)--University of Alaska Fairbanks, $122 \mathrm{p}$.

Ahr, W.M., 1973, The carbonate ramp: An alternative to the shelf model: Transactions of the Gulf Coast Association of Geological Sciences, v. 23, p. 221-225.

Armstrong, A. K., 1974, Carboniferous carbonate depostional models, preliminary lithofacies and paleotectonic maps, Arctic Alaska: American Association of Petroleum Geologists Bulletin, v. 58, p. 621-645.

Armstrong, A. K., and B. L. Mamet, 1972, Lisburne Group, Franklin and Romanzof Mountains, northeastern Brooks Range, Alaska, U. S. Geological Society Professional Paper 800-C, p. $127-144$.

Armstrong, A. K., and B. L. Mamet, 1974, Carboniferous biostratigraphy, Prudhoe Bay State 1 to northeastern Brooks Range, Arctic Alaska: American Association of Petroleum Geologists Bulletin, v. 58, p. 646-660.

Armstrong, A. K., and B. L. Mamet, 1975, Carboniferous biostratigraphy, northeastern Brooks Range, Arctic Alaska, U. S. Geological Survey Professional Paper 884, 29 p.

Armstrong, A. K., and B. L. Mamet, 1978, Microfacies of the Carboniferous Lisburne Group, Endicott Mountains, Arctic Alaska, in C. R. Stelck, and B. D. E. Chatterton, eds., Western and Arctic Canadian Biostratigraphy: Geological Association of Canada Special Paper No. 18, p. 333-394.

Armstrong, A. K., and B. L. Mamet, 1989, Stratigraphy of the Lisburne Group in the central Brooks Range, in C. G. Mull, and K. E. Adams, eds., Dalton Highway, Yukon River to Prudhoe Bay: Alaska Division of Geological and Geophysical Surveys Guide Book No. 7, p. 253-265.

Bird, K., and C. Molenaar, 1992, The North Slope Foreland Basin, Alaska, in R. W. Macqueen, and D. A. Leckie, eds., Foreland Basins and Foldbelts: American Association of Petroleum Geologists Memoir 55, p. 363-393.

Bird, K. J., 1991, North Slope of Alaska, in H. J. Gluskoter, D. D. Rice, and R. B. Taylor, eds., Economic Geology: U. S.: The Geology of North America, Boulder, Colorado, Geological Society of America, p. 447-462.

Bird, K. J., and D. W. Houseknecht, 2002, U.S. Geological Survey 2002 Petroleum Resource Assessment of the National Petroleum Reserve in Alaska (NPRA): Play Maps and Technically Recoverable Resource Estimates, U.S. Geological Survey Open-File Report 02-207, $18 \mathrm{p}$.

Bird, K. J., and C. F. Jordan, 1977, Lisburne Group (Mississippian and Pennsylvanian), potential major hydrocarbon objective of Arctic Slope, Alaska: American Association of Petroleum Geologists Bulletin, v. 61, p. 1493-1512.

Bird, K. J., and C. M. Molenaar, 1987, Stratigraphy, in K. J. Bird, and L. B. Magoon, eds., Petroleum Geology of the Northern Part of the Arctic National Wildlife Refuge, Northeastern Alaska, U. S. Geological Survey Bulletin 1778, p. 37-59.

Bowsher, A. L., and J. T. Dutro, Jr., 1957, The Paleozoic section in the Shainin Lake area, central Brooks Range, Alaska, Exploration of Naval Petroleum Reserve No. 4 and 
Adjacent Areas, Northern Alaska, 1944-53: Part 3, Areal Geology, U. S. Geological Survey Professional Paper 303 A, B, p. 1-39.

Brosgé, W. P., J. T. Dutro, M. D. Mangus, and H. N. Reiser, 1952, Stratigraphy and structure of some selected localities in the eastern Brooks Range, Alaska, U. S. Geological Survey Geological Investigations of the Naval Petroleum Reserve No. 4, Alaska, Preliminary Report No. 42, 28 p.

Brosgé, W. P., J. T. Dutro, M. D. Mangus, and H. N. Reiser, 1962, Paleozoic sequence in eastern Brooks Range, Alaska: American Association of Petroleum Geologists Bulletin, v. 46, p. 2174-2198.

Brosgé, W. P., H. N. Reiser, J. T. Dutro, R. L. J. Detterman, and I. L. Tailleur, 2001, Geologic Map of the Arctic Quadrangle, Alaska, Geologic Investigations Series I-2673 (1:200,000): U.S. Geological Survey.

Burchette, T. P., 1987, Carbonate-barrier shorelines during the basal Carboniferous transgression: The Lower Limestone Shale Group, South Wales and western England, in J. Miller, A. E. Adams, and V. P. Wright, eds., European Dinantinan Environments, Chichester, John Wiley, p. 239-263.

Burchette, T. P., and V. P. Wright, 1992, Carbonate ramp depositional systems: Sedimentary Geology, v. 79, p. 3-57.

Carlson, R. C., 1987, Depositional environments, cyclicity, and diagenetic history of the Wahoo Limestone, eastern Sadlerochit Mountains, northeastern Alaska: M. S. thesis, University of Alaska, Fairbanks, 189 p.

Carlson, R. C., 1995, Diagenesis of the Lisburne Group, northeastern Brooks Range, Alaska: Ph. D. thesis, University of Kansas, Lawrence, Kansas, 285 p.

Clementz, D. M., G. J. Demaison, and A. R. Daly, 1979, Well site geochemistry by programmed pyrolysis: Offshore Technology Conference Proceedings, OTC 3410, p. 465-470.

Detterman, R. L., 1970, Sedimentary history of the Sadlerochit and Shublik Formations in northeastern Alaska, in W. L. Adkison, and M. M. Brosgé, eds., Geological Seminar on the North Slope of Alaska, 1970, Proceedings, Palo Alto, California, American Society of Petroleum Geologists Pacific Section, p. 01-013.

Dumoulin, J. A., K. F. Watts, and A. G. Harris, 1997, Stratigraphic contrasts and tectonic relationships between Carboniferous successions in the Trans-Alaska crustal transect corridor and adjacent areas, northern Alaska: Journal of Geophysical Research, v. 102, p. 20709-20726.

Dunham, R. J., 1962, Classification of carbonate rocks according to texture, in W. E. Ham, ed., Classification of Carbonate Rocks, American Association of Petroleum Geologists Memoir No. 1, p. 108-121.

Eckelmann, W. R., R. J. De Witt, and W. L. Fisher, 1975, Prediction of fluvial-deltaic reservoir geometry, Prudhoe Bay field, Alaska: 9th World Petroleum Cong. Proceedings, p. 223227.

Embry, A. F., and J. E. Klovan, 1971, A late Devonian reef tract on northeastern Banks Island, Northwest Territories: Bulletin of Canadian Petroleum Geology, v. 19, p. 730-781.

Enos, P., 1983, Shelf environment, in P. A. Scholle, D. G. Bebout, and C. H. Moore, eds., Carbonate Depositional Environments, Memoir No. 33, p. 268-295.

Epstein, A. G., J. B. Epstein, and L. D. Harris, 1977, Conodont color alteration: An index to organic metamorphism, U. S. Geological Survey Professional Paper 995, 27 p. 
Espitalie, J., M. Madec, and B. Tissot, 1977, Source rock characterization method for petroleum exploration: Offshore Technology Conference Proceedings, OTC 2935, p. 439-444.

Folk, R., 1959, Practical petrographic classification of limestones. American Association of Petroleum Geologists Bulletin, v. 43, p. 1-38.

Gruzlovic, P. D., 1991, Stratigraphic evolution and lateral facies changes across a carbonate ramp and their effect on parasequences of the Carboniferous Lisburne Group: M. S. thesis, University of Alaska, Fairbanks, 201 p.

Hanks, C.L., Lorenz, J., Teufel, L., and Krumhardt, A.P., 1997, Lithologic and structural controls on natural fracture distribution within the Lisburne Group, northeastern Brooks Range and North Slope subsurface, Alaska: American Association of Petroleum Geologists Bulletin, vol. 81, no. 10, p. 1700-1720.

Hanks, C.L., Brinton, J., and Lorenz, J., 2001, Fracturing in the Lisburne Group as a function of carbonate lithology, mechanical stratigraphy and position in detachment folds in The Influences of fold and fracture development on reservoir behavior of the Lisburne Group of northern Alaska, DOE Annual Report, National Energy Technology Laboratory, National Petroleum Technology Office, U.S. Department of Energy, Tulsa Oklahoma, p. E9-E31.

James, N.P., 1997, The cool-water carbonate depositional realm, in James, N.P., and Clark, J.A.D., eds., Cool-Water Carbonates, SEPM (Society for Sedimentary Geology) Special Publication No. 56, p.1-20.

Jameson, J., 1994, Models of porosity formation and their impact on reservoir description, Lisburne field, Prudhoe Bay, Alaska: American Association of Petroleum Geologists Bulletin, v. 78, p. 1651-1678.

Jamison, H. C., L. D. Brockett, and R. A. McIntosh, 1980, Prudhoe Bay: A ten year perspective, in M. T. Halbouty, ed., Giant Oil and Gas Fields of the Decade: 1968-1978, American Association of Petroleum Geologists Memoir No. 30, p. 289-314.

Jones, G.D., and B.J., Ronstron, 2000, Analysis of flow constraints in regional-scale reflux dolomitization: Constant versus variable-flux hydrogeological models: Bulletin of Canadian Petroleum Geology, v. 48, p. 230-245.

Kastner, M., 1971, Authigenic feldspars in carbonate rocks: The American Mineralogist, v. 56, p. 1403-1442.

Kastner, M., J. B. Keene, and J. M. Gieskes, 1977, Diagensis of siliceous oozes. I. Chemical controls on the rate of Opal-A to Opal-CT transformation: An experimental study: Geochimica Cosmochimica Acta, v. 41, p. 1040-1059.

Kidder, D. L., 2001, Secular distribution of biogenic silica through the Phanerozoic: Comparison of silica-replaced fossils and bedded cherts at the series level: Journal of Geology, v. 109, p. 509-522.

Knauth, L. P., 1994, Petrogenesis of chert, in P. J. Heaney, C. T. Prewitt, and G. V. Gibbs, eds., Silica: Physical Behavior, Geochemistry, and Materials Applications, Washington, D. C., Mineralological Society of America, Review of Mineralogy No. 29, p. 233-258

LePain, D. L., 1993, Transgressive sedimentation in rift-flank region: Deposition of the Endicott Group (Early Carboniferous), northeastern Brooks Range, Alaska: Ph. D. thesis, University of Alaska, Fairbanks, Alaska, 325 p.

LePain, D. L., R. K. Crowder, and W. K. Wallace, 1994, Early Carboniferous transgression on a passive continental margin: Deposition of the Kekiktuk Conglomerate, northeastern 
Brooks Range, Alaska: American Association of Petroleum Geologists Bulletin, v. 78, p. 679-699.

Lerand, M., 1973, Beaufort Sea, Future petroleum Provinces of Canada: Their Geology and Potential, Canadian Society of Petroleum Geology Memoir No. 1, p. 315-386.

Light, J. M., and J. B. Wilson, 1998, Cool-water carbonate deposition on the West Shetland shelf: A modern distally steepened ramp, in V. P. Wright, and T. P. Burchette, eds., Carbonate Ramps, Geological Society of London Special Publication No. 149, p. 73-105.

Magoon, L. B., P. G. Lillis, K. J. Bird, C. Lampe, and K. E. Peters, 2003, Alaskan North Slope petroleum systems, U.S. Geological Survey.?????

Mamet, B. L., and A. K. Armstrong, 1972, Lisburne Group, Franklin and Romanzof Mountains, northeastern Alaska, Geological Survey Research 1972, U. S. Geologial Survey Professional Paper 800-C, p. C127-C144.

McGee, M. M., M. T. Whalen, and A. P. Krumhardt, 2002, Baseline stratigraphy of the Lisburne Group, The Influence of Fold and Fracture Development on Reservoir Behavior of the Lisburne Group of Northern Alaska: Department of Energy Second Semi-Annual Report (DE-AC26-98BC15102), January 2002, p. B1-B17.

Melim, L.A., and P.A., Scholle, 2002, Dolomitization of the Capitan Formation forereef facies (Permian, West Texas and New Mexico): Seepage reflux revisited: Sedimentology, v. 49, p. 1207-1227.

Melim, L.A., P.K. Swart, and R.G., Maliva, 1995, Meteoric-like fabrics forming in marine waters: implications for the use of petrography to identify diagenetic environments, Geology, v. 23, p. 755-758.

Melvin, J., 1987, Fluvio-paludal deposits in the lower Kekiktuk Formation (Mississippian), Endicott Field, northeast Alaska, in F. G. Ethridge, R. M. Flores, and M. D. Harvey, eds., Recent Developments in Fluvial Sedimentology, Contributions From 3rd Annual Fluvial Sedimentology Conference, SEPM Special Publication No. 39, p. 343-352.

Meyers, W. J., 1977, Chertification in the Mississippian Lake Valley Formation, Sacramento Mountains, New Mexico: Sedimentology, v. 24, p. 75-105.

Missman, R. A., and J. Jameson, 1991, An evolving description of a fractured carbonate reservoir: The Lisburne field, Prudhoe Bay, Alaska, The Integration of Geology, Geophysics, Petrophysics and Petroleum Engineering in Reservoir Delineation, Description, and Management: Proceedings of the First Archie Conference, Held October 22-25, 1990, in Houston, Texas, U. S. A., Tulsa, Oklahoma, The American Association of Petroleum Geologists, p. 204-224.

Mull, C. G., and M. D. Mangus, 1972, Itkilyariak Formation: New Mississippian formation of Endicott Group, Arctic Slope of Alaska: American Association of Petroleum Geologists Bulletin, v. 56, p. 1364-1369.

Nilsen, T. H., 1981, Upper Devonian and Lower Mississippian redbeds, Brooks Range, Alaska, in A. D. Miall, ed., Sedimentation and Tectonics in Alluvial Basins, Toronto, Geological Association of Canada Special Paper No. 23, p. 187-219.

Nolte, R. A., and D. J. Benson, 1998, Silica diagenesis of Mississippian carbonates of northern Alabama: Transactions of the Gulf Coast Association of Geological Societies, v. 48, p. 301-310.

Oschmann, W., 1991, Anaerobic-poikiloaerobic-aerobic: a new facies zonation for modern and ancient nertic redox facies, in Einsele, G, Ricken, W., and Seilacher, A., eds., Cycles and Events in Stratigraphy, Berlin, Springer-Verlag, p. 565-571. 
Osleger, D., and Read, J.F., 1991, Relation of eustasy to stacking patterns of meter-scale carbonate cycles, Late Cambrian, USA, Journal of Sedimentary Petrology, v. 61, p. 12251252.

Read, J. F., 1985, Carbonate platform facies models: American Association of Petroleum Geologists Bulletin, v. 69, p. 1-21.

Read, J. F., 1994, Milankovitch cycles, sequences and early diagenesis on carbonate platforms formed under greenhouse vs. icehouse conditions: Implications for reservoirs in carbonate rocks, in A. P. Schultz, and E. K. Rader, eds., Virginia Division of Mineral Resources Publication No. 132: Studies in Eastern Energy and the Environment, p. 141176.

Read, J. F., 1995, Overview of carbonate platform sequences, cycle stratigraphy and reservoirs in greenhouse and icehouse worlds, in J. F. Read, C. Kerans, and L. J. Weber, eds., Milankovitch Sea Level Changes, Cycles and Reservoirs on Carbonate Platforms in Greenhouse and Ice-house Worlds, SEPM Short Course Notes No. 35, Part 1, p. 1-102.

Read, J. F., and R. K. Goldhammer, 1988, Use of Fischer plots to define third-order sea-level curves in Ordovician peritidal cyclic carbonates, Appalachians: Geology, v. 16, p. 895899.

Schlager, W., 1992a, Carbonates versus siliclastics in sequence stratigraphy, Sedimentology and Sequence Stratigraphy of Reefs and Carbonate Platforms, Tulsa, OK, The American Association of Petroleum Geologists Continuing Education Course Note Series No.34, p. 44-56.

Schlager, W., 1992b, Rhythms and events in carbonate deposition, Sedimentology and Sequence Stratigraphy of Reefs and Carbonate Platforms, Tulsa, OK, The American Association of Petroleum Geologists Continuing Education Course Note Series No. 34.

Selleck, B. W., 1985, Chert and dolomite in the Onondaga Limestone (Devonian) of New York State: Northeastern Geology, v. 7, p. 136-143.

Shackleton, R.J., Hanks, C.L., and Wallace, W.K., 2002, The relationship between fracturing, asymmetric folding, and normal faulting in Lisburne Group carbonates: West Porcupine Lake Valley, northeastern Brooks Range, Alaska in The Influences of fold and fracture development on reservoir behavior of the Lisburne Group of northern Alaska, DOE Annual Report, National Energy Technology Laboratory, National Petroleum Technology Office, U.S. Department of Energy, Tulsa Oklahoma, p. D1-13.

Sinclair, H. D., Z. R. Sayer, and M. E. Tucker, 1998, Carbonate sedimentation during early foreland basin subsidence: The Eocene succession of the French Alps, in V. P. Wright, and T. P. Burchette, eds., Carbonate Ramps, Geological Society of London Special Publication No. 149, p. 205-218.

Siok, J.P., 1985, Geologic history of the Siksikpuk Formation on the Endicott Mountains and Picnic Creek allochthons, north central Brooks Range, Alaska Thesis (M.S.)--University of Alaska, Fairbanks, 253p.

Stone, J., 1987, Review of investigative techniques used in the study of conodonts, in R. L. Austin, ed., Conodonts: Investigative Techniques and Applications, United Kingdom, Ellis Horwood, p. 17-34.

Tailleur, I. L., C. F. Mayfield, and I. F. Ellersieck, 1977b, Late Paleozoic sedimentary sequence, southwestern Brooks Range, in K. M. Blean, ed., The United States Geological Survey in Alaska: Accomplishments During 1976, U. S. Geological Survey Circular 751-B, p. B25B27. 
Walker, T. R., 1960, Carbonate replacement of detrital crystalline silicate minerals as a source of authigenic silica in sedimentary rocks: Geological Society of America Bulletin, v. 71, p. 145-152.

Watts, K. F., A. G. Harris, R. C. Carlson, M. K. Eckstein, P. D. Gruzlovic, T. A. Imm, A. P. Krumhardt, D. K. Lasota, S. K. Morgan, J. A. Dumoulin, P. Enos, R. H. Goldstein, and B. L. Mamet, 1995, Analysis of reservoir heterogeneties due to shallowing-upward cycles in carbonate rocks of the Pennsylvanian Wahoo Limestone of northeastern Alaska, Final Report for 1989-1992 (DOE/BC/14471-19), Bartlesville Project Office, 433 p.

Wendte, J. C., 1992, Platform evolution and its control on reef inception and localization, Devonian-Early Mississippian Carbonates of the Western Canada Sedimentary Basin: A Sequence Stratigraphic Framework, Calgary, SEPM Short Course No. 28, p. 41-87.

Williams, L. A., and D. A. Crerar, 1985, Silica diagenesis. II. General mechanisms: Journal of Sedimentary Petrology, v. 55, p. 312-321.

Williams, L. A., G. A. Parks, and D. A. Crerar, 1985, Silica diagenesis. I. Solubility controls: Journal of Sedimentary Petrology, v. 55, p. 301-311.

Wilson, J. L., 1975, Carbonate Facies in Geologic History: New York, Springer-Verlag, 471 p.

Wind, F. H., 1998, Early silica mobilization and chertification in the Thirtyone Formation, Bryant G Devonian Unit, Midland Co., TX, The Search Continues Into the 21st Century: West Texas Geological Society Fall Symposium, v. 98-105, p. 67-72.

Woidneck, K., P. Behrman, C. Soule, and J. Wu, 1987, Reservoir description of the Endicott Field, North Slope, Alaska, in I. Tailleur, and R. Weimer, eds., Alaskan North Slope Geology, Pacific Section, SEPM, p. 43-59.

Wood, G. V., and Armstrong, A. K., 1975, Diagenesis and stratigraphy of the Lisburne Group Limestones of the Sadlerochit Mountains and adjacent areas, northeastern Alaska. U.S. Geological Survey Professional Paper 857, 47 p. 


\title{
Geometry and evolution of detachment folds and thrust-truncated asymmetrical folds in the eastern Brooks Range
}

by Wesley K. Wallace, Paul Atkinson, Margaret Jadamec, Ryan Shackleton and Catherine L. Hanks, Geophysical Institute and Department of Geology and Geophysics, University of Alaska, Fairbanks, Alaska, 99775-5780

\begin{abstract}
Carbonates of the Mississippian and Pennsylvanian Lisburne Group and the underlying Mississippian Kayak Shale display two different types of map-scale folds in the eastern Brooks Range of Alaska. This study characterized these folds, reconstructed their evolution, and identified factors that may have influenced their formation.
\end{abstract}

In the northeastern Brooks Range, the folds are upright and symmetrical detachment folds that are cut only rarely by thrust faults. The folds vary widely in shortening and geometry. At low to intermediate shortening, the folds range from angular throughout to an angular inner arc that grades outward to a box or rounded geometry. With increasing shortening, folds display increasing flattening by bulk strain, typically with thickening of hinges and thinning of limbs.

The mechanism of folding changed from flexural slip at low to intermediate shortening to fold flattening by bulk strain as shortening increased. Flattening probably superseded flexural slip due to some combination of resistance to continued folding by flexural slip and more ductile conditions of deformation. The formation of symmetrical detachment folds in the northeastern Brooks Range was favored by some combination of a regionally horizontal detachment, a weak detachment, a low ratio of competent to incompetent unit thickness, an absence of overlying thrust sheets, and an orogenic wedge with a low taper angle.

A hybrid geometric-kinematic model for the detachment folds of the northeastern Brooks Range is able to describe geometry at different stages of evolution, but does not predict how fold geometry will evolve.

Extension fractures may have formed normal to fold axes during layer-parallel shortening before or early during folding. Flexural-slip under brittle conditions may have resulted in fracturing due to shear strain related to bed-parallel slip and/or tangential longitudinal strain due to bending of beds. New fractures probably did not form during fold flattening under ductile conditions and existing fractures probably were closed and annealed. Formation of fractures likely resumed during minor late flexural slip.

South of the northeastern Brooks Range, the folds are inclined and asymmetrical and typically are cut and displaced by thrust faults. The folds are mostly angular, and display a smaller range of fold shortening and less fold flattening than in the northeastern Brooks Range. Forelimbs commonly contain a large parasitic anticline-syncline pair and backlimbs are long and gently folded. 
Forelimbs typically are cut and displaced above one or more thrust faults and backlimbs overlie a flat near the base of the Lisburne. Thrust faults commonly are gently folded into antiforms. Local folds that are not visibly cut by thrust faults display greater fold shortening, steeper inclination, and more thickness change than folds that have been cut by thrusts.

Origin of the folds as detachment folds is suggested by the competency contrast between Kayak and Lisburne, the presence of some folds that have not been cut by thrust faults, and a transition to detachment folds in the same rock units to the north. One fold with quite different characteristics may have formed as a tri-shear fault-propagation fold.

Folds began as detachment folds whose forelimbs were steepened and thickened, mainly by parasitic folding. Thrust faults broke through forelimbs as shortening increased and the truncated fold was fault-bend folded as it was displaced over the footwall ramp. Thrusts underlying displaced folds were gently folded by deformation in the footwall.

Inclination of layering with respect to maximum compressive stress or simple shear acting along layering favored formation of asymmetrical folds. Field observations support a top-to-north gradient in bed-parallel shear and that fold asymmetry favored thrust breakthrough.

The formation and eventual breakthrough of asymmetrical folds was favored by some combination of a regionally inclined detachment, a high ratio of competent to incompetent unit thickness, the presence of overlying and underlying thrust sheets, and an orogenic wedge that lacks an unusually low taper angle.

A quantitative model for the geometry and kinematics of thrust-truncated asymmetrical folds must both take into account how natural truncated and displaced folds are further folded.

Some fractures formed oblique to bedding as a result of bed-parallel shear prior to folding. Flexural-slip under brittle conditions may have been accompanied by fracturing related to bedparallel slip, mainly in limbs, and/or tangential longitudinal strain due to bending of beds, mainly in hinges. Fixed hinges would result in little overlap between hinge- and limb-related fractures. Fractures may have formed related to thrust breakthrough and thrust-related strain. Late bending of displaced folds resulted in abundant fractures and veins in or near hinges of displaced folds and the bends in their backlimbs.

\section{Introduction}

Two significantly different types of map-scale folds exist within the same rock units in the eastern Brooks Range of Alaska (Figure 1). The folds are formed within carbonates of the Mississippian and Pennsylvanian Lisburne Group above the Mississippian Kayak Shale. Throughout the northeastern Brooks Range (Figure 2), the folds are upright and symmetrical detachment folds that are only rarely cut by thrust faults (Wallace and Hanks, 1990; Wallace, 1993) (Figure 3a). To the south of the Continental Divide thrust front (Figure 2), the folds are inclined and asymmetrical and generally have been cut and displaced by thrust faults (Wallace, 1993; Wallace and Homza, in press) (Figure 3b). This structural style characterizes these rock units along the entire length of the northern part of the main axis of the Brooks Range (Moore et al., 1994; Wallace et al., 1997) (Figure 1). This study systematically documented well-exposed 
examples of both types of folds in order to define their characteristics and to reconstruct the evolution of each type of fold. The differences between the two areas offer some insights into the factors that may determine which of the two different types of folds forms.

This report includes a similar section on each of the two types of folds. Each includes:

-summary of the sources of observations

-brief discussion of mechanical stratigraphy

-description of fold characteristics

-interpretation of fold evolution

-discussion of possible controls on fold geometry and evolution

-questions identified in this study

The Introduction chapter of this report provides more details on the geologic setting and the Stratigraphy chapter provides a detailed discussion of the stratigraphy.

\section{Detachment folds}

\section{$\underline{\text { Basis for analysis }}$}

This analysis of detachment folds in the northeastern Brooks Range is based on a variety of different observations. The most detailed work was a Master's thesis study by Paul Atkinson in the Fourth Range and Shublik Mountains (Figures 2 and 3a) (Atkinson, 2000, 2001; Atkinson and Wallace, 2003). This work included field observations, mapping at 1:25,000, and laserrangefinder surveys of folds. Wes Wallace made field observations and mapped at 1:25,000 in three areas: the upper Echooka River, the Echooka anticlinorium, and east Franklin Creek (Figure 2) (Wallace, 2000, 2001, 2003, and unpublished field data). Wes Wallace also made ground and helicopter reconnaissance observations in various areas for this study, as well as previous detailed and reconnaissance observations in many parts of the northeastern Brooks Range from 1983 to 1998 (Wallace, 1993 and unpublished field data).

\section{Mechanical stratigraphy}

The stratigraphy of the Lisburne Group in the northeastern Brooks Range (Figure 4) is best known in the northern part of the range, from the Sadlerochit Mountains in the north to the north Franklin Mountains anticlinorium and south limb of the Echooka anticlinorium in the south (Figure 2) (Watts et al., 1995). Stratigraphic descriptions of Lisburne in the Fourth Range and Shublik Mountains are presented in this and previous reports on this study (Whalen, 2000, 2001, this report). The Lisburne displays significant changes in thickness and facies, but displays similar mappable units throughout the northeastern Brooks Range. For structural mapping purposes, the Lisburne is divided into lower and upper units that can be identified from a distance based on color, resistance to erosion, and bedding characteristics (Figure 4). These mapping units correspond roughly with the stratigraphic subdivisions of the Lisburne into Alapah (lower) and Wahoo (upper), but placement of the Alapah-Wahoo contact varies depending on microfossil zonation and facies and does not everywhere correspond with the mappable boundary between the darker-colored, less-resistant lower Lisburne and the lightercolored, more-resistant upper Lisburne. 
The Lisburne appears to display a relatively consistent pattern of mechanical stratigraphic behavior from the Shublik Mountains south to the Continental Divide thrust front (Figure 2). Within this area, well-defined mechanical layering is evident throughout the section, with a strong competency contrast between Kayak (very incompetent) and upper Lisburne (very competent) being separated by a zone of mechanical transition in the lower Lisburne (Figure 4). Lower Lisburne is $300 \mathrm{~m}$ thick and upper Lisburne is $200 \mathrm{~m}$ thick, for a total thickness of $\sim 500 \mathrm{~m}$. Kayak Shale is up to $200 \mathrm{~m}$ thick, but thins locally, especially to the north. Kayak Shale consists mostly of uniform shale that deforms incompetently by a combination of smallscale folds, thrust faults, and penetrative fabrics, including solution cleavage. Folds parasitic to map-scale detachment folds are locally displayed by 1-10 m thick competent interbeds of limestone near the top of Kayak and of sandstone lower in the section. In the lower Lisburne, well-defined and fairly evenly spaced bedding forms mechanical layering throughout, but is divided at a larger scale into alternating competent and incompetent intervals that vary in relative thickness throughout the section. The percentage and thickness of competent intervals generally increase upward, but the pattern is sufficiently nonsystematic to facilitate the development of parasitic folds that commonly vary in wavelength and are disharmonic throughout the section. The upper Lisburne also has well-defined, evenly spaced mechanical layering throughout, but these layers are thicker, more competent, and more uniform in competency than in lower Lisburne. The lower part of upper Lisburne forms massive cliffs and is the most competent interval in the Lisburne. A slight decrease in competency in the upper part of upper Lisburne results from more mechanically distinct beds that define topographic steps. The Lisburne is sharply overlain by a significantly less competent unit, the Sadlerochit Group, which consists dominantly of thin-bedded shale to fine-grained sandstone in the northeastern Brooks Range.

\section{Fold characteristics}

Most detachment folds in the northeastern Brooks Range are upright and symmetrical and are not cut by thrust faults (Figure 3a). Beyond these common characteristics, the folds display a wide range of variability (Figures 5 and 6, Table 1). Anticlines typically range in width from about 0.4 to $2 \mathrm{~km}$. The folds range from gentle to isoclinal, with a corresponding range in aspect ratio. Folds tend to be tighter and more widely spaced southward and within synclinoria, although interlimb angles typically vary considerably within any given area. Shape of fold profile varies in a continuum from angular throughout to an angular inner arc that grades outward to a box or rounded geometry. Second- and third-order folds typically are angular single-hinge folds, in contrast with the box-fold or rounded-hinge geometries more typical of first-order detachment folds. Thickness changes are common across folds, with the amount of thickening in hinges and thinning in limbs generally increasing with increasing shortening.

Fold geometry is strongly influenced by the gradational upward increase in competency from the Kayak Shale to the lower Lisburne to the upper Lisburne. Parasitic folds are typical in the Kayak Shale and common in the lower Lisburne, but are larger and less common in the upper Lisburne (Figures 6f, g and 7b1). Relief defined by the smaller folds in the lower Lisburne generally corresponds with the relief on the contact between upper and lower Lisburne, although the smaller folds are largely disharmonic in detail with the larger folds in the upper Lisburne (Figure $6 \mathrm{~g}$ ). Folds in the lower Lisburne display steeper limb dips and greater height than the much 
more subdued equivalent or comparable folds in the upper Lisburne. Folds in the Kayak Shale are comparable in size and geometry to those in the lower Lisburne. Based on fold geometry, the fold shortening in upper Lisburne commonly does not appear to be sufficient to account for the tighter, shorter-wavelength folds below (Figure 6g). Greater meso- to microscopic layer-parallel shortening in the competent upper Lisburne might account for this apparent discrepancy.

The "first-order" detachment folds actually are gently folded or tilted at the scale of the regional anticlinoria of the northeastern Brooks Range (Figure 3a). Where the upper surface of the basement is in the subsurface, it is difficult to assess whether these structures formed over horses in the basement or are larger, very gentle detachment folds that reflect variations in structural thickness of the underlying Kayak Shale.

The range in shortening observed in detachment folds of the northeastern Brooks Range records different stages of fold evolution with increasing shortening (Figure 7). Most of the folds in the northeastern Brooks Range are in a broad category representing intermediate shortening for the region. The less common folds at the low and high ends of the range of shortening display characteristics that offer insights into how fold processes may have changed as shortening increased.

\section{Intermediate shortening}

First-order detachment folds with straight to gently curved limbs characterize the upper Lisburne (Figures 6d, e and 7b). Hinges commonly branch outward to separate planar to gently curved panels in the outer arc of folds. Hinges between sub-planar panels typically are angular or narrow and curved. Hinge geometry changes between intervals of different competency by hinge thickening and detachment. Parasitic folds are large and uncommon, and are present mostly near the base of the upper Lisburne.

Second- and third-order folds that are parasitic to the first-order folds in the upper Lisburne characterize the lower Lisburne (Figures $6 \mathrm{~g}$ and $7 \mathrm{~b}$ ). Some of these folds die out upward at the top of the lower Lisburne, whereas others continue upward. These folds typically are tighter than the encompassing first-order fold, are angular, and commonly show structural changes in bed thickness. Platy solution cleavage is common in these folds.

More rounded hinges in the upper Lisburne and sharper, more angular hinges in the lower Lisburne commonly characterize the composite fold geometry defined by these two mechanical stratigraphic units (Figures $7 \mathrm{~b} 1$ and 8). Anticlines commonly display concave-upward limbs. Hinge zones have a gently curved crestal panel upward and cuspate hinges downward, which is transitional between concentric and flat-crested kink fold geometries. Synclines typically display straight to concave-upward limbs. Detachment and thickening in the hinge zones allow them to maintain a near-constant width downward, toward the outer arc of the syncline (Figures 6e and 8). The geometric differences between anticlines and synclines may reflect the upward increase in competency within the Lisburne.

The Lisburne commonly displays considerable variation in structural thickness across folds (Figure 8). Hinge zones of anticlines and synclines are thickened. Limbs most commonly are 
thinned, but locally are thickened. Thickness changes generally increase with increasing shortening, although significant thickness changes are present in some folds with relatively low shortening. Thickness changes are accommodated by some combination of parasitic folding and bulk strain, with a large range in the relative contribution of each in different folds and in different stratigraphic intervals within individual folds. Bulk strain is accommodated by solution cleavage and crystal-plastic deformation such as mechanical twinning of calcite. Fractures and minor faults may accommodate some thickness changes, but their contribution is relatively small.

\section{Low shortening}

The best examples of folds at the low end of the shortening range are in the Echooka anticlinorium and the Shublik Mountains (Figure 2). The subhorizontal crest of the Echooka anticlinorium displays small, closely spaced ( 75-300 $\mathrm{m}$ ) folds in the lower Lisburne that form culminations with a larger spacing of $\sim 350-450 \mathrm{~m}$ (Figure $6 \mathrm{a}$ ). These folds typically display a kink-style box-fold geometry with angular to rounded hinges. Anticlines have interlimb angles of $\sim 75-135^{\circ}$ that generally increase downward. Common thickening in hinges of anticlines accounts for downward decrease in amplitude and increase in interlimb angle. Significantly, the amplitude of the folds decreases downward into a nearly planar, sub-horizontal surface in the lowermost Lisburne.

The westward-plunging crest of the Echooka anticlinorium also exposes folds in upper Lisburne (Figure $6 b$ ). These are much larger folds (wavelength $\sim 2-3 \mathrm{~km}$ ) with interlimb angles of $\sim 110$ $130^{\circ}$. They are straight-limbed with narrow, rounded hinges. They have sparse parasitic folds with geometry comparable to the larger folds. The composite picture that emerges is that multiple small folds in the lower Lisburne overlie a planar detachment, and that culminations in these small folds core larger straight-limbed folds in the upper Lisburne. A well-studied lowshortening fold over the crest of the Fourth Range anticlinorium (Figures 5c and 6f) displays characteristics similar to the folds in both the lower and upper Lisburne in the Echooka anticlinorium.

Folds on the north limb of the Echooka anticlinorium and in the Shublik Mountains reflect shortening that is somewhat greater, but is still relatively low. These areas display large, widely spaced ( 750-1500 $\mathrm{m}$ ) folds in the upper Lisburne. These folds display a box-fold geometry defined by inward-converging inclined axial surfaces that bound planar to gently curved central panels (Figures 5d, e, 6c, and 7b1). Anticlines have interlimb angles of $\sim 55-110^{\circ}$ that generally increase downward. These folds reflect lower shortening than their interlimb angles would suggest because of their relatively low aspect ratio (wavelength $\geq$ fold height). Thickening in hinge zones accounts for the downward increase in interlimb angle and is accommodated by parasitic folding and layer-parallel shortening. Thickening is more pronounced in the lower Lisburne, although little lower Lisburne is well exposed in these areas. Angular second- and third-order parasitic folds are rare in upper Lisburne but common in lower Lisburne. 


\section{High shortening}

The best examples of folds at the high end of the shortening range are in the synclinoria that separate the three anticlinoria in the Franklin Mountains and the Fourth Range (Figure 2). In addition to these dominantly upright folds, inclined to recumbent folds along the north limb of the south Franklin Mountains anticlinorium provide exposures across the entire Lisburne mechanical stratigraphy in high-shortening folds.

The tightest folds in the synclinoria are upright and symmetrical and have high ratios of amplitude to wavelength (Figures 5a, b, 6h, 7d). Fold shape varies from the core to the outer arc. Cores are essentially isoclinal with very narrow hinge zones. Outer arcs display sharp angular hinges that curve gently to subisoclinal limbs, yielding an ogive shape (Figure 6h). This shape reflects significant thickening in narrow hinge zones relative to limbs, with the amount of thickening varying from interval to interval. Beds in both limbs and hinges display penetrative solution cleavage and internal strain. The high strain in limbs suggests that beds there were thinned and extended, while in hinges they were thickened and shortened. Parasitic folds typically are not present in the tightest folds, although a few are locally present within narrow anticlinal hinge zones in the upper Lisburne. Kayak Shale typically is not exposed in the synclinoria, but limitations on space in exposed lower Lisburne suggest that Kayak has been largely to totally squeezed out of fold cores.

Folds on the north limb of the south Franklin Mountains anticlinorium (Figure 2) also reflect high shortening, but have characteristics that suggest some differences in evolution. These folds are strongly inclined to recumbent, reflecting tilt and displacement over the underlying detachment. They display strong changes in geometry throughout controlled by their mechanical stratigraphy, with detachment between the upper and lower Lisburne as well as within the Kayak (Figure 6j). Thickening by parasitic folding is typical in the lower Lisburne. "Liftoff" by delamination along bedding planes within the upper Lisburne allows an upward tightening and increase in amplitude in some locations. The upper Lisburne displays parasitic folding in the hinge zone in other locations. The overturned limb in these folds commonly has been cut by a thrust fault to form a hangingwall anticline and footwall syncline.

\section{Interpretation of fold evolution}

The characteristics of detachment folds in the northeastern Brooks Range vary according to the amount of shortening. This variation provides a basis for a generalized interpretation of fold evolution with increasing shortening (Figure 7). The observations suggest that both fold geometry and mechanism change in a complex way with increasing shortening.

\section{Low shortening}

As shortening begins, closely spaced angular or box folds in the lower Lisburne underlie larger straight-limbed folds with narrow curved hinge zones in the upper Lisburne (Figures 6a, b, and 7a). This suggests early nucleation of many folds at short wavelength (second- to third-order detachment folds) in the lower Lisburne. Larger-wavelength culminations in these folds may 
represent amplification of anticlines at the larger preferred wavelength of the entire composite mechanical stratigraphic unit defined by the Lisburne, especially its more competent upper part.

With increasing shortening, limbs steepen and hinge zones widen, leading to box fold geometries in first-order detachment folds (Figures $6 \mathrm{c}$ and $7 \mathrm{~b} 1$ ). This is accompanied by an increase in fold aspect ratio (height/wavelength). Widening of hinge zones and increasing inclination of the bounding hinges may reflect, at least in part, the rotation of hinges required to maintain constant layer thickness.

The characteristics of the low-shortening folds suggest that folding occurs dominantly by flexural slip with rotation of limbs. Some layer-parallel shortening in the upper Lisburne may be required to account for the apparent discrepancy in fold shortening compared with the lower Lisburne, with its tighter and more abundant parasitic folds.

\section{Intermediate shortening}

As shortening increases, interlimb angles decrease and limbs steepen to form folds with an intermediate aspect ratio (Figures 6d, e, 7b, and 8). The amount of thickness change across folds increases and typically involves thickening of hinges and thinning of limbs. This is accommodated by flexural-slip parasitic folding and by bulk strain, the combination of which varies depending on location.

\section{High shortening}

As shortening reaches the high end of the range, folds decrease in width and increase in height to a high aspect ratio (Figures $6 \mathrm{~h}$ and $7 \mathrm{c}$ ). Shortening and fold amplification are accommodated mainly by bulk strain (fold flattening), with thickening of hinges and thinning of limbs. Some evidence exists for flexural slip that post-dated and occurred under different conditions (less ductile) than fold-flattening by bulk strain. It is not clear what made flexural-slip possible in folds with such steep limbs and small interlimb angles. However, local folds that underwent high shortening in a structurally higher position and under less ductile conditions may offer a clue. Detachment between different levels of these folds indicates that they tightened and amplified by flexural slip as material was squeezed out of the fold core by a "liftoff" mechanism (Figure 6j).

\section{Controls on fold geometry and evolution}

Many variables may influence fold geometry and evolution. It was beyond the scope of this study to obtain knowledge of fold geometry and kinematics, strain, and the conditions and timing of deformation in sufficient detail to isolate the role of individual variables. Nonetheless, variations in characteristics of folds throughout the northeastern Brooks Range provide some insights into the influence of different variables on detachment folding in the northeastern Brooks Range.

Mechanical stratigraphy is probably the single most important variable that influenced detachment folding in the northeastern Brooks Range. The mechanical stratigraphy is relatively 
consistent throughout the northeastern Brooks Range, although it varies in detail (Figure 4). At the simplest level, the competent Lisburne has folded above the incompetent Kayak, that has detached and thickened above the competent Kekiktuk and pre-Mississippian basement. At a more detailed level, the mechanical stratigraphy is complex and multi-layered. Most importantly, competency increases gradationally upward from the Kayak to the upper Lisburne, reflecting an increase upward in bed thickness and percentage of competent rock type. This facilitated the formation of larger and simpler detachment folds in the upper part of the stratigraphy above smaller and more complex disharmonic folds. The dominant rock types involved, shale and carbonates, are able to deform both by flexural slip and by bulk strain depending on the conditions of deformation.

The incompetent unit (Kayak Shale, $200 \mathrm{~m}$ ) is thick relative to the competent unit (Lisburne Group, $500 \mathrm{~m}$ ) (Figure 4). The low ratio of competent to incompetent unit thickness, about 2.5, facilitates the buckling of the competent unit. However, local stratigraphic or structural thinning of the incompetent unit could result in bottoming out of folds in the competent unit against the underlying detachment, thereby requiring a change in how increasing shortening is accommodated.

The geometry of the detachment that underlies the folds probably has played an important role. This detachment does not display a regional dip at the scale of the entire northeastern Brooks Range, but maintains a near-constant regional base-level (Figure 3a). This may have facilitated the formation of symmetrical and upright folds, rather than asymmetrical and inclined folds (Davis and Engelder, 1985). At a more detailed level, the detachment has been folded by formation of the regional-scale basement anticlinoria in the northeastern Brooks Range (Figure 3a). Local variations in the amount of shortening correspond strongly with position relative to the anticlinoria: shortening is lowest over the crests of anticlinoria and highest in the synclinoria. In general, fold aspect ratio and the degree of fold flattening increases with increasing confinement in synclinoria.

Folds in the competent unit display near-parallel geometry at low to intermediate shortening and appear to have formed dominantly by flexural-slip folding. With increasing shortening, however, thickness changes that result in non-parallel fold geometry become increasingly important and appear dominantly to reflect fold flattening. Folds in areas of maximum shortening and structural confinement are thickened in hinges and thinned in limbs. A variety of factors may have contributed to increasing fold flattening by bulk strain over flexural-slip folding. The mechanical difficulty of flexural-slip folding may increase as fold cross-sectional area decreases with decreasing interlimb angle (Homza and Wallace, 1995, 1997) and as the resistance to interlayer slip increases with increasing limb dip (Ramsay, 1967, 1974).

Consequent locking of folds may require that continued shortening be accommodated by different mechanisms. Increasing burial depth and the corresponding increase in temperature and pressure will favor the ductile deformation mechanisms that allow fold flattening by bulk strain.

Most of the folds that display strongly non-parallel geometries also occupy structurally low positions in synclinoria and clearly deformed under ductile conditions. Thus, it is difficult to assess the relative importance of fold locking and ductile conditions in the non-parallel flattening 
of folds. However, a few non-parallel folds that formed in structurally higher positions under less ductile conditions provide some interesting insights. Some folds with relatively large interlimb angles display considerable thickening by parasitic folding. In some cases, Kayak Shale may be sufficiently thin that synclines in the Lisburne "bottomed out" and continued shortening could not be accommodated by continued growth of large fixed-hinge anticlines. However, other examples in which Kayak Shale is thick require a different, but unknown, explanation. At the other end of the spectrum, some folds were able to attain very small interlimb angles by flexural slip. This appears to have been achieved by detachment that allowed a layer to "lift-off" and fold isoclinally above an underlying layer.

\section{Comparison with models for detachment folds}

Numerous geometric and kinematic models have been proposed for detachment folds (e.g., Jamison, 1987; Dahlstrom, 1990; Epard and Groshong, 1995; Homza and Wallace, 1995, 1997; Poblet and McClay, 1996; Atkinson and Wallace, 2003; Mitra, 2003). Existing evidence suggests that northeastern Brooks Range detachment folds formed by limb rotation in which at least the anticlinal hinges were fixed (Homza and Wallace, 1997; Atkinson and Wallace, 2003). Two models for such folds provide end members for the purposes of comparison. The Homza and Wallace $(1995,1997)$ model (Figure 9a) assumes that the competent unit deforms by parallel folding, which requires change in the thickness of the incompetent unit beneath synclines (i.e., variable detachment depth). By contrast, the Epard and Groshong (1995) model (Figure 9b) assumes no difference in competency throughout the section, which allows thickness to remain constant beneath synclines (i.e., constant detachment depth). Neither model fits observations of the natural detachment folds in the northeastern Brooks Range. Many folds show thickness changes in the competent unit, which violates a fundamental assumption of the Homza and Wallace model. Different degrees of thickness change throughout the section clearly reflect competency contrast in folds, and variations in thickness of the incompetent unit beneath synclines clearly indicate that detachment depth is not constant. Both of these observations violate fundamental assumptions of the Epard and Groshong model.

Atkinson and Wallace (2003) suggested that northeastern Brooks Range folds fit a hybrid model that includes elements of both the Homza and Wallace and Epard and Groshong models (Figure 9c). A model for northeastern Brooks Range detachment folds must allow strong competency contrast and variable detachment depth, as in the Homza and Wallace model. At the same time, it must allow some thickness variation in all layers, as in the Epard and Groshong model. Thickening in hinges of anticlines in the Epard and Groshong model accounts for downward decrease in amplitude and increase in interlimb angle, as is commonly observed in northeastern Brooks Range detachment folds.

In the hybrid model, different degrees of thickness change in different layers reflect differences in competency, and detachment depth is allowed to vary (Figure 9c). This model allows a close geometric match to the wide range of detachment folds in the northeastern Brooks Range (Figures 10 and 11). However, it is important to recognize that the large number of variables in the model does not permit unique prediction of fold geometry and kinematics from limited information. Specifically, the amount of thickness change within a fold cannot be predicted unless shortening or detachment depth is known. In addition, the model does not specifically 
predict the geometry and kinematics of the hinge zone of the fold. More information is required to ascertain how hinge zones evolve as fold evolution progresses and under different conditions of deformation. A better understanding of how hinges may migrate and/or rotate is particularly important.

A model that would allow more complete prediction of the geometry and kinematics of northeastern Brooks Range detachment folds would require more information of two types:

1. a detailed, quantitative description of the geometry of folds at different stages of evolution to form the basis for an empirical model of fold kinematics.

2. quantitative data on material properties and conditions of deformation to form the basis for a mechanical fold model.

Neither type of information alone is sufficient to predict fold geometry and kinematics fully. An empirical model will apply only if the material properties and conditions of deformation are identical to those for the folds that serve as the basis for the model. A mechanical model is valid only to the extent that it can be demonstrated to reproduce the geometry and kinematics of natural folds that formed with known material properties and conditions of deformation.

Mitra (2003) recently published a model for the evolution of detachment folds that has some characteristics applicable to northeastern Brooks Range detachment folds. Depth to detachment changes beneath synclines to maintain area balance in the incompetent unit, as in the Homza and Wallace $(1995,1997)$ and Atkinson and Wallace (2003) models. This is consistent with the variation in detachment depth observed beneath northeastern Brooks Range detachment folds. The model proposes a general progression from "disharmonic detachment folds", with parasitic folds in the fold core, to "lift-off" folds, in which fold aspect ratio increases as material is squeezed out of the fold core. The range in geometry of natural detachment folds in the northeastern Brooks Range suggests that such a progression is common, as previously reported by Homza and Wallace (1997). However, the Mitra (2003) model does not include thickness change in the competent unit as a consequence of fold flattening.

The Mitra model proposes that limbs rotate and change length as a result of very specific processes, including migration of hinges, formation of new hinges, and shear between fixed hinges. The model applies these processes at arbitrary times and locations during fold evolution, and so does not predict fold geometry and kinematics uniquely and quantitatively. The way that these processes occur in the model is not demonstrated to apply in natural folds. More specifically, the geometry and evolution of hinges in northeastern Brooks Range folds is not known well enough to assess whether the Mitra model applies to those folds.

\section{Questions about northeastern Brooks Range detachment folds}

This study has identified some significant questions that should be a focus of future research about detachment folds. The results of the study do not resolve these questions but commonly suggest some possible answers. The questions and some possible answers that should be considered are listed below. 
-What factors favor the formation of symmetrical folds? Possible contributing factors include: a regionally horizontal detachment, a weak detachment, a low ratio of competent to incompetent unit thickness, an absence of overlying thrust sheets, and an orogenic wedge with a low taper angle.

-What factors control formation of box-fold vs. angular geometry? Box fold geometry may be favored by a gradational upward increase in competency; angular geometry may be favored by a more abrupt competency contrast and by fold flattening.

-What controls parallel folding vs. fold flattening? Factors that may contribute to increasing fold flattening include decreasing interlimb angle and consequent decreasing cross-sectional area, increasing limb dip, "bottoming out" of the competent unit due to a locally thin incompetent unit, and conditions that favor ductile deformation.

-Were parasitic folds "unfolded" during fold flattening or were they never present in flattened folds? In either case, why?

-What allows late flexural slip where dips are steep and/or interlimb angles are small? Late flexural slip may be favored by less overburden, lift-off (detachment and tightening above an underlying layer), and relaxation (collapse rather than tightening as changed stress allows normal slip on steep beds).

\section{$\underline{\text { Summary and conclusions }}$}

\section{Fold geometry and evolution}

The detachment folds of the northeastern Brooks Range formed in competent Lisburne Group carbonates above the incompetent Kayak Shale. The competent to incompetent unit thickness ratio is about 2.5. The lower Lisburne represents a mechanical gradation between the incompetent Kayak and the competent upper Lisburne. This gradation probably had an important influence on fold geometry and evolution.

The folds typically are upright and symmetrical and are not usually cut by thrust faults. They display a wide range of interlimb angles and aspect ratios that reflect different amounts of shortening. At low to intermediate shortening, the folds range from angular throughout to an angular inner arc that grades outward to a box or rounded geometry. Angular parasitic folds are common in the Kayak and lower Lisburne. The upper Lisburne apparently displays less fold shortening, suggesting that it may have accommodated some layer-parallel shortening. With increasing shortening, folds display more flattening by bulk strain, typically with thickening of hinges and thinning of limbs.

The mechanism of folding changed throughout fold evolution. At low shortening, parasitic folding in the Kayak and lower Lisburne accompanied formation of large, low-amplitude folds and possible layer-parallel shortening in the upper Lisburne. Folding was dominantly by flexural slip at low to intermediate shortening. This was gradually superseded by fold-flattening by bulk strain as shortening increased. A small amount of flexural slip occurred late in fold evolution. 
Characteristics of the northeastern Brooks Range that may have favored the formation of symmetrical folds include a regionally horizontal detachment, a weak detachment, a low ratio of competent to incompetent unit thickness, an absence of overlying thrust sheets, and an orogenic wedge with a low taper angle. It is unknown which of these may have been most important in controlling fold evolution.

Flattening probably superseded flexural slip due to some combination of resistance to continued folding by flexural slip and more ductile conditions of deformation. Resistance to continued folding by flexural slip may have been due to decreasing interlimb angle and consequent decreasing cross-sectional area, increasing limb dip, or "bottoming out" of the competent unit due to a locally thin incompetent unit.

Local folds that formed at a higher level were able to accommodate high shortening by internal detachment (liftoff) rather than flattening. The same folds typically were not confined laterally, became asymmetrical, and were truncated by thrust faults.

A geometric-kinematic model for the detachment folds of the northeastern Brooks Range must accommodate differences in competency in the section, changes in detachment depth (thickness of the incompetent unit), and changes in layer thickness across the fold. A model (Atkinson and Wallace, 2003) that is a hybrid between earlier models by Homza and Wallace $(1995,1997)$ and Epard and Groshong (1995) meets these conditions. This model is able to describe geometry at different stages of evolution, but does not predict how geometry will evolve. A predictive model requires more information about hinge evolution and controls on thickness changes.

\section{Implications for fracture}

This study reached conclusions about fold geometry and evolution that suggest a number of implications about fracturing related to the folds. One of the most important conclusions is that the mechanism of folding changes throughout the evolution of a fold. This would result in a corresponding change in the conditions that may lead to fracturing. In general, early flexural slip is gradually superseded by fold flattening, with possible minor flexural-slip late in fold evolution.

Layer-parallel shortening before or early during folding, especially in more competent intervals, may result in extension fractures, most likely oriented normal to fold axes. Flexural-slip under brittle conditions could be accompanied by fracturing resulting from shear strain associated with bed-parallel slip and/or tangential longitudinal strain due to bending of beds. Fracturing during flexural-slip folding may be influenced by specific aspects of the geometry and kinematics of the folding. Fractures related to flexural slip likely would dominate in straight fold limbs, whereas fractures related to tangential longitudinal strain likely would dominate in hinge zones. The width and curvature of hinge zones would control fracturing resulting from tangential longitudinal strain. The kinematics of hinges would have major implications for fracturing: Hinge- and limb-related fractures would form in different areas throughout the evolution of fixed-hinge folds. By contrast, complex overprinting of hinge- and limb-related fractures would occur during evolution of migrating-hinge folds. The detachment folds of the northeastern 
Brooks Range are interpreted as fixed-hinge folds as a first approximation, but in detail, they likely rotate as folds tighten, and some may migrate to some extent. Further research is required to determine hinge kinematics in detail.

Flexural-slip is superseded by flattening of folds as a result of some combination of locking of folds and more ductile deformation conditions. Under ductile conditions, new fractures are unlikely to form and existing fractures are likely to close and anneal. If flattening occurs under less ductile conditions, fracture patterns are more likely to reflect the bulk strain field than foldrelated mechanisms like flexural slip or tangential longitudinal strain.

Fracturing is likely to occur in association with late flexural slip. However, the causes of late flexural slip are not well enough known to assess the related fracturing. In particular, very different patterns would be expected depending on whether late flexural slip is caused by contraction or extensional collapse.

The folds observed in this study clearly display significant changes along trend in geometry and kinematics, although those changes were not documented in detail. Fractures normal to fold axes would be expected in local areas of plunge and curvature along trend, as well as where regional extension has occurred along fold axes.

\section{Thrust-truncated asymmetrical folds}

\section{$\underline{\text { Basis for analysis }}$}

This analysis of thrust-truncated asymmetrical folds in the Porcupine Lake area (Figures 2 and $3 b$ ) is based on a variety of different observations. The most detailed work was a Master's thesis study by Margarete Jadamec (Jadamec, 2001, 2003; Jadamec and Wallace, 2002). This work included field observations, mapping at 1:25,000, and surveys of folds done with theodolite and laser-rangefinder. Another Master's thesis study by Ryan Shackleton emphasized fractures, but also included 1:25,000 mapping and observations of several asymmetrical folds not cut by thrust faults (Shackleton et al., 2001, 2002; Shackleton, 2003). Wes Wallace made field observations and mapped at 1:63,360 in other parts of the Porcupine Lake area for this study (Wallace, 2000, 2001, 2003, and unpublished field data). Wes Wallace also has made other detailed and reconnaissance observations of equivalent structures in other parts of the Brooks Range from 1983 to 2003 (Wallace, 1993 and unpublished field data; Wallace et al., 1997; Wallace and Homza, in press).

\section{Mechanical stratigraphy}

The stratigraphy of the Lisburne Limestone has been well described in the Porcupine Lake area in this and previous reports on this study (McGee and Whalen, 2001, 2003, this report; McGee et al., 2002). Well-defined mappable units are present throughout the area, with relatively minor variations in thickness and facies. For structural mapping purposes, the Lisburne is divided into lower, middle, and upper units that can be identified from a distance based on color, resistance to erosion, and bedding characteristics (Figure 12). These mapping units correspond with the 
stratigraphic subdivisions of the Lisburne into Wachsmuth and lower Alapah (lower), middle Alapah (middle), and upper Alapah and Wahoo (upper).

Overall, the mechanical stratigraphy of the Lisburne in the area is characterized by two uniformly competent intervals, lower Lisburne $(\sim 455 \mathrm{~m})$ and upper Lisburne $(\sim 295 \mathrm{~m})$, that are separated by the relatively thin and moderately competent middle Lisburne $(\sim 69 \mathrm{~m})$, for a total thickness of $\sim 820 \mathrm{~m}$ (Figure 12). The surfaces bounding the competent intervals are sharp. Mechanical layering throughout the unit is defined mainly by coarsening-upward cycles that grade from mudstone or wackestone to packstone or grainstone. The lower Lisburne is competent because cycles are relatively thick $(\sim 1-10 \mathrm{~m})$ and chert is abundant $(25-75 \%)$, although mudstone is a significant component of the unit. The middle Lisburne is less competent and is erosionally recessive because it has thinner cycles $(0.25-0.5 \mathrm{~m})$ and a significant mudstone component. The upper Lisburne is competent because cycles are relatively thick $(\sim 2-15 \mathrm{~m})$ and it contains abundant grainstone and little mudstone, although chert is uncommon.

The Lisburne is sharply underlain by the Kayak Shale. Kayak is not exposed throughout most of the area, but consists of $\sim 100 \mathrm{~m}$ of uniform black shale nearby to the east. The Lisburne is sharply overlain by uniform shales of the Sadlerochit Group or the equivalent Siksikpuk Formation.

\section{$\underline{\text { Fold and thrust characteristics }}$}

Anticlines in the Porcupine Lake area typically are asymmetrical, with forelimbs to the north and axial surfaces inclined to the north (Figures 13 and 14, Table 2). Hinges in the cores of anticlines are sharp and angular (chevron geometry), but hinge zones typically widen and decrease in curvature outward toward fold outer arcs and/or have axial surfaces that branch outward (Figures 13a, b, 14b, and 15). The change from a single narrow angular hinge to a wider hinge zone and/or multiple axial surfaces typically is located in the less-competent middle Lisburne and may reflect some detachment in this interval (Figure 12). Bed length increases upward in anticlines with single angular hinges. This requires either an upward increase in bedparallel shear or balancing of the excess bed length by a corresponding upward decrease in bed length in adjacent synclines.

Forelimbs have been thickened in a variety of ways in many anticlines of the area. Thickening is accommodated most commonly by parasitic map-scale anticline-syncline pairs that are secondorder to the host anticline (Figure 13a, 14a, 15). These parasitic folds are found preferentially within north-dipping limbs and have axial surfaces that are nearly orthogonal to the enveloping surfaces of those limbs. This suggests that they could have originated by preferential shortening of the north-dipping limbs of originally symmetrical folds. Some anticlines also display thickening by bulk strain, but this thickening typically is minor and restricted to hinges, and is most common within the less competent middle Lisburne (Figures 12, 13a, and 14a). Only a few anticlines display higher-order parasitic folds, either within the middle Lisburne or, more rarely, in the upper Lisburne (Figures 13d and 14e).

Backlimbs are planar to gently curved, with crests that commonly are segmented into several panels with small differences in dip (Figures 13a, c, 14c, and 16b, c). They dip much less 
steeply than forelimbs and nearly all clearly lack second-order folds like those common in forelimbs. Backlimbs are consistently significantly longer than forelimbs, but the observed lengths are mostly minimums because of thrust truncation of forelimbs and erosion of backlimbs (Table 2).

Some anticlines display a change upward in interlimb angle, typically within or between mechanical units (Figure 13). This change in interlimb angle reflects a compensatory change in layer thickness, although the required thickness change typically is minor. Interlimb angle most commonly decreases upward at the scale of an entire anticline because of hinge thickening, especially across incompetent intervals. Limbs are thinned locally in tighter folds. Interlimb angle locally increases upward as a result of hinge rounding. Less is known about the geometry typical of synclines because of lack of exposure, but some display a downward increase in interlimb angle due to hinge rounding.

Most anticlines in the Porcupine Lake area have been displaced above thrust faults that cut through their forelimbs (Figures 13b,c, 14b, c, d, 16b, c, and 17). Footwall cutoffs are only rarely exposed, so the exact location of thrust breakthrough with respect to the originally unbroken forelimb is uncertain (Figure 15). In the hangingwall, thrust breakthrough is below either a simple forelimb or a parasitic anticline-syncline pair. Thrusts have broken through both above and below a second-order anticline in the forelimbs of a few anticlines. A few folds also display one to several small-displacement thrust faults above the main thrust that has truncated the forelimb (Figures 13b, 14d). In several folds, no thrust faults are visible above the lowest part of the section that is exposed, which varies from near the base of the upper Lisburne down to the upper part of the lower Lisburne (Figures 13a, d, 14a, e, 16a, and 18). These folds may or may not have been cut by thrust faults below the level of exposure.

Thrust faults generally cut across anticlinal hinges at moderate to small angles $\left(\sim 30-50^{\circ}\right)$ (Figures 13b, c , 14b , c , d , 16b , c). Bedding is cut off at very high angles in anticline forelimbs $\left(\sim 110-130^{\circ}\right)$ and, in most folds, the forelimb is overturned with respect to the underlying thrust fault. In several folds, bedding is strongly overturned and highly strained within a panel immediately above and parallel to the thrust fault, reflecting shear strain localized in a narrow zone above the thrust (Figures 13b, c, 14c, d, 16b, c, and 17). In the backlimb, the thrust follows a flat that typically is located near the base of the Lisburne (Figures 13c, 14c, 16b, c, and 17) but is in the Kayak in a few folds.

Thrust faults commonly display a gentle convex-upward curvature (Figures 13c, 14c, 16b, c, and 17) and probably are folded because they follow folded bedding in the footwall. The folds overlying these folded thrusts display a distinctive profile that resembles a fault-bend fold with an overturned forelimb. These folds typically have an anticlinal hinge that is curved. The upward increase in inclination results in forward tilt of the backlimb as it approaches the anticlinal hinge. This curvature requires extension of the backlimb, which may be accommodated by fractures, normal faults, and/or thinning that are observed in some folds.

An upward increase in bed-parallel shear within folds is supported by a consistent top-to-north sense of shear indicated by fractures, strain, and parasitic folds. Such a shear gradient could help account for the asymmetry and thrust breakthrough of the folds, but its cause remains uncertain. 
The folds that are not cut by thrust faults (Figures 13d, 14e, 15a, and 18) display some differences in geometry from those that are (Table 2). In particular, both anticlines and synclines have smaller interlimb angles and steeper axial surfaces on average, and display greater thickness changes. On average, anticline forelimbs dip less steeply, whereas anticline backlimbs and syncline backlimbs dip more steeply.

Local folds with exceptional characteristics may provide insights into folding processes in the area. The forelimb of one fold is cut by multiple thrust faults that splay upwards from a thrust fault beneath the backlimb (Figures 13d, 14f). One splay tips out in the core of the syncline, two steeper splays cut the syncline backlimb, and a gentler splay flattens into a décollement in the syncline forelimb. The ramp tip and zone of strain associated with the multiple splays suggest that this fold may have originated as a tri-shear fault-propagation fold. Its characteristics differ so much from the other thrust-truncated folds in the area that it likely formed by different processes, although the reason why remains unknown. Although second-order parasitic folds are common in anticline forelimbs, only two anticlines display abundant higher-order parasitic folds in the hinge zone or backlimb (Figures 13c,d, 14e). Relatively large-displacement thrust faults lie immediately above the parasitic folds in both of these anticlines, which suggests that those thrusts played a significant role in the parasitic folding.

Thrust-truncated asymmetrical anticlines very similar to those in the Porcupine Lake area are found locally in the northeastern Brooks Range. Upright and symmetrical detachment folds are much more typical of this region, so the atypical occurrence of thrust-truncated asymmetrical anticlines in this area may offer clues to the conditions that favor their formation.

A large thrust-truncated asymmetrical detachment fold exposed in the East Franklin Creek area (Figures $14 \mathrm{~g}$ and $\mathrm{h}$ ) is very similar to those exposed in the Porcupine Lake area except that the footwall syncline is preserved. This footwall syncline is characterized by multiple hinges that define a box-fold geometry and by parasitic folds in some layers. The presence of both a hangingwall anticline and a footwall syncline suggests that the structure formed by truncation of the short limb of an asymmetrical anticline-syncline pair. The asymmetrical fold clearly originated as a detachment fold because the Kayak Shale is thickened in the core of the anticline above a smooth, non-folded surface defined by the underlying Kekiktuk Conglomerate. Upright and symmetrical detachment folds typical of those found throughout the northeastern Brooks Range lie immediately adjacent to and in the same stratigraphy as the thrust-truncated fold (Figure 6g).

The typical absence of thrust truncation in symmetrical folds throughout the northeastern Brooks Range combined with the coincidence of fold asymmetry with thrust truncation in this particular detachment fold provide a strong indication that thrust-truncation is related to fold asymmetry. The thrust-truncated fold formed over the forelimb of a basement-cored anticlinorium, where slip ahead of a basement horse or gravity-driven displacement from its top resulted in local fold asymmetry. Other examples of asymmetrical thrust-truncated folds exist in the same setting along strike and locally in other similar structural settings elsewhere in the northeastern Brooks Range. 


\section{Interpretation of fold and thrust evolution}

The evolution of the thrust-truncated asymmetrical folds of the Porcupine Lake area involves two major components: Formation of the folds and their later truncation by thrust faults. The thrust faults clearly post-date significant folding because they cut across anticline forelimbs at a high angle. Fold geometry suggests that the folds probably originated either as detachment folds (Figure 19) or fault-propagation folds (Figure 20) but does not allow easy distinction between the two possibilities (Wallace and Homza, in press).

\section{Detachment folds or fault-propagation folds?}

Several lines of evidence support the interpretation that the folds originated as asymmetrical detachment folds.

-The strong competency contrast between the Kayak Shale and the stronger and thicker Lisburne Group carbonates.

-The presence of folds that are not cut by thrusts in the middle to upper Lisburne, depending on level of exposure.

-The dominance of detachment folding in rocks of similar stratigraphy immediately to the north, in the northeastern Brooks Range.

-The northeastern Brooks Range detachment folds are mostly symmetrical and unbroken by thrust faults, but rare examples that are both asymmetrical and truncated by thrust faults are very similar to the thrust-truncated asymmetrical folds of the Porcupine Lake area.

Examples of two other lines of evidence are rare in the Porcupine Lake area, but are well documented along strike to the west and east (Homza, 1992; Wallace et al., 1997; Wallace and Homza, in press):

-The presence of footwall synclines.

-Structural thickening of Kayak and lower Lisburne in the cores of hangingwall anticlines.

Several lines of evidence are consistent with the folds not originating as fault-propagation folds:

-Lack of preserved ramp tips.

- Comparable cutoff angles in the hangingwall and footwall suggest truncation of an existing forelimb rather than folding as a consequence of ramp propagation (fault-propagation folding).

-Very different structural geometry and deformation character in the one known example of a fold that has a ramp tip and likely formed as a fault-propagation fold (Figures 13d and 14f).

Multiple lines of evidence favor formation of the folds as detachment folds, but still do not exclude the possibility that some may have originated as fault-propagation folds. This possibility could be tested using existing data by assessing how well detachment fold and fault-propagation fold models reproduce the geometry of unbroken folds and of folds restored to their geometry prior to truncation and displacement by thrust faults. Additional field observations could also help resolve this question. 


\section{History of evolution}

The available evidence supports evolution of the thrust-truncated asymmetrical folds of the Porcupine Lake area according to the following sequence (Figure 21):

-Detachment folding (Figures 21a and b). The preserved record indicates that long non-folded panels, now in anticline backlimbs, originally separated the detachment folds. However, it is not possible to determine whether the initial folds that separated the long flat panels were symmetrical (Figure 21a) or asymmetrical (Figure 21b) anticline-syncline pairs.

-Steepening and thickening of the forelimb (Figure 21c). Limbs that faced in the direction of tectonic transport (north) were thickened by second-order parasitic folding and subordinate hinge thickening by bulk strain.

-Thrust breakthrough (Figure 21c, dashed line). High cutoff angles in anticline forelimbs indicate that significant folding occurred before thrust breakthrough, but the interlimb angle and forelimb dip at the time of breakthrough are unknown. The interlimb angle must have been greater than or equal to that in the truncated folds (range of $110-45^{\circ}$ ), but the observed angles may have been reduced by further tightening during or after thrust breakthrough. The process of thrust breakthrough remains unclear. Fault-propagation folding during breakthrough is not indicated by any evidence such as preserved ramp tips or superposition of a fault-propagation fold on a detachment fold. No evidence was observed to indicate whether faults propagated outward from the competent unit or upward from the décollement.

-Superposition of a fault-bend fold geometry on the existing fold by displacement of the hangingwall over a ramp and onto an upper flat (Figure 21d). The forelimb of such folds is represented where the hangingwall ramp of a thrust-truncated fold rests on a footwall flat. However, no backlimbs of fault-bend folds can be identified directly because no footwall ramps are exposed in the area.

-Folding of the thrust (Figure 21e). Most thrusts in the area are folded into an antiform beneath the hangingwall anticline, mainly by emplacement of an underlying horse. This has resulted in a geometry in the hangingwall that is similar to a fault-bend fold. However, where the footwall is exposed beneath the backlimb in such folds in the Porcupine Lake area, it is a folded footwall flat rather than a footwall ramp.

Antiformal bending of an existing fold, either by displacement over a ramp or by folding of the underlying thrust, requires extension or a gradient in layer-parallel shear to accommodate lengthening of the outer arc of the fold (Figures 21d and e). Evidence exists to support accommodation of some extension by formation of fractures and veins, bulk thinning, and minor normal faulting. However, the extension observed probably is not enough to accommodate all of the bending. This suggests that at least some of the bending was accommodated by layer-parallel simple shear. 


\section{Controls on fold and thrust geometry and evolution}

More evidence is needed to determine uniquely the factors that led to the specific geometry and evolution of structures observed in this study. Nonetheless, the characteristics of the structures in the Porcupine Lake area--and their differences from the symmetrical and unbroken detachment folds of the northeastern Brook Range--suggest factors that may have had a controlling influence and provide some clues to which of those factors may have been most important.

A strong contrast in structural style exists between the symmetrical and unbroken detachment folds of the northeastern Brooks Range and the asymmetrical, thrust-truncated folds to the south (Figures 2 and 3). The difference in structural behavior must be attributable to a difference in one or more of the geological characteristics of the two regions.

Competent carbonates of the Lisburne Group overlie the incompetent Kayak Shale in both areas. In the northeastern Brooks Range, the Lisburne Group is about $500 \mathrm{~m}$ thick and the Kayak Shale is about $200 \mathrm{~m}$ thick, for a competent/incompetent unit thickness ratio of 2.5 (Figure 4). The lower Lisburne is a zone of mechanical transition $300 \mathrm{~m}$ thick from the incompetent Kayak Shale to the very competent upper Lisburne, which probably effectively decreases the competent/incompetent unit thickness ratio even more. In the Porcupine Lake area, the Lisburne Group is about $820 \mathrm{~m}$ thick and the Kayak Shale is about $100 \mathrm{~m}$ thick, for a competent/incompetent unit thickness ratio of 8.2 (Figure 12). In addition, the Lisburne Group is uniformly very competent except for a thin less competent interval just below the upper third of the unit.

The competent/incompetent unit thickness ratio may have an important influence on whether thrust faulting supersedes folding as the dominant means of accommodating shortening. The preferred wavelength of buckle folds is proportional to the thickness of the competent unit, whereas the availability of material to fill the core of a growing fold is controlled by the thickness of the incompetent unit. Thrust faulting may supersede folding if insufficient incompetent material is available to accommodate continued fold growth as shortening increases (e.g., Stewart, 1996, 1999). The significantly higher competent/incompetent unit thickness ratio in the Porcupine Lake area is consistent with the truncation of most folds in this area by thrust faults. A higher competent/incompetent unit thickness ratio may also favor fold asymmetry because, for a given arc wavelength, the cross sectional area of folds decreases with increasing asymmetry (Homza and Wallace, 1995).

The thickness and character of overburden may also have had a significant influence on structural style in the two areas. The stratigraphic overburden in the northeastern Brooks Range was $5 \mathrm{~km}$ or less (Bird and Molenaar, 1987), although thermal indicators suggest that maximum structural thickness could have been two to three times greater. In the Late Cretaceous, the Porcupine Lake area was at the leading edge of the Brooks Range fold-and-thrust belt and so probably was near the point of maximum subsidence in the foreland basin, with a stratigraphic overburden of at least $8 \mathrm{~km}$ (Bird and Molenaar, 1992). At least $2.5 \mathrm{~km}$ of stratigraphic overburden is preserved in a similar structural position along strike to the east at Bathtub syncline (Homza, 1992), but an unknown thickness of Lower Cretaceous and younger 
sedimentary rocks has been removed by erosion. Thermal indicators in the Porcupine Lake area and along strike suggest a maximum structural thickness comparable to that in the northeastern Brooks Range. At this point, it is not clear whether a significant difference in overburden thickness existed between the detachment folds of the northeastern Brooks Range and the thrusttruncated asymmetrical folds to the south.

A potentially critical difference is that the lower part of the overburden in the Porcupine Lake area consists of large-displacement thrust sheets. The Porcupine Lake structural low marks the northernmost edge of one or more allochthons that have been displaced at least $45 \mathrm{~km}$, and probably much farther (Wallace, 1993; Brosgé et al., 2001). The significant point is that the northern limit of those allochthonous rocks corresponds very closely with the northern limit of thrust-truncated asymmetrical folds in the structurally underlying Lisburne.

The Porcupine Lake structural low and a similar structural low at Bathtub syncline appear to mark the northern edge of a Late Devonian to Mississippian rift basin (Anderson et al., 1994; LePain et al., 1994). This is significant for two reasons. First, it marks the northern limit of a thick Upper Devonian to Mississippian clastic wedge that stratigraphically underlies the Lisburne within which the thrust-truncated asymmetrical folds formed. The layered sedimentary rocks of the wedge have been structurally detached and imbricated beneath the Lisburne with a structural geometry that is similar except that the folds are larger and the thrust sheets are thicker (e.g., Wallace et al., 1997). This contrasts with the northeastern Brooks Range, where the Lisburne forms detachment folds above pre-Middle Devonian basement in which much larger thrust sheets have formed. Second, the Upper Devonian to Mississippian rocks, including the Lisburne, probably dipped gently southward into the basin prior to deformation. Primary dips were probably nearly horizontal within what is now the northeastern Brooks Range.

Before assessing the potential significance of these observations, it is helpful to consider the relations between fold asymmetry and thrust breakthrough. Two significant observations suggest that fold asymmetry favors thrust breakthrough in the study area. First, cross-cutting relations in the thrust-truncated folds indicate that asymmetrical folds formed before thrust breakthrough. Second, thrust faults are generally absent in detachment folds of the northeastern Brooks Range except where the folds are asymmetrical. Fold flattening rather than thrust faulting accommodates large shortening in the symmetrical folds. Together, these observations suggest that fold asymmetry favors thrust breakthrough as a means to accommodate increasing shortening.

If it is assumed that fold asymmetry favors thrust breakthrough, then the cause of fold asymmetry is the next important question to answer. Two main causes have been suggested for the origin of asymmetrical folds: Mechanical layering that is inclined with respect to the maximum compressive stress (e.g., Treagus, 1973; Anthony and Wickham, 1978) and a component of simple shear during or after shortening (e.g., Reches and Johnson, 1976; Sanderson, 1979; Lan and Wang, 1987).

The observations above are consistent with either or both of these causes, but are not sufficient to determine the cause uniquely. A primary dip of bedding southward into the basin, although very gentle, likely would have favored fold asymmetry assuming that the principal compressive stress 
was subhorizontal to gently north dipping. This asymmetry would have favored thrust breakthrough. The Lisburne of the Porcupine Lake area is overlain by rocks with large thrust displacement, equivalent to the allochthons present along the entire northern part of the main axis of the Brooks Range (Moore et al., 1994). Furthermore, beneath the demonstrably allochthonous rocks, the layered sedimentary sequence that includes the Upper Devonian to Mississippian clastic wedge and the overlying Lisburne displays clear thrust imbrication, although the total amount of thrust displacement remains uncertain. Thus, the Lisburne lies within a structural sequence of rocks that contains northward-displaced thrust faults throughout and hence has undergone a significant component of top-to-north simple shear. Simple shear within this deforming orogenic wedge would favor the development of asymmetrical folds and their eventual breakthough by thrust faults.

Wedge taper has a direct relationship to symmetry of folds and thrust faults within a deforming wedge: Wedges with low taper typically lack a preferred sense of asymmetry whereas wedges with greater taper typically contain structures with a dominant vergence in the direction of wedge taper (e.g., Davis and Engelder, 1985). The structural geometry of the northeastern Brooks Range appears to define a wedge with low taper, which is consistent with the lack of preferred asymmetry in its detachment folds (Wallace, 1993), whereas the thrust-dominated structures to the south appear to have formed in a wedge with greater taper (e.g., Wallace et al., 1997). These observations do not, however, explain why a difference in taper existed between the two regions. Factors with a well-known influence on wedge taper include the dip and strength of the basal detachment and the internal strength of the wedge. Other factors that probably play an important role in wedge shape include the initial shape of the deforming body and the character and orientation of internal anisotropy. The mechanical stratigraphy, a primary dip, and the presence of overlying allochthons all may have contributed to a greater wedge taper to the south than in the northeastern Brooks Range.

In simplest terms, the difference in structural behavior of the Lisburne between the northeastern Brooks Range and the Porcupine Lake area can be summarized as folding under conditions of pure vs. simple shear. Folds to the north evolved by pure shear, shortening symmetrically and coaxially first by buckling and then by flattening. Folds to the south evolved by simple shear, shortening asymmetrically and non-coaxially first by buckling and then by thrust faulting. The reasons for the difference in behavior are undoubtedly complex and remain uncertain.

\section{Questions about thrust-truncated asymmetrical folds in the Porcupine Lake area}

This study has identified some significant questions that should be a focus of future research about thrust-truncated asymmetrical folds. The results of the study do not resolve these questions but commonly suggest some possible answers. The questions and some possible answers that should be considered are listed below.

-What factors favor the formation of asymmetrical folds? Possible contributing factors include a regionally inclined detachment, a high ratio of competent to incompetent unit thickness, the presence of overlying and underlying thrust sheets, and an orogenic wedge that does not have an unusually low taper angle. 
-Do folds begin as asymmetrical folds or are they modified from symmetrical folds? This can be addressed by assessing the relative importance of initial uneven spacing between an anticline and its bounding synclines vs. preferential shortening of anticline forelimbs.

-What factors favor angular over box-fold geometry? The typical dominance of angular geometry may be favored by sharp contrasts in competency, fold asymmetry, and a gradient in layer-parallel shear.

-What factors favor thrust breakthrough over fold tightening and flattening? Fold asymmetry likely is the dominant control on thrust breakthrough, but some of the same factors that favor fold asymmetry may also independently favor thrust faulting.

-How do faults propagate during breakthrough of folds? Thrust faults that truncate folds may propagate upward from the basal detachment, downward from the upper detachment, or outward (both down and up) from the competent unit.

-Do folds tighten during or after thrust breakthrough? The pre-breakthrough fold geometry may be modified by additional tightening by fault-propagation folding during breakthrough, drag folding during thrust displacement, or detachment folding during or after thrust displacement.

-How do truncated folds accommodate additional folding? Thrust sheets that contain truncated folds commonly are antiformally folded, either by fault-bend folding over a footwall ramp or by bending over an underlying horse. Bending of the existing fold must be accommodated by some combination of bed-parallel shear, tightening of the fold core, hinge rounding or collapse, and extension by fracture and veining, normal faulting, or thinning.

\section{$\underline{\text { Summary and conclusions }}$}

\section{Fold and thrust geometry and evolution}

The thrust-truncated asymmetrical folds of the Porcupine Lake area formed in competent Lisburne Group carbonates above the incompetent Kayak Shale. The competent to incompetent unit thickness ratio is about 8.2. Two uniformly competent intervals are separated by a thin, moderately competent interval. The competent intervals are sharply bounded above and below.

The folds typically are inclined and asymmetrical and are cut and displaced by thrust faults. The folds are mostly angular, with a relatively limited range of interlimb angles. Anticline hinges commonly branch upward from the middle Lisburne. Parasitic folds are rare except in forelimbs, which commonly contain a large anticline-syncline pair. Backlimbs are long and gently folded. Little thickness change is visible across folds.

Forelimbs typically are cut and displaced above one or more thrust faults. Bedding in forelimbs is cut at a high angle, and highly strained panels locally directly overlie thrust faults. Backlimbs overlie a flat near the base of the Lisburne. Thrust faults typically are gently folded into antiforms. 
Local folds that are not visibly cut by thrust faults display greater fold shortening, steeper inclination, and more thickness change than folds that have been cut by thrusts.

Most of the folds probably originated as detachment folds. This is suggested by the competency contrast between Kayak and Lisburne, the presence of some folds that have not been cut by thrust faults, and a transition to detachment folds in the same rock units to the north. One fold displays characteristics quite different from the other folds, including a ramp tip, multiple upward-diverging strands, and abundant strain. Its characteristics suggest that it may be a trishear fault-propagation fold.

Folds began as detachment folds that may have been either symmetrical or asymmetrical. Forelimbs were steepened and thickened, mainly by parasitic folding. Folding was superseded by thrust breakthrough as shortening increased. A fault-bend fold geometry was superimposed on the truncated fold as it was displaced over the footwall ramp. Thrusts underlying displaced folds were gently folded by deformation in the footwall.

Two observations suggest that fold asymmetry favors thrust breakthrough. First, asymmetrical folding preceded thrust breakthrough. Second, in the northeastern Brooks Range, thrusts typically are absent in symmetrical detachment folds but commonly are present where folds locally are asymmetrical.

Formation of asymmetrical folds is favored by inclination of layering with respect to maximum compressive stress or by simple shear acting along layering. A top-to-north gradient in bedparallel shear is supported by fold asymmetry, thrust breakthrough, chevron-geometry anticlines, and minor structures with northward vergence. Regional factors that may have favored the formation and eventual breakthrough of asymmetrical folds include a regionally inclined detachment, a high ratio of competent to incompetent unit thickness, the presence of overlying and underlying thrust sheets, and an orogenic wedge that does not have an unusually low taper angle. It is unknown which of these may have been most important in controlling fold and thrust evolution.

Bending of an existing fold must be accommodated by some combination of bed-parallel shear, tightening of the fold core, hinge rounding or collapse, and extension by fracture and veining, normal faulting, or thinning.

A quantitative model does not yet exist for the geometry and kinematics of thrust-truncated asymmetrical folds of the type observed in the Porcupine Lake area. Any such model must both take into account how natural truncated and displaced folds are further folded and solve the difficult problem of representing that additional folding accurately.

\section{Implications for fracture}

This study reached conclusions about the geometry and evolution of thrust-truncated asymmetrical folds that suggest a number of implications about fracturing related to the folds. One of the most important conclusions is that the mechanism of shortening changes from folding 
to thrust faulting throughout the evolution of a structure. This would result in a corresponding change in the conditions that may lead to fracturing.

Layer-parallel shortening may occur before or early during folding, especially in more competent intervals, and may result in extension fractures, most likely oriented normal to fold axes.

However, this study provided no evidence to assess the importance of layer-parallel shortening in thrust-truncated asymmetrical folds. Some evidence does exist for the formation of fractures oblique to bedding as a result of bed-parallel shear prior to folding.

Flexural-slip under brittle conditions appears to have been the dominant mechanism of folding. This could be accompanied by fracturing resulting from shear strain associated with bed-parallel slip and/or tangential longitudinal strain due to bending of beds. The folds typically have long straight limbs and narrow, angular hinge zones. Fractures related to flexural slip likely would dominate in limbs, whereas fractures related to tangential longitudinal strain likely would dominate in hinge zones and depend on their width and curvature. Hinges probably were relatively fixed throughout fold evolution, resulting in little overlap between hinge- and limbrelated fractures. However, some overprinting of hinge- and limb-related fractures may have occurred as a result of hinge rotation, especially in folds with wider curved hinge zones. Further research is required to determine hinge kinematics in detail.

Flexural-slip may be superseded by flattening of folds as a result of some combination of locking of folds and more ductile deformation conditions. Under ductile conditions, new fractures are unlikely to form and existing fractures are likely to close and anneal. Fold flattening under ductile conditions appears to have been significant in some unbroken folds, but not in folds cut by thrust faults.

Little is known about the mechanism and kinematics of breakthrough of fold limbs by thrust faults. However, fractures and veins oriented at high angles to bedding are common in areas of actual or potential breakthrough, and could have originated either as extension or shear fractures.

Shear strain is commonly associated with thrust displacement, particularly in narrow zones parallel and immediately adjacent to thrust faults. Existing fractures may be closed or annealed in these zones, but new fractures may also form oblique to bedding as a result of shear strain. Thus, fractures resulting from bed-parallel shear may form before folding, as a result of flexuralslip folding, or during thrust faulting.

Late bending of truncated and displaced folds results in the most obvious and abundant fractures and veins to form during the evolution of thrust-truncated asymmetrical folds. These essentially are the result of tangential longitudinal strain and are located in or near the hinge zones of both truncated and displaced folds and the bends in their backlimbs. 


\section{$\underline{\text { References }}$}

Anderson, A.V., Wallace, W.K., and Mull, C.G., 1994, Depositional record of a major tectonic transition in northern Alaska: Middle Devonian to Mississippian rift-basin margin deposits, upper Kongakut River region, eastern Brooks Range, Alaska, in Thurston, D., and Fujita, K., eds., 1992 Proceedings International Conference on Arctic Margins, U.S. Minerals Management Service Outer Continental Shelf Study 94-0040, p. 71-76.

Anthony, M., and Wickham, J., 1978, Finite-element simulation of asymmetric folding: Tectonophysics, v. 47, p. 1-4.

Atkinson, P.K., 2000, A geometric analysis of detachment folds in the Lisburne Limestone, in Wallace, W.K., Hanks, C.L., Whalen, M.T., Jensen, J., Atkinson, P.K., and Brinton, J.S., The influence of fold and fracture development on reservoir behavior of the Lisburne Group of northern Alaska: U.S. Department of Energy, semi-annual report for May-October 1999, DOE award DE-AC26-98BC15102, p. D-1-22

Atkinson, P.K., 2001, A geometric analysis of detachment folds in the northeastern Brooks Range, Arctic National Wildlife Refuge, Alaska, and a model for their kinematic evolution, in Wallace, W.K., Hanks, C.L., Whalen, M.T., Jensen, J., Lorenz, J., Atkinson, P.K., Brinton, J.S., and Karpov, A.V., The influence of fold and fracture development on reservoir behavior of the Lisburne Group of northern Alaska: Department of Energy, Fossil Energy, National Petroleum Technology Office, Tulsa, Oklahoma, Annual report for work performed under contract no. DE-AC26-98BC15102, May, 1999 - May, 2000, p. D-1-31.

Atkinson, P.K., 2001, A geometric analysis of detachment folds in the northeastern Brooks Range, Alaska, and a conceptual model for their kinematic evolution: Master of Science thesis, University of Alaska, Fairbanks, Alaska, 209 p.

Atkinson, P.K., and Wallace, W.K., 2003, Competent unit thickness variation in detachment folds in the northeastern Brooks Range, Alaska: geometric analysis and a conceptual model: Journal of Structural Geology, v. 25, no. 10, p. 1751-1771.

Bird, K.J., and Molenaar, C.M., 1987, Stratigraphy, in Bird, K.J., and Magoon, L.B., eds., Petroleum geology of the northern part of the Arctic National Wildlife Refuge, northeastern Alaska: U.S. Geological Survey Bulletin 1778, p. 37-59.

Bird, K.J., and Molenaar, C.M., 1992, The North Slope foreland basin, in Macqueen, R.W., and Leckie, D.A., eds., Foreland basins and foldbelts: American Association of Petroleum Geologists Memoir 55, p. 363-393.

Brosgé, W.P., Reiser, H.N., Dutro, J.T., Jr., Detterman, R.L., and Tailleur, I.L., 2001, Geologic map of the Arctic Quadrangle, Alaska: U.S. Geological Survey Geologic Investigations Series I-2673, scale 1:200,000.

Davis, D., and Engelder, T., 1985, The role of salt in fold and thrust belts: Tectonophysics, v. 119, p. 67-88.

Epard, J.-L., and Groshong, R.H., Jr., 1995. Kinematic model of detachment folding including limb rotation, fixed hinges and layer-parallel strain: Tectonophysics, v. 247, p. 85-103.

Homza, T.X., 1992, A detachment fold-truncation duplex, southwest Bathtub Ridge, northeastern Brooks Range, Alaska: Master of Science thesis, University of Alaska, Fairbanks, $110 \mathrm{p}$.

Homza, T.X., and Wallace, W.K., 1995, Geometric and kinematic models for detachment folds with fixed and variable detachment depths: Journal of Structural Geology, v. 17, no. 4, p. 475-588. 
Homza, T.X., and Wallace, W.K., 1997, Detachment folds with fixed hinges and variable detachment depth, northeastern Brooks Range, Alaska: Journal of Structural Geology, v. 19, p. 337-354.

Jadamec, M.A., 2001, Kinematic evolution of thrust-truncated folds, in Wallace, W.K., Hanks, C.L., Whalen, M.T., Jensen, J., Shackleton, J.R., Jadamec, M.A., McGee, M.M., and Karpov, A.V., The influence of fold and fracture development on reservoir behavior of the Lisburne Group of northern Alaska: Department of Energy, Fossil Energy, National Petroleum Technology Office, Tulsa, Oklahoma, Semi-annual report for work performed under contract no. DE-AC26-98BC15102, May, 2000 to January, 2001, p. C-1-16.

Jadamec, M.A., 2003, Geometric analysis of thrust-truncated asymmetric folds, upper Marsh Fork area, eastern Brooks Range, Alaska: Master of Science thesis, University of Alaska, Fairbanks, Alaska, 164 p.

Jadamec M.A., and Wallace, W.K., 2002, Geometry and evolution of thrust-truncated detachment folds in the upper Marsh Fork area of the eastern Brooks Range fold-and-thrust belt, Alaska, in Wallace, W.K., Hanks, C.L., Jensen, J., Whalen, M.T., Atkinson, P.K., Brinton, J.S., Bui, T., Jadamec, M.A., Karpov, A.V., Krumhardt, A.P., Lorenz, J., McGee, M.M., Shackleton, J.R., The influence of fold and fracture development on reservoir behavior of the Lisburne Group of northern Alaska: Department of Energy, Fossil Energy, National Petroleum Technology Office, Tulsa, Oklahoma, Semi-annual report for work performed under contract no. DE-AC26-98BC15102, January to June, 2001, p, C-1-27.

Jamison, W. R., 1987, Geometric analysis of fold development in overthrust terranes: Journal of Structural Geology, v. 9, p. 207-219.

Lan, L., and Wang, R., 1987, Finite-element analysis of an overturned fold using a viscous model: Tectonophysics, v. 139, p. 309-314.

LePain, D.L., Crowder, R.K., and Wallace, W.K., 1994, Early Carboniferous transgression on a passive continental margin: Deposition of the Kekiktuk Conglomerate, northeastern Brooks Range, Alaska: American Association of Petroleum Geologists Bulletin, v. 78, no. 5, p. 679699.

McGee, M.M., and Whalen, M.T., 2001, Baseline stratigraphy of the Lisburne Group, in Wallace, W.K., Hanks, C.L., Whalen, M.T., Jensen, J., Shackleton, J.R., Jadamec, M.A., McGee, M.M., and Karpov, A.V., The influence of fold and fracture development on reservoir behavior of the Lisburne Group of northern Alaska: U.S. Department of Energy, semi-annual report for May 2000-January 2001, DOE award DE-AC26-98BC15102, p. B-121.

McGee, M.M., and Whalen, M.T., 2003, Baseline stratigraphy of the Lisburne Group, in Wallace, W.K., Hanks, C.L., Jensen, J., Whalen, M.T., Brinton, J., Bui, T., and McGee, M.M., The influence of fold and fracture development on reservoir behavior of the Lisburne Group of northern Alaska: U.S. Department of Energy, semi-annual report for June 2001 to January 2002, DOE award DE-AC26-98BC15102, p. B-1-23.

McGee, M.M., Whalen, M.T., and Krumhardt, A.P., 2002, Baseline stratigraphy of the Lisburne Group, in Wallace, W.K., Hanks, C.L., Whalen, M.T., Jensen, J., Atkinson, P.K., Brinton, J., Bui, T., Jadamec, M.A., Karpov, A.V., Krumhardt, A.P., Lorenz, J.C., McGee, M.M., and Shackleton, J.R., The influence of fold and fracture development on reservoir behavior of the Lisburne Group of northern Alaska: U.S. Department of Energy, semi-annual report for January-June 2001, DOE award DE-AC26-98BC15102, p. B-1-17. 
Mitra, S., 2003, A unified kinematic model for the evolution of detachment folds: Journal of Structural Geology, v. 25, no. 10, p. 1659-1673.

Moore, T.E., Wallace, W.K., Bird, K.J., Karl, S.M., Mull, C.G., and Dillon, J.T., 1994, Chapter 3: Geology of northern Alaska, in Plafker, G., and Berg, H.C., eds., The geology of Alaska: The Geology of North America, Geological Society of America, Boulder, Colorado, v. G1, p. 49-140.

Poblet, J., and McClay, K., 1996, Geometry and kinematics of single-layer detachment folds: American Association of Petroleum Geologists Bulletin, v. 80, p. 1085-1109.

Ramsay, J. G., 1967, Folding and fracturing of rocks: McGraw Hill, New York, 568 p.

Ramsay, J. G., 1974, Development of chevron folds: Geological Society of America Bulletin, v. 85, p. 1741-1754.

Reches, Z., and Johnson, A.M., 1976, A theory of concentric, kink and sinusoidal folding and monoclinal flexuring of compressible, elastic multilayers. VI. Asymmetric folding and monoclinal kinking: Tectonophysics, v. 35, p. 295-334.

Sanderson, D.J., 1979, The transition from upright to recumbent folding in the Variscan fold belt of southwest England: a model based on the kinematics of simple shear: Journal of Structural Geology, v. 1, p. 171-180.

Shackleton et al., 2001, The relationship between fracturing, asymmetric folding, and normal faulting in Lisburne Group carbonates: West Porcupine Lake valley, northeastern Brooks Range, Alaska, in Wallace, W.K., Hanks, C.L., Whalen, M.T., Jensen, J., Shackleton, J.R., Jadamec, M.A., McGee, M.M., and Karpov, A.V., 2001, The influence of fold and fracture development on reservoir behavior of the Lisburne Group of northern Alaska: U.S. Department of Energy, semi-annual report for May 2000-January 2001, DOE award DEAC26-98BC15102, p. D-1-31.

Shackleton, J.R., Hanks, C.L., and Wallace, W.K., 2002, The relationship between fracturing, asymmetric folding, and normal faulting in Lisburne Group carbonates: West Porcupine Lake valley, northeastern Brooks Range, Alaska, in Wallace, W.K., Hanks, C.L., Jensen, J., Whalen, M.T., Atkinson, P.K., Brinton, J.S., Bui, T., Jadamec, M.A., Karpov, A.V., Krumhardt, A.P., Lorenz, J., McGee, M.M., Shackleton, J.R., The influence of fold and fracture development on reservoir behavior of the Lisburne Group of northern Alaska: Department of Energy, Fossil Energy, National Petroleum Technology Office, Tulsa, Oklahoma, Semi-annual report for work performed under contract no. DE-AC2698BC15102, January to June, 2001, p. D-1-32.

Shackleton, J.R., 2003, The relationship between fracturing, asymmetric folding, and normal faulting in Lisburne Group carbonates: west Porcupine Lake valley, northeastern Brooks Range, Alaska: Master of Science thesis, University of Alaska, Fairbanks, Alaska, 189 p.

Stewart, S.A., 1996, Influence of detachment layer thickness on style of thin-skinned shortening: Journal of Structural Geology, v. 18, no. 10, p. 1271-1274.

Stewart, S.A., 1999, Geometry of thin-skinned tectonic systems in relation to detachment layer thickness in sedimentary basins: Tectonics, v. 18, no. 4, p. 719-732.

Treagus, S.H., 1973, Buckling stability of a viscous single-layer system, oblique to the principal compression: Tectonophysics, v. 19, p. 271-289.

Wallace, W.K., 1993, Detachment folds and a passive-roof duplex: Examples from the northeastern Brooks Range, Alaska, in Solie, D.N., and Tannian, F., eds., Short Notes on Alaskan Geology 1993: Alaska Division of Geological and Geophysical Surveys Geologic Report 113, p. 81-99. 
Wallace, W.K., 2000, Detachment folds and their truncation by thrust faults, inWallace, W.K., Hanks, C.L., Whalen, M.T., Jensen, J., Atkinson, P.K., and Brinton, J.S., The influence of fold and fracture development on reservoir behavior of the Lisburne Group of northern Alaska: U.S. Department of Energy, semi-annual report for May-October 1999, DOE award DE-AC26-98BC15102, p. C-1-18.

Wallace, W.K., 2001, Detachment folds and their truncation by thrust faults, in Wallace, W.K., Hanks, C.L., Whalen, M.T., Jensen, J., Lorenz, J., Atkinson, P.K., Brinton, J.S., and Karpov, A.V., The influence of fold and fracture development on reservoir behavior of the Lisburne Group of northern Alaska: Department of Energy, Fossil Energy, National Petroleum Technology Office, Tulsa, Oklahoma, Annual report for work performed under contract no. DE-AC26-98BC15102, May, 1999 - May, 2000, p. C-1-28.

Wallace, W.K., 2003, Characteristics of detachment folds and thrust-truncated asymmetrical folds in the eastern Brooks Range, in Wallace, W.K., Hanks, C.L., Jensen, J., Whalen, M.T., Brinton, J., Bui, T., and McGee, M.M., The influence of fold and fracture development on reservoir behavior of the Lisburne Group of northern Alaska: U.S. Department of Energy, semi-annual report for June 2001 to January 2002, DOE award DE-AC26-98BC15102, p. C$1-18$.

Wallace, W.K., and Hanks, C.L., 1990, Structural provinces of the northeastern Brooks Range, Arctic National Wildlife Refuge, Alaska: American Association of Petroleum Geologists Bulletin, v. 74, no. 7,p. 1100-1118.

Wallace, W.K., and Homza, T.X., in press, Detachment folds, their truncation by thrust faults, and their distinction from fault-propagation folds, in McClay, K.R., editor, Thrust tectonics and petroleum systems: American Association of Petroleum Geologists Memoir.

Wallace, W.K., Moore, T.E., and Plafker, G., 1997, Multistory duplexes with forward dipping roofs, north central Brooks Range, Alaska: Journal of Geophysical Research, v. 102, no. B9, p. 20,773-20,796.

Watts, K.F., Harris, A.G., Carlson, R.C., Eckstein, M.K., Gruzlovic, P.D., Imm, T.A., Krumhardt, A.P., Lasota, D.K., Morgan, S.K., Dumoulin, J.A., Enos, P., Goldstein, R.H., and Mamet, B.L., 1995, Analysis of reservoir heterogeneities due to shallowing-upward cycles in carbonate rocks of the Pennsylvanian Wahoo Limestone of northeastern Alaska: United States Department of Energy, Final Report for 1989-1992 (DOE/BC/14471-19), Bartlesville Project Office, $433 \mathrm{p}$.

Whalen, M.T., 2000, Baseline stratigraphy of the Lisburne Group, in Wallace, W.K., Hanks, C.L., Whalen, M.T., Jensen, J., Atkinson, P.K., and Brinton, J.S., The influence of fold and fracture development on reservoir behavior of the Lisburne Group of northern Alaska: U.S. Department of Energy, semi-annual report for May-October 1999, DOE award DE-AC2698BC15102, p. B-1-13.

Whalen, M.T., 2001, Baseline stratigraphy of the Lisburne Group, in Wallace, W.K., Hanks, C.L., Whalen, M.T., Jensen, J., Lorenz, J., Atkinson, P.K., Brinton, J.S., and Karpov, A.V., The influence of fold and fracture development on reservoir behavior of the Lisburne Group of northern Alaska: U.S. Department of Energy, annual report for May 1999-May 2000, DOE award DE-AC26-98BC15102, p. B-1-14. 


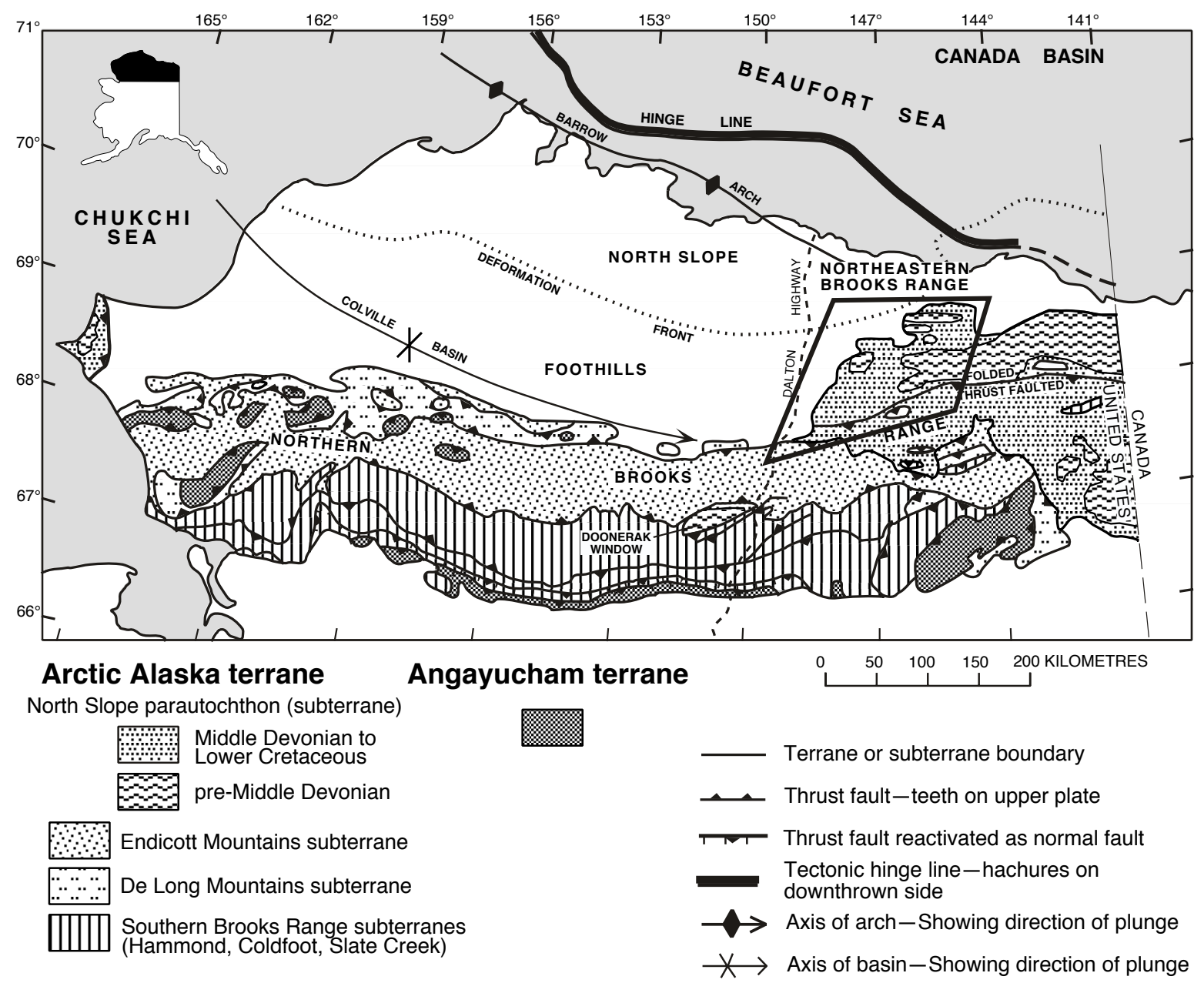

Figure 1. Tectonic map of northern Alaska, showing distribution of major structural features. Outlined area Shown in Figure 2. Modified from Wallace and Dthers, 1997. 
Mississippian Kayak Shale,

TrM Carboniferous Lisburne Limestone \&

Triassic Sadlerochit/Siksikpuk

7. pre-Mississippian metasedimentary rocks

$\angle \mathrm{pM}$ \& Mississippian Kekiktuk conglomerate

Middle Devonian to Mississippian clastic rocks

MPand

Devonian to Mississippian Kanayut Conglomerate \&

iMD

locally overlying Mississippian Kayak Shale \&

Carboniferous Lisburne Limestone

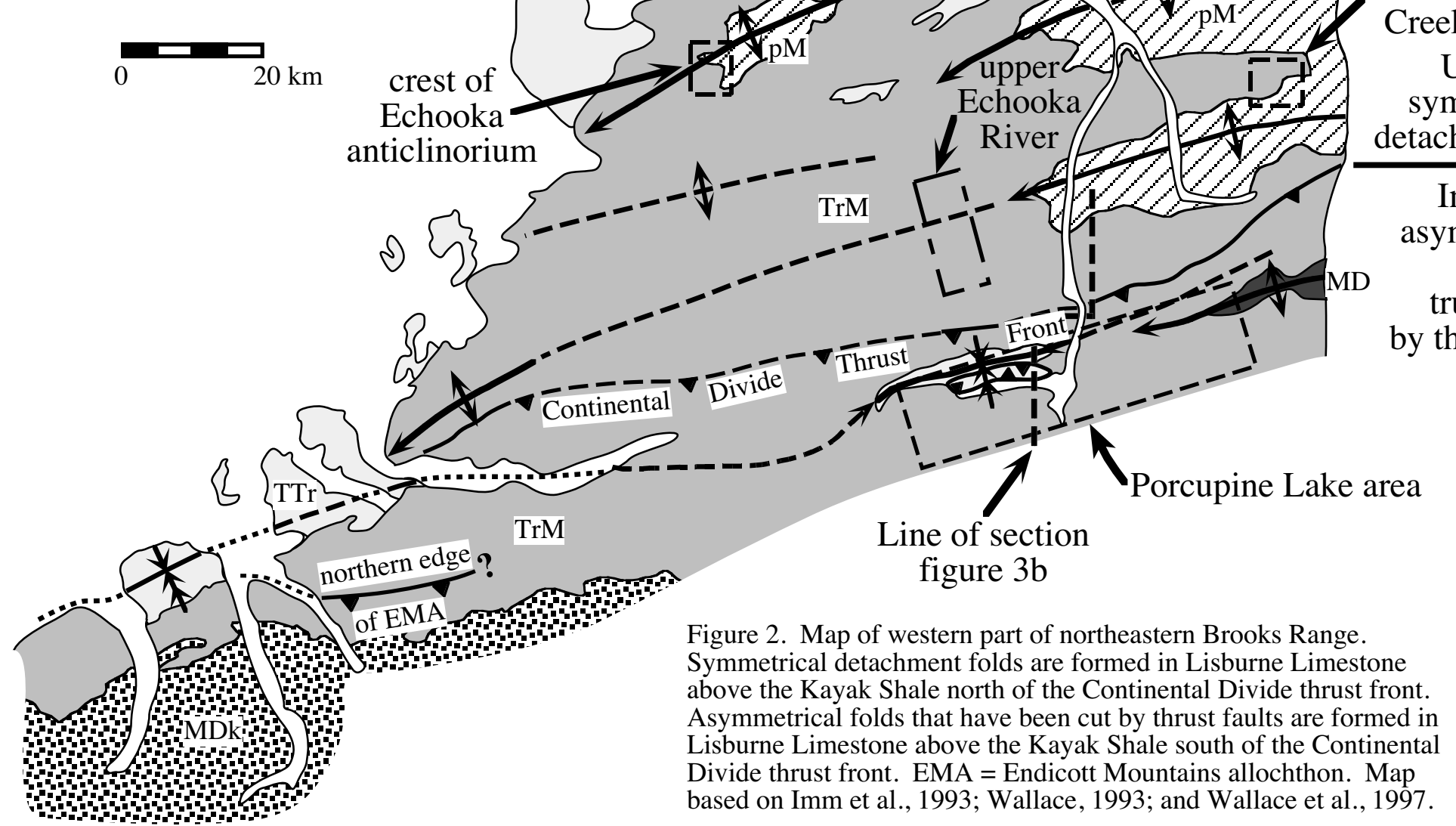




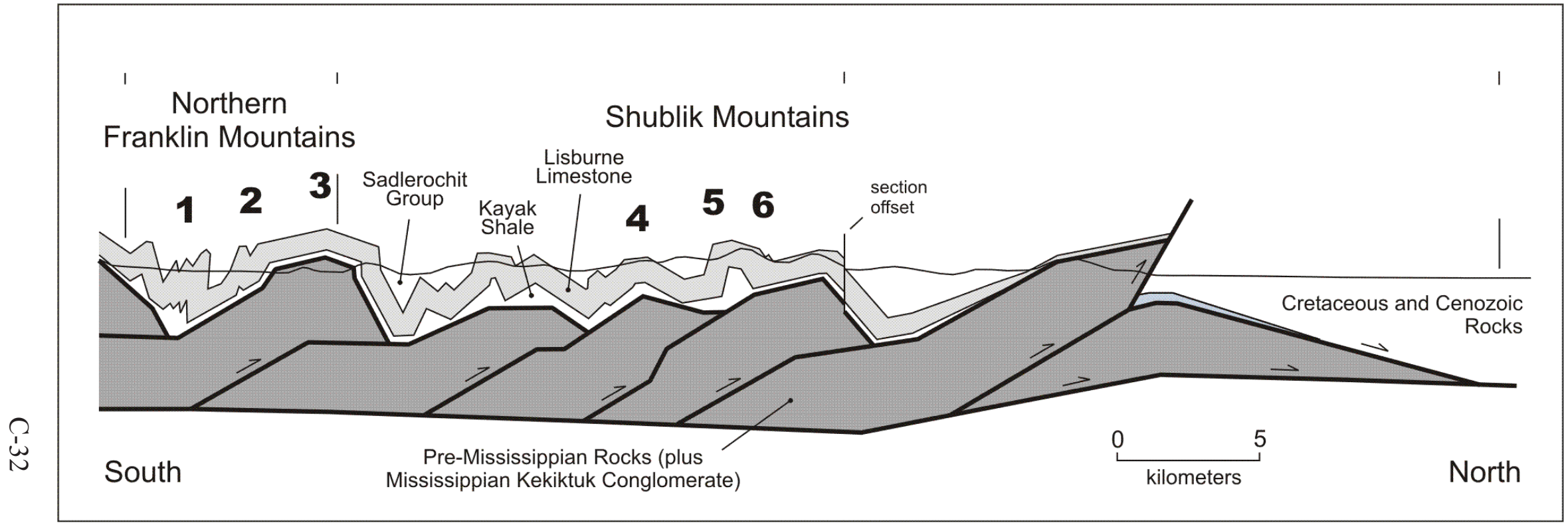

Figure 3a. Cross section across the northern part of the northeastern Brooks Range. Numbers indicate detachment folds described in Atkinson (2001) and Atkinson and Wallace (2003). Fold 3 is at the crest of the Fourth Range. Figure modified from Atkinson and Wallace (2003). 


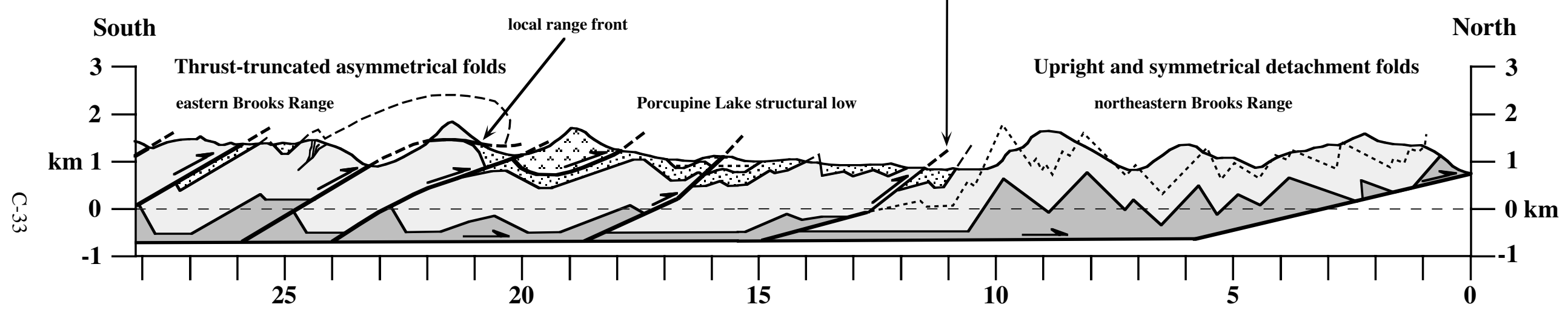

\begin{tabular}{|c|c|}
\hline$\therefore \cdots$ & $\begin{array}{l}\text { Mt. Annette allochthon } \\
\text { (klippe) }\end{array}$ \\
\hline & $\begin{array}{l}\text { Triassic Shublik Fm., } \\
\text { Jurassic-Lwr. Cretaceous Kingak Shale, } \\
\text { Lwr. Cretaceous Kongakut Fm. }\end{array}$ \\
\hline & $\begin{array}{l}\text { Permian-Triassic Sadlerochit Group } \\
\text { (upper detachment unit) }\end{array}$ \\
\hline & $\begin{array}{l}\text { Mississippian-Pennsylvanian } \\
\text { Lisburne Limestone } \\
\text { (competent unit) }\end{array}$ \\
\hline & $\begin{array}{l}\text { Mississippian Kayak Shale } \\
\text { (lower detachment unit) }\end{array}$ \\
\hline
\end{tabular}

Figure 3b. Cross section showing difference in structural style across the Continental Divide thrust front. Upright and symmetrical detachment folds characterize the northeastern Brooks Range to the north, whereas thrust-truncated asymmetrical folds characterize the eastern Brooks Range to the south. Modified from Wallace and Homza, in press. 


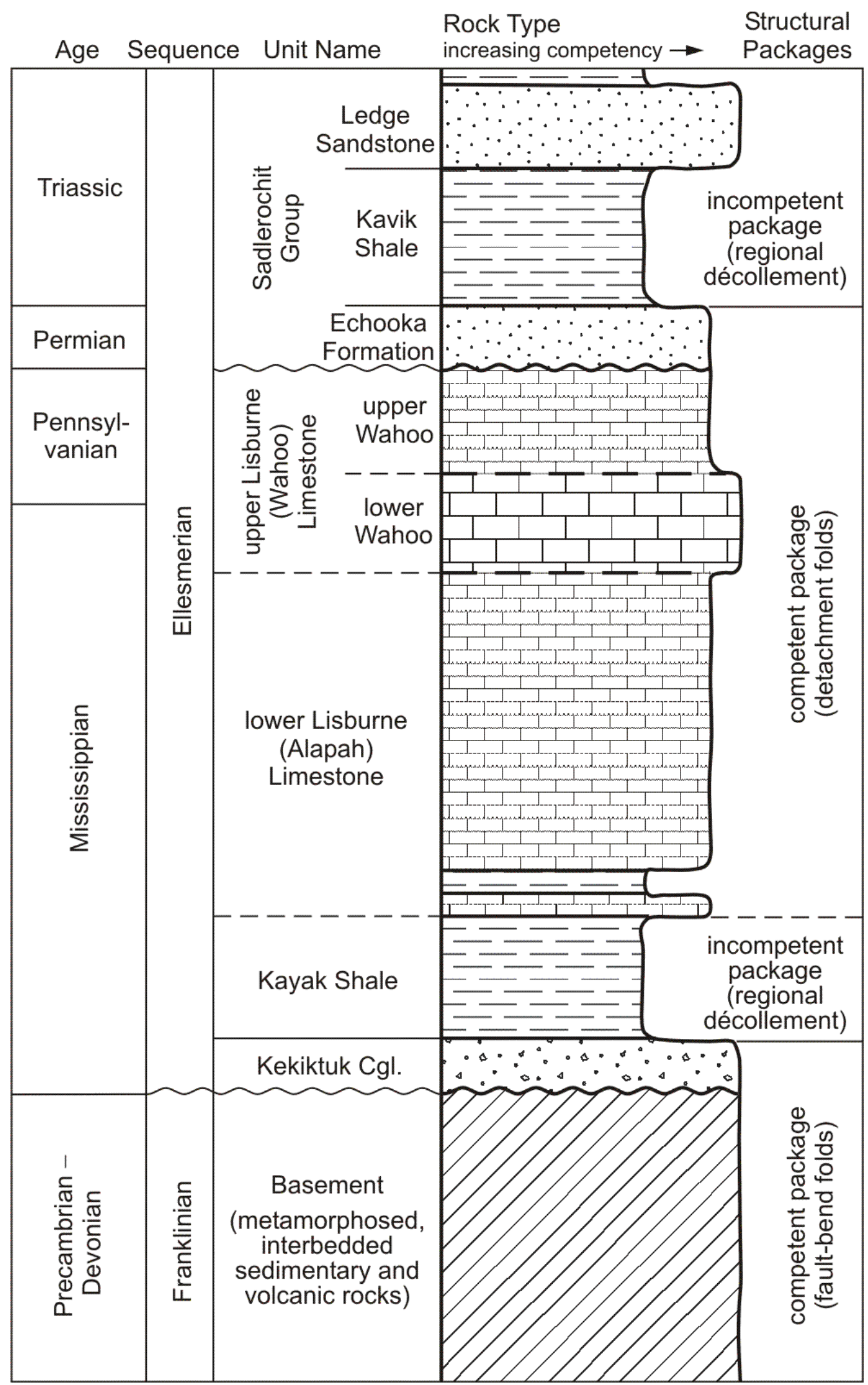

Figure 4. Mechanical stratigraphy of the northeastern Brooks Range. 
(a) Fold 1

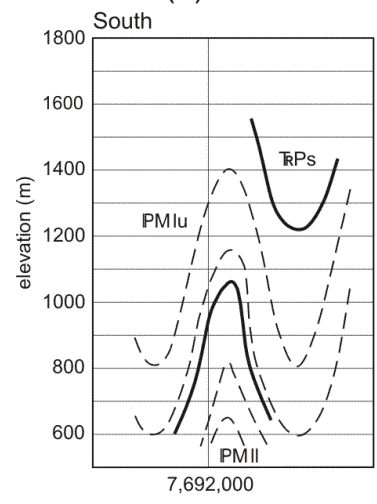

Northern Franklin Mountains

(b) Fold 2

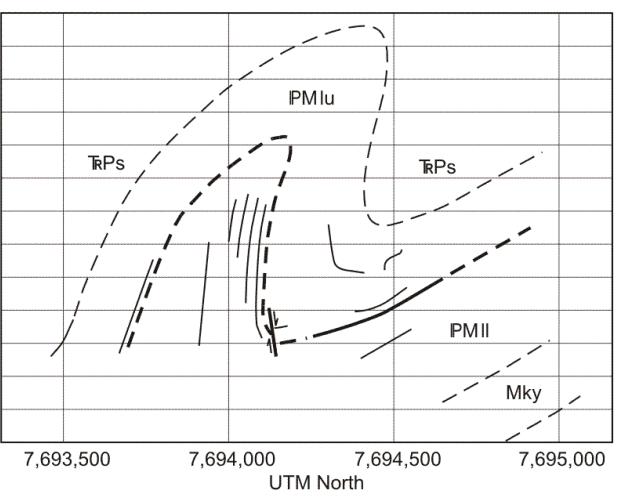

(d) Shublik Mountains (southwest and northeast ridges): Folds 4, 5, and 6

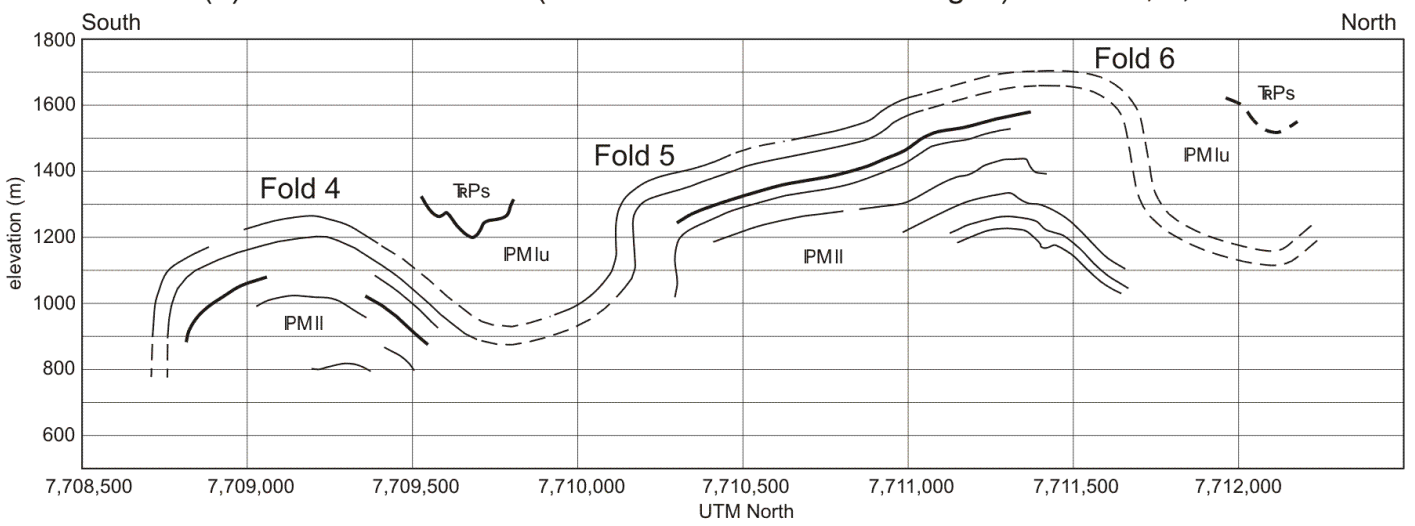

(e) Shublik Mountains (southeast and northeast ridges): Folds 4, 5, and 6

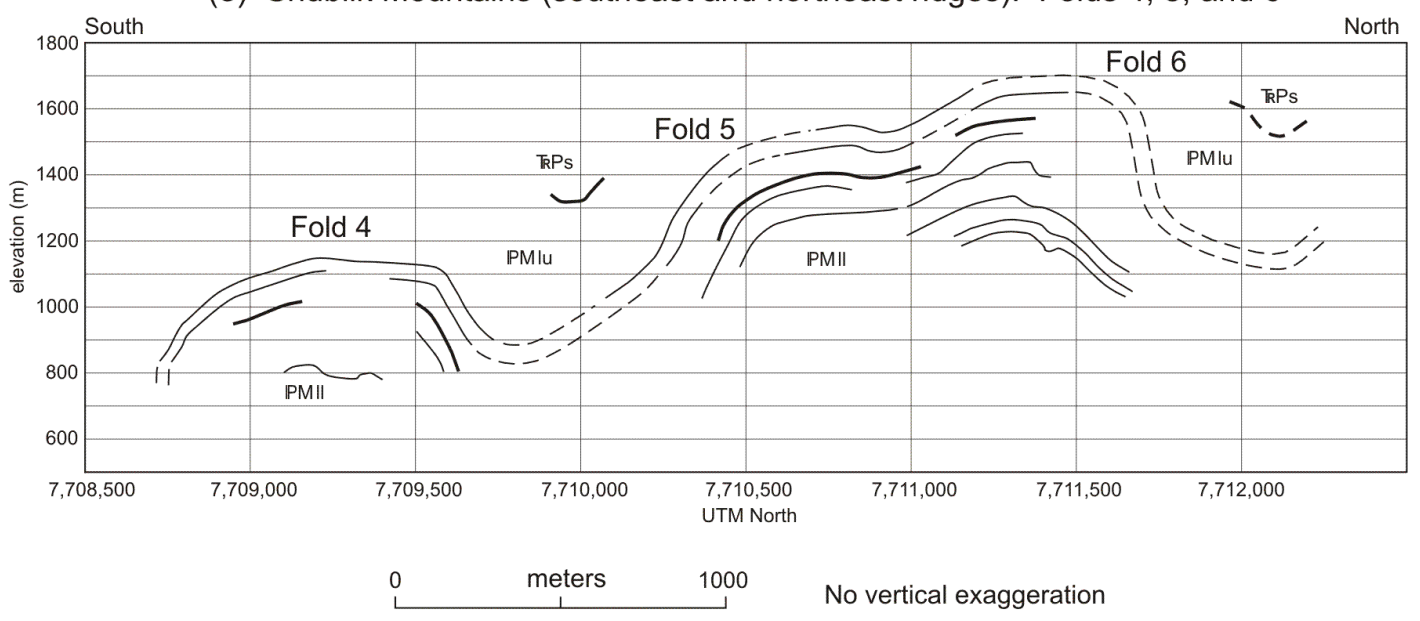

- $-\ldots$ Marker horizons

Figure 5. Surveys of detachment folds from the northeastern Brooks Range. Locations shown in figure $3 \mathrm{a}$. 


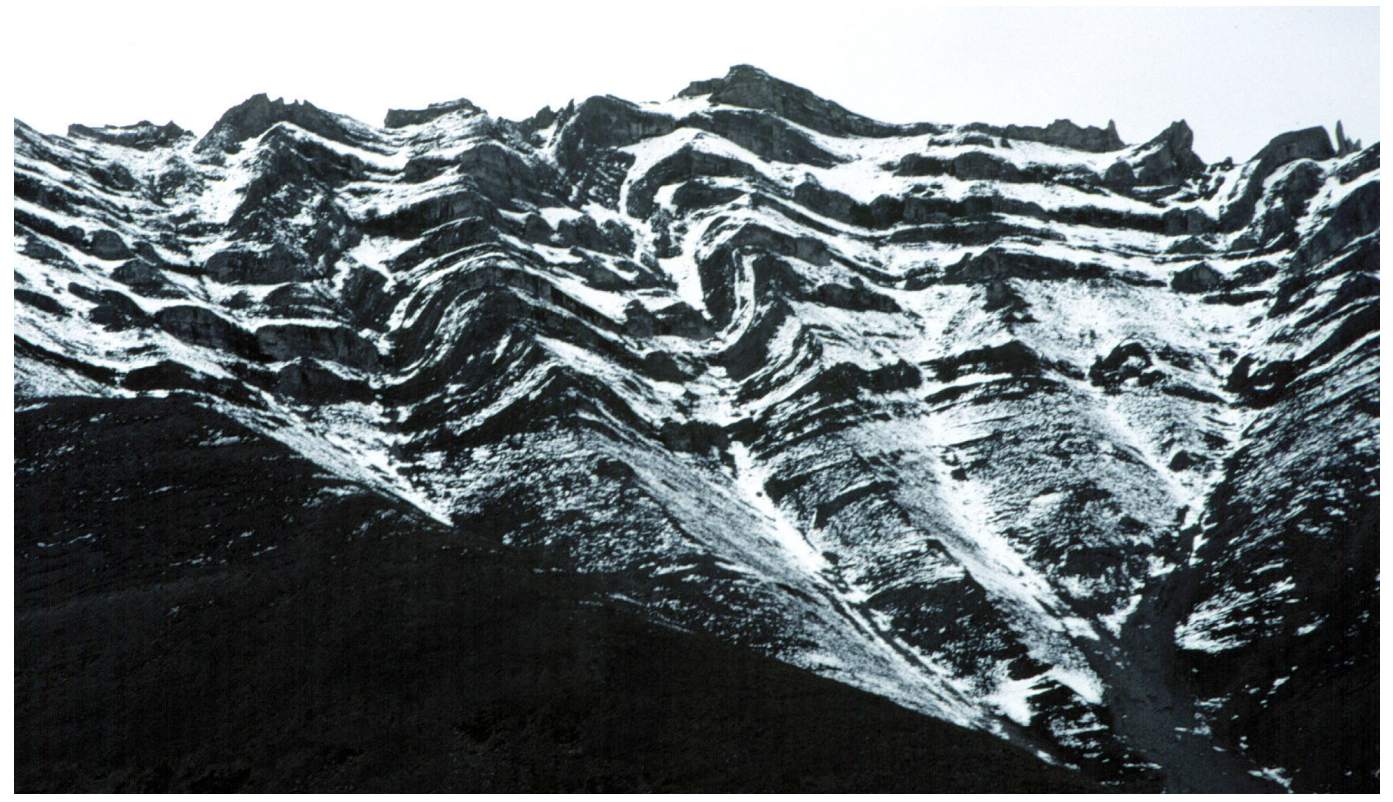

Figure 6a. Low-shortening detachment folds within lower Lisburne in the crest of the Echooka anticlinorium. Folds are detached above a horizon within lowermost Lisburne. Highest peaks are near the lower-upper Lisburne contact, but upper Lisburne is mostly eroded. Culmination to left defined by multiple small folds may represent the cores of a larger anticline within upper Lisburne. Hinge zones widen outward within folds, upward within anticlines and downward within synclines. Angular hinges grade outward to curved or box-like hinge zones.

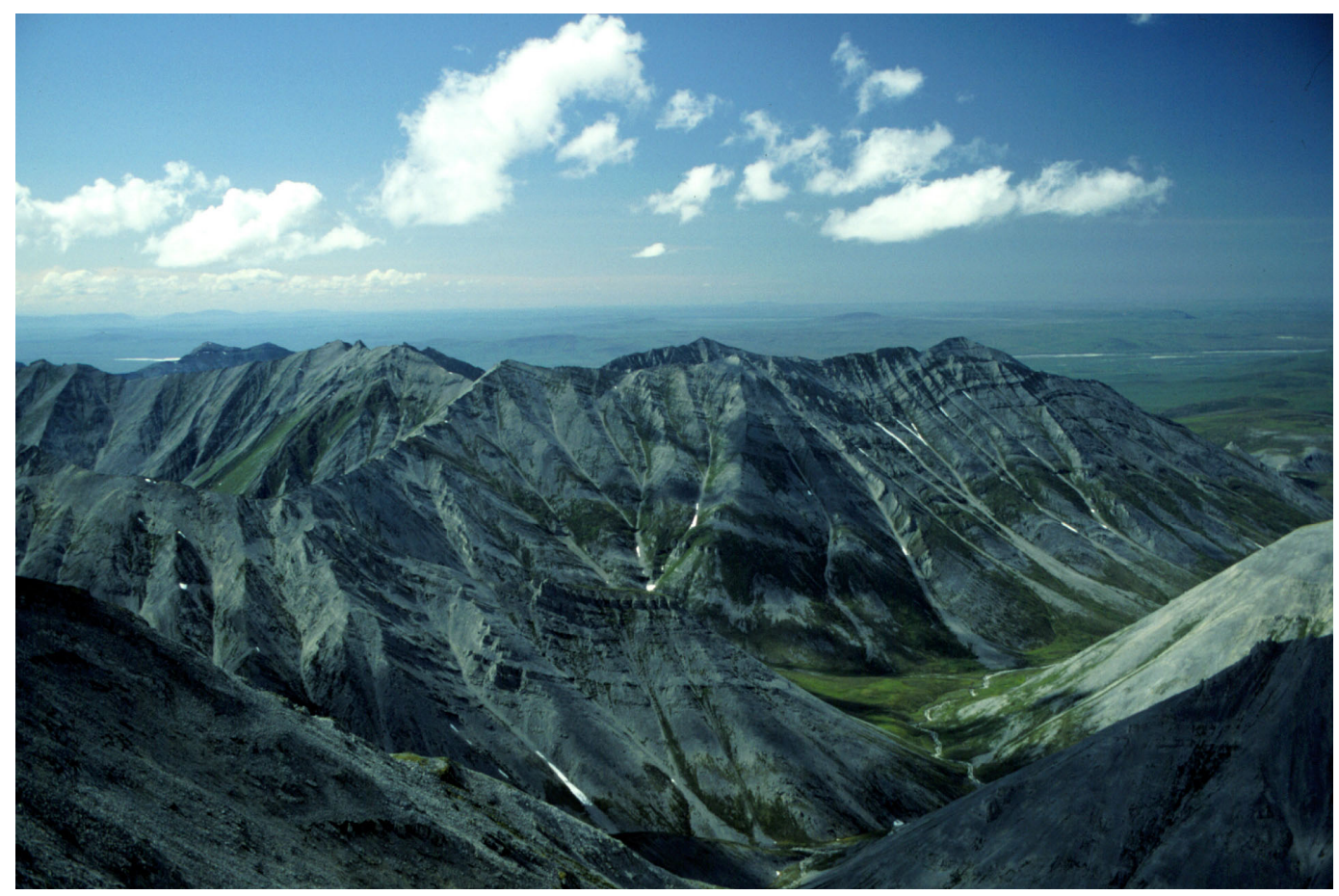

Figure 6b. Low-shortening detachment folds within upper Lisburne in the crest of the Echooka anticlinorium. The anticline to the left lies along strike with the culmination in Figure 6a. 


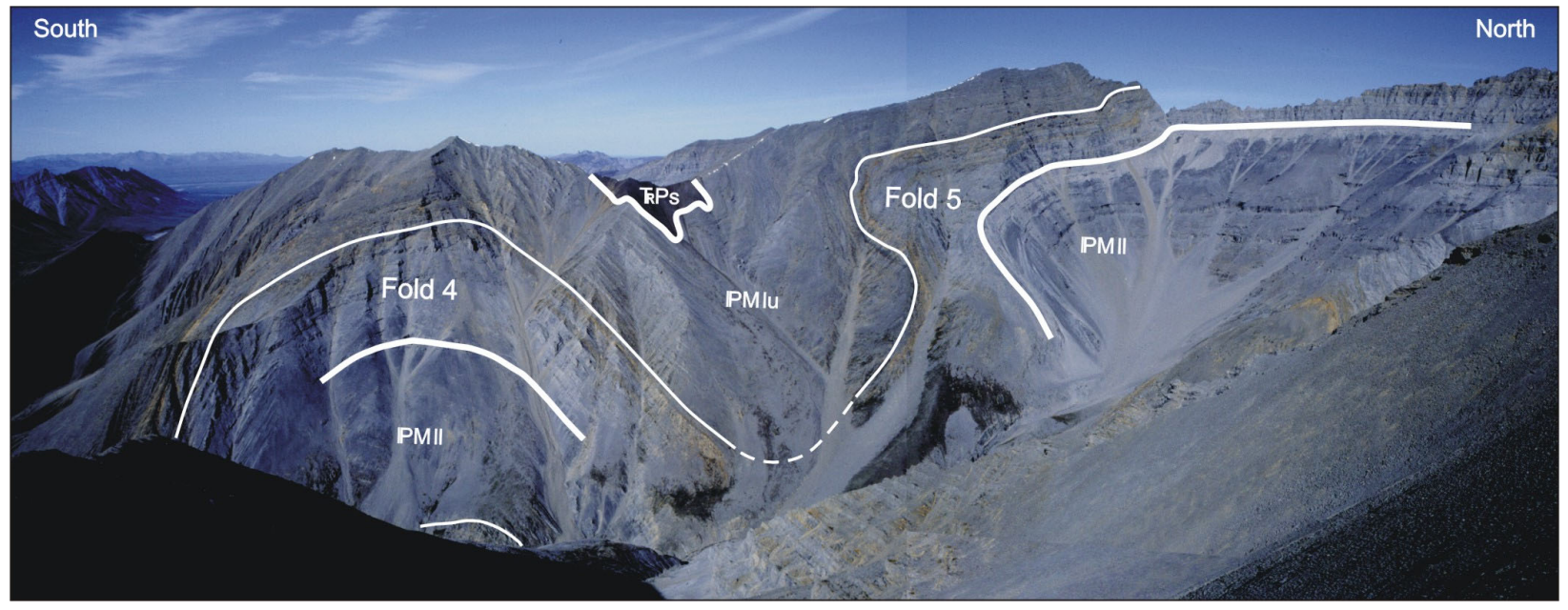

Figure 6c. Detachment folds in the Shublik Mountains that display box-fold geometry common in low- to intermediate-shortening folds. Surveyed folds in the southern part of figure $5 \mathrm{~d}$.

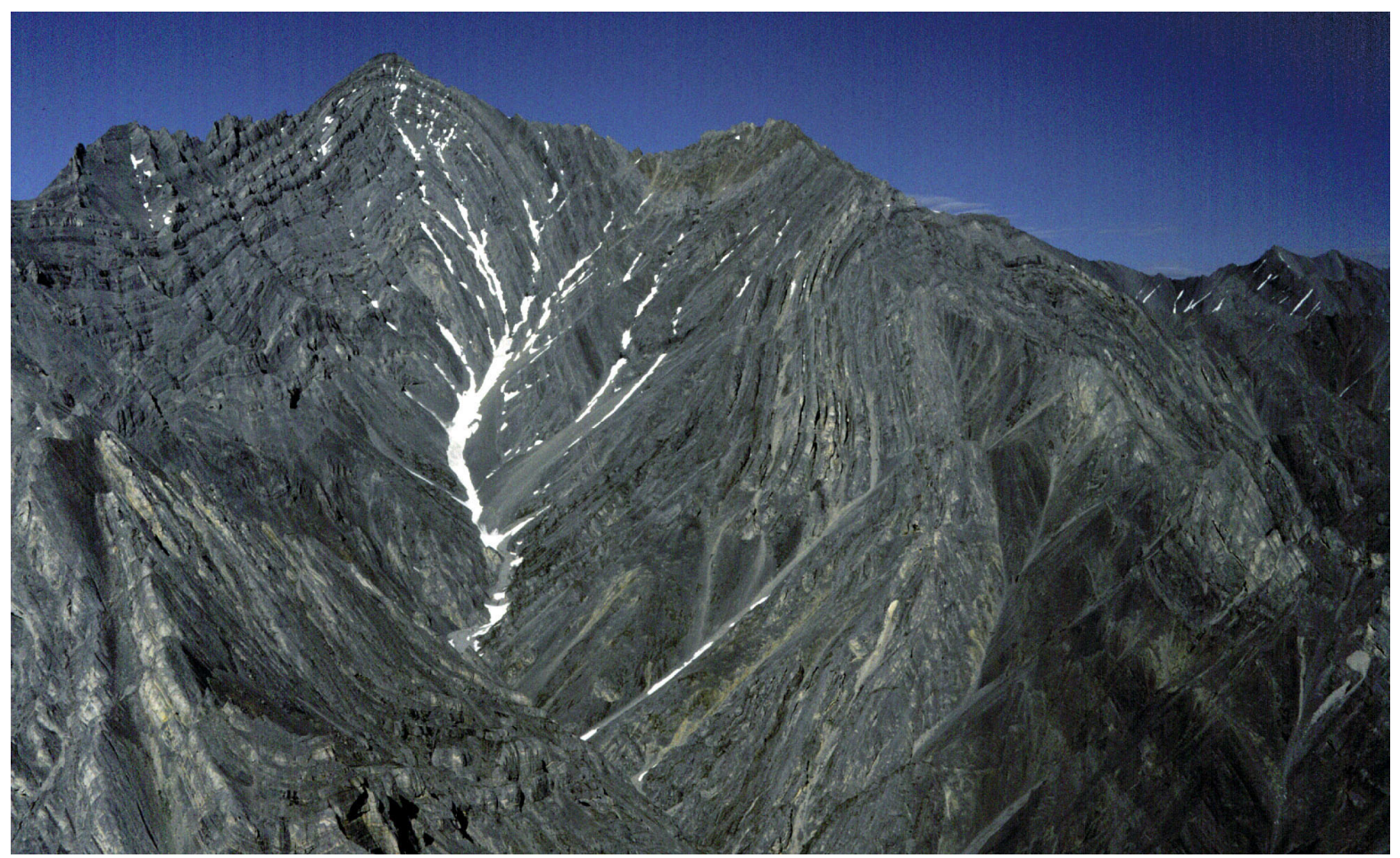

Figure 6d. Typical intermediate-shortening detachment folds. West side of upper Echooka River valley. 


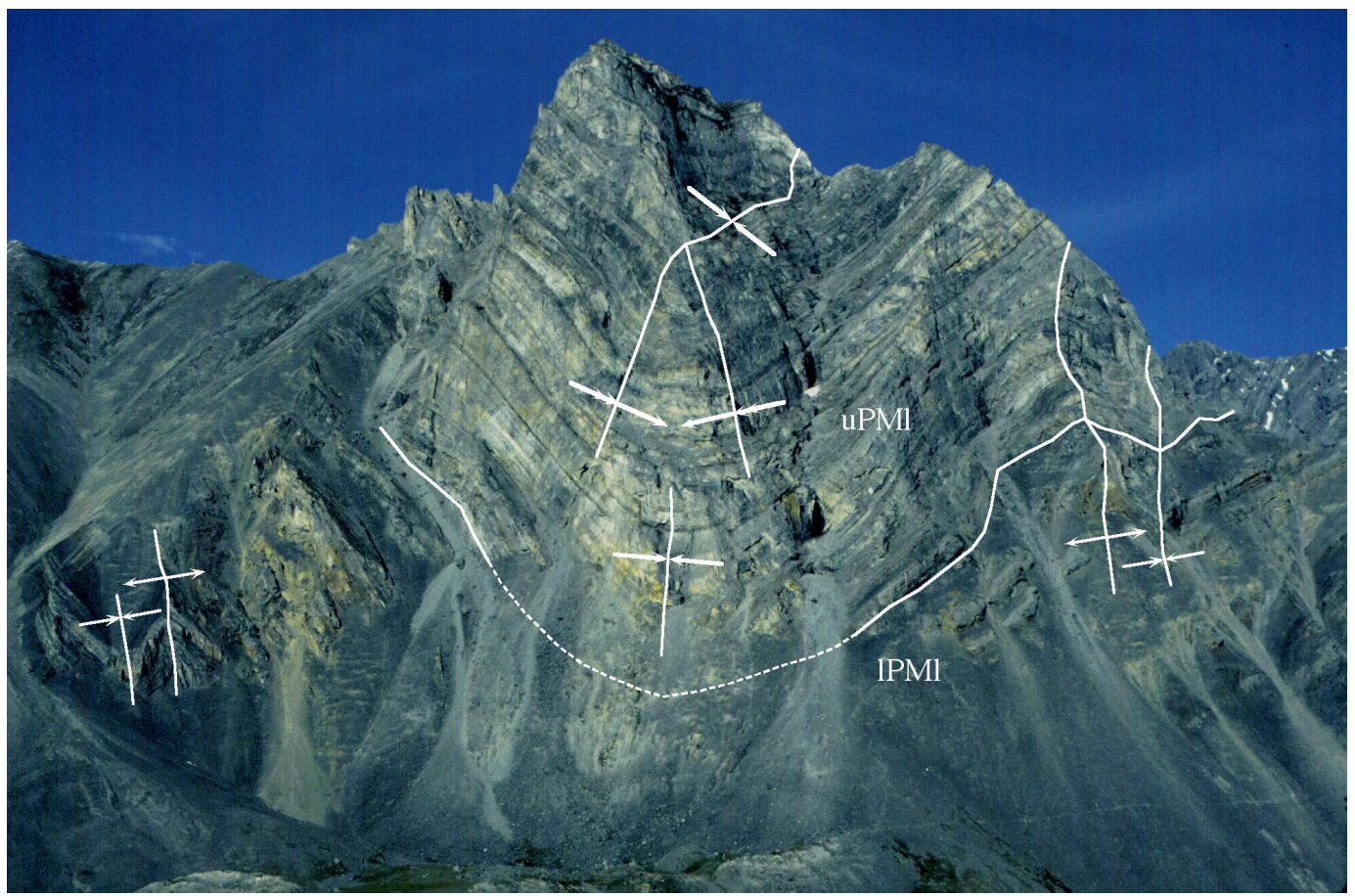

Figure 6e. Well-exposed intermediate-shortening syncline within upper Lisburne that displays upward internal changes in hinge zone width, curvature, and interlimb angle. Parasitic folds are best developed within lower Lisburne. West side of upper Echooka River valley.

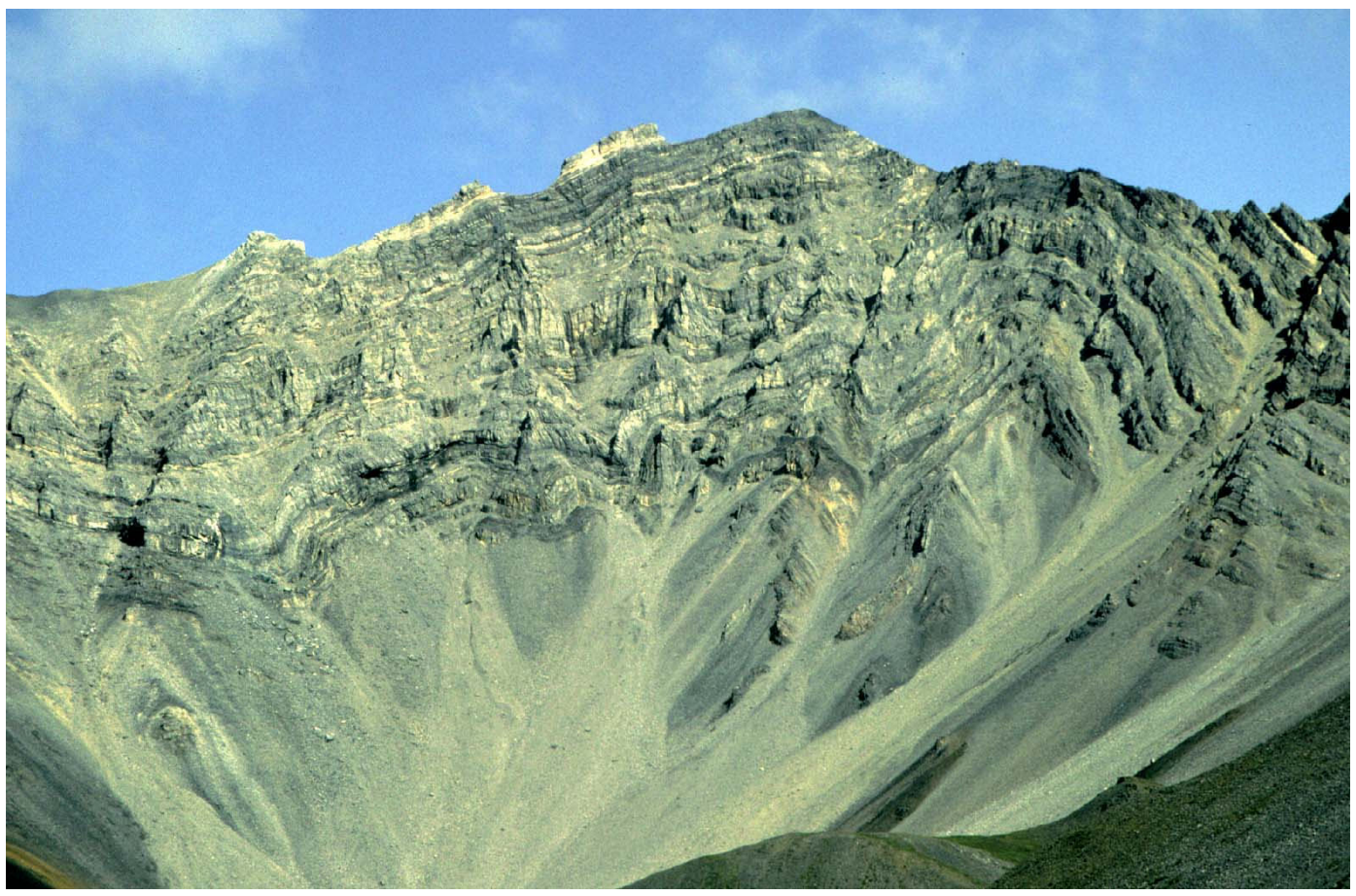

Figure 6f. Low-shortening anticline in lower Lisburne. Abundant parasitic folds in lower and underlying Kayak Shale (dark scree-covered slopes). At crest of Fourth Range anticlinorium. Surveyed fold in figure $5 \mathrm{c}$. 


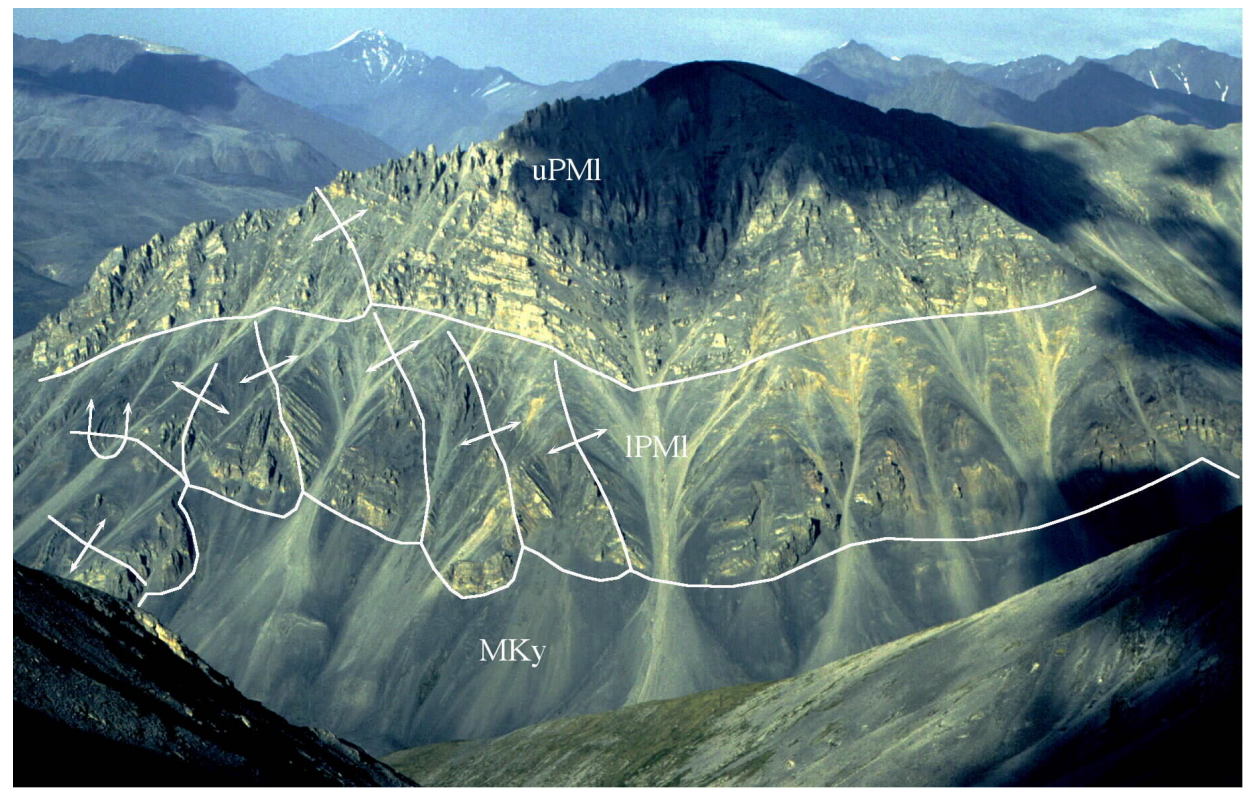

Figure 6g. Anticline-syncline pair exposed from the Kayak to the upper Lisburne. Parasitic folds are tighter and more abundant within the Kayak and lower Lisburne and die out upward near the contact between lower and upper Lisburne. Fewer, gentler, and larger folds in upper Lisburne appear to reflect less fold shortening upward. South of eastern Franklin Creek.

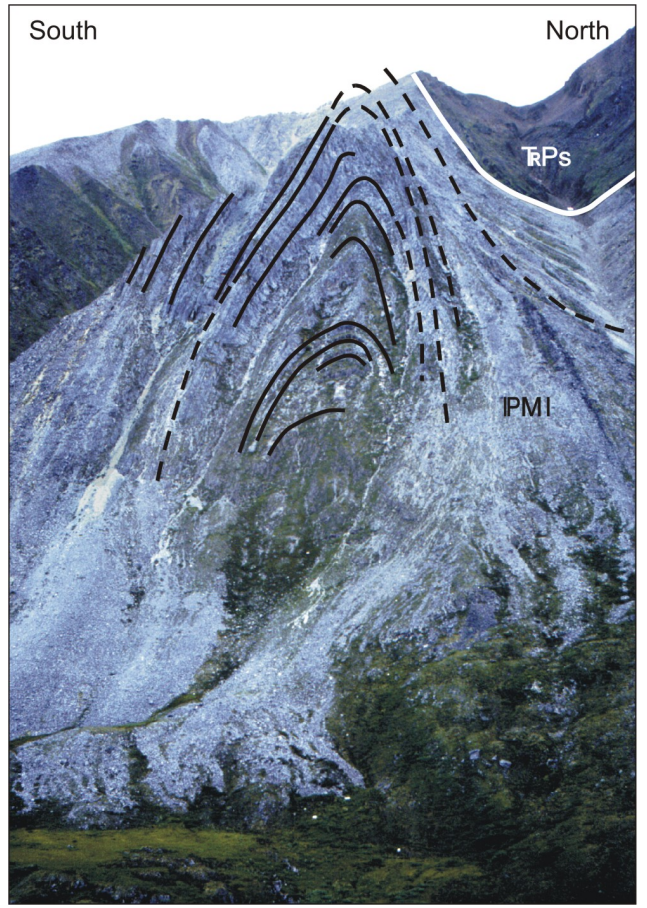

Figure 6h. High-shortening detachment fold south of Fourth Range. Fold flattening has resulted in thickened hinges and thinned limbs. Surveyed fold in figure 5a. 


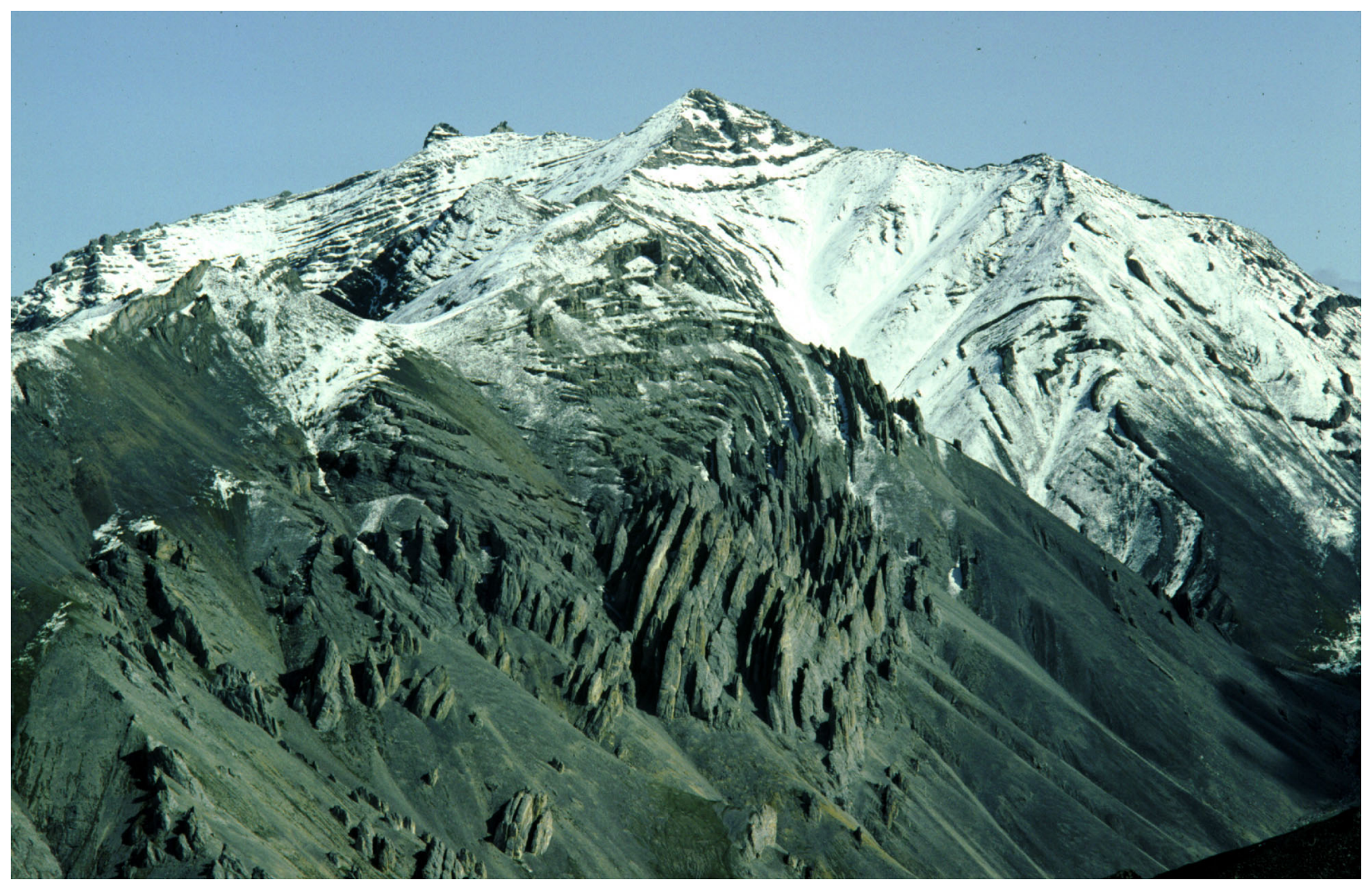

Figure 6j. Recumbent detachment anticline along the north flank of the south Franklin Mountains anticlinorium. Well-bedded upper Lisburne (upper left) forms isoclinal "liftoff fold" above less competent interval in lower Lisburne (snow covered area in upper center). Base of lower Lisburne displays a different geometry in well-defined box-fold cored by Kayak Shale (center right). 


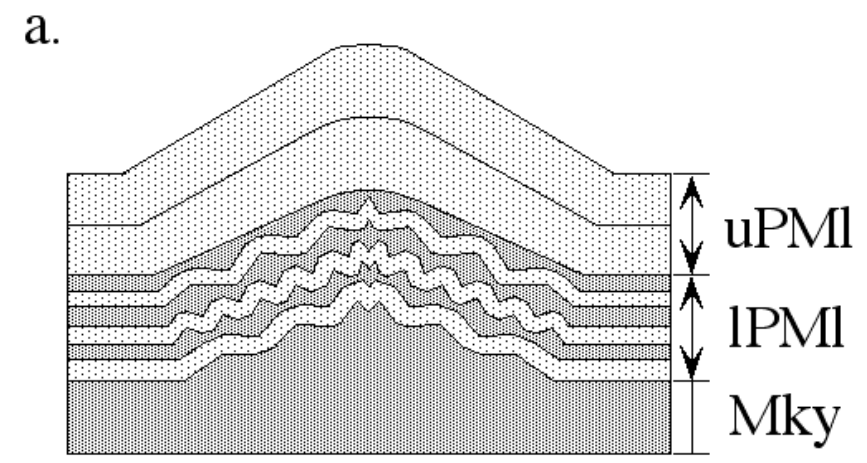

b.1.

b. 2 .
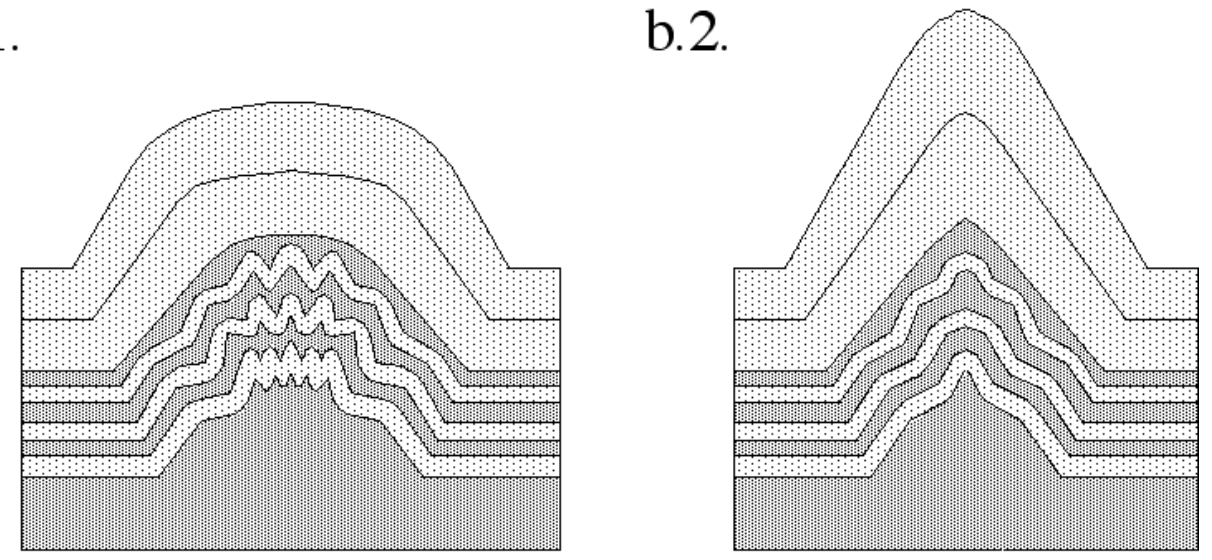

C.

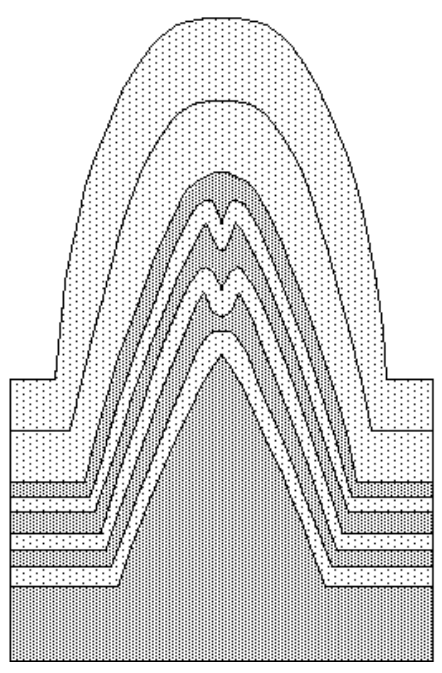

Figure 7. Evolution of detachment folds in the northeastern Brooks Range. Schematic and not balanced. A single isolated fold with constant detachment depth is shown for simplicity. a. Low shortening; b.1. Intermediate shortening, box-fold geometry; b.2. Intermediate shortening, chevron fold geometry; c. High shortening. The flat crest of the box-fold geometry allows these folds to become isoclinal (interlimb angle of $0^{\circ}$ ) yet still represent only intermediate shortening. Mky: Kayak Shale (incompetent); 1PMl: lower Lisburne Limestone (transitional competency); uPMl: upper Lisburne Limestone (competent). 


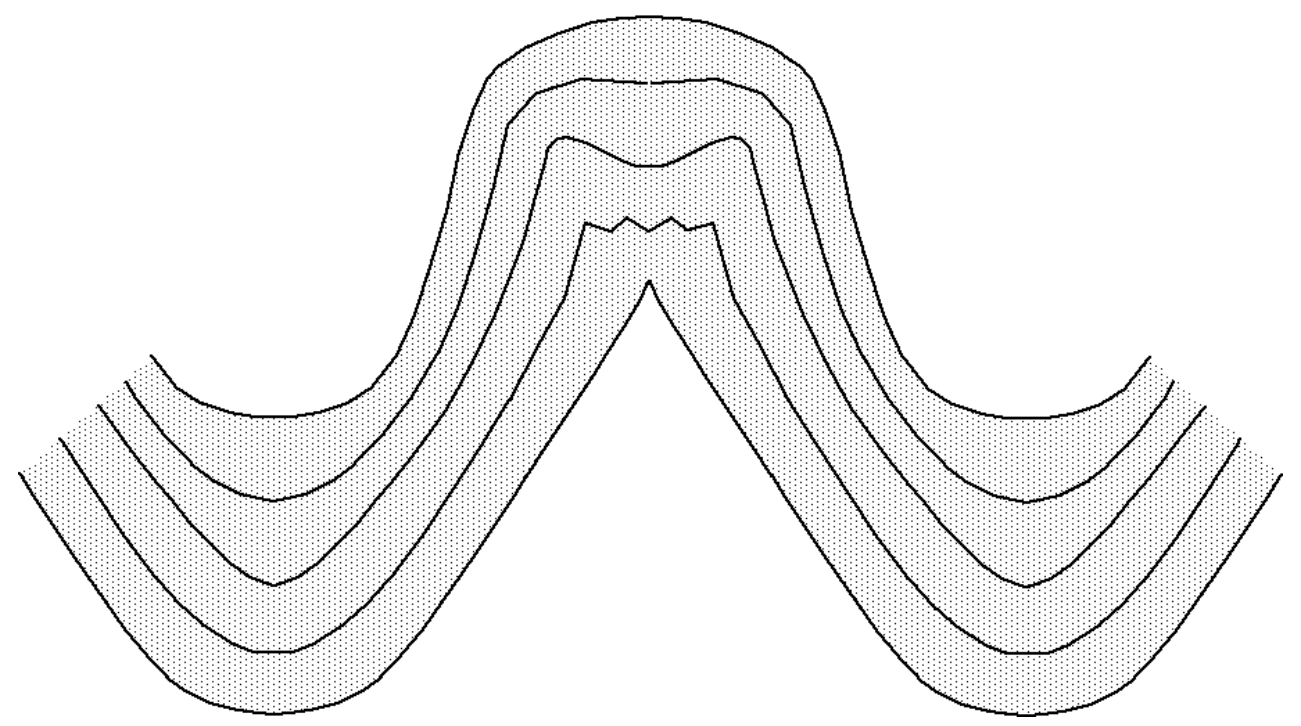

Figure 8. Idealized geometry of intermediate-shortening detachment folds in the northeastern Brooks Range. In anticlines, limbs are straight to gently curved and hinge zones widen upward. Parasitic folding decreases upward to gently rounded anticlinal crests. Synclines tend to display less widening of the hinge zone downward, into the outer arc of the fold. This is accommodated by differing amounts of hinge thickening in different parts of the stratigraphy.

(a)

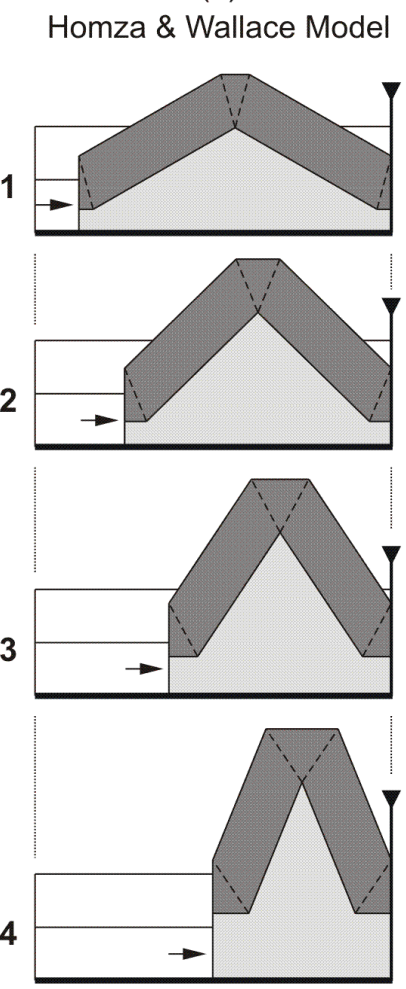

(b)

Epard \& Groshong Model

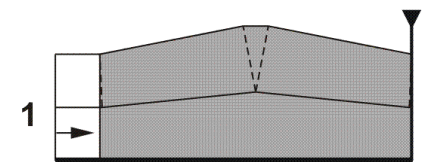

2

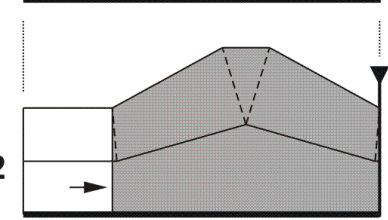

3

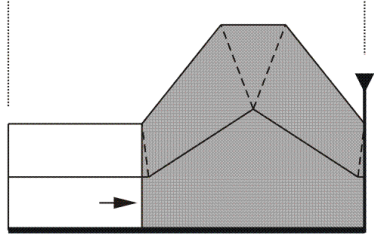

4

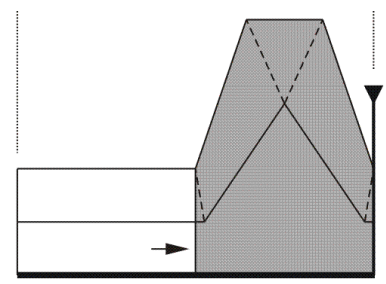

(c)

Hybrid Model

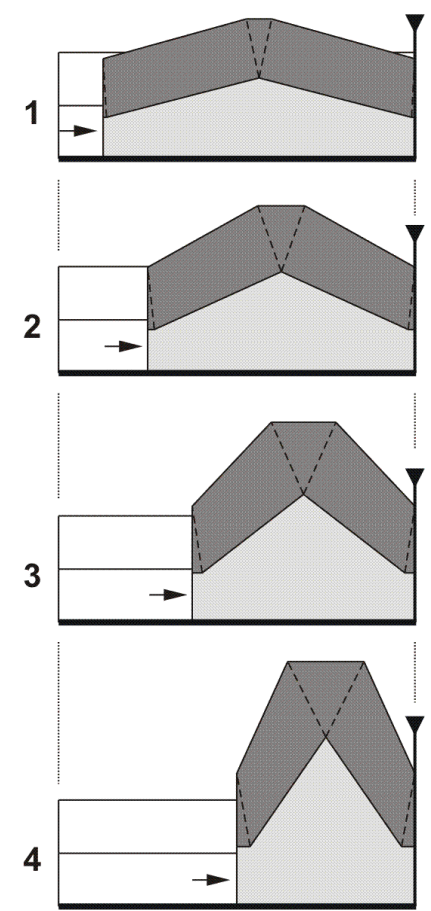

Figure 9. Idealized models for geometry and evolution of detachment folds. Based on models by: a. Homza and Wallace, 1995, 1997; b. Epard and Groshong, 1995; c. Atkinson and Wallace, 2003. (From Atkinson and Wallace, 2003) 
Final report

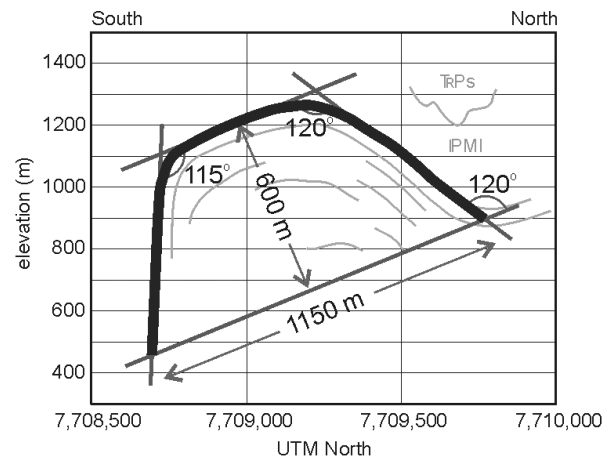

(b)

Homza \& Wallace Model $\mathrm{IBL}=1200 \mathrm{~m}$

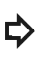

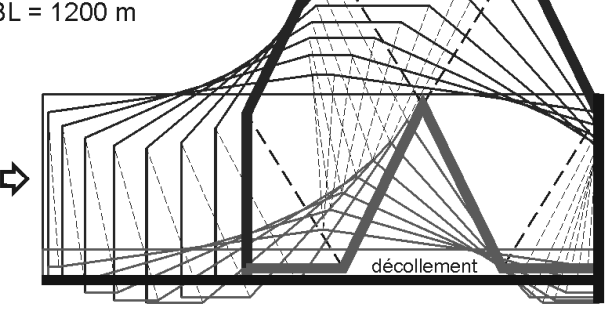

(d)

Hybrid Model

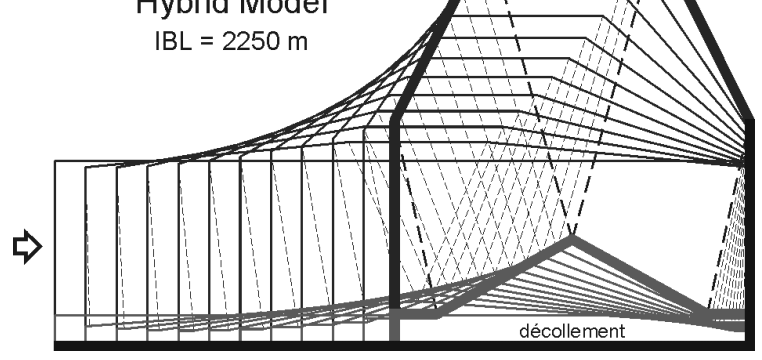

(a)

Fold Measurements arc length $=1800 \mathrm{~m}$

(c)

Epard \& Groshong Model $\mathrm{IBL}=2000 \mathrm{~m}$

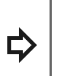

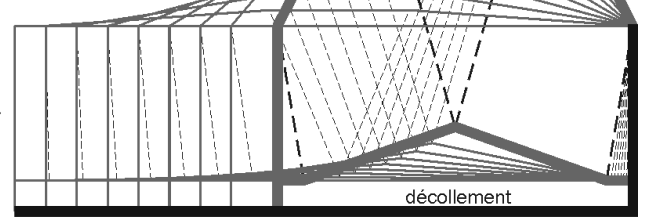

(e)

Hybrid Model $\mathrm{IBL}=2550 \mathrm{~m}$

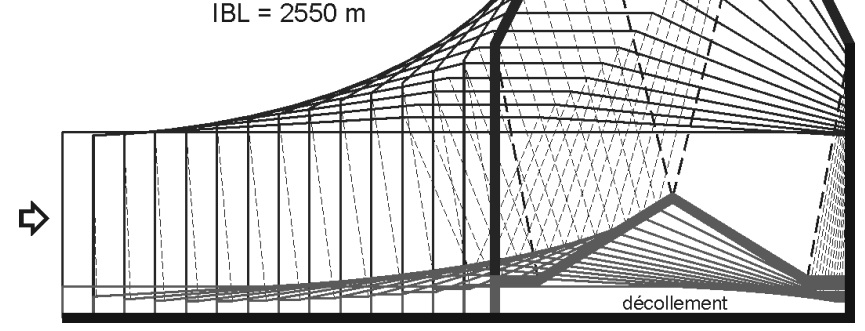

Figure 10. Comparison of surveyed fold in Shublik Mountains (Figure 5d) with different detachment fold models (Figure 9). (From Atkinson and Wallace, 2003) 
(a)

Fold Measurements

arc length $=1250$

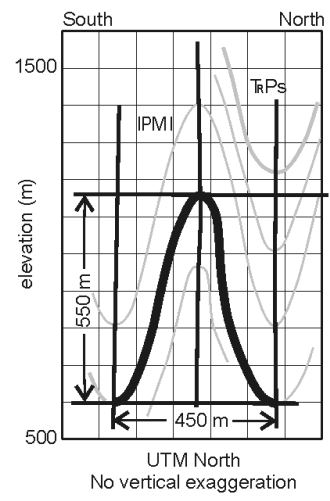

(b)

Homza \& Wallace Model $\mathrm{IBL}=1250 \mathrm{~m}$

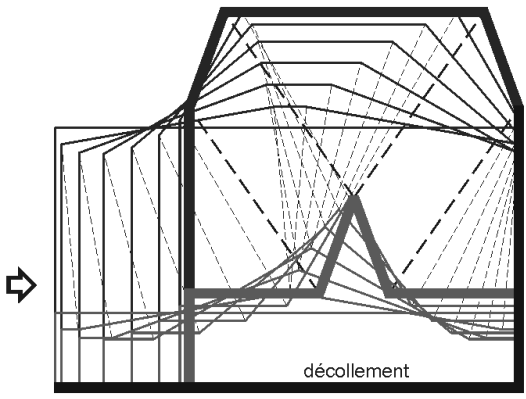

(e)

Hybrid Model

$\mathrm{IBL}=1150 \mathrm{~m}$

$\Rightarrow$

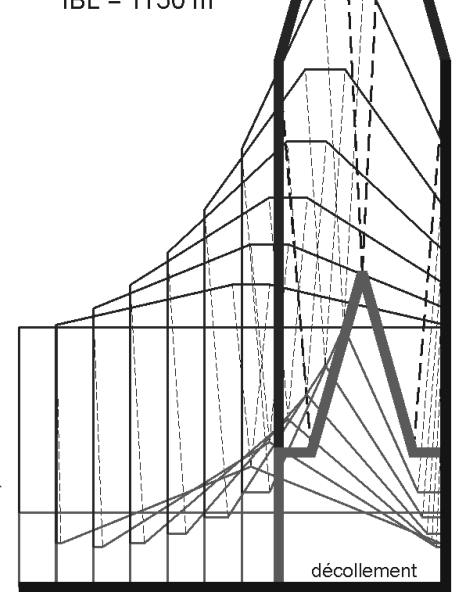

(f)

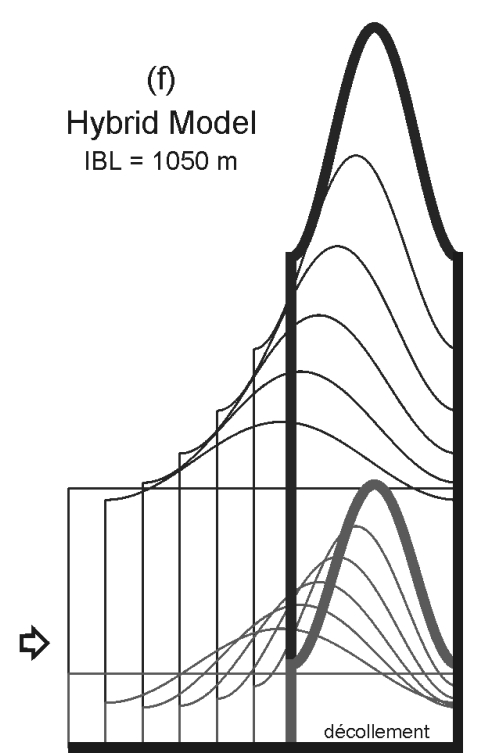

(c) and (d)

Epard \& Groshong Model

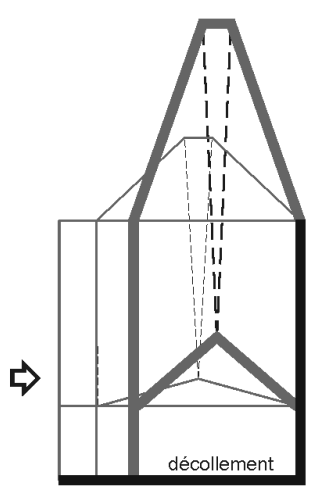

$\mathrm{IBL}=650 \mathrm{~m}$

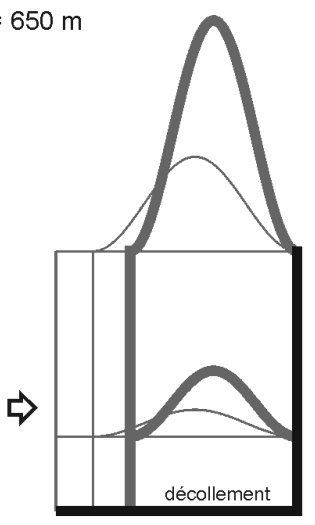

(g)

Hybrid Model $\mathrm{IBL}=1250 \mathrm{~m}$

$\Rightarrow$

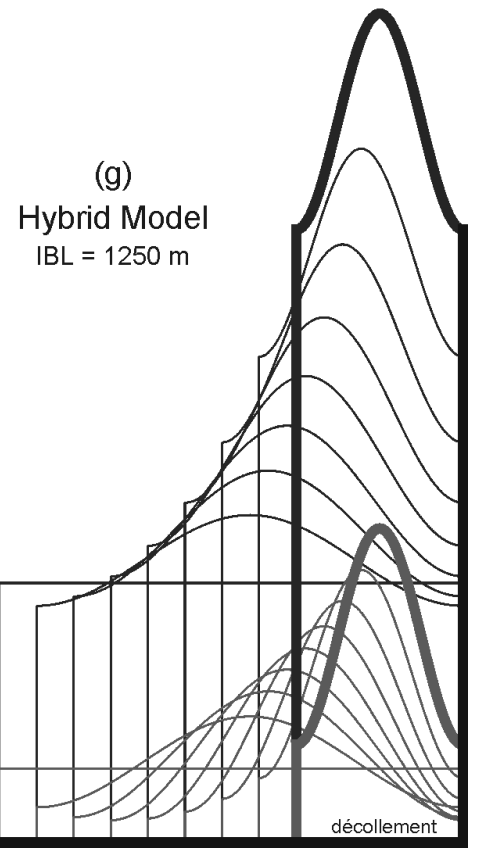

Figure 11. Comparison of surveyed fold south of Fourth Range (Figure 5a) with different detachment fold models (Figure 9). (From Atkinson and Wallace, 2003) 


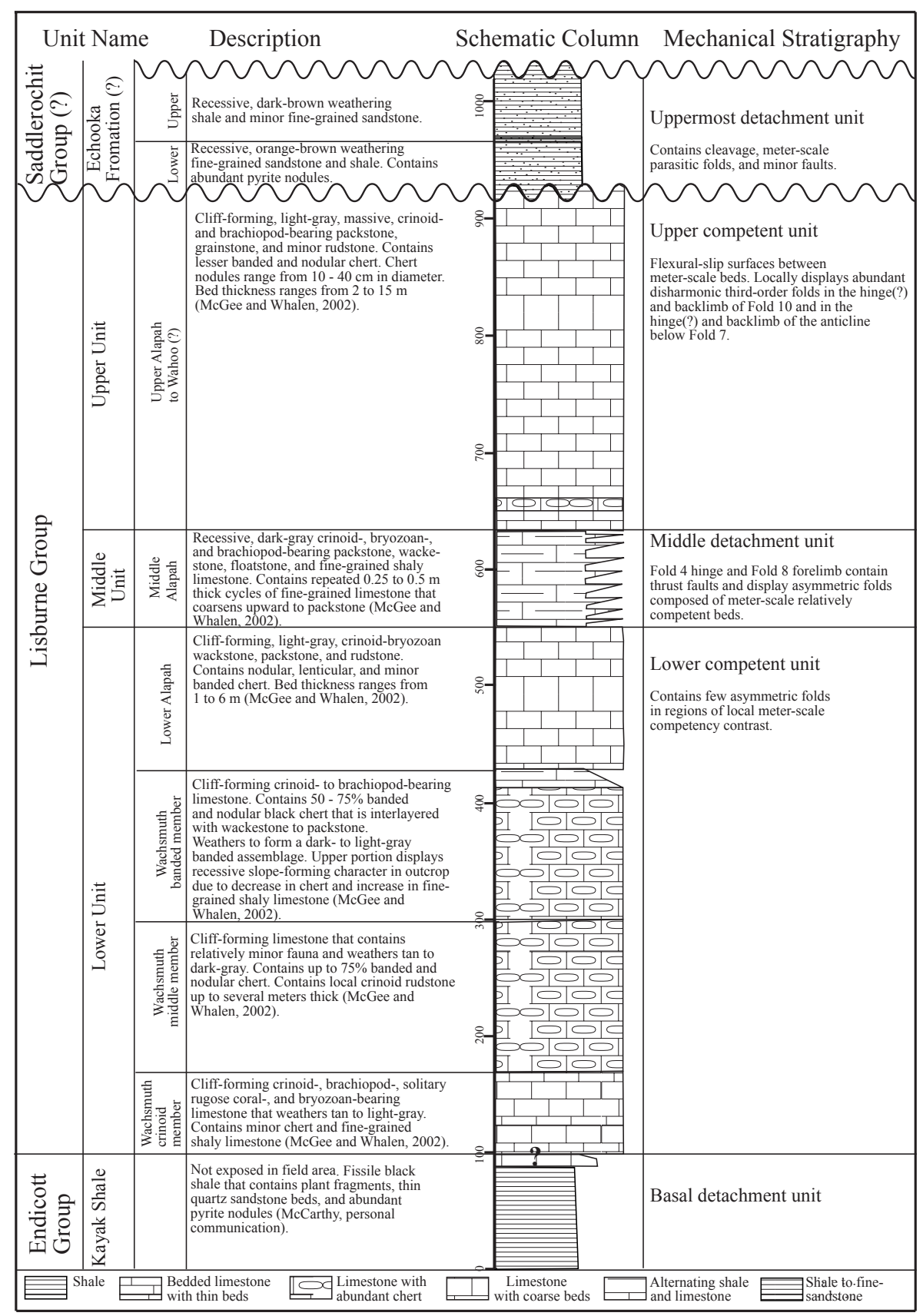

Figure 12. Schematic sratigraphic column of Lisburne Group and surrounding units, Porcupine Lake area. Lisburne Group is divided into lower, middle, and upper units on the basis of outcrop pattern and mechanical stratigraphy. Scale bar is in meters. Column indicates slope- to cliff-forming weathering patterns from left to right. Figure from Jadamec, 2003. 
Final report

DE-AC26-98BC15102

A

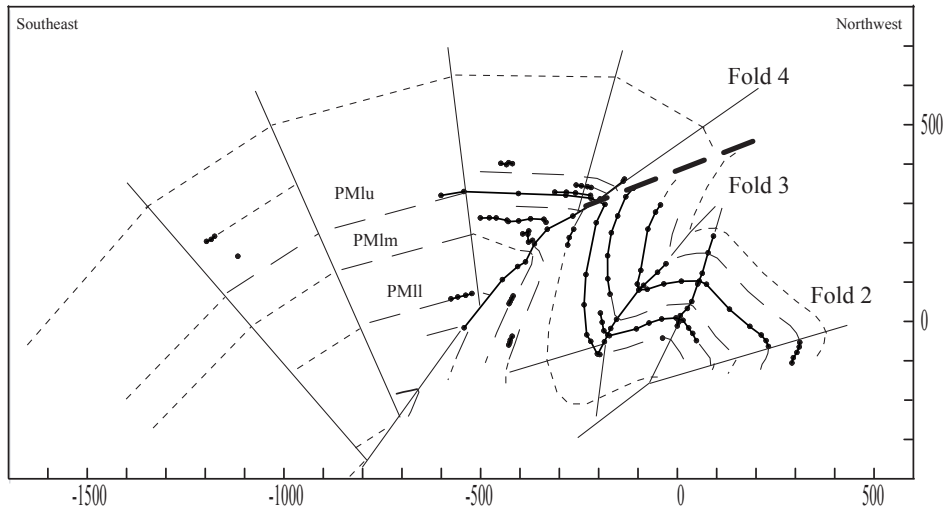

B

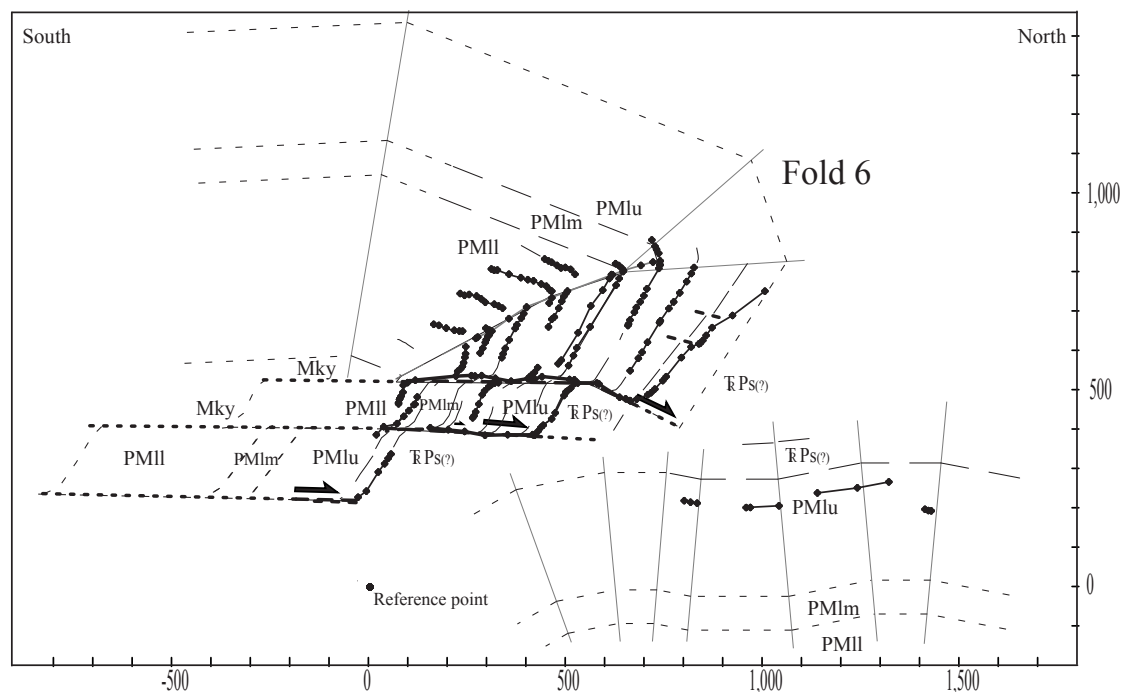

Figure 13. (Continued on next page.) 
C

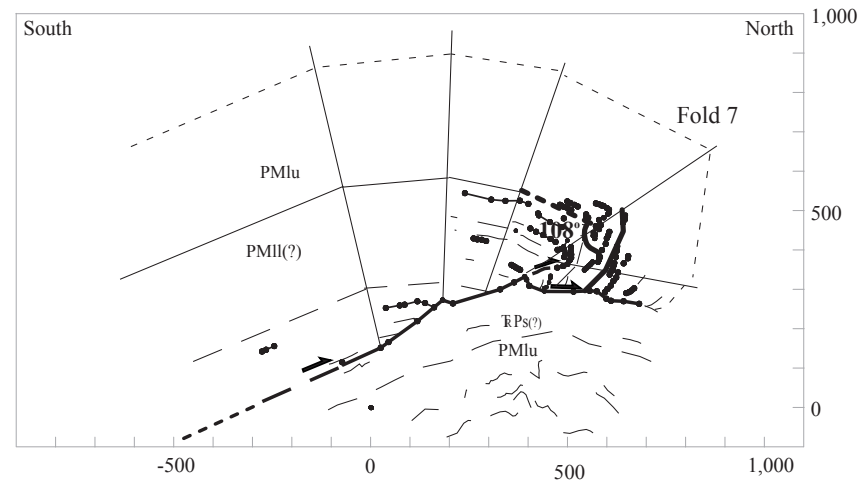

$\mathrm{D}$

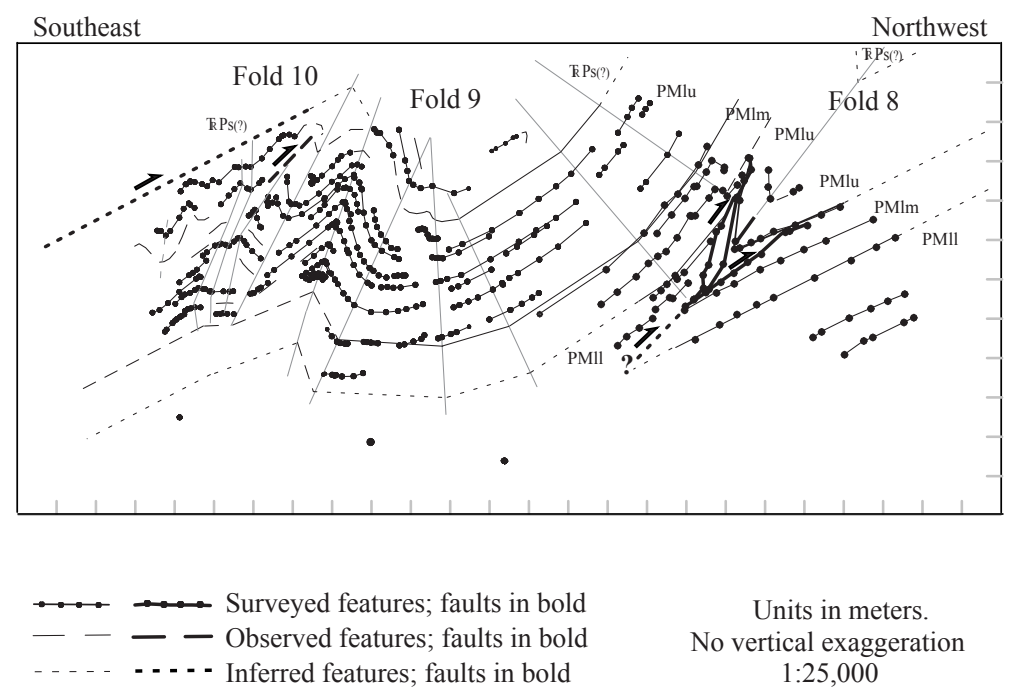

Figure 13 (continued). Asymmetrical folds surveyed using theodolite and laser rangefinder. All but folds 9 and 10 (in D) are truncated by thrust faults. Fold 8 (in D) is interpreted to be a tri-shear fault-propagation fold. Modified from Jadamec, 2003. 


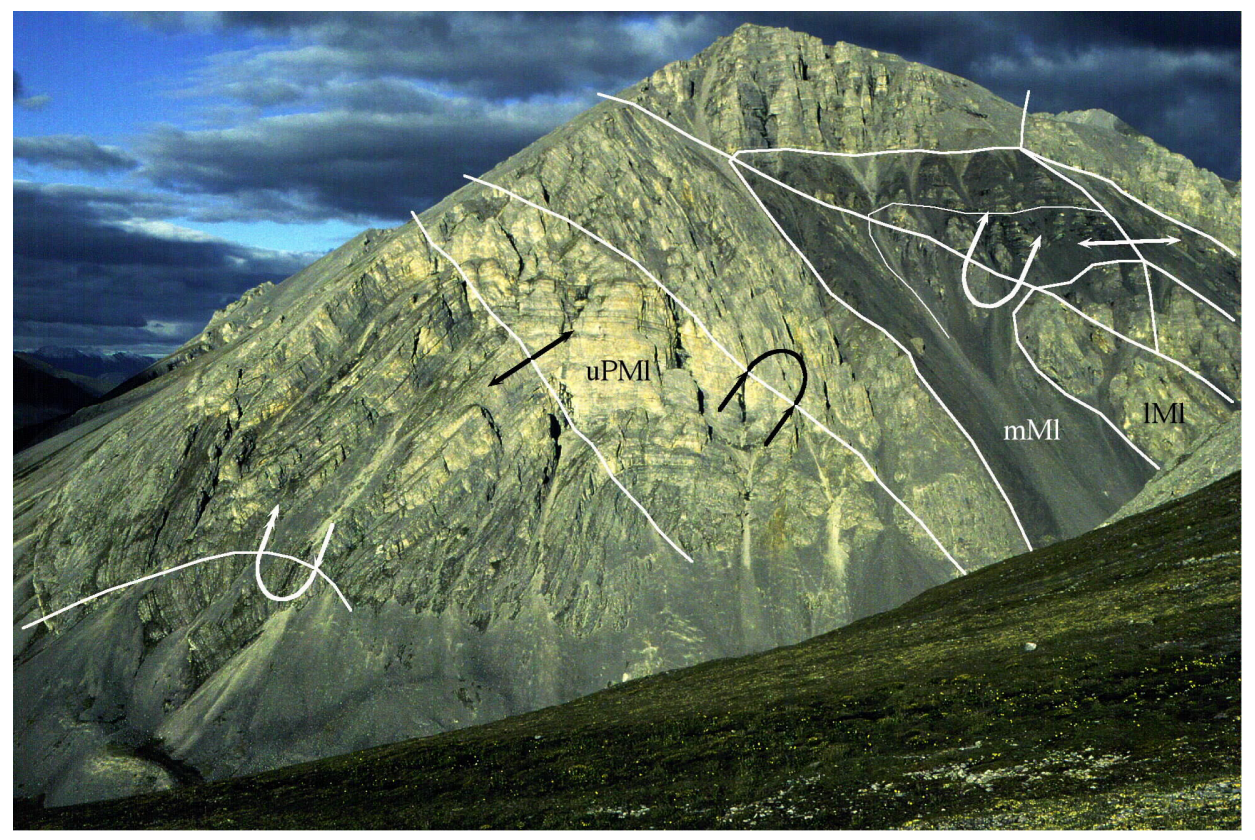

Figure 14a. View to east of folded forelimb of large asymmetrical anticline. Thickening in middle Lisburne in hinge zone of main anticline (to right) accommodates different fold geometries in the more competent lower and upper Lisburne. North-dipping forelimb displays parasitic anticline-syncline pair (to left). Forelimb may be truncated by a covered thrust fault below the overturned panel (lower left) at the base of the forelimb. Surveyed fold shown in figure 13a. South of Porcupine Lake.

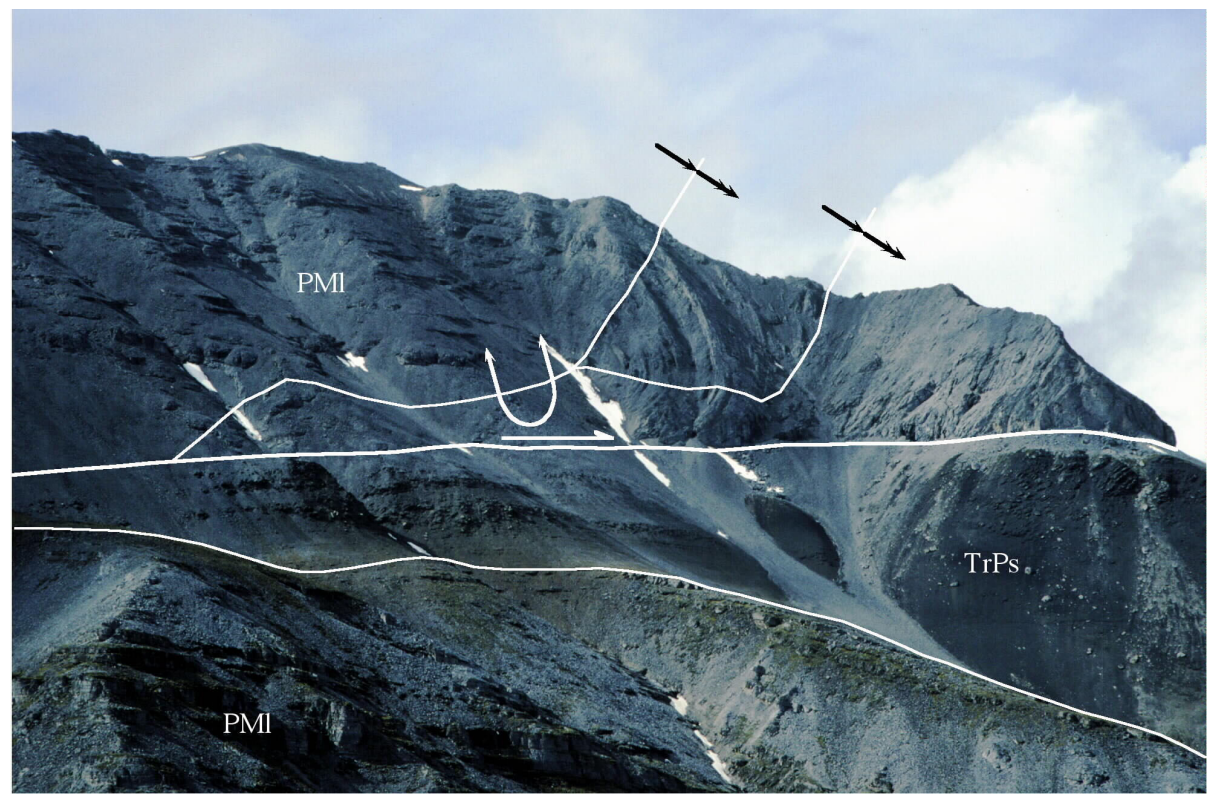

Figure 14b. View to west of truncated and displaced asymmetrical anticline. Thrust cuts across inclined anticline hinge at low angle and overturned bedding in the forelimb at a high angle. Anticline hinge branches upward to define box-fold geometry. Thrust follows a flat in the Sadlerochit Group in the footwall. Near south fork of Canning River. 


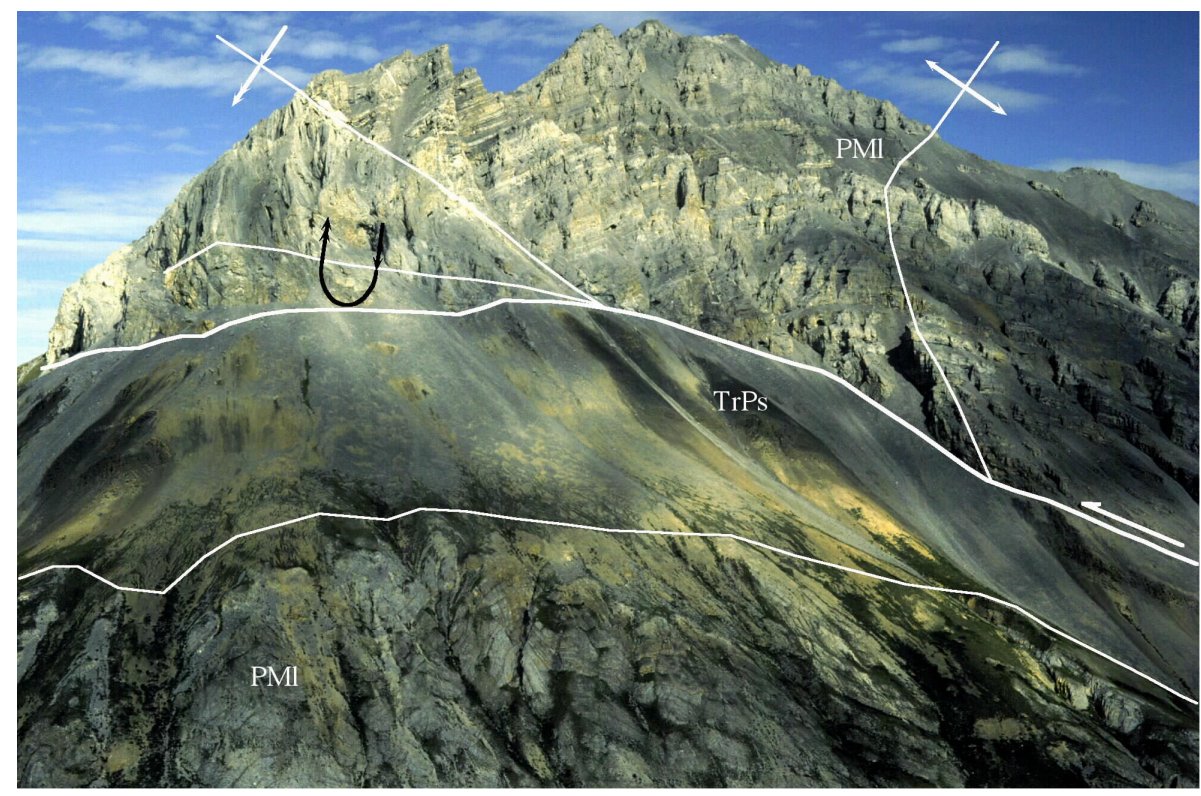

Figure 14c. View to east of truncated and displaced asymmetrical anticline. Steeply dipping panel of forelimb is bounded between two inclined hinges that branch upward. Bedding in a narrow zone above the thrust fault is deflected in a sense consistent with fault displacement. Thrust follows a flat in the lowermost Lisburne in the backlimb of the anticline in the hangingwall. Thrust follows a flat in the Sadlerochit Group in the footwall. Surveyed fold shown in figure 13c. East of Marsh Fork of Canning River.

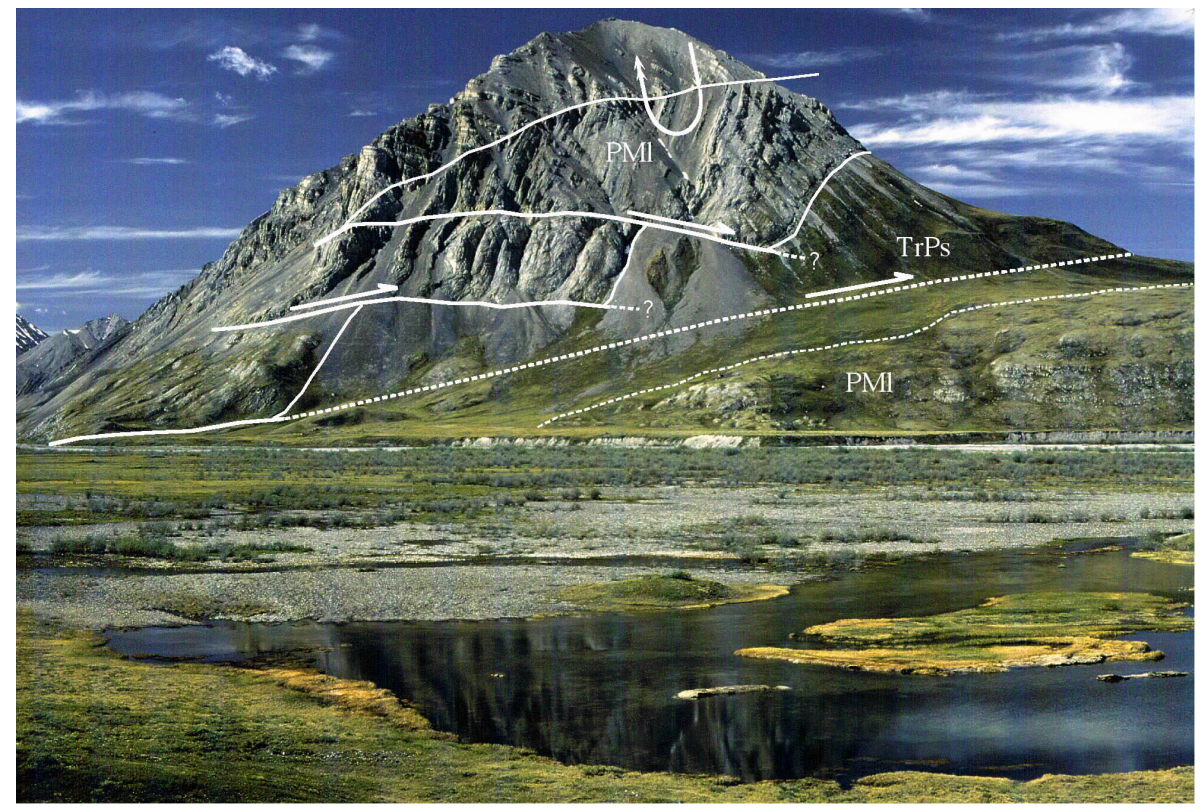

Figure 14d. View to west of truncated and displaced asymmetrical anticline with angular hinge. Forelimb below inclined anticline hinge is cut at high angle by two thrust faults that are subsidiary to the main thrust fault at the base of the anticline. Bedding in a narrow zone above and below each fault is deflected in a sense consistent with fault displacement. Surveyed fold shown in Figure 13b. West of Marsh Fork of Canning River. 


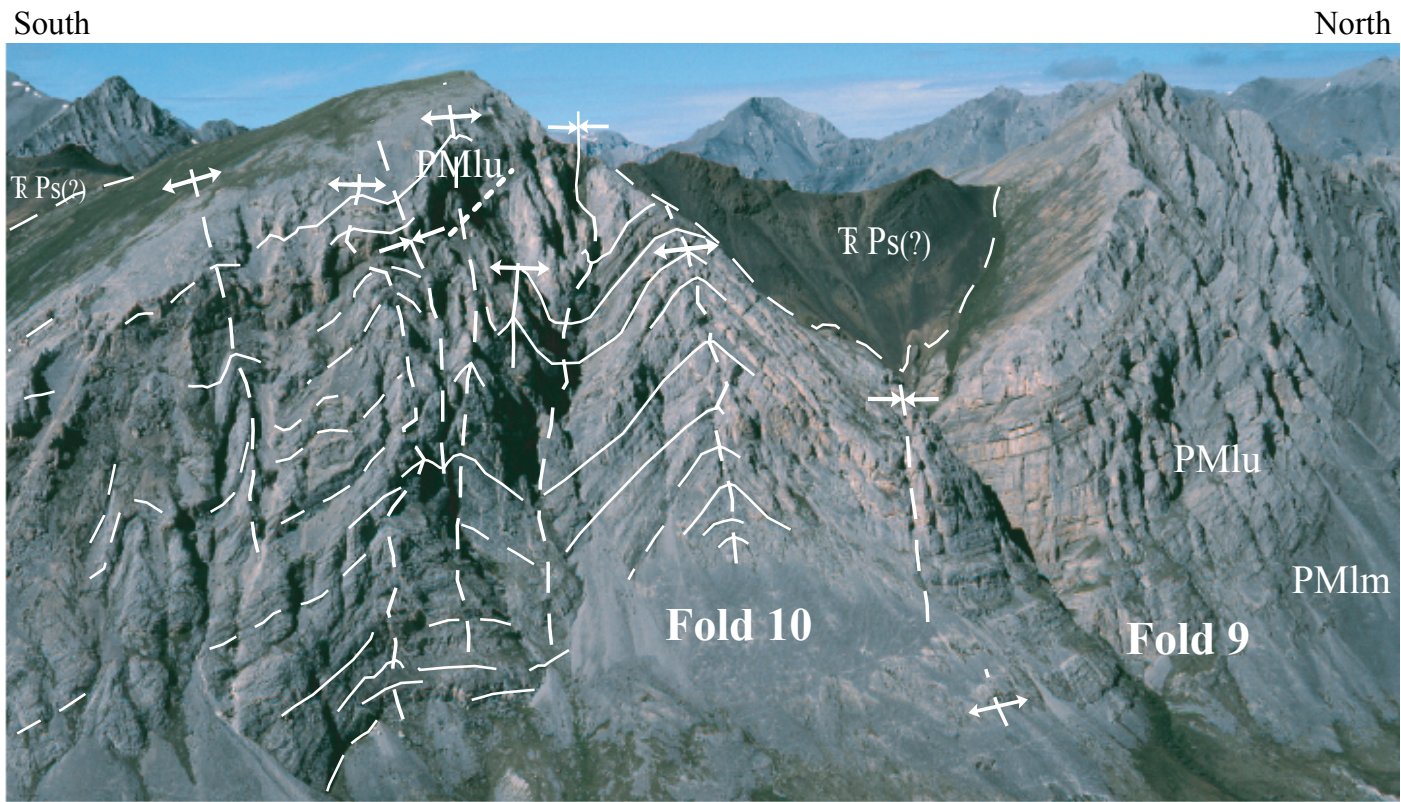

Figure 14e. Anticline-syncline pair that is not cut by a thrust fault. Parasitic folds in backlimb of anticline are in footwall of thrust to south of photo. North limb of syncline is south limb of truncated anticline shown in Figure 14f. Surveyed folds shown in Figure 13d. Figure modified from Jadamec, 2003.

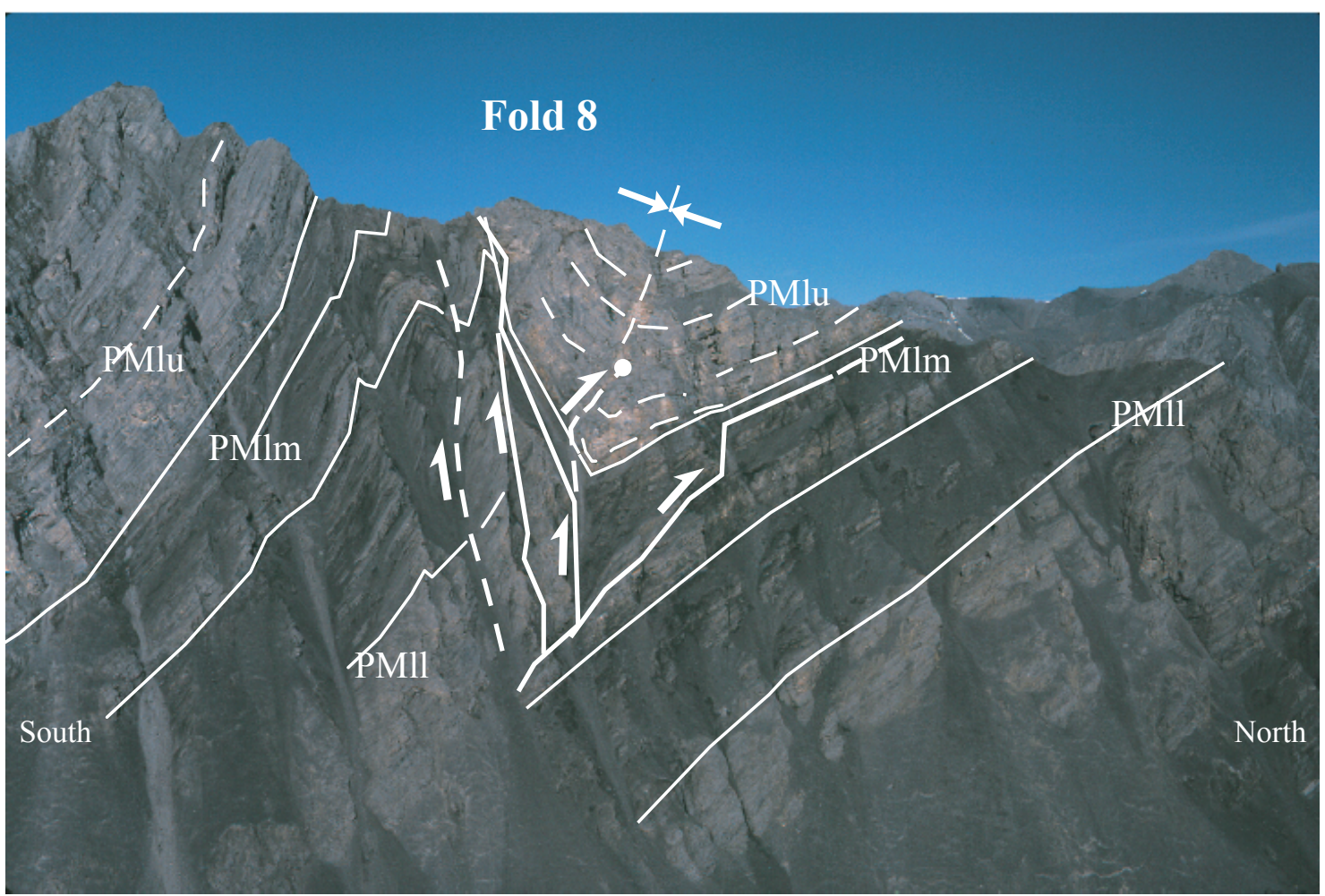

Figure 14f. Probable tri-shear fault-propagation fold. Anticline to south is truncated by several thrust splays that diverge up-section. The tip of one splay is in the core of the syncline. Surveyed fold shown in figure 13d. Figure modified from Jadamec, 2003. 


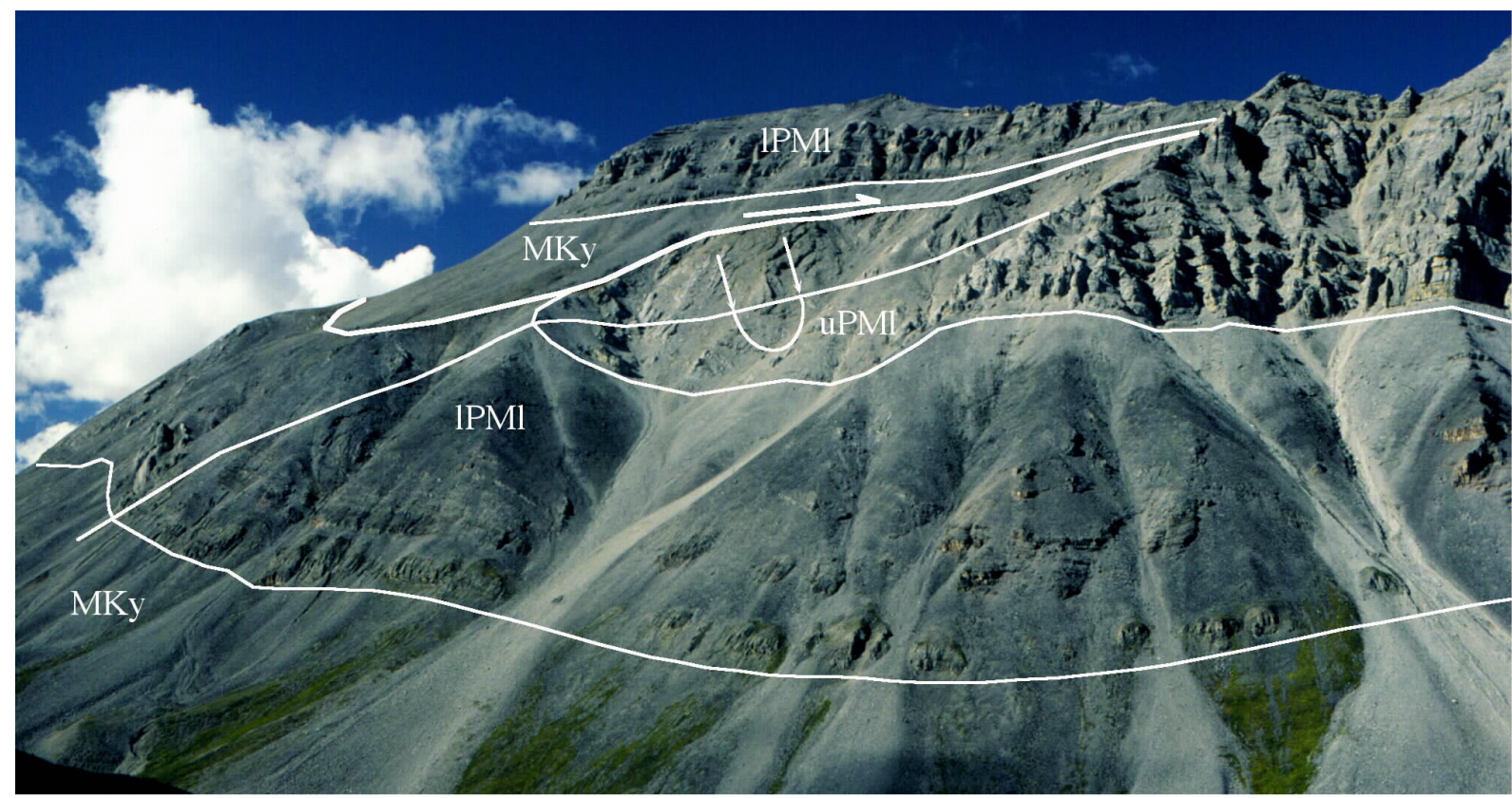

Figure 14g. Footwall syncline of thrust-truncated asymmetrical anticline-syncline pair. Disharmonic parasitic folds are present in the core of the syncline in both the lower and upper Lisburne. South of eastern Franklin Creek, view to northwest.

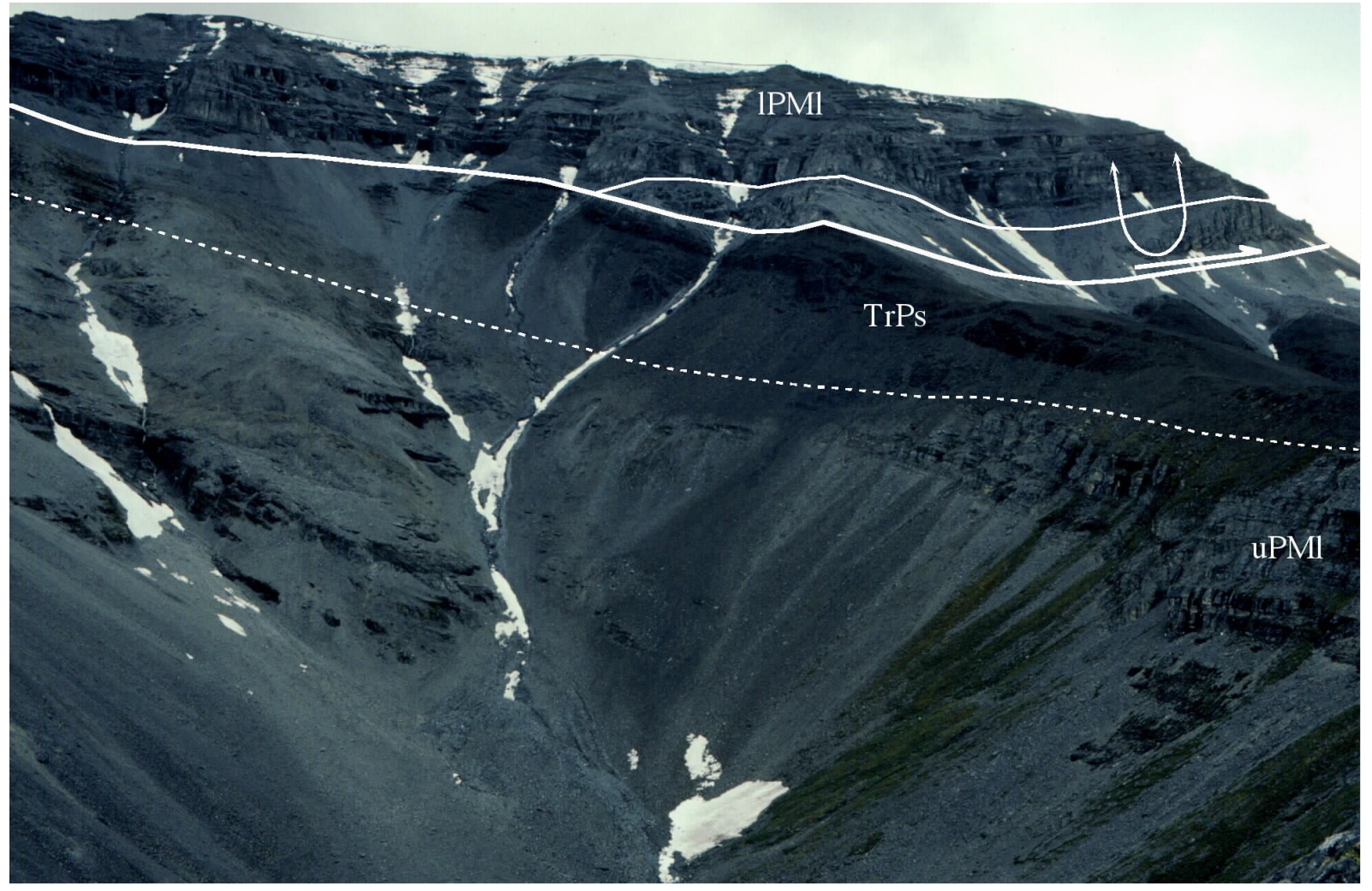

Figure 14h. Tight, angular hangingwall anticline of thrust-truncated asymmetrical anticlinesyncline pair. South of eastern Franklin Creek, view to southeast. 


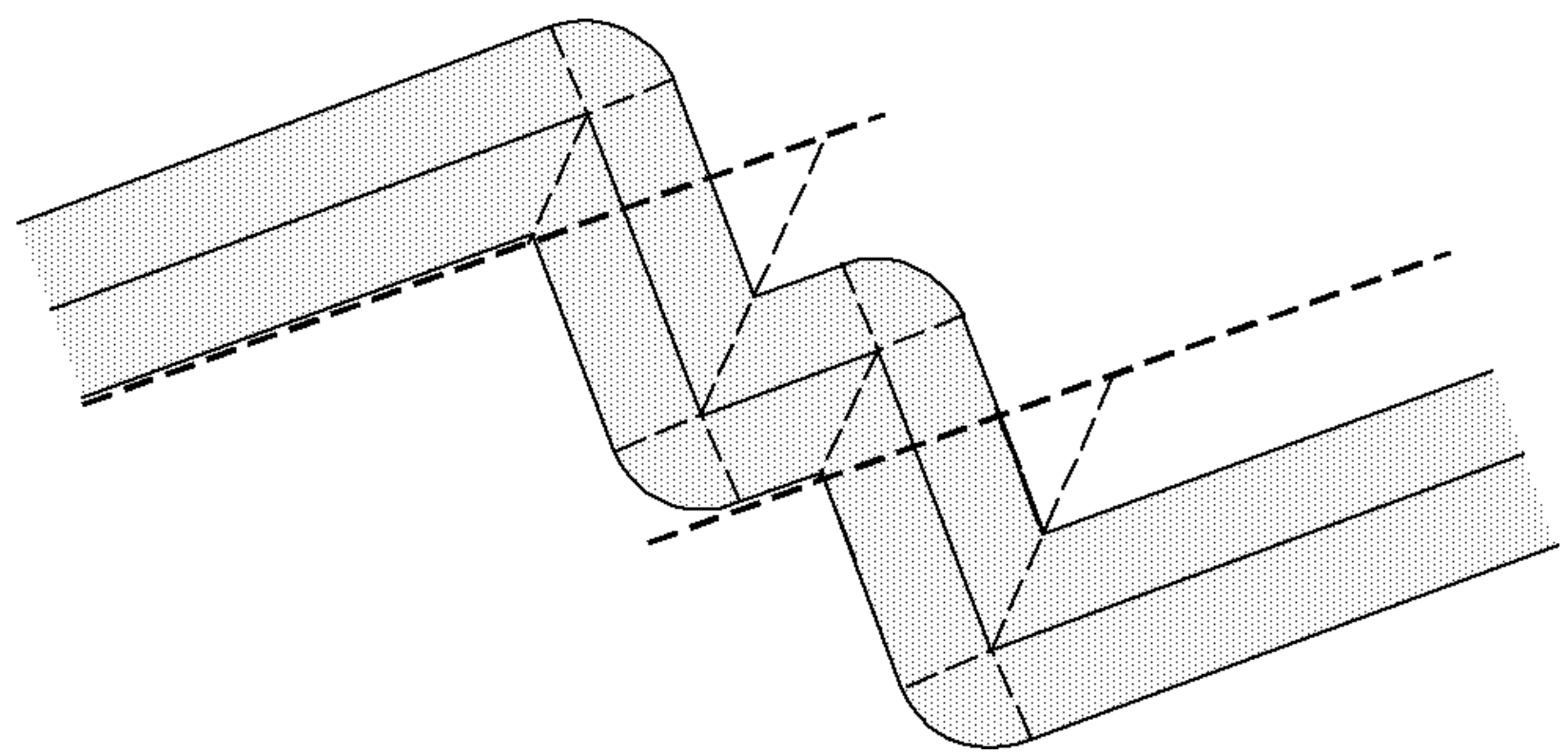

Figure 15. Idealized asymmetrical fold geometry as observed in the Porcupine Lake area. Backlimbs of anticlines (to south) are long and straight, whereas forelimbs (to north) are commonly thickened by parasitic folds, typically a single syncline-anticline pair. Angular hinge zones widen outward into the outer arcs of folds between diverging axial surfaces with branch points typically located in the middle Lisburne. Bold dashed lines mark the typical location of thrust faults that break through the forelimbs. 
A
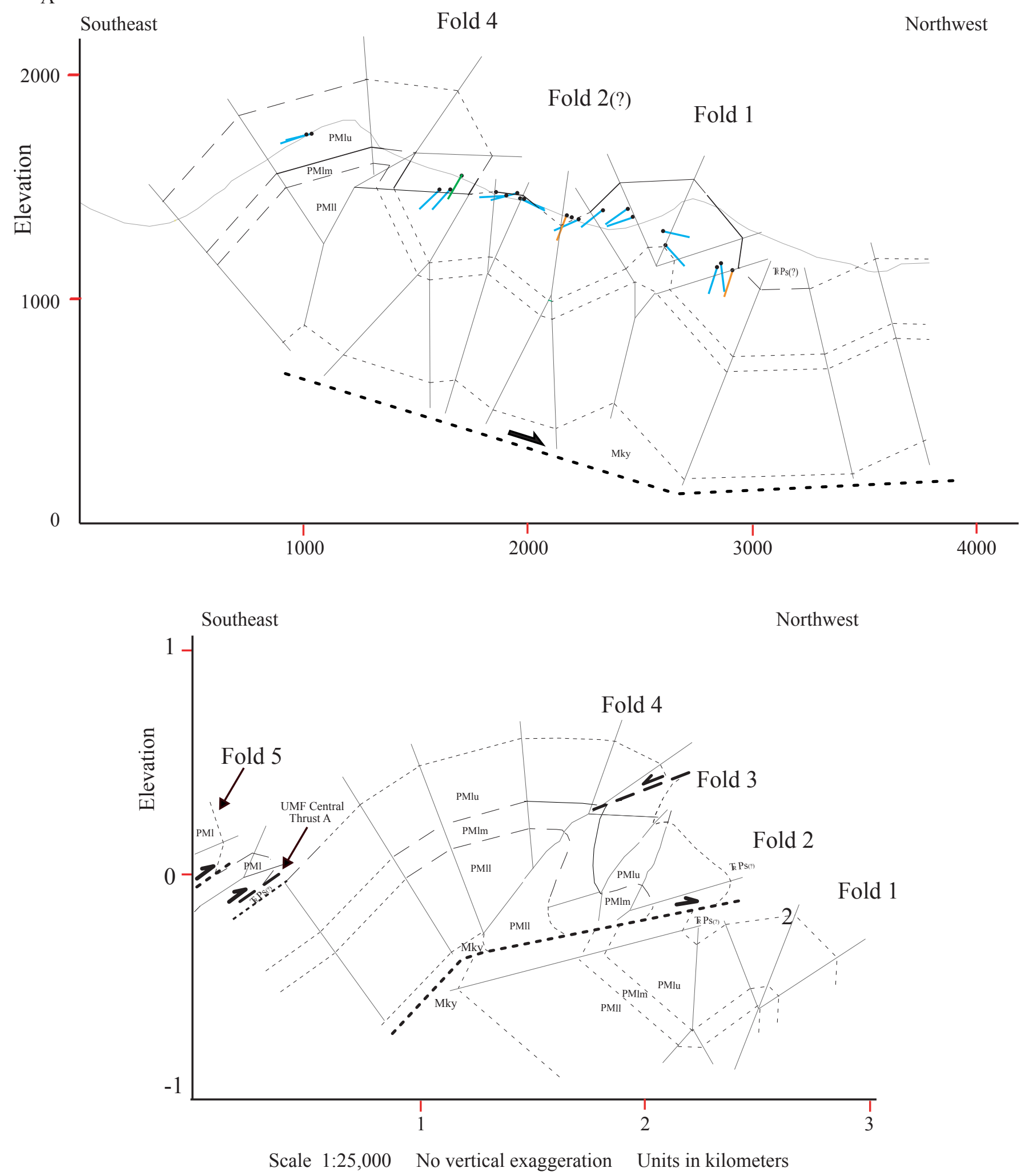

Figure 16. (Continued on next page) 
$\mathrm{C}$

Southeast

Northwest

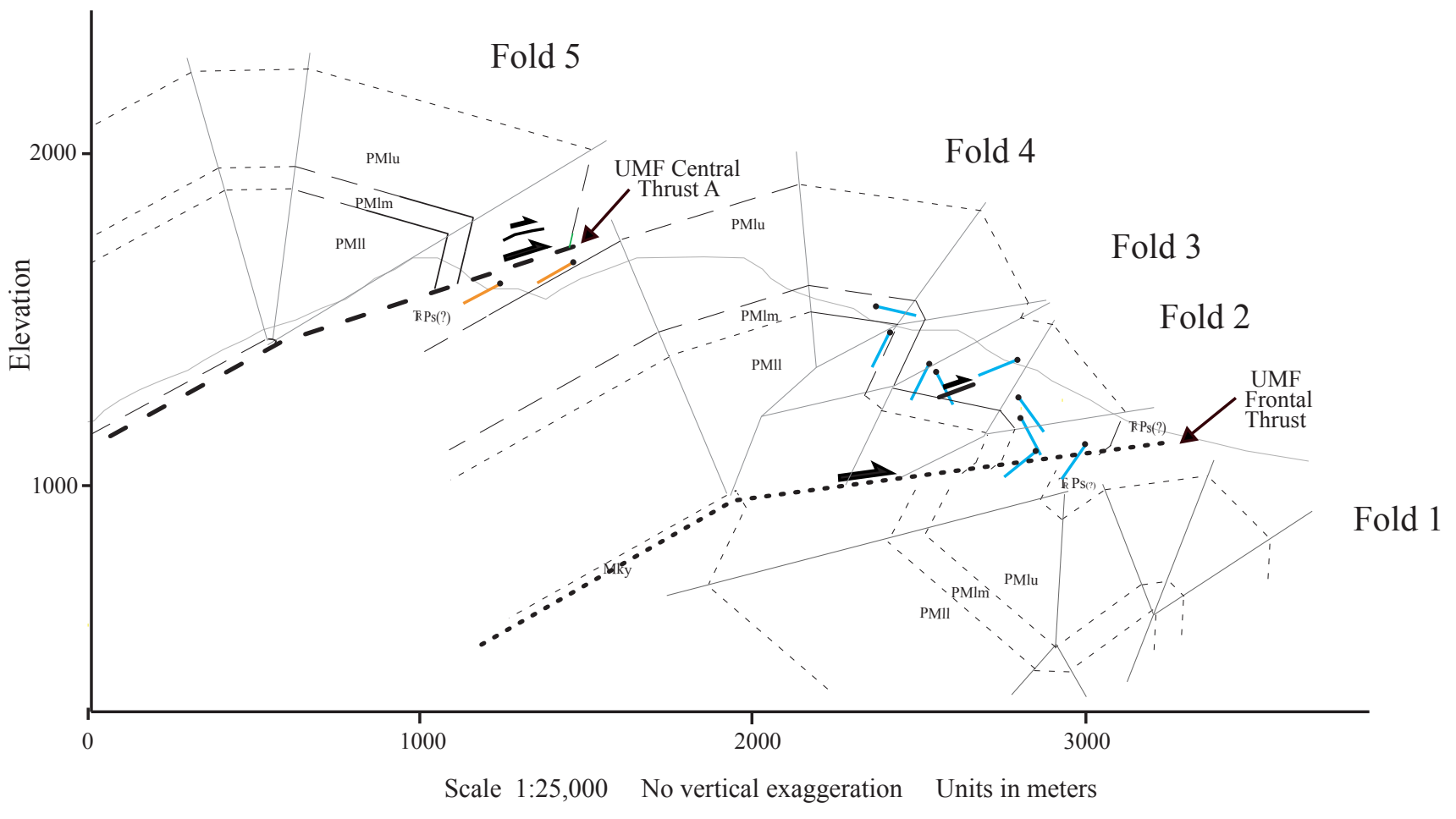

Observed features; faults in bold $\quad \ldots \ldots \ldots-$ Inferred features; faults in bold

Interpretive features; faults in bold

Figure 16. Serial cross sections south of Porcupine Lake show change along strike from apparently unbroken detachment folds (section A, to west) to thrust-truncated asymmetrical folds (sections B and C, to east). Figure modified from Jadamec, 2003. 


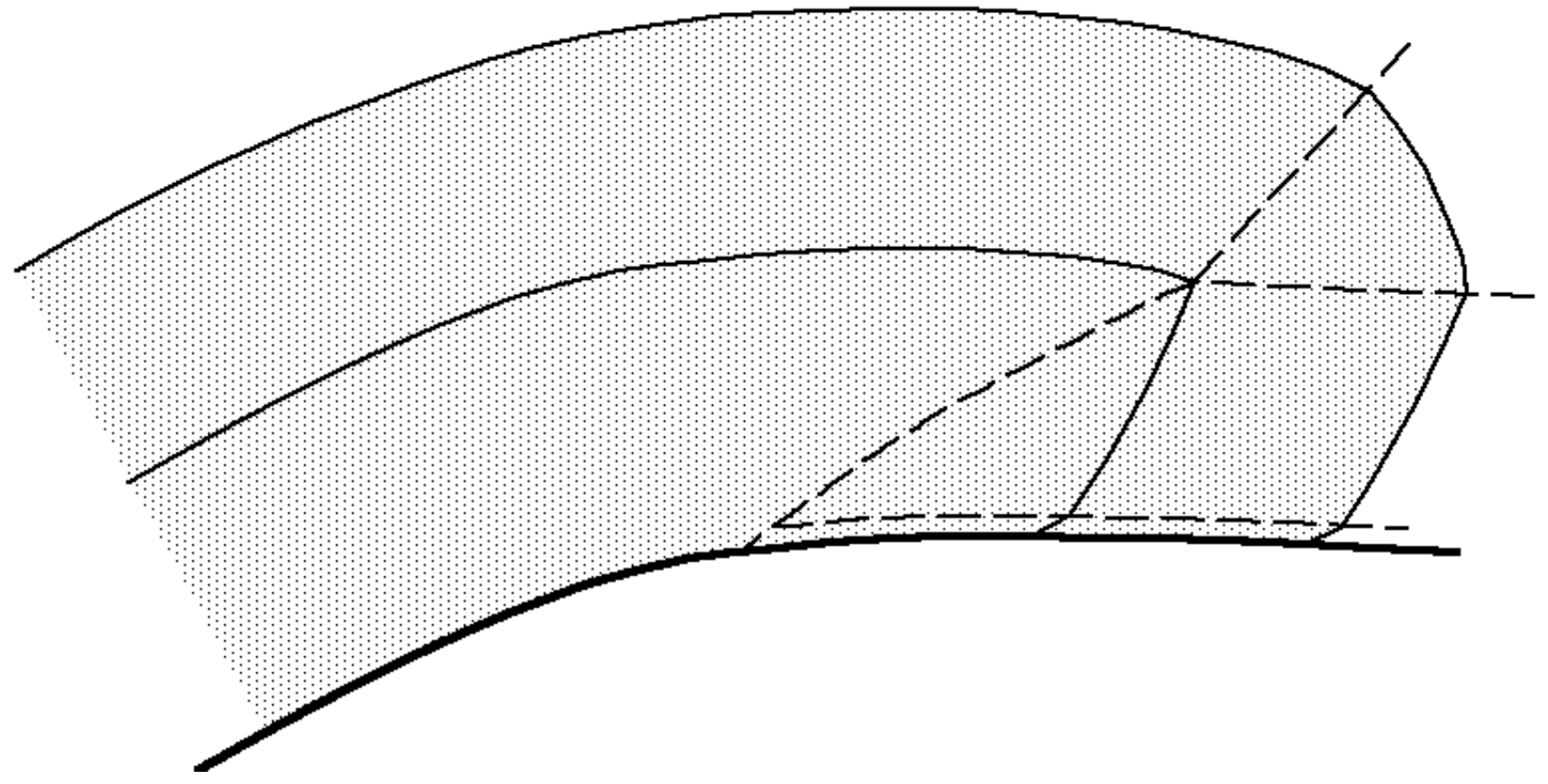

Figure 17. Idealized geometry of thrust-truncated asymmetrical fold as observed in the Porcupine Lake area. Anticline geometry as illustrated in Figure 12 is modified by displacement on a thrust fault that follows a flat in the backlimb and cuts across the forelimb at a high angle. Bedding in the forelimb is typically rotated in the sense of thrust displacement in a panel immediately above the thrust. The thrust and overlying anticline are commonly gently curved above an anticline in the footwall. 

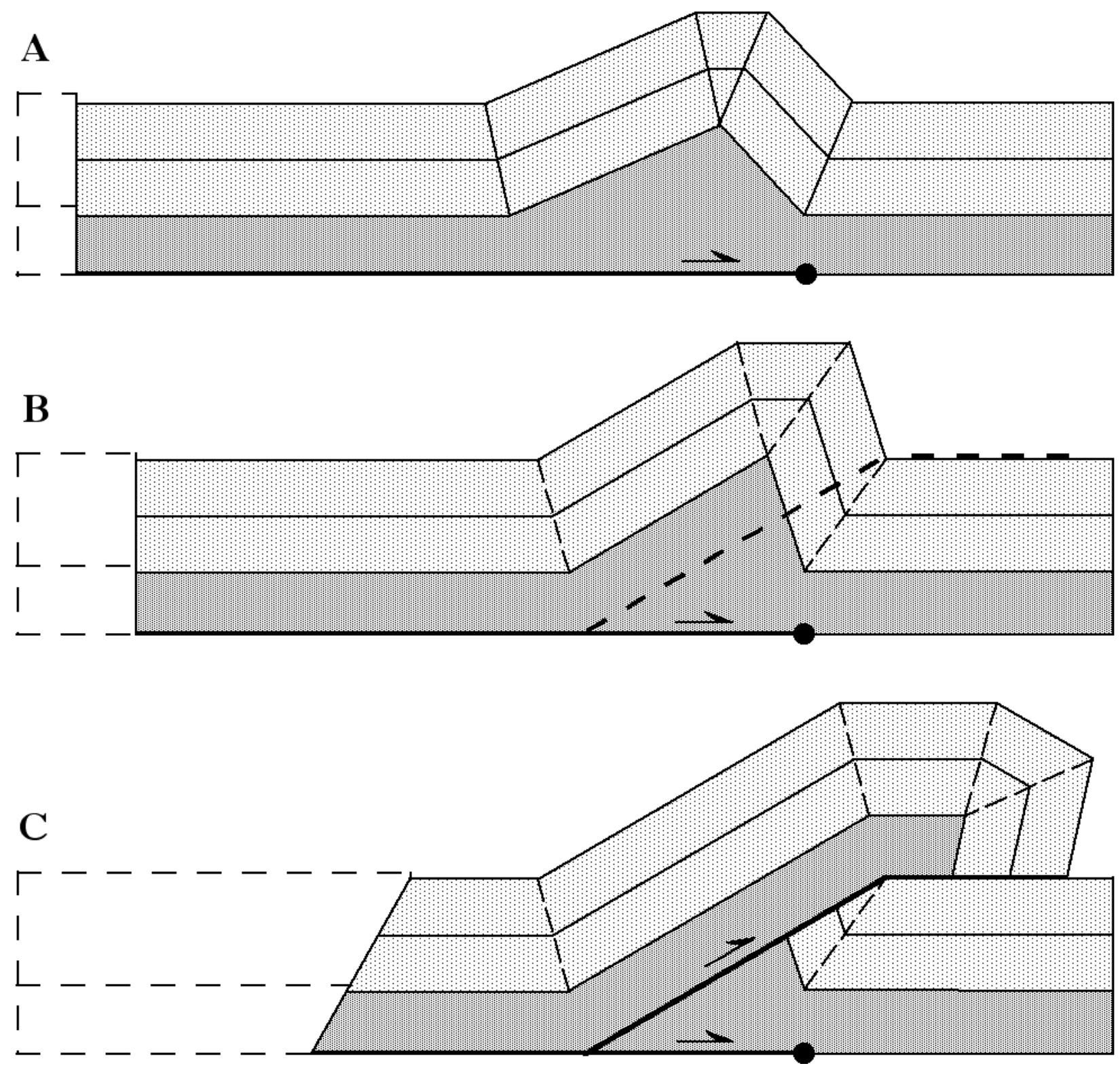

Figure 18. Kinematic evolution of a thrust-truncated detachment fold. Lower dark gray layer is incompetent, upper light gray layer is competent. (A) and (B) Evolution of a detachment fold with fixed hinges and rotating limbs. The level of the décollement was arbitrarily chosen to differ from the fixed detachment depth of the fault-propagation fold in figure 19. This is to emphasize that the depth to the décollement of a detachment fold is not uniquely determined by fold geometry if detachment depth varies during fold growth by structural thinning or thickening of the incompetent layer. (C) Modification of the fold in (B) by truncation and displacement along the trajectory shown by the dashed line. Simple rotation of the hangingwall ramp over the footwall ramp-to-upper-flat transition results in the layer-parallel shear gradient shown. The trajectory of the breakthrough in the backlimb of (B) is at the same stratigraphic level as the lower flat so that a planar backlimb forms in $(\mathrm{C})$. Figure modified from Wallace and Homza (in press). 

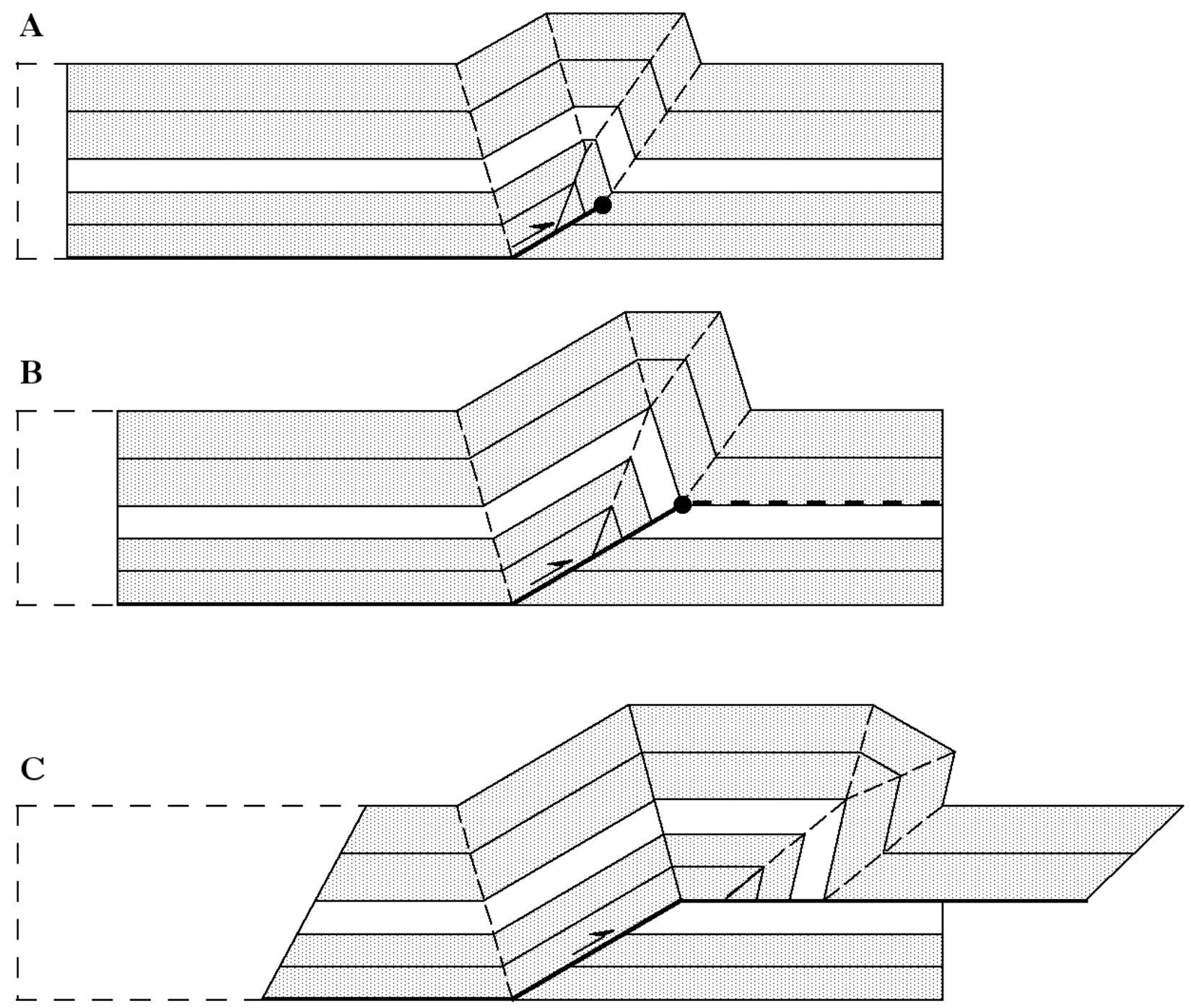

Figure 19. Kinematic evolution of a thrust-truncated fault-propagation fold. White layer is a marker that has no mechanical significance. (A) and (B) Evolution of a fold formed by propagation of a ramp tip according to the model of Suppe and Medwedeff (1990). Note that a unique depth to the lower flat is determined by the fold geometry. (C) Modification of the fold in (B) by truncation and displacement along the trajectory shown by dashed lines. Breakthrough is from the ramp tip to an upper flat, thereby destroying the ramp tip. Simple rotation of the hangingwall ramp over the footwall ramp-to-upper-flat transition results in the layer-parallel shear gradient shown. Figure modified from Wallace and Homza (in press). 
A.
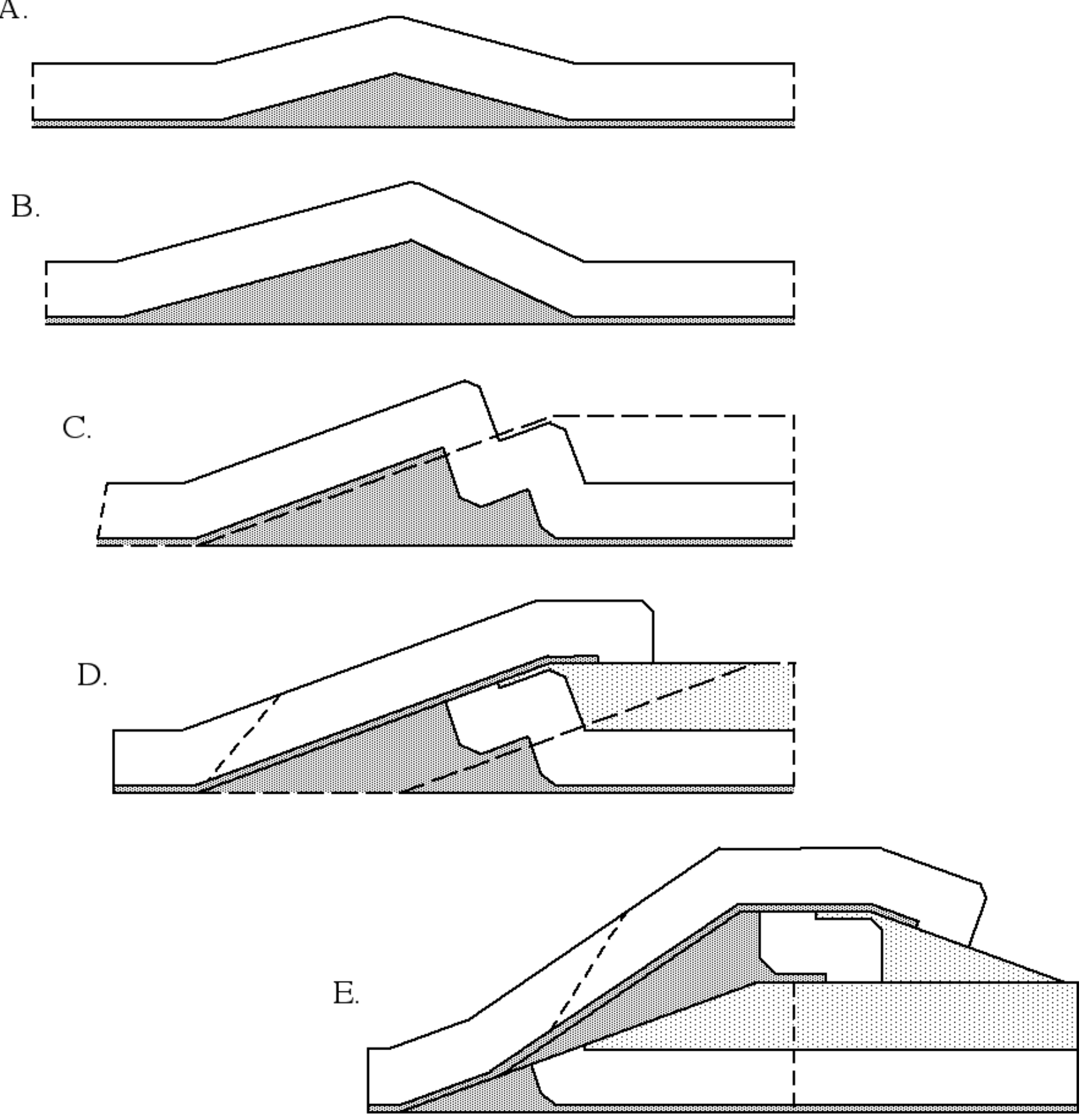

Figure 20. Evolution of a thrust-truncated asymmetrical fold. (A) and (B) Two different possible origins of the fold as a detachment fold. (A) is originally symmetrical and (B) is originally asymmetrical. (C) Forelimb is shortened by parasitic folding, which requires migration of the hinge of the trailing syncline. (D) Superposition of fault-bend fold on existing fold by breakthrough of forelimb and displacement over ramp. (E) Folding of thrust due to thrust-related deformation in footwall. Short dashed lines are markers whose position is shown in $(\mathrm{C})$ to $(\mathrm{E})$ : trailing-edge marker is deformed (loose line); leading-edge marker is fixed (pin line). Long dashed lines show position of thrust breakthrough in succeeding step. 


\begin{tabular}{|l|l|}
\hline Limb dip & $30^{\circ} \mathrm{U}-90^{\circ}$, rarely to $45^{\circ} \mathrm{OT}$ \\
\hline Interlimb angle & $0^{\circ}-125^{\circ}$ \\
\hline Axial surface dip, single hinge & $80^{\circ}-90^{\circ}$ \\
\hline Axial surface dip, double hinge (box fold) & $50^{\circ}-70^{\circ}$ \\
\hline Aspect ratio (height/width) & $0.3-1.5$ \\
\hline Limb length (top of Lisburne) & $250-3000 \mathrm{~m}$ \\
\hline
\end{tabular}

Table 1. Characteristics of detachment folds of the northeastern Brooks Range.

\begin{tabular}{|l|l|l|l|l|}
\hline & Anticline, cut & Anticline, uncut & Syncline, cut & Syncline, uncut \\
\hline Forelimb dip & $75^{\circ} \mathrm{OT}-20^{\circ} \mathrm{OT}$ & $65^{\circ} \mathrm{U}-75^{\circ} \mathrm{OT}$ & $20^{\circ} \mathrm{U}-50^{\circ} \mathrm{U}$ & $20^{\circ} \mathrm{U}-60^{\circ} \mathrm{U}$ \\
\hline Backlimb dip & $5^{\circ} \mathrm{U}-35^{\circ} \mathrm{U}$ & $35^{\circ} \mathrm{U}-70^{\circ} \mathrm{U}$ & $60^{\circ} \mathrm{U}-75^{\circ} \mathrm{U}$ & $65^{\circ} \mathrm{U}-85^{\circ} \mathrm{OT}$ \\
\hline Interlimb angle & $45^{\circ}-110^{\circ}$ & $35^{\circ}-90^{\circ}$ & $60^{\circ}-115^{\circ}$ & $35^{\circ}-80^{\circ}$ \\
\hline Axial surface dip & $10^{\circ}-40^{\circ}$ & $65^{\circ}-90^{\circ}$ & $15^{\circ}-55^{\circ}$ & $65^{\circ}-80^{\circ}$ \\
\hline Forelimb length & $50-400 \mathrm{~m}$ & $150-300 \mathrm{~m}$ & $200-300 \mathrm{~m}$ & $300-900 \mathrm{~m}$ \\
\hline Backlimb length & $200-110 \mathrm{~m}$ & $200-550 \mathrm{~m}$ & $250-400 \mathrm{~m}$ & $150-300 \mathrm{~m}$ \\
\hline
\end{tabular}

Table 2. Characteristics of asymmetrical folds of the Porcupine Lake area, central-eastern Brooks Range. 


\title{
IMPLICATIONS OF FRACTURE DISTRIBUTION AND CHARACTER IN DETACHMENT FOLDS IN THE LISBURNE GROUP OF NORTHEASTERN ALASKA
}

\section{C.L. Hanks ${ }^{1}$, J.R. Shackleton ${ }^{2}$, J. Brinton ${ }^{3}$, J. Jensen ${ }^{4}$, T. Bui ${ }^{4}$, A. Karpov ${ }^{4}$, T. Parris ${ }^{5}$ and J. Lorenz ${ }^{6}$}

\begin{abstract}
In detachment-folded Lisburne Group carbonates of the northeastern Brooks Range, fractures formed at different times in the evolution of individual detachment folds, providing clues to the mechanism of folding and the conditions under which the fold formed. Rocks in advance of the visible thrust front experienced low magnitude differential stresses of the same orientation as experienced in the fold-and-thrust belt, resulting in orogen-perpendicular extension fractures in undeformed rocks of the foredeep basin. These rocks were later incorporated into the thrust belt, where they were thrust-faulted and folded. The distribution of fractures and other mesoscopic structures in individual folds suggests that folding occurred by both flexural slip and homogeneous flattening. Flexural slip and associated fracturing occurred early in the development of the fold and/or in the outer arc of the fold. These early fractures may be overprinted and/or destroyed by ductile strain as later homogeneous flattening accommodated additional shortening. The penetrative strain is in turn overprinted by late extension fractures, which probably formed during the waning phases of folding and/or unroofing of the orogenic wedge.
\end{abstract}

The distribution and character of open fractures at any particular stage of the

\footnotetext{
${ }^{1}$ Geophysical Institute, University of Alaska Fairbanks, Alaska

2 present address: Department of Geosciences, University of Massachusetts, Amherst, Massachusetts

${ }^{3}$ Dept. of Geology and Geophysics, University of Alaska Fairbanks, Alaska

${ }^{4}$ Dept. of Petroleum Engineering, Texas A\&M University, Texas

${ }^{5}$ Petro-Fluid Solutions, Loveland, Colorado

${ }^{6}$ Sandia National Lab, Albuquerque, New Mexico
} 
evolution of the fold-and-thrust belt has significant implications for fluid flow into reservoirs active at that time. Subsequent fluid flow out of those same reservoirs (including production) may be governed by an entirely different set of open fractures. However, fracture spacing and character are controlled by a variety of complex factors, including lithostratigraphy, mechanical stratigraphy, and structural position. Because of this, simple univariant statistical techniques do not adequately predict fracture distribution in detachment folds. Neural network analysis has some potential for addressing this issue, but further study needs to be done.

\section{Introduction}

It has long been assumed that the fractures observed associated with folded rocks in a fold-and-thrust belt are directly related to the formation of those folds (e.g., Stearns and Friedman, 1972; Cosgrove, 2000). The orientation of shear and extension fractures is interpreted as related to the orientation of stresses during folding. (e.g., Stearns and Friedman, 1972; Cosgrove, 2000). Fracture characteristics, such as height and spacing, are interpreted to be related to structural position and the amount of bed curvature (e.g. Jamison, 1997).

However, pervasive fracturing is not limited to deformed rocks. Regional extension fractures are also observed in flat-lying rocks. These extension fractures are interpreted as forming either at depth under low differential stresses and high pore fluid pressure (e.g. Lorenz and others, 1991) or at near surface conditions as a result of uplift and erosion and subsequent removal of lithostatic load (e.g. Hancock and Engelder, 1989).

This study suggests that fracturing occurs repeatedly during the evolution of a fold-andthrust belt. In detachment folded Lisburne Group carbonates of the northeastern Brooks Range (Fig. 1), fractures predate folding, are apparently related to folding, and postdate peak folding. This has important implications for the migration of hydrocarbons and the evolution of reservoirs and traps in a fold-and-thrust. In this report, we will summarize some of the key observations on the fracture character and distribution in the Lisburne Group, and the implications for fold development and fracture prediction. The report is divided into two sections: I. Conditions and timing of fracture formation and the implications for regional and local structural implications and II. Controls on fracture spacing. 


\section{Background}

\section{Detachment folds}

A detachment fold is a fold that develops in a competent layer above a bedding-parallel thrust fault in an underlying incompetent layer (Jamison, 1997). Several conceptual models for the evolution of detachment folds have been proposed, all of which have implications as to the process by which folding takes place (e.g., figure $2 \mathrm{~A}-\mathrm{C}$ ). These models are discussed in detail in chapter $\mathrm{C}$ of this report (Wallace and others, this report).

Geometrically, the detachment folds of the northeastern Brooks Range appear to be most accurately described by a 'hybrid' model that combines various aspects of earlier models (Wallace and others, this report). This model differs from previous models in that it assumes that both detachment depth in the incompetent layer and bed length and thickness within the competent layer may vary during folding. Thus, this model is consistent with a fold that forms by a combination of flexural slip and homogeneous flattening in the competent unit. However, the relative timing of flexural slip vs. homogeneous flattening in fold formation is not constrained by the purely geometric model. This can be partially addressed by documentation of the distribution and timing of fractures and other mesoscopic structures related to formation of actual detachment folds and relating them to fold mechanisms that may be active during folding.

\section{Fold mechanisms: Flexural Flow, Flexural Slip and Homogeneous Flattening}

Three different fold mechanisms may be active at various times and at various scales during the formation of detachment folds in the Lisburne Group carbonates.

Both flexural slip and flexural flow are important mechanisms in the formation of parallel folds in layered rocks (Figure 3 A \& B; Ramsay and Huber, 1987; Tanner, 1989). In both mechanisms, folding is accommodated by displacement parallel to bedding and bed thickness does not change. Flexural slip folding (Figure 3 A) occurs where such 
displacement occurs at discrete and discontinuous intervals, commonly at a lithologic discontinuity, such as a bedding surface. Evidence of slip on such surfaces includes quartz-fiber veins or sheets, slickenlines, and/or displaced markers (such as root structures, burrows and crosscutting veins). Overlying and underlying beds may show macroscopic and microscopic evidence of tangential longitudinal strain, with extension in the outer arc and compression in the inner arc (Figure $3 \mathrm{~A}$ ). In contrast, flexural flow folding occurs where layer-parallel displacement is distributed continuously throughout a volume of rock, typically in an incompetent rock type such as a shale (Figure $3 \mathrm{~B}$ ). This results in shear strain being distributed more-or-less evenly throughout the rocks, with no obvious strain gradient perpendicular to bedding. However, bed thickness is still maintained. Tangential longitudinal strain in competent beds could still occur (Figure 3 B).

Folding via flexural slip and flexural flow can only proceed so far before the folds 'lock up' and are unable to accommodate additional shortening (Tanner, 1989; Yang and Gray, 1994; Twiss and Moores, 1992). After this point, additional shortening can be accommodated by homogeneous flattening of the existing fold. During homogeneous flattening, bed thickness is not maintained. Material flows from the limbs into the hinge area, resulting in thinned beds in the limbs and thickened beds in the hinge area. This process allows additional shortening and fold amplification (Twiss and Moores, 1992). Evidence that the fold has undergone homogeneous flattening includes bed thickening in the hinges and thinning in the limbs. Homogeneous flattening is commonly accomplished by penetrative strain.

\section{Controls on fracture spacing}

\section{Lithostratigraphy \& mechanical stratigraphy}

A distinction between lithostratigraphy and mechanical stratigraphy is important when considering the structural response of a package of rocks. 'Lithostratigraphy' refers to the lithology of the rocks, the order in which those lithologies are organized and the 
bed/unit thicknesses of the lithologic layers. In contrast, the term "mechanical stratigraphy" or "mechanical layering" has been used to describe the way in which a given package of lithologically heterogeneous rocks responds to deformation (Narr and Suppe, 1991; Erickson, 1996). A description of mechanical stratigraphy usually takes into account 1) the rheology of each lithologic unit and how rheology changes during deformation, 2) the relative thicknesses and nature of interfaces between rock layers, 3) boundary conditions on the stratigraphic section, and 4) the scale of the deformed layers (Ramsay and Huber, 1987). Fracturing is one particular mechanical or rheological response of the stratigraphy to deformation.

Understanding both the lithostratigraphy and the mechanical stratigraphy of a package of rocks is important for studies of fracture density since laboratory experiments as well as field research have shown that there is a general relationship between fracture spacing, lithology, and bed thickness. In its simplest form, higher densities of fractures tend to occur in finer grained lithologies and/or in thinner beds (Ladeira and Price, 1981; Hancock and Engelder, 1989; Narr and Suppe, 1991; Hanks and others, 1997).

Major differences in lithology other than grain-size may or may not lead to differences in fracture density. As a result, lithology alone is not an adequate predictor of fracture density. The relationship of adjacent lithologies also plays an important role. For example, a major difference between lithostratigraphy and mechanical stratigraphy is the nature of bedding. Lithologic layers and/or bedding that are identified in a stratigraphic column may or may not act as independent mechanical layers. When looking at fracture density, this distinction becomes important because the nature of interfaces between layers plays an important role in fracture propagation. In many cases, stratigraphic beds are not "seen" by fractures if the contacts between beds are not significant mechanical contacts. Well bonded contacts commonly do not serve as mechanical contacts, whereas mudstone layers, slip surfaces, and other lithologies that offer significant lithologic contrast to the surrounding more competent rock commonly act as significant mechanical boundaries (Narr and Suppe, 1991; Cooke and others, 2000; Underwood and others, 2003). Differential slip and friction along bedding or mechanical contacts can 
concentrate stresses that favor fracturing, such that bed contacts that are free to slip generally have significantly more associated fractures (Narr and Suppe, 1991; Cooke and others, 2000).

If bedding contacts don't always act as mechanical contacts, the mechanical unit thickness will not coincide with bed thickness. Since fracture spacing is controlled (at least in part) by the thickness of the unit (Ladeira and Price, 1981), identification of the functional mechanical unit is critical for understanding and predicting fracture spacing.

\section{Structural position}

The majority of conceptual models for fracturing related to folding are based on the idea of tangential longitudinal strain within a homogenous layer (Stearns, 1968; Price and Cosgrove, 1990). Tangential longitudinal strain occurs when a layer of a given thickness is flexed, producing layer parallel compression on the inner arc and layer parallel extension on the outer arc of the fold (figure 3). Extensional and compressional domains are bounded by a neutral surface that may migrate toward the core of a fold as stress is relieved and/or thickness changes within a given bed (or mechanical package) (Price and Cosgrove, 1990).

Hinge zones are areas of increased curvature that localize tangential longitudinal strain, and likely favor the formation of fractures and other strain indicators (Homza and Wallace, 1997; Salvini and Storti, 2000). It has been suggested that fracture density increases with increasing curvature, due to increased tangential longitudinal strain.

The migration of hinges, or the passage of strata through a synclinal or anticlinal hinge, is a requirement of many detachment fold, fault propagation fold, and fault bend fold models (Suppe, 1983; Suppe and Medwedeff, 1990; Mitra, 1990; Erslev, 1991; Zehnder and Allmendinger, 2000; Salvini and Storti, 2000). Since hinge migration and flexural slip are both important processes in many folded rocks, the final fracture sets at any given structural position in a fold may reflect a variety of stress states related to shear and bed-parallel slip prior to folding, and tangential longitudinal strain in fold hinges and/or flexural slip during folding (figure 4). Thus different geometric and kinematic models for detachment folding, fault propagation folding, and fault bend folding imply a 
variety of different strain patterns during folding, and therefore would result in different fracture patterns and densities.

\section{Methodology}

This study focussed on detachment folds involving the Lisburne Group of the northeastern Brooks Range (figures 5, 6 and 7). Eighteen folds of wavelengths, amplitudes interlimb angle were studied at various levels of detail, but all with an emphasis on the distribution, character and relative age of fractures and other mesoscopic structures. The field data and results of individual studies are summarized in previous project reports to DOE (e.g, Hanks and others, 2000, 2003), two Masters Theses (Brinton, 2002; Shackleton, 2003), numerous abstracts, and a referreed publication (Hanks and others, 2004)

This fracture data was used to develop fluid flow models in deformed and undeformed Lisburne. The results of these analyses have been incorporated into this and prior DOE reports (all the Jensen chapters), a M.S. thesis (Karpov, 2001), a Ph.D. dissertation nearing completion (Bui, in prep), a referreed publication (Bui and others, 2003), and numerous abstracts.

\section{Part I: Conditions \& timing of fracture formation-observations and interpretation}

\section{$\underline{\text { Summary of field observations }}$}

Fractures and other mesoscopic structures preserved in the Lisburne Group fall into three broad age categories--pre-folding, syn-folding and post-folding (Table 1). Fractures are described here with respect to their apparent 3D geometric morphology (ie., extensional, en échelon fractures, shear fractures). Sets of fractures were identified based on common characteristics, such as (in order of importance) age relationships to other fractures and structures, orientation, presence or absence of fill, apparent type of fracture (extensional 
vs. shear), and vertical extent. (See Hanks and others, in press, 2001 \& 2003 for detailed descriptions of fractures and other mesoscopic structures.)

A variety of both brittle and ductile mesoscopic structures are present in detachmentfolded Lisburne carbonates (Table 1, this study; Hanks et al., 1997; Homza and Wallace, 1997; Atkinson, 2001; Atkinson and Wallace, 2003). A period of ductile deformation that coincides with peak folding provides a key constraint on the relative ages of the fractures.

\section{Thermal constraints}

Thermometric analysis of fluid inclusions in fracture cements can provide information about the temperature, pressure, and fluid composition conditions of cement formation (e.g. Kisch and Van Den Kerkhof, 1991; Evans and Battles, 1999). Thermometric measurements made in this study include: (1) homogenization temperature of aqueous two-phase inclusions, which is a measure of the temperature of cement formation; (2) final ice melting temperature of aqueous two-phase inclusions, which is a measure of bulk salinity; and (3) homogenization temperature of single-phase gas-rich inclusions, which can be used qualitatively assess gas composition. Measurements were made on inclusions trapped during (i.e. primary and pseudosecondary) and after crystal growth (i.e. secondary). For more details of the systematics of inclusion measurements and their interpretation the reader is referred to Roedder (1984) and Goldstein and Reynolds (1994). In addition, all samples were analyzed for oil inclusions using ultraviolet light as outlined by Burruss (1991). No oil inclusions were found.

Fluid inclusion data generated to date are from fracture sets 2 and 3, and are summarized in Table 2. Fracture set 1 was also cemented, but was often overprinted and/or reactivated by set 4 and thus difficult to identify reliably in the field. For more detailed description of fluid inclusion results, see Hanks and others, 2003.

\section{$\underline{\text { Discussion }}$}

Implications of ductile vs. brittle structures for folding mechanism 
The observed sequence of ductile and brittle structures and their relationship to the fold geometry suggest that folding was accommodated by both flexural slip and homogeneous flattening. However, flexural slip and homogeneous flattening probably occurred under different deformational conditions, and thus happened sequentially, not concurrently, during fold development.

Homogeneous flattening increased in importance as a folding mechanism as shortening increased. While the penetrative strain that results from homogeneous flattening is relatively rare in open detachment folds, the amount of strained carbonate in the hinges of the observed detachment folds increases as the axial angles of the folds decrease. In the hinges of folds of moderate axial angle $\left(\sim 90-125^{\circ}\right)$, individual beds commonly exhibit dissolution cleavage, strained crinoids and/or strained stylolites. In the hinges of tight folds (axial angles $<90^{\circ}$ ) the strain is often extreme, with significant transposition of layering and thickening. It should be noted that any preexisting brittle structures that formed prior to or early in the folding process would be destroyed or significantly modified during this period of homogeneous flattening and penetrative strain.

Brittle structures developed both before and after bulk thickening by penetrative strain in the detachment fold hinges. The prefolding, vertically extensive, orogen-perpendicular extension fractures seen in the Sadlerochit Mts. and North Slope subsurface are probably related to in situ horizontal stresses in the foreland of the fold-and-thrust belt (Hanks and others, 1997; Lorenz and others, 1991). However, few demonstrably pre-fold extension fractures of this set were seen in the detachment folds studied. This is not surprising, in that it is not likely that such fractures survived subsequent ductile deformation in the core of the detachment folds, at least not as unfilled planar fractures.

However, several different sets of fractures are visible in the detachment folds that are probably related to or postdate folding. These fractures vary in character from en echelon tension gashes in fold limbs to extension fractures parallel to the axial plane that terminate at bedding planes to vertically extensive extension fractures that are perpendicular to the fold axes. All appear to have a geometric relationship to the folds. 
In a few cases, fractures in the fold limbs appear to predate penetrative strain; however, almost all brittle structures in the hinge overprint the penetrative strain.

The systematic overprinting of ductile and semi-ductile structures by fractures of different origins and types suggest that deformational conditions varied systematically, and possibly predictably. In all the observed folds where high amounts of strain were accommodated by ductile processes, penetrative strain in the hinges is overprinted by strike-parallel and/or strike-perpendicular conjugate and extension fractures. The consistency of this timing relationship suggests that folding by homogeneous flattening dominated during the intermediate phase of growth on these high-strain folds, with flexural slip folding dominating during the waning phases of folding. Evidence of early flexural slip is preserved in the limbs of the folds, where early fractures are subsequently deformed by penetrative strain.

\section{General deformation conditions - structural constraints}

Whether folding was dominated by penetrative strain or flexural slip at any given point in the growth of the fold probably depended upon a variety of factors. These factors include pressure, temperature, strain rate, amount of total shortening (i.e., fold interlimb angle), the thickness of the competent unit, and the relative thickness of competent vs. incompetent units.

Experimental data indicates that rocks generally deform brittlely at surface or near surface pressure and temperature (Griggs and Handin, 1960; Twiss and Moores, 1992). However, the ductility of the rock increases with increasing temperature and confining pressure and decreasing strain rate. Thus, under geologically reasonable conditions, a rock will deform ductilely in upper parts of the crust if the strain rate is sufficiently low, and/or temperature is sufficiently high and/or confining pressure is sufficiently high. An increase in strain rate and/or decrease in temperature or confining pressure could result in brittle deformation of the same rock. 
Using these general concepts, a conceptual model of potential deformation paths as a function of depth (i.e., pressure and temperature) and cumulative shortening explains the various sequence of structures seen in the detachment folds of the northeastern Brooks Range (Figure 8). In this model, different folds may exhibit different types and sequences of structures depending upon the depth at which deformation occurred and the amount of cummulative shortening the fold accommodated. Rocks folded at shallow levels and/or at low amounts of shortening would be expected to develop primarily brittle structures (A); folds that are formed at greater depths and/or accommodated greater amounts of shortening are more likely to exhibit penetrative structures (B).

This conceptual model illustrates how one fold can experience both ductile and brittle deformation as shortening progresses and/or depth varies during folding. If the in situ stress regimes are similar at different times during deformation, the resulting mesoscopic structures may look very similar. This would explain why extension fractures that form late during folding or even after folding can superficially resemble extension fractures that formed prior to or early during folding.

\section{$\underline{\text { Sequence of fracture formation: Pressure-Temperature-Time-Deformation Path }}$}

The relative age of the four different fracture sets, temperature information from fluid inclusions in the fracture-fills and existing regional uplift ages are used to construct a burial-deformation history for the Lisburne Group in the Fourth Range area (Figure 9).

\section{Pre-60 Mybp}

Burial of the Lisburne Group during the late Paleozoic and early Mesozoic was predominantly related to subsidence along a south facing (present coordinates) passive continental margin. Approximately 1300 meters of Late Paleozoic, Triassic and Jurassic sediments were deposited on top of the Lisburne Group during this time. Initiation and growth of the main axis of the Brooks Range south of this location during late Jurassic/Early Cretaceous time resulted in approximately 4000 meters of southerlyderived Cretaceous clastic sediments being deposited in the foreland basin in the future location of the northeastern Brooks Range (Bird, 1999). 
Burial of the Lisburne Group and overlying sediments in the foreland basin was accompanied by heating, compaction and dewatering. Structural and thermal modeling by Cole et al. (1999) suggests that the Lisburne Group and overlying source rocks in the Shublik Formation were probably at 4-6 km depth at this time and well within the oil generation window (assuming a $25^{\circ} \mathrm{C}$ paleogeothermal gradient). The earliest fractures probably formed at this time (Figure 9), in response to low differential stresses and high fluid pressures in the growing foreland basin. These fractures formed perpendicular to the thrust front to the south and would have been open at considerable depths, possibly forming good migration pathways for the hydrocarbons being generated.

\section{Ma regional deformational event}

Regional apatite and zircon fission track data, and ${ }^{40} \mathrm{Ar} /{ }^{39} \mathrm{Ar}$ data suggest that a major uplift event occurred in the northeastern Brooks Range at 60 mybp (O’Sullivan and others, 1995; Peapples and others, 1997). This uplift can be interpreted to reflect development of the regional pre-Mississippian cored anticlinoria in the northeastern Brooks Range. It is not clear how much deformation of the passive roof of this regional duplex (Lisburne Group and younger rocks) occurred at this time. It is likely that some detachment folding of the cover rocks began during this initial deformational episode, probably accompanied by fracturing related to flexural slip folding (Figure 9). Fluid inclusion data from set 2 fracture cements suggest that this folding and associated fracturing occurred at fairly high temperatures $\left(200^{\circ}-225^{\circ} \mathrm{C}\right)$.

However, deformation of the Lisburne Group at this time was probably not accompanied by local uplift. Conodont alteration indices indicate that these rocks experienced temperatures as high as $\sim 280^{\circ} \mathrm{C}$, probably accompanied by penetrative deformation in fold cores. This increase in paleotemperature reflects continued burial of the rocks and/or an increase in the geothermal gradient. Progressive burial was probably facilitated by the combination of continued deposition of Brookian clastic rocks and deformational thickening of the foreland basin, with structural depression of the lower parts of the deformational wedge. With an assumed geothermal gradient of $25^{\circ} \mathrm{C} / \mathrm{km}$, Ellesmerian sequence rocks would have been heated to temperatures exceeding those for oil generation $\left(\sim 100^{\circ}-150^{\circ} \mathrm{C}\right)$ and would have reached temperatures for dry gas generation (Bird et al., 1999). 


\section{Early Tertiary deformation and uplift}

Contractional deformational in the northeastern Brooks Range continued episodically into the Tertiary, with three different regional events recorded by apatite fission track analysis (45, 35 \& 25 mybp; e.g., O’Sullivan and others, 1995). This deformation tightened individual folds and thickened the overall tectonic wedge. In the Fourth Range, the Lisburne Group initially experienced an increase in temperature, probably reflecting an increase in structural burial as deformation intensified (path A, Figure 9). Peak folding occurred under temperature and pressure conditions that facilitated penetrative strain-- $280^{\circ} \mathrm{C}$ as suggested by the conodont alteration indices (Johnsson et al., 1992).

Subsequent tightening of the folds and uplift resulted in late-folding to post-folding fractures of set 3 . Cements in these fractures suggest that the fractures formed and filled at temperatures significantly lower that those experienced during peak folding $\left(\sim 153^{\circ} \mathrm{C}\right.$ vs $280^{\circ} \mathrm{C}$; Figure 9 , path A).

However, these deformational events may not have affected all areas or all parts of the stratigraphic column equally. Different burial and uplift paths are possible depending upon the regional structural setting and/or the stratigraphic position of the sample (paths A, B \& C, Figure 9). Rocks low in the stratigraphic section and/or located in a major synclinorium (such as the Lisburne Group in the Fourth Range) could see continual burial and temperature increase during these Cenozoic events (path A, Figure 9). Higher parts of the stratigraphic section in the same location may have experienced a flatter burial curve and never experienced the highest temperatures (path B, Figure 9). Rocks located on the crests of anticlinoria may have only experienced uplift and an overall reduction of temperatures during these deformation episodes (path C, Figure 9).

At this point there are no constraints on the depth and temperature of formation of the north-south striking, post-fold fractures (set 4, Table 2). These fractures are unfilled and appear quite young. They could have formed at 3-5 km depth in response to the low differential stresses in the upper part of the deformational wedge, if pore fluid pressures were sufficiently high. Alternatively, they could have formed very near to the surface due to uplift and removal of overburden. The first hypothesis is preferred, as bore hole breakouts in wells near the thrust front suggest that in situ stresses become highly variable near the surface (Hanks and others, 2000) 


\section{Part II: Controls on fracture spacing-observations and interpretation}

Fracture spacing and lithostratigraphy/mechanical stratigraphy

Previous work on fracture density in undeformed Lisburne Group carbonates suggests that there is a definite correlation between fracture density and lithology, with finer grained mudstones having a greater fracture density than other carbonate lithologies (Hanks and others, 1997). However, the same study indicated there was no clear relationship between bed thickness and fracture density.

The results from our studies show that in detachment folded Lisburne Group, there is not a simple relationship between fracture density and either carbonate lithology or bed thickness. Figure 10 show a variety of simple, univariant plots of fracture density and various lithologic features as observed across ten different detachment folds. The only lithologic element that appears to have any relationship to fracture density is overall lithology (Figure 10). In this plot, wackestones show the smallest fracture spacing (greatest fracture density), followed by packstones and grainstones. Carbonate mudstones show the greatest average spacing between fractures (lowest fracture density). Other approaches, including fracture spacing vs. average grain size and matrix type, showed no obvious correlation (Figure 10)

These observations suggest that fracture spacing is controlled at least in part by lithotype, but not necessarily by grain size or matrix type. The initial observations do not agree with those made by Hanks and others (1997) on relatively undeformed examples of the same rocks. This disagreement suggests that some other factor comes into play in these folded rocks that affects fracture density, such as degree of sorting, dolomite content, structural position or degree of deformation.

In addition to an ambiguous relationship between fracture density and lithology, there is also not a simple relationship between lithologic bed thickness and fracture density in folded Lisburne Group carbonates (Figure 10). This contradicts other studies where there is a clear relationship between fracture density and bed thickness (McQuillan, 1973; 
Ladeira and Price, 1981; Hanks and others, 1997), especially in beds $<1$ meter thick. This contradiction suggests that either other factors, such as folding and lithology, are influencing fracture spacing, or what is being identified as 'bedding' does not coincide with 'mechanical layering.'

Several stratigraphic sections in the same structural position (fold limb) were studied in an effort to identify which of these multiple stratigraphic and lithologic factors could be linked to increased fracture density (Shackleton, 2003). An example of one of these sections is illustrated in Figure 11. Note that in this approach, it is possible to at least visually evaluate the effect of stratigraphic packaging and the presence of slip horizons on fracture density. Even using this approach, however, there is still not an unambiguous relationship between any single lithostratigraphic element and fracture density.

Shackleton used formulaic models in an attempt to evaluate the effect of multiple factors on fracture density. Input variables for the stratigraphic models consisted of carbonate lithology, bed thickness, and chert content, assuming that each variable has an effect on fracture density. Three different models were developed that used the same formula, but varies in the treatment of the lithology variable. The mathematical basis of the three models is summarized in Table 3.

The three predictive models agree with the observed data in a gross way, although each fails at different stratigraphic intervals in different stratigraphic sections (e.g. Figure 12). Models 1 and 2 fit the overall trends in the data fairly well and offer a relatively "conservative" prediction of fracture density. Where Models 1 and 2 fail is in their prediction of some of the larger individual peaks in the section. Model 3 highlights some of these individual peaks in the section, suggesting that higher fracture densities at these locations may be due to changes in lithology and/or presence of chert. Model 3 commonly over-predicts fracture density and fits stratigraphic sections with more lithologic heterogeneity better than the other sections. In general, Model 1 is more accurate than Model 2, which suggests that grain size variation is a more effective 
method of predicting fracture density than grain scale heterogeneities. Model 3 provides the best prediction of fracture spacing in the section that is suspected to have undergone the most shortening, but commonly provides a poorer prediction than Models 1 and 2 in other stratigraphic sections.

However, $\mathrm{R}^{2}$ values and variance calculations for each of the models suggests that all three models are relatively ineffective at predicting fracture density in the stratigraphic sections. This relatively poor fit between the models and the data may be due to: 1 ) different relationships between the explanatory variables and fracture spacing; 2) other factors besides lithology, bed thickness, and chert (such as dolomite and the thickness of mechanical 'packages') or 3) vertical fracture swarms that are not related to mechanical stratigraphic variables.

An alternative hypothesis for the discrepancy between the data and models may lie in the grouping of all fracture sets by summing the fracture spacing measurements at each stratigraphic interval. Since fracture sets in the stratigraphic sections clearly formed during different stages in the structural history of the study area, variation in the data may be due to tectonic influence and not mechanical stratigraphic factors. Similarly, mechanical stratigraphic factors may have different influences on the spacing of each fracture set that formed under different pressure and temperature conditions or at different orientations.

These observations suggest that future studies should address the relationship between fracture density and mechanical (not lithologic) boundaries, including the thickness of mechanical units and the location of slip surfaces.

\section{Incorporating structural position}

Besides stratigraphic factors, fracture density also has been related to structural position, ie., proximity to faults, location on a fold, etc. For example, increasing fracture density has been related to increased fold curvature (e.g., Salvini and Storti, 2000). In 
detachment folded carbonates, fracture density would hypothetically be greatest in the hinge area, assuming the folds evolve with fixed hinges (e.g., Homza and Wallace, 1997). In both cases, an important assumption is that the observed fractures are related to folding. As noted in the first part of this report, that assumption may not always be valid.

Initial statistical analysis of fold interlimb angle and fracture spacing across 10 detachment folds (Figure 13) suggests that, as the folds tighten, the spacing of both the EW and NS-striking fracture sets increases by a factor of two or three and becomes slightly more variable. This behavior is opposite from that expected if the fractures were closely related to folding. It suggests that the two sets are similar to each other and are only weakly related to the folding.

However, statistical analysis did suggest that the length of these late fractures increased in tighter folds (Bui, Ch. G, this report). This suggests that whatever factor is controlling the character of late EW and NS-striking fractures does have some relationship to folding.

\section{Neural network analysis}

Univariant and bivariant statistical analysis of both stratigraphic and structural factors on fracture spacing suggested that fracture spacing could be a function of multiple factors. (e.g., Figures $11 \& 13$ ). However, it is not possible to distinguish which factors are most important by using standard statistical analysis.

Neural network analysis is a statistical technique that investigates the role multiple factors have in determining an observed result. The analysis gives each factor a weight, and then combines the weighted factors in order to predict a hypothetical outcome. Bui and others (Ch. G, this report) discuss the technique and results in detail.

Neural network analysis of fracture spacing in detachment folded Lisburne suggests that all of the previously-discussed stratigraphic and structural factors influence fracture 
density to some degree, but some factors more than others. Surprisingly, overall the stratigraphic position (i.e, Wahoo vs. Alapah) appeared to play the most important role in average fracture spacing distribution, followed by the lithology and bed thickness. The degree of folding and the structural position were the least influential parameters on average fracture spacing. However, the effect of structural position depends upon the fracture set. On the fold limbs, the average fracture spacing in the EW orientation is systematically larger than in the NS direction. In the hinge, the average fracture spacing of EW fractures is systematically smaller than the average spacing of NS fractures.

Unlike more traditional approaches, this technique allowed us to recognize and evaluate the multiple factors that could interact and result in the observed fracture density. However, our data set is a relatively small one for this type of analysis and thus is not as useful a predictive tool as we would hope. Future work should explore how to use neural networks to explore small data sets.

\section{Implications}

\section{Fracture evolution in fold-and-thrust belts}

Multiple generations of fractures and mesoscopic structures have been observed in many compressional settings and have been related to changes in in-situ stress orientations (e.g., Evans, 1994; Eyal, et al 2001), incorporation of regional fractures in local folding (e.g., Dunne, 1985; Barton, 1983; Currie and Reik, 1977) or variations in the deformation mechanism (e.g., Guermani and Pennacchioni, 1998). This study highlights how different generations of mesoscopic structures may be related to the kinematics of a specific fold-and-thrust belt, the northeastern Brooks Range. While a similar sequence of events might be expected in any fold-and-thrust belt, the specific mesoscopic structures that develop would be constrained by both the mechanical stratigraphy of the rocks involved and the conditions of deformation.

The distribution of fold-related fractures and other mesoscopic structures within 
detachment folds of the Lisburne Group suggest that these folds developed by both flexural slip and penetrative strain. Fold-related fractures did not show an marked increase in density at the fold hinges. A similar pattern was seen in Monkshood Anticline of western Canada (Jamison, 1997). Both studies suggest that fold curvature (e.g., Murray, 1968; Lisle, 1994) is not a reliable method of predicting fold-related fracture location and density in detachment folds.

The complex history of deformation and related fracturing in detachment-folded Lisburne Group carbonate rocks suggests that fracturing can occur at multiple times in a continuum with other structures as originally flat-lying rocks are progressively folded. Regional NNW-striking extension fractures are well-developed in the Lisburne Group of the Sadlerochit Mountains and in the subsurface at Prudhoe Bay (Hanks et al., 1997). These fractures probably formed parallel to the maximum horizontal in situ stress ahead of and orthogonal to the northeastern Brooks Range fold-and-thrust belt (at location a, Figure 14). These early strike-normal fractures were a brittle response to layer-parallel shortening under relatively low temperature, low differential stress, and high pore fluid pressure conditions.

As the fold-and-thrust belt advanced into the foreland, previously flat-lying Lisburne strata were buried by the advancing deformational wedge and eventually incorporated into it (e.g., location b, Figure 14). In the process, these carbonate rocks experienced increased pressure and temperature as well as higher differential stress. Subsequent detachment folding of these layered rocks was dominated initially by flexural slip, with formation of associated en échelon fractures. However, folding via ductile processes became important as folding progressed, especially in the cores of the folds. Fold flattening by ductile deformation was favored by the increasing temperature and confining pressure and decreasing fold interlimb angle. The resulting penetrative strain in the hinges during folding resulted in the development of dissolution cleavage and local transposition of layering. As shortening progressed and structural thickening increased, the zone of penetrative strain expanded, overprinting and destroying earlier fractures. 
Flexural slip folding and fracturing associated with tangential longitudinal strain in the rigid layers again became important as folding waned and temperature, confining pressure and differential stress decreased with uplift and unroofing (e.g., location c, Figure 14). Late, post-fold strike-normal extension fractures developed as a result of low differential in situ stresses in the rising deformational wedge (e.g., location d, Figure 14).

This study suggests that when evaluating folded and fractured carbonate reservoirs, it is critical to distinguish clearly between the different fracture sets and to determine when and under what conditions each set formed. Extension fractures that could act as excellent permeability conduits in undeformed rocks may be destroyed if the same rocks have been folded. However, fractures of the same orientation and character may form after folding, providing a second opportunity for enhanced permeability. In addition, the amount of folding and the conditions under which detachment folding occurred influences the amount, distribution, type and timing of fracturing related to the actual folding. Fracturing may occur early in the fold's development, thus potentially providing significant enhanced permeability. However, continued folding could lead to significant destruction of this permeability by penetrative strain, resulting in a reduction in reservoir quality.

Timing \& conditions of fracturing in the Colville basin and implications for petroleum exploration and production

In order to accumulate hydrocarbons, trap formation must precede or coincide with oil generation and migration. This is a complex process in fold-and-thrust belts, where burial and generation of hydrocarbons in any one location generally precedes deformation. Effective migration pathways out of the 'hydrocarbon kitchen' are necessary to fill distant traps and reservoirs.

The sequence of fracturing and fracture cementation with respect to folding at this one location in the northeastern Brooks Range provides important constraints on the relative timing of deformation versus burial and heating. Fracturing occurred prior to folding, during folding and after folding. 
The earliest fracture set may have formed in early Mesozoic time, coincident with early hydrocarbon generation and migration. While it is unlikely that there were any structural traps at this time, hydrocarbons might have accumulated in stratigraphic traps.

In detachment folded Lisburne Group, fracturing occurred during early folding, probably in latest Cretaceous-Early Tertiary time, at temperatures exceeding those for oil generation $\left(\sim 100^{\circ}-150^{\circ} \mathrm{C}\right)$. Thus traps in these types of structures would have post-dated local hydrocarbon generation and migration. This does not preclude hydrocarbons generated elsewhere in the basin migrating into these traps. However, the temperatures at which fractures formed were probably too high for significant hydrocarbons to be preserved. Peak folding and penetrative strain occurred at very high temperatures, probably destroying much existing porosity and permeability, including much of the fracture network.

Late fold and post-fold fractures occurred at significantly lower temperatures, but by this time the local hydrocarbon generation potential was probably exhausted. However, these deformed and fractured rocks were thrust over significantly younger rocks in the foredeep to the north, which could possibly provide a source mechanism.

\section{Influence of mechanical stratigraphy and structural position on fracture character}

Fracture density and character has a complex relationship to mechanical stratigraphy. 'Mechanical stratigraphy' incorporates a number of different lithologic characteristics (e.g., lithology, bed thickness, thickness of shale horizons). Each of these factors alone are known to influence fracture character (e.g., Ladeira and Price, 1981; Narr and Suppe, 1991). However, the Lisburne has varied carbonate lithologies, bed thickness, and complex interlayering of incompetent and competent lithologies. This study suggests that all of these factors has some influence on fracture density, with no single one factor have an overriding effect. In addition, the thickness of mechanical packages and the location of flexural slip horizons may be more of a controlling factor on fracture density than simple lithologic bed thickness.

There is not a strong statistical correlation between fracture density and structural position, suggesting that most of the obvious unfilled extension fractures are not directly related to folding. This implies that fracturing was not a major deformation mechanism in these particular detachment folds, possibly due to the elevated temperature and 
pressures present during folding. However, the length of post-folding fractures appeared statistically greater in tighter folds, suggesting some influence of folding on the fracture character.

This study also suggests that we need to develop more sophisticated statistical techniques capable of evaluating the relative importance of a number of causative factors in relatively small datasets. Neural networks may offer a potential way of addressing this issue.

\section{$\underline{\text { Conclusions }}$}

Fractures and other mesoscopic structures formed at different times during the evolution of individual detachment folds in Lisburne Group carbonates of the northeastern Brooks Range. These structures provide clues to the mechanism of folding, the conditions under which folds evolved and the paragenesis of fractures in the fold-and-thrust belt as a whole.

The earliest fractures strike NNW and probably represent orogen-normal extension fractures that developed in the foreland basin in advance of the fold-and-thrust belt. These rocks and fractures were later incorporated into the thrust belt, where they were thrust-faulted and folded. Later fractures, strained markers and dissolution cleavage developed during detachment folding as a result of flexural slip and homogeneous flattening. Fracturing associated with flexural slip occurred early in the development of folds. These early fractures were commonly overprinted or destroyed by ductile strain as later homogeneous flattening accommodated additional shortening. This episode of flattening and peak fold development occurred at relatively high temperatures $\left(>200^{\circ} \mathrm{C}\right)$. The penetrative strain was in turn overprinted by late extension fractures that formed at substantially lower depths and temperatures, probably due to either flexural slip in the waning phases of folding or unroofing of the orogenic wedge. 
Early fracturing, overprinting by ductile structures and subsequent later fracturing in detachment-folded Lisburne Group emphasizes the importance of understanding the unique character and history of each fold-and-thrust belt in a successful hydrocarbon exploration effort. In particular, the mechanical stratigraphy and conditions of deformation play an important role in the type of fold that develops, the fold mechanisms that are active and the subsequent distribution and character of fractures and other mesoscopic structures.

In the Lisburne Group, most of the obvious fractures were not directly related to folding, but post-dated peak folding. Fracture distribution and character were controlled by the mechanical stratigraphy, in particular the thickness of mechanical units (in contrast to lithologic bed thickness), the lithology of the mechanical units, and the location of slip horizons.

While our observations suggest that hydrocarbon generation predated trap formation at this location, it does not necessarily constrain the regional evolution of the petroleum system through time. Thus, hydrocarbons generated elsewhere could migrate into these rocks. Juxtaposition of these deformed rocks with less mature sediments capable of generating oil and/or gas could occur via thrusting. Alternatively, traps could be filled by lateral migration of gas from the Colville basin from the west. Collecting and integrating structural, thermal and geochronologic data from various locations throughout the North Slope, the Brooks Range and the northeastern Brooks Range fold-and-thrust belt would provide additional important clues as to the evolution of this particular petroleum system.

Standard statistical univariant analysis was inadequate for identification of the important factors controlling fracture spacing and distribution in folded Lisburne Group carbonates. Preliminary studies using neural network analysis suggest that this approach may prove capable of evaluating the effect of multiple geologic variables on fracture spacing. However, standard neural network analysis requires very large datasets, while fieldgenerated datasets are usually relatively small. Additional geostatistical work is needed to develop techniques to use neural network analysis in the analysis of small datasets. 


\section{REFERENCES}

Atkinson, P.K., 2001, A geometric analysis of detachment folds in the northeastern Brooks Range, Alaska, and a conceptual model for their kinematic evolution: Master of Science thesis, University of Alaska, Fairbanks, Alaska, 209 p.

Atkinson, P.K., and Wallace, W.K. 2003. Competent unit thickness variation in detachment folds in the northeastern Brooks Range, Alaska: geometric analysis and a conceptual model. Journal of Structural Geology, v. 25, no. 10, p. 17511771.

Barton, C.D. 1983. Systematic jointing in the Cardium Sandstone along the Bow Rivers, Alberta, Canada. PhD thesis, Yale, 302 p.

Bird, K.J., and Molenaar, C.M., 1992, The North Slope foreland basin, in Macqueen, R.W., and Leckie, D.A., eds., Foreland basins and foldbelts: American Association of Petroleum Geologists Memoir 55, p. 363-393.

Bird, K., 1999, Geographic and Geologic setting: in The Oil and Gas Resource Potential of the Arctic National Wildlife Refuge 1002 area, Alaska: USGS Open File Report 98-34, pp GG-1-GG-51.

Brinton, J., 2002. Natural Fracturing in Carbonate Rocks as a Function of Lithology and Structural Position in a Detachment Fold: Examples from the Northeastern Brooks Range, Alaska. M.S. thesis, University of Alaska, Fairbanks.

Burruss, R.C., 1991, Practical aspects of fluorescence microscopy of petroleum fluid inclusions, in, Barker, C.E., and Kopp, O.C., eds., Luminescence Microscopy and Spectroscopy: SEPM Short Course 25, 195 p.

Bui, T., Brinton, J., Karpov, A.V., Hanks, C.L., and Jensen,J. L., 2003, Evidence and Implications for Significant Late and Post-Fold Fracturing on Detachment Folds in the Lisburne Group of the Northeastern Brooks Range: SPE publication 76754.

Cole, F., Bird, K.J., Mull, C.G., Wallace, W.K., Sassi, W., Murphy, J.M., and Lee, M., 1999, A balanced cross section and kinematic and thermal model across the northeastern Brooks Range mountain front, Arctic National Wildlife Refuge, Alaska: in The Oil and Gas Potential of the 1002 Area, Arctic National Wildlife Refuge, Alaska: U.S. Geological Survey Open file Report 98-34.

Cooke, M.L., Mollema, P.N., Pollard, D.D., and Aydin, A., 2000. Interlayer slip and joint localization in the East Kaibab Monocline, Utah: field evidence and results from 
numerical modeling. In: Cosgrove, J.W., and Ameen, M.S., (Eds.), Forced folds and fractures. Geological Society of London, Special Publication 169, pp. 23-49.

Cosgrove, J.W., 2000, Forced folds and fractures: An introduction: in Cosgrove, J.W. and Ameen, M.S., Forced Folds and Fractures, Geological Society Special Publication no. 169, pp. 1-6.

Currie, J.B., and Reik, G.A. 1977. A method of distingusihing regional direcitoins of jointing and of identifying joint sets associated with individual geologic structures. Canadian Journal of Earth Science v. 14, p. 1211-1228

Decker, P.L., 1990, Structural analysis of the fault and fracture systems of the Lisburne field, North Slope, Alaska: unpublished company report, ARCO Alaska, Inc., 23 p., 6 figs.

Dunne, W.M. 1985. Mesostructural development in detached folds: an example from West Virginia. Journal of Geology, v. 94, p. 473-488

Epard, J. L., and Groshong, R. H., Jr., 1995, Kinematic model of detachment folding including limb rotation, fixed hinges and layer-parallel strain: Tectonophysics, v. 247, p. 85-103.

Erickson, S.G., 1996. Influence of mechanical stratigraphy on folding vs. faulting. Journal of Structural Geology 18, 443-450.

Erslev, E.A., 1991. Trishear fault-propagation folding. Geology 19, 617-620.

Evans,M.A. 1994. Joints and decollement zones in Middle Devonian shales: evidence for multiple deformation evnets in the central Appalachian Plateau. Geological Society of America Bulletin, volume 106, no. 4, p. 447-460.

Evans, M.A., and Battles, D.A., 1999, Fluid inclusion and stable isotope analyses of veins from the central Appalachian Valley and Ridge province: Implications for regional synorogenic hydrologic structure and fluid migration: Geological Society of America Bulletin, v. 111, p. 1841-1860.

Eyal, Y., Gross, M.R., Engelder, T., and Becker, A. 2001. Joint development during fluctuation of the regional stress field in southern Israel. Journal of Structural Geology, volume 23, no. 2-3, p. 279-296.

Goldstein, R.H., and Reynolds, T.J., 1994, Systematics of fluid inclusions in diagenetic minerals: SEPM Short Course 31, 199 p.

Grantz, A., and May, S.D., 1983, Rifting history and structural development of the continental margin north of Alaska, in Watkins, J.S., and Drake, C.L., eds., Studies in continental margin geology: AAPG Memoir 34, p. 77-100. 
Grantz, A., May, S.D., and Hart, P.E., 1990, Geology of the Arctic continental margin of Alaska, in Grantz, A., Johnson, L., and Sweeney, J.F., eds, The Arctic Ocean region: Boulder, Colorado, GSA, The Geology of North America, v. L., p. 257288.

Griggs, D.T., and Handin, J., 1960, Rock Deformation, Geological Society of America Memoir 79, $382 \mathrm{pp}$.

Guermani, A and Pennacchioni, G. 1998. Brittle precursors of plastic deformation in granite: an example from the Mont Blanc Massif (Helvitic, Western Alps). Journal of Structural Geology, volume 20, no. 2-3, p. 135-148.

Hancock, P.L. and Engelder, T. 1989. Neotectonic Joints. Geological Society of America Bulletin, vol. 101, p. 1197-1028.

Hanks, Catherine L., Brinton, J., and Lorenz, J., 2000, Fracturing in the Lisburne Group as a function of lithology and position in detachment folds: in Wallace, W.K. and others, The influence of fold and fracture development on reservoir behavior of the Lisburne Group of northern Alaska: First annual report, period May 1999 to May 2000. Report to Department of Energy, Award DE-AC26-98BC15102, p. E1-E52.

Hanks, C.L., Parker, M., and Jameson, E. 2000. Regional stress patterns of the northeastern North Slope, Alaska. Alaska Division of Geological and Geophysical Surveys' Short Notes on Alaskan Geology, 1999, p. 33-44.

Hanks, C.L., Parris, T.M. , and Wallace, W. K., 2003, Using fracture paragenesis to develop a depth/temperature/deformation time path for detachment folded Lisburne Group, Fourth Range, northeastern Alaska: in Wallace, W.K., and others, 2002, The influence of fold and fracture development on reservoir behavior of the Lisburne Group of northern Alaska: fifth semiannual report. Department of Energy, award DE-AC26-98BC15102.

Hanks ,C.L., Wallace, W.K., Atkinson, P.K., Brinton, J. , Bui, T., Jensen, J., Lorenz, J., 2004, Character, relative age and implications of fractures and other mesoscopic structures associated with detachment folds: an example from the Lisburne Group of the northeastern Brooks Range, Alaska: Bulletin of the Canadian Society of Petroleum geologists, vol. 52, no. 2 (June, 2004), p. 121-138.

Hanks, C.L., Wallace, W.K., and O’Sullivan, P., 1994, The Cenozoic structural evolution of the northeastern Brooks Range, Alaska, in Thurston, D., and Fujita, K., eds., 1992 Proceedings International Conference on Arctic Margins, U.S. Minerals Management Service Outer Continental Shelf Study 94-0040, p. 263-268. 
Hanks, C.L., Lorenz, J., Teufel, L., and Krumhardt, A.P. 1997, Lithologic and structural controls on natural fracture distribution within the Lisburne Group, northeastern Brooks Range and North Slope subsurface, Alaska: American Association of Petroleum Geologists Bulletin, vol. 81, no. 10, p. 1700-1720.

Homza, T.X., and Wallace, W.K., 1997, Detachment folds with fixed hinges and variable detachment depth, northeastern Brooks Range, Alaska: Journal of Structural Geology, v. 19, nos. 3-4 (special issue on fault-related folding), p. 337-354.

Jamison, W.R. 1997. Quantitative evaluation of fractures on Monkshood anticline, a detachment fold in the foothills of western Canada. American Association of Petroleum Geologists Bulletin, volume 81, no. 7, p. 1110-1132.

Johnsson, M.J., Pawlewicz, M., Harris, A.G., and Valin, Z.C., 1992, Vitrinite reflectance and conodont color alteration index from Alaska: U.S. Geological Survey OpenFile Report 92-409, 3 computer disks, 1 sheet.

Kisch, H.J., and Van Den Kerkhof, A.M., 1991, $\mathrm{CH}_{4}$-rich inclusions from quartz veins in the Valley and Ridge province and anthracite fields of the Pennsylvanian Appalachians: American Mineralogist, v. 76, p. 230-240.

Ladeira, F.L., and Price, N.J., 1981. Relationship between fracture spacing and bed thickness. Journal of Structural Geology 3, 179-183.

Lane, L.S., 1991, The pre-Mississippian "Neruokpuk Formation," northeastern Alaska and northwestern Yukon: review and new regional correlation: Canadian Journal of Earth Sciences, v. 28, pp. 1521-1533

Lisle, R.J. 1994. Detection of zones of abnormal strains in structures using Gaussian curvature analysis. American Association of Petroleum Geologists Bulletin, v. 78, p. 1811-1819.

Lorenz, J. C., Teufel, L. W., and Warpinski, N. R., 1991, Regional fractures 1: A mechanism for the formation of regional fractures at depth in flat-lying reservoirs: American Association of Petroleum Geologists Bulletin, v. 75, no. 11, p. 17141737,16 figs.

Mayfield, C.F., Tailleur, I.L., and Ellersieck, I., 1988, Stratigraphy, structure, and palinspastic synthesis of the western Brooks Range, northwestern Alaska: in Gryc, G. ed., Geology and Exploration of the National Petroleum Reserve in Alaska, 1974 to 1982: U.S. Geological Survey Professional Paper 1399, p. 143186.

McQuillan, H., 1973, Small-scale fracture density in Asmari Formation of southwest Iran and its relatin to bed thickness and structural setting: American Association of Petroleum Geologists Bulletin, v. 57, p. 2367-2385. 
Missman, R.A., and Jameson, J., 1991, An evolving description of a fractured carbonate reservoir: the Lisburne field, Prudhoe Bay, Alaska: in R. Sneider, W. Massell, R. Mathis, D. Loren, and P. Wichmann, editors, The Integration of Geology, Geophysics, Petrophysics and Petroleum Engineering in Reservoir Delineation, Description, and Management, AAPG-SPE-SPWLA Archie Conference, p. 204224.

Mitra, S., 1990. Fault propagation folds: geometry, kinematic evolution, and hydrocarbon traps. American Association of Petroleum Geologists Bulletin 74, 921-945.

Moore, T.E., Wallace, W.K., Bird, K.J., Karl, S.M., Mull, C.G., and Dillon, J.T., 1994, Chapter 3: Geology of northern Alaska, in Plafker, G., and Berg, H.C., eds., The geology of Alaska: The Geology of North America, Geological Society of America, Boulder, Colorado, v. G1, p. 49-140.

Mull, C.G., 1982, Tectonic evolution and structural style of the Brooks Range, Alaska: An illustrated summary, in Powers, R.B., Ed., Geologic studies of the Cordilleran thrust belt: Rocky Mountain Association of Geologists, Denver, Co., v.1, p.1-45.

Murray, G.H. Jr. 1968. Quantitative fracture study-Sanish Pool, McKenzie County, North Dakota. American Association of Petroleum Geologists Bulletin, v. 52, p. $57-65$.

Narr, W., and Suppe, J., 1991. Joint spacing in sedimentary rocks. Journal of Structural Geology 13, 1037-1048.

O’Sullivan, P.B., Hanks, C.L., Wallace, W.K., and Green, P.F., 1995, Multiple episodes of Cenozoic denudation in the northeastern Brooks Range: Fission track data from the Okpilak batholith, Alaska: Canadian Journal of Earth Sciences, v. 32, no. 8 , p. 1106-1118.

Peapples, P.R., Wallace, W.K., Hanks, C.L., O’Sullivan, P.B., and Layer, P.W., 1997, Style, controls, and timing of fold-and-thrust deformation of the Jago stock, northeastern Brooks Range, Alaska: Canadian Journal of Earth Sciences, vol. 34, p. 992-1007.

Ramsay, J.G., and Huber, M.I., , 1987, The techniques of modern structural geology, volume 2: Folds and fractures: Academic Press, 700 p.

Reiser, H.N., 1970, Northeastern Brooks Range--a surface expression of the Prudhoe Bay section, in W.L. Adkison and M.M. Brosgé, eds., Proceedings of the geological seminar on the North Slope of Alaska: AAPG Pacific Section, p. K1-K13. 
Reiser, H.N., Brosgé, W.P., Dutro, J.T., Jr., and Detterman, R.L., 1980, Geologic map of the Demarcation Point quadrangle, Alaska: U. S. Geological Survey Miscellaneous Investigations Series Map I-1133, scale 1:250,000, 1 sheet.

Roedder, E., 1984, Fluid inclusions: Mineralogical Society of America, Reviews in Mineralogy, v. 12, 646 p.

Salvini, F., and Storti, F., 2000. The distribution of deformation in parallel fault-related folds with migrating axial surfaces: comparison between fault propagation and fault bend folding. Journal of Structural Geology, 23, 25-32.

Shackleton, J.R., 2003, The relationship between fracturing, asymmetric folding, and normal faulting in the Lisburne Group Carbonates: West Porcupine Lake Valley, northeastern Brooks Range, Alaska: M.S. thesis, University of Alaska Fairbanks, Alaska, 189 p.

Stearns, D.W., 1968. Certain aspects of fracture in naturally deformed rocks. In: Riecker, R.E., (Ed.), NSF Advanced Science Seminar in Rock Mechanics. Bedford, Massachusetts, Air Force Cambridge Research Lab. Special Report, pp. 97-118.

Stearns, D. and Friedman, M. 1972. Reservoirs in fractured rock in stratigraphic oil and gas fields: Classification, exploration methods, and case histories. American Association of Petroleum Geologists Memoir 16, p. 82-106.

Suppe, J., 1983. Geometry and kinematics of fault-bend folding. American Journal of Science 283, 684-721.

Suppe, J., and Medwedeff, D.A., 1990. Geometry and kinematics of fault-propagation folding. Ecolgae Geologicae Helvetiae 83, 409-454.

Tanner, P.W.G, 1989, The flexural-slip mechanism: Journal of Structural Geology, vol. 11 , no. 6 , pp. 635-655.

Twiss, R.J, and Moores E.M., 1992, Structural Geology, Freeman, New York, 532 pp.

Underwood, C.A., Cooke, M.L., and Simo, J.A., and Muldoon, M.A., 2003. Stratigraphic Controls on Vertical Fracture Patterns in Silurian Dolomite, Northeastern Wisconsin. American Association of Petroleum Geologists Bulletin 87, 121-142.

Wallace, W.K., 1993, Detachment folds and a passive-roof duplex: Examples from the northeastern Brooks Range, Alaska, in Solie, D.N., and Tannian, F., eds., Short Notes on Alaskan Geology 1993: Alaska Division of Geological and Geophysical Surveys Geologic Report 113, p. 81-99. 
Wallace, W.K., and Hanks, C.L., 1990, Structural provinces of the northeastern Brooks Range, Arctic National Wildlife Refuge, Alaska: American Association of Petroleum Geologists Bulletin, v. 74, no. 7, p. 1100-1118.

Wallace, W.K., and Homza, T.X., in press (2000), Detachment folds vs. faultpropagation folds and their truncation by thrust faults, in McClay, K.R., editor, Thrust tectonics and petroleum systems: American Association of Petroleum Geologists Memoir.

Wallace, W.K., Moore, T.E., and Plafker, G., 1997, Multistory duplexes with forward dipping roofs, north central Brooks Range, Alaska: Journal of Geophysical Research, v. 102, no. B9 (special section on the USGS Trans-Alaska Crustal Transect), p. 20,773-20,796.

Yang, X. and Gray, D.R., 1994, Strain, cleavage and microstructure variations in sandstone: implications for stiff layer behaviour in chevron folding: Journal of Structural Geology, vol. 16, no. 10, pp. 1353-1365.

Zehnder, A.T. and Allmendinger, R.W., 2000. Velocity field for the trishear model. Journal of Structural Geology 22, 1009-1014. 


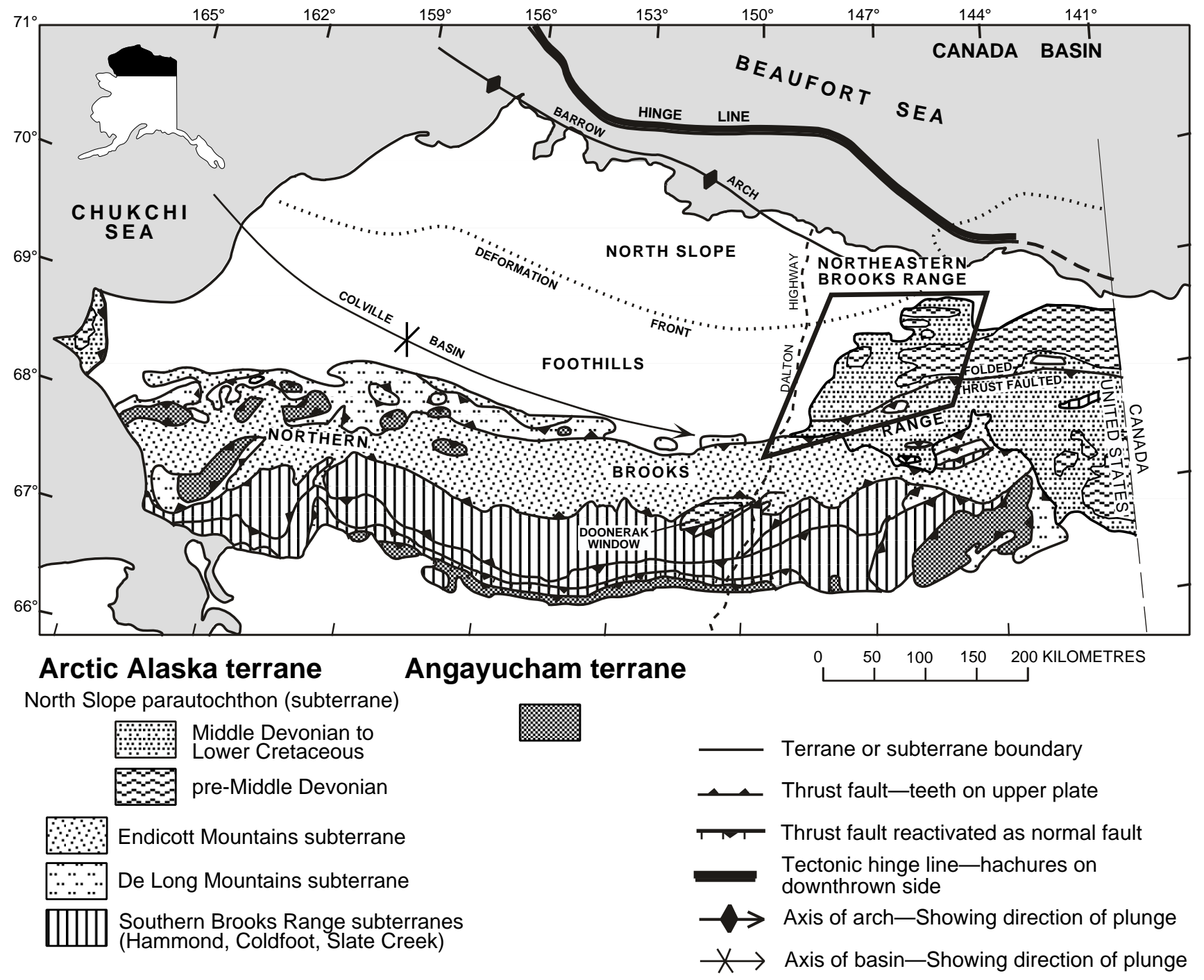

Figure 1. Tectonic map of northern Alaska, showing distribution of major structural features. Outlined area shown in Figure 5. Modified from Wallace and others, 1997. 
A. Homza \& Wallace
Model

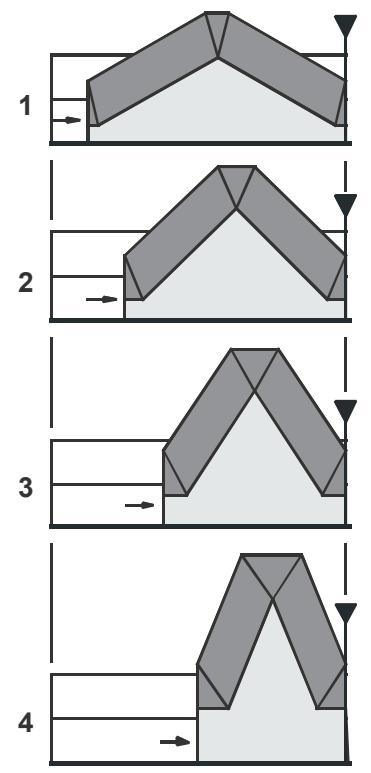

Constant thickness of competent layer

Variable depth to detachment

$\square$ incompetent
B. Epard \& Groshong Model

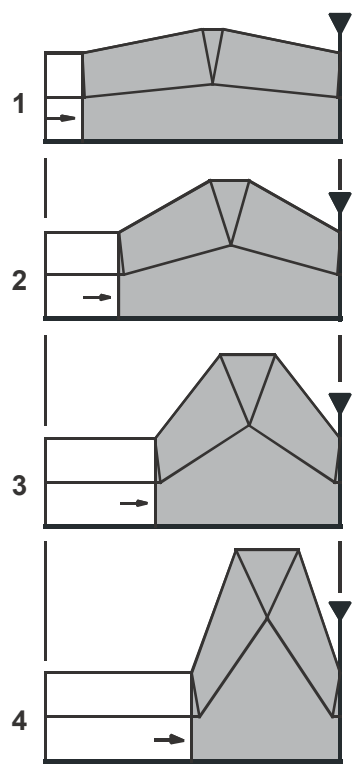

Variable thickness

Constant depth to detachment

competent

\section{Atkinson Hybrid Model}

1

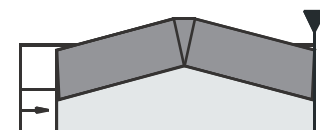

2
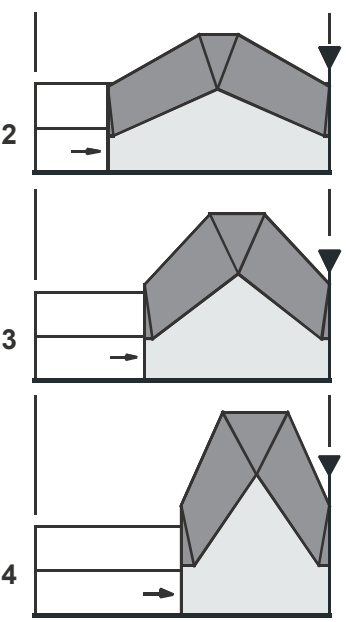

Variable thickness

Variable depth to detachment

Figure 2. Detachment fold models. A. Homza and Wallace, 1997; B.

Epard and Groshong, 1995; C. 'Hybrid' model, Atkinson, 2001. 

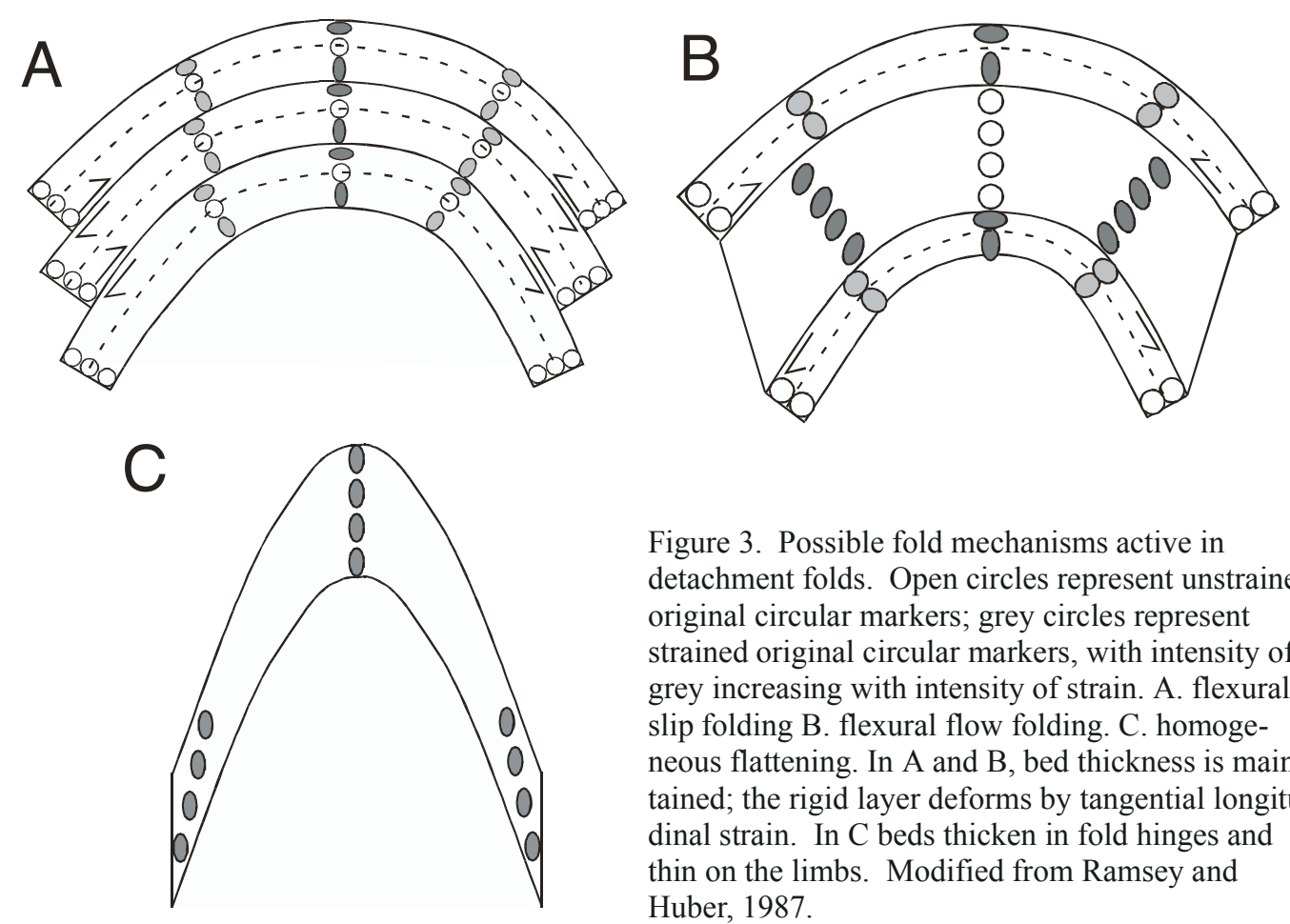

Figure 3. Possible fold mechanisms active in detachment folds. Open circles represent unstrained original circular markers; grey circles represent strained original circular markers, with intensity of grey increasing with intensity of strain. A. flexural slip folding B. flexural flow folding. C. homogeneous flattening. In A and B, bed thickness is maintained; the rigid layer deforms by tangential longitudinal strain. In $\mathrm{C}$ beds thicken in fold hinges and thin on the limbs. Modified from Ramsey and Huber, 1987. 


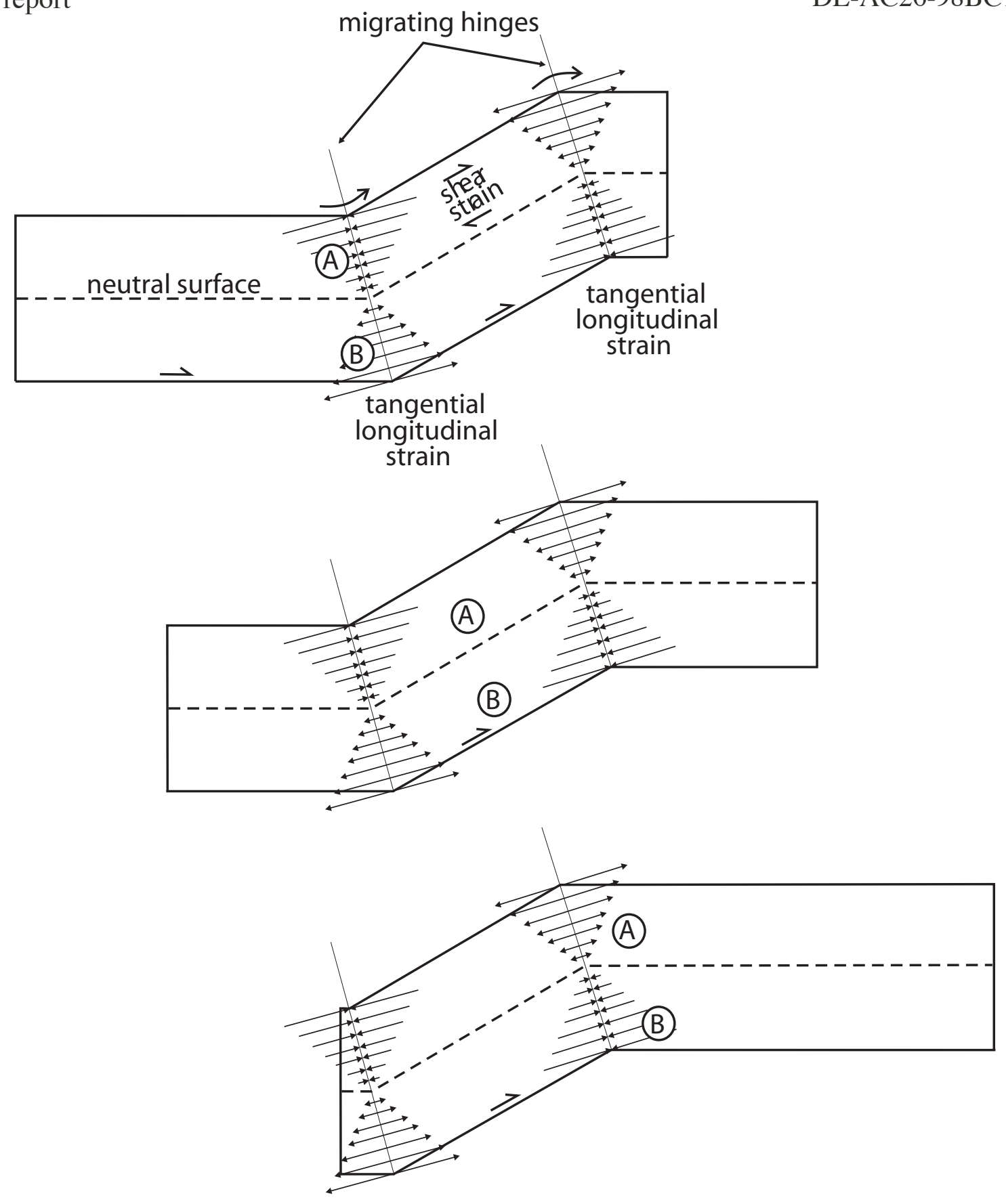

Figure 4: Example of temporal stress changes associated with migrating hinges. Arrows indicate the magnitude and direction of stresses near kink axes. Note that the polarity of tangential longitudinal strain reverses from the left hinge to the right hinge, leading to different strain histories above and below the neutral surface. For example, as the unit is displaced up and over the ramp, circle Aexperiences compressional tangential longitudinal strain first, followed by shear strain, and finally extensional tangential longitudinal strain. Conversely, circle B experiences extensional tangential longitudinal strain first, followed by shear strain, and finally compressional tangential longitudinal strain. This could apply to a single layer, or a mechanical package where shear strain could be accommodated by flexural slip between individual layers. From Shackleton, 2003. 


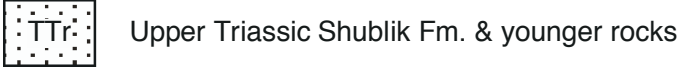

Mississippian Kayak Shale, Carboniferous Lisburne
Limestone \& Triassic Sadlerochit/Siksikpuk Limestone \& Triassic Sadlerochit/Siksikpuk

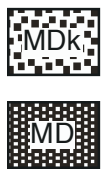

Devonian Kanayut Conglomerate \& overlying Mississippian Kayak Shale \& Carboniferous Lisburne Limestone

Middle Devonian to Mississippian clastic rocks

Q1 pre-Mississippian metasedimentary \& metavolcanic rocks \& Mississippian Kekiktuk conglomerate

EMA: Endicott Mountains allochthon 尔location of fracture studies

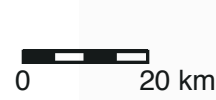

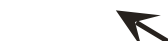

K支

Lisburne Field
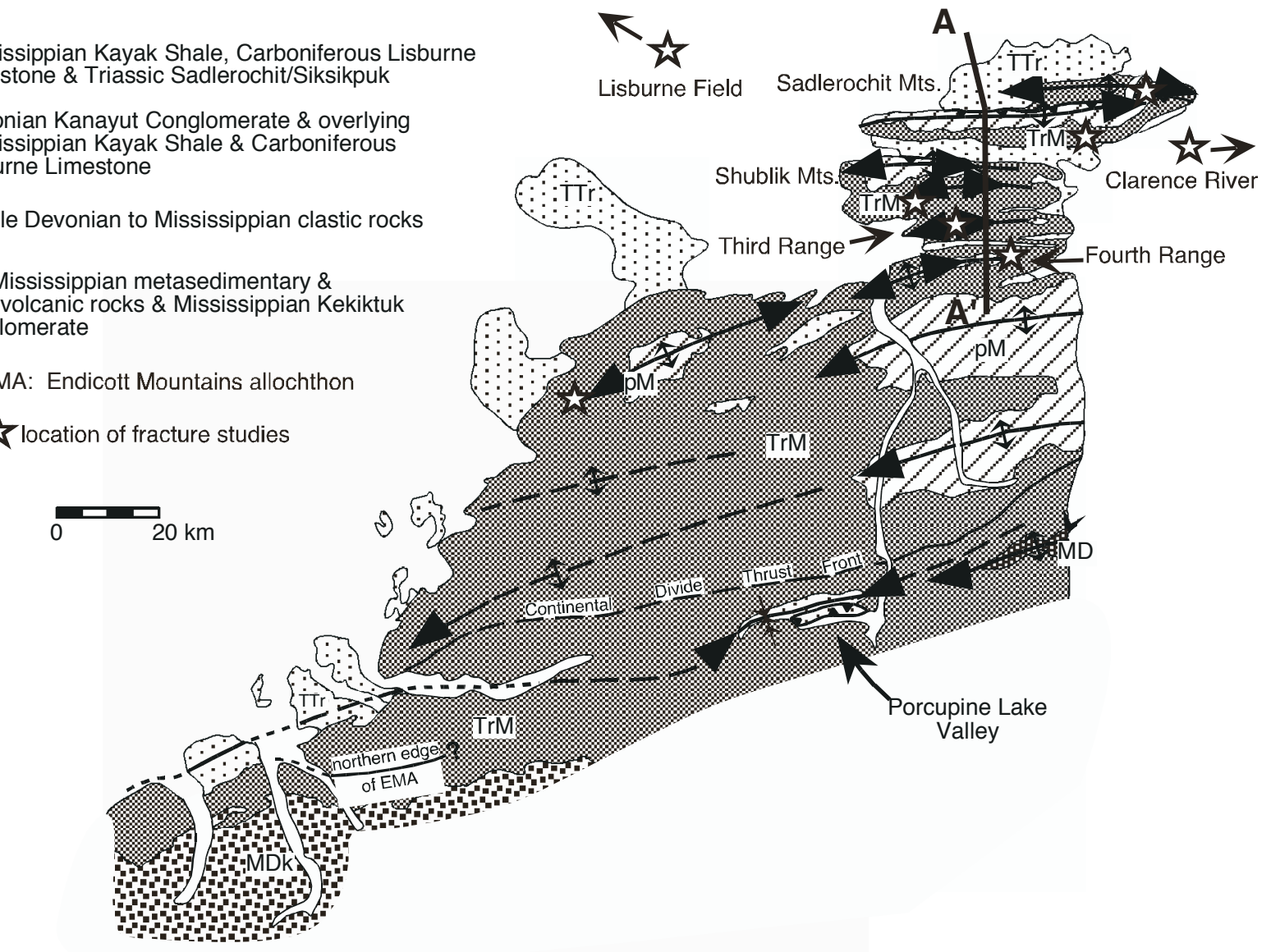

Figure 5. Tectonic map of the western part of the northeastern Brooks Range. $\square$ indicates locations where fracture data and observations have been incorporated into this paper. A$\mathrm{A}^{\prime}$ is regional section shown in Figure 6. 


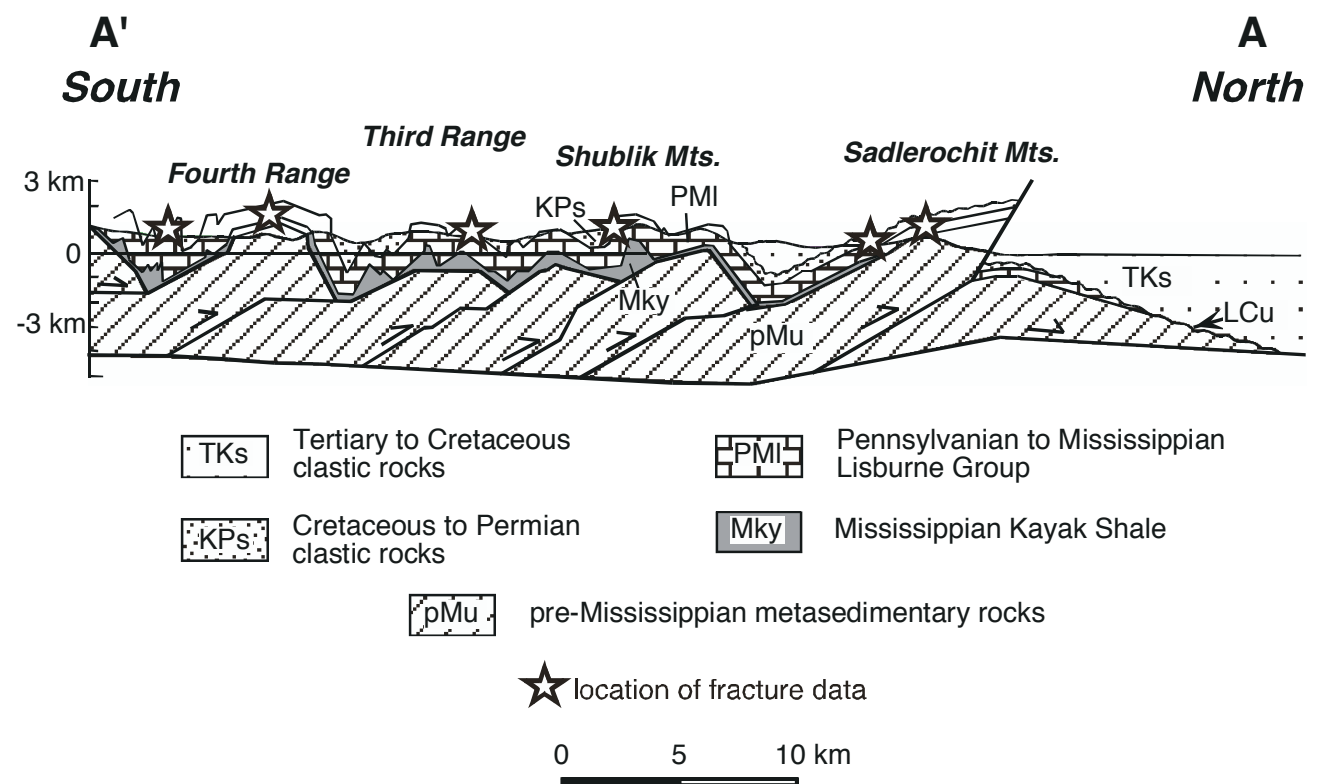

Figure 6. Regional balanced cross section across the northwestern part of the northeastern Brooks Range. Location of section line shown on Figure 5. Modified from Wallace, 1993. 


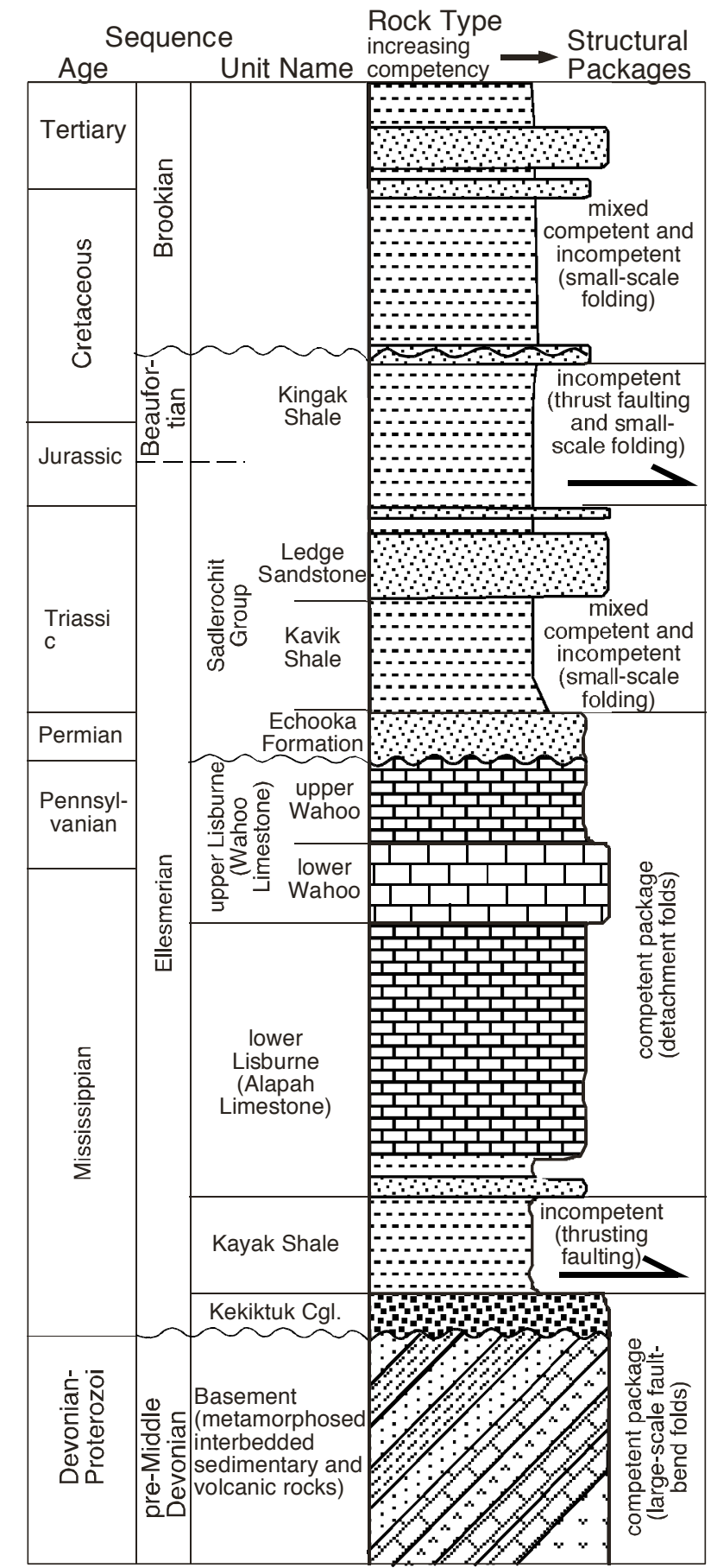

\section{3sandstone 돌orbonate ronic rocks}

\section{Exconglomerate $\mathrm{Eshale}$}

\section{major detachment horizon}

Figure 7. Generalized stratigraphy of the northeastern Brooks Range, emphasizing the mechanical stratigraphy of structural packages.

D-37 
i. orogen-perpendicular extension fractures
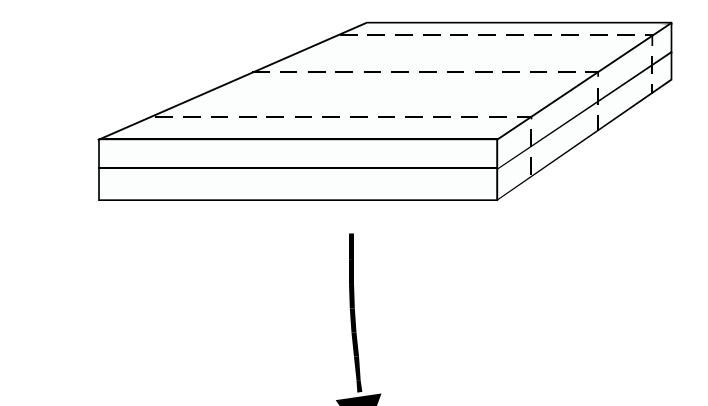

Actively-forming
fold-related fractures

Pre-existing

fold-related fractures

- Set 1 fractures

28 Penetrative strain

Pre-existing

$\mathrm{B}$ penetrative strain

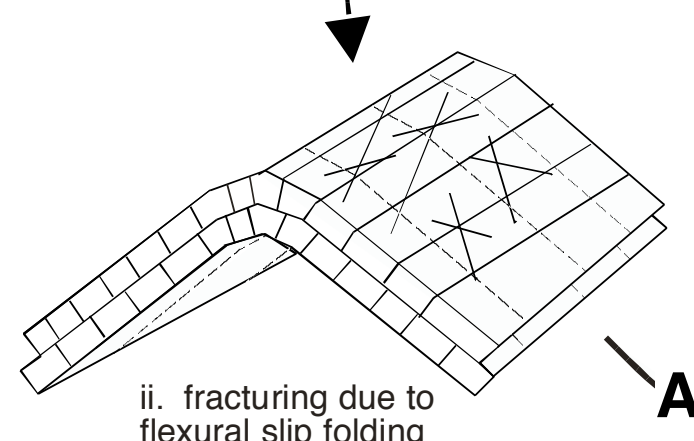

fi. fracturing due to

flexural slip folding

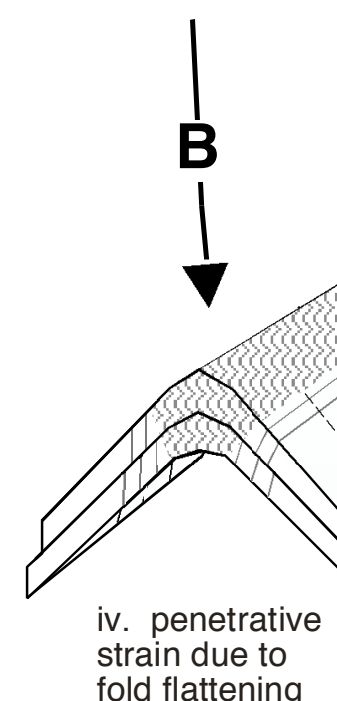

strain due to

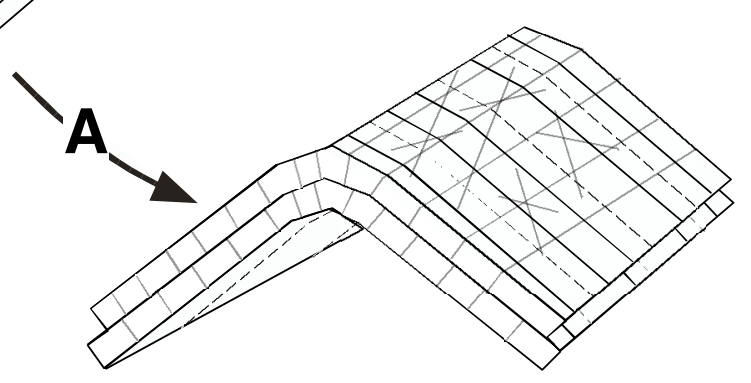

iii. fracturing due to low differential stresses,

high pore pressures,

uplift and unroofing

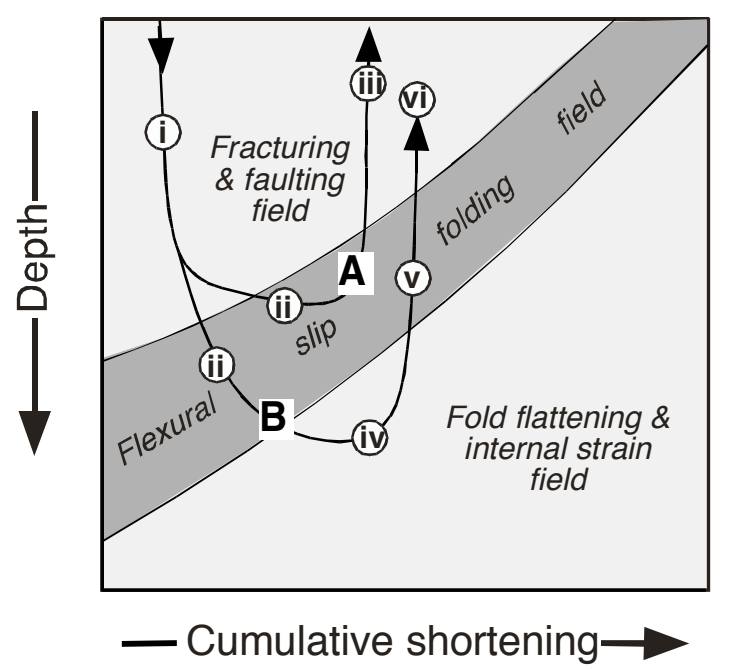

Figure 8. Conceptual relationship between folding mechanism, fracture development, depth of deformation and overall amount of shortening. Rocks folded at shallow levels and low amounts of shortening would be expected to develop primarily brittle structures $(\mathbf{A})$; folds that formed at greater depths and/or greater amounts of shortening are more likely to exhibit penetrative structures (B). Structures shown in black are actively forming; grey fractures or structures are those formed during an earlier event.

v. fracturing due to
flexural slip folding

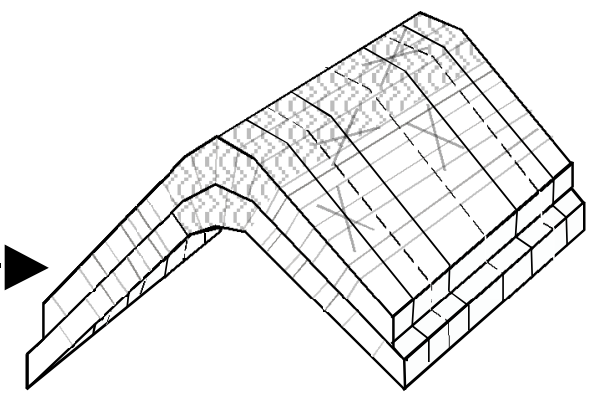

vi. fracturing due to low differential stresses, high pore pressures, uplift and unroofing 


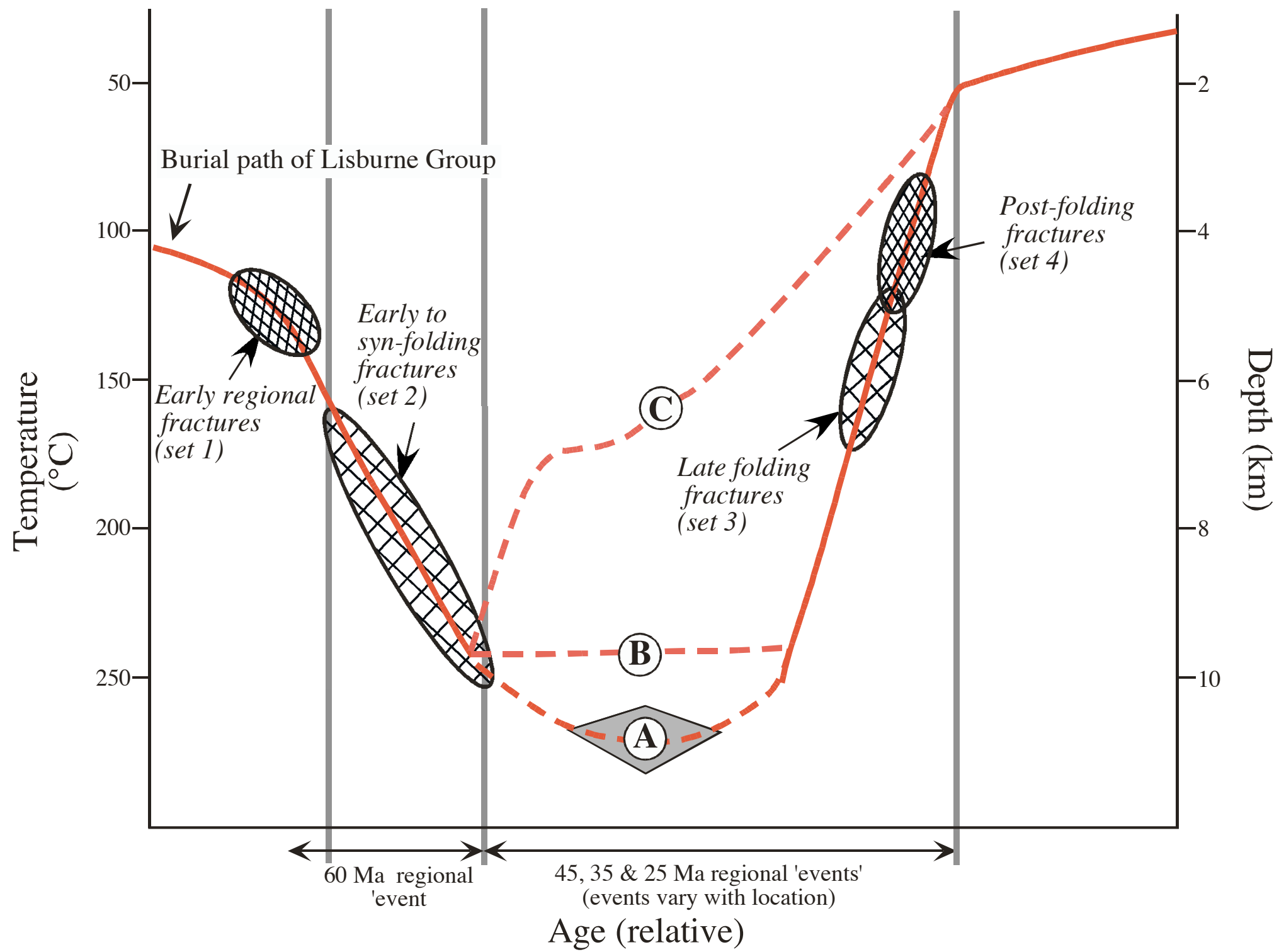

Figure 9. Depth/Temperature/Time graph showing the possible burial and uplift path of the Lisburne Group and lower PermoTriassic Echooka Formation in the Fourth Range. Curves A, B and C discussed in text. Temperature constraints are provided by fluid inclusion measurements from fracture fill (this report), conodont alteration indices (Watts and others, 1995, Rejebian, and others, 1987;

Atkinson, 2001), and vitrinite reflectance data (Bird, 1999; Cole and others, 1999). Temperature is converted to depth using a constant geothermal gradient of $25^{\circ} \mathrm{C} / \mathrm{km}$. Age of deformational events as plotted on the horizontal axis is relative, and based on regional apatite fission track data from various localities in the northeastern Brooks Range (Peapples and others, 1997, O'Sullivan and others, 1995). 
A

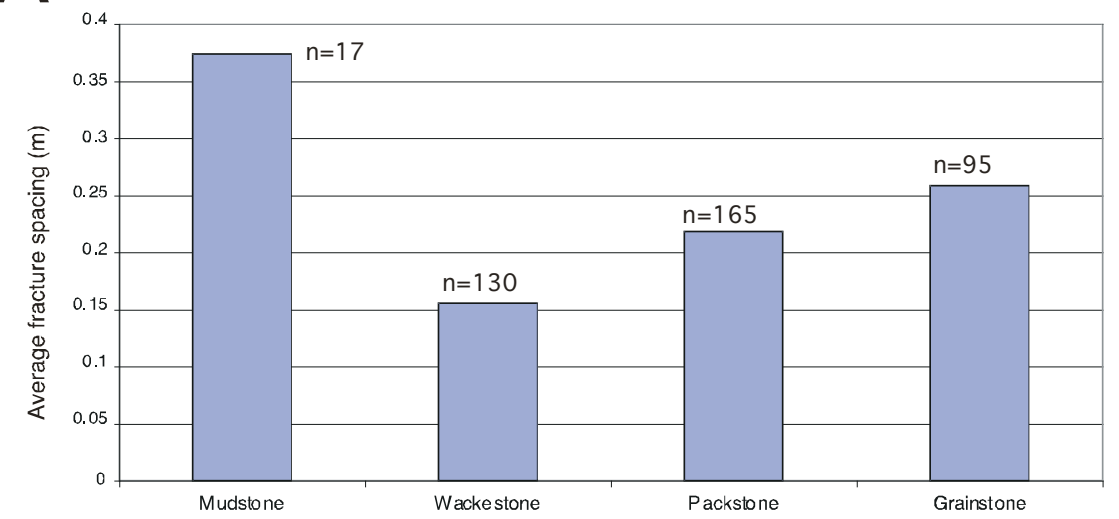

Lithology

C

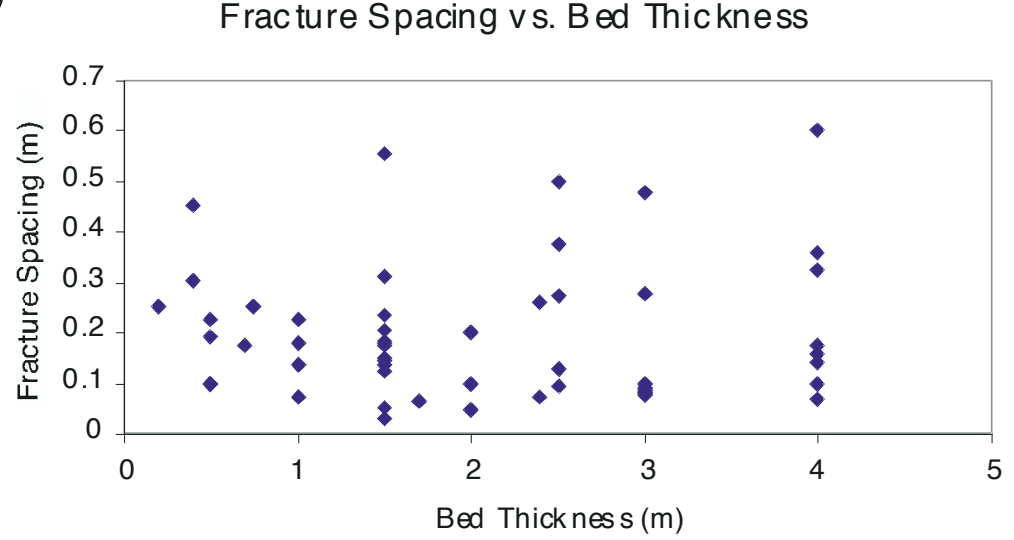

B Average Fracture Spacing Vs. Grain Size

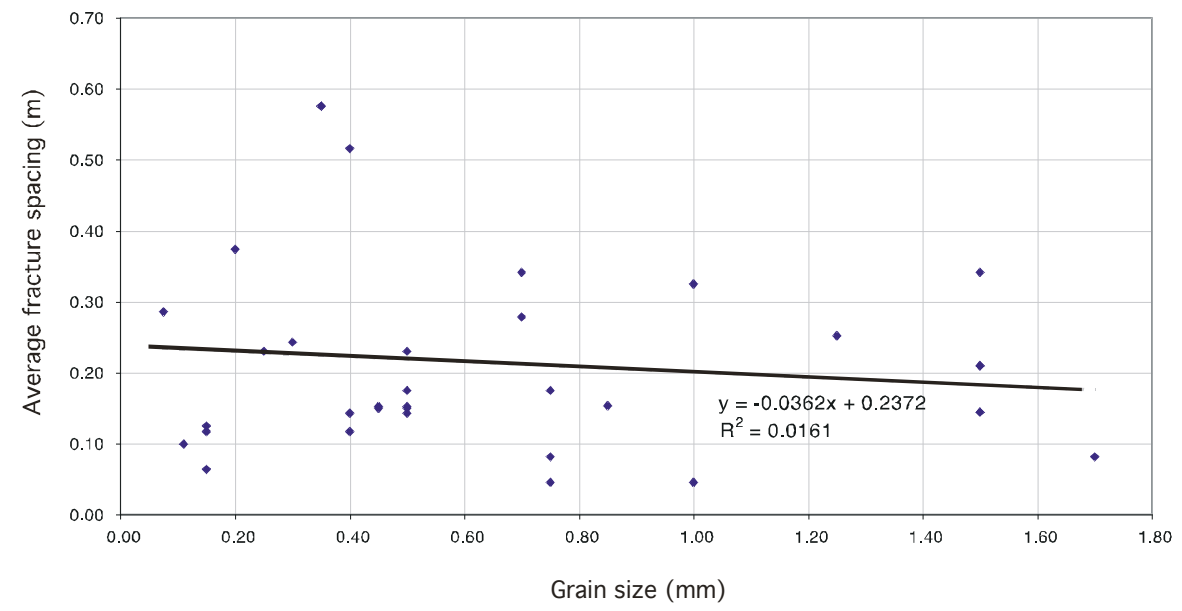

D

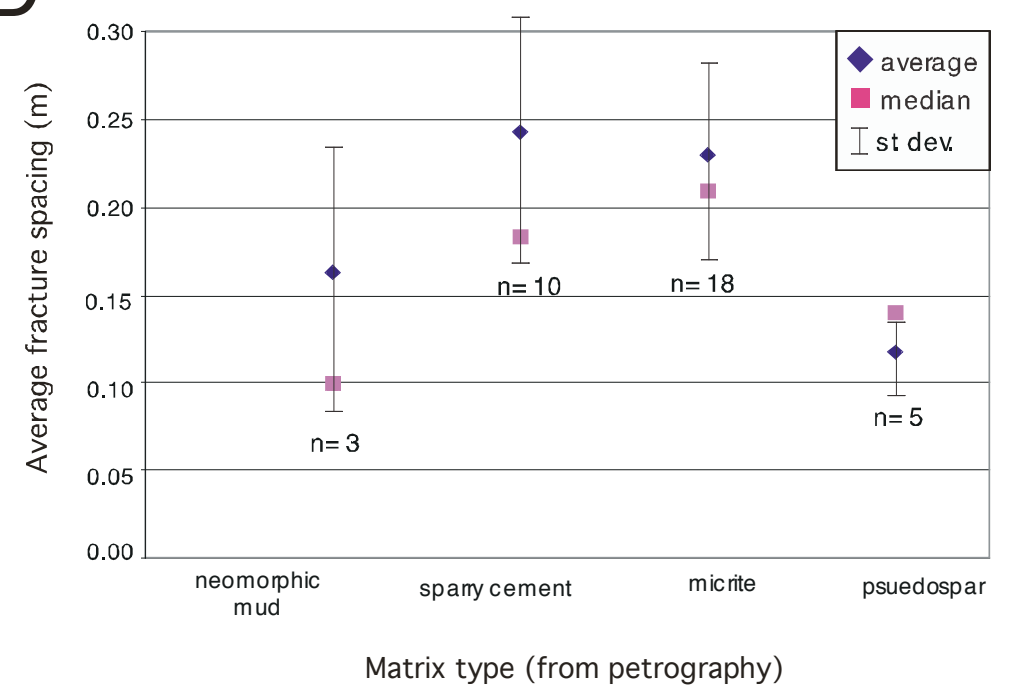

Figure 10. Univariant plots of observed fracture spacing vs. host lithologic characteristics. From Brinton, 2002. 


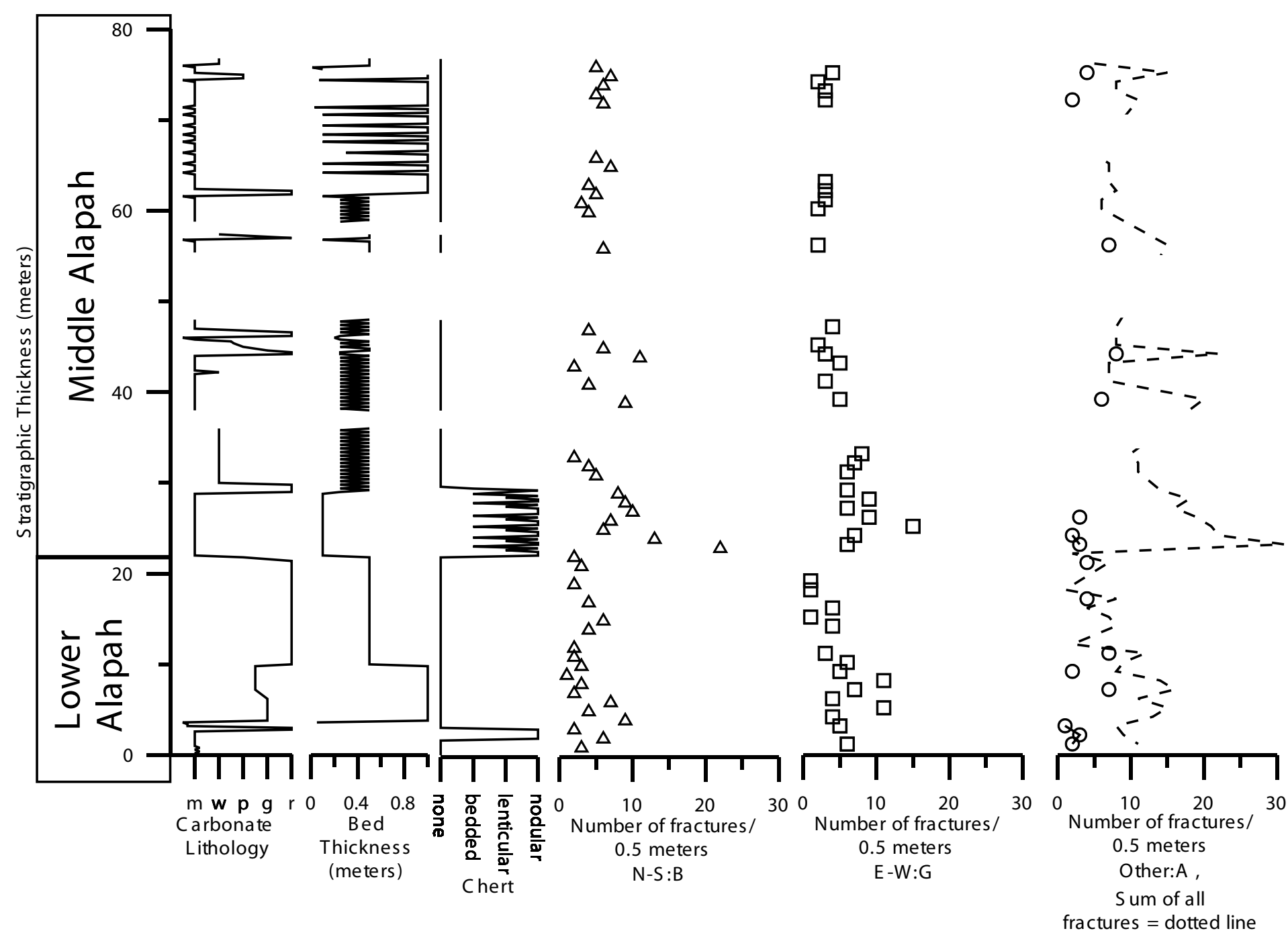

Figure 11A: Section showing stratigraphic attributes and fracture density in part of the lower and middle Alapah (lower Lisburne). From Shackleton, 2003. 


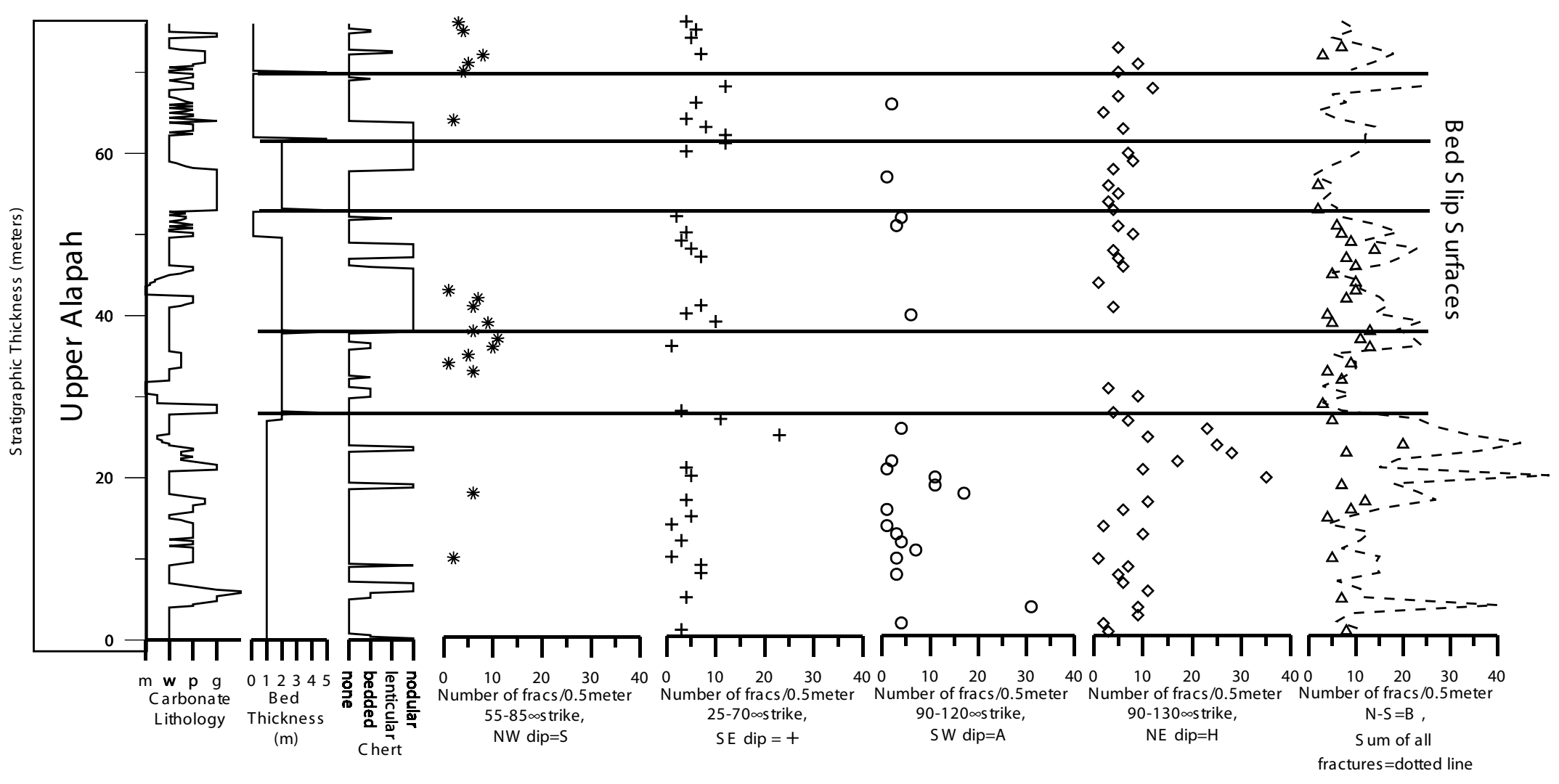

Figure 11B: Section showing stratigraphic attributes and fracture density in the upper Alapah (upper Lisburne). Flexural slip surfaces were documented in the field by slickensides and fault gouge between bed contacts, and en echelon vein sets along bed contacts. From Shackleton, 2003. 


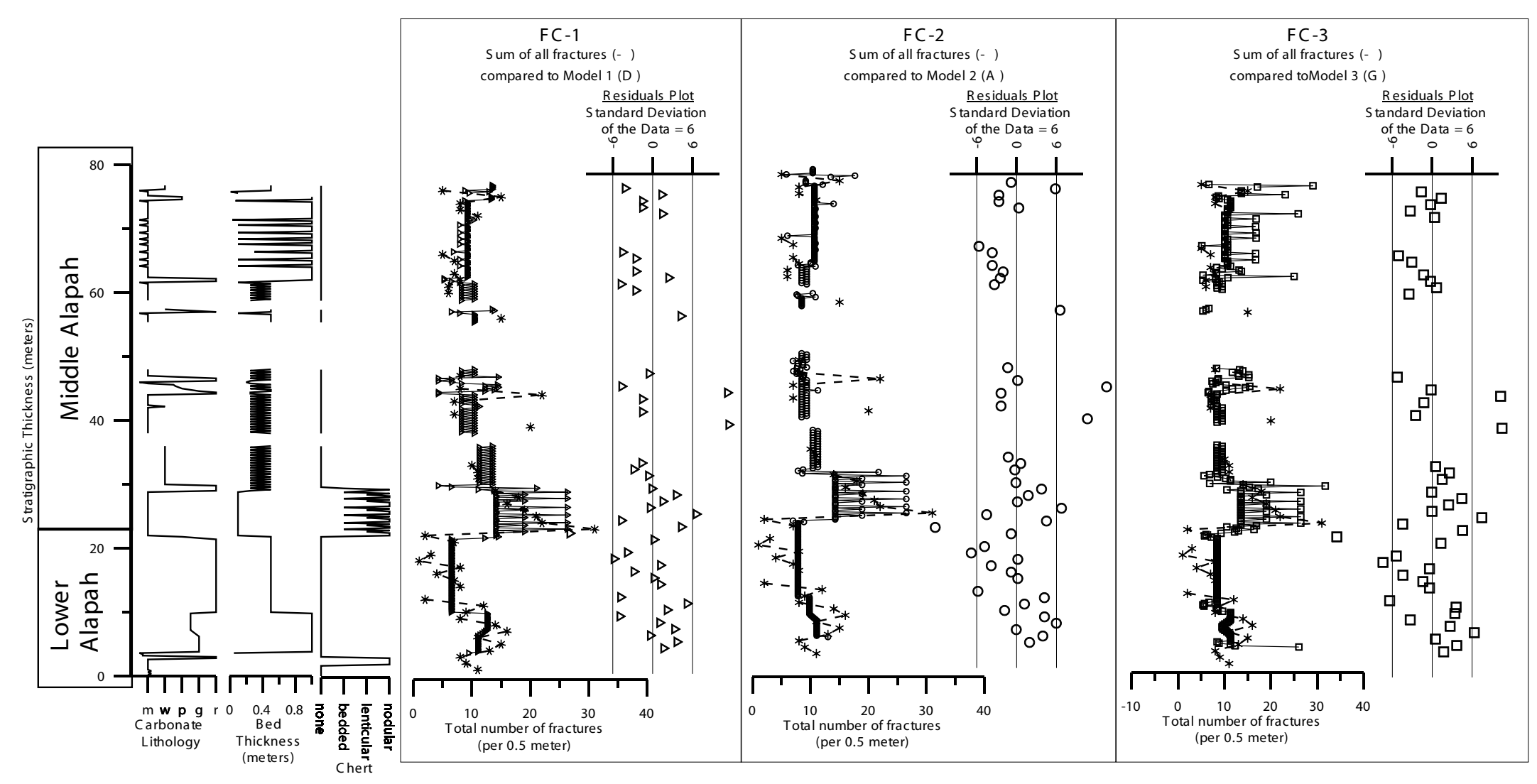

Figure 12A: Lower/middle Alapah fracture stratigraphy. Sum of All Fractures $\left(^{*}\right)$ ís compared to models with residuals (observed-predicted.) Note that the gridlines correspond to one standard deviation of the fracture data. For more discussion of models, see Shackleton, 2003. 


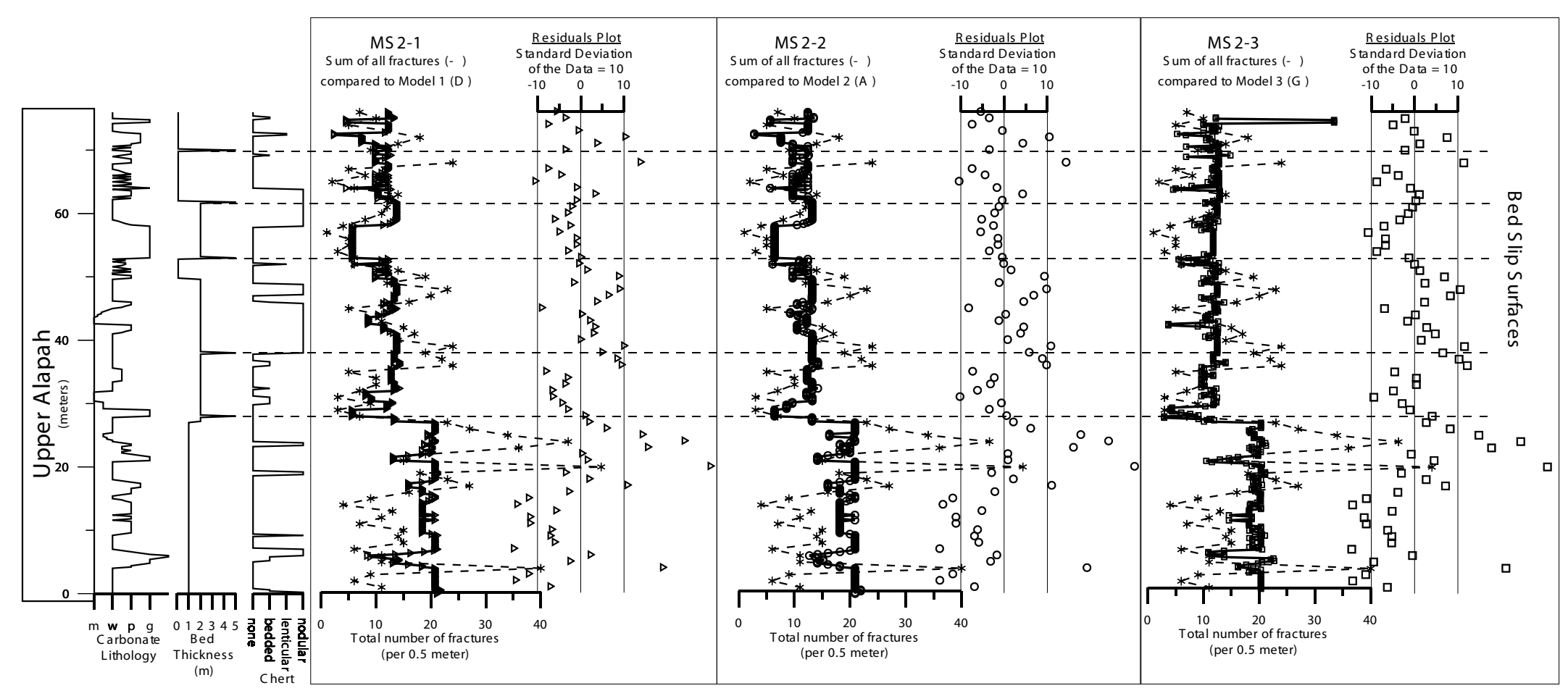

Figure 12B: Upper Alapah fracture stratigraphy. Sum of all fractures $\left(^{*}\right)$ ís compared to models with residuals (observed- predicted.) Note that the gridlines correspond to one standard deviation of the fracture data (sum of all fractures). Note the relatively good fit of the overall trend of the data, despite inaccurate prediction of the large "peaks" in the data. For more information, see Shackleton, 2003. 

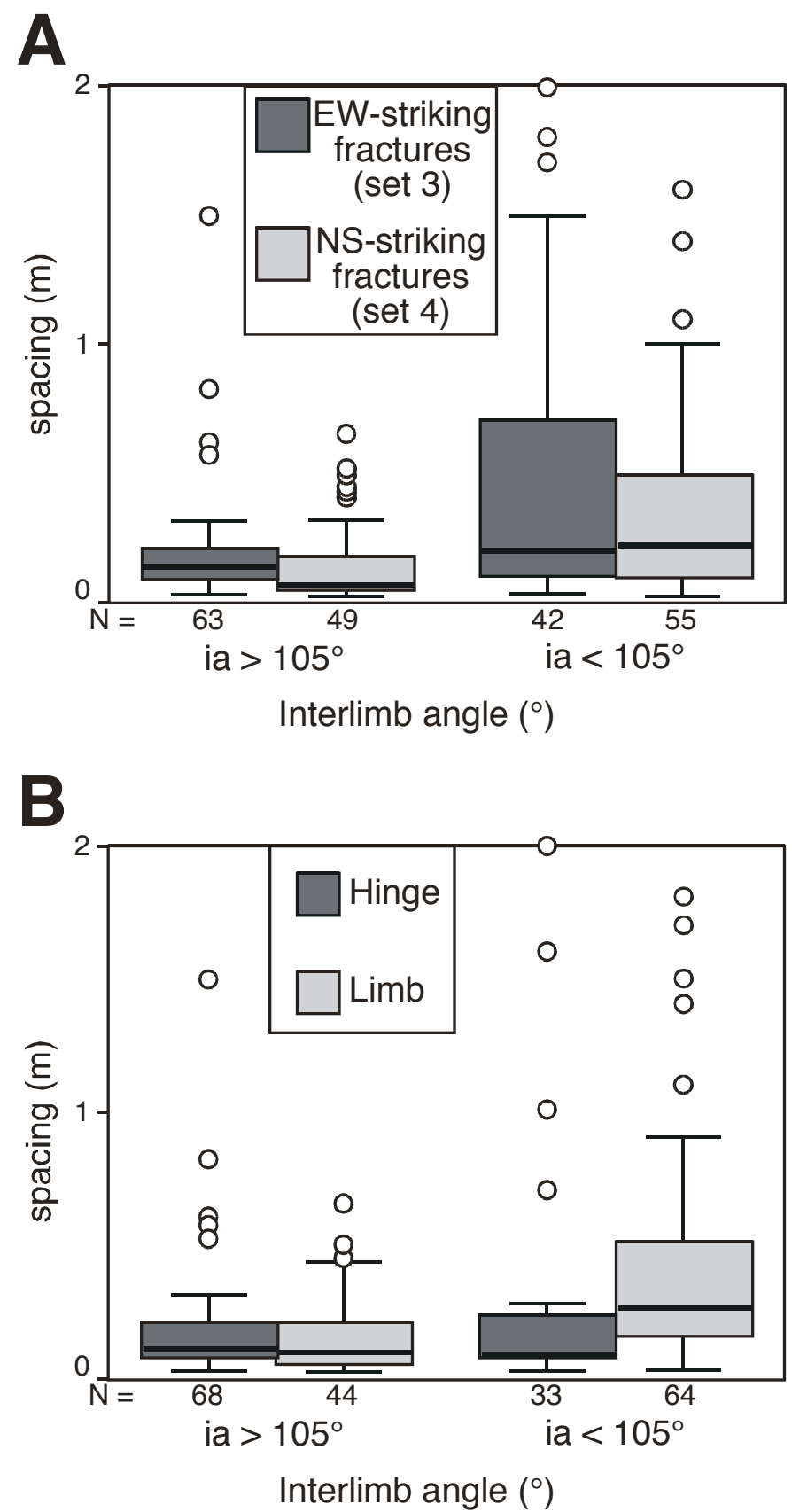

Figure 13. Summary statistics (box plots) of Sets 3 and 4 fracture spacing, showing effects of interlimb angle, fracture orientation (A) and structural position (B). Sets 3 and 4 were combined in B to give a more statistically robust data set. The upper and lower edges of the boxes represent the upper (75th percentile) and lower (25th percentile) quartiles, respectively. The heavy line is the median (50th percentile). The range bars (whiskers) extending from the top and bottom of the boxes enclose fracture spacings which are within 1.5 box lengths of the upper or lower quartiles, respectively. Circles show spacings which are "outlier values." See Siegel and Morgan (1996) for more details. 


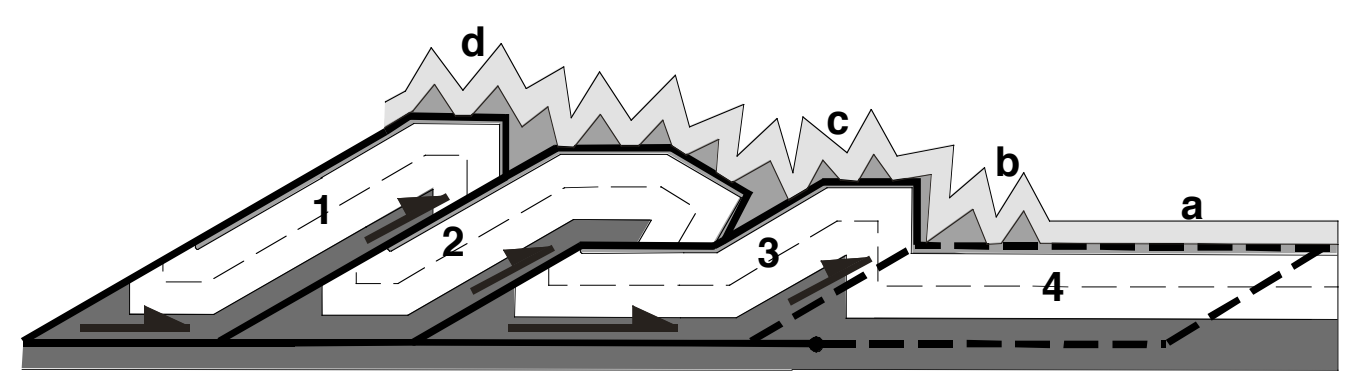

Figure 14. Schematic diagram of a fold-and-thrust belt. A fold-andthrust belt generally grows at its leading edge, with thrust sheet 1 the oldest sheet and thrust sheet 4 the future thrust sheet. Locations a-d are different positions within the thrust sheet where fractures could form, and are discussed in text. 


\begin{tabular}{|c|c|c|c|c|c|c|c|c|}
\hline \multirow{2}{*}{$\begin{array}{l}\text { Fracture } \\
\text { Set }\end{array}$} & \multirow{2}{*}{$\begin{array}{c}\text { Fracture } \\
\text { Orientation }\end{array}$} & \multirow[t]{2}{*}{ Fracture Characteristics } & \multirow{2}{*}{$\begin{array}{c}\text { Abundance in } \\
\text { typical } \\
\text { outcrop }\end{array}$} & \multicolumn{5}{|c|}{ Relative Age with respect to folding } \\
\hline & & & & Pre & Early & Peak Folding & Late & Post \\
\hline 1 & NNW-striking & $\begin{array}{l}\text { extension fractures with occa- } \\
\text { sional plumose structures on } \\
\text { fracture surface; large apertures, } \\
\text { calcite-filled; vertically extensive, } \\
\text { crossing multiple bedding } \\
\text { planes; evenly distributed \& per- } \\
\text { vasive; common in relatively } \\
\text { undeformed Lisburne Group but } \\
\text { difficult to reliably identify in fold- } \\
\text { ed Lisburne Group. }\end{array}$ & $\begin{array}{l}\text { rarely identifi- } \\
\text { able except in } \\
\text { outcrops with } \\
\text { little to no } \\
\text { folding; proba- } \\
\text { bly reactivat- } \\
\text { ed as set } 4 .\end{array}$ & & & \multirow{3}{*}{ 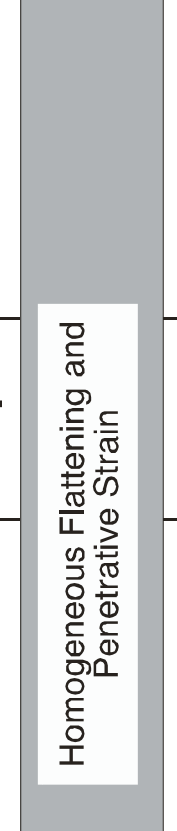 } & & \\
\hline 2 & $\begin{array}{l}\text { parallel and sub- } \\
\text { parallel to fold axis; } \\
\text { some parallel to } \\
\text { bedding }\end{array}$ & $\begin{array}{l}\text { Both apparent extension and } \\
\text { shear fractures; some en echelon } \\
\text { geometries; some large apertures; } \\
\text { calcite filled; all fracture geome- } \\
\text { tries widely spaced, not evenly } \\
\text { distributed \& not pervasive }\end{array}$ & $\begin{array}{l}\text { occasional-- } \\
1-3 \text { examples/ } \\
\text { outcrop }\end{array}$ & & & & & \\
\hline 3 & $\begin{array}{l}\text { 3A: parallel and } \\
\text { subparallel to fold } \\
\text { axis, perpendicu- } \\
\text { lar to bedding } \\
\text { 3B: fracture pairs } \\
\text { at } 60-90^{\circ} \text {; acute } \\
\text { bisectors parallel } \\
\text { or perpendicular } \\
\text { to fold axis }\end{array}$ & $\begin{array}{l}\text { 3A: filled and unfilled extension } \\
\text { fractures with small apertures; } \\
\text { evenly spaced across fold hinges; } \\
\text { terminate at bedding surfaces. } \\
\text { 3B: filled and unfilled extension } \\
\text { fractures with conjugate geometry } \\
\text { and small apertures; relatively } \\
\text { rare. }\end{array}$ & $\begin{array}{l}\text { very common; } \\
\text { most obvious } \\
\text { fracture set at } \\
\text { any one outcrop } \\
\text { common, } \\
\text { with lower } \\
\text { abundances } \\
\text { than } 3 \mathrm{~A}\end{array}$ & & & & \multicolumn{2}{|c|}{$--=$} \\
\hline 4 & $\begin{array}{l}\text { NNW-striking; per- } \\
\text { pendicular to fold } \\
\text { axis }\end{array}$ & $\begin{array}{l}\text { unfilled extension fractures with } \\
\text { plumose surface ornamentation; } \\
\text { vertically extensive, crossing } \\
\text { multiple bedding planes; evenly } \\
\text { distributed \& pervasive; small } \\
\text { apertures }\end{array}$ & $\begin{array}{l}\text { very common; } \\
\text { abundant at } \\
\text { all outcrops }\end{array}$ & & & & & \\
\hline
\end{tabular}

Table 1. Characteristics, orientation and relative age of fracture sets observed in detachment folded Lisburne in the northeastern Brooks Range. Fracture sets are numbered in their apparent relative age, with 1 being the oldest fracture set. Fracture sets were identified based on similar fracture characteristics, such as (in order of importance) age relationships to other fractures and to episode of penetrative strain, orientation, presence or absence of fill, apparent type of fracture (extensional vs. shear), and vertical extent. 


\begin{tabular}{|c|c|c|c|c|c|}
\hline $\begin{array}{c}\text { Sample } \\
\text { (unit, lithology) }\end{array}$ & \begin{tabular}{|c|}
$\begin{array}{c}\text { Fracture } \\
\text { sets }\end{array}$ \\
\end{tabular} & $\begin{array}{l}\text { Characteristics of fracture and } \\
\text { fracture fill }\end{array}$ & Fluid Inclusion re & Its ${ }_{\text {mean } \mathrm{Th}(\mathrm{n})}$ & mean Tmice $(\mathrm{n})$ \\
\hline $\begin{array}{l}\text { STRK01 1D } \\
\text { (TrPe, } \\
\text { silty shale) }\end{array}$ & 2 and 3 & $\begin{array}{l}2 \text { generations of fractures: } \\
\text { A. early quartz-filled fractures (set 2?). } \\
\text { Parallel to bedding, highly sheared with } \\
\text { shear bands. Contains zones of unde- } \\
\text { formed, possibly younger quartz } \\
\text { B. younger, relatively undeformed, nar- } \\
\text { row, quartz-filled fractures (set 3?) at } \\
\text { high angle to bedding. }\end{array}$ & $\begin{array}{l}\text { aqueous inclusions, } \\
\text { possible primary origin } \\
\\
\text { no inclusions analyzed to date }\end{array}$ & $153^{\circ} \pm 11^{\circ} \mathrm{C}(5)$ & $-3.9^{\circ} \pm 0.6^{\circ} \mathrm{C}(5)$ \\
\hline $\begin{array}{l}\text { STRK01 4D } \\
\text { (Ma, } \\
\text { fossiliferous } \\
\text { pelletal } \\
\text { wackestone) }\end{array}$ & 2 & $\begin{array}{l}\text { Calcite-cemented fracture, parallel to } \\
\text { bedding (set 2). Fracture fill is rela- } \\
\text { tively undeformed }\end{array}$ & 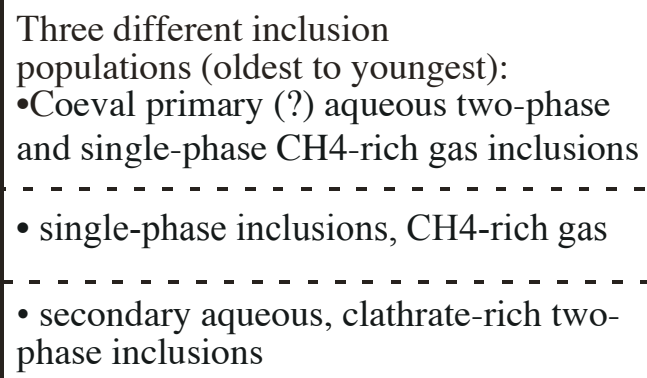 & $\begin{array}{c}223^{\circ} \pm 4^{\circ} \mathrm{C}(4) \\
-\ldots-\ldots \\
- \\
147^{\circ} \pm 5.5^{\circ} \mathrm{C}(5)\end{array}$ & $\begin{array}{c}-3.4^{\circ} \pm 0.2^{\circ} \mathrm{C}(4) \\
- \\
\quad>5^{\circ} \mathrm{C}(5)\end{array}$ \\
\hline $\begin{array}{c}\text { STRK01 5A } \\
\text { (Ma, crystalline } \\
\text { dolomitic } \\
\text { limestone) }\end{array}$ & 2 and 3 & $\begin{array}{l}2 \text { generations of fractures: } \\
\text { A. early, calcite-filled fractures (set 2); } \\
\text { calcite cement is heavily twinned and } \\
\text { deformed; syntectonic quartz with crack- } \\
\text { seal and bent fiber textures replaces } \\
\text { some calcite cement } \\
\text { B. - - - - - - - - - - - - _ounger, calcite- filled fractures (set } \\
\text { 3) at a high angle to set } 2 \text { fractures; cal- } \\
\text { cite cement is less deformed and less } \\
\text { twinned; some quartz replacement }\end{array}$ & $\begin{array}{l}2 \text { generations of fluid inclusions in } \\
\text { syntectonic quartz replacement: } \\
\text { - primary aqueous inclusions } \\
\text { - secondary inclusions } \\
\text { No inclusions analyzed to date }\end{array}$ & $\begin{array}{l}194^{\circ} \pm 7^{\circ} \mathrm{C}(7) \\
226^{\circ} \pm 7^{\circ} \mathrm{C}(6) \\
-\end{array}$ & $\begin{array}{l}-2.2^{\circ} \pm 0.2^{\circ} \mathrm{C}(9) \\
-2.2^{\circ} \pm 0.1^{\circ} \mathrm{C}(6)\end{array}$ \\
\hline $\begin{array}{c}\text { STRK01 5E } \\
\text { (Ma, } \\
\text { fossiliferous } \\
\text { wackestone, } \\
\text { highly sheared) }\end{array}$ & 2 and 3 & $\begin{array}{l}2 \text { generations of fractures: } \\
\text { A. calcite-filled fracture (set 2) at low } \\
\text { angle to bedding; calcite cement } \\
\text { twinned and sheared during later defor- } \\
\text { mation } \\
\text { B. partially calcite-filled fractures (set } 3 \text { ) } \\
\text { at high angle to set 2; has untwinned, } \\
\text { undeformed calcite cement. }\end{array}$ & $\begin{array}{l}\text {-aqueous inclusions of unknown origin } \\
\text { Thermometric analysis not successful due } \\
\text { This behavior suggests, however, that the }\end{array}$ & $\begin{array}{l}273^{\circ} \pm 4.4^{\circ} \mathrm{C}(\mathrm{n}=7) \\
\text { Th should be used } \\
\text { considerable strain } \\
\text { res) } \\
\text { stretching and leak } \\
\text { clusions formed at }\end{array}$ & $\begin{array}{l}-3.7^{\circ} \pm 0.3^{\circ} \mathrm{C}(2) \\
\text { with caution due } \\
\text { in set } 2 \\
\text { ing of inclusions. } \\
<80^{\circ} \mathrm{C} \text {. }\end{array}$ \\
\hline
\end{tabular}

Table 2. Results of fluid inclusion analyses of fracture fill from selected samples of Carboniferous Lisburne Group and PermoTriassic Echooka Formation from the Fourth Range. Abbreviations: Th: aqueous homogenization temperature; Tmice: final ice melting temperature. 
Model 1

bed thickness

chert content

carbonate lithology ized bed thickness.
$\mathrm{Bn}=(\mathrm{Bmax}-\mathrm{B}) / \mathrm{Bmax}$, where $\mathrm{B}=$ observed bed thickness, $\mathrm{B} \max =$ largest observed bed thickness and $\mathrm{Bn}=$ normal-

$\mathrm{Cn}=\mathrm{C} / \mathrm{Cmax}$, where $\mathrm{C}=$ observed chert content, $\mathrm{Cmax}=$ maximum nominal chert value and $\mathrm{Cn}=$ normalized chert value .

Chert content $(\mathrm{C})$ was given a numerical value based on continuity of the chert ie., no chert $=0$, bedded chert $=1$, lenticular chert $=2$, nodular chert $=3$.

Lithologies were ordered on a continuous scale (0-6) such that lithologies

with smaller grain size have larger values. i.e., shale $=6-5.6$, mudstone $=5.5$ 4.6 , wackestone $=4.5-3.6$, packstone $=$ $3.5-2.6$, grainstone $=2.5-1.6$, floatstone, rudstone $=1.5-0$.

$\mathrm{L} 1=\mathrm{Li} / \mathrm{Lmax}$, where $\mathrm{Li}=$ observed lithology value \& $\mathrm{Lmax}=6$

Hypothesis tested: fractures form more readily in lithologies with smaller grain sizes.
Model 2

As in Model 1

Lithologies (L2) were given continuous values such that wackestones have high values, followed by packstones, grainstones, floatstones and rudstones. Mudstones and shales have the lowest values since they are the most lithologically and mechanically homogeneous. wackestones $=6-5.1$, packstone $=5-4.1$, grainstone $=4-3.1$, floatstone $=3-2.1$, rudstone $=2-1.1$, mudstone $/$ shale $=1-0$.

$\mathrm{L} 2=\mathrm{Li} / \mathrm{Lmax}$, where $\mathrm{Li}$ is observed lithology value \& Lmax $=6$

Hypothesis tested: carbonate grain scale heterogeneities serve as initiation points for fractures and therefore lithologies with more heterogeneity will have higher fracture density.
As in Model 1

\section{Model 3}

As in Model 1
Lithologic and mechanical properties vary continuously based on grain size. shale $=6$ 5.5 , mudstone $=5.4-4.6$, wackestones $=$ 4.5-3.6, packstone $=3.5-2.6$, grainstone $=$ 2.5-1.6, floatstone, rudstone $=1.4-0$

L3 = absolute value of the differences between lithologies at a point in the section (Ly) and lithologies within $0.8 \mathrm{~m}$ of Ly sampled at 0.2 meter intervals (Ly $-\mathrm{x}$ meters)

$\mathrm{L} 3=|\mathrm{L}(\mathrm{y})-\mathrm{L}(\mathrm{y}+0.2 \mathrm{~m})|+\mathrm{I}(\mathrm{y})-\mathrm{L}(\mathrm{y}+$
$0.4 \mathrm{~m})|+| \mathrm{L}(\mathrm{y})-\mathrm{L}(\mathrm{y}+0.6 \mathrm{~m}) \mid+\mathrm{L}(\mathrm{y})-$
$\mathrm{L}(\mathrm{y}+0.8 \mathrm{~m})|+| \mathrm{L}(\mathrm{y})-\mathrm{L}(\mathrm{y}-0.2 \mathrm{~m}) \mid+$
$\mathrm{I}(\mathrm{y})-\mathrm{L}(\mathrm{y}-0.4 \mathrm{~m})|+| \mathrm{L}(\mathrm{y})-\mathrm{L}(\mathrm{y}-0.6 \mathrm{~m})$
$\mathrm{I}+\mathrm{IL}(\mathrm{y})-\mathrm{L}(\mathrm{y}-0.8 \mathrm{~m}) \mid$
$\begin{aligned} & \text { Hypothesis tested: lithologic variation in } \\ & \text { the stratigraphic section affects fracture } \\ & \text { spacing. }\end{aligned}$
$0.4 \mathrm{~m})|+| \mathrm{L}(\mathrm{y})-\mathrm{L}(\mathrm{y}+0.6 \mathrm{~m})|+| \mathrm{L}(\mathrm{y})-$ $\mathrm{L}(\mathrm{y}+0.8 \mathrm{~m})|+| \mathrm{L}(\mathrm{y})-\mathrm{L}(\mathrm{y}-0.2 \mathrm{~m}) \mid+$ $|\mathrm{L}(\mathrm{y})-\mathrm{L}(\mathrm{y}-0.4 \mathrm{~m})|+\mid \mathrm{IL}(\mathrm{y})-\mathrm{L}(\mathrm{y}-0.6 \mathrm{~m})$ $\mathrm{I}+\mathrm{IL}(\mathrm{y})-\mathrm{L}(\mathrm{y}-0.8 \mathrm{~m}) \mid$

the stratigraphic section affects fracture spacing.

Table 3. Input parameters used to generate the predicitive fracture density models shown in figures $12 \mathrm{~A} \& \mathrm{~B}$. Predicted fracture densities $(\mathrm{Fm})=\mathrm{aLn} 4+\mathrm{bLn} 3+\mathrm{cLn} 2+\mathrm{dLn}+\mathrm{eBn} 4+\mathrm{fBn} 3+\mathrm{gBn} 2+\mathrm{hBn}+\mathrm{iCn} 4+\mathrm{jCn} 3+\mathrm{kCn} 2+\mathrm{lCn}+\mathrm{m}$. Ln, Bn, and Cn are normalized lithology, bed thickness, and chert values, and a, b, c, .., l, m, are constants. The values of constants were optimized for each stratigraphic section to give the least error between Fm and the observed fracture density, Fo. 


\section{Connectivity and wellbore placement in the Lisburne Group}

A.V. Karpov, J. L. Jensen, Texas A\&M University, and C. L. Hanks, University of Alaska Fairbanks

\section{Abstract}

Fractures play a key role in the Lisburne Group fluid flow behavior. Field data from grainstone intervals of the Wahoo Limestone in the eastern Sadlerochit Mountains, a relatively undeformed area, have been analyzed to develop fracture distributions and models.

The models covered a range of possible cases. The "base" case assumed vertical fractures with either of two azimuths (to correspond to the two fracture sets observed in the field) and no effect of fracture intersection. Other models allowed more variability in fracture strike and interaction. These models were interrogated for wellbore placement and hydraulic connectivity behavior. The wellbore trajectory analysis showed:

- A positive correlation was observed for the "base" case between number and area of fractures connected to wellbores. This relationship, however, diminished for other cases.

- Optimal horizontal well azimuth orientations for the base case and the case with variable fracture strike and dip are in the range $0^{\circ}$ to $30^{\circ}$. Wells with such orientation will be connected to the maximum number and area of fractures.

- Variability in strike and dip increases the number and area of fractures connected to the wellbore. However, it does not change the optimal wellbore orientation.

- ENE fracture termination increases the number and decreases the area of fractures connected to the wellbore. It also shifts the optimal wellbore trajectory from the bisector between the two sets $\left(30^{\circ}\right)$ towards the direction normal to the NNW set $\left(60^{\circ}\right)$.

The hydraulic connectivity analyses showed:

- The fracture network is weakly anisotropic if uniform fracture transmissivity is assumed.

- The system remains weakly anisotropic when the transmissivity of either set is diminished.

- ENE fractures provide critical connections for flow in any direction, as opposed to the NNW set, whose transmissivity is important only for the NNW flow.

- The fracture system is above the percolation threshold in all the cases.

- The smaller fractures become important if ENE fracture termination and strike and dip variability are included in the model. This case is less interconnected, closer to the percolation threshold, and more sensitive to removal of smaller fractures.

\section{Introduction}

An essential part of the study of fractured systems includes fracture distribution analysis and development of statistical models describing the behavior of various fracture features (e.g. height and spacing). The assigned distribution types and parameters are being used in fracture set generation for wellbore placement and single phase fluid flow modeling in the Lisburne Group.

The goal of the wellbore analysis was to find an "optimal" wellbore trajectory in the fracture system. The maximum number of fracture intersections with the wellbore can be the first criterion of optimal wellbore placement in a fracture domain because it may provide the highest well productivity. The second, but not less important, goal is to find a wellbore trajectory where fractures, both directly and indirectly connected to the wellbore, have the maximum total area. In this case, a larger matrix area is exposed to drainage during primary 
depletion or water imbibition in waterflooding and, therefore, higher sweep efficiency can be achieved.

The flow modeling examined the importance of several characteristics for fluid flow in the Lisburne Group. In particular, the relative influence of the two fracture sets on system connectivity was assessed, including how the influence varied according to effects such as variability in fracture strike and termination percentage. All modeling assumed that the matrix had zero permeability.

\section{Literature Overview}

Fracture Statistical Properties

It is generally recognized that a variety of different mathematical and statistical models can describe fractures. Many studies of fracture property statistical behavior are available in the literature. A few results and conclusions, as well as different approaches in data analysis, are covered here.

Dershowitz and Einstein (1988) cite various studies on observed distribution types of fracture properties. Distributions for fracture trace length include exponential, lognormal, hyperbolic and Gamma-1 distributions. Models based on different processes suggest three distributions: random placement processes lead to exponential distributions; multiplicatory processes as they occur in breakage lead to lognormal distributions; and continuity of the process from smallest to largest sizes produces hyperbolic (fractal) distributions. However, a rigorous association of fracture size distribution with underlying geologic processes does not exist at present.

Fracture spacing often follows an exponential distribution, which is natural if fractures are created by a Poisson or Markov process. In the Poisson process, fractures are located independently according to a uniform distribution; a Markov process implies a dependence of fracture location on the preceding one. There is also evidence of lognormal distributions of fracture spacing (e.g. Rouleau and Gale, 1985). Wu and Pollard (1995) argue that lognormal spacing distributions imply under-developed fractures as opposed to normal distribution, which was suggested to indicate that a fracture set is exceptionally well developed or "saturated".

Guo et al. (1999) inspected thirty-six sets of surface fractures mapped from satellite images and aerial photos. Twenty-five hypothesized probability distribution functions were used to fit each data set. The best-fit distribution was selected using a chi-square goodness-of-fit value. Fracture lengths were best-fit by PearsonVI, PearsonV, lognormal2, or extreme-value distributions; the spacing data were best-fit by PearsonVI or lognormal distributions.

There are also cases where different size distributions can be observed in the same geological processes. Korvin (1989), as quoted in Korvin (1992), analyzed the statistical geometry of the network of faults on the structural map of the Paleozoic Basement of the Gulf of Suez. The trend sides $\left(\mathrm{N} 10-60^{\circ} \mathrm{W}\right)$ of the fault blocks were exponentially distributed, the "cross trend" block sides (N20-70 E) were lognormally distributed.

Reported values of fractal dimensions vary; they appear to depend on how uniformly the sampling is performed through the whole range of scales, as well as on sampling methods. Barton (1992) found that the fractal dimension of intervals in a borehole was in the range of 0.6 -0.8 , while the dimension of two-dimensional patterns of fractures on related outcrops was in the range of 1.6-1.8.

Fracture Property Assessment 
The variety of possible distribution types that can potentially mimic fracture geometry raises a question of adequate techniques for choosing and validating statistical models. Histograms and descriptive statistics provide a general "feel" of a data set but seldom allow fitting a unique distribution type to the observed values. Data located at the ends of the observed range, i.e. the extreme values, are especially hard to model using histograms. Since several analytical curves can approximate an analyzed histogram, there is a need to use more sophisticated techniques.

Jensen et al (1997, p. 84) suggest probability plots to test the hypothesis of a normal distribution of a sample. The procedure can be easily adjusted to test other hypotheses. Rouleau and Gale (1985) used this approach, for example, when they tested exponential, log-normal and Weibull as candidate distributions to fit fracture spacing data. They also performed Kolmogorov - Smirnov goodness-of-fit tests to validate candidate distributions. This allowed quantitative comparisons between possible statistical models for the best-fit selection. Guo et al (1999) took a similar approach, using chi-squared goodness-of-fit statistics to choose best candidates for data fitting.

\section{Wellbore Placement in Fractured Reservoirs}

The problem of sweep efficiency of a high priority in many naturally fractured reservoirs (e.g., Putra and Schechter, 1999), where waterflooding fails to bring significant increase in hydrocarbon recovery. Optimal well placement, among other measures, has a potential to improve fractured reservoir management.

Little has been reported in the literature regarding the subtler aspects of optimum wellbore placement. Two characteristics have, however, been discussed: 1) the number of intersecting fractures increases with wellbore deviation, and 2) horizontal wells encounter the maximum number of fractures for vertical fracture systems (e.g., Putra and Schechter, 1999; Sato, 2000).

\section{Connectivity and Flow in Fractured Systems}

A fracture system can be represented by a network of channels or pipes with given parameters or assigned hydraulic properties to the fracture intersections. Then, it is possible to calculate fluid flow through the network (Cacas et al., 1990; Billaux et al., 1989). However, real fracture systems are complex and such calculations are computationally demanding. Flow is related to connectivity and studying the network connectivity can be the first step in a fluid flow analysis (Chiles and de Marsily, 1993 ).

A network of fractures would conduct fluid if the fractures intersect. If we gradually decrease the number of intersections in an initially pervious fracture system, the connectivity of the system will also decrease and at some point the system will become impervious. This connectivity behavior is addressed by percolation theory, which studies relationships between interconnectivity of a system and its geometry (e.g., Sahimi, 1994).

\section{Lisburne Group Fracture Data Analysis}

\section{Data Description}

The object of our analysis is two fracture sets in the relatively undeformed section of the Lisburne carbonates (massive grainstones of the lower Wahoo Limestone): an early NNWoriented set of extension fractures and a later ENE-oriented set of extension and shear fractures. Outcrop photographs provided quantitative information about fracture height and spacing. These 
data were obtained by screening fracture properties along scan-lines on the photograph. Thus, for the NNW set, we had 100 values of fracture height and 98 values of fracture spacing. There were 26 height and 25 spacing values available for ENE fractures.

\section{Analysis Results}

The first step in the data analysis was an inspection of general statistical characteristics of the fracture properties. All property distributions were skewed to the left, which is very typical behavior. Further analysis was undertaken, particularly testing if the properties came from the exponential or lognormal distribution models.

\section{NNW fractures}

NNW fracture height

Probability plot analysis suggested the exponential model may be more appropriate than lognormal (Fig. 1). To further assess the suitability of the two distribution models, Monte Carlo simulations were performed. Ten lognormally and ten exponentially distributed sets were generated with the mean and standard deviation of the actual data set (Fig. 1). The exponential model, though poorly fitting heights below 1.2 meters, mimics the larger values fairly well. The lognormal model tends to predict larger values than actual for heights greater than 10 meters. Since larger fractures may dominate fluid flow, the exponential height model seems to be more appropriate. This assessment, however, overlooks an important feature of the exponential model.

The exponential model has only one parameter. Attempting to choose the value which best suits the larger heights causes a substantial misfit for approximately two-thirds of the data (i. e. heights below 7 meters). The degree of mismatch could significantly influence flow assessments. Therefore, the lognormal model becomes the preferred distribution because it has two parameters and still gives an acceptable fit.

An L-moment plot (see Appendix A for more details) was also used to assess fracture height distribution (Fig. 2). The NNW height does not tend definitely to any of the standard distributions, lying in the vicinity of exponential, lognormal, Pearson III and generalized Pareto curves on the plot. A special type of simulation, "jack-knifing" was applied to look at possible variations of the sample points on the L-moment plot (Appendix B). Results of the simulations (Fig. 3) show a fairly "tight" cloud for NS fracture height, apparently due to the large sample size and therefore, lower variability (comparing to EW sample). Thus, any of several models could be used for height in this set according to the L-moment procedure. For fracture height we therefore chose the lognormal model.

\section{NNW fracture spacing}

NNW fracture spacing on the probability plots is poorly approximated by the exponential model for both small and large values. The lognormal distribution, on the contrary, fits fairly well, including the extreme values (Fig. 4). The L-moment plot (Fig. 2) also shows the lognormal model as the best fit for this property. The sample point is located exactly on the lognormal curve. Thus, a lognormal distribution was used for the NNW fracture spacing.

ENE fracture set

Similar to the NNW set analysis, the ENE set was assessed for appropriate height and spacing distribution models. 


\section{ENE fracture height}

A probability plot (Fig. 5) shows that fracture height is well approximated by a lognormal distribution. Although both the exponential and lognormal models both capture the large and medium fracture behavior, the lognormal model better suits fractures smaller than 1.5 meters. The cloud of simulated points on the L-moment plot (Fig. 3) is also located further from the exponential point than from the lognormal curve. While some of the points are located almost on the lognormal curve, most of the cloud is in the vicinity to the generalized Pareto distribution, which has a power-law form in this region of the L-moment plot (Hoskins and Wallis, 1997). Montroll and Schlesinger (1983) argue that sometimes the lognormal distribution can mimic power-law behavior and it is hard to distinguish between them. The lognormal model appears to be a good final selection for the ENE fracture height.

ENE fracture spacing

As with the fracture height, the fracture spacing is well fit by the lognormal model on the probability plots (Fig. 6). However, on the L-moment plot (Fig. 3), the sample cloud is somewhat apart from the majority of the standard curves, being close only to the Generalized Extreme Value distribution. Perhaps, such deviation is due to the small sample size (25 points). Based on the probability plots for the ENE fracture spacing, the lognormal model was chosen.

\section{Lisburne Group Fracture Modeling}

After the distribution type selection we need to assign specific parameter values, such as mean and standard deviation, to each fracture property. We can do so by minimizing the error between the model and sample points, iterating parameters of the model. Table 1 shows the results of these iterations.

Table 1. Model distribution types and parameters for fracture properties

\begin{tabular}{|l|l|l|l|l|l|l|}
\hline \multirow{2}{*}{$\begin{array}{l}\text { Fracture set } \\
\text { Parameter }\end{array}$} & \multicolumn{3}{|c|}{ NS } & \multicolumn{3}{c|}{ EW } \\
\cline { 2 - 7 } & Distribution & Mean & St dev & Distribution & Mean & St dev \\
\hline Height & lognormal & 7.78 & 6.09 & lognormal & 5.11 & 4.4 \\
\hline Spacing & lognormal & 1.57 & 1.61 & lognormal & 1.97 & 1.73 \\
\hline
\end{tabular}

The selected statistical models for the fracture properties are not considered to be final. As the study progresses, we should be flexible in the model assignment, adjusting it if additional data become available and comparing different models in sensitivity studies. Preliminary results of fracture generation (using Fracman) are shown in Figs 7 and 8. The input for the model is shown in Table 2. 
Table 2 Input parameters for fracture generation in Fracman.

Model:

Poisson Rectangles

Region: Box 10x10x10 $\mathrm{m}^{3}$

Fracture set

Parameter

Orientation of trend, degrees

Orientation of plunge, degrees

Height (length in Fracman), $m$

Length (width in Fracman), $m$

Intensity, $\mathrm{P}_{32}, \mathrm{~m}^{2} / \mathrm{m}^{3}$

NS

distribution mean

constant

constant

\begin{tabular}{l|l} 
lognormal & 7.78 \\
\hline
\end{tabular}

\begin{tabular}{l|l|l|l|}
\hline 330 & & constant & 75 \\
\hline 0 & & constant & 0 \\
\hline 7.78
\end{tabular}

EW

correlated, Length $=(0.5$ to 1.0$) \times$ height

The limitations and assumptions of this model include:

1. Orientation of fracture trend and plunge is constant.

2. No quantitative length data are available at this point. Based on geological experience in the area, values 0.5 to 1.0 times the height value were used.

3. Appropriate fracture spacing is obtained by adjusting the fracture intensity, which has a constant value.

4. No fracture termination percent is assigned.

This model and variants will be used for flow modeling.

\section{Fracture Models}

Based on the statistical analysis of the fracture data and initial modelling of the ESM fractures, a "base" case and three alternatives (Fig. 9) were formulated to examine the wellbore placement and system connectivity for a range of possible conditions. Based on the geological information, these cases are all viable alternatives and were intended to evaluate fracture system features which could be important to flow.

1. "Base" case. This is the simplest case, allowing no variability in fracture strike and dip and no fracture termination.

2. "Variable strike and dip" case. This case allows strike and dip variability in both sets. Standard deviations of $5^{\circ}$ were assigned to both the strike and dip of the NNW set, $10^{\circ}$ standard deviations were used for the ENE fracture strike and dip. All other parameter values were adopted from the base case.

3. "ENE Terminated" case. For this case $100 \%$ termination of ENE fractures against the NNW set was designated. Since the termination caused a decrease in the ENE fracture size, a fracture intensity $\left(\mathrm{P}_{32}\right)$ adjustment was necessary.

4. "Realistic" case. This case combines fracture strike and dip variability in both sets and 100 $\%$ ENE fracture termination. The "ENE Termination" $\mathrm{P}_{32}$ values were used for this case.

\section{Wellbore Modelling Results}

For the "base" model, wellbores of $0^{\circ}$ and $30^{\circ}$ orientation intersect the largest number of directly-connected fractures and have the largest area of fractures both directly and indirectly connected to the wellbores. Indirectly connected fractures obtain a maximum number in the $30^{\circ}$ and $60^{\circ}$ - oriented wellbores. A weak correlation is observed between the number of fractures and fracture area for both directly and indirectly connected fractures (Fig. 10). 
When variability in strike and dip is incorporated in the model, the number and area of fractures directly connected to the wellbores do not change. However, the number and area of indirectly connected fractures increase by $10-20 \%$. Apparently, variability in fracture orientation allows more fracture intersections. The overall pattern observed in the "variable strike and dip" model is similar to that of the "base" case, showing optimal orientations of $0^{\circ}$ and $30^{\circ}$.

A different pattern emerges when ENE fracture terminations are incorporated in the model. Directly connected fractures have the maximum number of intersections with a $0^{\circ}-$ oriented wellbore, while the largest area of fractures obtains for a $60^{\circ}$ - oriented wellbore.

There is no correlation between number and area for directly connected fractures. Indirectly-connected fractures show consistent maxima at the $60^{\circ}$ orientation for both number of intersections and fracture area. Number of fractures connected to the wellbores in the "terminated" case is roughly at the same level as in the "base case"; however, the area decreases significantly (more than 2 times). This implies that the effect of fracture termination on the system connectivity is stronger than that of the variability in strike and dip.

The "realistic" case has no azimuth at which there is a pronounced maximum of directlyconnected fractures. Wellbores oriented at $60^{\circ}$ still have the maximum number of indirectlyconnected fractures and maximum amount of area for both directly- and indirectly-connected fractures. Compared to the "base" case, the number of indirectly connected fractures is increased in the "realistic" observations. Indirect connections increase their number and area by $30-60 \%$.

\section{Wellbore Modelling Comments}

Judging from the "base" model wellbore analysis results, no fracture set clearly dominates in the system. The optimal wellbore trajectory is a bisector between the two fracture strikes $\left(330^{\circ}\right.$ and $\left.75^{\circ}\right)$, in accord with results from other studies (Aguilera et al., Ch. 8, 1991). Variability in dip and strike increases the number and area of fractures connected to the wellbores but does not change the relative influence of the two sets.

The situation changes when $100 \%$ ENE fracture termination is incorporated in the model. Although there are 10 times more ENE fractures than NNW fractures in the system, the average area of the latter is 7 times larger. Allowing ENE terminations, we apparently diminish the relative contribution of this set to the system connectivity. The optimal wellbore trajectory shifts to the orientation of $60^{\circ}$, which is exactly perpendicular to the NNW set strike. Again, strike and dip variability incorporated in the "Realistic" case does not change the pattern observed in the "ENE termination" model since fracture geometry and intensity are the same.

The optimal wellbore trajectory for the "realistic" case is $60^{\circ}$; the horizontal wellbore of such an orientation has the maximum number and area of fractures connected to it. This result indicates that the wellbore perpendicular to the NNW set strike has the greatest potential of involving matrix into drainage or imbibition and, therefore, increasing oil recovery in a reservoir with characteristics similar to those presented here.

Variability in strike and dip improves connectivity of the system, allowing more fracture intersections and an increasing number of fractures connected to the wellbore. The number of fractures in the "variable strike and dip" is larger than that in the "base" case by approximately $10 \%$. The fracture area also increases, by $30 \%$ on average. Even a greater impact of the fracture strike and dip variability is observed when we compare "terminated" and "realistic" cases. Both number and area of fractures connected to the wellbores increase in the "realistic" case by 40 to $50 \%$. 
Allowing ENE terminations increases the total number of fractures connected to the wellbores by roughly $30 \%$ compared to the "base" model. This happens because there are almost 3 times more fractures in the "terminated" case, than in the "base" case. However, fracture area decreases 2.4 times on average in the "terminated" case, due to the decreased size of the ENE fractures. A similar tendency is observed if we compare "variable strike and dip" and "realistic" cases. Once we incorporate ENE termination in the "variable strike and dip" case, the total number of fractures connected to the wellbores increases by almost $50 \%$, and the corresponding area is halved.

The analysis indicates that fracture termination, unlike dip and strike variability, influences the relative contributions of fracture sets to fluid flow in the modeled fracture system. Having the same initial values of fracture size and spacing and changing termination of the ENE set, we observed a noticeable change in the way the fracture network interconnects and connects with simulated wellbores.

One of the important observations of the wellbore analysis is that the number of fractures connected to a wellbore is not necessarily related to the area of the connected fractures (e.g. number and area of directly connected fractures in the "terminated" case). To assess the potential area of matrix exposed to the wellbore, one needs to examine both number and area of fractures connected to the wellbore.

\section{Fracture System Conductivity Evaluation}

Several models were used to assess the hydraulic properties of the fracture models. All used either the "base" or the "realistic" cases of fracture distributions described above.

System anisotropy was evaluated using the arrangement shown in Fig. 11, assuming equal aperture size for both fracture sets. The first two wells have a $17 \mathrm{~m}$ distance and azimuth $60^{\circ}$, so that the simulated flow direction between them would be parallel to the NNW fracture set strike. In a similar manner, the second pair of wells is located $17 \mathrm{~m}$ apart and oriented at $345^{\circ}$, sampling flow along the ENE fractures.

The "base" case system exhibits some anisotropy (Fig. 12); the difference in conductance between wellbore pairs is less than one order of magnitude. Decreasing the transmissivity of either fracture set by one order of magnitude (Cases 1 and 4, Fig. 12) did not affect the well-towell conductivity in either set of wellbores. Larger decreases (Cases 2, 3, 5, and 6, Fig. 12), however, did affect the system. An ENE set transmissivity decrease of more than 1 order of magnitude substantially affected flow in both directions (Cases 5 and 6, Fig. 12). A NNW set transmissivity decrease significantly affected conductivity only in the NNW direction (Cases 2 and 3, Fig. 12).

The "realistic" case yielded slightly different results. The inclusion of strike and dip variation and ENE set termination reduced the system sensitivity to the ENE set transmissivity. However, the system anisotropy increased with reduced ENE set transmissivity.

We assessed the effects of removing certain size fractures on the system conductivity and, therefore, the relative contribution of different size fractures to fluid flow. The simulation was performed in a $20 \times 20 \times 20 \mathrm{~m}^{3}$ region using two 20 - meter long parallel wells oriented eastwest and located 20 meters apart (Fig. 13).

For the "base" case, $88 \%$ of the smaller fractures were removed before there was any effect on conductance. $99 \%$ of the smaller fractures had to be removed to drop conductance to zero (with radius less than $7 \mathrm{~m}$ ). On the other hand, a removal of only $2 \%$ of the largest fractures 
significantly decreased conductance and a removal of the largest $12 \%$ (radius greater than $4 \mathrm{~m}$ ) of the fractures makes the fracture network non-conductive.

In the "realistic" case, $97 \%$ of the smallest and or 3\% of the largest fractures have to be removed to make the system non-conductive. After removal of fractures with radius less than 4 $\mathrm{m}$ or more than $3 \mathrm{~m}$, the conductance dropped to zero. Apparently, variability in strike and dip made the system more interconnected and restored some of the connectivity loss caused by the ENE fracture termination.

Similar trends were seen when studying the effect of fracture removal on the network connectivity. The system tolerates removal of the smaller fractures (i.e. $<4 \mathrm{~m}$ "base" and $<1 \mathrm{~m}$ "realistic" cases), which have only a small role in interconnecting the larger fractures. Removal of a few larger fractures, however, substantially reduces connectivity. These results indicate that the system is operating at or above the percolation threshold (Sahimi, 1994).

\section{Conductivity Comments}

A few large NNW fractures dominate the system connectivity, with the smaller but more numerous ENE set largely limited to connecting up the NNW fractures. This suggests (e.g., Putra et al., 1999) that viscous-force dominated displacements (e.g., waterfloods with a favorable mobility ratio) would likely benefit from injection - production well placements having positions along an ENE line. In displacements where diffusion is important, system conductivity is not as important as the fracture contact area with the matrix. The ENE set then plays a more important part.

This part of the study assumed no flow through the matrix; all flow was by fractures. Consequently, the sensitivities observed here would be mitigated by the permeable matrix. For example, the loss of very few large fractures reducing the system connectivity to nil may not be observed if flow through the matrix is included. Nonetheless, the trends observed may be important for wellbore placement and injection strategy in producing formations with fracture properties similar to those of the models.

The relative importance of the fracture sets to wellbore connectivity and system connectivity have implications for appropriate sampling of fractures in producing formations. The displacement process, fracture intensity, geometry, and relationships, and matrix conductivity all play a part in defining whether a particular set of fractures is important to flow. Outcrop-based evaluations are particularly difficult in this respect because a variety of displacement processes may be possible. Therefore, which set(s) should be sampled and to what degree has no simple solution. The obvious priority is evaluation of the largest fractures but deciding which fractures are "large" may not become clear until numerous measurements are made.

\section{Conclusions}

Fracture systems in the relatively undeformed region of the Wahoo Limestone were modelled. The wellbore trajectory analyses of several cases showed:

- A positive correlation was observed for the base case between number and area of fractures connected to wellbores. This relationship, however, diminished for the other cases.

- Optimal horizontal well azimuth orientations for the base case and the case with variable fracture strike and dip are in the range $0^{\circ}$ to $30^{\circ}$. Wells with such orientation will be connected to the maximum number and area of fractures. 
- Variability in strike and dip increases the number and area of fractures connected to the wellbore. However, it does not change the optimal wellbore orientation.

- ENE fracture termination against the NNW fractures increases the number and decreases the area of fractures connected to the wellbore. It also affects wellbore placement, shifting the optimal wellbore trajectory from the bisector between the two sets $\left(30^{\circ}\right)$ towards the direction perpendicular to the NNW set $\left(60^{\circ}\right)$.

The hydraulic connectivity analyses showed:

- The fracture network is weakly anisotropic if uniform fracture transmissivity is assumed.

- The system remains weakly anisotropic when the relative transmissivities of the sets are changed.

- ENE fractures provide critical connections in the fracture network, as opposed to the NNW set, whose transmissivity is important only for the NNW flow.

- The fracture system is above the percolation threshold in all the cases.

The smaller fractures become important if ENE fracture termination and strike and dip variability are included in the model: the "realistic" case is less interconnected, closer to the percolation threshold and more sensitive to removal of smaller fractures.

\section{Acknowledgements}

We thank Golder and Associates for the use of FracMan software in this project.

\section{References}

1. Aguilera, R., et al.: Horizontal Wells, Gulf Pub. Co., Houston, 1991, 401p.

2. Barton, C.C. 1992. Fractal Analysis of Scaling and Spatial Clustering of Fractures, in Fractals in the Earth Sciences (C. C. Barton and P.R.LaPointe, eds.) Plenum Press, New York and London

3. Billaux, D., J. P. Chiles, K. Hestir and J. Long, 1989, Three-dimensional statistical modeling of a fracture rock mass - an example from the Fanay-Augeres mine: International Journal of Rock Mechanics and Mining Sciences, v. 26, no.3/4, p. 281-299.

4. Cacas, M.C., E. Ledoux, G. de Marsely, B. Tillie, A. Barbreau, E. Durand, B. Feuga and P. Peaudecerf, 1990, Modeling fracture flow with a stochastic discrete fracture network: calibration and validation. 1: The flow model: Water Resources Research, v. 26, p. 479-489.

5. Chiles, J. P. and G. de Marsily, 1993, Stochastic models of fracture systems and their use in flow and transport modeling, in J. Bear, C. F. Tsang and G. de Marsily, eds., Flow and contaminant transport in fractured rock: San Diego, Academic Press, p. 169-231.

6. Dershowitz, W.S., and Einstein, H. H. 1988. Characterizing Rock Joint Geometry with Joint System Models", Rock Mechanics and Rock Engineering, No. 21, p. 21-51.

7. Guo, G., George, S. A., and Lindsey, R. P., 1999. Statistical Analysis of Surface Lineaments and Fractures for Characterizing Naturally Fractured Reservoirs, in R. Schatzinger and J. Jordan, eds., Reservoir Characterization - Recent Advances, AAPG Memoirs 71, p. 221-250

8. Hanks, C.L., Lorenz, J., Teufel, L., Krumhardt, A.P.: "Lithologic and structural controls on natural fracture distribution and behavior within the Lisburne Group, Northeastern Brooks Range and North Slope Subsurface, Alaska”, AAPG Bulletin, v. 81, No. 10, 1997, p. 17001720 . 
9. Hosking, J. R. M. and Wallis, J. R., Regional Frequency Analysis, Cambridge University Press, Cambridge, United Kingdom (1997)

10. Jensen, J. L. et al., Statistics for petroleum engineers and geoscientists, Prentice Hall, Upper Saddle River, NJ (1997)

11. Karpov, A.: "Lisburne formation fracture characterization and flow modeling," MS Thesis, Texas A\&M University, 2001.

12. Lorenz, J. C. and Hill, R.E. 1995. Subsurface Fracture Spacing: Comparison of Inferences From Slant/Horizontal and Vertical Cores", SPE Formation Evaluation, March 1995, p. 6672.

13. Montroll, E. W. and Schlesinger, M. F., 1983. Maximum Entropy Formalism, Fractals, and 1/f Noise: A Tale of Tails, J. Stat. Phys., 32: 209-230

14. Putra, E., Fidra, Y., and Schechter, D. S.: Use of experimental and simulation results for estimating critical and optimum water injection rates in naturally fractured reservoirs," 1999 SPE Annual Conference and Exhibition, SPE Paper 56431.

15. Rock fractures and fluid flow: contemporary understanding and applications, Committee on Fracture Characterization and Fluid Flow et al., National Academy Press, Washington, DC (1996)

16. Rouleau, A., and Gale, J. E., 1985. Statistical Characterization of the Fracture System in the Stripa Granite, Sweden, International Journal of Rock Mechanics and Mining Sciences, Vol. 22, p. 353

17. Sahimi, M.: Applications of Percolation Theory: Taylor \& Francis Ltd, London, 1994, 258 p.

18. Sato, K., 2000, Productivity correlation for horizontal sinks completed in fractured reservoirs: Society of Petroleum Engineers Annual Conference and Exhibition, SPE Paper 62581.

19. Wu, H., and Pollard, D.D.: "An Experimental Study of the Relationship Between Joint Spacing and Layer Thickness", Journal of Structural Geology, v. 17,1995, p. 887-905.

\section{Appendix A. Sample L-moment calculations}

Hoskins and Wallis (1997) formulated several important principles of the regional frequency analysis, some of which are relevant to our task:

1. Frequency analysis should be robust. In many cases, it is unreasonable to expect a model to be an exact representation of a physical process. Much more important the modeling procedure to be robust, i.e. it "should yield quantile estimates whose accuracy is not seriously degraded when the true physical process deviates from the model's assumptions in a plausible way."

2. Use Monte Carlo simulation to establish the properties of a frequency analysis procedure, or to compare two or more procedures.

3. Frequency distributions need not to be "textbook" distributions. For an adequate modeling, it is wise to include candidates having a wide range of moderate- and heavy-tailed behavior or distributions with enough free parameters.

4. L-moments are useful summary statistics. Sample moment statistics, particularly skewness and kurtosis, are often used to judge the closeness of an observed sample to a postulated distribution. However, these statistics have algebraic bounds depending on a sample size and therefore they are not reliable in certain cases. A better approach uses L-moment statistics which are "able to characterize a wider range of distributions and, when estimated from a sample, are more robust to the presence of outliers in the data." The authors propose a plot 
of L-skewness versus L-kurtosis for various standard distribution types. This plot is used for diagnostic purposes, i.e. location of sample points on the diagram can show the best-fit distribution. A procedure of L-moment calculation is described below.

Estimation of L-moments is based on a sample of size $n$, arranged in ascending order. Let $x_{1: n} \leq x_{2: n} \leq \ldots \leq x_{n: n}$ be the ordered sample. It is convenient to begin with an estimator of the probability weighted moment $\beta_{\mathrm{r}}$. An unbiased estimator of $\beta_{\mathrm{r}}$ is

$$
b_{r}=n^{-1}\left(\begin{array}{c}
n-1 \\
r
\end{array}\right)^{-1} \sum_{j=r+1}^{n}\left(\begin{array}{c}
j-1 \\
r
\end{array}\right) x_{j: n}
$$

This may alternatively be written as

$$
\begin{aligned}
& b_{0}=n^{-1} \sum_{j=1}^{n} x_{j: n}, \\
& b_{1}=n^{-1} \sum_{j=2}^{n} \frac{(j-1)}{(n-1)} x_{j: n}, \\
& b_{2}=n^{-1} \sum_{j=3}^{n} \frac{(j-1)(j-2)}{(n-1)(n-2)} x_{j: n},
\end{aligned}
$$

and, in general,

$$
b_{r}=n^{-1} \sum_{j=r+1}^{n} \frac{(j-1)(j-2) \ldots(j-r)}{(n-1)(n-2) \ldots(n-r)} x_{j: n}
$$

The sample L-moments are defined by

$l_{1}=b_{0}$

$l_{2}=2 b_{1}-b_{0}$

$l_{3}=6 b_{2}-6 b_{1}+b_{0}$

$l_{3}=20 b_{3}-30 b_{2}+12 b_{1}-b_{0}$

and, in general,

$l_{r+1}=\sum_{k=0}^{r} p_{r, k}^{*} b_{k} ; \quad r=0,1, \ldots, n-1$

where

$$
p_{r, k}^{*}=(-1)^{r-k}\left(\begin{array}{l}
r \\
k
\end{array}\right)\left(\begin{array}{c}
r+k \\
k
\end{array}\right)=\frac{(-1)^{r-k}(r+k) !}{(k !)^{2}(r-k) !}
$$

\section{Appendix B. Jack-knifing Analysis}

Assume we have a sample of size $n$. Any statistical properties, for example L-Skewness $\left(\mathrm{T}_{3}\right)$ and L-Kurtosis $\left(\mathrm{T}_{4}\right)$ are calculated for whole set. The jack-knifing starts with a removal of the first data point. $T_{3}$ and $T_{4}$ now are re-calculated for the remaining $n-1$ data points. Then, the first is replaced and the second data point is removed from the full set of $n$ numbers. Another pair of L-moments is calculated, etc. The procedure is repeated until the last $\left(n^{\text {th }}\right)$ data point is removed and the L-moments are calculated. As a result we have $n-1$ L-moment pairs calculated for sub-sets with one removed point and L-moments calculated for the full data set. This is 
illustrated on Fig. 3 where, for each fracture property, we can see point clouds formed by the $n$ values.

\section{Figures}
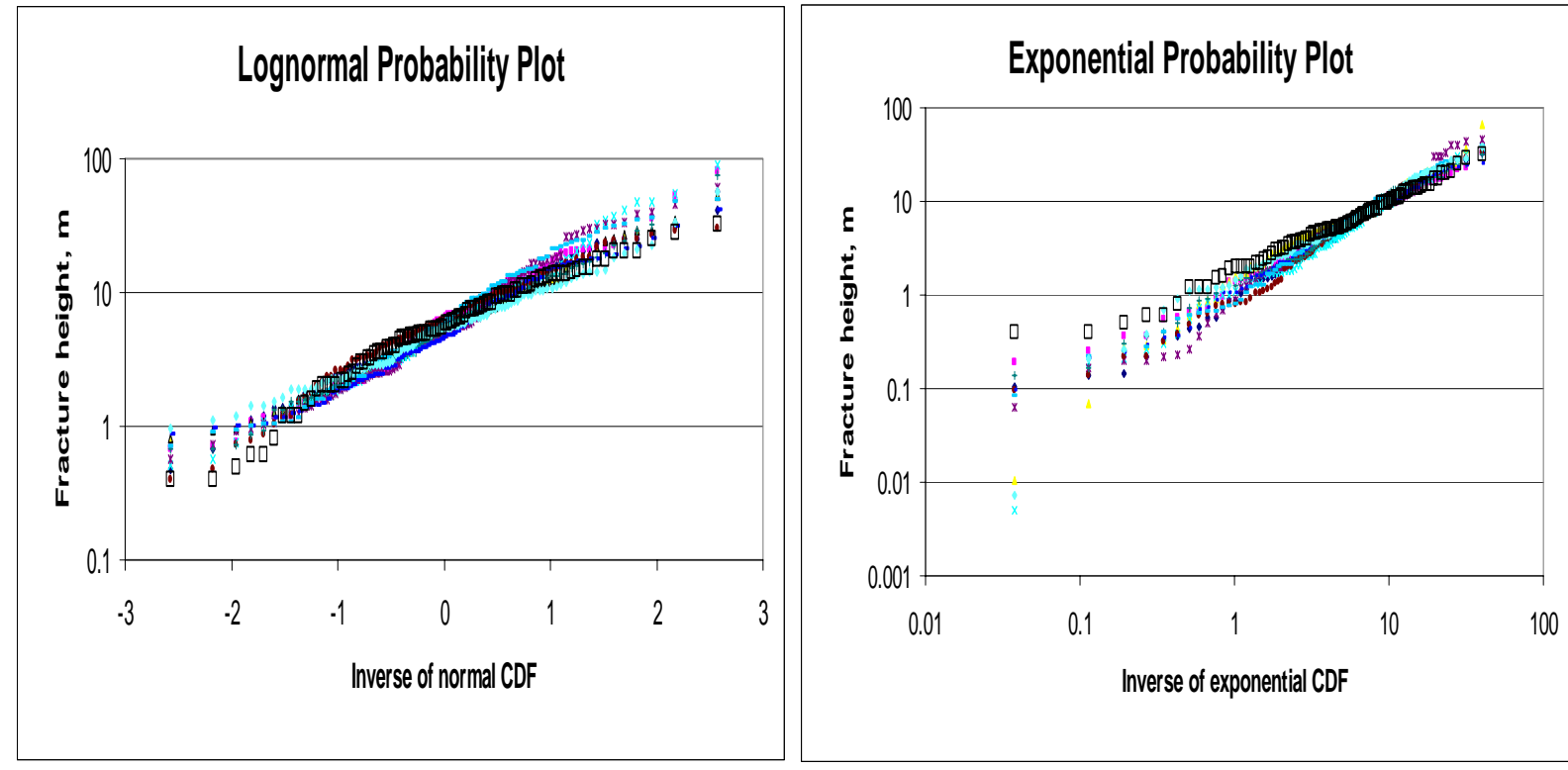

Figure 1 Results of Monte Carlo simulations on probability plots for NS fracture height. Squares represent values from data, dots show Monte Carlo simulated values.

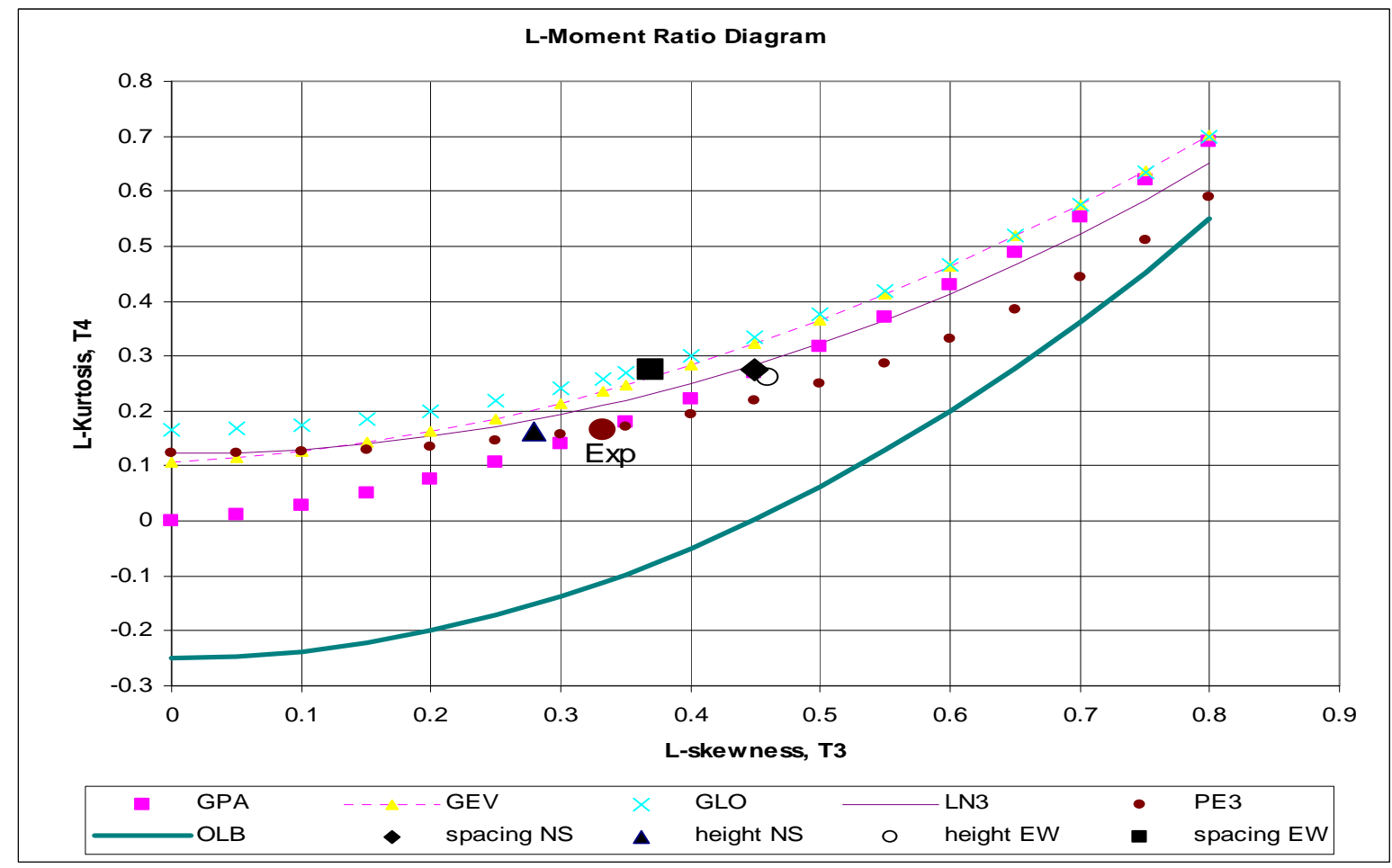

Figure 2 L-moment plot with fracture height and spacing sample points. 


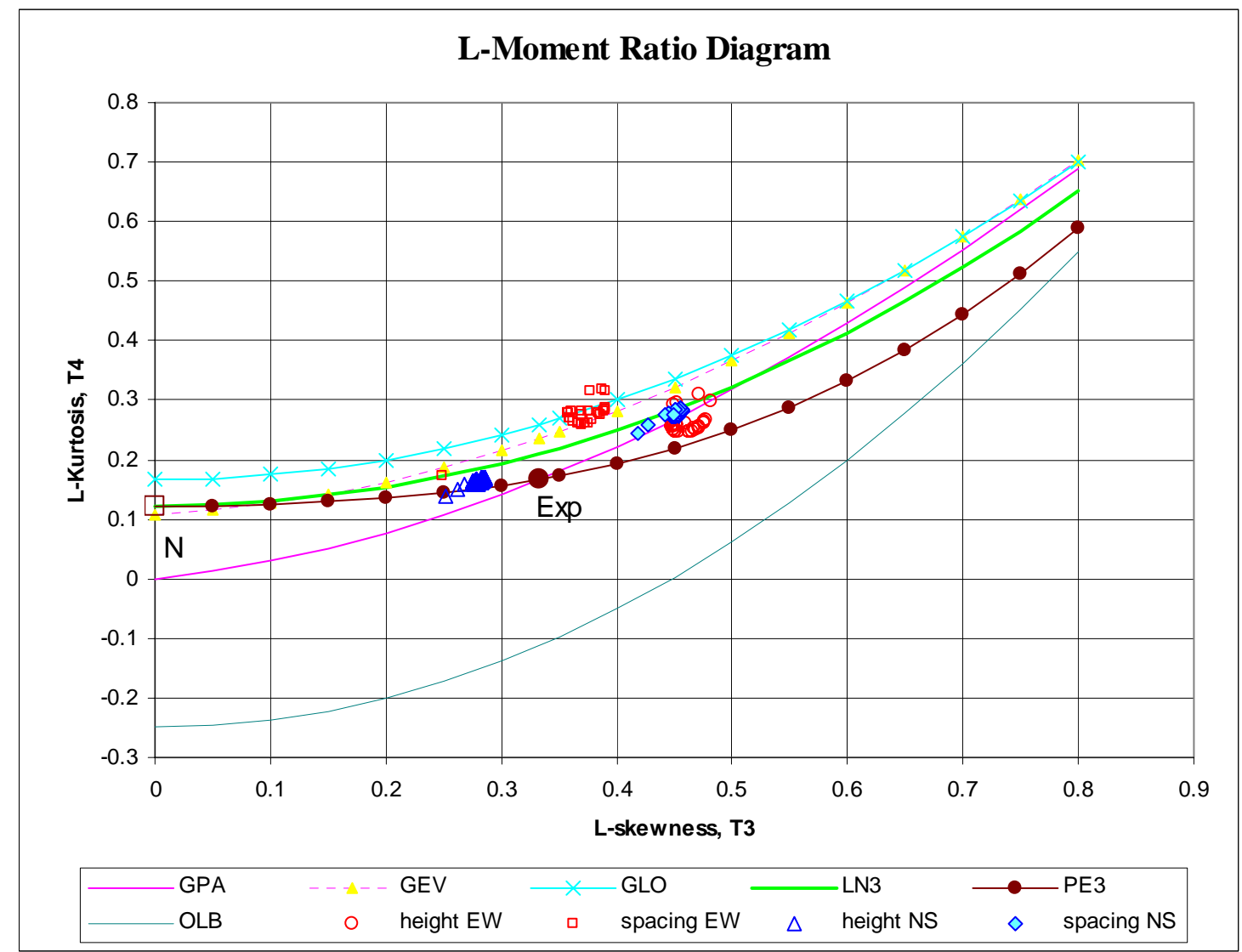

Figure 3 “Jack-knifing” simulation results shown on L-moment plot.

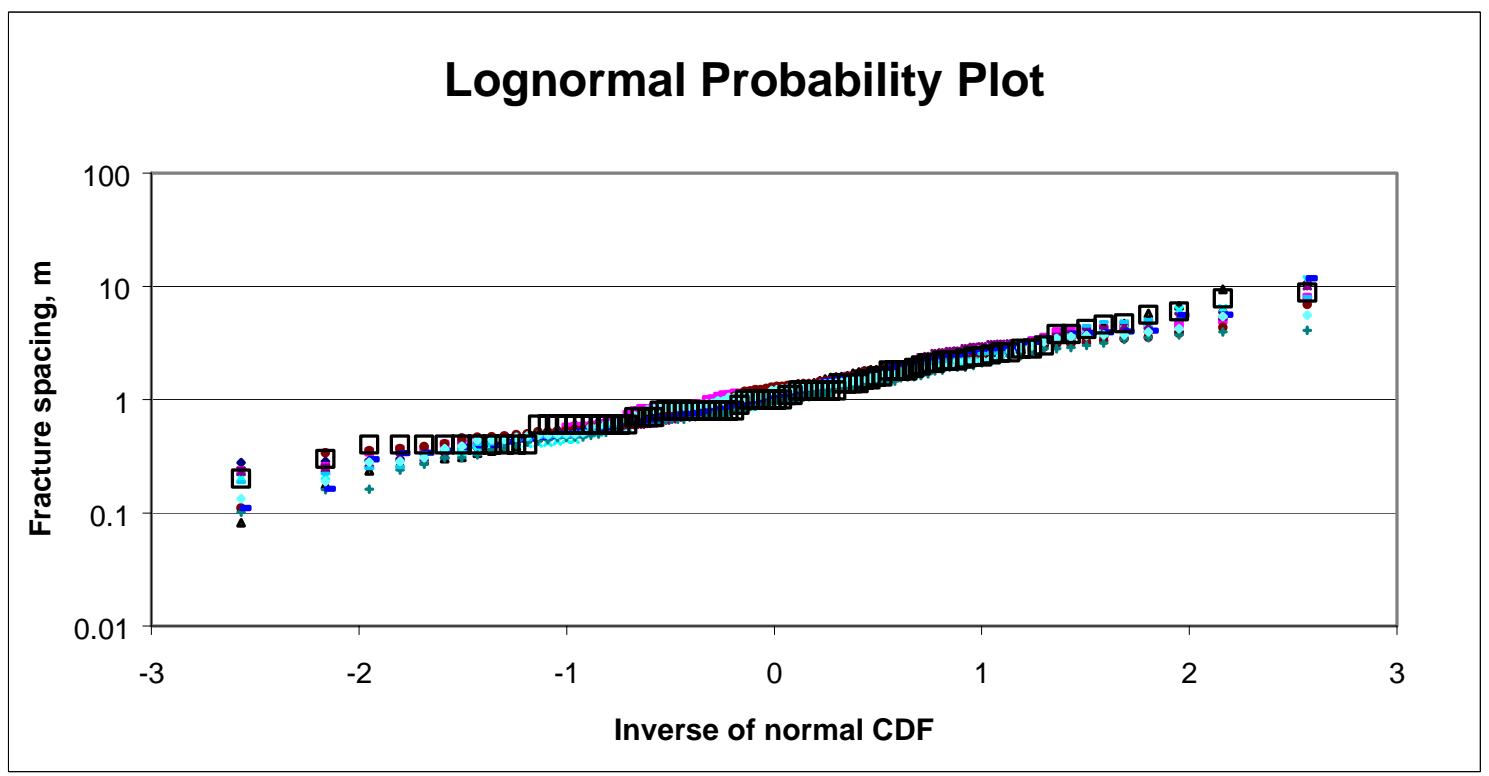

Figure 4 Probability plots for NS fracture spacing. Squares represent sample, dots show Monte Carlo simulated values. 


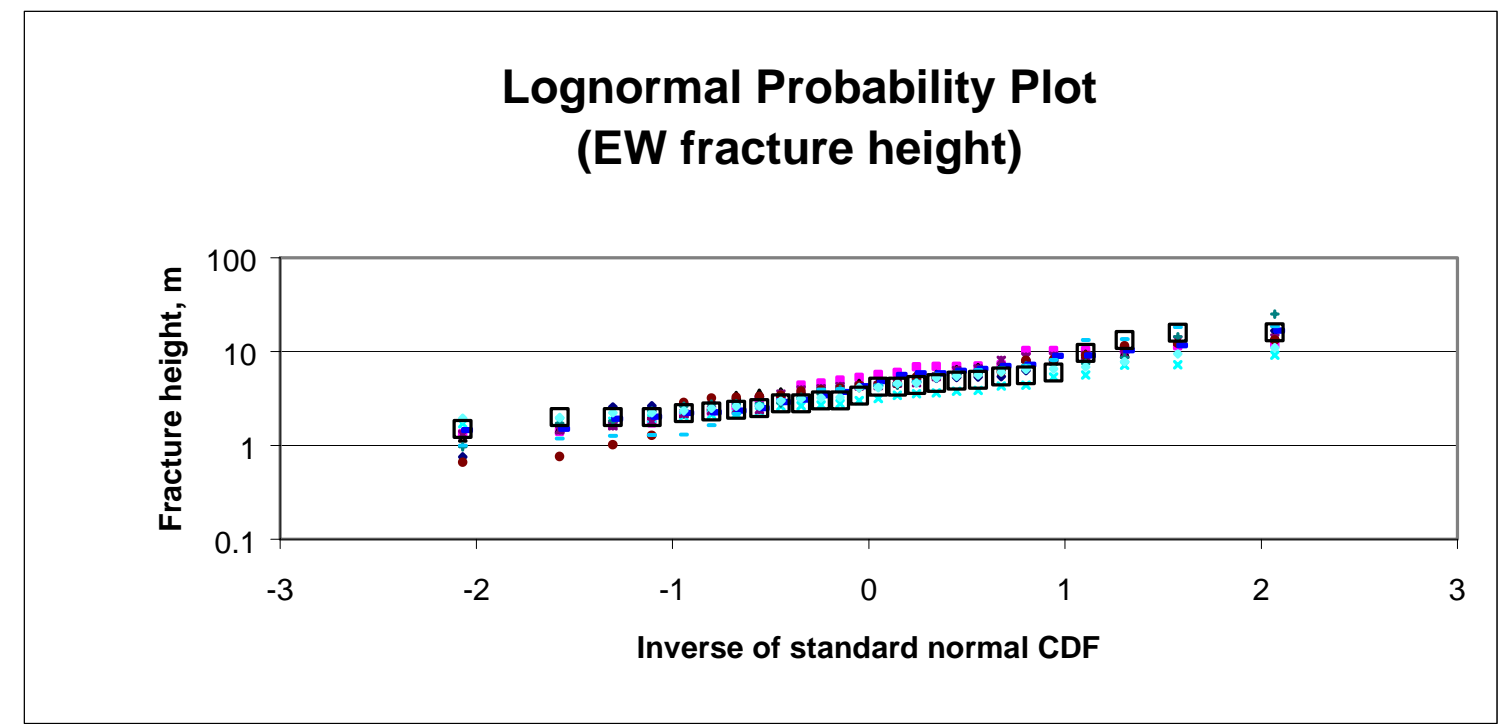

Figure 5 Probability plots for EW fracture height. Squares represent sample, dots show simulated values.

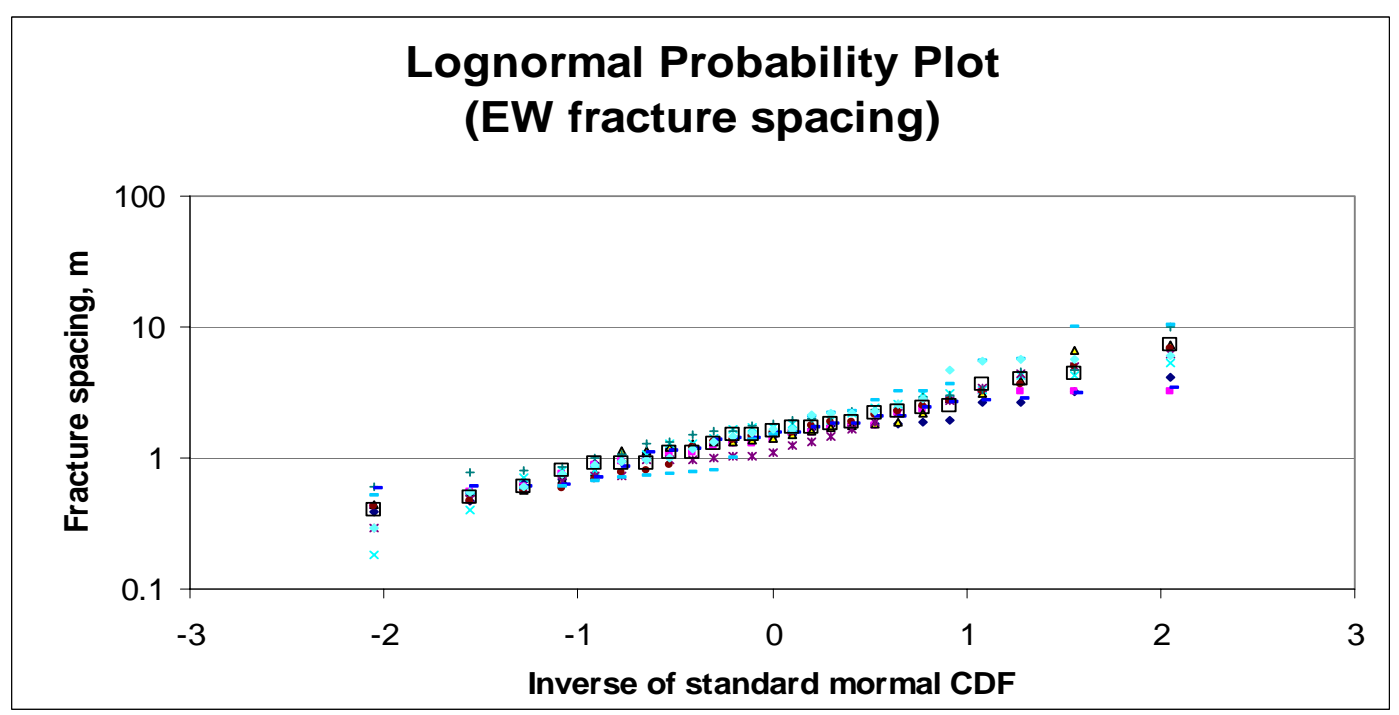

Figure 6 Probability plots for EW fracture spacing. Squares represent sample, dots show simulated values. 


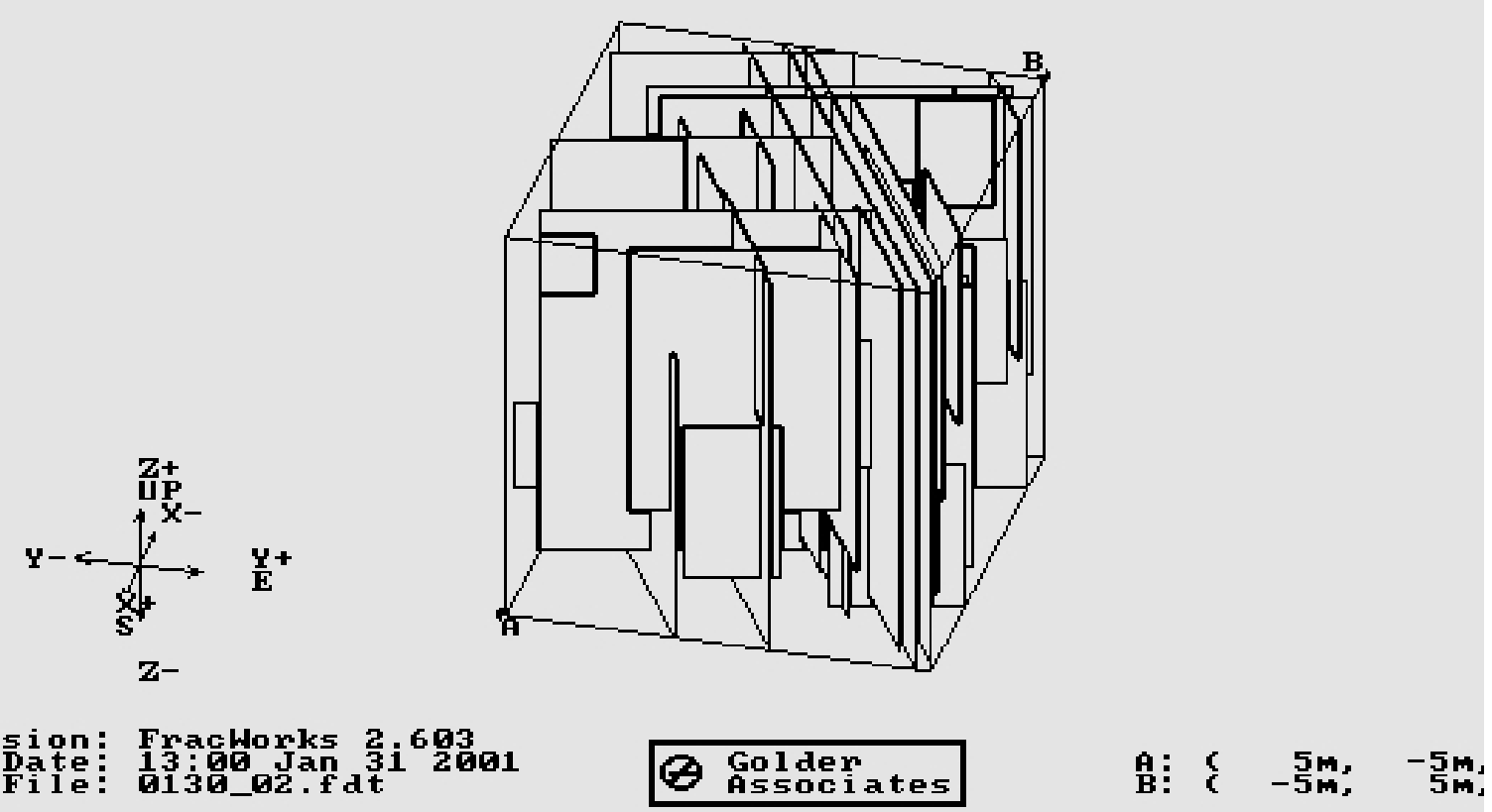

Figure 7 Fracman model of megafractures $\left(10 \times 10 \times 10 \mathrm{~m}^{3}\right)$

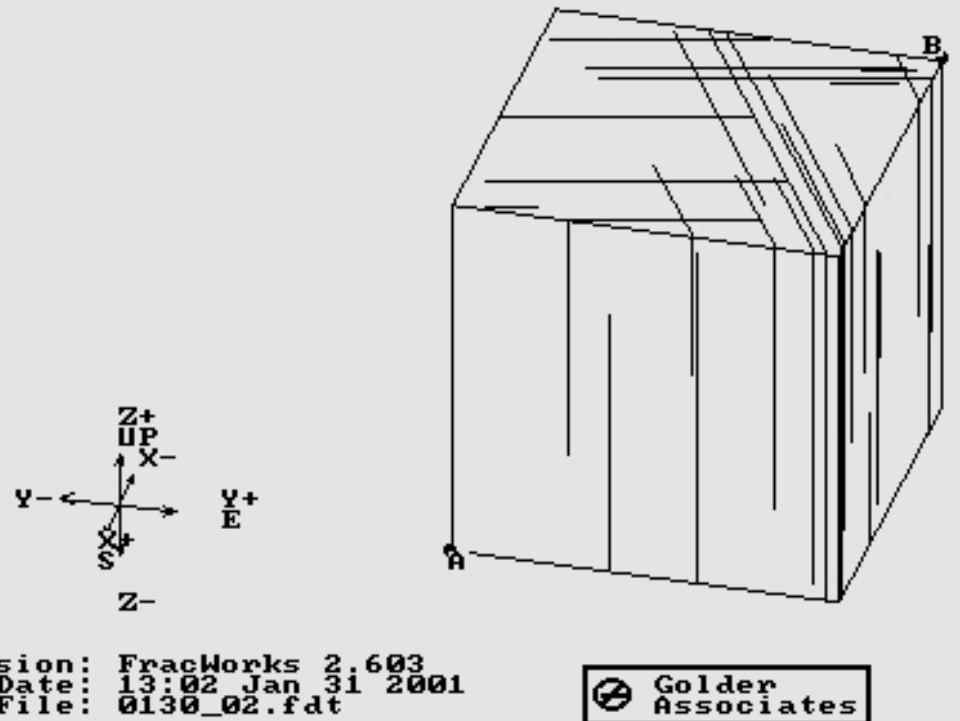

Figure 8 Fracman model showing only fracture traces $\left(10 \times 10 \times 10 \mathrm{~m}^{3}\right)$ 


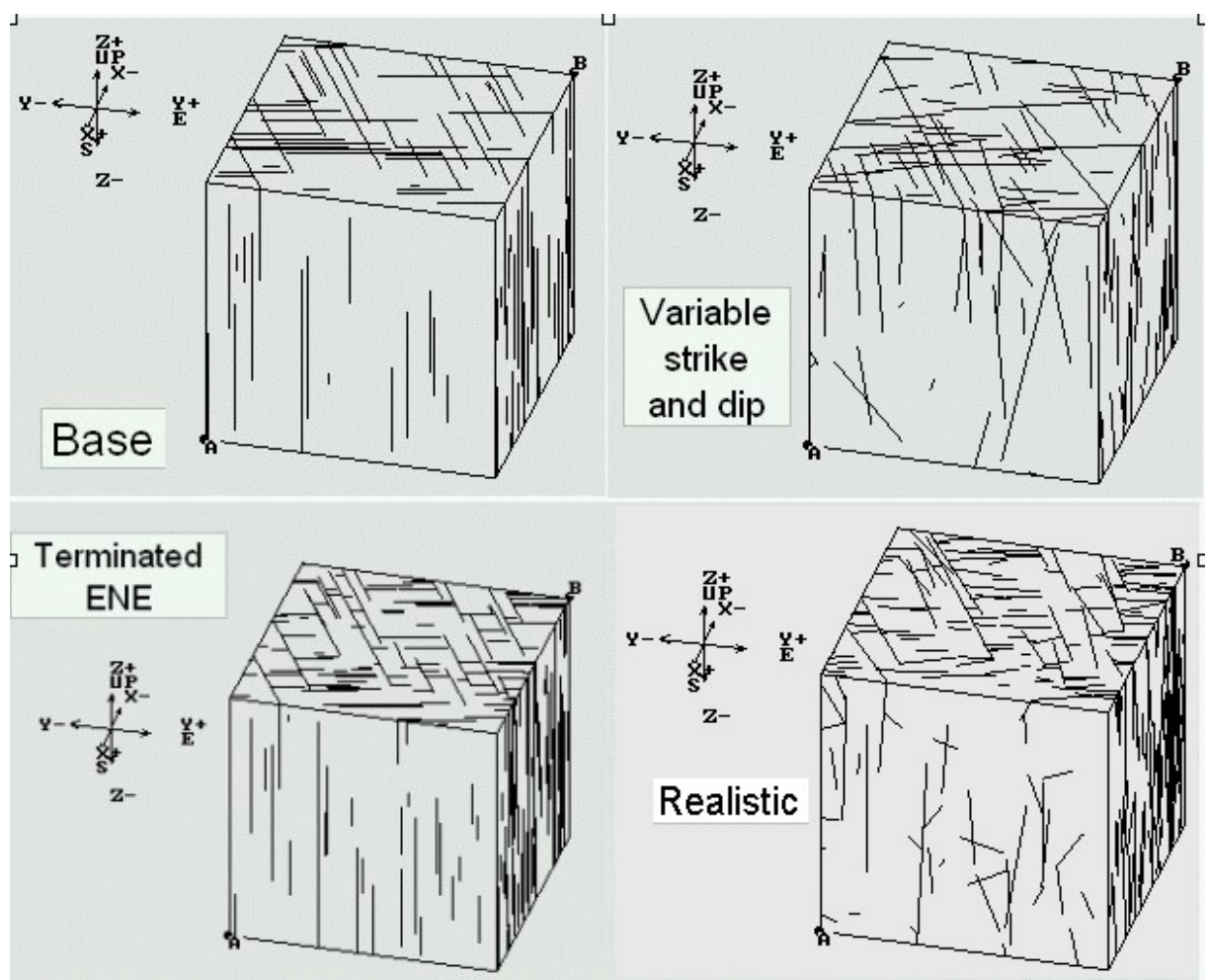

Figure 9 Different cases simulated in FracMan software. 20x20x20 $\mathrm{m}^{3}$ generation region is shown. S - south, E - east.
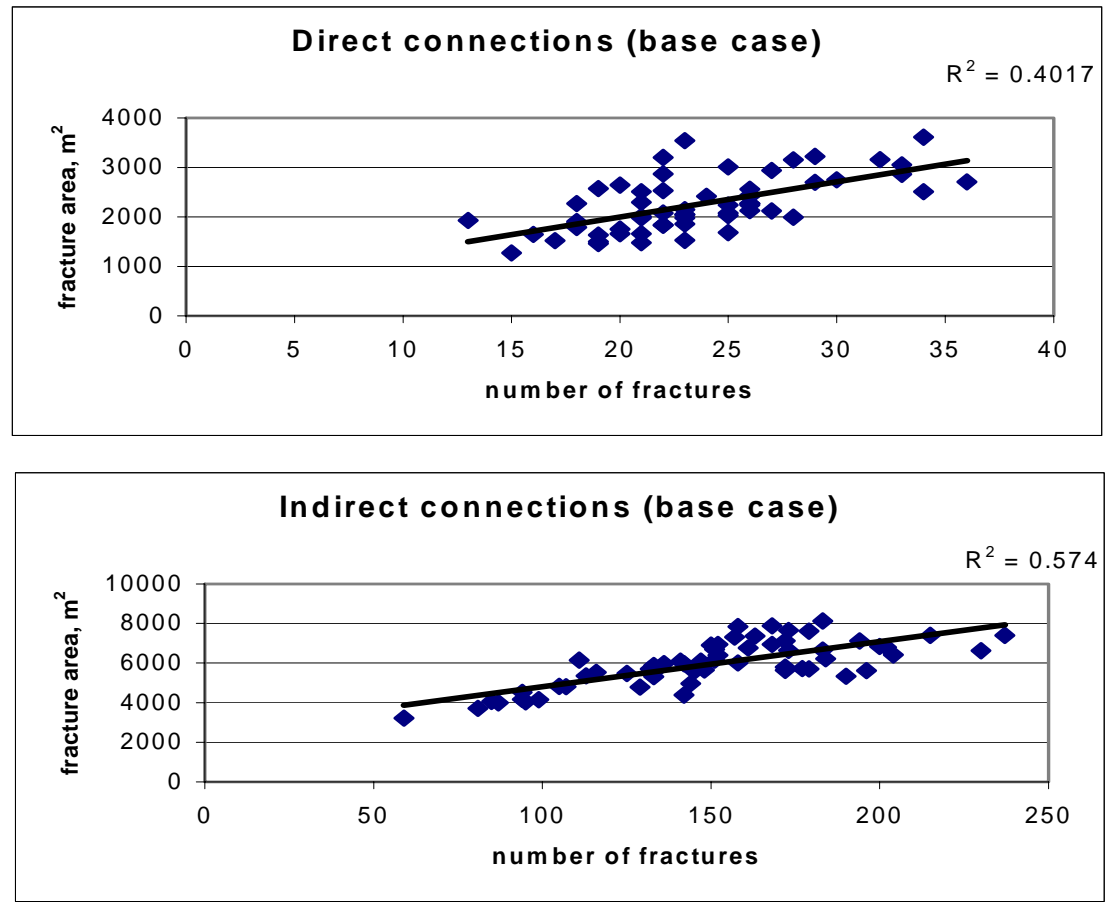

Figure 10 Fracture number contacted by the wellbore vs. matrix area accessed for the "base" case model. 

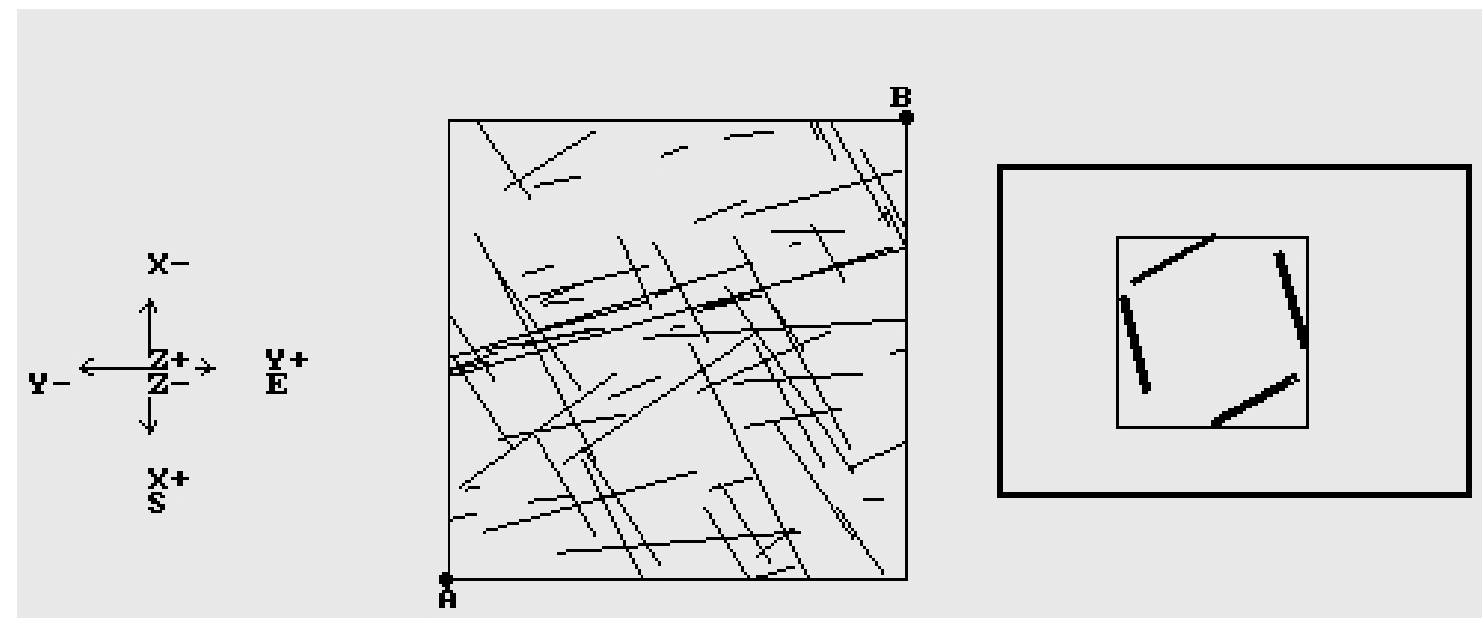

Figure 11 FracMan working window showing orientations of four 10 - meter long wellbores used for the anisotropy analysis.

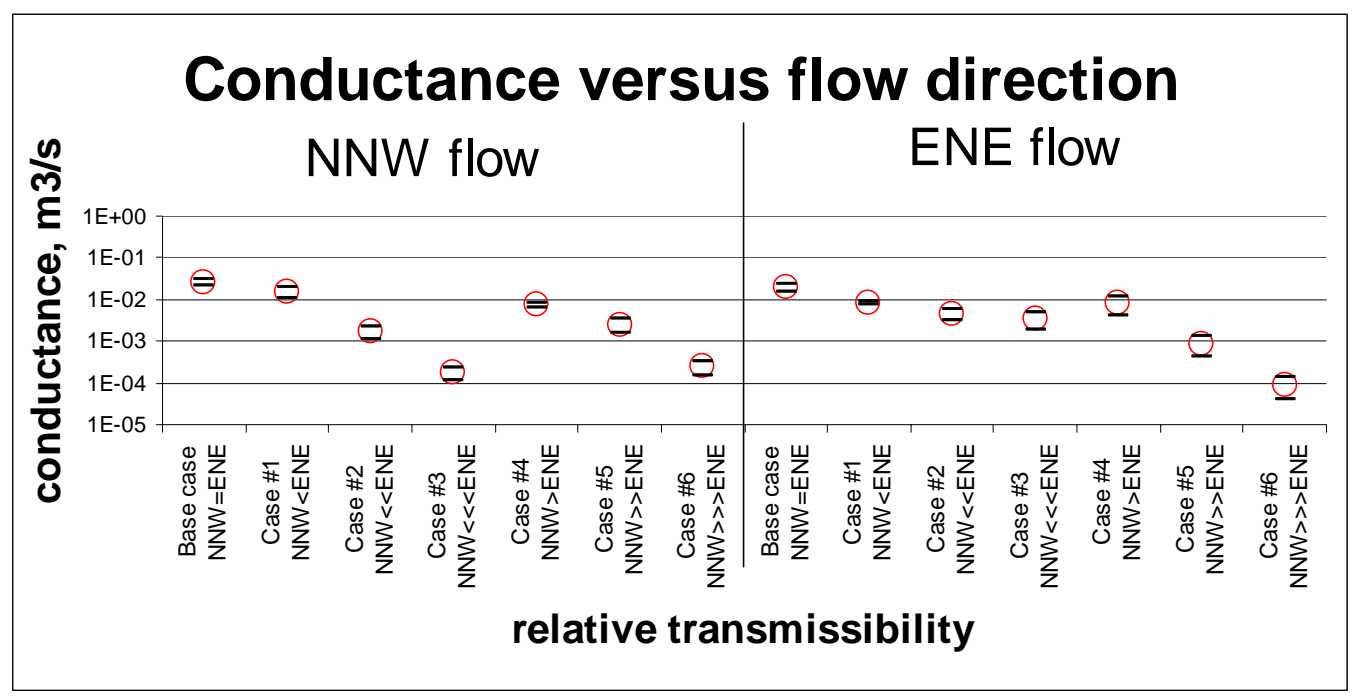

Figure 12 Conductance versus flow direction for the "base" case and 6 cases with variable relative transmissibility of the sets. "NNW $<$ ENE", "NNW $<<$ ENE", "NNW $<<<$ ENE" denote cases with NNW fracture transmissivity 1, 2, and 3 orders of magnitude lower than ENE fracture transmissivity (similar notation are used for the inverse cases). Circles show average value; bars indicate standard error deviation from the average value. 


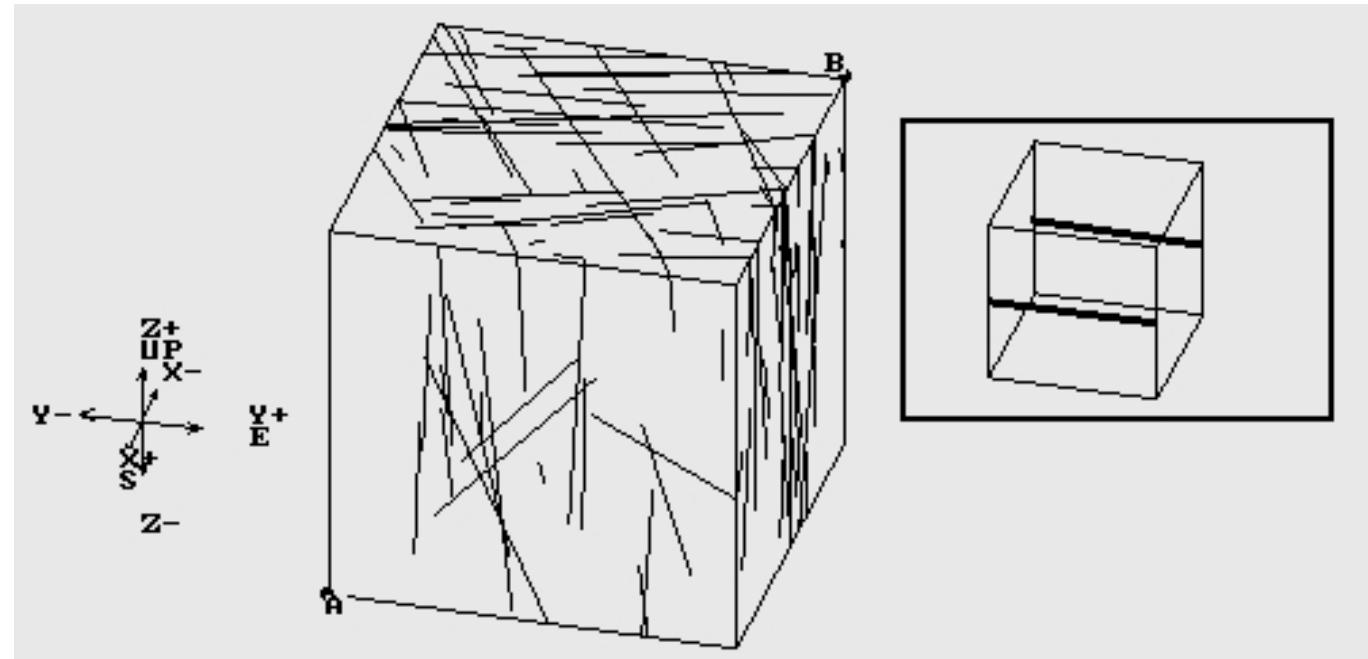

Figure 13 FracMan working window showing orientation of 2 wellbores used for the sensitivity study. $20 \times 20 \times 20 \mathrm{~m}^{3}$ generation region is shown; wellbore length is $20 \mathrm{~m}$. 


\title{
Fracture Timing and Flow Implications in Folded Lisburne
}

T. D. Bui, J. L. Jensen, Texas A\&M University

and J. Brinton, C. L. Hanks, University of Alaska Fairbanks

\begin{abstract}
In exposed detachment-folded Lisburne Group carbonates, field evidence and statistical analysis suggest that a significant population of fractures are either late folding or post-date folding.

Both prefold fractures and penetrative strain associated with peak folding are overprinted by late-folding and post-folding fractures. The late fold fractures strike EW parallel to the fold axes, are perpendicular to bedding, are often only partially filled with cement, and generally terminate at bedding planes. These and the earlier structures are consistently overprinted by pervasive late NS-striking extension fractures. These later fractures strike perpendicular to the fold axes, are vertically extensive, evenly spaced and unfilled. Both the late fold and post fold fracture sets have similar average and median spacing.

Statistical analysis of fold angle and fracture spacing indicates that, as the folds tighten, the spacing of both the EW and NS-striking fracture sets increases by a factor of two or three and becomes slightly more variable. This behavior is opposite from that expected if the fractures were closely related to folding. It suggests that the two sets are similar to each other and are only weakly related to the folding.

This weak genetic relationship between folding and formation of the most obvious and open fractures serves as an important example with major consequences for reservoir modeling. Complex genetic and timing relationships between fractures and folds may result in several fracture sets, each having different characteristics (e.g., size, amount of fill, and termination type). Unless recognized, genetically disparate fractures may be combined into one or a few sets to produce a reservoir model with fracture properties which do not apply to any of the sets. This could result in inappropriate wellbore placement or inaccurate productivity and recovery estimates.
\end{abstract}

\section{Introduction}

Understanding and quantifying the fracture distribution can be critical for the exploitation of a fractured reservoir. Unfortunately, surveying and measuring fractures in the subsurface is usually difficult and very costly. Examination of fractures in outcrops of the equivalent formation may be a useful means of studying the fracture properties and their distribution under the influence of different parameters. This research examines the fracture distributions within detachment-folded Carboniferous Lisburne Group carbonates, exposed in northeastern Brooks Range of Alaska.

The Carboniferous Lisburne Group in the northeastern Brooks Range is the closest exposed stratigraphic equivalent to the reservoir of the Lisburne oil field, located approximately $120 \mathrm{~km}$ to the northwest (Fig. 1). A thrust front separates the subsurface Lisburne field from the Lisburne Group exposed in the northeastern Brook Range fold and thrust belt (Hanks et al., 1997). The Lisburne Group has deformed primarily by detachment folding and thrusting throughout most of the northeastern Brook Range (Homza and Wallace, 1997). In the Fourth Range and the Shublik Mountains, the Lisburne Group deformed into detachment folds over regional anticlinora (Fig. 2). Detailed structural and stratigraphic aspects of the Lisburne Group and the northeastern Brooks 
Range are discussed by Homza and Wallace (1997), Wallace and Hanks (1990), and Hanks et al. (1997). The exposed detachment folds in this area serve as a target of the fracture study in this work.

Numerous studies have investigated the relationship between fracture properties and parameters related to the mechanical-stratigraphy parameters. Many suggest that the average fracture spacing is directly proportional to the formation bed thickness (McQuillan, 1973; Ladeira and Price, 1981; Huang and Angelier, 1989; Narr and Suppe, 1991; Ji and Saruwatari, 1998; Bai and Pollard, 2000). Fracture spacing also appears to be a function of rheology, with more competent rocks having more closely spaced fractures (Huang and Angelier, 1989). McQuillan (1973) investigated the Asmari limestone outcrops over an extensive area of the Zagros Mountains and proposed that fracture density has an inverse logarithmic relation to bed thickness but is independent of structural setting.

Others have investigated the effect of the lithology on the fracture distribution. Hanks et al. (1997) showed that lithology is the primary controlling factor on fracture properties and characteristics in relatively undeformed sections of the upper Lisburne Group in the eastern Sadlerochit Mountains. In these undeformed carbonates, grainstones are the least fractured, with wider and more through-going individual fractures. Dolomitic mudstones are the most fractured, but have narrower fractures of limited vertical extent that generally terminate at bed boundaries. Homza and Wallace (1997) discussed the effect of the contrast between layers on the fracture distribution and termination.

Some other researchers have investigated the effects of the structural setting on the fracture distribution. Murray (1969) assumed that fracture aperture increased as the strain or the degree of the curvature of the bed increased. Several studies (Nelson and Serra, 1993; Lisle, 1994; Jamison, 1997; Henning, 2000) suggest that fracture density increases with increasing bed curvature. It is now recognized that there are different types of fault-related folds (e.g. fault bend, fault propagation and detachment folds). These folds are thought to develop by different mechanisms, so that the fracture distribution between folds may vary depending upon the type of fold and the mechanism by which that fold formed. For example, Jamison (1997) suggested that the highest fracture density could be found in the mid-limb region instead of in the region of greatest curvature (the hinge).

Thus, the studies of the fracture distribution as a function of mechanical stratigraphy in folded bedded rocks have generally focused on following major parameters: bed thickness, degree of deformation, lithology, and the contrast between layers in layered formations. The observations are that the average fracture spacing is linearly proportional to bed thickness, fracturing is enhancing by the degree of strata bending, and lithology controls the difference in fracture spacing in beds of equal thickness and in the same structural position.

In contrast to these observations, our analysis of fracture data from detachment-folded Lisburne Group Carbonates in the northeastern Brooks Range, suggests that:

1. Stratigraphic bed thickness does not have a consistent effect on fracture spacing.

2. Fracture density does not increase with increasing curvature.

These observations and other field observations indicate a complex relationship between fracture and folds. Our observations suggest that bedded rocks in folded systems may experience multiple fracture generation episodes before, during and after folding. Complex genetic and timing relationships between fractures and folds may result in several fracture sets, each having different characteristics (e.g., size, amount of fill, and termination type). Unless recognized, the 
genetically distinct fractures may be combined into one or a few sets to produce a reservoir model with fracture properties which do not apply to any of the sets.

\section{Fracture data}

A total 464 fractures were collected from 3 places: Fourth Range, North Shublik and South Shublik Mountains (Figs. 1 and 2). The data represented 25 outcrop locations, from which 19 are on the limb, 2 are on synclinal hinges, and 4 are on anticline hinges of 5 folds resulting in a total of 64 fracture sets. Outcrops to be studied were chosen based on proximity to or location on a detachment fold and accessibility to measurable fractures. Exposed bedding planes were chosen instead of outcrop face exposures whenever available, due to the greater ease and accuracy of measurement. Fracture data were collected by J. Brinton at University of Alaska during the summer of 1999. Brinton (2001) gave detailed description of how data were collected and processed. A brief summary of the fracture data is given below.

At each outcrop, general geologic data were collected, including bed thickness, orientation and lithology. Fracture data were collected using a "scan-line" technique. At each location, a nylon tape measure was laid out along a line perpendicular to the fracture set of interest. Each fracture encountered along the scan line was then counted and described and its distance from the beginning of the measuring tape was recorded. The following aspects of each fracture were described: the orientation (strike and dip); fracture height (the linear measurement of the fracture perpendicular to bedding); fracture length/depth (the linear measurement of the fracture parallel to bedding); and fracture aperture (as measured perpendicular to the fracture walls).

Lithologies sampled ranged from carbonate mudstone to grainstone with 57 fractures associated with mudstone, 87 with wackestone, 286 with packstone and 166 with grainstone. Stratigraphic bed thicknesses ranged from $0.1 \mathrm{~m}$ to $4 \mathrm{~m}$. The interlimb angle of the surveyed folds ranged from $90^{\circ}$ to $160^{\circ}$.

\section{Data observations}

General observations are as follows.

Orientation. Two major fracture orientations can be distinguished throughout the area of study. The fractures in the first set strike EW parallel to the fold axes and are mostly perpendicular to bedding. The later, NS-striking fractures are perpendicular to the fold axes, vertically extensive, and more evenly spaced. Fig. 3 illustrates the range in fracture strike.

Filling. The majority of the fractures are partially filled with calcite, the rest are unfilled. The number of unfilled fractures varies depending on the fracture orientation and location on the fold. Generally, NS fractures are less filled than the EW fractures.

Fracture Termination. In both hinge and limb zones, the fractures terminate primarily at bedding planes, and less frequently terminate at other fractures. In many locations, the age relationship between the two fracture sets (as determined by abutment patterns) is not clear. In general, the NS fractures are usually more through-going than the EW fractures.

As these observations show, the two fracture sets observed on detachment-folded Lisburne Group carbonates have distinctive differences in orientation, amount of fill and the nature of their termination. These differences could have a significant impact on the role of each fracture set in fluid flow within the reservoir. 


\section{Statistical analysis}

Brinton (2001) gave the detailed fold-by-fold analysis of the fracture characteristics. His analysis suggests that the NS fractures formed late, or after folding, while EW fractures showed evidence of having formed during folding. In the following section, we shows some results from the refined area-wide scale analysis of the effect of bed thickness, degree of folding, and structural position on the fracture characteristics. This analysis aimed at identifying any areawide patterns or useful information toward understanding of fracturing in this geological setting.

At first glance, the NS and EW fracture sets have very similar spacing statistics: averages, medians, and standard deviations (Table 1). A plot (Fig. 4) of fracture spacing versus bed thickness shows that, as bed thickness increases, fracture spacing and its variability in both sets increases. A plot (Fig. 5) of fracture spacing versus interlimb angle shows a different trend: in each set, the average fracture spacing decreases and the spacing becomes more variable with increasing interlimb angle. Thus, both sets appear to have similar behavior with respect to the effects of bed thickness and tightness of the fold. On closer inspection, however, there are differences.

In subsequent statistical analysis, the fracture spacings were divided into subsets according to the values of bed thickness and interlimb angle (Figures $6 \& 7$ ). The thickness threshold was $2.0 \mathrm{~m}$ and the interlimb angle threshold was $105^{\circ}$. The criterion for the thresholds was that they maximized the differences between the resulting subsets. Along with graphical comparison of the different subsets, we applied several statistical tests to quantify and to assess the relationships between fracture spacing and mechanical stratigraphical parameters. We used the t-test for the average fracture spacing, the Kolmogorov-Smirnov (KS) test for the general difference between distributions, and a bootstrapping technique for the median (Neave and Worthington, 1988; Mooney and Dulal, 1995).

Spacing, Bed Thickness, and Interlimb Angle. A box plot of fracture spacing for the interlimb angle and bed thickness subsets (Fig. 6), shows that the fracture spacing is not affected by the value of bed thickness as it seems to be on Fig. 4. Within each range of interlimb angle, fracture spacing remains relatively unchanged for variations in bed thickness. This effect contrasts with the often-reported relationship between fracture spacing and bed thickness (McQuillan, 1973; Ladeira and Price, 1981; Huang and Angelier, 1989; Narr and Suppe, 1991; Ji and Saruwatari, 1998; Bai and Pollard, 2000). On Fig. 6, we also note that the fracture spacing increases for both subsets of bed thickness as the interlimb angle decreases. This relationship is contrary to the expectation that fracturing would be enhanced by folding i.e., fracture spacing is expected to be smaller for the tighter folds or small interlimb angle (Nelson and Serra, 1993; Lisle, 1994; Jamison, 1997; Henning, 2000). The observed relationship between fracture spacing and interlimb angle in these detachment folds suggests that the fractures may not be closely or wholly related to the folding. At the $95 \%$ confidence level, all three statistical tests confirmed what we observed graphically, i.e.:

- Bed thickness does not have significant effect on the fracture spacing distribution.

- As interlimb angle decreases, the fracture spacing increases and becomes more variable.

Spacing, Interlimb Angle, and Orientation. As already noted, the results of comparing the two fracture sets indicated that both sets are statistically similar. When plotted against interlimb angle, fracture spacing in both fracture sets appears to behave similarly (Fig. 7). Fracture spacing in both the NS and EW-striking fracture sets increases and becomes more variable as the 
interlimb angle decreases. A t-test confirms this. The KS and median test, however, reveal that the distribution and the median of the fracture spacing are significantly different for the two fracture orientations with large interlimb angle (Tables 4-6). As the fold tightens, the difference in fracture spacing between the two fracture sets decreases.

Spacing and Structural Position. The position of the sample location on the fold also has an effect on the fracture spacing distributions. Most of the differences in spacing distribution noted earlier are due to the fractures on the limbs of folds with small interlimb angles (Fig. 8). The fracture spacing on the hinge of folds is only weakly affect by the interlimb angle. Comparing the distribution of the fracture spacing of the NS and EW fractures on the limb of folds indicated that the variability of the fracture spacings is contributed mainly by the EW fractures. Fracture spacings for EW fractures on the limbs of folds with small interlimb angles are considerably larger than on the limb of folds with large interlimb angle (Fig. 9). The spacings of the NS fractures, however, only slightly change with the interlimb angle.

Fracture Size Analysis. The height distributions of the NS and EW-striking fracture sets are significantly different (Table 2). In particular,

- The average height distribution of the NS-striking set is twice the average of the EW-striking and the median height distribution of the NS-striking fracture set is $76 \%$ greater than the that of the EW set

- The $90^{\text {th }}$ percentile of the height distribution for the NS set is $114 \%$ greater than the $90^{\text {th }}$ percentile of the EW set.

These results agree with the visual assessment of fracture characteristics noted earlier. All statistical tests indicate significant height differences between the NS and EW sets.

The length distributions of NS and EW fractures are also significantly different (Table 3). While the median length distribution of the NS fractures is only $50 \%$ greater than the median length distribution of the EW fractures, the averages differ by $160 \%$, and the $90^{\text {th }}$ percentiles differ by $233 \%$. The average length of the largest $10 \%$ of NS fractures is 3.2 times the corresponding EW value.

Since the flow characteristics of fractured reservoirs can be controlled by a few large fractures, these differences in height and length between fracture sets can play an important role in the reservoir flow behavior.

\section{Implications for reservoir performance}

Based strictly on spacing, one could assume that the fracture flow properties for the EW and NS fracture sets would be similar. For example, if one only had borehole observations of fracture spacing, these sets would appear similar. The differences in termination, size, and fill observed between the subsets, however, could lead to significant differences in connectivity and wellbore placement.

In this study, we used the FracMan - a discrete fracture network modeling software by Golder Associates to generate the fracture system and to investigate its flow characteristics. The effects of termination, size and filling of different sets were assessed by studying the connectivity and the flow conductance along the principal fracture directions. In FracMan, flow conductance is defined as the minimum cutoff value of the network conductance between the source and the sink:

$$
C_{p}=\min _{i=1, n_{f}}\left\{T_{f i} W_{f}\right\}
$$


where $\mathrm{T}_{\mathrm{fi}}$ and $\mathrm{W}_{\mathrm{f}}$ are the transmissivity and width perpendicular to flow of the fractures within the network and $\mathrm{n}_{\mathrm{f}}$ is the number of fractures in the network.

Seven different scenarios of fracture termination and filling were studied. Each scenario consists of 20 realizations of each fracture set. The fracture characteristics shown in Tables 1-3 were used in generating the fracture sets. The fracture aperture of both fracture sets in this study is represented by an arbitrary constant. The flow conductivity in each direction was calculated between two horizontal wellbores placing perpendicular to the mean fracture orientation, at the distance of $8 \mathrm{~m}$ from each other. The plot of average flow conductance in the EW and NS direction is shown in Fig. 10.

The results of this modeling suggest several things. (1) The termination of EW fractures on the NS system significantly reduces the EW conductance while making little impact on the NS system conductance. (2) The degree of filling of the NS fractures has a critical effect on EW flow. The average EW system conductance decreases by half when the filling of $40 \%$ of NS fractures is introduced. (3) For the system studied here, it is clear that the larger NS fractures have a greater probability of interconnection with the EW set than the EW fractures do. The connectivity and conductance in the NS direction is less sensitive to the EW filling and termination. The EW connectivity, however, is very sensitive to the NS fracture properties.

Given two fracture sets with similar spacing characteristics, the set with the greater length and height plays an important role, not only for flow along their principal direction but also in the orthogonal direction. The implication of this is that the optimal well placement should be chosen based on all factors: the number of fractures connected, the primary area connected, and the flow conductance in different directions. The relationship of termination and filling of different fracture sets in the system play an important role in the assessment of the network characteristics.

The above results are similar to those obtained in a study by Karpov (2001) who used the same technique to examine flow performance of a less tectonically altered region of the Lisburne Group in the eastern Sadlerochit Mtns (Fig. 1). Karpov's (2001) evaluation indicated that the NS permeability drops by $1 / 2$ order of magnitude for each order of magnitude reduction in EW fracture permeability.

Karpov (2001) also demonstrated that optimum orientation for horizontal wellbores was affected by fracture size and their termination relationship. Given the differences in size of the two fracture sets, orienting the wellbore to intersect the maximum number of EW fractures intersected may give disappointing results. In that study, termination of the EW set against the NS fracture set changed the optimal wellbore orientation by $30^{\circ}$ and reduced the area of matrix contacted by $50 \%$.

\section{Conclusions}

Two distinct fracture sets were observed in detachment-folded examples of the Carboniferous Lisburne Group carbonates of northeastern Alaska: a EW-striking set that formed late during folding and a post-folding NS- striking set. Stastical analysis of outcrop fracture data shows that bed thickness does not have significant effect on the fracture spacing distribution of either set. Fracture density is only weakly related to the fold geometry, with fracture density greater on the limbs than in the hinge area. These results contradict the results of most other studies.

The weak or lack of effect of folding on the fracture spacing of each set suggests that both fracture sets are only weakly related or unrelated to the folding process. This and the above observations suggest that detachment fold geometry cannot always be used as a reliable predictive tool for fracture distribution within the Lisburne Group. 
This study clearly demonstrates that the local geological setting plays an important role in fracture spacing distribution. Determining the characteristics of the fractures, the relative age of the different fracture sets, and the relationship between the fractures and their local geologic setting can be an important factor in reservoir performance.

\section{Acknowledgements}

An expanded version of this work has been reported in SPE paper 76754, presented at the May, 2002 Western Regional Meeting in Anchorage. We wish to thank Golder \& Associates for the donation of Fracman software for this project.

\section{References}

1. Bai, T. and Pollard, D.D, 2000, Fracture Spacing in Layered Rocks: A New Explanation Based on the Stress Transition: Journal of Structural Geology, v. 22, p. 43-57.

2. Brinton J., 2001, Natural Fracturing in Carbonate Rocks as a Function of Lithology and Structural Position in a Detachment Fold: Examples From the Northeastern Brooks Range, Alaska: MS Thesis, University of Alaska, Fairbanks, AK, 158p.

3. Hanks, C.L., J. Brinton, and J. Lorenz, 2000, Fracturing in the Lisburne Group as a Function of Carbonate Lithology, Mechanical Stratigraphy and Position in Detachment Folds: Annual Report, DE-AC26-98BC15102.

4. Hanks, C.L., J. Lorenz, L. Teufel, and A.P. Krumhardt, 1997, Lithologic and Structural Controls on Natural Fracture Distribution and Behavior Within the Lisburne Group, Northeastern Brooks Range and North Slope Subsurface, Alaska: AAPG Bulletin, v. 81, no 10, p. 1700-1720.

5. Henning, P.H., 2000: "Combining Outcrop Data and Three-Dimensional Structural Models to Characterize Fractured Reservoirs: An Example from Wyoming," AAPG Bulletin, v. 84, no 6, p. 830-849.

6. Homza, T.X. and Wallace, W.K., 1997: "Detachment Folds With Fixed Hinges and Variable Detachment Depth, Northeastern Brooks Range, Alaska," Journal of Structural Geology, v. 19, p. 337-354.

7. Huang, Q. and Angelier, J., 1989, Fracture Spacing and its Relation to Bed Thickness: Geoogical Magazine, v. 126, p. 355-362.

8. Jamison, W. R., 1997, Quantitative Evaluation of Fractures on Monshood Anticline, a Detachment Fold in the Foothills of Western Canada: AAPG Bulletin, v. 81, no 7, p. 11101132.

9. Ji, S. and Saruwatari, K., 1998, A Revised Model for the Relationship Between Joint Spacing and Layer Thickness: Journal of Structural Geology, v. 20, p.1495-1508.

10. Karpov, V.A, 2001, Lisburne Formation Fracture Characterization and Flow Modeling: MS Thesis, Texas A\&M U., College Station, TX, 112p.

11. Ladeira, F.L. and Price, N.J., 1981, Relationship between Fracture Spacing and Bed Thickness: Journal of Structural Geology, v. 3, p. 179-183.

12. Lisle, R.J., 1994, Detection of Zones of Abnormal Strains in Structures Using Gausian Curvature Analysis: AAPG Bulletin, v. 78, p. 1811-1819.

13. McQuillan, H., 1973, Small-Scale Fracture Density in Asmari Formation of Southwest Iran and its Relation to Bed Thickness and Structural Setting: AAPG Bulletin, v. 57, p. 23672385 . 
14. Mooney, C.Z., and Dulal, R.D., 1995, Bootstrapping - A nonparametric approach to statistical inference, SAGE publications, CA, 212p.

15. Murrays, G.H.Jr., 1968, Quantitative Fracture Study - Spanish Pool, Mckenzie Co., North Dakota: AAPG Bulletin, v. 52, p. 57-65.

16. Narr, W. and Suppe, J., 1991, Joint Spacing in Sedimentary Rocks: Journal of Structural Geology, v. 13, p.1037-1037-1048.

17. Neave, H. R. and Worthington, P. L. 1998, Distribution Free Tests: Unwin Hyman Ltd., London, UK, 322p.

18. Nelson, R.A. and Serra, S., 1993, Vertical and Lateral Variations in Fracture Spacing in Folded Carbonate Sections and its Relation to Locating Horizontal Wells: Proc. Canadian SPE/CIM/CANMET International Conference on Recent Advances in Horizontal Well Applications, Canadian Society of Petroleum Engineers, Paper HWC94-41, 10.

19. Wallace, W.K. and Hanks, C.L., 1990, Structural Provinces of the Northeastern Brooks Range, Arctic National Wildlife Refuge, Alaska: AAPG Bulletin, v. 74, no 7, p. 1100-1118.

20. Wu, H. and Pollard, D.D., 1995, An Experimental Study of the Relationship Between Joint Spacing and Layer Thickness: Journal of Structural Geology, v. 17, p. 887-905.

TABLE 1 - FRACTURE SPACING SUMMARY

\begin{tabular}{|l|l|l|l|}
\hline & $\begin{array}{l}\text { EW } \\
\text { fracture }\end{array}$ & $\begin{array}{l}\text { NS } \\
\text { fracture }\end{array}$ & $\begin{array}{l}\text { Difference } \\
, \%\end{array}$ \\
\hline Number of fractures & 176 & 215 & - \\
\hline Average, $\mathrm{m}$ & 0.26 & 0.28 & 6.7 \\
\hline Median, $\mathrm{m}$ & 0.14 & 0.15 & 7.1 \\
\hline Standard deviation, $\mathrm{m}$ & 0.455 & 0.370 & -18.6 \\
\hline $90^{\text {th }}$ percentile, $\mathrm{m}$ & 0.45 & 0.65 & 44.4 \\
\hline
\end{tabular}

TABLE 2 - FRACTURE HEIGHT SUMMARY

\begin{tabular}{|l|c|c|c|}
\hline & $\begin{array}{c}\text { EW } \\
\text { fracture }\end{array}$ & $\begin{array}{c}\text { NS } \\
\text { fracture }\end{array}$ & $\begin{array}{c}\text { Difference } \\
, \%\end{array}$ \\
\hline Number of fractures & 203 & 250 & - \\
\hline Average, $\mathrm{m}$ & 0.595 & 1.165 & 96 \\
\hline Median, $\mathrm{m}$ & 0.34 & 0.6 & 76 \\
\hline Standard deviation, $\mathrm{m}$ & 0.708 & 1.639 & 131 \\
\hline $90^{\text {th }}$ percentile, $\mathrm{m}$ & 1.4 & 3.0 & 114 \\
\hline
\end{tabular}

TABLE 3 - FRACTURE LENGTH SUMMARY

\begin{tabular}{|l|c|c|c|}
\hline & $\begin{array}{c}\text { EW } \\
\text { fracture }\end{array}$ & $\begin{array}{c}\text { NS } \\
\text { fracture }\end{array}$ & $\begin{array}{c}\text { Difference, } \\
\%\end{array}$ \\
\hline Number of fractures & 192 & 247 & - \\
\hline Average spacing, $\mathrm{m}$ & 0.327 & 0.853 & 161 \\
\hline Median, $\mathrm{m}$ & 0.2 & 0.3 & 50 \\
\hline Standard deviation, $\mathrm{m}$ & 0.382 & 1.848 & 383 \\
\hline $90^{\text {th }}$ percentile, $\mathrm{m}$ & 0.6 & 2.0 & 233 \\
\hline
\end{tabular}


TABLE 4 - T TEST ON MEAN FRACTURE SPACING

\begin{tabular}{|l|c|c|c|c|}
\hline \multirow{2}{*}{} & \multicolumn{2}{|c|}{ Small interlimb angle } & \multicolumn{2}{c|}{ Large interlimb angle } \\
\cline { 2 - 5 } & EW & NS & EW & NS \\
\hline Small interlimb angle, EW & - & 1.463 & $\mathbf{2 . 9 9 9}$ & - \\
\hline Small interlimb angle, NS & & - & - & $\mathbf{3 . 9 9 7}$ \\
\hline Large interlimb angle, EW & & & - & 1.230 \\
\hline Large interlimb angle, NS & & & & - \\
\hline
\end{tabular}

*) Value in bold indicates that it is greater than the critical value at $95 \%$ confidence.

TABLE 5 - KS TEST ON FRACTURE SPACING

\begin{tabular}{|l|c|c|c|c|}
\hline \multirow{2}{*}{} & \multicolumn{2}{|c|}{ Small interlimb angle } & \multicolumn{2}{c|}{ Large interlimb angle } \\
\cline { 2 - 5 } & EW & NS & EW & NS \\
\hline Small interlimb angle, EW & - & 0.146 & $\mathbf{0 . 3 6 9}$ & - \\
\hline Small interlimb angle, NS & & - & - & $\mathbf{0 . 3 9 3}$ \\
\hline Large interlimb angle, EW & & & - & $\mathbf{0 . 3 5 1}$ \\
\hline Large interlimb angle, NS & & & & - \\
\hline
\end{tabular}

*) Value in bold indicates that it is greater than the critical value at $95 \%$ confidence.

TABLE 6 - BOOTSTRAPPED INFERENCE ON MEDIAN FRACTURE SPACING

\begin{tabular}{|l|c|c|c|c|}
\hline \multirow{2}{*}{} & \multicolumn{2}{|c|}{ Small interlimb angle } & \multicolumn{2}{c|}{ Large interlimb angle } \\
\cline { 2 - 5 } & EW & NS & EW & NS \\
\hline Small interlimb angle, EW & - & ND & D & - \\
\hline Small interlimb angle, NS & & - & - & D \\
\hline Large interlimb angle, EW & & & - & D \\
\hline Large interlimb angle, NS & & & & - \\
\hline
\end{tabular}

*) D indicates a significant different at 95\% confidence. ND: no significant difference. 


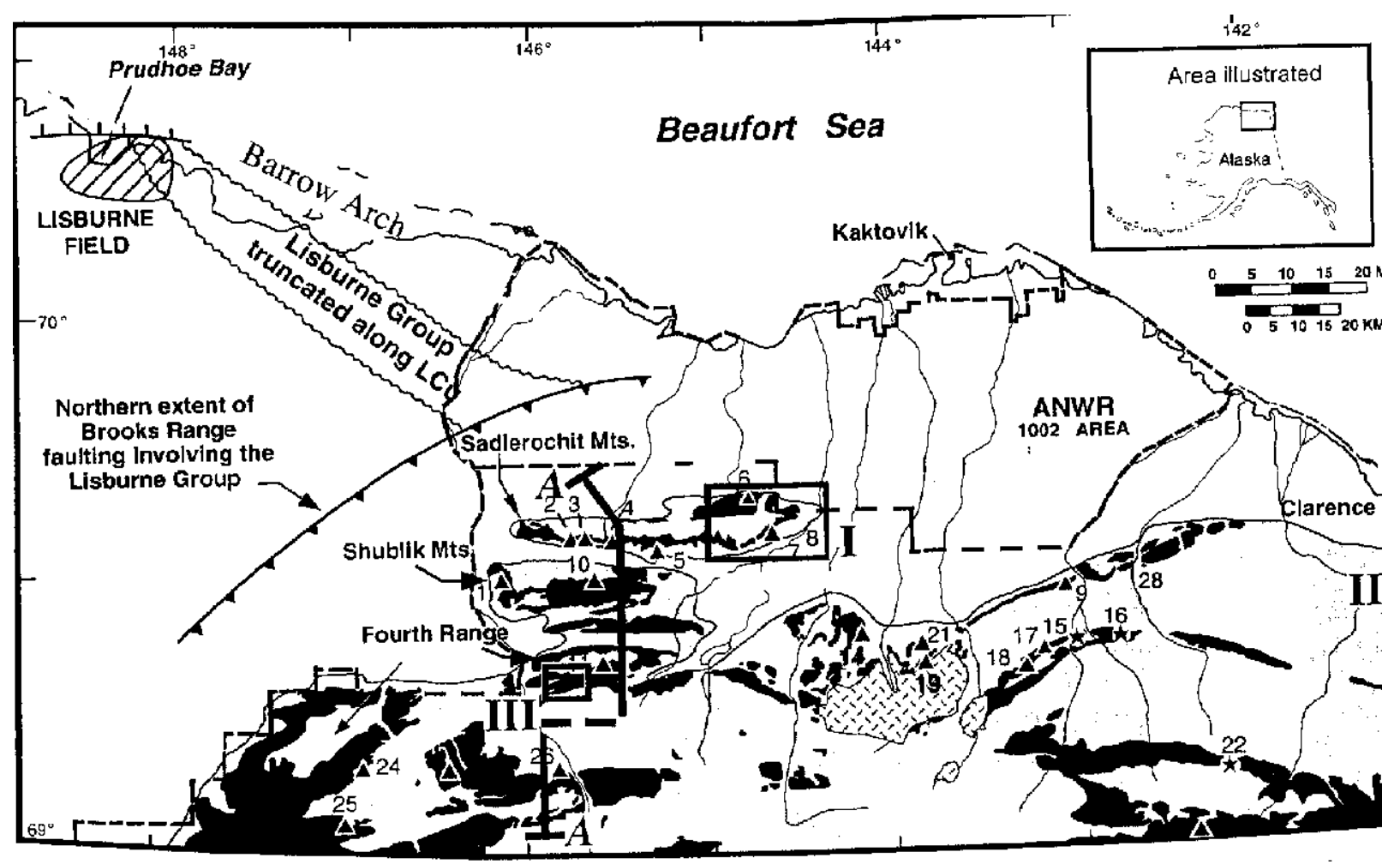

Figure 1 - Generalized geologic map of the northern part of the northeastern Brooks Range (from Hanks et al, 1997)

1704 Controls on Fracture Distribution
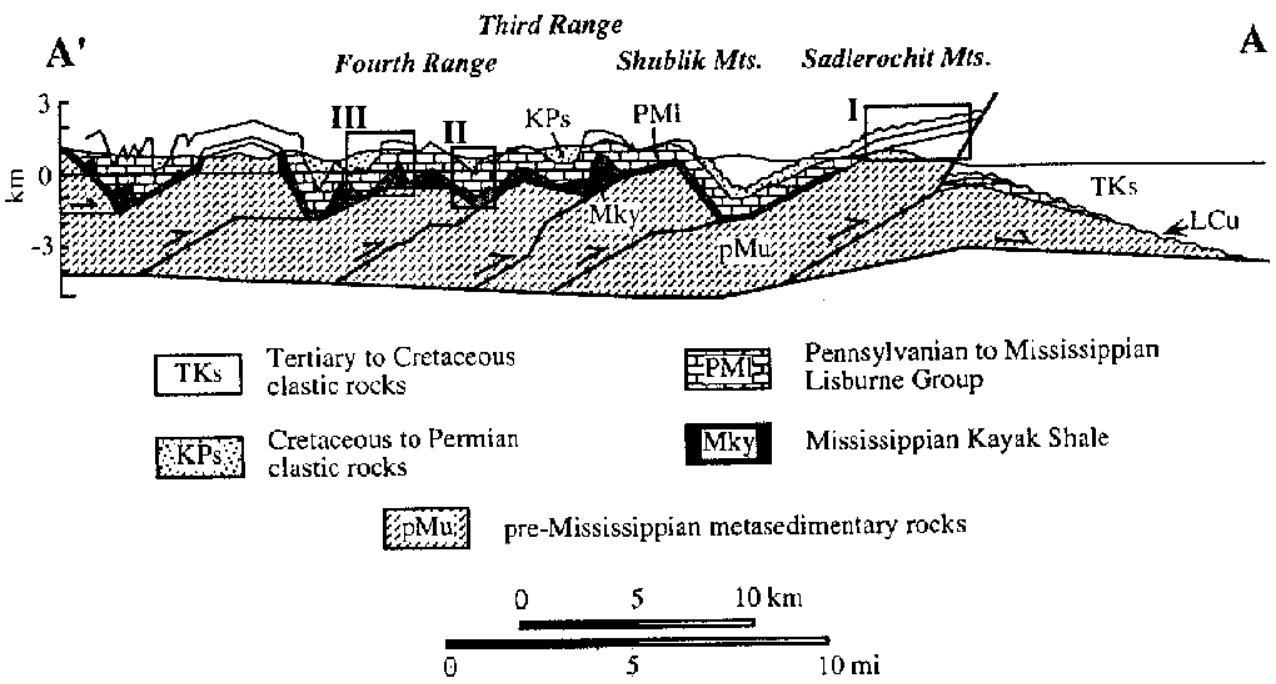

Figure 2 - Balanced cross section through the western part of the northeastern Brooks Range. (from Hanks et al, 1997) 


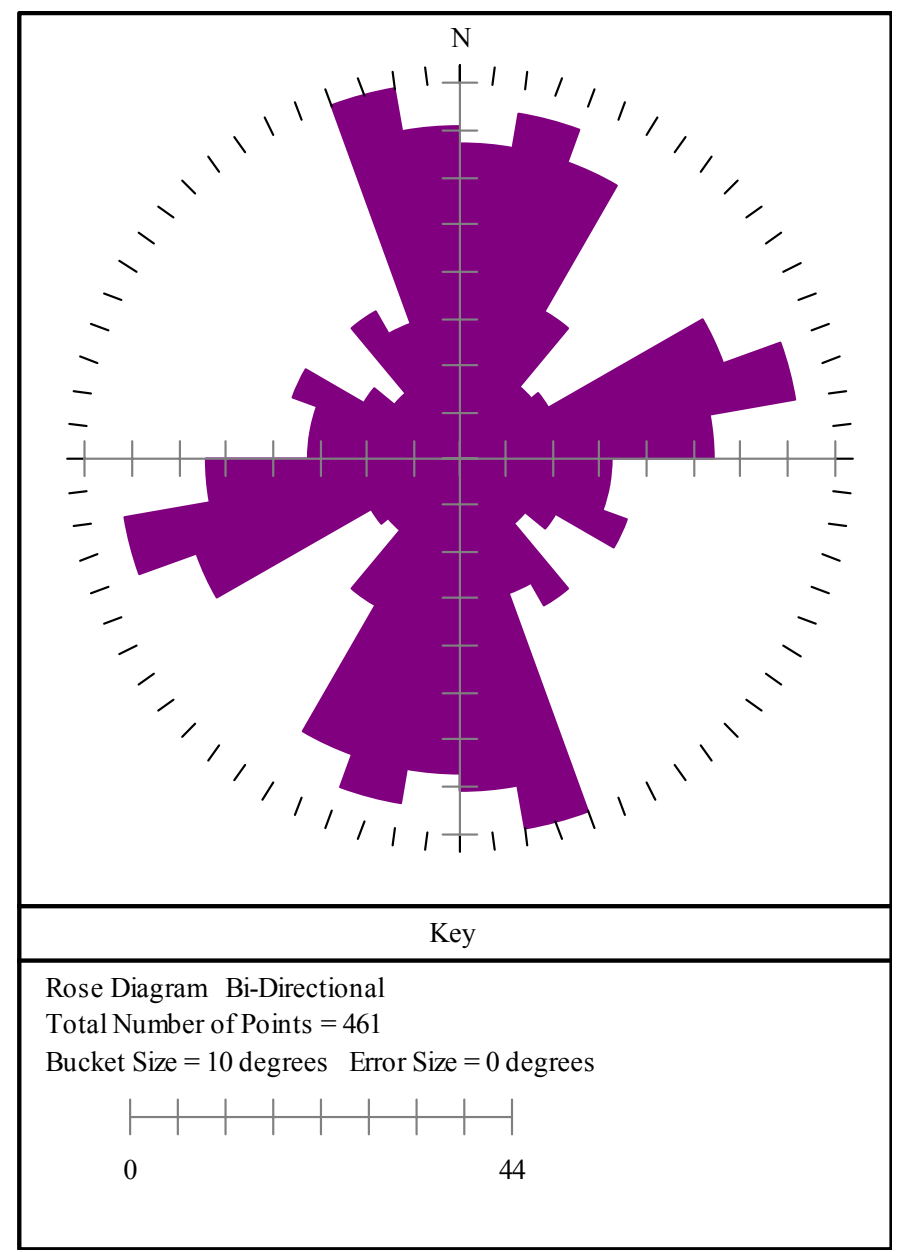

Figure 3 - Fracture orientation for all fracture data shows two major directions: East-West and North-South striking. 


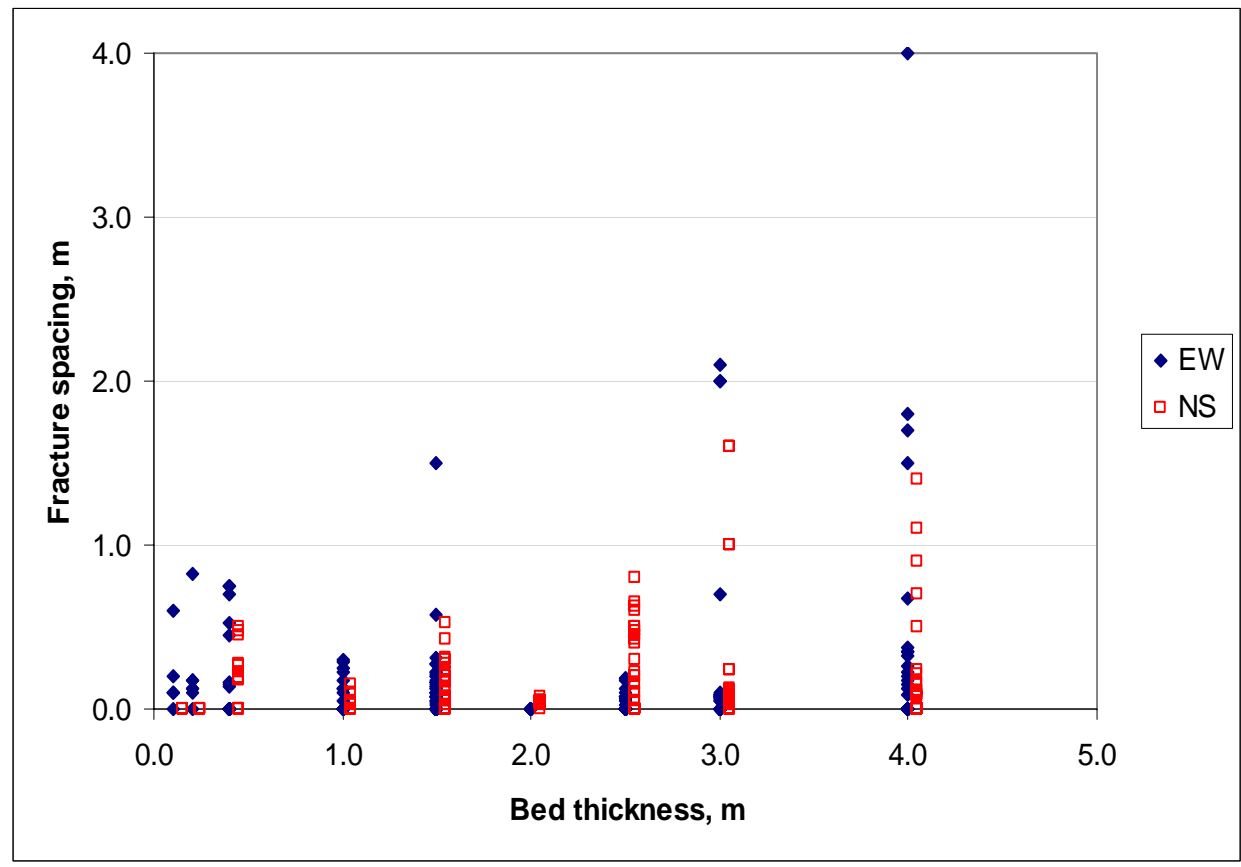

Figure 4 - Fracture spacing versus bed thickness for two orientations: the fracture spacing increases with the bed thickness.

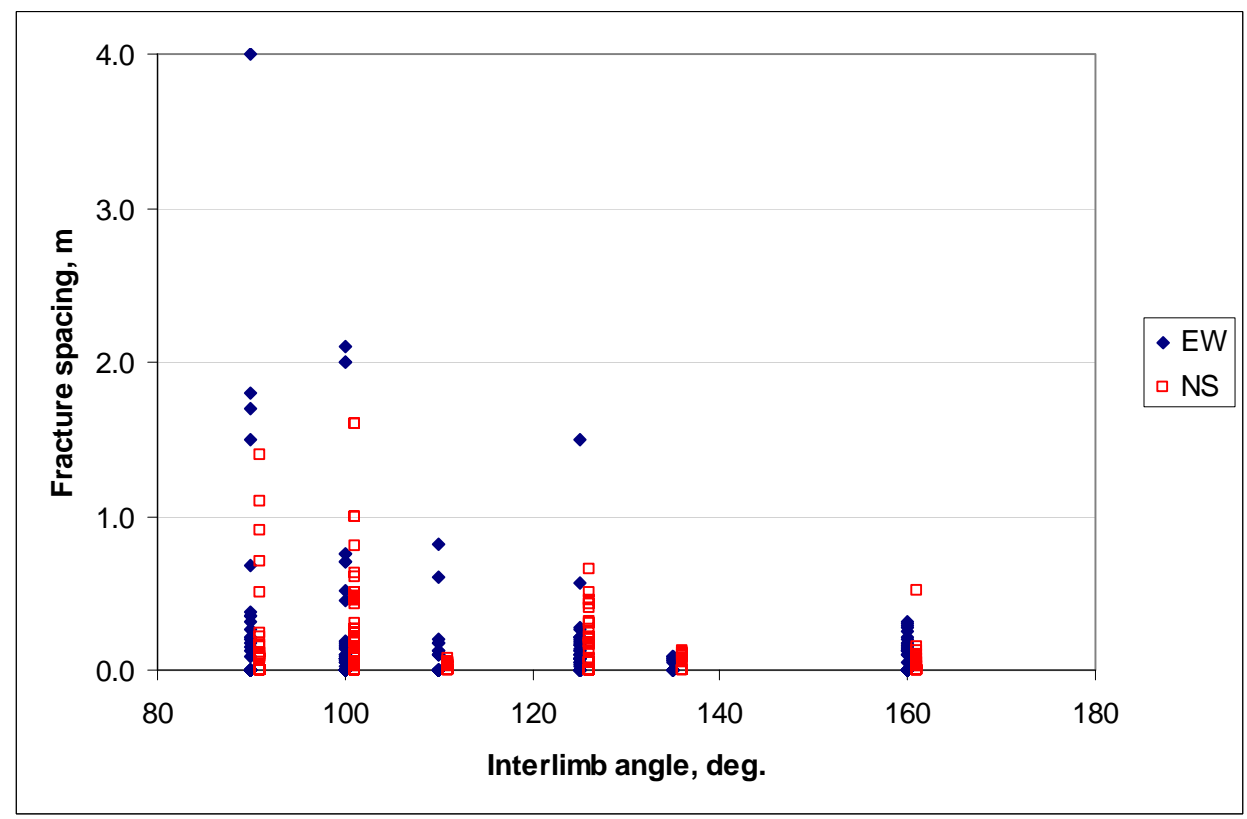

Figure 5 - Fracture spacing and interlimb angle for two orientations. As interlimb angle decreases, fracture spacing and its variability increases. 


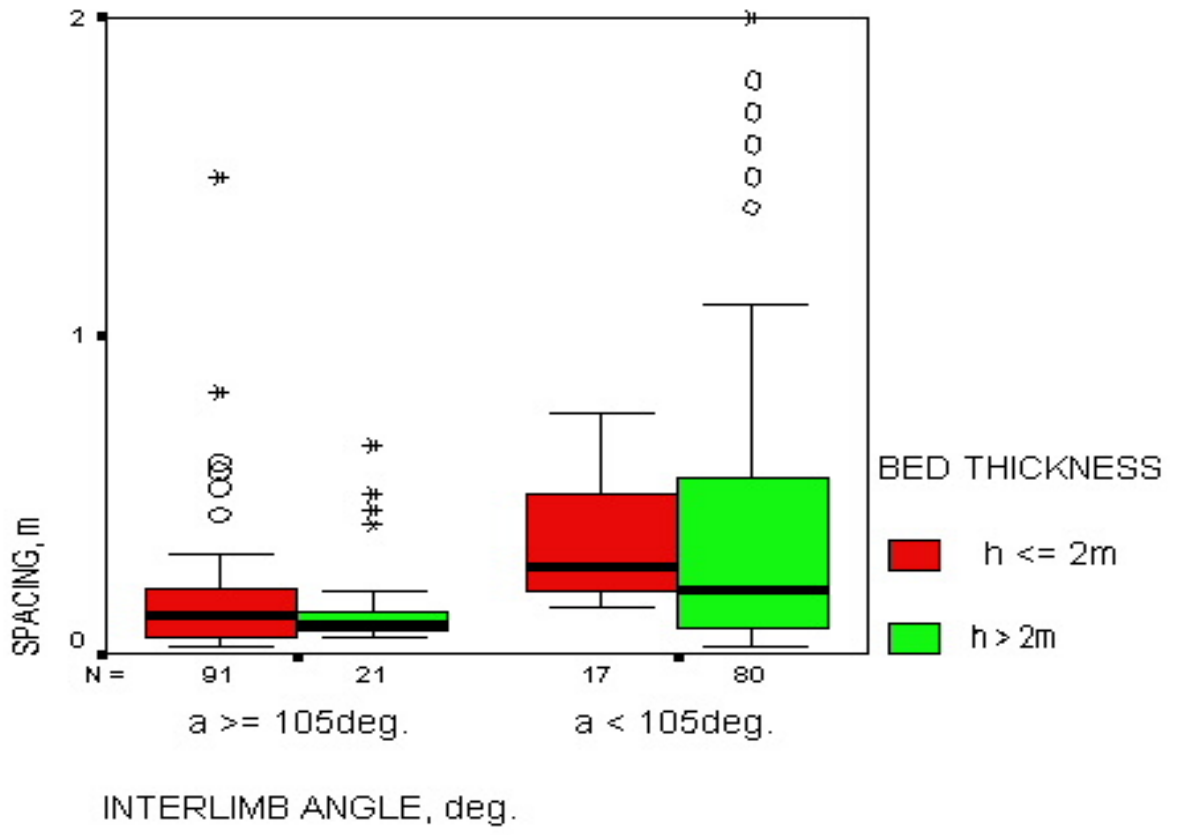

Figure 6 - Box plot of fracture spacing for two groups of interlimb angle. Fracture spacing and its variability increase as the interlimb angle decreases for both groups of bed thickness.

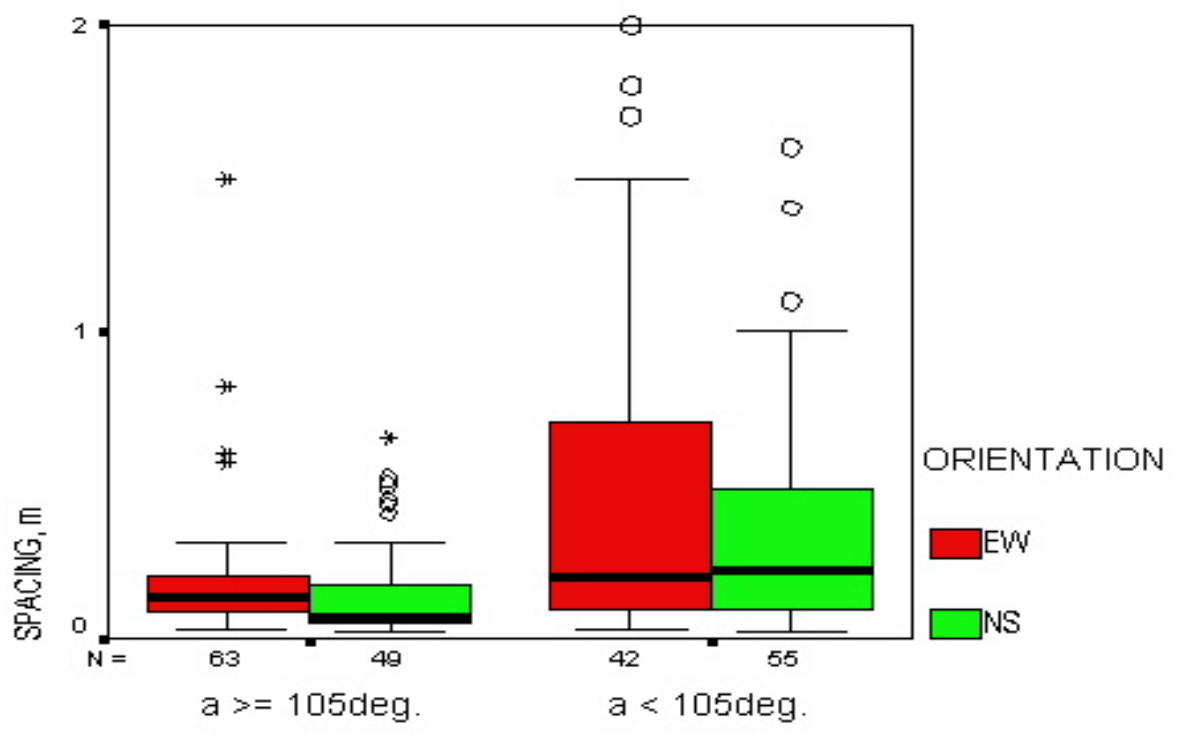

INTERLIMB ANGLE, deg.

Figure 7 - Box plot of fracture spacing for different interlimb angles and orientations. As folding increases, fracture spacing and its variability increases in both directions. 


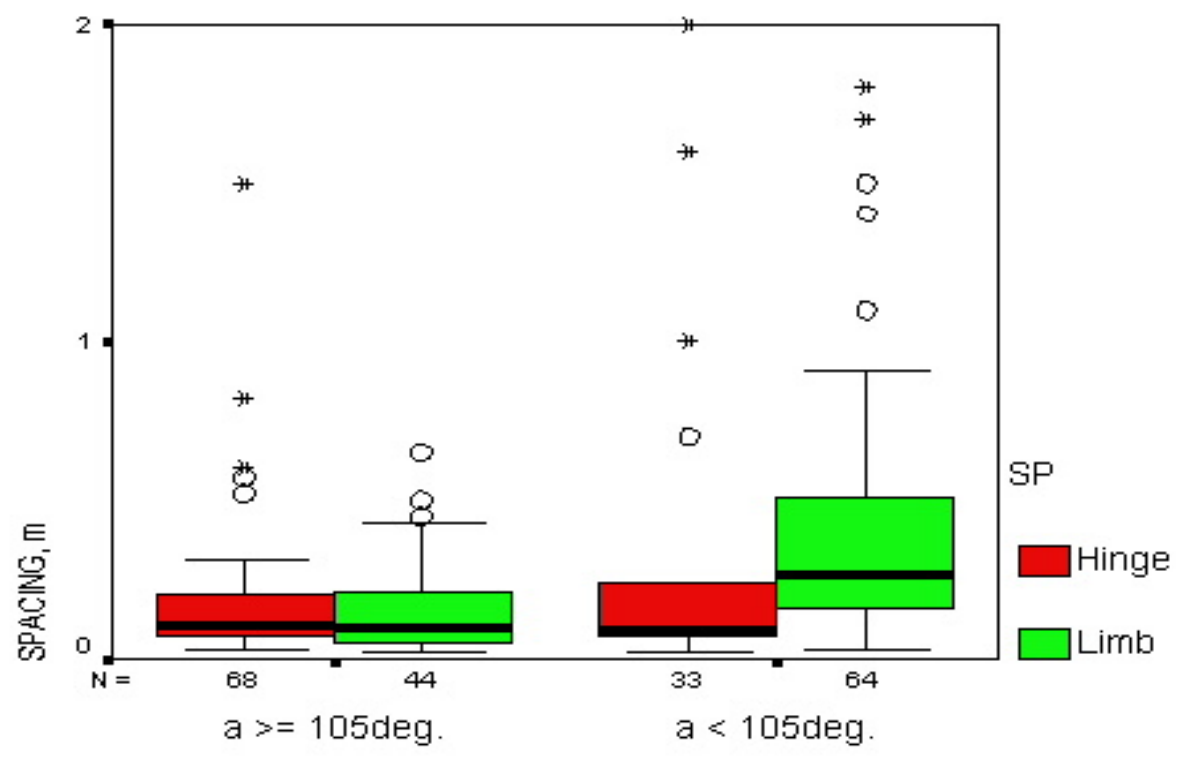

INTERLIMB ANGLE, deg.

Figure 8 - Box plot of fracture spacing for different interlimb angle and structural position. As folding increases, fracture spacing and its variability increases in both limb and hinge, especially in limb.

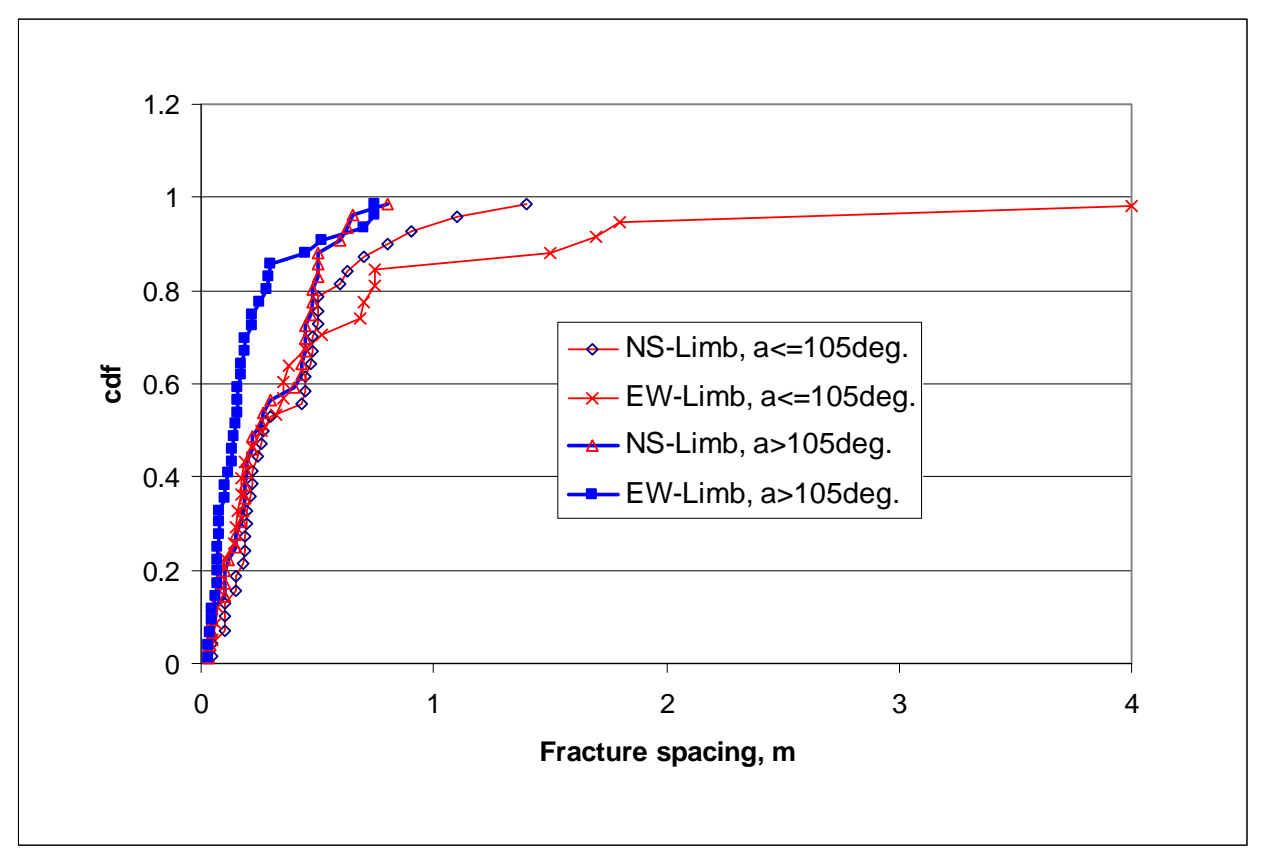

Figure 9 - Fracture spacing for two orientations in limbs of different folds. The fractures in folds with large interlimb angle are smaller than the others. 


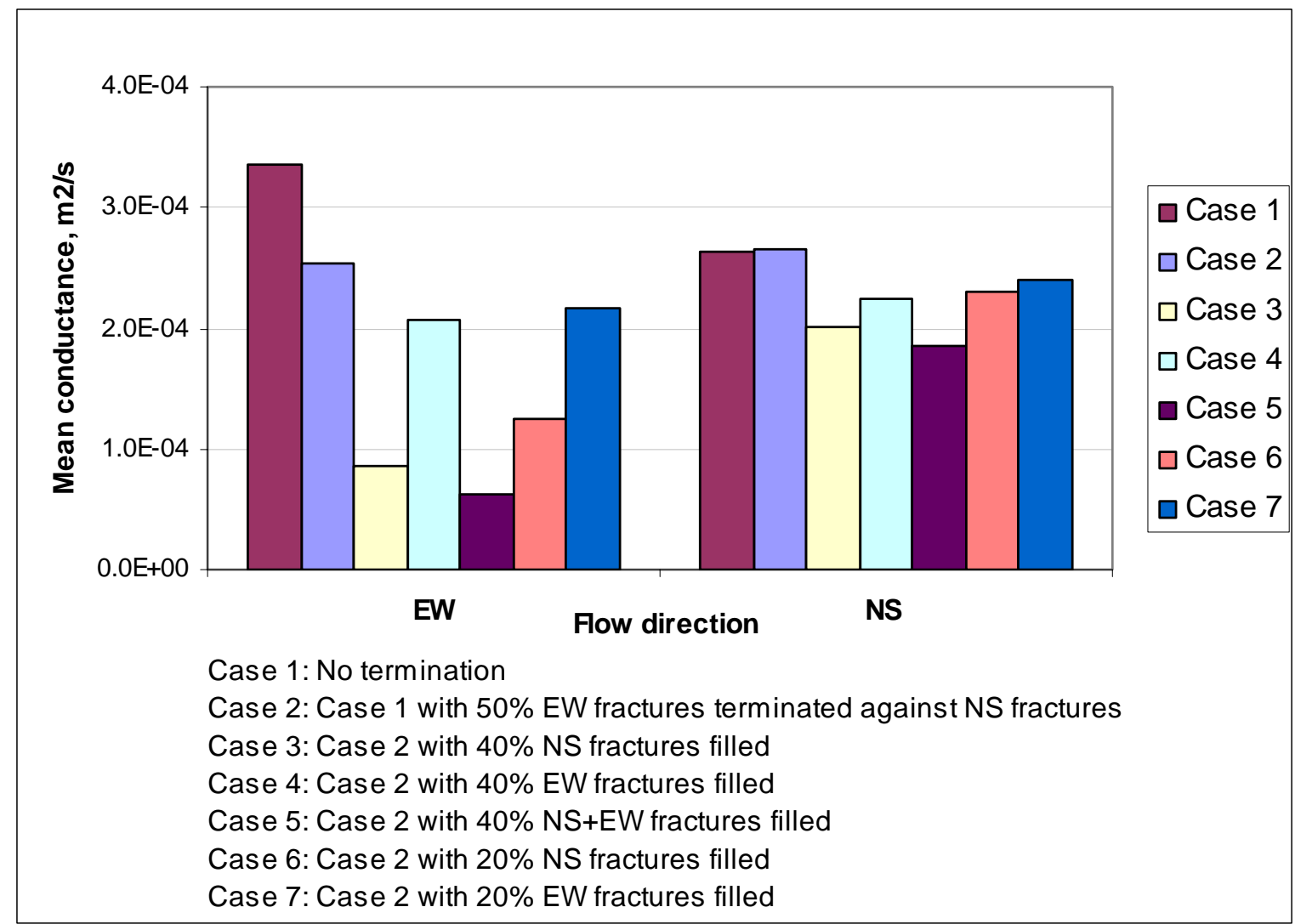

Figure 10 - Average conductance in EW and NS directions for different fracture termination and filling. The conductance in the EW direction is very sensitive to the NS fractures properties, while the conductance in the NS direction is affected only by NS filling. 


\title{
Relationships of Fracture Density and Mechanical Stratigraphy in Folded Lisburne Using Neural Nets
}

\author{
T. D. Bui, J. L. Jensen, Texas A\&M University \\ and J. Brinton, C. L. Hanks, University of Alaska Fairbanks
}

\begin{abstract}
In this research we used a neural network to investigate the relationship between fracture spacing and mechanical stratigraphic parameters for fracture data in exposed detachment-folded Lisburne Group carbonates. The results suggest a complex relationship between fracture spacing and mechanical properties. Bed thickness has the greatest effect on the fracture density, followed by the interlimb angle and formation lithology. The use of neural networks enabled us to trace the effect of single parameters on fracture spacing and to give us more insight into the relationship between the mechanical properties and fracture density.
\end{abstract}

\section{Background}

Neural networks. A neural network is a nonlinear mathematical model for investigating and establishing the relationship between variables. Such models are characterized by a structure of interconnected processing elements, called neurons or nodes (e.g., Figure 1). At each neuron, an activation function is applied upon the input signal to generate an output signal, which is sent as an input to other neurons for further processing until it reaches the output of the model. The input, before being fed to the neuron, is multiplied by a weight factor that reflects the strength of the connection between neurons. The neural network models the relationship between variables by adjusting these weights so that the output from the network satisfies some predetermined criteria, given a set of actual data is supplied to the network. 
There are many types of neural networks that have been reported and implemented, each with unique properties. The most widely used neural network class is the multilayer perceptron (MLP) or feed-forward neural network (Figure 1). In this neural network, the neurons are organized into layers. The output of a neuron in one layer is directed as input to each and every neuron in the immediate following layer. There are no lateral connections between neurons in the same layer and no feedback connection to neurons in previous layers.

The first layer of an MLP is called the input layer. Each neuron in this layer usually represents an independent (or explanatory) variable. Its task is simply to supply the input it received to the neuron in the next layer. The last layer is the output layer. The neuron in this layer represents the dependent (or response) variable of the model. The layers of neurons between input layer and output layer are called hidden layers. The introduction of the hidden layer is essential for the feed forward neural network because it introduces nonlinearity into the model. The following section gives a brief description of how MLP's work.

MLP's. MLP's are mostly used for two types of problem: 1) nonlinear correlation and 2) pattern classification. In both cases, the network has to be trained before it can be used to perform the prediction or pattern recognition task. For example, suppose that we have $\mathrm{N}$ records of data, each record consists of four values, corresponding to four parameters $\mathrm{X} 1, \mathrm{X} 2, \mathrm{X} 3$, and $\mathrm{X} 4$. We assume that X4 is a function of the other three and would like to use a neural network to establish the relationship between X4 and other three variables. Then, the feed forward neural network can be constructed as shown in Figure 1 with three input nodes, three hidden nodes, and one output node. The output of the network can be expressed as: 


$$
Y 1(w)=f\left(\sum_{i=1}^{3} w_{n i} f\left(\sum_{j=0}^{3} w_{n j} X j\right)\right)
$$

where $\mathrm{Y} 1$ is the output of the network; $\mathrm{w}_{\mathrm{nj}}$ are the connection weights between hidden nodes and output node; $\mathrm{w}_{\mathrm{ni}}$ are the connection weight between input nodes and hidden nodes; $\mathrm{f}$ denotes the activation function at hidden and output nodes; and $\mathrm{Xj}$ denotes the input variables.

Before it is used to solve the task that the neural network is designed for, it has to be trained on the observed data. During the training (or learning) process, the input values from training samples $(\mathrm{X} 1, \mathrm{X} 2, \mathrm{X} 3)$ are repeatedly supplied to network, and the output from the network (Y1) is compared with the value of the presumably dependent variable (X4) for the corresponding training sample. The training process consists of estimating the weights of the connection $W_{n i, n j}$ that minimize the sum of square error (SSE):

$$
E(w)=\sum_{i=1}^{N}\left[X 4_{i}-Y 1_{i}(w)\right]^{2}
$$

The algorithm, called error back propagation, is used in this research for minimizing this error. At first, an initial set of connection weight among the neurons is randomly assigned a value between -0.5 and +0.5 . The training process then consists of the following steps:

1. Apply the input values from the training samples to the network and calculate the output from the network using the assigned weights. This is called the feed forward calculation.

2. Calculate the error between the output of the network and the value of the response variable from the training samples.

3. The values of the connection weights are adjusted to reduce the SSE. The most widely used algorithm to adjust the weight of neural network is back propagation method.. 
These three steps are repeated until it reaches the stopping criterion. There are many variations of this algorithm in the literature. Many of them use different schemes to update the connection weights using the momentum and learning rate during the back propagation of the error. The training process and its variations have been described in detail in texts such as Faussett (1994) and Ripley (1996). Once the network is trained, the final connection weights are stored and used for prediction. In this research, a feed forward neural network using back propagation with a fixed learning rate and momentum is used.

\section{Modeling the Fracture Density}

Geological setting. The Carboniferous Lisburne Group in the northeastern Brooks Range is the closest exposed stratigraphic equivalent to the reservoir of the Lisburne oil field, located approximately $120 \mathrm{~km}$ to the northwest. A thrust front separates the subsurface Lisburne field from the Lisburne Group exposed in the northeastern Brook Range fold and thrust belt. The Lisburne Group has deformed primarily by detachment folding and thrusting throughout most of the northeastern Brook Range. In the Fourth Range and the Shublik Mountains, the Lisburne Group deformed into detachment folds over regional anticlinora. The exposed detachment folds in this area serve as a target for this fracture study. The detailed geological and stratigraphic setting of the region are presented in other parts of this report and in Hanks et al. (2000).

Fracture data. Fracture data collected by J. Brinton (Department of Geology, University of Alaska) during the summer of 1999 were used in this study. The data represent 25 outcrop locations, from which 19 are on the limb, 2 are on synclinal hinges, and 4 are on anticline hinges 
of 5 folds with the interlimb angle ranging from $90^{\circ}$ to $160^{\circ}$. Fractures are oriented in two major orientation: NS and EW direction.

A statistical analysis on the effects of bed thickness, interlimb angle, and stuctural position on fracture density distribution has been performed. Fracture data were grouped into small subsets to investigate the effects of mechanical stratigraphy on fracture density. Under the assumption that the effects of other parameters are similar for different subsets of data, the results of this analysis suggested that:

- Bed thickness does not have a significant effect on the fracture spacing distribution.

- As the interlimb angle decreases, the fracture spacing increases and becomes more variable.

- Fracture spacing in both the NS and EW-striking fracture sets increases and becomes more variable as the interlimb angle decreases

These observations and other field observations indicate a complex relationship between fracture and folds. Our observations suggest that bedded rocks in folded systems may experience multiple fracture generation episodes before, during and after folding (Hanks et al, 2000; Bui et al, 2002).

In this study, we assume six parameters that may affect the fracture density in exposed detachment-folded Lisburne Group carbonates and that have been described with each fracture. Those parameters are: bed thickness, degree of folding, lithology, structural position on a fold, fracture orientation, and the stratigraphic location of the fracture sample. With the use of a neural network, we expect to get more information about the effects of each parameter on fracture density without relying on the assumption of the equal effects of other parameters. 
Data preparation. To assist the convergence of the network, we screened the data to keep only the ones of interest in this study. Only fracture data in folds with a known interlimb angle are kept. Those fractures identified as conjugate or shear fractures were discarded because there is not an appropriate variable associated with these fractures. In some locations, more than one fracture set oriented in the same direction is recorded. In this case, an average fracture density from all fractures being identified as NS- or EW-oriented is taken. The data screening resulted in 25 cases for use by neural network analysis. These cases are shown in Table 1.

Before they can be used in the neural network, fracture data have to be appropriately rescaled. For the two continuous variables in the model: bed thickness and interlimb angle, the data are rescaled into the range from 0 to 1 by the following equation:

$$
X^{n n}=\frac{X-X_{\min }}{X_{\max }-X_{\min }},
$$

where $\mathrm{X}_{\max }$ and $\mathrm{X}_{\min }$ are the maximum and minimum values of interlimb angle and bed thickness respectively.

Variables with discrete values are coded as follows. A value of 1 is assigned if the orientation is NS, -1 is assigned if the orientation is EW. A value of 1 is applied if fractures were at the hinge of a fold, -1 if they were taken at the limb. A value of 1 obtains if the formation is Alapah, - 1 if the formation is Wahoo. The lithology is assigned a value of 0.25 if mudstone, 0.5 if wackestone, 0.75 if packstone, and 1 if grainstone. For all discrete variables, a value 0 is applied if the variable is unknown.

Our network consists of three layers (Figure 2). The input layer consists of six nodes to represent the six input variables of interest: interlimb angle, bed thickness, fracture orientation, lithology, structural position, and formation in which the samples were taken. The output layer has one node representing the average fracture spacing. The number of hidden units is subject to 
choice, and we have studied the cases with 2 and 3 hidden nodes. We elaborate on this in the discussion section.

Parameters of the model. We use the back propagation algorithm with fixed momentum and learning rate. The training is on all available data. The training process terminates when the gradient of SSE is smaller than 0.001 (Garson, 1998; Twomey and Smith, 1998).

\section{Results}

The neural network converges in less than 2000 iterations, resulting in a value of SSE of approximately 0.2 (Figure 3). Figure 4 shows the model-generated fracture spacing plotted against actual fracture spacing for the data used in the training.

The network is used to generate the average fracture spacing for different interlimb angles and bed thicknesses for particular lithology, fracture orientation, structural position, and formation. For the purposes of comparison with the statistical analysis results, the network results were presented in the form of line graphs of fracture spacing as a function of interlimb angle for two values of bed thickness: $1 \mathrm{~m}$ and $3 \mathrm{~m}$ (Figures 5-12). These two values of bed thickness were chosen to represent the two classes of bed thickness $(h<2 \mathrm{~m}$ and $\mathrm{h}>2 \mathrm{~m})$ used in the statistical analysis (Bui et al., 2002). The average fracture spacing is calculated for different value of lithology, structural position and orientation.

\section{Discussion}

Fracture spacing and interlimb angle. Graphs of the fracture spacing versus interlimb angle (Figures 5-12) suggest that there are 3 classes of curves: those that increase with the degree of 
folding (Figures 5, 11 and 12), those do not change with interlimb angle (Figures 7, 8, 9, 10), and those that decrease with the degree of folding (Figures 6, 8). The increasing of the fracture spacing with the degree of folding occurs mainly at the fold hinge located in Alapah formation (Figure 5, 11). It is also noted that the majority of the curves show no change with interlimb angle.

Fracture spacing and bed thickness. Plots of fracture spacing also suggests that, in most cases (Figures $7,8,9,12$ ), the fracture spacing behaves similarly with the change of interlimb angle for both values of bed thickness. The fracture spacing in thin beds $(\mathrm{h}=1 \mathrm{~m})$ seems to be more sensitive to the change of the interlimb angle than in thick bed $(h=3 m)$, especially in the fold hinge (Figures 5, 11).

Fracture spacing and structural position. The magnitude of fracture spacing in the hinges is similar to that in the limbs. This is in contrast to one of the results from the statistical analysis, where the combined data showed smaller fracture spacing in the limb of the fold with large interlimb angle than in the fold hinge (Bui et al, 2002). For most cases shown here, the fracture spacing in the hinge shows greater variability than the fracture spacing in the limb with the change of interlimb angle (Figures 5, 11).

Fracture spacing and fracture orientation. Comparison of the fracture spacings for the two orientations suggests that they behave similarly with the change of the interlimb angle. This result is in agreement with the result from statistical analysis (Bui et al, 2002). 
Fracture spacing and formation. The fracture density is greater in the Wahoo Formation than the Alapah (Figures 7, 8, 9, 10). This may be due, in part, to the different lithologies. Fractures in the Wahoo evaluated for this study are mainly from packstones, while those in the Alapah are mainly from grainstones. It should be noted that the lithology in neural network is mainly comprised of packstone and grainstone. The results of neural network for wackestone and mudstone were not presented since the neural network, like other regression techniques, is weak in extrapolation. However, the small effect of lithology on the fracture spacing prediction (as is pointed out in the next section) suggested that others factors could play an importance role in explaining the difference between fractures in Alapah and Wahoo formations.

Relative Importance of Input Variables in Explaining Fracture Spacing. Using the neural network, it is difficult to compare the effects of the input variables on the fracture spacing sideby-side for the whole range of the input variables. Several researchers have tried to interpret the results from neural networks to answer the question: how does one input variable contribute to the output of the model. Ozesmi and Ozesmi (1999) proposed a Neural Interpretation Diagram for providing a visual interpretation of the connection weights among neurons, where the relative magnitude of each connection is represented by line thickness (i.e. thicker lines representing greater weights) and line shading represent the direction of the weight (i.e. black lines representing positive and grey lines representing negative weights). The interpretation of connection weights through the interpretation diagram is not an easy task because of the complexity of connection among the neurons. Furthermore, the non-uniqueness of the connection weights of the model may lead to wrong conclusions about the contribution of the input variable in the model. 
The same considerations apply to the sensitivity analysis of the network result and the assessment of the prediction variance of the model. Garson (1991) presented a simple method to partition the relative share of the output prediction associated with each input variable. This analysis used the connection weight to calculate the relative importance of input in a model as follows:

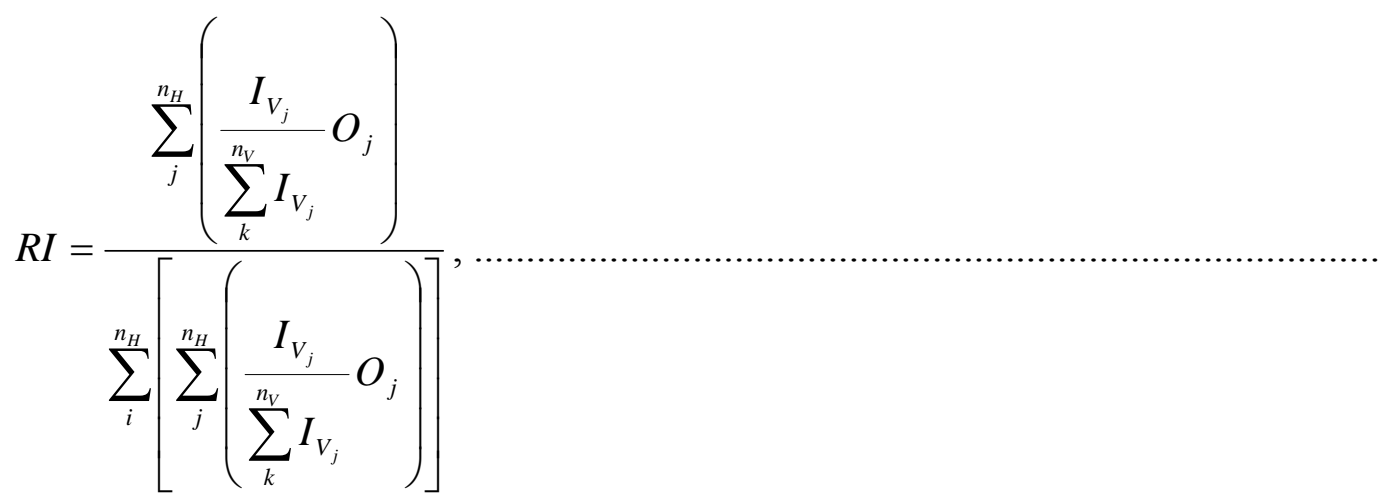

where: $\mathrm{O}_{\mathrm{j}}$ is the connection weight to output node from hidden node $\mathrm{j} . I_{V_{j}}$ is the connection weight from input node I to hidden node $\mathrm{j} . \mathrm{n}_{\mathrm{H}}$ and $\mathrm{n}_{\mathrm{V}}$ are the number of hidden and input nodes, respectively. Since the final connection weights of the model may depend on the starting point, it is important that the conclusion of the relative importance should not be based solely from the results of one training pass. Figure 13 shows the distribution of the relative importance of bed thickness, calculated from Equation 4. The graph is built from the connection weights of our model for 100 different sets of initial connection weights. Table 2 shows the relative importance of six input variables of the model. According to these results, bed thickness is the most influential parameter $(23.7 \%)$ on explaining the average fracture spacing, followed by interlimb angle $(22.6 \%)$, lithology $(18.4 \%)$, formation (14.6\%), and structural position $(12.0 \%)$. Fracture orientation is the least influential parameter $(8.7 \%)$ on the value of fracture spacing. A pair-wise F test between the relative importance of a variable and the one next to it (in Table 2) suggests 
that the difference in relative importance according to Garson equation is significant for all pairs, except for the difference between the relative importance of the bed thickness and the interlimb angle.

One of the simplest and most commonly asked questions is: how many hidden units should we use in the model. The answer depends on the unknown function which the neural network is approximating (Ripley, 1996). It also depends on the number of data available for training. Models with a large number of hidden nodes can approximate complex functions but it requires longer times for training the network. It also increases the danger of overfitting the data; a phenomenon which occurs when the model is trying to "memorize" the data instead of approximating the relationship between variables. A common practice in using neural networks is to iteratively apply the neural network with different numbers of hidden units and choose the one with the least hidden units but which can still converge on the training data. Carpenter (1996) suggested an initial numbers of nodes on a single hidden layer model:

$$
J=\frac{\frac{N}{\alpha}-K}{I+K+1},
$$

where $\mathrm{N}$ is the number of data sets for training, $\mathrm{K}$ is the number of output nodes, and $\mathrm{I}$ is the number of input variables. $\alpha$ is the coefficient that defines the degree of determination of the model. This equation is similar to one reported by Garson (1998). Carpenter suggests that $\alpha$ should be greater than one. Others suggest that $\alpha$ should be in the range from 5 to 10 (Garson, 1998). Applying equation 5 to our problem, we found that the number of hidden units should not be greater than three. Several attempts have been made with the number of hidden units ranging from 1 to 3 . The results of this investigation show that the network with both $J=3$ and $J=2$ will converge with our fracture data (Note that $\mathrm{J}=2$ and $\mathrm{J}=3$ is equal to $\alpha=1.5$ and $\alpha=1$, respectively). 
These small values of $\alpha$ suggest that we are on the margin of data sufficiency for training. Twice the number of data sets would give an $\alpha$ more in accordance with recommended values.

One of the potential problems in using neural networks is the stability of the model resulting from multiple optima. That is, a network with different starting values of weights can still converge but will have rather different performance. Figure 14 shows the distribution of the connection weights between the bed thickness unit and the first hidden unit for different starting sets of weights. In all cases, the model converges to the same value of error but, clearly, the weights can change considerably. Several authors (Baxt, 1992; Ripley, 1996) suggest solving this problem by averaging the neural network at different local minima for the final prediction. This approach has failed on our fracture data; the final model gives large errors, pointing to the fact that the average value of weights from multiple minima is just another random number. Moody and Utans (1995), studying the methods of bootstraping and jackknifing to assess the variance of the model, proposed that the training on different data set be started with the same set of weights. However, this could bias the procedure, because another set of weights may give total different performance (Ripley, 1996; Zapranis and Refenes, 1999).

\section{Conclusions}

- The result from the neural network show complex relationships between fracture density and mechanical properties. This may support the conclusion drawn from field evidence and statistical analysis of the fracture data that the fractures are weakly related to the folding process of the formation and they may have been generated at different times by different geological events. 
- The number of data sets used in the neural network training is considered to be small. To satisfy the suggested value for the minimum sample cases in the training, the number of data sets should be at least double of what we have.

- With the existing data, the neural network can still be a valuable tool to investigate the effect of mechanical stratigraphical parameters on fracture density. The relative importance of the single parameters can be assessed. For the data under investigation, bed thickness and interlimb angle are the most affecting parameters on the fracture density, following by lithology, stratigraphical location, structural position on the fold, and fracture orientation.

- It is important that one should be careful when using neural networks for approximation in multivariable problems. Due to non-uniqueness of the connection weight of the neural network model, it is desirable to check for the stability of the model for the same training data set by training the model with different initial values of the connection weights.

\section{Acknowledgement}

\section{References}

Baxt, W. G. (1992), Improving the accuracy of an artificial neural network using multiple differently trained networks, Neural Computation, v. 4, p.772-780.

Bui, T., J. Jensen, J. Brinton, C.L. Hanks (2002), Folded Lisburne Group fracture distribution and flow modeling, Progress Report, DE-AC26-98BC15102.

Carpenter, W. and M. Hoffman (1995), Selecting the architecture of neural networks used as approximators. In: Intelligent Engineering Systems through Artificial Neural Networks, v. 5, C.H. Dagli, M. Akay, C.L.P. Chen, B.R. Fernandez, and J. Ghosh (Eds.), New York, p.117122. 
Fausett, L. (1994), Fundamentals neural networks: architecture, algorithm and applications: Prentice-Hall, Englewood Cliffs, NJ, p.461.

Garson, G.D (1998), Neural networks - an introductory guide for social scientists: SAGE Publication, 194p.

Garson, D. G. (1991), Interpreting neural network connection weights: AI Expert, v. 6, p.47-51.

Hanks, C.L, J. Brinton, and J. Lorenz (2000), Fracturing in the Lisburne Group as a function of carbonate lithology, mechanical stratigraphy and position in detachment folds: Progress Report, DE-AC26-98BC15102.

Moody, J, and Utans, J. (1995), Architecture selection strategies for neural networks: application to corporate bond rating prediction. In: A.P.Refenes (Ed.) Neural Networks in the Capital Markets, Wiley, p.277-300.

Ozesmi, S.L., and U. Ozesmi (1999), An Artificial Neural Network Approach to Spatial Habitat Modeling with Interspecific Interaction: Ecological Modeling, v. 116, p.15-31.

Ripley, B.D. (1996), Pattern Recognition and Neural Networks: Cambridge University Press, Cambridge, $403 \mathrm{p}$.

Twomey, J. M. and A. E. Smith (1998), Bias and Variance of Validation Methods for Function Approximation Neural Networks under Conditions of Sparse Data: IEEE Transactions on System, Man, and Cybernetics, v. 28, p.417-430.

Zapranis, A., and A.P. Refenes (1999), Principles of Neural Model Identification, Selection and Adequacy, London, 190p. 
Table 1 - Fracture Data Used in Neural Network Modeling

\begin{tabular}{|c|c|c|c|c|c|c|c|c|c|}
\hline \multirow[t]{2}{*}{$\begin{array}{l}\text { Fracture Data } \\
\text { Set }\end{array}$} & \multirow[t]{2}{*}{ SP } & \multirow[t]{2}{*}{ Litho. } & \multirow[t]{2}{*}{ Formation } & \multirow{2}{*}{$\begin{array}{l}\text { Bed } \\
\text { Thickness } \\
\text { m }\end{array}$} & \multirow{2}{*}{$\begin{array}{l}\text { Interlimb } \\
\text { Angle } \\
\text { deg. }\end{array}$} & \multirow[t]{2}{*}{ Orientation } & \multirow[t]{2}{*}{$\begin{array}{l}n \\
\text { frax }\end{array}$} & \multicolumn{2}{|c|}{ Spacing, $\mathrm{m}$} \\
\hline & & & & & & & & Mean & Std_dev \\
\hline FR-7-10-1EW & $\mathrm{Hs}$ & $\mathrm{Gr}$ & Alapah & 1.5 & 125.0 & $\mathrm{EW}$ & 18 & 0.2452 & 0.2847 \\
\hline FR-7-10-1NS & Hs & $\mathrm{Gr}$ & Alapah & 1.5 & 125.0 & NS & 14 & 0.1234 & 0.0727 \\
\hline FR-7-19-1EW & L & $\mathrm{Gr}$ & uWahoo & 1.5 & 125.0 & EW & 10 & 0.1233 & 0.0815 \\
\hline FR-7-19-1NS & L & $\mathrm{Gr}$ & uWahoo & 1.5 & 125.0 & NS & 4 & 0.2400 & 0.1359 \\
\hline FR-7-19-2NS & L & $\mathrm{Gr}$ & Alapah & 2.5 & 125.0 & NS & 5 & 0.5000 & 0.0935 \\
\hline FR-7-19-2EW & L & $\mathrm{Gr}$ & Alapah & 2.5 & 125.0 & EW & 4 & 0.1300 & 0.0490 \\
\hline NS-7-27-1EW & L & $\mathrm{Gr}$ & uAlapah & 4 & 90.0 & EW & 10 & 0.3413 & 0.1278 \\
\hline NS-7-27-1NS & L & $\mathrm{Gr}$ & uAlapah & 4 & 90.0 & NS & 5 & 0.1750 & 0.0541 \\
\hline NS-7-27-2a & $\mathrm{Ha}$ & $\mathrm{Gr}$ & UN & 4 & 90.0 & EW & 5 & 0.1425 & 0.0396 \\
\hline NS-7-27-2b & $\mathrm{Ha}$ & $\mathrm{Gr}$ & UN & 4 & 90.0 & NS & 7 & 0.1000 & 0.0294 \\
\hline NS-7-29-1NS & L & $\mathrm{Ps} / \mathrm{Gr}$ & Alapah & 2.5 & 100 & NS & 20 & 0.3189 & 0.2166 \\
\hline NS-7-29-1EW & L & $\mathrm{Ps} / \mathrm{Gr}$ & Alapah & 2.5 & 100 & $\mathrm{EW}$ & 10 & 0.0922 & 0.0507 \\
\hline NS-7-29-2NS & $\mathrm{Ha}$ & $\mathrm{Ps} / \mathrm{Gr}$ & Alapah & 3 & 100 & NS & 16 & 0.4640 & 0.1484 \\
\hline NS-7-29-2EW & $\mathrm{Ha}$ & $\mathrm{Ps} / \mathrm{Gr}$ & Alapah & 3 & 100 & EW & 11 & 0.5613 & 0.1871 \\
\hline NS-7-29-3NS & L & Ps & Alapah & 0.4 & 100 & NS & 10 & 0.3044 & 0.1257 \\
\hline NS-7-29-3a & L & Ps & Alapah & 0.4 & 100 & EW & 9 & 0.4525 & 0.2543 \\
\hline SS-8-2-2a & L & Ps & Wahoo & 2 & 110 & NS & 12 & 0.0455 & 0.0144 \\
\hline SS-8-2-3a & $\mathrm{Ha}$ & Ps & Wahoo & 0.2 & 110 & EW & 7 & 0.2533 & 0.2549 \\
\hline SS-8-2-3b & $\mathrm{Ha}$ & Ps & Wahoo & 0.1 & 110 & EW & 5 & 0.2500 & 0.2062 \\
\hline SS-8-4-1EW & L & Ps & Wahoo & 1 & 160 & EW & 10 & 0.1811 & 0.0833 \\
\hline SS-8-4-1NS & L & Ps & Wahoo & 1 & 160 & NS & 6 & 0.0740 & 0.0450 \\
\hline SS-8-4-2NS & $\mathrm{Ha}$ & Ps & Wahoo & 1.5 & 160 & NS & 10 & 0.1310 & 0.0714 \\
\hline SS-8-4-2EW & $\mathrm{Ha}$ & Ps & Wahoo & 1.5 & 160 & $\mathrm{EW}$ & 10 & 0.1824 & 0.0709 \\
\hline SS-8-4-3EW & $\mathrm{Hs}$ & Ps & Wahoo & 3 & 135 & EW & 9 & 0.0750 & 0.0150 \\
\hline SS-8-4-3NS & $\mathrm{Hs}$ & Ps & Wahoo & 3 & 135 & NS & 7 & 0.0900 & 0.0238 \\
\hline
\end{tabular}

Table 2 - Relative Importance of the Mechanical Stratigraphical Variables on Fracture Density from the Neural Network.

\begin{tabular}{|l|c|c|c|}
\hline & Average Relative Importance & Standard Deviation & F - statistic \\
\hline Bed Thickness & 0.2371 & 0.07528 & $\mathbf{0 . 6 8}$ \\
\hline Interlimb Angle & 0.2261 & 0.05599 & $\mathbf{1 6 . 5 2}$ \\
\hline Lithology & 0.1839 & 0.04690 & $\mathbf{1 0 . 9 6}$ \\
\hline Formation & 0.1462 & 0.06495 & $\mathbf{5 . 3 1}$ \\
\hline Structural Position & 0.1198 & 0.04776 & $\mathbf{1 1 . 9 3}$ \\
\hline Fracture Orientation & 0.0869 & 0.04702 & \\
\hline
\end{tabular}

*) The critical $\mathrm{F}$ value is: $\mathrm{F}_{0.05,1,98}=3.94$ 


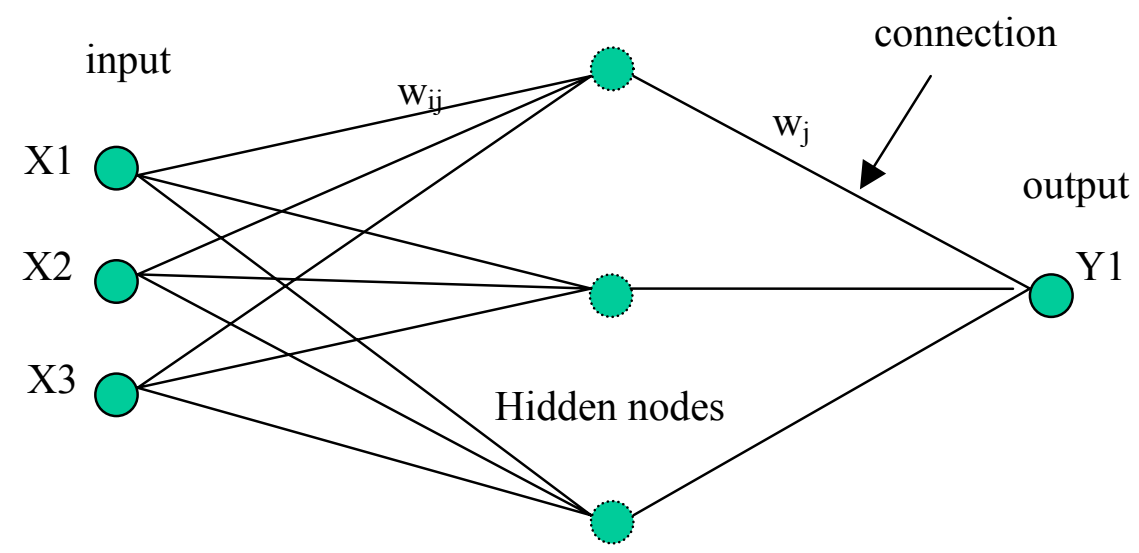

Figure 1 - Multilayer neural network. Each circle represents a neuron or processing unit. The connections between neuron represent weights or network parameters. The network is trained to the given set of data by adjusting the weights so that the output from network represents the dependent variable from data.

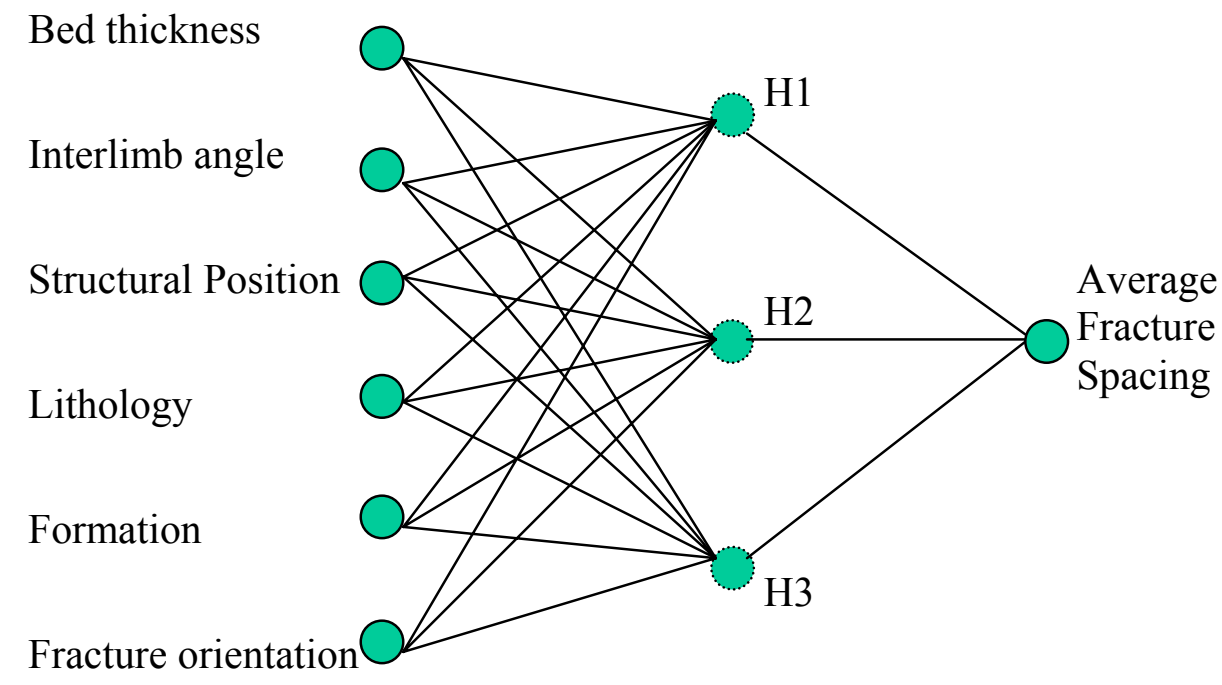

Figure 2 - Neural network used for the fracture spacing study. The output from network is average fracture spacing for given input variables. The network has one hidden layer and six input variables. 


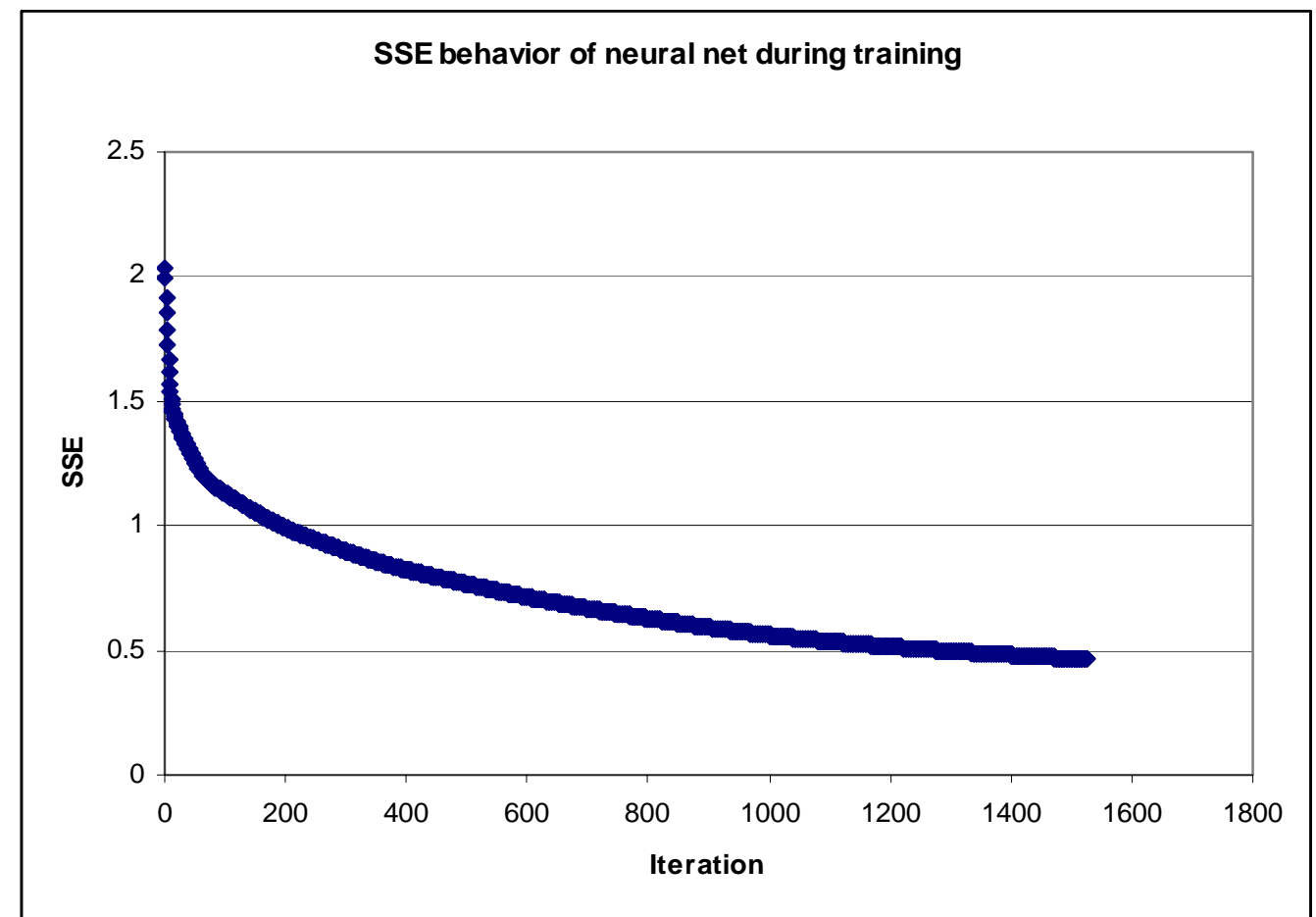

Figure 3 - During network training, the error decreases. The training stops when the change in error is small enough.

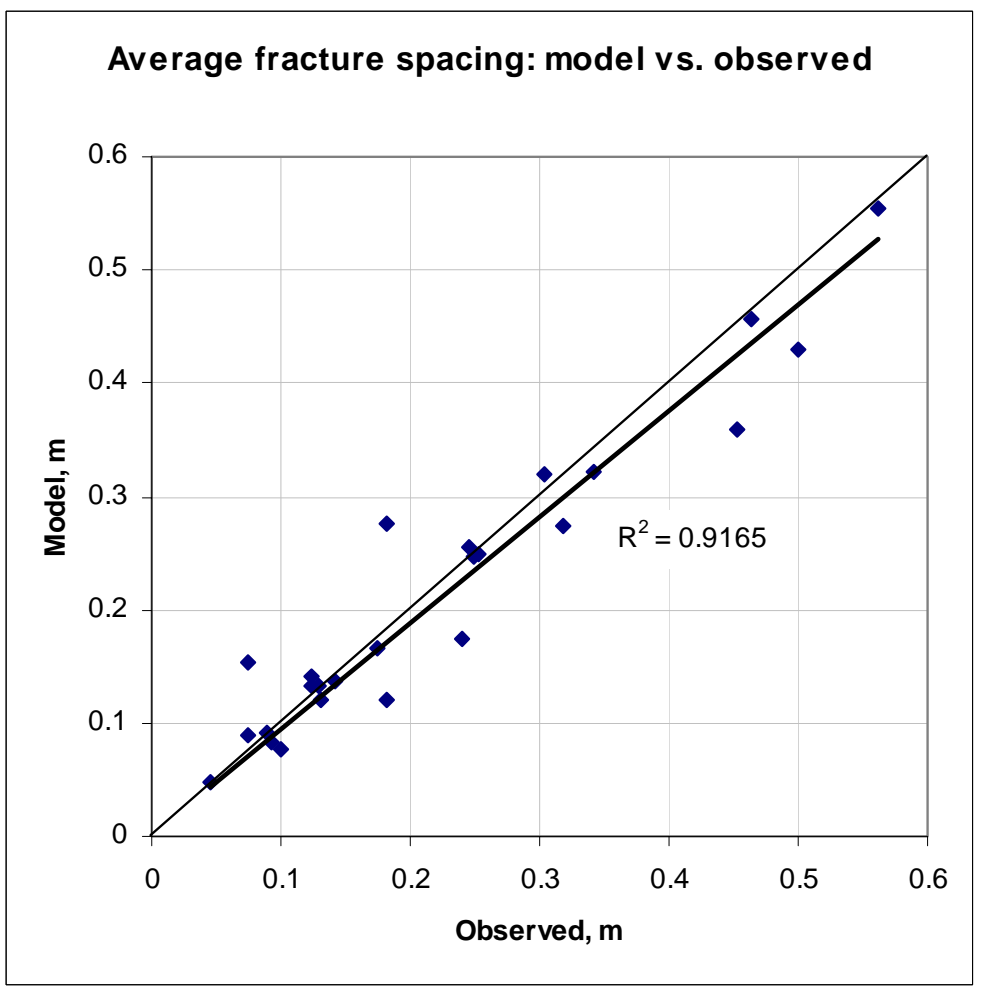

Figure 4 - Neural network represents the fracture spacing data very well. 

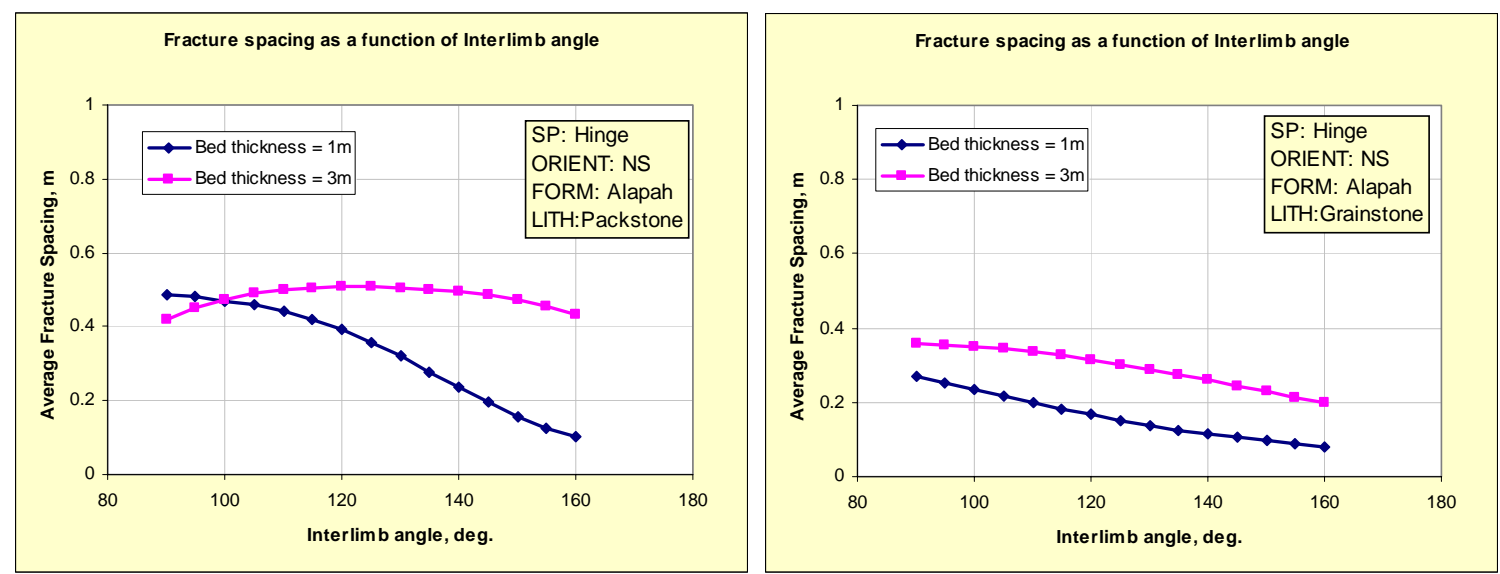

Figure 5 - Predicted fracture spacing of NS fractures in fold hinge as a function of interlimb angle. The general trend is that fracture spacing increases with folding. The magnitude of the increasing is large for thin bed.
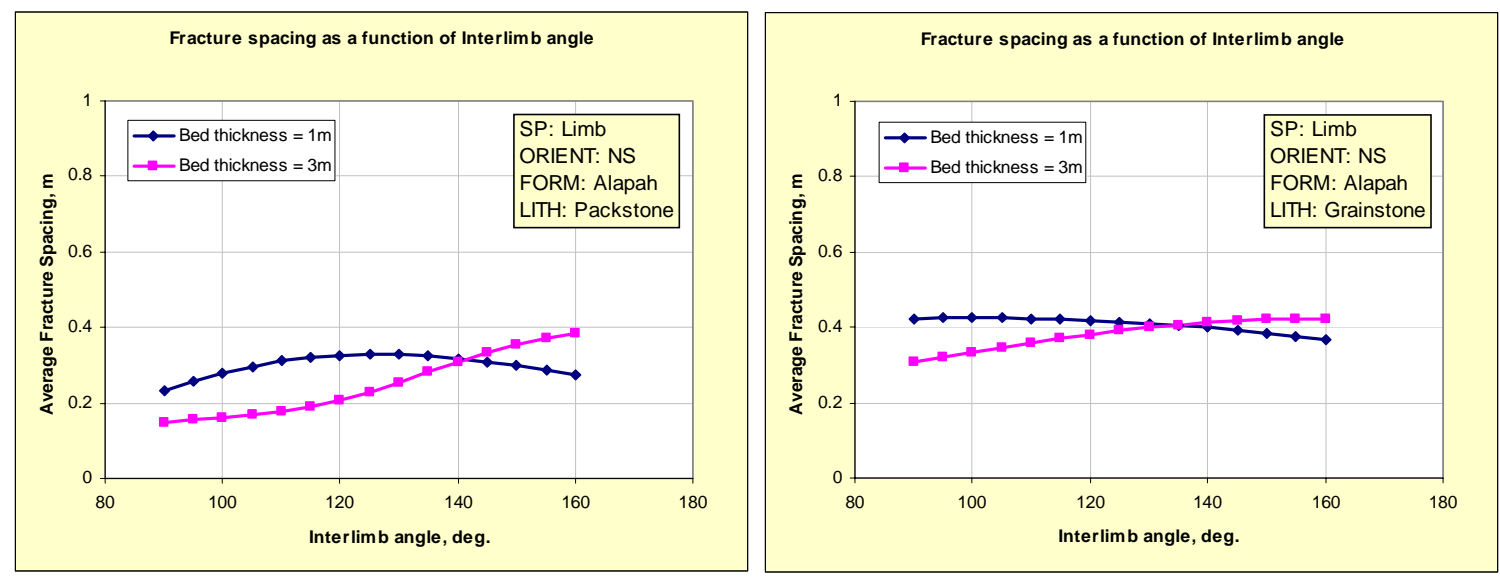

Figure 6-Predicted fracture spacing of NS fractures in fold limb as a function of interlimb angle. The trend is that the fracture does not change or slightly decreases with folding. For both values of bed thickness, fracture spacing is similar. 

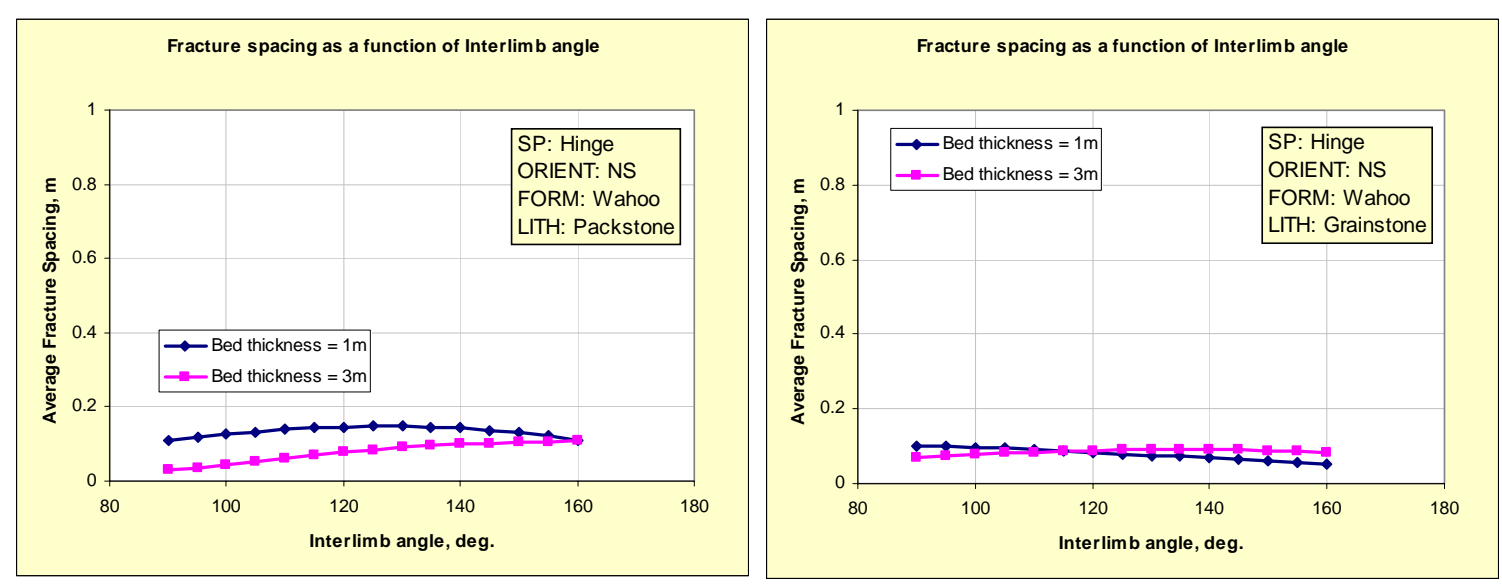

Figure 7 - Predicted fracture spacing of NS fractures in fold hinge as a function of interlimb angle. The trend is that the fracture does not change or slightly decreases with folding. For both values of bed thickness, fracture spacing is similar. The fracture spacing is much smaller than in Alapah formation.
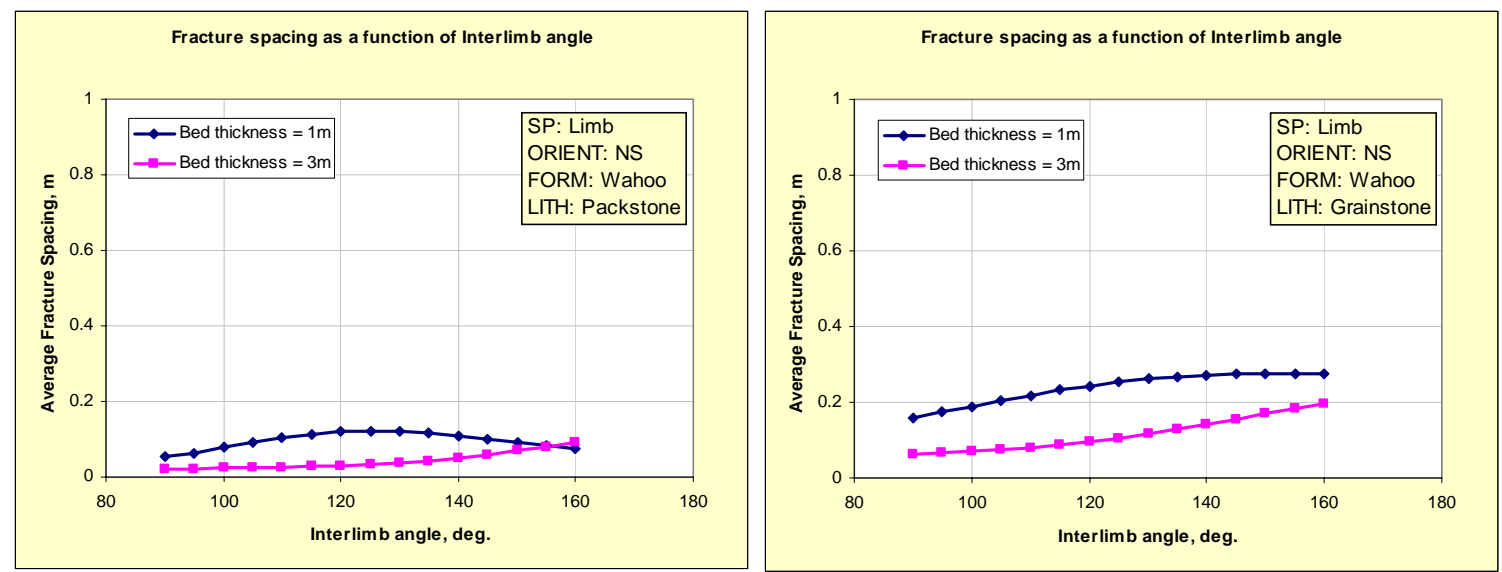

Figure 8 - Predicted fracture spacing of NS fractures in fold limb as a function of interlimb angle. The trend is that the fracture does not change or slightly decreases with folding. Grainstone shows more difference for different bed thickness than packstone. 

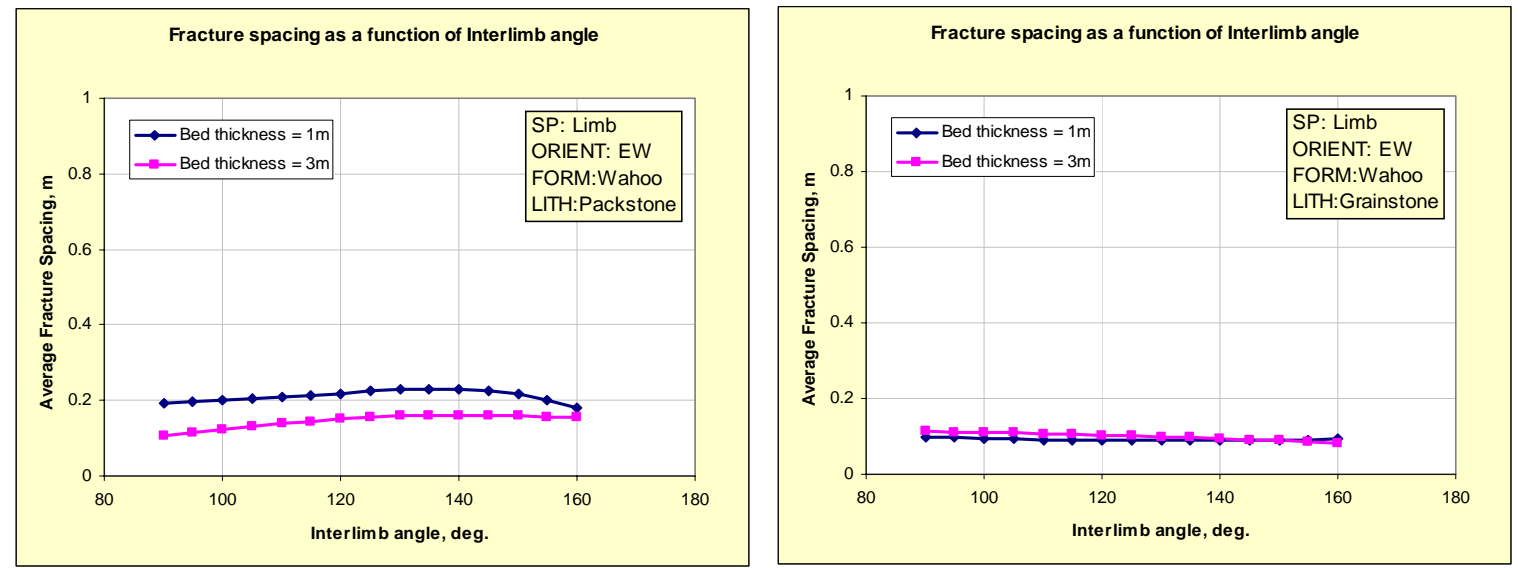

Figure 9 - Predicted fracture spacing of EW fractures in fold limb as a function of interlimb angle. The trend is that the fracture does not change with folding.
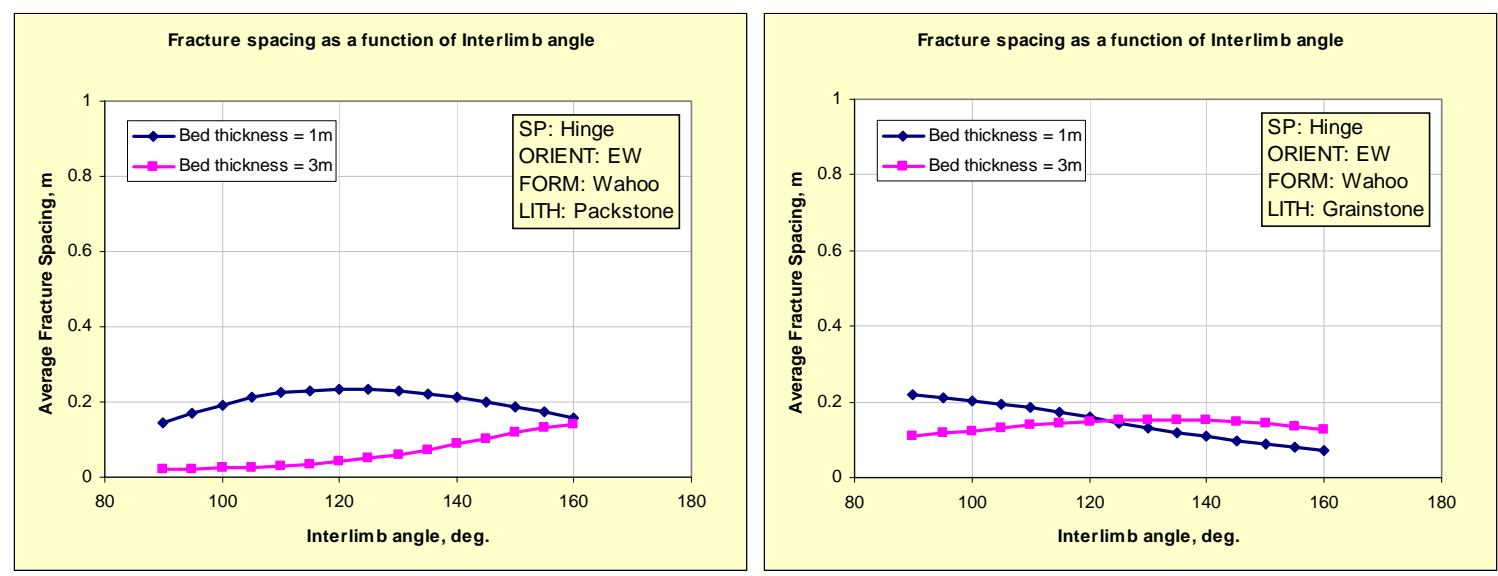

Figure 10 - Predicted fracture spacing of EW fractures in fold hinge as a function of interlimb angle. Fracture spacing in thin bed shows greater variability with the change of interlimb angle than in thick bed for grainstone, but the opposite is true for packstone. 

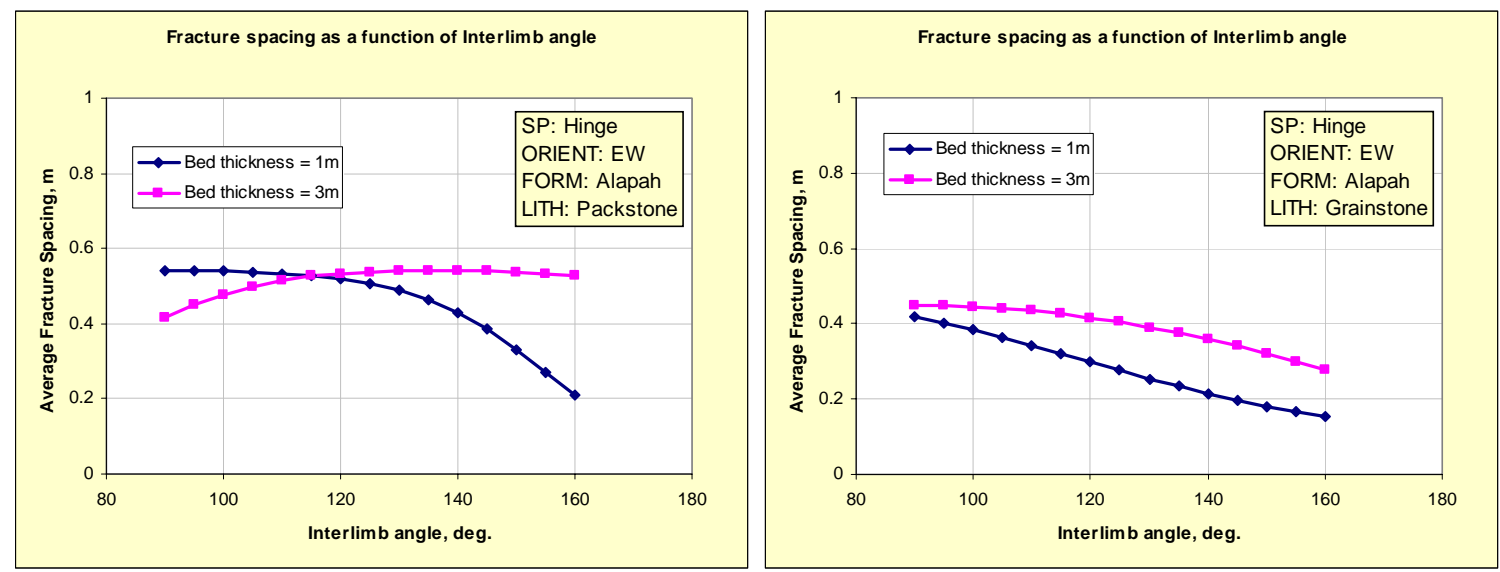

Figure 11 - Predicted fracture spacing of EW fractures in fold hinge as a function of interlimb angle. Fracture spacing in thin bed shows greater variability with the change of interlimb angle than in thick bed. General trend is that the fracture spacing is increasing with folding.
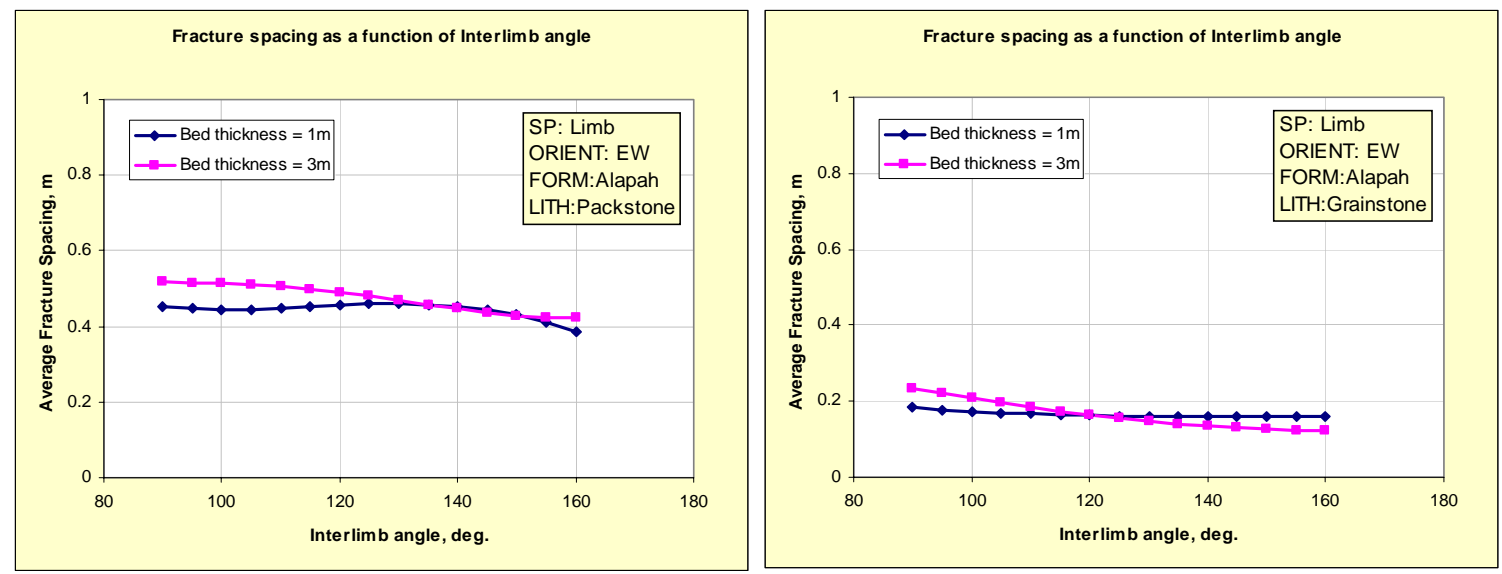

Figure 12 - Predicted fracture spacing of EW fractures in fold limb as a function of interlimb angle. Fracture spacing is similar for both values of bed thickness and does not change with folding. 


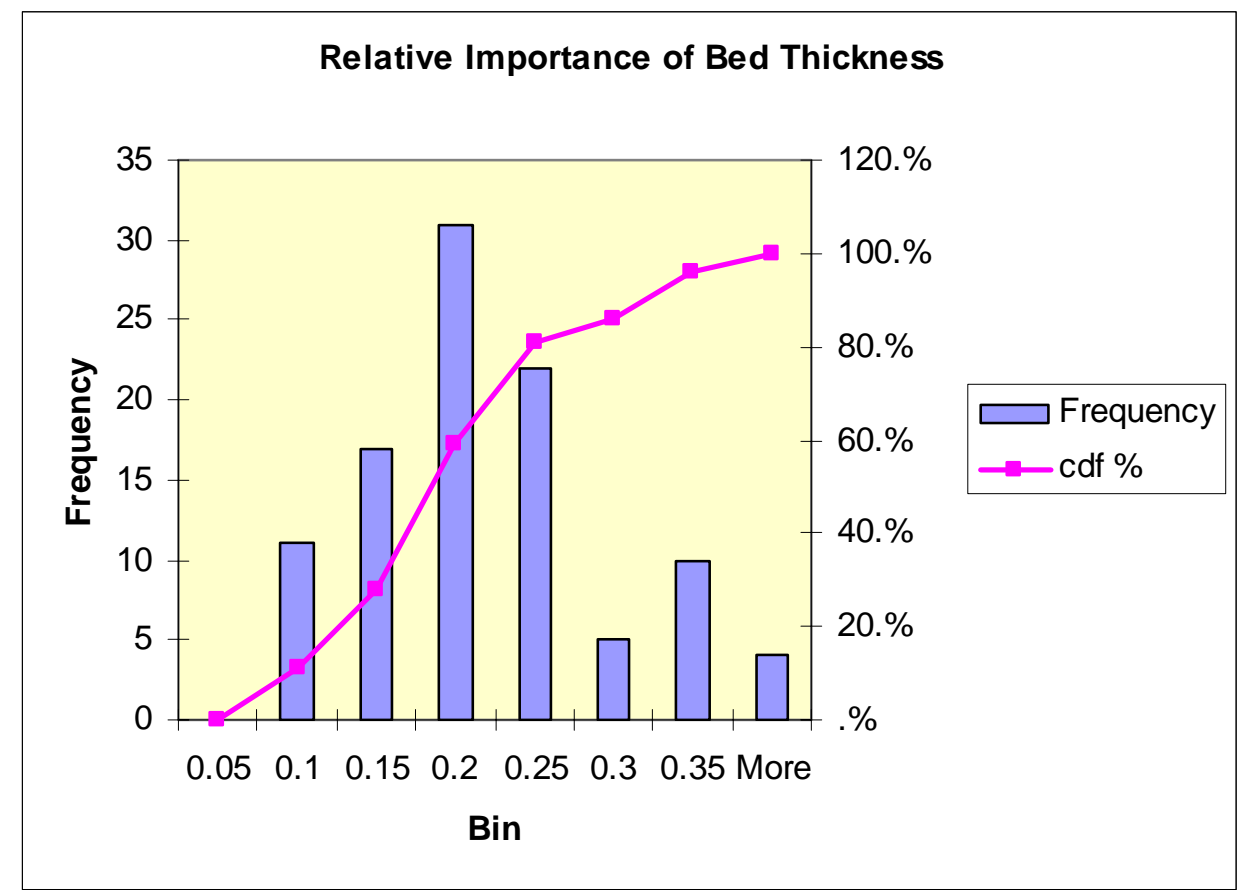

Figure 13 - Relative importance of each input variable can be estimated. The variability of the connection weight resulted in the variability of the estimated importance.

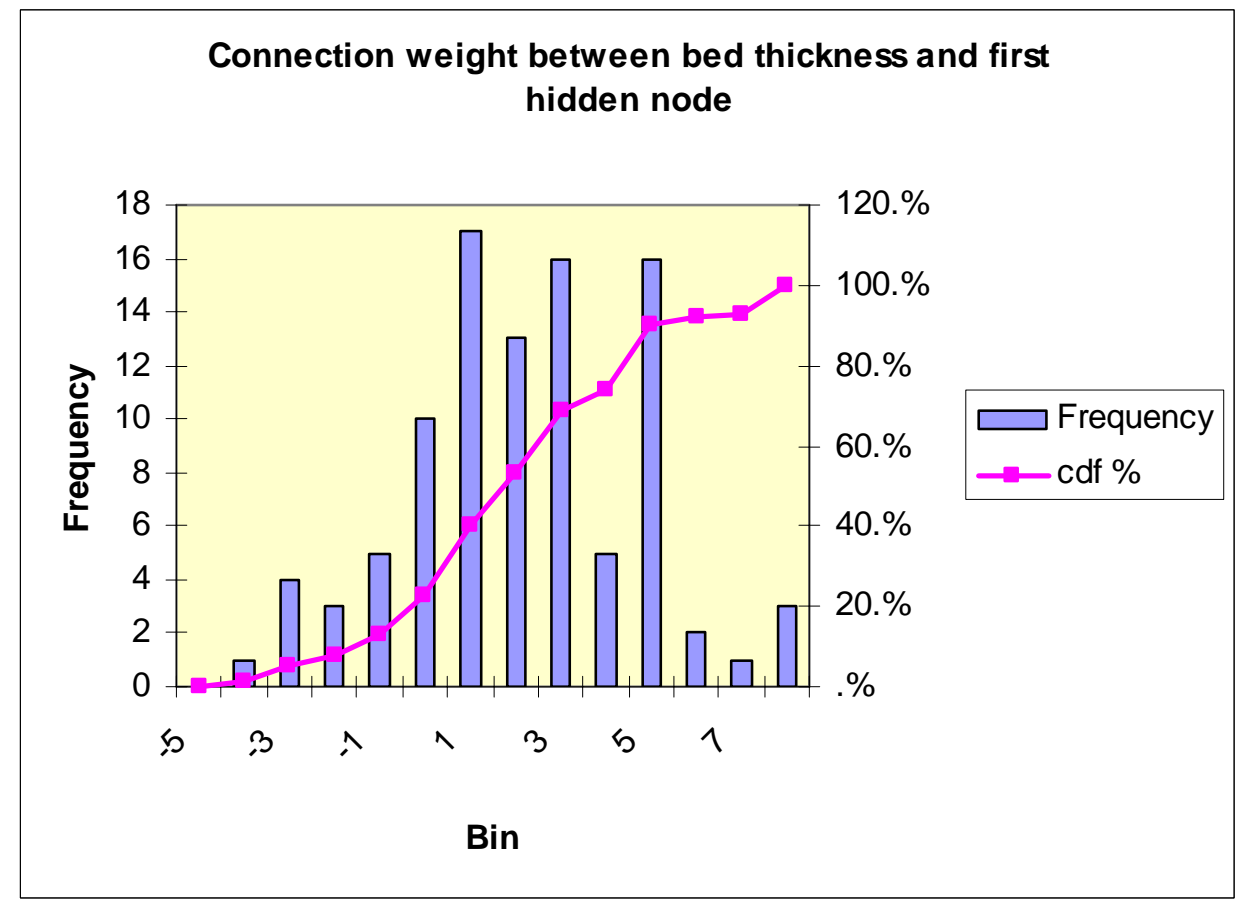

Figure 14 - Connection weight can vary in a wide range because of the small sample data set. 


\section{$\underline{\text { Summary and conclusions }}$}

\section{Stratigraphy}

The Lisburne Group represents a laterally extensive carbonate ramp that was deposited during the middle Carboniferous (middle Mississippian to middle Pennsylvanian). This study focused on Lisburne in two areas, the northeastern Brooks Range in the north and the central-eastern Brooks Range to the south, as well as analysis of subsurface drill core and gamma ray logs. The Lisburne gradationally overlies the Kayak Shale, the uppermost unit in the Endicott Group, or rests unconformably over pre-Mississippian Rocks. Locally, in the Sadlerochit Mountains and the North Slope subsurface, the Lisburne overlies siliciclastic-rich and carbonate rocks of the Itkilyariak Formation. From bottom to top, the Lisburne includes the Wachsmuth, Alapah, and Wahoo Limestones. Field studies for this project focused on the bottom two units. The Wahoo Limestone was examined in outcrop but no detailed data were collected except from the subsurface. The Wachsmuth and Alapah are both subdivided into three members. The Wachsmuth consists of the crinoidal limestone, middle, and banded limestone members. The Alapah is subdivided into lower, middle, and upper members. Stratigraphic relationships between the two field areas are quite complex. The Wachsmuth Limestone occurs mainly in the central-eastern Brooks Range and partly in the southernmost northeastern Brooks Range. The Alapah is much thicker in the south and the three members in the north are almost entirely represented, chronostratigraphically, by the upper Alapah in the south. Like the Wachsmuth, the lower and middle Alapah have no temporal equivalents to the north except in the southernmost northeastern Brooks Range.

Detailed facies analysis for this study was confined mainly to rocks of the central-eastern Brooks Range. We defined 16 facies within the Wachsmuth and Alapah Limestones. These facies were deposited dominantly in middle- to outer-ramp environments that include open-marine settings both below and above fairweather wavebase on the outer ramp, shoal and near-shoal environments, and open- and restricted-platform environments on the middle ramp. Facies commonly are stacked in either non-cyclic or cyclic packages. Cyclic packages, or parasequences, are bounded by flooding surfaces that signify significant changes in relative sea level. Parasequences shallow upward, recording a relative fall in sea level. Four different types of parasequences were identified in the central-eastern Brooks Range. These usually record deposition in open-marine environments near fairweather wave base that shallow upward to shoal or open- or restricted-platform environments. Open-marine facies are typically skeletal wackestones and packstones with some chert. Shoal facies consist of skeletal packstones, grainstones, and locally rudstones. Platform facies are dominated by skeletal and peloidal wackestones and packstones, with more cherty facies that indicate restricted platform environments. Parasequences in the northeastern Brooks Range are significantly different because of their more proximal paleogeographic setting. They usually contain shoal, open- and restricted-platform, and intertidal or supratidal facies with evidence of subaerial exposure.

Three subsurface drill cores, five subsurface gamma ray logs, and one composite outcrop gamma ray log provided criteria for subsurface stratigraphic subdivisions and correlation between the outcrops in the Brooks Range and the North Slope subsurface. These data were combined with outcrop stratigraphic data, information on facies stacking patterns, and biostratigraphy to provide 
criteria for the identification of depositional sequences and associated systems tracts. We have subdivided the Lisburne Group into six depositional sequences. Sequences 1 and 2 are entirely within the Wachsmuth Limestone and only lap as far north as the southernmost northeastern Brooks Range. Sequence 3 is represented by the uppermost Wachsmuth and the lower and middle Alapah and is the first package to onlap into the northern northeastern Brooks Range, where it is represented by a very thin shallow-water succession in the lowermost Alapah.

Sequence 4 is represented by the upper Alapah in the central-eastern Brooks Range and by the entire remainder of the Alapah in the northeastern Brooks Range. Sequences 5 and 6 are roughly equivalent to the lower and upper Wahoo Limestones, respectively, and are preserved only in the northeastern Brooks Range and the adjacent subsurface. If they were ever deposited to the south, they were subsequently eroded.

The mechanical stratigraphy of the Lisburne Group is reflected in part by large-scale outcrop weathering patterns. In the central-eastern Brooks Range, the Wachsmuth crinoidal limestone member is generally incompetent, the Wachsmuth middle $(\sim 130 \mathrm{~m})$ and banded limestone $(\sim 140$ m) members and the lower and upper Alapah are mechanically competent. The middle Alapah is comparable to or slightly less competent than the Wachsmuth crinoidal limestone. In the northeastern Brooks Range, the lower Alapah is relatively incompetent but becomes increasingly more competent in the upper $25 \mathrm{~m}$ of the unit. The middle Alapah is less competent than the lower Alapah or the generally competent upper Alapah.

The Lisburne Group is a poor reservoir rock with very low porosities in most of the field area. The low porosities probably indicate low permeability although permeability was not measured. Fracturing of the Lisburne likely enhances both porosity and permeability but the presence of many shale-based parasequences that would serve as barriers to flow further reduces the reservoir potential. Some thin dolomitized intervals within the Alapah in the subsurface are oil stained and might be reservoir intervals. Rock eval analyses of organic-rich shales interbedded with Lisburne carbonates in the central-eastern Brooks Range imply that some of these could have been source rocks, albeit fair to poor, gas-prone source rocks.

\section{Detachment folds}

\section{Fold geometry and evolution}

The detachment folds of the northeastern Brooks Range formed in competent Lisburne Group carbonates above the incompetent Kayak Shale. The competent to incompetent unit thickness ratio is about 2.5. The lower Lisburne is mechanically gradational between the incompetent Kayak and the competent upper Lisburne, which probably influenced fold geometry and evolution.

The folds typically are upright and symmetrical and are not usually cut by thrust faults. A wide range of interlimb angles and aspect ratios reflects different amounts of shortening. At low to intermediate shortening, the folds range from angular throughout to an angular inner arc that grades outward to a box or rounded geometry. Angular parasitic folds are common in the Kayak and lower Lisburne. The upper Lisburne displays less apparent fold shortening and may have 
accommodated some layer-parallel shortening. With increasing shortening, folds display more flattening by bulk strain, typically with thickening of hinges and thinning of limbs.

The folding mechanism changed throughout fold evolution. At low shortening, parasitic folding in the Kayak and lower Lisburne accompanied formation of large, low-amplitude folds and possible layer-parallel shortening in the upper Lisburne. Flexural slip at low to intermediate shortening was gradually superseded by fold-flattening by bulk strain as shortening increased. A small amount of flexural slip occurred late in fold evolution.

The formation of symmetrical folds in the northeastern Brooks Range may have been favored by a regionally horizontal detachment, a weak detachment, a low ratio of competent to incompetent unit thickness, an absence of overlying thrust sheets, and an orogenic wedge with a low taper angle. It is unknown which of these may have been most important in controlling fold evolution.

Flattening probably superseded flexural slip due to some combination of resistance to continued folding by flexural slip and more ductile conditions of deformation. Resistance to continued folding by flexural slip may have been due to decreasing interlimb angle and consequent decreasing cross-sectional area, increasing limb dip, or "bottoming out" of the competent unit due to a locally thin incompetent unit.

A geometric-kinematic model for the detachment folds of the northeastern Brooks Range must accommodate differences in competency in the section, changes in detachment depth (thickness of the incompetent unit), and changes in layer thickness across the fold. A model (Atkinson and Wallace, 2003) we developed meets these conditions and is a hybrid between earlier models by Homza and Wallace $(1995,1997)$ and Epard and Groshong (1995). The model describes geometry at different stages of evolution, but does not predict how geometry will evolve. A predictive model requires more information about hinge evolution and controls on thickness changes.

\section{Implications for fracture}

Our conclusions about fold geometry and evolution suggest implications about fracturing related to the folds. The important conclusion that fold mechanism changes throughout the evolution of a fold suggests corresponding changes in conditions that may lead to fracturing.

Layer-parallel shortening before or early during folding, especially in more competent intervals, may result in extension fractures, most likely oriented normal to fold axes. Flexural-slip under brittle conditions could lead to fracturing resulting from shear strain associated with bed-parallel slip and/or tangential longitudinal strain due to bending of beds. Fractures related to flexural slip likely would dominate in straight fold limbs, whereas fractures related to tangential longitudinal strain likely would dominate in hinge zones. The width and curvature of hinge zones would control fracturing resulting from tangential longitudinal strain. Hinge- and limb-related fractures would form in different areas throughout the evolution of fixed-hinge folds, whereas complex overprinting of hinge- and limb-related fractures would occur during evolution of migratinghinge folds. The detachment folds of the northeastern Brooks Range are interpreted as fixed- 
hinge folds as a first approximation but, in detail, they likely rotate as folds tighten and some may migrate.

Flexural-slip is superseded by flattening of folds as a result of some combination of locking of folds and more ductile deformation conditions. Under ductile conditions, new fractures are unlikely to form and existing fractures are likely to close and anneal. Flattening under less ductile conditions is likely to result in fracture patterns that reflect the bulk strain field rather than fold-related mechanisms like flexural slip or tangential longitudinal strain.

Fracturing is likely to occur during late flexural slip, but the causes of late flexural slip are not well enough known to assess the related fracturing. In particular, very different patterns would be expected depending on whether late flexural slip is caused by contraction or extensional collapse.

The folds observed in this study clearly display significant changes along trend in geometry and kinematics. Fractures normal to fold axes would be expected in local areas of plunge and curvature along trend, as well as where regional extension has occurred along fold axes.

\section{Thrust-truncated asymmetrical folds}

\section{$\underline{\text { Fold and thrust geometry and evolution }}$}

The thrust-truncated asymmetrical folds of the Porcupine Lake area formed in competent Lisburne Group carbonates above the incompetent Kayak Shale. The competent to incompetent unit thickness ratio is about 8.2. Two uniformly competent intervals are separated by a thin, moderately competent interval. The competent intervals are sharply bounded above and below.

The folds typically are inclined and asymmetrical and are cut and displaced by thrust faults. The folds are mostly angular, with a relatively limited range of interlimb angles. Anticline hinges commonly branch upward from the middle Lisburne. Parasitic folds are rare except in forelimbs, which commonly contain a large anticline-syncline pair. Backlimbs are long and gently folded. Little thickness change is visible across folds.

Forelimbs typically are cut and displaced above one or more thrust faults. Bedding in forelimbs is cut at a high angle, and highly strained panels locally directly overlie thrust faults. Backlimbs overlie a flat near the base of the Lisburne. Thrust faults typically are gently folded into antiforms. Local folds that are not visibly cut by thrust faults display greater fold shortening, steeper inclination, and more thickness change than folds that have been cut by thrusts.

Most of the folds probably originated as detachment folds as suggested by the competency contrast between Kayak and Lisburne, the presence of some folds that have not been cut by thrust faults, and a transition to detachment folds in the same rock units to the north. One fold displays quite different characteristics that suggest it may be a tri-shear fault-propagation fold. These include a ramp tip, multiple upward-diverging strands, and abundant strain, 
Folds began as either symmetrical or asymmetrical detachment folds. Forelimbs steepened and thickened, mainly by parasitic folding. Folding was superseded by thrust breakthrough as shortening increased. A fault-bend fold geometry was superimposed on the truncated fold as it was displaced over the footwall ramp. Thrusts underlying displaced folds were gently folded by deformation in the footwall. Some combination of bed-parallel shear, tightening of the fold core, hinge rounding or collapse, and extension by fracture and veining, normal faulting, or thinning must accommodate such bending of an existing fold.

Two observations suggest that fold asymmetry favors thrust breakthrough. First, asymmetrical folding preceded thrust breakthrough. Second, in the northeastern Brooks Range, thrusts typically are absent in symmetrical detachment folds but commonly are present in local asymmetrical folds.

Asymmetrical folding is favored by inclination of layering with respect to maximum compressive stress or by simple shear acting along layering. Top-to-north bed-parallel shear is supported by fold asymmetry, thrust breakthrough, chevron-geometry anticlines, and minor structures with northward vergence. The formation and eventual breakthrough of asymmetrical folds may have been favored by a regionally inclined detachment, a high ratio of competent to incompetent unit thickness, the presence of overlying and underlying thrust sheets, and an orogenic wedge lacking an unusually low taper angle. It is unknown which of these may have been most important in controlling fold and thrust evolution.

A quantitative model does not yet exist for the geometry and kinematics of thrust-truncated asymmetrical folds of the type observed in the Porcupine Lake area. Any such model must accurately represent how natural truncated and displaced folds are further folded.

\section{Implications for fracture}

Our conclusions about the geometry and evolution of thrust-truncated asymmetrical folds suggest implications about fracturing related to the folds. The important conclusion that the mechanism of shortening changes from folding to thrust faulting throughout the evolution of a structure suggests corresponding changes in conditions that may lead to fracturing.

Layer-parallel shortening may occur before or early during folding, especially in more competent intervals, and may result in extension fractures, most likely oriented normal to fold axes. This study provided no evidence to assess the importance of layer-parallel shortening in thrusttruncated asymmetrical folds, but some evidence exists for fractures formed oblique to bedding as a result of bed-parallel shear prior to folding.

Flexural-slip under brittle conditions could lead to fracturing resulting from shear strain associated with bed-parallel slip and/or tangential longitudinal strain due to bending of beds. Fractures related to flexural slip likely would dominate in long straight limbs, whereas fractures related to tangential longitudinal strain likely would dominate in narrow, angular hinge zones. Hinges probably were relatively fixed throughout fold evolution, resulting in little overlap between hinge- and limb-related fractures. However, some overprinting of hinge- and limb- 
related fractures may have occurred as a result of hinge rotation, especially in folds with wider curved hinge zones.

Flexural-slip may be superseded by flattening of folds as a result of some combination of locking of folds and more ductile deformation conditions. Under ductile conditions, new fractures are unlikely to form and existing fractures are likely to close and anneal. Fold flattening under ductile conditions appears to have been significant in some unbroken folds, but not in folds cut by thrust faults.

Fractures and veins oriented at high angles to bedding are common in areas of actual or potential breakthrough, and could have originated either as extension or shear fractures associated with the breakthrough of fold limbs by thrust faults. Shear strain is commonly associated with thrust displacement, particularly in narrow zones parallel and immediately adjacent to thrust faults. Existing fractures may be closed or annealed in these zones, but new fractures may also form oblique to bedding as a result of shear strain. Thus, fractures may result from bed-parallel shear before folding, as a result of flexural-slip folding, or during thrust faulting.

Late bending of truncated and displaced folds results in the most obvious and abundant fractures and veins to form during the evolution of thrust-truncated asymmetrical folds. These essentially are the result of tangential longitudinal strain in or near the hinge zones of both truncated and displaced folds and the bends in their backlimbs.

\section{Fractures}

Fractures and other mesoscopic structures formed at different times during the evolution of individual detachment folds in Lisburne Group carbonates of the northeastern Brooks Range. These structures provide clues to the mechanism of folding, the conditions under which folds evolved, and the paragenesis of fractures in the fold-and-thrust belt as a whole.

The earliest fractures strike north-northwest and probably represent orogen-normal extension fractures that developed in the foreland basin in advance of the fold-and-thrust belt. These rocks and fractures were later incorporated into the thrust belt, where they were folded and thrustfaulted . Later fractures, strained markers, and dissolution cleavage developed during detachment folding as a result of flexural slip and homogeneous flattening. Fracturing associated with flexural slip occurred early in the development of folds but these early fractures commonly were overprinted or destroyed by ductile strain as later homogeneous flattening accommodated additional shortening. This episode of flattening and peak fold development occurred at relatively high temperatures $\left(>200^{\circ} \mathrm{C}\right)$. Penetrative strain was overprinted in turn by late extension fractures that formed at substantially less depth and lower temperature, probably due either to flexural slip in the waning phases of folding or to unroofing of the orogenic wedge.

Early fracturing, overprinting by ductile structures, and subsequent later fracturing in detachment-folded rocks of the Lisburne Group emphasizes the importance of understanding the unique character and history of each fold-and-thrust belt in a successful hydrocarbon exploration effort. In particular, the mechanical stratigraphy and conditions of deformation play an 
important role in the type of fold that develops, the fold mechanisms that are active, and the subsequent distribution and character of fractures and other mesoscopic structures.

Most of the obvious fractures in the Lisburne Group were not directly related to folding, but post-dated peak folding. Fracture distribution and character were controlled by the mechanical stratigraphy, especially the thickness of mechanical units (in contrast to lithologic bed thickness), the lithology of the mechanical units, and the location of slip horizons.

Our observations suggest that hydrocarbon generation predated trap formation at the site of folding, but they do not necessarily constrain the regional evolution of the petroleum system through time. Thus, hydrocarbons generated elsewhere could migrate into the folded rocks. Juxtaposition of these deformed rocks with less mature sediments capable of generating oil and/or gas could occur by thrust faulting. Alternatively, traps could be filled by lateral migration of gas from the Colville basin from the west. Collecting and integrating structural, thermal, and geochronologic data from various locations throughout the North Slope, the Brooks Range, and the northeastern Brooks Range would provide additional important clues to the evolution of this particular petroleum system.

Standard statistical univariant analysis was inadequate to identify the important factors controlling fracture spacing and distribution in folded Lisburne Group carbonates. Preliminary studies using neural network analysis suggest that this approach may prove capable of evaluating the effect of multiple geologic variables on fracture spacing. However, standard neural network analysis requires very large data sets, while field-generated data sets are usually relatively small. Additional geostatistical work is needed to develop techniques to use neural network analysis in the analysis of small datasets.

\section{Petroleum Engineering}

\section{Connectivity and wellbore placement in the Lisburne Group}

Fracture systems were modelled in the relatively undeformed region of the Wahoo Limestone. The wellbore trajectory analyses of several cases showed:

-A positive correlation was observed for the base case between number and area of fractures connected to wellbores. This relationship, however, diminished for the other cases.

-Optimal horizontal well azimuth orientations are in the range $0^{\circ}$ to $30^{\circ}$ for the base case and the case with variable fracture strike and dip. Wells with this orientation will be connected to the maximum number and area of fractures.

-Variability in strike and dip increases the number and area of fractures connected to the wellbore. However, it does not change the optimal wellbore orientation.

-Termination of ENE-striking fractures against the NNW-striking fractures increases the number and decreases the area of fractures connected to the wellbore. It also affects wellbore placement by shifting the optimal wellbore trajectory from the bisector between the two sets $\left(30^{\circ}\right)$ toward the direction perpendicular to the NNW-striking set $\left(60^{\circ}\right)$.

The hydraulic connectivity analyses showed:

-The fracture network is weakly anisotropic if uniform fracture transmissivity is assumed. 
-The system remains weakly anisotropic if the relative transmissivities of the sets are changed.

-ENE-striking fractures provide critical connections in the fracture network, as opposed to the NNW-striking set, whose transmissivity is important only for NNW flow.

-The fracture system is above the percolation threshold in all cases.

The smaller fractures become important if termination of ENE-striking fractures and strike and dip variability are included in the model: the "realistic" case is less interconnected, closer to the percolation threshold, and more sensitive to removal of smaller fractures.

Fracture timing and flow implications in folded Lisburne

Two distinct fracture sets were observed in detachment-folded examples of the Carboniferous Lisburne Group carbonates of northeastern Alaska: an EW-striking set that formed late during folding and a NS-striking set that formed after folding. Statistical analysis of outcrop fracture data shows that bed thickness does not have significant effect on the fracture spacing distribution of either set. Fracture density is only weakly related to the fold geometry, with fracture density greater on the limbs than in the hinge area. These results contradict the results of most other studies.

The weak or lack of effect of folding on the fracture spacing of each set suggests that both fracture sets are only weakly related or unrelated to the folding process. This suggests that detachment fold geometry cannot always be used as a reliable predictive tool for fracture distribution within the Lisburne Group.

This study clearly demonstrates that the local geological setting plays an important role in fracture spacing distribution. Determining the characteristics of the fractures, the relative age of the different fracture sets, and the relationship between the fractures and their local geologic setting can be an important factor in assessing reservoir performance.

Relationships of fracture density and mechanical stratigraphy in folded Lisburne using neural nets

-The results from the neural network analysis show complex relationships between fracture density and mechanical properties. This may support the conclusion drawn from field evidence and statistical analysis of the fracture data that the fractures are weakly related to the process of folding the formation and that they may have been generated at different times by different geological events.

-The number of data sets used in the neural network training is considered to be small. To satisfy the suggested value for the minimum sample cases in the training, the number of data sets should be at least double what we have.

-With the existing data, the neural network can still be a valuable tool to investigate the effect of mechanical stratigraphical parameters on fracture density. The relative importance of the single parameters can be assessed. For the data under investigation, bed thickness and interlimb angle are the parameters that have the most effect on the fracture density, following by lithology, stratigraphic location, structural position on the fold, and fracture orientation. 
-It is important to be careful when using neural networks for approximation in multivariable problems. Due to non-uniqueness of the connection weight of the neural network model, it is desirable to check for the stability of the model for the same training data set by training the model with different initial values of the connection weights. 